Universidad deValladolid

PROGRAMA DE DOCTORADO EN FÍSICA

TESIS DOCTORAL:

\title{
ANALYSIS OF THE COMPOSITION-STRUCTURE- PROPERTIES RELATIONSHIP OF OPEN-CELL POLYOLEFIN-BASED FOAMS WITH TAILORED LEVELS OF GAS-PHASE TORTUOSITY
}

Presentada por Eduardo López González para optar al grado de Doctor por la Universidad de Valladolid

Dirigida por:

Prof. Dr. Miguel Ángel Rodríguez Pérez

Dr. Cristina Saiz Arroyo 



\section{CONTENTS}

\section{RESUMEN EN CASTELLANO}

0.1 Introducción........................................................................................................................ V

0.2 Marco de la tesis y motivación .........................................................................VIII

0.3 Objetivos .................................................................................................................... XI

0.4 Novedades................................................................................................................ XIII

0.5 Estructura de la tesis ................................................................................ XIV

0.6 Publicaciones, conferencias y actividades complementarias.....................XVII

0.7 Principales resultados y conclusiones .............................................................XXI

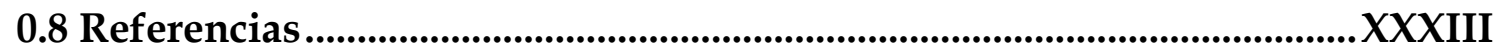

\section{INTRODUCTION}

1.1 Introduction .......................................................................................................................

1.2 Framework and motivation ..........................................................................

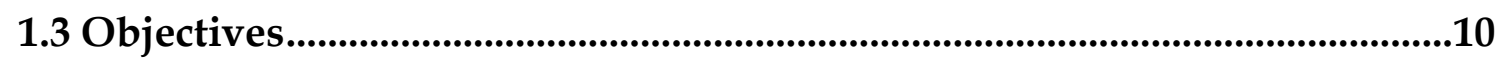

1.4 Novelties....................................................................................................................12

1.5 Structure of the thesis ............................................................................................13

1.6 Publications, conferences and complementary activities ................................15

1.7 References .................................................................................................................20

\section{BACKGROUND AND STATE OF THE ART}

2.1 Introduction ..................................................................................................................27

2.2 Basic concepts of the cellular structure of polymer foams: ...........................27

2.2.1 Cellular structure interconnectivity ........................................................27

2.2.2 Gas-phase tortuosity .............................................................................29

2.3 Polyurethane (PU) foams: Basic concepts and associated problematic .......31

2.3.1 Introduction. The chemistry …………………………...................................31

2.3.2 Market relevance and main properties ..................................................34 
2.3.3 Problematic and limitations of use .....................................................37

2.4 Crosslinked cellular polymers based on polyolefins.......................................39

2.4.1 General concepts ...................................................................................................39

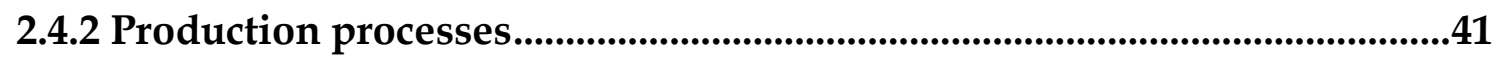

2.4.2.1 Continuous processes ......................................................43

2.4.2.2 Discontinuous process: Block foams .............................46

2.5 Physical properties of low-density flexible foams.........................................55

2.5.1 Mechanical properties..................................................................................55

2.5.2 Acoustic properties ........................................................................62

2.5.3 Oil- absorption properties......................................................................67

2.5.4 Other properties ........................................................................................72

2.5.4.1 Vibration dampening ........................................................72

2.5.4.2 Thermal stability ............................................................73

2.5.4.3 Thermal conductivity ............................................................74

2.5.4.4 Summary ......................................................................................77

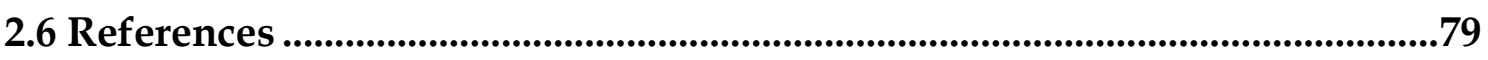

\section{MATERIALS AND FABRICATION PROCESS}

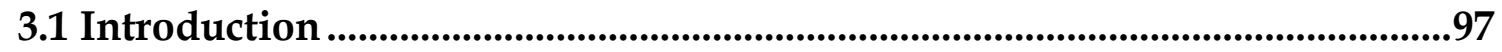

3.2 Polymeric matrices, blowing and crosslinking agents...................................97

3.3 Formulation, fabrication process and materials ............................................99

3.3.1 Preparation of the solid precursors ............................................................101

3.3.2 Two-steps compression molding process: first step ................................102

3.3.3 Two-steps compression molding process: second step ...........................103

3.3.4 Description of the foamed materials...........................................104

3.3.5 Crystalline morphology of the foamed materials .......................107

3.3.6 Analysis of the morphology of the cellular structure ...................111

3.4 Crosslinking

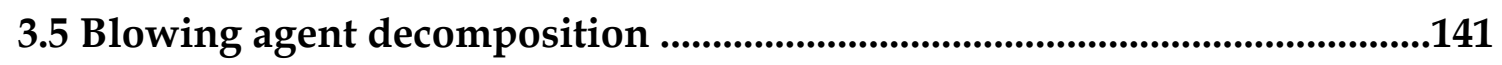

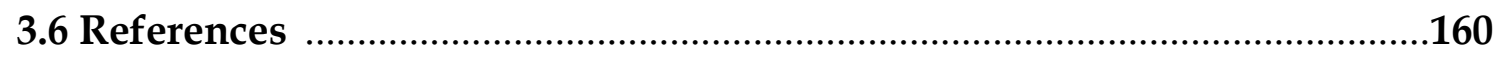




\section{MECHANICAL PROPERTIES}

4.1 Introduction ..............................................................................................................167

4.2 Mechanical properties: Foams based on LDPE and EVA 18 ........................169

4.3 Mechanical properties: Foams based on EVA 12 and EBA............................190

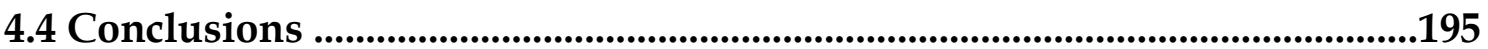

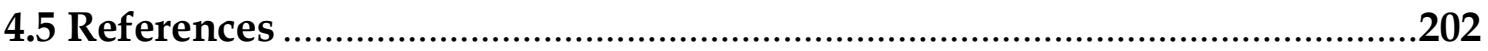

\section{ACOUSTIC PROPERTIES}

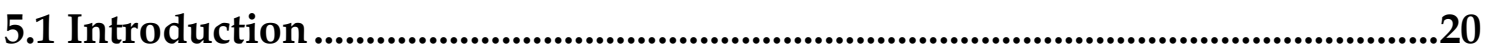

5.2 Acoustic absorption: Foams based on LDPE and EVA 18 .............................210

5.3 Acoustic absorption: Foams based on EVA 12 and EBA ................................218

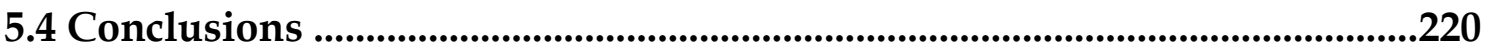

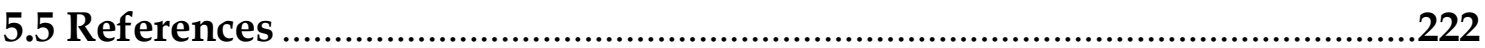

\section{OIL ABSORPTION}

6.1 Introduction ...........................................................................................................227

6.2 Oil Absorption: Foams based on LDPE and EVA 18 ......................................229

6.3 Oil Absorption: Foams based on EVA 12 and EBA ………………………......250

6.4 Conclusions .............................................................................................................25

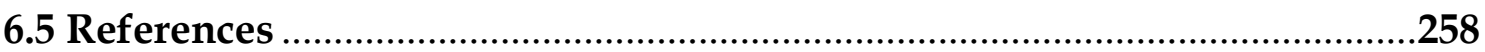

\section{GENERAL PROPERTIES}

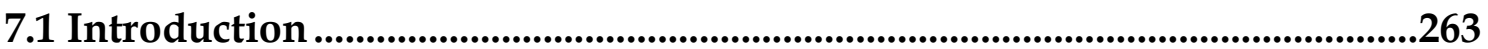

7.2 General properties: EBA......................................................................................264

7.3 DMA analysis and thermal stability: LDPE, EVA 12 and EVA 18 foams. 287

7.4 Thermal conductivity...............................................................................................291

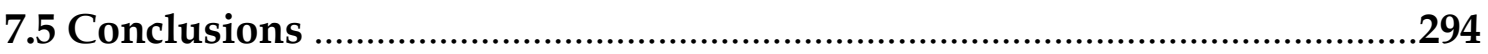

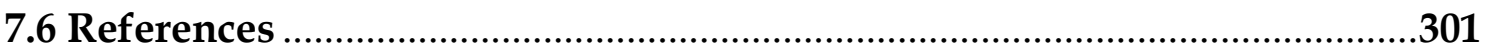




\section{CONCLUSIONS AND FUTURE WORK}

8.1 Conclusions .....................................................................................................................307

8.1.1 Production and cellular structure of the open-cell polyolefin-based foams 308

8.1.2 Analysis of the physical properties.............................................................310

8.1.2.1 Mechanical properties .......................................................................................310

8.1.2.2 Acoustic properties …………………………………….......312

8.1.2.3 Oil absorption ........................................................................

8.1.2.4 Viscoelasticity, thermal stability and thermal conductivity .316

8.2 Future work 318 
RESUMEN EN CASTELLANO 



\section{ÍNDICE}

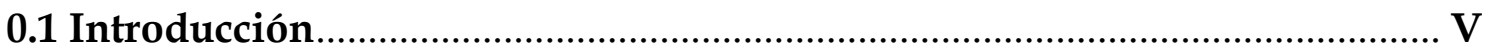

0.2 Marco de la tesis y motivación ...................................................................... VIII

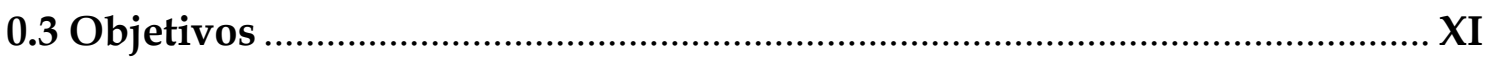

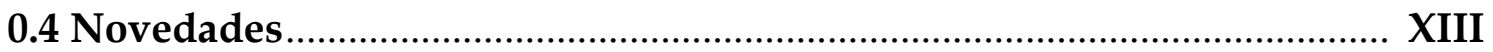

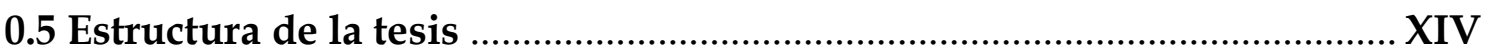

0.6 Publicaciones, conferencias y actividades complementarias....................XVII

0.7 Principales resultados y conclusiones ..........................................................

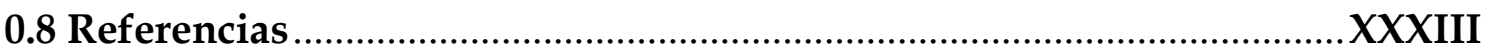




\subsection{Introducción}

El consumo de plásticos ha ido incrementándose sucesivamente durante los últimos años. De acuerdo a los datos publicados por PlasticsEurope (PEMRG) [1], la producción de plástico ha aumentado desde los 322 millones hasta los 335 millones de toneladas en tan solo un año (desde 2015 a 2016) y en Europa concretamente, la producción se ha incrementado en un 3.45\% (Figura 0.1).
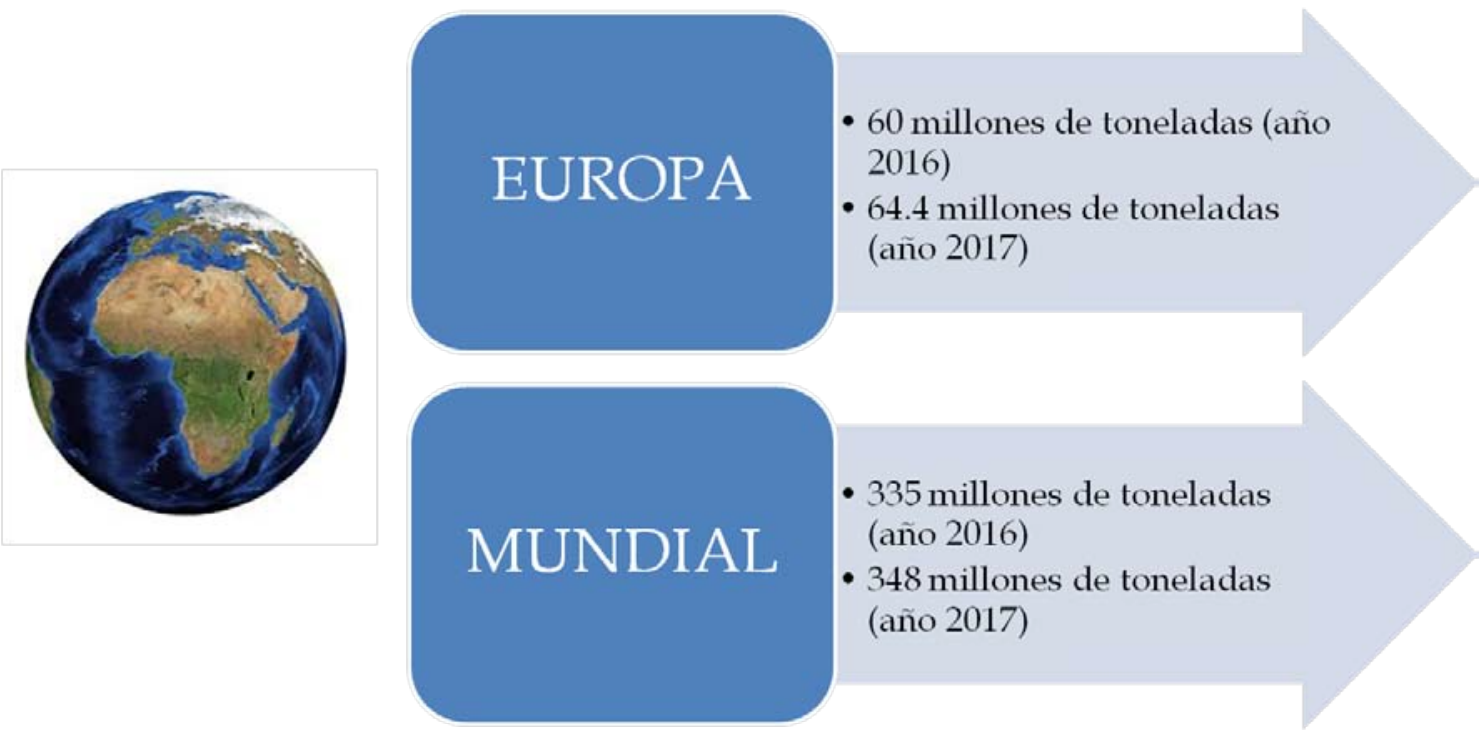

Figura 0.1. Producción mundial y europea de plásticos [1].

Sin embargo, las políticas orquestadas de los estamentos europeos se dirigen hacia una restricción considerable del consumo de plásticos. Un ejemplo concluyente es la próxima prohibición de utensilios plástico de un solo uso, tales como cubertería, platos o los bastoncillos para los oídos [2]. Los polímeros celulares se encuentran dentro de las soluciones potenciales para limitar o reducir el consumo de plástico [3-9]. Los polímeros celulares (también llamados espumas poliméricas) son materiales bifásicos, en los que una fase gaseosa se ha dispersado en una fase sólida, la matriz polimérica. Desde el primer ejemplo de polímero celular reportado en literatura, con la fabricación de un polímero celular de poliestireno en 1935, la producción y las aplicaciones de este tipo de materiales han ido aumentado considerablemente [10,11]. Los polímeros celulares ofrecen una amplia versatilidad gracias a sus propiedades, que se pueden controlar variando la matriz polimérica, la densidad y el grado de interconectividad de la estructura celular. Algunas de las propiedades generales de los polímeros celulares se enuncian a continuación:

- Ligereza

- Adaptabilidad en propiedades mecánicas en función de la densidad

- Alta absorción de energía

- Confort para espumas flexibles

- Baja conductividad térmica

- Excelente absorción de sonido para espumas de celda abierta

- Afinidad por aceites e hidrofobicidad en función de la matriz polimérica 
Gracias a este amplio abanico de propiedades de los polímeros celulares, el rango de aplicaciones en donde se encuentran presentes este tipo de materiales es muy variado, como se puede observar en la Figura 0.2.

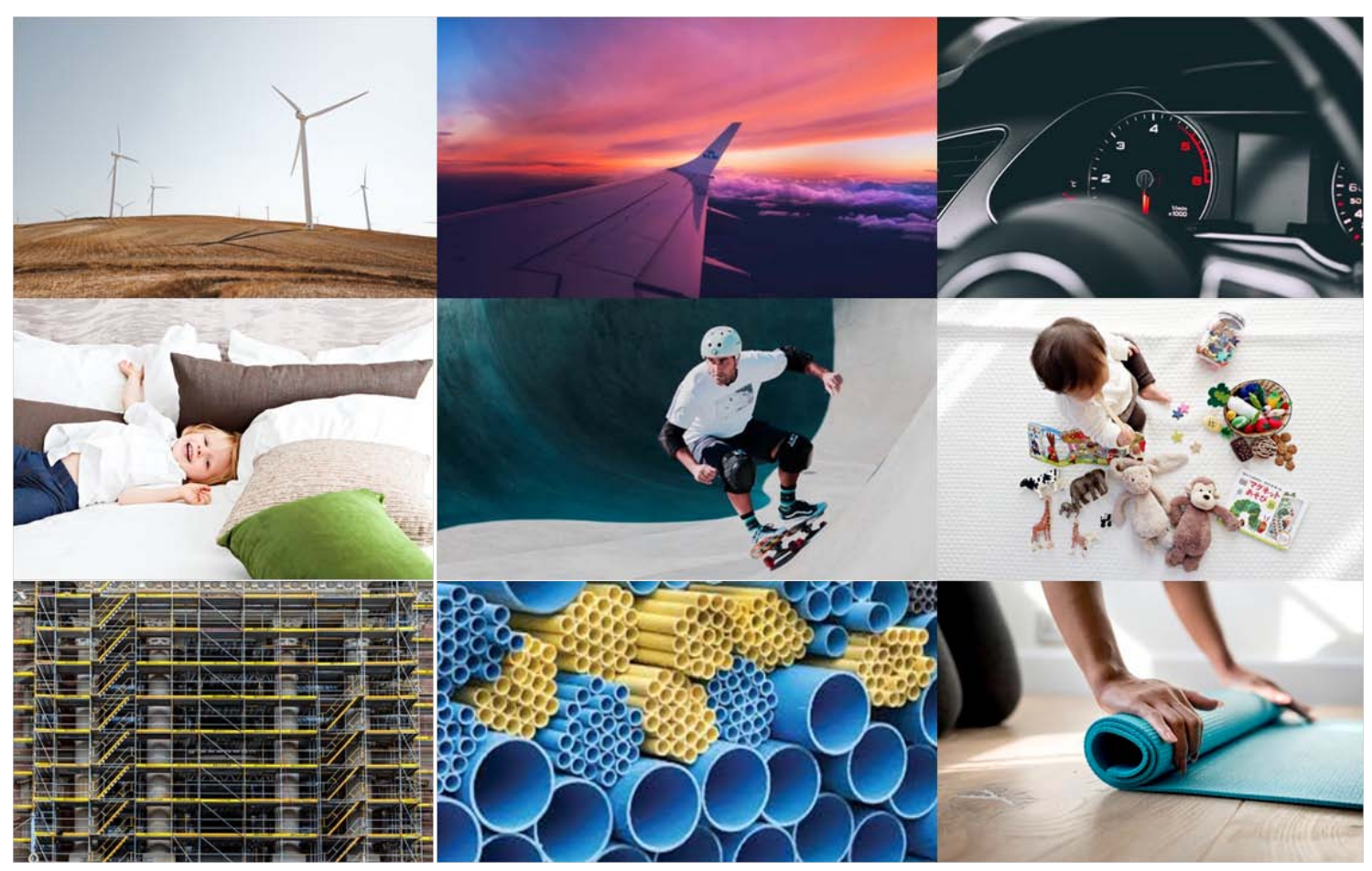

Figura 0.2. Algunos ejemplos de las aplicaciones en donde se utilizan polímeros celulares.

Las espumas de poliuretano (PU) constituyen uno de los grupos más importantes dentro del campo de los polímeros celulares. Son materiales muy versátiles y dependiendo del tipo de espuma, pueden ser utilizadas en un amplio rango de aplicaciones.

Las espumas de PU pueden ser clasificadas de acuerdo a diferentes criterios. Uno de ellos es la rigidez de la matriz polimérica, y en función de este parámetro las espumas de PU pueden dividirse en rígidas o flexibles.

Según los datos mostrados en el informe sobre el mercado global de PU [12], más de un $50 \%$ del mercado del PU es dominado por las espumas flexibles de celda abierta. Gracias a las excelentes propiedades viscoelásticas de estas espumas y la alta interconectividad de la estructura celular, estos materiales de celda abierta son empleados para aplicaciones relacionadas con el confort, tales como colchones, asientos, reposacabezas o reposabrazos. Además, es importante destacar que las espumas flexibles de PU son muy interesantes para aplicaciones tales como absorción acústica o la absorción de líquidos [13,14].

Las propiedades que presentan estos materiales les convierten en la única opción disponible en el mercado. Sin embargo, las espumas de PU presentan una serie de desventajas, que podrían limitar o reducir su uso a corto plazo. Por ejemplo, en el sector de la automoción, la emisión de volátiles es un factor crítico para la 
estandarización de las diferentes partes de los vehículos. Los catalizadores en base amina utilizados en la fabricación de las espumas de PU son los principales responsables de las altas emisiones de volátiles de estas espumas. Además, otros aditivos como por ejemplo los antioxidantes presentes en los polioles también contribuyen a incrementar los niveles de volátiles emitidos.

Aunque la emisión la volátiles constituye un serio problema, otras restricciones al uso de poliuretano se encaminan a proteger nuestra salud, contribuyendo a minimizar sus efectos adversos. Un ejemplo conocido y estudiado, son los isocianatos. El isocianato es uno de los reactivos usados en la fabricación de los poliuretanos. Se han publicado numerosos estudios acerca de la peligrosidad a la exposición a estos compuestos, llegándose a considerar como un reactivo cancerígeno.

Otra problemática presente en las espumas de PU se relaciona directamente con la toxicidad de los gases emitidos por estas espumas cuando se incineran, por ejemplo en un incendio. Estos gases tóxicos pueden ser letales en periodos relativamente cortos de tiempo, constituyendo una limitación crítica en el uso de estos materiales.

Por otro lado, el poliuretano tiende a degradarse completamente generándose monómeros o parcialmente, formándose oligómeros y otros compuestos. Una reacción importante relacionada con esta degradación es la reacción con agua (hidrólisis) descomponiéndose el poliuretano en poliol y poliamida:

\section{PU espuma $+\mathrm{H}_{2} \mathrm{O} \rightarrow$ Poliol + poliamida}

Sin embargo, las espumas de PU no sólo reaccionan con agua sino que pueden degradarse mediante otras reacciones como por ejemplo, la alcoholisis, acidólisis, glicolisis o aminolisis [15]. Se puede decir por tanto, que estos materiales tienen una resistencia química limitada.

Además, las espumas de PU tienden a degradarse después de una exposición prolongada a luz ultravioleta (UV). Algunos de los enlaces presentes en la compleja química del poliuretano son susceptibles de ser afectados por la irradiación UV, amarilleándose la espuma o incluso apareciendo defectos en su estructura.

Teniendo en cuenta esta serie de inconvenientes, la búsqueda de potenciales alternativas a las espumas flexibles de PU comienza a ser indispensable. Sin embargo, el desarrollo de materiales con propiedades similares a estas espumas flexibles no es una tarea sencilla, sin existir a día de hoy opciones reales en el mercado. Considerando el amplio rango de aplicaciones de las espumas flexibles de PU, es sin lugar a dudas lógico perseguir el desarrollo de alternativas que reproduzcan las propiedades mostradas por estos materiales.

Las poliolefinas (PO) han emergido en los últimos años como materias primas interesantes en la fabricación de espumas de celda abierta [15-19]. Las poliolefinas son los polímeros resultantes de la polimerización de olefinas. Polímeros tan ampliamente estudiados y empleados como el polietileno (PE), el polipropileno (PP), los copolímeros 
de etileno y acetato de vinilo (EVA) o los copolímeros de etileno y acrilato de butilo (EBA) pertenecen a este grupo. PE, EVA y EBA presentan propiedades muy interesantes tales como flexibilidad, resistencia química o hidrofobicidad. Considerando la rápida recuperación de las espumas flexibles de celda abierta de PU, la flexibilidad de la matriz polimérica se antoja como un factor clave, y por tanto se requieren polímeros flexibles para la posible sustitución de estos materiales.

En comparación con el poliuretano, los análisis toxicológicos de poliolefinas no han arrojado ningún dato alarmante para la salud pública [21]. Además, las poliolefinas son mucho más estables frente a la luz o la humedad que el poliuretano, ya que los enlances $\mathrm{C}-\mathrm{H}$ presentes en las cadenas, se caracterizan por su fortaleza, su carácter inerte y su muy escasa polaridad. Además, las poliolefinas liberan pocos volátiles a temperatura ambiente [22].

La investigación enmarcada en esta tesis tiene como uno de sus objetivos desarrollar nuevos materiales de baja densidad y celda abierta basados en poliolefinas dirigidos a reproducir las propiedades presentes en las espumas flexibles de celda abierta de PU.

Teniendo en mente todos estos aspectos, el marco de la tesis y la motivaciones de este trabajo se explican en la siguiente sección.

\subsection{Marco de la tesis y motivación}

Esta tesis se enmarca dentro de las ayudas para contratos para la formación de investigadores en empresas (Doctorandos Industriales) financiado por el Ministerio de Economía y Competitividad (aunque en la actualidad estas ayudas son gestionadas por el Ministerio de Ciencia, Innovación y Universidades). CellMat Technologies S.L. y el estudiante de doctorado recibieron una ayuda de este programa (DI-15-07952) el 28 de septiembre de 2016.

CellMat Technologies S.L. (www.cellmattechnologies.com) es una spin-off establecida en el año 2012 por investigadores anteriormente pertenecientes al laboratorio de materiales celulares (CellMat) de la Universidad de Valladolid. La principal actividad de esta compañía se basa en la implementación de tecnologías avanzadas en plantas del sector del plástico, especializándose principalmente en dos campos: los polímeros celulares o espumas poliméricas y los bioplásticos. Además, la compañía colabora activamente con otras entidades nacionales e internacionales mediante la ejecución de diversos proyectos de investigación.

La directora de esta tesis en la compañía, la Dr. Cristina Saiz Arroyo, lleva trabajando más de 10 años en el campo de los materiales celulares poliméricos. Se unió en el año 2005 al laboratorio de materiales celulares (CellMat) de la Universidad de Valladolid, donde comenzó su tesis doctoral bajo la supervisión del Profesor Miguel Ángel Rodríguez Pérez. Además de realizar las actividades relacionadas con su tesis, participó en varios proyectos de investigación financiados tanto a través de entidades tanto públicas como privadas, pero en su mayoría relacionados con el desarrollo de 
formulaciones específicas para la producción de materiales celulares con propiedades avanzadas para diversos tipos de aplicaciones.

En octubre de 2009, Cristina Saiz se unió al equipo del Centro Tecnológico de Miranda de Ebro, (Programa Torres Quevedo, PTQ-09-01-00790, Ministerio de Economía y Competitividad) donde trabajó como Responsable de Proyectos. Su trabajo en este centro se realizó en colaboración con CellMat, gestionando durante esta etapa varios proyectos relacionados con los materiales celulares poliméricos. En el año 2012 presentó su tesis doctoral titulada "Fabrication of improved polyolefin based celular materials. Process-composition-structure-properties relationship" [23].

En febrero de 2013, Cristina Saiz se incorporó a la empresa CellMat Technologies (Programa Torres Quevedo, PTQ-12-05504, Ministerio de Economía y Competitidad), como Responsable de Nuevos Productos e I+D. Desde su incorporación a CellMat Technologies S.L. ha participado en más de 50 proyectos con empresas del sector productor y transformador de plásticos. Sus actividades en la empresa se centran principalmente en la gestión de proyectos relacionados con el diseño y desarrollo de formulaciones destinadas a aplicaciones de espumado. Después de más de una década trabajando en este campo, Cristina, tiene una amplia experiencia y un profundo conocimiento de las necesidades y características específicas que deben tener las formulaciones empleadas para la producción de materiales celulares.

CellMat Technologies colabora activamente con el laboratorio de materiales celulares, CellMat ( $\underline{w w w . c e l l m a t . e s})$, de la Universidad de Valladolid en la implementación de proyectos de investigación. Gracias a esta colaboración, ha sido posible llevar a cabo la parte experimental de esta tesis en los laboratorios de CellMat, mediante la realización de dos proyectos de investigación financiados por la compañía:

\begin{tabular}{|l|}
\hline Proyecto: "Desarrollo de nuevos materiales celulares" \\
\hline Financiado por: CellMat Technologies S.L. \\
\hline Duración: Junio 2013- Diciembre 2015 \\
\hline Investigador principal: Miguel Ángel Rodríguez Pérez \\
Proyecto: "Desarrollo y optimización de materiales celulares de celda abierta para \\
$\quad$ aplicaciones de confort y de absorción de líquidos" \\
\hline Financiado por: CellMat Technologies S.L. \\
\hline Duration: Diciembre 2016- Diciembre 2019 \\
\hline Investigador principal: Miguel Ángel Rodríguez Pérez \\
\hline
\end{tabular}

CellMat se estableció en el año 1999 por los catedráticos José Antonio de Saja Sáez y Miguel Ángel Rodríguez Pérez, este último, codirector de esta tesis. En una primera etapa, la investigación desempeñada en el laboratorio estaba orientada a una profunda caracterización de polímeros celulares producidos industrialmente. Esta caracterización se enfocaba en la caracterización estructural y en la determinación de las propiedades físicas de polímeros celulares principalmente poliolefínicos 
producidos por diferentes procesos de fabricación [18,24-30]. Después de este periodo inicial, en el año 2005, el laboratorio empieza a adquirir el equipamiento que permitía poder fabricar los materiales. Actualmente el laboratorio puede producir espumas utilizando diferentes tecnologías de fabricación (extrusión, moldeo por inyección, espumado por disolución de gas, espumado reactivo, espumado de perlitas extruídas y moldeo por compresión).

CellMat atesora una gran experiencia en la fabricación y en la caracterización de espumas entrecruzadas de poliolefina de celda cerrada y baja densidad. M.A. Rodríguez-Pérez y O. Almanza iniciaron la investigación en este campo modelizando y caracterizando las propiedades mecánicas y térmicas de espumas poliolefínicas de celda cerrada fabricadas por la empresa SEKISUI Chemical Co., Ltd y Zotefoams Plc. $[18,24]$. En el año 2004, J.L. Ruiz-Herrero analizó durante su tesis el compartimiento a impacto y fluencia de estas espumas de celda cerrada [25]. F. Hidalgo también llevó a cabo la caracterización de materiales celulares de celda cerrada producidos por el proceso de moldeo por compresión en dos etapas suministrados por la empresa Microcel S.A. [28].

Como se ha visto, la caracterización de materiales celulares poliolefínicos de celda cerrada y baja densidad ha sido ampliamente analizada en el laboratorio CellMat. CellMat también ha desarrollado un amplio conocimiento en la caracterización de polímeros celulares entrecruzados de celda abierta basados en poliolefinas producidos por el proceso de moldeo por compresión en dos etapas. Los primeros trabajos al respecto, se basaron en la caracterización de la estructura celular y en el análisis de las propiedades térmicas, mecánicas y acústicas de materiales comerciales suministrados por la compañía japonesa SANWA KAKO Co., Ltd [30].

Las excelentes propiedades de estas espumas de poliolefina de celda abierta despertó el interés en desarrollar un nuevo proceso de fabricación (diferente al utilizado por SANWAKAKO) para producir estos materiales. CellMat Technologies y el laboratorio CellMat desarrollaron una metodología para producir espumas de poliolefina de celda abierta usando el proceso de moldeo por compresión en dos etapas sin la necesidad de incluir procesos adicionales para favorecer la ruptura de las paredes celulares (aproximación llevada a cabo por SANWA KAKO). Esta novedosa metodología se describe en una patente asignada a CellMat Technologies desarrollada por M.A. Rodríguez-Pérez, C. Saiz-Arroyo y J. Tirado en el año 2015 [31].

Esta patente ha sido el punto de partida para el trabajo desarrollado en esta tesis. Esta tesis se puede considerar como el siguiente paso una vez desarrollada la metodología. Sin embargo, para producir materiales con propiedades interesantes se tuvieron que implementar varias actividades, como por ejemplo, mejorar el proceso de producción, aumentar el número de materiales a producir utilizando diferentes matrices poliméricas consiguiendo diferentes grados de tortuosidad de la estructura celular y por último estudiar la relación estructura-propiedades de estos nuevos materiales. Es precisamente en estos aspectos en los que incide esta tesis. 
En base a este contexto científico y a las motivaciones de este trabajo, la siguiente sección de este capítulo se centra en explicar los principales objetivos generales establecidos al comienzo de esta tesis y a los objetivos específicos de la misma.

\subsection{Objetivos}

Esta tesis presentas dos objetivos: un objetivo científico y otro técnico, como se muestra en la Figura 0.3.

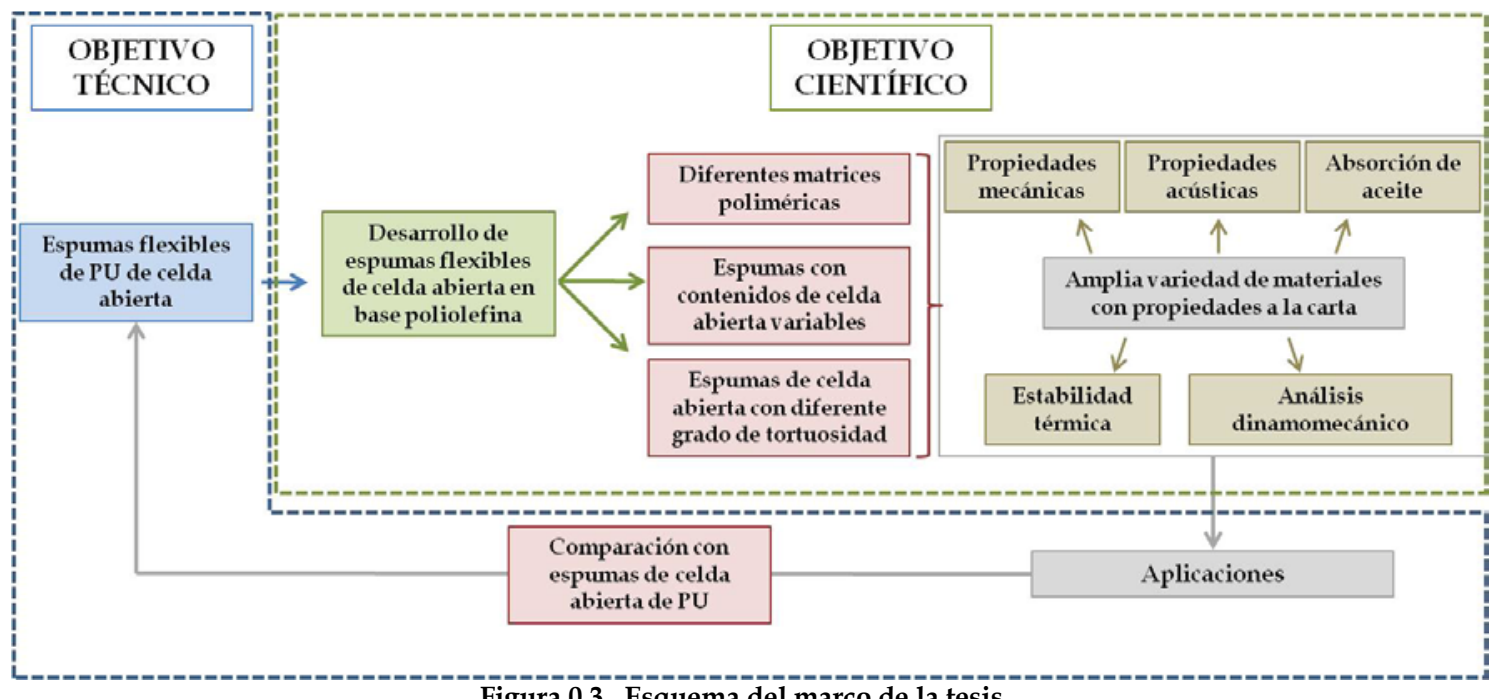

Figura 0.3. Esquema del marco de la tesis.

En lo relativo al contexto científico, el objetivo principal se puede enunciar de la siguiente manera:

\section{ESTUDIAR LA RELACIÓN ESTRUCTURA-PROPIEDADES EN ESPUMAS FLEXIBLES DE POLIOLEFINA DE CELDA ABIERTA}

Para cumplir con este objetivo, inicialmente y como se expondrá en los siguientes capítulos de esta tesis, se desarrollaron diferentes tipos de espumas flexibles de celda abierta con diferentes contenidos de celda abierta y tortuosidad utilizando diferentes matrices poliméricas, como se indica en la Figura 0.3. A continuación, se analizará la estructura celular poniendo especial atención en dos parámetros: la interconectividad y el grado de tortuosidad de la estructura celular. Finalmente, se caracterizaron diferentes propiedades físicas y los resultados obtenidos se relacionaron con el tipo de espuma, y por tanto con parámetros tales como la naturaleza de la matriz polimérica, la interconectividad y la tortuosidad de la estructura celular. Estas ideas se muestran en la Figura 0.3, en donde este objetivo aparece esquematizado (cuadro verde de línea discontinua).

Además, también se puede definir un objetivo técnico. Hasta ahora, la mayor parte de los productos comerciales de espuma de celda abierta son en base poliuretano. Sin embargo, como ya se ha discutido previamente, las espumas de PU presentan serias limitaciones, que hacen necesario la búsqueda de alternativas a estos materiales. En 
consecuencia, el desarrollo de estas nuevas espumas de celda abierta abrió el camino para establecer un objetivo técnico realmente ambicioso:

\begin{tabular}{c}
\hline LA PRODUCCIÓN DE NUEVAS ESPUMAS DE POLIOLEFINAS \\
ENTRECRUZADAS DE CELDA ABIERTA Y DE BAJA TORTUOSIDAD PARA \\
REEMPLAZAR A LAS ESPUMAS DE PU DE CELDA ABIERTA EN \\
DIFERENTES APLICACIONES
\end{tabular}

Las investigaciones iniciales desarrolladas en CellMat (antes de iniciarse esta tesis) contribuyeron a considerar a las poliolefinas como candidatos perfectos para reemplazar al poliuretano. Los primeros prototipos fabricados en CellMat comenzaron a despejar el camino, pero la alta tortuosidad de la estructura celular limitaba las propiedades de estos materiales. Como resultado, surgió la idea de continuar desarrollando este proceso para generar materiales con una baja tortuosidad de la estructura celular y este hecho se convirtió en el principal objetivo de esta tesis.

Un aspecto clave para alcanzar el objetivo final fue seguir una metodología sistemática que permitiera ir alcanzando objetivos específicos. Algunos de esos objetivos específicos se enuncian a continuación:

1) Mejorar la reproducibilidad del proceso de fabricación con el objetivo de poder obtener muestras de suficiente calidad para su caracterización.

2) Extender el proceso a un número más amplio de poliolefinas, no sólo basando el estudio en LDPE como en los estudios previos a esta caracterización. Dos matrices poliméricas adicionales se han considerado: EVA y EBA.

3) Desarrollar espumas de poliolefina de celda abierta con diferentes grados de celda abierta y de tortuosidad.

4) Estudiar la relación estructura-propiedades de los materiales.

5) Analizar y comparar las propiedades físicas de estos nuevos materiales de celda abierta con las propiedades presentes en las espumas flexibles de PU de celda abierta.

La fabricación de poliolefinas celulares entrecruzadas de celda abierta de baja tortuosidad mediante un proceso de moldeo por compresión en dos etapas no estaba reportada en bibliografía, y este hecho constituyó un reto para esta investigación.

Como se verá en los sucesivos capítulos de esta tesis, el control del grado de tortuosidad de las espumas de celda abierta es un elemento crítico en las propiedades físicas, variando completamente dependiendo de si la estructura celular del material es poco o muy tortuosa.

Una vez obtenidos los materiales, el siguiente paso se centró en el análisis de las propiedades físicas de los mismos para finalmente poder establecer comparativas con los resultados obtenidos para la espuma de PU de celda abierta usada como referencia. 
Empleando esta metodología, se evaluó si estos nuevos materiales de celda abierta presentaban propiedades similares a las espumas de PU de celda abierta, y si podían ser susceptibles de reemplazar a las espumas flexibles de PU de celda abierta en las aplicaciones de estos materiales tales como confort, absorción de sonido, absorción de aceite o atenuación de vibraciones mecánicas.

Por último, también es importante señalar, que al comienzo de la investigación se evaluó la posibilidad de explorar el entrecruzamiento de la matriz polimérica mediante el empleo de fuentes de alta energía (entrecruzamiento físico) en detrimento del entrecruzamiento químico. El entrecruzamiento físico presenta una serie de ventajas con respecto al entrecruzamiento químico, tales como un control preciso del grado de entrecruzamiento alcanzado o la ausencia de subproductos químicos en la espuma. Esta aproximación supuso la publicación de dos artículos científicos incluidos en el Capítulo 3 de esta tesis. Sin embargo, después de valorar el potencial real de esta alternativa, se decidió optar exclusivamente por la vía del entrecruzamiento químico, ya que a pesar de las ventajas del entrecruzamiento físico, existían limitaciones claras al respecto:

- La precisión y la homogeneidad del grado de entrecruzamiento alcanzado por el entrecruzamiento físico dificultaba la apertura de las celdas, incrementando la complejidad asociada a la obtención de espumas de poliolefina de celda abierta.

- El entrecruzamiento físico no es compatible con el proceso de moldeo por compresión en dos etapas usado en esta tesis. La razón principal es que los precursores sólidos de gran espesor (como las usadas en el proceso de moldeo por compresión en dos etapas) no pueden entrecruzarse de una manera homogénea utilizando entrecruzamiento físico.

\subsection{Novedades}

Este trabajo presenta varias novedades que han contribuido a incrementar el conocimiento en el campo de las espumas de poliolefina entrecruzadas. El hito más importante ha sido la producción de espumas flexibles de celda abierta, baja densidad $\mathrm{y}$ con un grado de tortuosidad controlada utilizando poliolefinas como matriz polimérica (LDPE, EVA, EBA) usando un proceso reproducible.

Además, el análisis de las propiedades físicas y la comparativa de espumas con diferentes contenidos de celda abierta y diferente grado de tortuosidad han permitido incrementar el conocimiento en este campo. Algunas de estas contribuciones, que se relacionan con el objetivo científico de esta tesis, se enuncian a continuación:

- El uso de EBA como matriz polimérica para generar polímeros celulares (no hay trabajos previos en bibliografía).

- Determinar cómo afecta el grado de tortuosidad a las propiedades físicas (propiedades mecánicas, propiedades acústicas, absorción de aceite, estabilidad térmica o atenuación de vibraciones mecánicas) en espumas de poliolefina de 
celda abierta. Estos resultados serían extrapolables a otras espumas de otras composiciones.

Acerca del último punto, se han encontrado resultados interesantes en el estudio de la relación estructura-propiedades de las espumas. Las novedades más importantes relativas a estas caracterizaciones se describen a continuación:

- En lo relativo a las propiedades mecánicas, se ha demostrado que, independientemente de la matriz polimérica, las espumas de celda abierta de alta tortuosidad presentan un interesante doble comportamiento mecánico en función de la velocidad de deformación del ensayo de compresión: se comportan como un material de celda abierta a bajas velocidades de deformación y como espumas de celda cerrada a altas velocidades de deformación. Por tanto, se pueden cubrir aplicaciones de confort y de absorción energía con un único material.

- Aunque la espuma de PU de celda abierta presentó una absorción de sonido excelente, las espumas de celda abierta de baja tortuosidad presentaron mucha mejor absorción acústica que la espuma de PU en el rango de bajas frecuencias (500-2000 Hz). Esto constituye un resultado relevante, si se tiene en cuenta, que muchos de los ruidos producidos por los motores de los vehículos se localizan en este rango de frecuencias.

- Las espumas de celda abierta de baja tortuosidad son capaces de absorber cantidades considerables de aceite (hasta 43 gramos de aceite por gramo de espuma) sin absorber agua. Este resultado se obtuvo sin la necesidad de tratar superficialmente las espumas. Además los materiales pueden ser reutilizados casi en todos los casos (excepto para LDPE) al menos 50 veces. Los materiales desarrollados en esta tesis son las espumas de poliolefina de celda abierta con las absorciones más altas encontradas en la literatura e incluso, estos valores no están tan alejados de las absorciones de varias espumas de PU de celda abierta tratadas superficialmente.

- Es también destacable, la excelente capacidad de las espumas de celda abierta tanto de alta como de baja tortuosidad para atenuar vibraciones mecánicas. Se obtuvieron valores mucho más altos de $\tan \delta$ para las espumas de celda abierta de poliolefina que para la espuma de PU en los ensayos de análisis dinámicomecánico (DMA).

\subsection{Estructura de la tesis}

Esta tesis se ha redactado siguiendo la modalidad de compendio por publicaciones acorde al Real Decreto 99/2011. Se han escrito seis artículos, de los cuales cuatro ya han sido aceptados y publicados y otros dos se encuentran en proceso de aceptación y posterior publicación. Dos de los artículos ya publicados se encuadran en el capítulo 3 del presente documento. Los otros artículos constituyen en sí mismo capítulos completos de esta tesis (capítulos 4, 5, 6 y 7). Además esta tesis cumple los 
requerimientos para ser acreditada con las menciones de "Doctorado Internacional" y “Doctorado Industrial".

Este documento se divide en ocho capítulos, que se describen brevemente a continuación:

- Capítulo 1. Introducción: en esta sección se define brevemente el concepto de polímero celular y su importancia en el campo de la ciencia de materiales. Así mismo, se explican brevemente las motivaciones, objetivos, y novedades de este trabajo. Finalmente, se enuncian todos los resultados surgidos a lo largo de esta investigación (artículos, conferencias, pósters, proyectos y otras actividades).

- Capítulo 2. Estado del arte: se realiza una revisión profunda de los trabajos ya existentes principalmente relativos a polímeros celulares de celda abierta. Mención especial reciben las espumas flexibles de PU de celda abierta, ya que como se ha descrito previamente, un objetivo de este trabajo se basa en la búsqueda de alternativas a estos materiales. Se incluye el estado del arte relativo a la producción de espumas de poliolefina entrecruzadas de baja densidad. Se definen conceptos relativos a la estructura celular, tales como la interconectividad de las celdas o la tortuosidad, claves durante esta investigación. Finalmente, se explicarán en profundidad conceptos relacionados con las propiedades físicas determinadas en esta investigación (propiedades mecánicas, acústicas, absorción de aceite, propiedades termomecánicas, propiedades dinamomecánicas y conductividad térmica), detallando los trabajos previos en estos campos.

- Capítulo 3. Materiales y proceso de fabricación: en este capítulo se describen tanto los materiales como el proceso de fabricación empleados en esta tesis. En la fabricación de los materiales se han empleado cuatro matrices poliméricas distintas: LDPE, EVA con un contenido de acetato de vinilo del 12.5\%, EVA con un contenido de acetato de vinilo del $18.0 \%$ y EBA con un contenido de acrilato de butilo del $17.0 \%$. Para cada matriz polimérica, se han fabricado cuatro tipos de materiales: celda cerrada (CC), celda semiabierta (MO), celda abierta de alta tortuosidad (OC HT) y celda abierta de baja tortuosidad (OC LT), por tanto un total de 16 materiales han sido producidos y caracterizados durante esta tesis. Además, se utilizó una muestra de PU de celda abierta como referencia.

En este capítulo, también se describe cómo se ha caracterizado la estructura celular de las espumas, empleando en algunas caracterizaciones técnicas novedosas como la tomografía de rayos $X$. Además, también se muestran resultados relativos a la morfología de la matriz polimérica, con la determinación del grado de cristalinidad tanto de los polímeros sólidos como de los espumados y con la determinación del punto de fusión de la fase cristalina (todos los polímeros empleados en esta tesis son semicristalinos).

Para las espumas de poliolefina, el entrecruzamiento se ha producido por vía química. Sin embargo, como ya se ha explicado previamente, existe otra alternativa a esta vía química, basada en el empleo de fuentes de alta energía 
(irradiación electrónica) que permite el entrecruzamiento de las cadenas poliméricas. Esta segunda alternativa también se abordó durante esta tesis, analizándose el efecto de la dosis en los mecanismos de espumado de materiales basados en HDPE. Además también se analizó el efecto de la irradiación electrónica en la azodicarbonamida, agente espumante empleado en esta tesis. Estos estudios paralelos generaron dos publicaciones que se incluyen en este capítulo de la tesis.

- Capítulo 4. Propiedades mecánicas: se analizaron las propiedades mecánicas de los dieciséis materiales de esta tesis a altas y bajas velocidades de deformación. El análisis se centró en la determinación de tres parámetros: la presión efectiva de gas en la zona post-colapso, el esfuerzo de colapso y la densidad de energía absorbida. Se abordó el efecto de la interconectividad y de la tortuosidad de la estructura celular en las propiedades. Este capítulo incluye una publicación sobre el efecto de la interconectividad y la tortuosidad de la estructura celular en LDPE y EVA 18. Si bien es cierto que este artículo no contiene resultados sobre EVA 12 y EBA, al final del capítulo se incluye una sección en donde se describen los resultados obtenidos para estos materiales.

- Capítulo 5. Propiedades acústicas: la absorción acústica se caracterizó en un rango de frecuencias desde los 500 hasta los $6400 \mathrm{~Hz}$. Las absorciones fueron comparadas con las obtenidas para la espuma de PU de celda abierta usada como referencia (material con gran absorción acústica), obteniéndose absorciones excelentes para los materiales en base poliolefina de celda abierta de baja tortuosidad. Este estudio dio lugar a la redacción y publicación de una breve comunicación, en donde se detallan los resultados obtenidos para EVA 12 y LDPE. En este capítulo también se incluyen en una sección final los resultados relativos a las absorciones acústicas de EVA 12 y EBA.

- Capítulo 6. Absorción de aceite: en esta sección se presentan los resultados correspondientes a la absorción de aceite de estos materiales. Las excelentes absorciones de aceite de los materiales de baja tortuosidad permitieron escribir un artículo que gira en torno a dos conceptos: la alta absorción de aceite y el papel que desempeña la tortuosidad en la absorción de aceite. Como en anteriores trabajos, el artículo recoge los resultados para LDPE y EVA 18. Este capítulo también incluyó en una sección adicional las absorciones de aceite para los materiales de EVA 12 y EBA.

- Capítulo 7. Propiedades generales: este capítulo muestras los principales resultados obtenidos en la caracterización de espumas de EBA. Es importante indicar, que este es el primer trabajo basado en el espumado de EBA, no existiendo ningún antecedente en bibliografía. Por ello, se decidió realizar una profunda caracterización de estos materiales. Además de las propiedades comentadas anteriormente (respuesta mecánica a bajas y altas velocidades de deformación, absorción acústica y absorción de aceite), la estabilidad térmica y las propiedades viscoelásticas también fueron analizadas. Se redactó un artículo que engloba todas las propiedades medidas. En este capítulo también se incluyen los datos de estabilidad térmica y propiedades viscoelásticas de los 
materiales restantes. Por último, se describirán los resultados relativos a las medidas de conductividad térmica de los materiales.

- Capítulo 8. Conclusiones: en este capítulo se presentan las conclusiones más relevantes de este trabajo. Además, también se incluyen posibles líneas futuras para continuar con esta investigación.

\subsection{Publicaciones, conferencias y actividades complementarias}

Las investigaciones asociadas a esta tesis han originado la redacción y publicación de una serie artículos, que en algunos casos ya se encuentran publicados y en otros están en proceso o bajo revisión. El título, autores, revista y el capítulo de la tesis en el que se encuadra, se exponen en la siguiente tabla:

Analysis of the Foaming Mechanisms of Materials Based on High-Density Polyethylene (HDPE) Crosslinked with Different Irradiation Doses

E. López-González, L.O. Salmazo, A. López-Gil, E. Laguna-Gutiérrez, M.A. Rodríguez-Pérez

Journal of Applied Polymer Science, 135, 46276-46302

Capítulo: 3

Study of the Effect of Different Electron Irradiation Doses on the Decomposition Temperature of Azodicarbonamide

E. López-González, L.O. Salmazo, A. López-Gil, M.A. Rodríguez-Pérez

Polymer Engineering and Science, DOI: 10.1002/pen.25007

Capítulo: 3

Effect of the Gas Phase Tortuosity on the Mechanical Properties of Low-Density Open-Cell Polyolefin Foams at Low and High Strain Rates

E. López-González, S. Muñoz-Pascual, C. Saiz-Arroyo, M.A. Rodríguez-Pérez

Journal of Applied Polymer Science, aceptado

Capítulo: 4

Influence of the Cellular Structure Tortuosity on the Acoustic Absorption of OpenCell Polyolefin Foams

E. López-González, C. Saiz-Arroyo, M.A. Rodríguez-Pérez

Materials Letters, enviado

Capítulo: 5

Flexible Low Density Open-Cell Polyolefin Foams as Efficient Materials for Oil Absorption: Influence of the Tortuosity on Oil Absorption

E. López-González, C. Saiz-Arroyo, M.A. Rodríguez-Pérez

International Journal of Environmental Science and Technology, enviado

Capítulo: 6

Crosslinked Flexible Ethylene Butyl Acrylate Copolymer (EBA) Foams with

Different Cellular Structure Interconnectivity and Tortuosity: Microstructure and Physical Properties

E. López-González, S. Muñoz-Pascual, C. Saiz-Arroyo, M.A. Rodríguez-Pérez

Journal of Applied Polymer Science, DOI: 10.1002/app.48161

Capítulo: 7

Tabla 0.1. Publicaciones asociadas a esta tesis. 
Además, estos trabajos han sido presentados en diferentes congresos nacionales e internacionales. El congreso, el tipo de comunicación, los autores, el conferenciante, la fecha y el lugar de celebración de los mismos se describen en la Tabla 0.2:

Study of the Cellular Structure of LDPE Foams Irradiated at Different Doses

E. López-González, L.O. Salmazo, A. López-Gil, M.A. Rodríguez-Pérez

XII Simposio de Investigadores Jóvenes RSEQ-Sigma Aldrich, Barcelona (España), del 3 al 6 de noviembre de 2015

Pó2640ster

Effect of the Electron Irradiation Dose on the Foaming Behaviour of High-Density Polyethylene (HDPE)

E. López-González, L.O. Salmazo, A. López-Gil, M.A. Rodríguez-Pérez

XIV Reunión del Grupo Especializado de Polímeros (GEP) de la RSEQ y RSEF, Burgos (España), del 5 al 8 de septiembre de 2016

Póster

Open-Cell Flexible Foams with High Tortuosities and a Strain Rate Dependent Mechanical Performance

C. Saiz-Arroyo, E. López-González, S. Muñoz-Pascual, M.A. Rodríguez-Pérez $4^{\text {th }}$ CellMAT 2016 - Cellular Materials, Dresde (Alemania), del 7 al 9 de diciembre de 2016

Presentación oral: C. Saiz-Arroyo

Low-Density Open-Cell Flexible Polyolefin Foams with Tunable Tortuosities: Mechanical Behavior at Low and High Strain Rates

E. López-González, S. Muñoz-Pascual, C. Saiz-Arroyo, M.A. Rodríguez-Pérez

SPE FOAMS 2017. 15th International Conference on Advances in Foam Materials and Technology, Bayreuth (Alemania), del 9 al 12 de octubre de 2017

Póster

Crosslinked Open-Cell Low-Density Flexible Foams as Highly Efficient Materials for Oil Absorption

E. López-González, C. Saiz-Arroyo, M.A. Rodríguez-Pérez

SPE FOAMS 2017. 15 th International Conference on Advances in Foam Materials and Technology, Bayreuth (Alemania), del 9 al 12 de octubre de 2017

Presentación oral: E. López-González

Multifunctional Open-Cell Flexible Foams: From Comfort and Impact Protection to High Oil Absorption Capacity in One Single Material

E. López-González, C. Saiz-Arroyo, S. Muñoz-Pascual, M.A. Rodríguez-Pérez Polymer Foam 2017, Colonia (Alemania), del 28 al 29 de noviembre de 2017 Presentación oral: C. Saiz-Arroyo 
Crosslinked Open-Cell Ethylene Butyl Acrylate Copolymer (EBA) Foams: Properties and Applications

E. López-González, S. Muñoz-Pascual, C. Saiz-Arroyo, M.A. Rodríguez-Pérez

$5^{\text {th }}$ CellMAT 2018 - Cellular Materials, Bad Staffelstein (Alemania), del 24 al 26 de octubre de 2018, Premio al major póster

Póster

Crosslinked Open-Cell Flexible Polyolefin Foams with Different Cellular Structure Tortuosity: Properties and Applications

E. López-González, S. Muñoz-Pascual, C. Saiz-Arroyo, M.A. Rodríguez-Pérez

$5^{\text {th }}$ CellMAT 2018 - Cellular Materials, Bad Staffelstein (Alemania), del 24 al 26 de octubre de 2018

Presentación oral: E. Lopez-Gonzalez

Tabla 0.2. Conferencias, posters y contribuciones en congresos nacionales e internacionales.

La participación en otros trabajos científicos educacionales, cursos y actividades complementarios se incluyen en las Tablas $0.3,0.4,0.5$ y $\mathbf{0 . 6}$ :

\section{Anisotropic Polypropylene Cellular Polymers Filled with Nanoclays: \\ Microstructure and Properties}

A. López-Gil, M. Benanti, E. López-González, J.L. Ruiz-Herrero, L. Oliveira, F. Briatico, M.A. Rodríguez-Pérez

Polymer Composites, DOI: 10.1002/ pc.24858

Effect of the Mold Temperature on the Impact Behavior and Morphology of

Injection Molded Foams Based on Polypropylene Polyethylene-Octene Copolymer Blends

S. Muñoz-Pascual, E. López-González, C. Saiz-Arroyo, M.A. Rodríguez-Pérez

Polymers, DOI: $10.3390 /$ polym11050894

Tabla 0.3. Contribución en otros trabajos científicos

Evolution of the Practical Training in Materials Physics: from a Constrained

Research in the Polymer Science Field to a Multidisciplinary Methodology

E. López-González, S. Muñoz-Pascual, V. Bernardo, E. Laguna-Gutiérrez, J.M. de León, S. Pérez-Tamarit, J. Pinto, M.A. Rodríguez-Pérez

EDULEARN 2018. 10 th Annual International Conference on Education and New Learning Technologies, Palma de Mallorca (España), del 2 al 4 de julio de 2018

Transferring Knowledge from the University to the Industry: Internships at the University of Valladolid

S. Pérez-Tamarit, J.M. de León, V. Bernardo, E. López-González, S. Muñoz-Pascual, J. Pinto, E. Laguna-Gutiérrez, M.A. Rodríguez-Pérez

EDULEARN 2018. 10 $0^{\text {th }}$ Annual International Conference on Education and New Learning Technologies, Palma de Mallorca (España), del 2 al 4 de julio de 2018

Development of a Postgraduate Training Program on Surface Functionalization of Polymers/Polymers Foams

S. Barroso-Solares, B. Merillas, E. López-González, M.A. Rodríguez-Pérez, J. Pinto EDULEARN 2018. 10th Annual International Conference on Education and New Learning Technologies, Palma de Mallorca (España), del 2 al 4 de julio de 2018

Tabla 0.4. Contribución a congresos educacionales. 
37th Berlin School on Neutron Scattering

Curso. Berlín (Alemania), del 2 al 10 de marzo de 2017

Tabla 0.5. Asistencia a cursos.

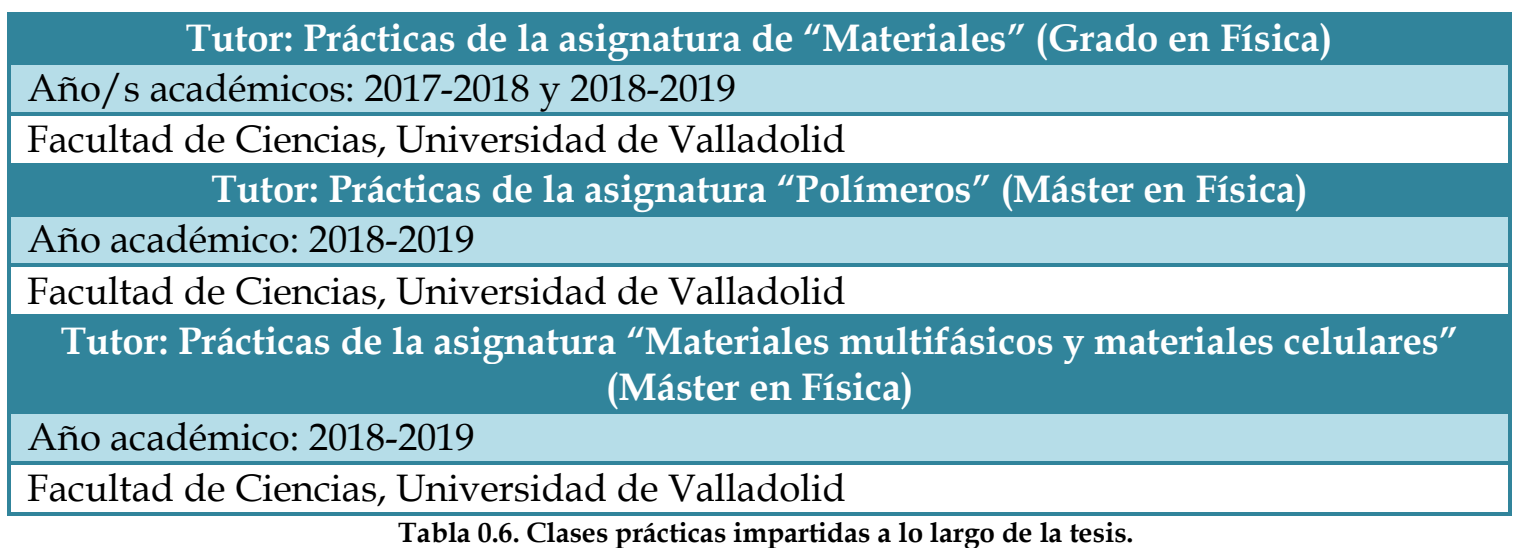

Finalmente, la participación en diferentes proyectos de investigación se incluye en la Tabla 0.7:

Proyecto: "Desarrollo de polímeros nanocelulares avanzados"

Financiado por: CellMat Technologies S.L.

Duración: Enero 2015- Diciembre 2016

Investigador principal: Miguel Ángel Rodríguez Pérez

Proyecto: " Desarrollo de materiales celulares ligeros y resistentes mediante el control de la composición química y estructura celular: material micro y nanocelulares"

Financiado por: CellMat Technologies S.L.

Duración: Diciembre 2013- Diciembre 2015

Investigador principal: Miguel Ángel Rodríguez Pérez

Proyecto: "Desarrollo de nuevos materiales celulares"

Financiado por: CellMat Technologies S.L.

Duración: Junio 2013- Diciembre 2015

Investigador principal: Miguel Ángel Rodríguez Pérez

Proyecto: "Desarrollo y optimización de materiales celulares de elevada resistencia al impacto"

Financiado por: CellMat Technologies S.L.

Duración: Diciembre 2016- Diciembre 2018

Investigador principal: Miguel Ángel Rodríguez Pérez

Proyecto: "Desarrollo y optimización de materiales celulares de celda abierta para aplicaciones de confort y de absorción de líquidos"

Financiado por: CellMat Technologies S.L.

Duration: Diciembre 2016- Diciembre 2019

Investigador principal: Miguel Ángel Rodríguez Pérez

Proyecto: "Desarrollo de estrategias para fabricar polímeros nanocelulares en procesos industriales: extrusión y perlitas expandidas"

Financiado por: CellMat Technologies S.L.

Duration: Diciembre 2015- Diciembre 2018

Investigador principal: Miguel Ángel Rodríguez Pérez Tabla 0.7. Participaciones en proyectos. 


\subsection{Principales resultados y conclusiones}

Para concluir, en esta sección se describen los principales resultados y conclusiones derivados de la presente investigación.

A la hora de enunciar los principales resultados y las conclusiones de esta tesis, se han tenido en cuenta dos efectos:

1) Aquellas conclusiones que se pueden extraer del desarrollo de los materiales y de la caracterización de la estructura celular.

2) Los resultados obtenidos de la caracterización de las propiedades físicas de las espumas.

Inicialmente, se van a exponer los principales resultados obtenidos del análisis relativo al primer punto.

\section{1) Producción y estructura celular de las espumas de poliolefina de celda abierta}

Espumas en base poliolefina con diferente grado de interconectividad y diferente grado de tortuosidad se han fabricado usando el proceso de moldeo por compresión en dos etapas. Esta tecnología es común a nivel industrial en la fabricación de espumas de poliolefina de celda cerrada. Sin embargo, este proceso solamente es empleado por una compañía a nivel mundial para producir espumas de celda abierta. No obstante, es necesario un proceso adicional de ruptura de las celdas mediante deformación de las mismas para generar estos materiales.

El laboratorio CellMat y CellMat Technologies S.L. desarrollaron en el año 2015 una metodología para producir espumas de poliolefina de celda abierta sin necesidad de recurrir a procesos adicionales de ruptura de las celdas. Sin embargo, estos prototipos iniciales no eran homogéneos debido a la presencia de defectos internos. El grado de tortuosidad de estos materiales estaba en un rango muy alejado del que muestran las espumas flexibles de PU de celda abierta. Además, se empleo únicamente LDPE como matriz polimérica en la fabricación de los materiales.

Teniendo en cuenta el fondo científico de esta tesis, las principales conclusiones extraídas durante la producción y desarrollo de las espumas de poliolefina de celda abierta se resumen a continuación:

- Se optimizó el proceso de fabricación con el objetivo de producir espumas de celda abierta de alta y de baja tortuosidad sin la presencia de defectos internos, utilizando cuatro tipos de matrices poliméricas (LDPE, EVA 12, EVA 18 y EBA).

- Se fabricaron materiales de celda cerrada (menor de un contenido de 50\% de celda abierta), materiales de celda semiabierta (alrededor de un contenido de $65 \%$ de celda abierta) y dos tipos de espumas de celda abierta (contenidos de celda abierta superiores al 95\%; alta y baja tortuosidad) empleando las cuatro matrices poliméricas mencionadas previamente. 
- El tipo de interconectividad de la estructura celular de las espumas de poliolefina de celda abierta es totalmente diferente a la estructura presentada por las espumas flexibles de PU de celda abierta. Las celdas en las espumas de PU están formadas únicamente por aristas, mientras que la interconectividad en las espumas de poliolefina de celda abierta se produce por la presencia de agujeros en las paredes celulares.

- El grado de tortuosidad de las espumas de poliolefina de celda abierta viene dado por el tamaño y el número de agujeros existentes en las paredes. Las espumas de celda abierta de alta tortuosidad (valor aproximado de tortuosidad de 4.0) presentan un número reducido de agujeros, siendo estos pequeños. En cambio, las espumas de celda abierta de baja tortuosidad (valor aproximado de tortuosidad de 2.0) se caracterizan por tener un número considerable de agujeros de gran tamaño.

- Se estimó la cristalinidad de los polímeros sólidos y de las correspondientes espumas. En lo relativo a los polímeros sólidos, el orden de los mismos en función de su cristalinidad es el siguiente:

\section{LDPE $(46 \%)>\operatorname{EBA}(31 \%)>$ EVA $12(30 \%)>$ EVA $18(17 \%)$}

La cristalinidad del polímero espumado se reduce respecto al sólido de partida independientemente del tipo de interconectividad de la estructura celular. A continuación, se muestra la cristalinidad obtenida en materiales de celda cerrada:

\section{LDPE CC (35\%) > EBA CC $(22 \%)>$ EVA 12 CC $(20 \%)>$ EVA 18 CC $(16 \%)$}

La reducción en cristalinidad en espumas se puede explicar teniendo en cuenta estos dos efectos:

1) Para la fabricación de la espumas los polímeros se entrecruzaron. Este proceso de unión de cadenas dificulta una cristalización ordenada.

2) En espumas, el polímero tiene que cristalizar en las paredes, siendo este espacio muy restringido.

No se ha hallado ninguna tendencia que relacione la cristalinidad con la interconectividad o la tortuosidad de la estructura celular.

- Respecto al proceso de entrecruzamiento, se exploró el uso de fuentes de alta energía para entrecruzar la matriz polimérica. Este estudio se llevó a cabo usando polietileno de alta densidad (HDPE) como matriz polimérica. Se encontró que eran necesarias altas dosis de irradiación para obtener espumas homogéneas con tamaños de celda pequeños. Sin embargo, esta alternativa no se consideró en la producción de las espumas desarrolladas en esta tesis.

- Además, se investigó también el efecto de la irradiación en la azodicarbonamida en polvo (agente espumante empleado en esta tesis). Se 
observó que la interacción de la radiación con el polvo modificaba la estructura cristalina de las partículas de azodicarbonamida, reduciéndose la distancia interplanar. Esta reducción de la distancia interplanar conllevaba una reducción de la temperatura de descomposición de la azodicarbonamida en función de la dosis de irradiación empleada (desde $216{ }^{\circ} \mathrm{C}$ para la azodicarbonamida no irradiada hasta los $210^{\circ} \mathrm{C}$ para la azodicarbonamida irradiada con una dosis de 150 kGy).

Llegados a este punto, se puede concluir que se han desarrollado nuevas espumas de poliolefina de celda abierta de baja tortuosidad. A primera vista, estas espumas parecían ser más similares a las espumas flexibles de PU de celda abierta que los prototipos iniciales desarrollados antes de iniciarse esta tesis. Por este motivo, resultó obligatorio caracterizar algunas propiedades físicas de estas series de espumas con diferente interconectividad y tortuosidad y de una espuma flexible de PU de celda abierta empleada para asientos en el sector de la automoción, con el objetivo de establecer analogías y diferencias entre ellos. A continuación, se exponen las principales conclusiones obtenidas de la caracterización física de los materiales.

\section{2) Propiedades físicas}

Las propiedades mecánicas, acústicas y viscoelásticas, la absorción de aceite, la estabilidad térmica y la conductividad térmica de las espumas han sido caracterizadas a lo largo de esta tesis. En las siguientes secciones se enuncian los principales resultados y conclusiones derivados de la caracterización de cada propiedad. Es importante señalar que la espuma flexible de PU de celda abierta de referencia se ha caracterizado de manera similar a las espumas de poliolefina, estableciéndose comparativas necesarias para definir el objetivo técnico de la tesis. A continuación, se exponen los principales resultados y conclusiones para las distintas propiedades.

\section{1) Propiedades mecánicas}

Las propiedades mecánicas de los materiales bajo estudio se han caracterizado tanto a bajas como a altas velocidades de deformación. Se han medido tres parámetros: la presión de gas efectiva (región post-colapso), el esfuerzo de colapso y la densidad de energía absorbida (área bajo la curva del ciclo de carga completo). Se han tenido en cuenta tres efectos a la hora de explicar los resultados: el efecto de la interconectividad, el efecto de la tortuosidad y el efecto de la matriz polimérica.

\section{Efecto de la interconectividad de la estructura celular: celda cerrada frente celda abierta}

Se pueden extraer varias conclusiones de la caracterización de las propiedades mecánicas dependiendo de la interconectividad de la estructura celular:

- Se observó el efecto esperado tanto a bajas como a altas velocidades de deformación: la contribución de gas en la zona post-colapso crecía a medida que disminuía la interconectividad. Se obtuvieron contribuciones de alrededor de un $70 \%$ para espumas de celda cerrada tanto a bajas como a altas 
velocidades deformación, mientras que para celda abierta estas contribuciones fueron mucho menores a bajas velocidades de deformación (menores del 5\% a bajas velocidades de deformación). A altas velocidades de deformación, la contribución del gas depende considerablemente de la tortuosidad.

- Las espumas de celda cerrada presentaban mayores valores del esfuerzo de colapso que las espumas de celda abierta. En el caso de las espumas de EBA, en los ensayos a bajas velocidades de deformación, el esfuerzo de colapso de la espuma de celda cerrada fue 13.24 veces mayor que el obtenido para la espuma de celda abierta de baja tortuosidad. A altas velocidades de deformación, se obtuvieron esfuerzos de colapso 4.03 veces mayor para la espuma de LDPE de celda cerrada respecto a la de celda abierta de baja tortuosidad.

- Las espumas de celda cerrada fueron capaces de absorber más energía que las espumas de celda abierta. La comparativa de los materiales de celda cerrada y de los de celda abierta de baja tortuosidad muestra una diferencia considerable en las energías absorbidas (hasta 18.57 veces mayor en el caso de LDPE a bajas velocidades de deformación y hasta 6.32 para EBA a altas velocidades de deformación).

Por tanto, como era esperable, el grado de interconectividad de la estructura celular tiene una contribución relevante en las propiedades mecánicas.

\section{Efecto de la tortuosidad de la estructura celular: alta tortuosidad frente baja tortuosidad}

El efecto de la interconectividad en las propiedades mecánicas ha sido ampliamente estudiado y publicado. Sin embargo, el efecto de la tortuosidad no se había analizado previamente, y este estudio ha permitido obtener una serie de conclusiones válidas no solamente para espumas de poliolefina de celda abierta, sino que también es válido para otros materiales de celda abierta.

- El efecto de la tortuosidad a bajas velocidades de deformación es despreciable, mostrando las espumas de poliolefina de celda abierta de baja y de alta tortuosidad un comportamiento similar al de PU de referencia.

- El efecto despreciable de la tortuosidad a bajas velocidades de deformación se confirmó en las estimaciones de las energías absorbidas. Las absorciones de energía de ambas espumas de celda abierta fueron muy bajas (menores de 0.80 $\mathrm{J} / \mathrm{cm}^{3}$ ) y similares a las de la espuma de PU de referencia.

- Sin embargo, a altas velocidades de deformación, la tortuosidad es un parámetro crítico en la respuesta mecánica. Por un lado, la contribución de gas en las espumas de celda abierta y de alta tortuosidad se incrementó considerablemente, siendo las mismas muy similares a las contribuciones de gas en las espumas de celda cerrada. Por otro lado, la contribución de gas en las espumas de celda abierta de baja tortuosidad sólo se incrementó ligeramente, como en el caso de la espuma de PU. 
- Este efecto se confirmó en las estimaciones de las energías absorbidas. Las espumas de celda abierta de alta tortuosidad absorbían 26.14 veces más energía a altas velocidades de deformación respecto a bajas velocidades (para EVA 18).

- Considerando la velocidad del ensayo y las dimensiones de las muestras usadas, se realizó una estimación sencilla de la cantidad de gas que permanece dentro de la espuma durante el ensayo obteniéndose que un $70 \%$ del gas permanecía dentro de la espuma de celda abierta de alta tortuosidad durante el ensayo a altas velocidades de deformación. Este resultado se explica teniendo en cuenta la velocidad del ensayo. A bajas velocidades de deformación, el gas tiene tiempo suficiente para salir de la muestra independientemente de la tortuosidad. Sin embargo, a altas velocidades de deformación, el tiempo disponible para que el gas abandone la muestra se reduce considerablemente, y por tanto el gas no puede escapar a través de los pequeños agujeros de las espumas de alta tortuosidad.

- Por tanto, las espumas de celda abierta de alta tortuosidad presentan un doble comportamiento mecánico en función de la velocidad de deformación, incrementado la versatilidad y la aplicabilidad del material: aplicaciones de confort a bajas velocidades de deformación y para embalaje o protección a altas velocidades de deformación.

El efecto de la tortuosidad es crucial para explicar los resultados obtenidos para las espumas de poliolefina de celda abierta. Se ha encontrado una respuesta mecánica distinta dependiendo de este parámetro y de la velocidad de deformación.

\section{Efecto de la matriz polimérica}

Cuatro matrices poliméricas con diferentes propiedades (grado de cristalinidad, punto de fusión, etc...) se han usado en esta tesis. Por tanto, es importante determinar su efecto en las propiedades mecánicas. Además, una espuma flexible de PU de celda abierta se ha empleado como referencia. Los principales resultados y conclusiones se exponen a continuación:

- Se ha determinado un efecto de la matriz polimérica en las propiedades mecánicas en las espumas de celda cerrada. Sin embargo, no se han encontrado tendencias para el resto de materiales de la serie, cuyas propiedades dependen fundamentalmente del contenido de celda abierta y de la tortuosidad.

- Para materiales de celda cerrada, se ha encontrado una relación entre la cristalinidad de la matriz polimérica y el esfuerzo de colapso y de la densidad de energía absorbida. A medida que disminuye la cristalinidad los parámetros mecánicos se reducen:

\section{Propiedades mecánicas: LDPE CC > EBA CC > EVA 12 CC > EVA 18 CC}


A modo de ejemplo, el esfuerzo de colapso de la espuma de LDPE de celda cerrada era 3.89 veces mayor que el obtenido para la espuma de EVA 18 de celda cerrada y la densidad de energía absorbida 1.62 veces mayor.

- Con respecto al PU, se puede concluir que a bajas velocidades de deformación las espumas de poliolefina de celda abierta de alta y baja tortuosidad presentaban un comportamiento similar a esta espuma. Sin embargo, a altas velocidades de deformación, únicamente las espumas de celda abierta de baja tortuosidad presentaron una respuesta mecánica similar a la de la espuma de PU de referencia.

\section{2) Propiedades acústicas}

Las espumas de celda abierta de PU son utilizadas en aplicaciones en donde se requiere una alta absorción de sonido gracias a la excelente atenuación de las ondas sonoras en estas espumas. Sin embargo, sus prestaciones empeoran en el rango de bajas frecuencias (por debajo de $2000 \mathrm{~Hz}$ ).

La absorción acústica fue medida para las espumas de polilefina y la referencia de PU. Los resultados y las conclusiones obtenidas de esta caracterización se describen a continuación aislando los tres efectos previamente discutidos:

\section{Efecto de la interconectividad de la estructura celular: celda cerrada frente celda abierta}

- La absorción acústica depende críticamente de la interconectividad de la estructura celular. La absorción acústica de las espumas de celda abierta es considerablemente superior que las de celda cerrada.

- Los valores normalizados del coeficiente de absorción acústica para las espumas de celda cerrada no superaron valores de 0.25 , mientras que los valores para las espumas de celda abierta de baja tortuosidad se situaron por encima de 0.65 .

- Este resultado está de acuerdo con estudios previos y con la teoría, que indica que los materiales más adecuados para esta aplicación son aquellos cuya estructura celular se encuentra altamente interconectada.

Efecto de la tortuosidad de la estructura celular: alta tortuosidad frente baja tortuosidad

- La tortuosidad influye en la absorción acústica de las espumas, mostrando las espumas de baja tortuosidad absorciones acústicas superiores a las espumas de celda abierta de alta tortuosidad. Se obtuvieron mejoras de hasta el $80 \%$ (comparativa en espumas de EBA) en el rango completo de medida (desde 500 hasta $6400 \mathrm{~Hz}$ ) cuando se comparan materiales de celda abierta de alta y de baja tortuosidad.

- Las espumas de celda abierta de alta tortuosidad no se pueden considerar como materiales prometedores para esta aplicación, ya que sus coeficientes de absorción normalizados se encontraban en un rango desde 0.35 hasta 0.50 , muy 
alejados de los valores obtenidos para la espuma de PU de celda abierta de referencia (0.73).

- Los coeficientes de absorción normalizados para las espumas de celda abierta de baja tortuosidad son ligeramente inferiores que el valor obtenido para la espuma referencia de PU en el rango completo de medida. Estas diferencias en el valor del coeficiente son de 0.05 lejos de ser relevantes. Incluso, la espuma de EBA de celda abierta de baja tortuosidad presentó un valor del coeficiente (0.74) de absorción normalizado por encima de 0.73 (PU de referencia). Sin embargo, es importante indicar que esta espuma de PU se emplea en asientos de automoción no para absorción acústica.

Efecto de la matriz polimérica

- No se encontraron diferencias notorias en función de la matriz polimérica. Como los mecanismos envueltos en la atenuación de las ondas sonoras se relacionan más con la estructura celular que con la matriz polimérica, no se esperaban diferencias considerables en los valores normalizados del coeficiente de absorción acústica entre materiales con interconectividades y tortuosidades similares.

- Debido a las bajas prestaciones de las espumas de celda abierta de PU a bajas frecuencias, se estimó la absorción acústica en un rango de 500 a 2000 Hz con el objetivo de determinar si las espumas de celda abierta en base poliolefina mejoraban los resultados presentados por la espuma de PU.

- Las espumas de poliolefina de celda abierta de alta y de baja tortuosidad mejoraron las absorciones acústicas obtenidas para PU debido a la aparición de máximos de absorción por debajo de $2000 \mathrm{~Hz}$.

- Es remarcable el hecho de que los valores normalizados del coeficiente de absorción acústica de las espumas de poliolefina celda abierta de baja tortuosidad (0.68), fueron dos veces mejor que el valor de la espuma de PU (0.34).

- Este gran resultado amplía la aplicabilidad de las espumas de poliolefina de celda abierta de baja tortuosidad ya que estos materiales presentan altas absorciones acústicas por debajo de $2000 \mathrm{~Hz}$.

\section{3) Absorción de aceite}

Las propiedades anteriormente descritas están enfocadas a mejorar y a facilitar nuestro día de día. Sin embargo, es también esencial cubrir propiedades que permitan preservar el medio ambiente.

La naturaleza apolar de las poliolefinas puede convertirse en una solución en la reducción del impacto ecológico de los vertidos de aceite en el ecosistema. En consecuencia, se ha caracterizado la absorción de aceite de las espumas desarrolladas en esta tesis. Además, se tiene que tener en cuenta el hecho de que los materiales a emplear en esta aplicación deben mostrar una alta selectividad agua-aceite, 
caracterizándose por tanto la hidrofobicidad de los materiales. Finalmente, la reusabilidad de los materiales fue analizada, ya que estos materiales deben poder reutilizarse un número elevado de veces.

Algunos de los resultados y de las conclusiones se exponen a continuación:

Efecto de la interconectividad de la estructura celular: celda cerrada frente celda abierta

- La interconectividad de la estructura celular juega un papel clave en esta propiedad. Son necesarios materiales con una alta interconectividad de la estructura celular para absorber cantidades importantes de aceite.

- La absorción de aceite en función de la interconectividad se clasifica de la siguiente manera:

espumas de celda abierta > espumas de celda semiabierta > espumas de celda cerrada

- Diferencias considerables en la cantidad de aceite absorbido se obtuvieron cuando los materiales de celda cerrada se comparan con los materiales de celda abierta de baja tortuosidad. Por ejemplo, la espuma de LDPE de celda abierta de baja tortuosidad fue capaz de absorber hasta 7 veces más gramos de aceite que la espuma de LDPE de celda cerrada.

\section{Efecto de la tortuosidad de la estructura celular: alta tortuosidad frente baja tortuosidad}

- Al igual que en las propiedades mecánicas y acústicas, la tortuosidad también tiene una gran influencia en los resultados obtenidos. Las absorciones de aceite de las espumas de celda abierta de baja tortuosidad fueron 3.26 mayores que las de alta tortuosidad para EVA 18 o 4.13 en el caso del EBA.

- Se obtuvieron altas absorciones de aceite (incluso mayores de 40 gramos de aceite por gramo de espuma) para las espumas de baja tortuosidad.

- Para aislar el efecto de la densidad de la espuma, se estimó la eficiencia en la absorción de aceite. Los materiales de baja tortuosidad presentaron valores de eficiencia por encima del $60 \%$ e incluso de hasta el 90\%. La eficiencia para la espuma de PU también fue alta (alrededor de un 80\%), confirmando que la alta densidad de esta espuma limitaba la absorción de aceite (menores absorciones que las espumas de celda abierta de baja tortuosidad).

- Las espumas de poliolefina pueden considerarse hidrofóbicas, ya que las absorciones de agua fueron menores de 1 gramo de agua por gramo de espuma. Esto constituye una gran ventaja respecto al PU, cuyas absorciones de agua fueron mayores.

- A pesar de utilizar tres tipos diferentes de aceites (aceite de girasol, aceite de motor $15 \mathrm{~W} 40$ y aceite de motor 80W90), no se pudo aislar el efecto de la viscosidad del aceite en la absorción debido a la baja homogeneidad de la estructura celular de las espumas y a la metodología empleada en esta caracterización. El gran tamaño de muchas de las celdas y el alto contenido en celda abierta limitaron la medida, ya que se emplearon muestras de 
dimensiones reducidas. En el hipotético caso de partir de materiales con estructuras celulares similares, debería observarse como los aceites menos viscosos son absorbidos más fácilmente que los más viscosos por el efecto asociado a la capilaridad.

- La reusabilidad de las espumas de celda abierta de baja tortuosidad se analizó mediante dos vías: 1) ensayos de compresión a bajas velocidades de deformación y 2) varios ciclos de reabsorción. Ambas metodologías simulan la recogida y la eliminación del aceite de la estructura celular. Este estudio nos permite afirmar que las espumas de baja tortuosidad pueden utilizarse al menos 50 veces, excepto en el caso del LDPE, en donde la espuma colapsaba debido a la alta rigidez de la matriz polimérica en comparación con el EVA o el EBA.

\section{Efecto de la matriz polimérica}

- El efecto de la matriz polimérica en la absorción de aceite no ha podido ser analizado debido a las razones expuestas previamente para explicar por qué no se pudo analizar el efecto de la viscosidad del aceite. En el hipotético caso de partir de materiales con una estructura celular similar, la absorción de aceite variaría en función de la matriz polimérica de la siguiente manera:

\section{espumas de LDPE > espumas de EBA > espumas de EVA $12>$ espumas de}

\section{EVA 18}

Este orden se relaciona con la polaridad de las cadenas poliméricas. LDPE es un polímero apolar y por tanto su absorción debería ser la máxima de la serie, seguido del EBA y el EVA 12. El alto contenido en acetato de vinilo del EVA 18 incrementa considerablemente la polaridad del mismo, disminuyendo su afinidad por el aceite. En agua, debería observarse por tanto la tendencia opuesta.

- Centrando los resultados en torno a la espuma de PU, se ha observado que las espumas de poliolefina de celda abierta de baja tortuosidad presentaban absorciones superiores a la espuma de PU. Sin embargo, es necesario indicar que existen ejemplos en bibliografía de estudios basados en espumas de PU de celda abierta con mejores absorciones que las presentadas por las espumas de poliolefina de celda abierta de baja tortuosidad, aunque si bien es cierto que es necesario llevar a cabo un tratamiento superficial para mejorar la hidrofobicidad de las mismas.

- Se puede concluir que, las espumas de EVA 18 y EBA de celda abierta de baja tortuosidad pueden considerarse como alternativas tanto a las espumas de PU, como a los métodos actualmente empleados en la limpieza de vertidos. 


\section{4) Propiedades viscoelásticas, estabilidad térmica y conductividad térmica}

Como se ha visto en las secciones previas, las espumas de poliolefina de celda abierta de alta y de baja tortuosidad presentan propiedades muy interesantes que les convierten en materiales prometedores para ciertas aplicaciones tales como confort, absorción de energía en ensayos de impacto, absorción acústica o absorción de aceite.

No obstante, se creyó conveniente extender la caracterización física de estos materiales. Tres propiedades adicionales fueron analizadas para las espumas producidas en esta tesis: propiedades viscoelásticas, estabilidad térmica de los materiales y la conductividad térmica de los mismos.

A continuación, se presentan los resultados y conclusiones más importantes de estos estudios siguiendo el patrón empleado previamente en la discusión de las conclusiones relativas a otras propiedades físicas.

Efecto de la interconectividad de la estructura celular: celda cerrada frente celda abierta

- En los ensayos dinámico-mecánicos (DMA), se ha observado que el módulo del módulo complejo $\left(\mathrm{E}^{*}\right)$ de las espumas de celda cerrada era más alto que los módulos correspondientes a espumas de celda abierta.

- La tangente de pérdidas ( $\tan \delta$ ) era más alta para las espumas de celda abierta. Valores de $\tan \delta$ hasta de 6.40 veces superiores para EBA y hasta de 6.90 para LDPE se observaron cuando las espumas de celda cerrada se comparan con las espumas de celda abierta de baja tortuosidad. El mecanismo detrás de este resultado se relaciona con la posibilidad de movimiento del aire a través de la estructura celular de las espumas de celda abierta durante el ciclo mecánico, mientras que ese movimiento se restringe en espumas de celda cerrada ya que el gas se encuentra ocluido en las celdas.

- En lo relativo a la estabilidad térmica, las espumas de celda cerrada mostraron los mejores resultados de estabilidad térmica independientemente del tipo de matriz polimérica. La estabilidad térmica puede relacionarse con la interconectividad de acuerdo a la siguiente clasificación:

\section{espumas de celda cerrada > espumas de celda semiabierta > espumas de celda abierta}

- Diferencias de temperatura de $15{ }^{\circ} \mathrm{C}$ para EBA, $30{ }^{\circ} \mathrm{C}$ para EVA y hasta $67^{\circ} \mathrm{C}$ para LDPE se encontraron cuando las espumas de celda cerrada se comparan con las espumas de celda abierta de baja tortuosidad.

- Además, se analizó el efecto de este parámetro en la conductividad térmica, observándose que los valores más bajos de conductividad térmica se correspondían con los presentados por las espumas de celda cerrada. La conductividad térmica aumentaba a medida que también aumentaba la interconectividad de la estructura celular: 


\section{$\lambda$ (espumas de celda cerrada) $<\lambda$ (espumas de celda semiabierta) $\approx \lambda$ (espumas de celda abierta de alta tortuosidad) $<\lambda$ (espumas de celda abierta de baja tortuosidad)}

La diferencia de los valores de conductividad térmica entre las espumas de celda cerrada y las espumas de celda abierta de baja tortuosidad alcanzaron valores de hasta $7 \mathrm{~mW} / \mathrm{m} \cdot \mathrm{K}$ a $20{ }^{\circ} \mathrm{C}$ para LDPE y EBA y de hasta $8 \mathrm{~mW} / \mathrm{m} \cdot \mathrm{K}$ a la misma temperatura para EVA 12 y EVA 18.

Efecto de la tortuosidad de la estructura celular: alta tortuosidad frente baja tortuosidad

- Diferencias despreciables en el módulo complejo se obtuvieron para las espumas de celda abierta de alta y baja tortuosidad.

- Ambos tipos de materiales de celda abierta mostraron valores altos de $\tan \delta$ medidos a $0{ }^{\circ} \mathrm{C}$, y por lo tanto estas espumas son capaces de atenuar eficientemente las vibraciones mecánicas debido al mecanismo relativo al movimiento del gas ya previamente discutido.

- La combinación de alta absorción acústica y alta atenuación de vibraciones mecánicas convierten a las espumas de celda abierta de baja tortuosidad en materiales prometedores para ser usados en sectores tales como el de la automoción o y el aeronáutico.

- La limitación crítica de las espumas de poliolefina de celda abierta es su pobre estabilidad térmica. Las espumas de celda abierta de alta tortuosidad fueron capaces de soportar temperaturas superiores (desde 51 hasta los $90{ }^{\circ} \mathrm{C}$ ) que las soportadas por las espumas de celda abierta de baja tortuosidad (desde 34 hasta $\left.70^{\circ} \mathrm{C}\right)$.

- La pobre estabilidad térmica de los materiales podría ser una restricción severa para las aplicaciones industriales analizadas en esta tesis.

- En lo relativo a la conductividad térmica, las espumas de celda abierta de alta tortuosidad presentaron valores más bajos de conductividad que las espumas de baja tortuosidad.

- Los valores de conductividad térmica de las espumas de celda abierta de alta tortuosidad oscilaron en un rango de entre 37.20 a $39.40 \mathrm{~mW} / \mathrm{m} \cdot \mathrm{K}$ a $20{ }^{\circ} \mathrm{C}$, mientras que los valores para las espumas de celda abierta de baja tortuosidad se situaron en valores en torno a 44.50 a $45.40 \mathrm{~mW} / \mathrm{m} \cdot \mathrm{K}$ a la misma temperatura.

Efecto de la matriz polimérica

- Se observó el efecto de la matriz polimérica en las propiedades viscoelásticas de las espumas de celda cerrada. Sin embargo, no se encontraron tendencias para espumas de celda abierta. Para estos materiales, los parámetros de los que dependen las propiedades viscoelásticas son el contenido de celda abierta y la tortuosidad de la estructura celular. 
- Para espumas de celda cerrada, la espuma de LDPE mostró el valor más alto de módulo complejo medido a una temperatura de $0{ }^{\circ} \mathrm{C}$, mientras que la espuma de EVA 18 presentó el valor más bajo del mismo (7 veces superior para LDPE respecto a EVA 18). Este resultado se debe al mayor grado cristalinidad del LDPE respecto a los restantes polímeros empleados en este estudio.

- Respecto a la espuma de PU, el módulo complejo de este material medido a 0 ${ }^{\circ} \mathrm{C}$ fue superior a los valores de módulo de las espumas de poliolefina de celda abierta de baja tortuosidad (1.54 veces superior) debido a su mayor densidad.

- La tangente de pérdidas de la espuma de PU a $0{ }^{\circ} \mathrm{C}$ fue inferior a los valores mostrados por las espumas de poliolefina de celda abierta (independientemente del grado de tortuosidad), indicando que las espumas de poliolefina de celda abierta presentaban una mejor respuesta a la atenuación de las vibraciones mecánicas.

- Siguiendo con la estabilidad térmica, se ha observado es espumas de celda cerrada como este parámetro depende del tipo de matriz polimérica debido al diferente punto de fusión de cada material. La espuma de celda cerrada de LDPE presentó la mejor estabilidad térmica llegando a soportar temperaturas de hasta $101^{\circ} \mathrm{C}$, mientras que la espuma de celda cerrada de EVA 18 comenzó a colapsar a temperaturas inferiores $\left(79^{\circ} \mathrm{C}\right)$. Además, se ha podido comprobar el efecto del contenido de acetato de vinilo en la estabilidad térmica, soportando la espuma de EVA 12 (menor contenido de acetato de vinilo) temperaturas superiores $\left(85^{\circ} \mathrm{C}\right)$ que el EVA $18\left(6^{\circ} \mathrm{C}\right.$ de diferencia entre ambas).

- Finalmente, se obtuvo una relación entre los valores de conductividad térmica y el tipo de matriz polimérica. Se determinó la siguiente tendencia en la caracterización de este parámetro:

$$
\lambda(\text { LDPE })>\lambda(\text { EVA 18) }>\lambda(\text { EVA 12) }>\lambda(\text { EBA })
$$

- La espuma de PU presentaba valores muy bajos de conductividad, incluso inferiores a los obtenidos para las espumas de poliolefina de celda cerrada $\left(35.65 \mathrm{~mW} / \mathrm{m} \cdot \mathrm{K}\right.$ a $\left.20^{\circ} \mathrm{C}\right)$. Las diferencias entre los valores correspondientes a la espuma de PU y las espumas de celda abierta y baja tortuosidad a $20{ }^{\circ} \mathrm{C}$ fueron de hasta $9.78 \mathrm{~mW} / \mathrm{m} \cdot \mathrm{K}$.

Este trabajo ha supuesto una extensión de estudios previos realizados en CellMat. Basándonos en ellos, se ha conseguido diseñar una batería de nuevos materiales entrecruzados de celda abierta con propiedades totalmente diferentes a los desarrollados hasta la fecha.

Estos nuevos materiales pueden ser catalogados como potenciales sustitutos de la espuma de PU de celda abierta para diferentes aplicaciones tales como el confort, la absorción acústica, la absorción de fluidos apolares o como atenuadores de las vibraciones mecánicas. Finalmente, es importante destacar el amplio interés que han suscitado estos materiales desde un punto de vista industrial, por lo que la escalabilidad industrial de los mismos es una posibilidad real. 


\subsection{Referencias}

[1]. Plastics - the Facts 2018. PlasticsEurope, Association of Plastics Manufacturers.

[2]. https:// ec.europa.eu/commission/news/single-use-plastics-2018-may-28_en

[3]. L.J. Gibson, M.F. Ashby. Cellular Solid: Structure and Properties, 2ndedn. Pergamon., Oxford, 1998.

[4]. D. Klempner, K.C. Frisch. Handbook of Polymeric Foams and Foam Technology. Hanser Publishers., Munich, 1991.

[5]. N.C. Hilyard, A. Cunningham. Low Density Cellular Plastics: Physical Basis of Behavior. Chapman and Hall., London, 1994.

[6]. N.J. Mills. Polyolefin Foams. Rapra Technology Limited., Shawbury, 2003.

[7]. D. Eaves. Handbook of Polymer Foams. Rapra Technology Limited., Shawbury, 2004.

[8]. S.T. Lee, C.B. Park, N.S. Ramesh. Polymeric Foams: Science and Technology. Taylor \& Francis Group., Boca Raton, 2007.

[9]. B.E. Obi. Polymeric Foams: Structure-Property-Performance. A Design Guide.

[10]. C.G. Munters, J.G. Tandberg. US Patent, 2023024.

[11]. G. Wypych. Handbook of Foaming and Blowing Agents. ChemTec Publishing., Toronto, 2017.

[12].https:/ /www.businesswire.com/news/home/20161214005038/en/High-

Demand-Emerging-Economies-Boost-Global-Polyurethane.

[13]. G. Oertel. Polyurethane Handbook 2nd Edition. Hanser Publishers., Munich, 1985.

[14]. M. Szycher. Szycher's Handbook of Polyurethanes, CRC Taylor \& Francis., Boca Raton, 2013.

[15]. S. Thomas, A.V. Rane, K. Kanny, V.K. Abitha, M.G. Thomas. Recycling of Polyurethane Foams, Elsevier., Amsterdam, 2018.

[16]. R.B. Seymour, T. Cheng. Advances in Polyolefins: The World's Most Widely Used Polymers. Springer., Berlin, 1987.

[17]. C. Vasile. Handbook of Polyolefins. Marcel Dekker., New York, 2000.

[18]. M.A. Rodriguez-Perez. Thermal and Mechanical Properties of Polyolefin Foams. PhD Thesis, University of Valladolid, 1999.

[19]. M.A. Rodriguez-Perez. Advances in Polymer Science, 184, 97-126, 2005.

[20]. A. C. Albertsson. Long-Term Properties of Polyolefins. Springer., Berlin, 2004.

[21].https://www.plasticseurope.org/application/files/1215/1704/0199/20160817_po lyolefin_oligomers_research_project_for_risk_assessment.pdf 
[22]. K. Yamashita, N. Yamamoto, A. Mizukoshi, M. Noguchi, Y. Ni, Y. Yanagisawa. Journal of the Air \& Waste Management Association. 59, 273-278, 2009.

[23]. C. Saiz-Arroyo. Fabrication of Improved Polyolefin Based Cellular Materials. Process-Composition-Structure-Properties Relationship. PhD Thesis, University of Valladolid, 2012.

[24]. O. A. Almanza. Modelling of Thermal and Mechanical Properties of Polyolefin Foams. PhD Thesis, University of Valladolid, 2000.

[25]. L.O. Arcos y Rabago. Thermal and Mechanical Properties of Polyolefin Foams Produced by Compression Molding. PhD Thesis, University of Valladolid, 2002.

[26]. J.L. Herrero. Impact and Creep Behavior of Polyethylene Based Foams. PhD Thesis, University of Valladolid, 2004.

[27]. J.I. Gonzalez-Peña. Effect of Thermal Treatments in Low Density Polyethylene Foamed Blocks Produced by Compression Molding. PhD Thesis, University of Valladolid, 2006.

[28]. F. Hidalgo. Design and Opmitization of Process Parameters in the Production of Crosslinked Polyolefin Foams by Compression Molding. PhD Thesis, University of Valladolid, 2008.

[29]. R. A. Campo-Arnaiz. Application of Spectroscopic Techniques for Studying the Morphology and the Thermal and Emission Properties of Low Density Polyolefin Foams. PhD Thesis, University of Valladolid, 2011.

[30]. M. Alvarez-Lainez. Thermal, Mechanical and Acoustic Properties of Open Cell Polyolefin Foams. PhD Thesis, University of Valladolid, 2007.

[31]. M.A. Rodriguez-Perez, C. Saiz-Arroyo, J. Tirado-Mediavilla. Process to Produce a Highly Expanded Open Cell Cross-Linked Polyolefin Foam. Patent, WO 2015/140374 A1. 
1. INTRODUCTION 



\section{INDEX}

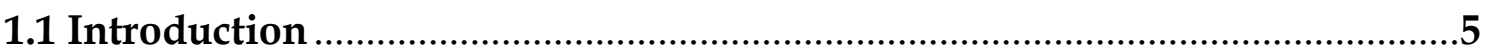

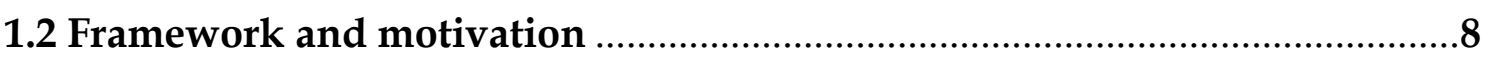

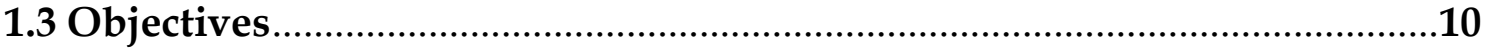

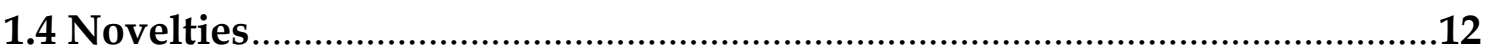

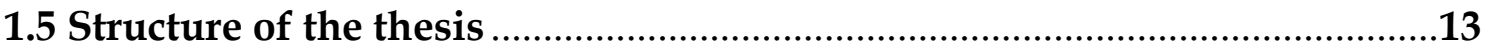

1.6 Publications, conferences and complementary activities ..............................15

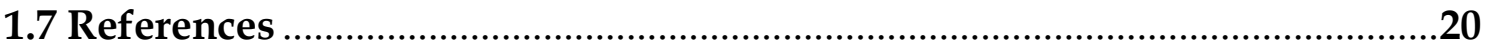




\subsection{Introduction}

The consumption of plastic is still growing in the last years. According to the data divulged by PlasticsEurope (PEMRG) [1], the worldwide plastic production has increased from 335 to 348 million tonnes in one single year (from 2016 to 2017). In Europe, production has increased by $7.33 \%$ (Figure 1.1).
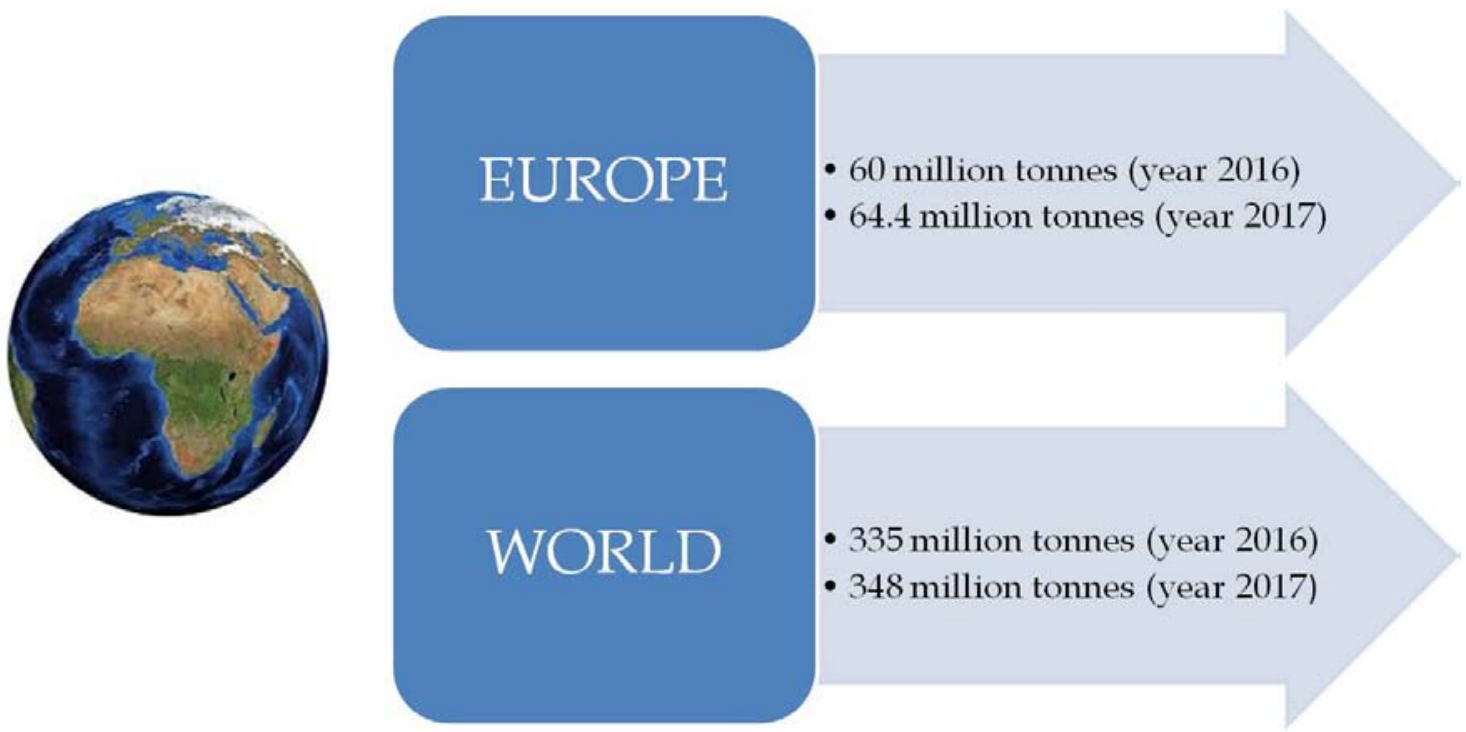

Figure 1.1. Plastic production worldwide and Europe.

However, European policies are conducted to restrict the use of plastics. One clear example is the ban of some single-use items, such as cutlery, plates, straws or cotton swab sticks [2]. As a consequence, other alternatives must be considered to reduce the use of plastics. Cellular polymers are found inside the potential solutions to limit plastic consumption [3-9]. Cellular polymers (also known as polymer foams) are twophase materials in which a gaseous phase is dispersed in the polymer matrix. Since the first case reported of polymer foam (polystyrene foams in 1935), the production and use of cellular polymers have unceasingly increased $[10,11]$. Cellular polymers offer a wide versatility due to their inherent properties depending on the type of polymer matrix, the density and the type of cellular structure interconnectivity. Some of their properties are listed below:

- Light weight

- Adaptable mechanical properties as a function of the density

- High energy absorption

- Comfort for flexible foams

- Thermal insulation

- Sound absorption for open-cell foams

- Oleophilicity and hydrophobicity depending on the polymer matrix

Due to this wide variety of properties, cellular polymers can be used for many applications, as it can be observed in Figure 1.2. 


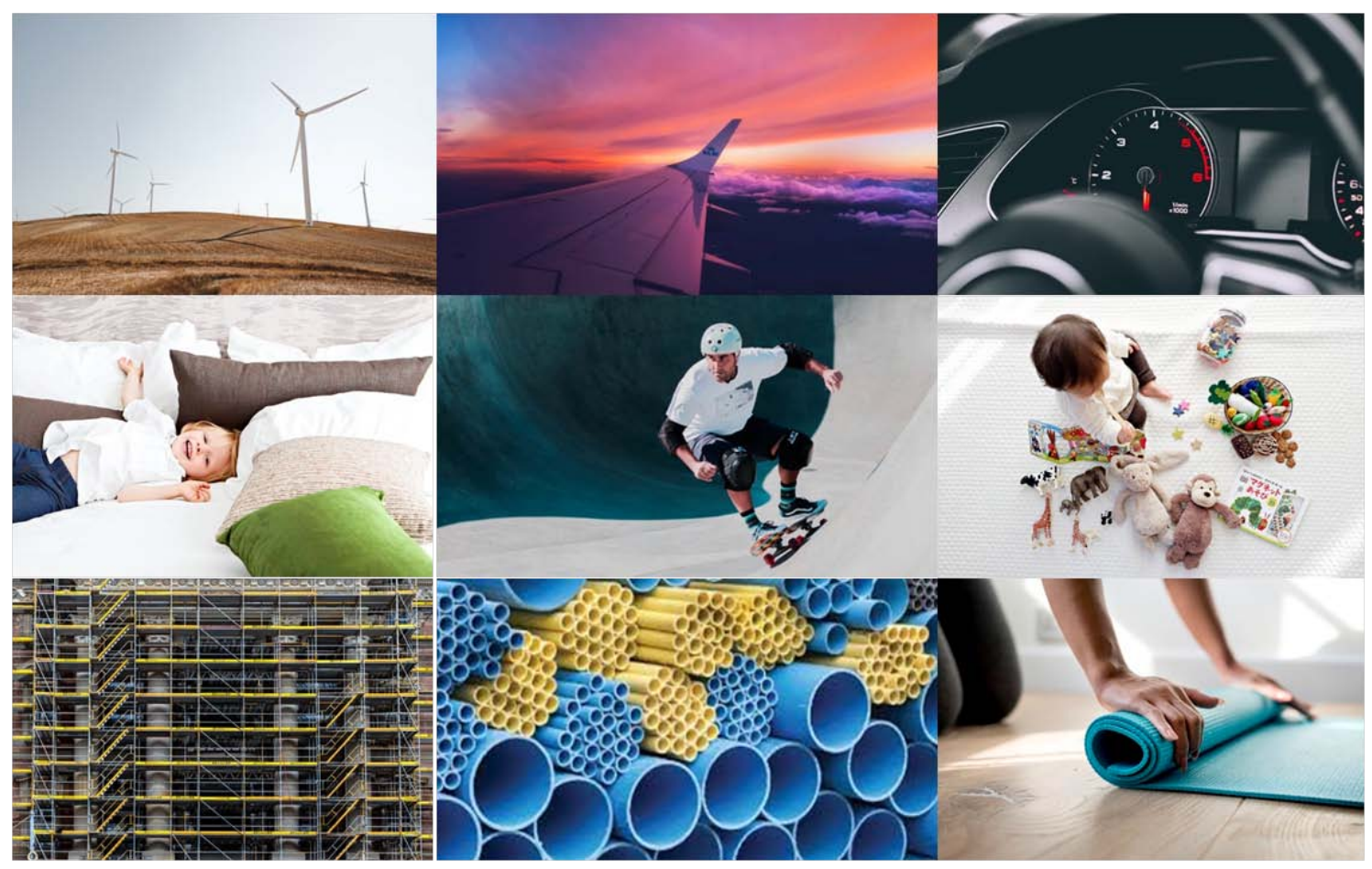

Figure 1.2. Some examples of the applications where cellular polymers are used.

Polyurethane (PU) foams constitute one of the most important groups within the field of polymer foams. PU foams are very versatile materials and depending on the type of foam, they can be used in a wide range of applications. As will be described in chapter 2, PU foams can be classified as rigid or flexible.

According to the data displayed by the report "Global Polyurethane Foam Market 20162020" [12], more than $50 \%$ of the PU market is dominated by open-cell flexible PU foams. Due to their excellent viscoelastic properties and fully interconnected cellular structure, open-cell flexible PU foams are widely presented in applications where comfort is required: mattresses, seats, cushions, headrest, automotive parts, sports industry, etc. Furthermore, it is also important to stand out, that these flexible open-cell PU foams are also interesting for applications such as sound absorption or the absorption of fluids $[13,14]$.

The outstanding properties of these materials make them almost the unique option for this range of applications. However, PU foams present several limitations, which could restrict their use shortly. For instance, in the automotive sector, the emission of volatiles is a critical factor in the standardization of different parts of the vehicles. The amine catalysts used in the production of PU foams are the main responsible for the relatively high volatiles emissions of PU foams. In addition, other components such as antioxidants in the polyols also contribute to releasing high levels of volatiles.

Even though the emission of volatiles is a serious factor, restrictions on the use of PU are conducted to minimize the effects of PU on human health. It has been reported that isocyanates, one of the key reactants in the PU production, are considered hazardous for human health. 
Another limitation related to human health is the toxic gases released by PU foams when they burn, as in the case of a fire. These toxic gases can be lethal in a short period of time, which constitutes an additional limitation for these materials.

PU foams can also suffer from chemical degradation, depolymerizing the polymer to monomers or oligomers and other chemical substances. One important type of chemical reaction involved in the degradation of PU is the hydrolysis, in which the polymer reacts with water following this reaction:

$$
\text { PU foam }+\mathrm{H}_{2} \mathrm{O} \rightarrow \text { Polyol }+ \text { polyamide }
$$

However, PU foams react not only with water but also with other chemicals. Reactions, such as alcoholysis, acidolysis, glycolysis and aminolysis, may take place degrading the polymer [15]. This means that the chemical resistance of these materials is poor.

Furthermore, PU foams tend to degrade after prolonged ultraviolet (UV) light exposure. Some chemical linkages present in the chemistry of PU are susceptible to be affected by UV radiation, yellowing the areas promoting the presence of surface cracks.

Looking at all these problems, the search for potential alternatives to PU foams is becoming indispensable. However, the production of materials with the same properties of PU foams is not an easy task. Focusing on flexible open-cell PU foams, nowadays there are no alternatives in the market. Considering the numerous applications of these foams and their limitations, it is logical to pursue the development of materials which could resemble the properties exhibited by flexible open-cell PU foams.

Polyolefins (PO) have emerged in recent years as interesting polymers for the production of open-cell foams [16-20]. Polyolefins are the resulting polymers formed by the polymerization of olefins, and well-known polymers such as polyethylene (PE), polypropylene (PP), ethylene vinyl acetate copolymers (EVA) or ethylene butyl acrylate copolymers (EBA) belong to this group. LDPE, EVA and EBA present several interesting properties such as flexibility, chemical resistance or hydrophobicity. Flexibility is a key property, considering the fast recovery after compression of opencell PU foams. The potential substitutes must have this property, and therefore, flexible polymers are required for this purpose.

In comparison to PU, the toxicology of polyolefin has been evaluated, giving "no evidence of hazardous properties relevant to human health for the oligomers" [21]. Furthermore, polyolefins are most stable against light or moisture than PU due to, first, the strong chemical bonding $\mathrm{C}-\mathrm{H}$ present in the polymer chains, being these bonds inertness and quite difficult to cleave, and second, the non-polar chemical nature of polyolefins, which avoids the chemical reaction with water. In addition, the emission of volatiles by pure polyolefins is very limited since the volatiles are released with polymer degradation only by applying high temperatures [22]. 
Taking into account this scientific background, the research framed in this thesis pursues the objective of developing novel flexible low-density open-cell foams based on polyolefins aiming at imitating the outstanding properties of flexible open-cell PU foams.

Bearing in mind all these aspects, the framework and the motivation of this work is explained in the following sub-section.

\subsection{Framework and motivation}

This thesis is framed within the program of training of doctoral students in companies "Doctorandos Industriales", from the Ministry of Economy and Competitiveness of Spain. CellMat Technologies S.L. and the $\mathrm{PhD}$ candidate received a grant from this program (DI-15-07952) on September 28th 2016.

CellMat Technologies S.L. (www.cellmattechnologies.com) is a spin-off company established in 2012 by researchers of the Cellular Materials Laboratory (CellMat) of the University of Valladolid. The main activity of the company is the implementation of advanced technologies in the production facilities of the plastic sector, focusing on two fields: cellular materials (foams) and bioplastics. Furthermore, the company collaborates with other national and international entities by performing several R\&D projects. The supervisor of this thesis in the company, Dr Cristina Saiz Arroyo, carried out her doctoral work in CellMat Laboratory and presented her thesis entitled "Fabrication of improved polyolefin-based cellular materials. Process-compositionstructure-properties relationship" in 2012 [23]. She joined CellMat Technologies S.L. in 2013 becoming the manager of R\&D and new products of the company. Dr Cristina Saiz has a wide expertise in the field of plastics and cellular materials, taking part in more than 50 research projects.

CellMat Technologies S.L. actively collaborates with the CellMat Laboratory of the University of Valladolid (www.cellmat.es) in the implementation of research projects. Thanks to this collaboration, it has been possible to perform the experimental part of this thesis in the facilities of CellMat Laboratory by developing two research projects funded by the company:

\section{Project: "Development of Novel Cellular Materials"}

Funded by: CellMat Technologies S.L.

Duration: June 2013- June 2016

Main researcher: Miguel Ángel Rodríguez Pérez

Project: "Development and Optimization of Open-Cell Cellular Materials for

Comfort Applications and Liquid Absorption"

Funded by: CellMat Technologies S.L.

Duration: December 2016- December 2019

Main researcher: Miguel Ángel Rodríguez Pérez 
CellMat Laboratory was established in 1999 by Prof. Jose Antonio de Saja and Prof. Miguel Angel Rodriguez Perez, co-supervisor of this PhD thesis.

During the first years, the research developed in CellMat Laboratory was oriented to the characterization of cellular polymers produced industrially. This characterization was focused on analyzing the cellular structures and determining the physical properties of polyolefin foams produced by using different technologies [18,24-30]. After this initial period, in 2005, CellMat Laboratory started with the acquisition of facilities for the production of cellular polymers. Currently, the lab can produce foams using many different technologies (extrusion, injection moulding, gas dissolution foaming, reactive foaming, bead foaming and compression moulding).

CellMat Laboratory has a wide experience in the production and characterization of low-density crosslinked closed-cell polyolefin foams produced by the two-steps compression molding process. Rodriguez-Perez and Almanza started the research on this field by modelling and characterizing the cellular structure and the thermal and mechanical properties of commercial closed-cell cellular polymers produced by SEKISUI Chemical Co., Ltd and Zotefoams Plc. [18,24]. In 2004, Jose Luis Ruiz presented in his thesis the impact and creep behavior of these closed-cell cellular materials based on LDPE [26]. Further characterizations of commercial crosslinked closed-cell materials provided by the company Microcel S.A. and produced by a twosteps compression molding process were performed in the thesis written by Fernando Hidalgo [28].

Not only closed-cell but also open-cell polyolefin cellular materials have been previously analyzed in CellMat Laboratory. The characterization of low-density crosslinked open-cell foams produced by using the two-steps compression molding process, which included a post foaming step to break the cell walls by deforming the foam, started with the analysis of the cellular structure and the physical properties (thermal, acoustic and mechanical properties) of commercial cellular materials developed by the Japanese company SANWA KAKO Co., Ltd [30]. Some interesting properties were found, but also some weak aspects of these foams were detected.

The interesting properties of these open-cell polyolefin cellular materials awoke an interest in developing a novel production process (different to the one used by SANWA KAKO) to fabricate these materials. CellMat Technologies S.L. developed few years ago a methodology to produce low-density crosslinked open-cell polyolefin foams by using the two-steps compression molding process without performing any additional step to induce the cell walls rupture (as in the SANWA KAKO approach). This novel methodology was described in a patent written by Miguel Angel Rodriguez, Cristina Saiz Arroyo and Josias Tirado [31].

This patent has been the starting point for the work performed in this thesis. This thesis can be considered the following step, once the basic methodology was previously designed. However, to produce materials with interesting properties, several activities were needed such as improving the production process, widening the materials 
produced by using different polymeric matrices and by establishing different degrees of cellular structure interconnectivity and studying the structure-property relationships of these new materials.

Basing on this scientific background and the motivations behind this research, the next section of this chapter is focused on explaining the main objectives set out at the beginning and during the research associated with this work.

\subsection{Objectives}

This thesis has both industrial and scientific objectives, as it is shown in Figure 1.4.

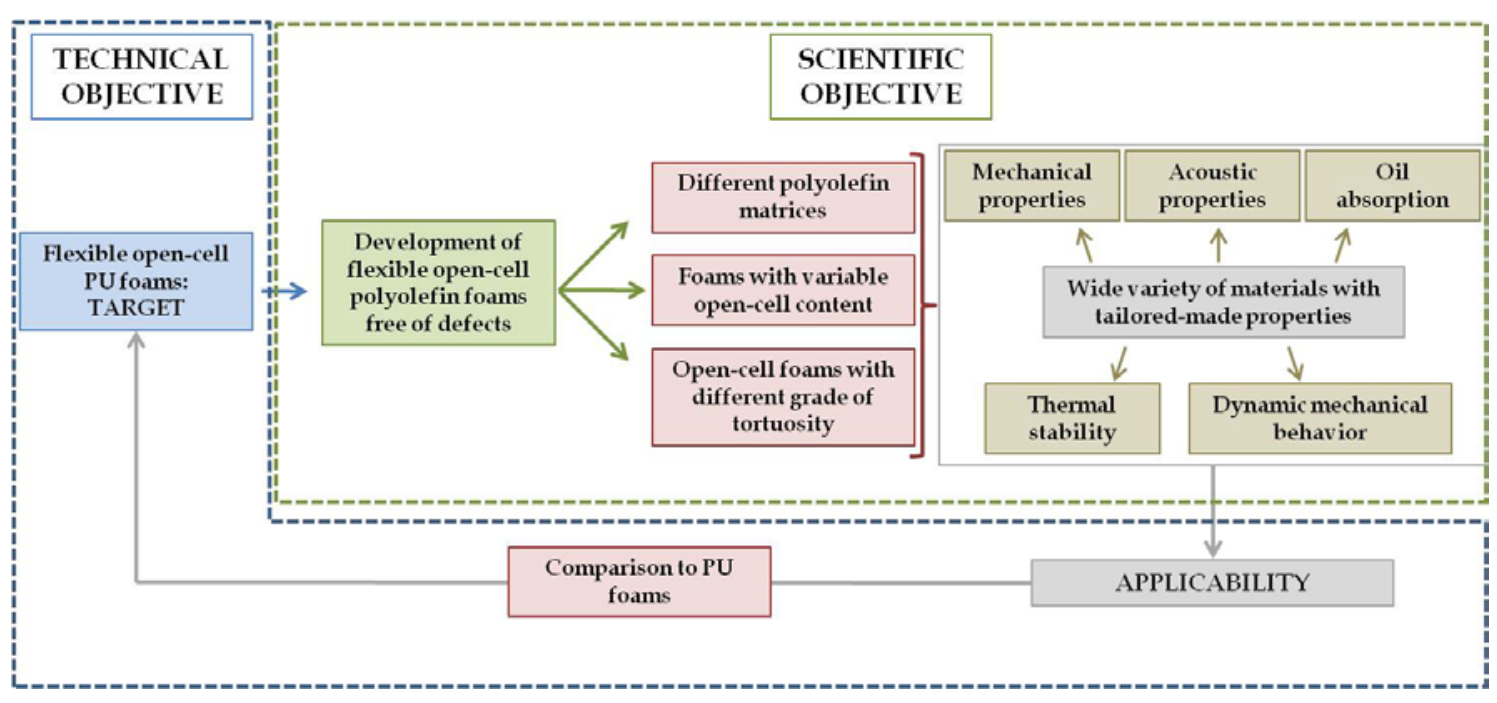

Figure 1.3. Scheme followed during the research lead to fulfill both technical and scientific objectives.

Concerning the scientific part, the main objective can be enounced as:

\section{STUDY OF THE STRUCTURE-PROPERTIES RELATION OF FLEXIBLE OPEN- CELL POLYOLEFIN BASED FOAMS}

Aiming at fulfilling this objective, initially and as it will be discussed in the successive chapters of this thesis, different flexible open-cell foams with different levels of opencell content and tortuosity were produced by using different polymer matrices, as it is indicated in Figure 1.3. Secondly, the cellular structure was analyzed, focusing the attention on two parameters: the cellular structure interconnectivity (open-cell content) and the grade of tortuosity. Finally, different physical properties were characterized, and the results obtained were connected to the type of foam and therefore, to the polymer matrix, the interconnectivity and the tortuosity of the cellular structure. These ideas are shown in Figure 1.3., in which this objective is schematized (scheme inside of the green dash line box).

In addition, a technical objective was also defined. Up to now, the open-cell commercial products are based on PU. However, as it previously discussed, open-cell 
PU foams present several considerable limitations, which makes necessary the search for potential alternatives to them. As a consequence, the development of these novel open-cell foams opened the path to establish an ambitious technical objective (Figure 1.3):

\section{THE PRODUCTION OF NOVEL FLEXIBLE CROSSLINKED OPEN-CELL CELLULAR POLYMER BASED ON POLYOLEOFINS TO REPLACE FLEXIBLE OPEN-CELL PU FOAMS IN SEVERAL APPLICATIONS}

The initial research in CellMat (before this thesis started) on polyolefin-based cellular polymers contributed to consider polyolefins as candidates to replace PU due to their properties. As a result, the first open-cell materials were produced by performing an exhaustive work. However, these materials presented properties not very similar to the ones shown by open-cell PU foams. As a consequence, the idea of improving the methodology to achieve novel open-cell materials with similar characteristics to the flexible open-cell PU foams became a critical issue in this work (controlling the grade of tortuosity of the foams and widening the number of polymers used).

The key aspect to reach both objectives was to follow a systematic methodology to fulfill several specific objectives:

1) To improve the reproducibility of the production process.

2) To extend the production to a wide number of polyolefins, not only based on LDPE as in the preliminary tests. Two additional polymers have been considered: EVA and EBA.

3) To produce open-cell polyolefin foams with tunable grades of open-cell content and gas-phase tortuosity.

4) To study the structure-property relationships.

5) To analyze and compare the physical properties of the novel open-cell polyolefin foams with those of open-cell PU foams.

The production of chemically crosslinked open-cell polyolefins with variable grades of tortuosity by using the two-steps compression molding process was not previously reported in the bibliography, and this fact was a critical challenge to this research. The control of this parameter is very important. It will be described in the successive chapters how the physical properties can be modified by controlling it.

Once the materials were developed, the following step was to analyze the physical properties of them and finally to compare them with the properties of a commercial open-cell PU foam used in the automotive sector.

By using this methodology, it was evaluated, if these novel open-cell foams presented similar characteristics than those exhibited by open-cell PU foams, and thus if they could replace open-cell PU foams in several applications, such as comfort or as sound or oil absorbers. 
It is also important to mention that at the beginning of the thesis, it was explored the possibility of physical crosslinking (electron irradiation) as a technology to be used in this thesis. Physical crosslinking presents some advantages over chemical crosslinking, such as the accurate control of the crosslinking degree or the absence of chemical residues in the foamed product. These initial approximations lead to the publication of two scientific articles, which have been included in Chapter 3. However, after valuing the real potential of this alternative, it was decided to use exclusively chemical crosslinking in the production of the materials developed in this thesis. Despite the advantages of physical crosslinking, it also has some limitations related to the production of open-cell polyolefin foams:

- The accurate and constant crosslinking degree given by physical crosslinking hinders the cell opening during the foaming process, and thus, it is quite complex to obtain cellular structures with high interconnectivity between cells.

- Physical crosslinking is not compatible with the two-steps compression molding technique. The main reason is that thick solid parts (as the ones used in the two-steps compression molding) cannot be crosslinked in a homogeneous way by using physical crosslinking.

\subsection{Novelties}

This work presents some novelties over the current literature. One of the main milestones reached during this research is the production of novel flexible crosslinked open-cell cellular polymers with a controlled grade of tortuosity based on polyolefins (LDPE, EVA and EBA) using a reproducible process.

Furthermore, the analysis of the properties and the comparative with the ones obtained for other polyolefin-based cellular polymers with different cellular structure interconnectivity and tortuosity and with an open-cell PU foam used as a reference, allowed us to extend the knowledge in this field. These novelties are related to the scientific objective previously described. Some of the contributions related to the materials are as follows:

- The use of EBA to produce cellular polymers, as far as the author knows, there is not previous literature based on the use of EBA as polymer matrix.

- To determine how the tortuosity affects the physical properties (mechanical properties, acoustic and oil absorption, dynamic mechanical properties and thermal stability) of open-cell polyolefin foams.

Concerning the last point, several interesting contributions were achieved by characterizing the physical properties of the foams and therefore, can be connected to the technical objective of this study. The most important findings relative to the structure-property relationship of each physical property are listed next:

- Concerning mechanical properties, it has been proven, that regardless of the polymer matrix, open-cell foams with high tortuosity present an interesting 
double mechanical behavior depending on the strain rate of deformation: as open-cell foams at low strain rates and as closed-cell foams at high strain rates. As a result, comfort and energy absorption applications are fulfilled with just one single material.

- Even though the open-cell PU foam had an excellent sound absorption, the acoustic absorption of open-cell foams with low tortuosity at low frequencies (between 500 and $2000 \mathrm{~Hz}$ ) improved considerably the results obtained for the open-cell PU foam. This is a relevant result if it is taken into account that several noises coming from engines in automobiles are located in this frequency range, being these materials excellent solutions for decreasing the noise levels produced by vehicles.

- The open-cell foams with low tortuosity are able to absorb considerable amounts of oil (up to 43 grams of oil per gram of foam) without absorbing water. This remarkable result is obtained without the need for treating the materials superficially. They can be reused in almost all cases (except for LDPE) at least 50 times. These are the open-cell polyolefin-based foams with the highest oil absorptions ever reported in the literature, and even these values are not very far from those obtained for several open-cell superficially treated PU foams.

- It also stands out, the excellent capacity of both open-cell foams with high and low tortuosity to damp mechanical vibrations. The analysis by DMA resulted in very high $\tan \delta$ values for the open-cell foams, much higher than the value of the open-cell PU foam.

\subsection{Structure of the thesis}

This thesis is written as a compendium of publications. Up to now, six articles have been written. Four of them have been already accepted and published, and the other two are pending of publication. Two of these published papers belong to chapter 3 , dedicated to the description of the materials. The other articles constitute entire sections (chapters 4, 5, 6 and 7). Furthermore, this thesis fulfils the requirements to be accredited with the International and the Industrial Mentions.

This document is divided into eight chapters, which are described below:

- Chapter 1. Introduction: This section briefly introduces the concept of cellular polymer and its importance in the field of material science. The framework, motivation, objectives and novelties of this work are defined. Finally, the scientific articles, conferences, poster and projects arise from this work are listed.

- Chapter 2. Background and state of the art: a major revision of the work available in the field of open-cell foams is described. The concept of the cellular structure and in particular, the concept of tortuosity is carefully defined. Special mention receives the open-cell PU because one of the main technical objectives of this work is to look for an alternative to this material. The current state of the 
art on the production of low-density crosslinked polyolefin materials is also included. Finally, the state of the art on the physical properties characterized in this work is also presented.

- Chapter 3. Materials and fabrication process: the materials developed in this work and the fabrication process are described in this chapter. Sixteen different materials were produced in this thesis. Four different polymer matrixes were used: LDPE, EVA with a vinyl acetate content of 12.5\% (EVA 12), EVA with a vinyl acetate content of $18 \%$ (EVA 18) and EBA with a butyl acrylate content of $17 \%$. Four types of materials were produced for each polymer matrix: closedcell (CC), a material with an intermediate open-cell content (MO), open-cell with high tortuosity (OC HT) and open-cell with low tortuosity (OC LT). An open-cell PU foam was used as the reference. The decomposition of the blowing agent (azodicarbonamide) and the crosslinking process are also explained in this section. The cellular materials produced during this work were crosslinked by using organic peroxides. However, there is another option to perform the crosslinking of the polymer matrix: the use of electron irradiation. This second path was also studied, and as a consequence, this section also includes two published papers: the first one is based on the analysis of the foaming mechanisms of high-density polyethylene (HDPE) crosslinked with different irradiation doses and the second one discusses the effect of different electron irradiation doses on the decomposition temperature of the azodicarbonamide, the foaming agent used in this research.

- Chapter 4. Mechanical properties: the mechanical properties of the cellular polymers were analyzed at low and high strain rates. Three main mechanical parameters were measured: the effective gas pressure, the collapse stress and the density of absorbed energy. The effect of the cellular structure interconnectivity on the mechanical properties was analyzed. As a result, this section contains a paper about the effect of the cellular structure tortuosity on the mechanical properties for LDPE and EVA 18. Even though this paper does not include data of EVA 12 and EBA, a similar study was performed for both polymer matrixes, and the results are also included at the end of this chapter.

- Chapter 5. Acoustic properties: the sound absorption of the materials was characterized in a frequency range from 500 to $6400 \mathrm{~Hz}$. The results were compared to those obtained for the reference open-cell PU foam, obtaining excellent sound absorptions for the open-cell materials with low tortuosities. This work leads to a scientific letter, describing the results obtained for the EVA 18 and LDPE. However, in this chapter, the results obtained for EVA 12 and EBA are also included.

- Chapter 6. Oil absorption: this section describes the oil absorption performance of the open-cell materials described in this thesis. The effect of the tortuosity on the oil absorption was determined. The excellent oil absorptions of the materials with low tortuosity allowed us to write a paper based on two concepts: the high oil absorption efficiency and the role played by the cellular structure tortuosity on the oil absorption. The paper shows the results for LDPE 
and EVA 18, but the results obtained for EVA 12 and EBA are also included at the end of this chapter.

- Chapter 7. General Properties: the production of EBA cellular polymers has been firstly reported during this thesis. As a result, it was decided to perform a deep characterization of the materials based on this polymer matrix. In addition to the properties reported in previous chapters (mechanical response at low and high strain rates, acoustic behavior and oil absorption), the thermal stability and the dynamic mechanical properties were also studied. As a result, a paper based on the general properties of EBA cellular polymers was written. This section includes not only this paper but also the thermal stability and the dynamic mechanical properties of the other materials, properties which have not been addressed before. Finally, this chapter includes a section related to the thermal conductivity of the foamed materials.

- Chapter 8. Conclusions: the most remarkable conclusions of the work are presented in this section. Furthermore, possible interesting future lines are also included.

\subsection{Publications, conferences and complementary activities}

The research developed during this thesis has resulted in several scientific papers, which in some cases are already published and other cases are sent and are under revision. The title, authors, journal and chapter of the thesis of the papers are listed below:

\section{Analysis of the Foaming Mechanisms of Materials Based on High-Density} Polyethylene (HDPE) Crosslinked with Different Irradiation Doses

E. Lopez-Gonzalez, L.O. Salmazo, A. Lopez-Gil, E. Laguna-Gutierrez, M.A. Rodriguez-Perez

Journal of Applied Polymer Science, 135, 46276-46302

Chapter: 3

Study of the Effect of Different Electron Irradiation Doses on the Decomposition Temperature of Azodicarbonamide

E. Lopez-Gonzalez, L.O. Salmazo, A. Lopez-Gil, M.A. Rodriguez-Perez

Polymer Engineering and Science, DOI: 10.1002/pen.25007

Chapter: 3

Effect of the Gas Phase Tortuosity on the Mechanical Properties of Low-Density

Open-Cell Polyolefin Foams at Low and High Strain Rates

E. Lopez-Gonzalez, S. Muñoz-Pascual, C. Saiz-Arroyo, M.A. Rodriguez-Perez

Journal of Applied Polymer Science, accepted

Chapter: 4

Influence of the Cellular Structure Tortuosity on the Acoustic Absorption of OpenCell Polyolefin Foams

E. Lopez-Gonzalez, C. Saiz-Arroyo, M.A. Rodriguez-Perez

Materials Letters, submitted

Chapter: 5 
Flexible Low Density Open-Cell Polyolefin Foams as Efficient Materials for Oil Absorption: Influence of the Tortuosity on Oil Absorption

E. Lopez-Gonzalez, C. Saiz-Arroyo, M.A. Rodriguez-Perez

International Journal of Environmental Science and Technology, submitted Chapter: 6

Crosslinked Flexible Ethylene Butyl Acrylate Copolymer (EBA) Foams with

Different Cellular Structure Interconnectivity and Tortuosity: Microstructure and Physical Properties

E. Lopez-Gonzalez, S. Muñoz-Pascual, C. Saiz-Arroyo, M.A. Rodriguez-Perez

Journal of Applied Polymer Science, DOI: 10.1002/app.48161

Chapter: 7

Table 1.1. Scientific papers written during this thesis.

Furthermore, some of the research carried out has been presented in different national and international conferences. The name of the Conferences, type of communication, authors, speaker, the date and place where they were held, are summarized in Table 1.2:

Study of the Cellular Structure of LDPE Foams Irradiated at Different Doses

E. Lopez-Gonzalez, L.O. Salmazo, A. Lopez-Gil, M.A. Rodriguez-Perez

XII Simposio de Investigadores Jóvenes RSEQ-Sigma Aldrich, Barcelona (Spain), November $3^{\text {th }}-6^{\text {th }}, 2015$

Poster Presentation

Effect of the Electron Irradiation Dose on the Foaming Behaviour of High-Density Polyethylene (HDPE)

E. Lopez-Gonzalez, L.O. Salmazo, A. Lopez-Gil, M.A. Rodriguez-Perez

XIV Reunión del Grupo Especializado de Polímeros (GEP) de la RSEQ y RSEF, Burgos (Spain), September $5^{\text {th }}-8^{\text {th }}, 2016$

Poster Presentation

Open-Cell Flexible Foams with High Tortuosities and a Strain Rate Dependent Mechanical Performance

C. Saiz-Arroyo, E. Lopez-Gonzalez, S. Muñoz-Pascual, M.A. Rodriguez-Perez

$4^{\text {th }}$ CellMAT 2016 - Cellular Materials, Dresden (Germany), December $7^{\text {th }}-9^{\text {th }}, 2016$

Oral Presentation: C. Saiz-Arroyo

Study of the Effect of Different Electron Irradiation Doses on the Decomposition Temperature of the Azodicarbonamide

E. Lopez-Gonzalez, L.O. Salmazo, A. Lopez-Gil, C. Saiz-Arroyo, M.A. RodriguezPerez

37th Berlin School on Neutron Scattering, Berlin (Germany), March 2nd $-10^{\text {th }}, 2017$

Poster Presentation

Study of the Relationship between Cellular Interconnectivity and Mechanical

Response of Low-Density Polyolefin Cellular Materials

E. Lopez-Gonzalez, S. Muñoz-Pascual, C. Saiz-Arroyo, M.A. Rodriguez-Perez

ANTEC 2017 The Plastic Technology Conference, Anaheim (USA), May 8nd $-10^{\text {th }}, 2017$

Oral Presentation: M. A. Rodriguez-Perez 
Low-Density Open-Cell Flexible Polyolefin Foams with Tunable Tortuosities: Mechanical Behavior at Low and High Strain Rates

E. Lopez-Gonzalez, S. Muñoz-Pascual, C. Saiz-Arroyo, M.A. Rodriguez-Perez

SPE FOAMS 2017. 15 $5^{\text {th }}$ International Conference on Advances in Foam Materials and Technology, Bayreuth (Germany), October $9^{\text {th }}-12^{\text {th }}, 2017$

Poster Presentation

Crosslinked Open-Cell Low-Density Flexible Foams as Highly Efficient Materials for Oil Absorption

E. Lopez-Gonzalez, C. Saiz-Arroyo, M.A. Rodriguez-Perez

SPE FOAMS 2017. 15th International Conference on Advances in Foam Materials and Technology, Bayreuth (Germany), October $9^{\text {th }}-12^{\text {th }}, 2017$

Oral Presentation: E. Lopez-Gonzalez

Multifunctional Open-Cell Flexible Foams: From Comfort and Impact Protection to High Oil Absorption Capacity in One Single Material

E. Lopez-Gonzalez, C. Saiz-Arroyo, S. Muñoz-Pascual, M.A. Rodriguez-Perez

Polymer Foam 2017, Cologne (Germany), November 28th $-29^{\text {th }}, 2017$

Oral Presentation: C. Saiz-Arroyo

Crosslinked Open-Cell Ethylene Butyl Acrylate Copolymer (EBA) Foams: Properties and Applications

E. Lopez-Gonzalez, S. Muñoz-Pascual, C. Saiz-Arroyo, M.A. Rodriguez-Perez

$5^{\text {th }}$ CellMAT 2018 - Cellular Materials, Bad Staffelstein (Germany), October $24^{\text {th }}-26^{\text {th }}$, 2018 Award-winning Poster

Poster Presentation

Crosslinked Open-Cell Flexible Polyolefin Foams with Different Cellular Structure Tortuosity: Properties and Applications

E. Lopez-Gonzalez, S. Muñoz-Pascual, C. Saiz-Arroyo, M.A. Rodriguez-Perez $5^{\text {th }}$ CellMAT 2018 - Cellular Materials, Bad Staffelstein (Germany), October 24th $-26^{\text {th }}$, 2018

Oral Presentation: E. Lopez-Gonzalez

Table 1.2. Oral communications, posters and contributions to national and international conferences.

The participation in other scientific works, educational conferences, courses and complementary activities are included in Tables 1.3, 1.4, 1.5 and 1.6:

\section{Anisotropic Polypropylene Cellular Polymers Filled with Nanoclays: Microstructure and Properties}

A. Lopez-Gil, M. Benanti, E. Lopez-Gonzalez, J.L. Ruiz-Herrero, L. Oliveira, F. Briatico, M.A. Rodriguez-Perez

Polymer Composites, DOI: 10.1002/ pc.24858

Effect of the Mold Temperature on the Impact Behavior and Morphology of

Injection Molded Foams Based on Polypropylene Polyethylene-Octene Copolymer Blends

S. Muñoz-Pascual, E. Lopez-Gonzalez, C. Saiz-Arroyo, M.A. Rodriguez-Perez

Polymers, DOI: $10.3390 /$ polym11050894 Table 1.3. Contribution in other scientific papers. 
Evolution of the Practical Training in Materials Physics: from a Constrained

Research in the Polymer Science Field to a Multidisciplinary Methodology

E. Lopez-Gonzalez, S. Muñoz-Pascual, V. Bernardo, E. Laguna-Gutierrez, J.M. de Leon, S. Perez-Tamarit, J. Pinto, M.A. Rodriguez-Perez

EDULEARN 2018. 10 $10^{\text {th }}$ Annual International Conference on Education and New Learning Technologies, Palma de Mallorca (Spain), July $2^{\text {nd }}-4^{\text {th }}, 2018$

Transferring Knowledge from the University to the Industry: Internships at the University of Valladolid

S. Perez-Tamarit, J.M. de Leon, V. Bernardo, E. Lopez-Gonzalez, S. Muñoz-Pascual, J. Pinto, E. Laguna-Gutierrez, M.A. Rodriguez-Perez

EDULEARN 2018. 10 $10^{\text {th }}$ Annual International Conference on Education and New Learning Technologies, Palma de Mallorca (Spain), July $2^{\text {nd }}-4^{\text {th }}, 2018$

Development of a Postgraduate Training Program on Surface Functionalization of Polymers/Polymers Foams

S. Barroso-Solares, B. Merillas, E. Lopez-Gonzalez, M.A. Rodriguez-Perez, J. Pinto EDULEARN 2018. 10 $0^{\text {th }}$ Annual International Conference on Education and New Learning Technologies, Palma de Mallorca (Spain), July $2^{\text {nd }}-4^{\text {th }}, 2018$

Table 1.4. Contribution to educational conferences.

\section{7th Berlin School on Neutron Scattering}

Course. Berlin (Germany), March $2^{\text {nd }}-10^{\text {th }}, 2017$

Table 1.5. Assistance to courses.

Tutor: Practical Lectures in Material Physics (Physics Degree)

Academic years: 2017-2018 and 2018-2019

Faculty of Science, University of Valladolid

Tutor: Practical Lectures in Polymers (Master in Physics)

Academic year: 2018-2019

Faculty of Science, University of Valladolid

Tutor: Practical Lectures in Multiphase and Cellular Materials (Master in Physics) Academic year: 2018-2019

Faculty of Science, University of Valladolid

Table 1.6. Practical lectures given at the University of Valladolid.

Finally, the participation in several research projects in the field of cellular polymers is mentioned below.

Project: Development of Advanced Nanocellular Polymers

Financed by: CellMat Technologies S.L.

Duration: January 2015- December 2016

Main researcher: Miguel Ángel Rodríguez Pérez

Project: "Development of Light and Resistant Cellular Materials by Controlling the

Chemical Composition and the Cellular Structure: Micro and Nanocellular

\section{Materials"}

Financed by: CellMat Technologies S.L.

Duration: December 2013- December 2015

Main researcher: Miguel Ángel Rodríguez Pérez 
Project: "Development of Novel Cellular Materials"

Financed by: CellMat Technologies S.L.

Duration: June 2013- June 2016

Main researcher: Miguel Ángel Rodríguez Pérez

Project: "Development and Optimization of Cellular Materials with High Impact Resistance"

Financed by: CellMat Technologies S.L.

Duration: December 2016- December 2018

Main researcher: Miguel Ángel Rodríguez Pérez

Project: "Development and Optimization of Open-Cell Cellular Materials for Comfort Applications and Liquid Absorption"

Financed by: CellMat Technologies S.L.

Duration: December 2016- December 2019

Main researcher: Miguel Ángel Rodríguez Pérez

Project: "Development of Strategies to Produce Nanocellular Polymers in Industrial

Processes: Extrusion and Expanded Beads"

Financed by: CellMat Technologies S.L.

Duration: December 2015- December 2018

Main researcher: Miguel Ángel Rodríguez Pérez

Table 1.7. Participation in several research projects. 


\subsection{References}

[1]. Plastics - the Facts 2018. PlasticsEurope, Association of Plastics Manufacturers.

[2]. https:/ / ec.europa.eu/commission/news/single-use-plastics-2018-may-28_en.

[3]. L.J. Gibson, M.F. Ashby. Cellular Solids: Structure and Properties, 2ndedn. Pergamon., Oxford, 1998.

[4]. D. Klempner, K.C. Frisch. Handbook of Polymeric Foams and Foam Technology. Hanser Publishers., Munich, 1991.

[5]. N.C. Hilyard, A. Cunningham. Low Density Cellular Plastics: Physical Basis of Behavior. Chapman and Hall., London, 1994.

[6]. N.J. Mills. Polyolefin Foams. Rapra Technology Limited., Shawbury, 2003.

[7]. D. Eaves. Handbook of Polymer Foams. Rapra Technology Limited., Shawbury, 2004.

[8]. S.T. Lee, C.B. Park, N.S. Ramesh. Polymeric Foams: Science and Technology. Taylor \& Francis Group., Boca Raton, 2007.

[9]. B.E. Obi. Polymeric Foams: Structure-Property-Performance. A Design Guide.

[10]. C.G. Munters, J.G. Tandberg. US Patent, 2023024.

[11]. G. Wypych. Handbook of Foaming and Blowing Agents. ChemTec Publishing., Toronto, 2017.

[12].https://www.businesswire.com/news/home/20161214005038/en/High-

Demand-Emerging-Economies-Boost-Global-Polyurethane.

[13]. G. Oertel. Polyurethane Handbook 2nd Edition. Hanser Publishers., Munich, 1985.

[14]. M. Szycher. Szycher's Handbook of Polyurethanes, CRC Taylor \& Francis., Boca Raton, 2013.

[15]. S. Thomas, A.V. Rane, K. Kanny, V.K. Abitha, M.G. Thomas. Recycling of Polyurethane Foams, Elsevier., Amsterdam, 2018.

[16]. R.B. Seymour, T. Cheng. Advances in Polyolefins: The World's Most Widely Used Polymers. Springer., Berlin, 1987.

[17]. C. Vasile. Handbook of Polyolefins. Marcel Dekker., New York, 2000.

[18]. M.A. Rodriguez-Perez. Thermal and Mechanical Properties of Polyolefin Foams. PhD Thesis, University of Valladolid, 1999.

[19]. M.A. Rodriguez-Perez. Advances in Polymer Science, 184, 97-126, 2005.

[20]. A. C. Albertsson. Long-Term Properties of Polyolefins. Springer., Berlin, 2004.

[21].https://www.plasticseurope.org/application/files/1215/1704/0199/20160817_po lyolefin_oligomers_research_project_for_risk_assessment.pdf. 
[22]. K. Yamashita, N. Yamamoto, A. Mizukoshi, M. Noguchi, Y. Ni, Y. Yanagisawa. Journal of the Air \& Waste Management Association. 59, 273-278, 2009.

[23]. C. Saiz-Arroyo. Fabrication of Improved Polyolefin Based Cellular Materials. Process-Composition-Structure-Properties Relationship. PhD Thesis, University of Valladolid, 2012.

[24]. O. A. Almanza. Modelling of Thermal and Mechanical Properties of Polyolefin Foams. PhD Thesis, University of Valladolid, 2000.

[25]. L.O. Arcos y Rabago. Thermal and Mechanical Properties of Polyolefin Foams Produced by Compression Molding. PhD Thesis, University of Valladolid, 2002.

[26]. J.L. Herrero. Impact and Creep Behavior of Polyethylene Based Foams. PhD Thesis, University of Valladolid, 2004.

[27]. J.I. Gonzalez-Peña. Effect of Thermal Treatments in Low Density Polyethylene Foamed Blocks Produced by Compression Molding. PhD Thesis, University of Valladolid, 2006.

[28]. F. Hidalgo. Design and Opmitization of Process Parameters in the Production of Crosslinked Polyolefin Foams by Compression Molding. PhD Thesis, University of Valladolid, 2008.

[29]. R. A. Campo-Arnaiz. Application of Spectroscopic Techniques for Studying the Morphology and the Thermal and Emission Properties of Low Density Polyolefin Foams. PhD Thesis, University of Valladolid, 2011.

[30]. M. Alvarez-Lainez. Thermal, Mechanical and Acoustic Properties of Open Cell Polyolefin Foams. PhD Thesis, University of Valladolid, 2007.

[31]. M.A. Rodriguez-Perez, C. Saiz-Arroyo, J. Tirado-Mediavilla. Process to Produce a Highly Expanded Open Cell Cross-Linked Polyolefin Foam. Patent, WO 2015/140374 A1. 
2. BACKGROUND AND STATE OF THE ART 



\section{INDEX}

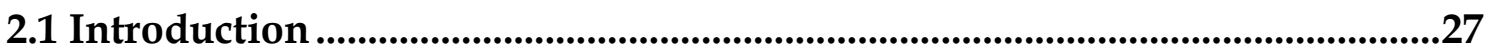

2.2 Basic concepts of the cellular structure of polymer foams: .......................27

2.2.1 Cellular structure interconnectivity …...................................................27

2.2.2 Gas-phase tortuosity ....................................................................................29

2.3 Polyurethane (PU) foams: Basic concepts and associated problematic .......31

2.3.1 Introduction. The chemistry …..................................................................31

2.3.2 Market relevance and main properties ..................................................34

2.3.3 Problematic and limitations of use .......................................................37

2.4 Crosslinked cellular polymers based on polyolefins..........................................39

2.4.1 General concepts .............................................................................................39

2.4.2 Production processes......................................................................................41

2.4.2.1 Continuous processes ………………………………………..... 43

2.4.2.2 Discontinuous process: Block foams ......................................... 46

2.5 Physical properties of low-density flexible foams.............................................55

2.5.1 Mechanical properties...................................................................................55

2.5.2 Acoustic properties .........................................................................................62

2.5.3 Oil- absorption properties..............................................................................67

2.5.4 Other properties ............................................................................................72

2.5.4.1 Vibration dampening ................................................................72

2.5.4.2 Thermal stability .........................................................................73

2.5.4.3 Thermal conductivity ..................................................................74

2.5.5 Summary............................................................................................................77

2.6 References ..................................................................................................................79 


\subsection{Introduction}

The background and state of the art are addressed in the second chapter, where the revision of the concepts covered during this work is presented. Basic concepts relative to the cellular structure are described firstly, paying special attention to two key aspects that would play a very important role in the following chapters: cellular structure interconnectivity and tortuosity.

Bearing in mind the main technical objective of this work (the search of potential alternatives to flexible open-cell polyurethane (PU) foams based on polyolefins), a section explaining the chemistry of the PU foams, their economic importance and the critical drawbacks of this material is also included on this chapter.

Due to the nature of the materials considered for this thesis, several aspects concerning crosslinked polyolefin-based materials, such as current applications, market relevance, properties or the technologies employed to fabricate them are also covered in this part of the thesis.

The last part of this chapter comprises a revision of the state of the art of the main physical properties (acoustic, thermal or mechanical, among others) of low-density flexible foams. All the materials considered during this work can be included in this classification, and due to that, the revision of the state of the art has been focused on this group of materials.

\subsection{Basic concepts of the cellular structure of polymeric foams: \\ 2.2.1 Cellular structure interconnectivity}

Foams can be classified according to different criteria, such as density, the stiffness of the polymer matrix or the morphology of the cellular structure. Focusing on the last criterion, foams can be divided into three groups: closed-cell foams, foams with intermediate open-cell contents and open-cell foams [1,2].

In closed-cell foams, the gas is enclosed inside the cells, and it cannot move freely through the cellular structure. On the other hand, open-cell foams are characterized by a high level of interconnectivity between the cells, allowing the movement of gas through the cellular structure. Foams with intermediate open-cell contents can be considered as hybrids between closed and open-cell foams, being their cellular structure partially interconnected.

Figure 2.1 shows the cellular structures of closed-cell foams, open-cell foams and foams with intermediate open-cell contents: 


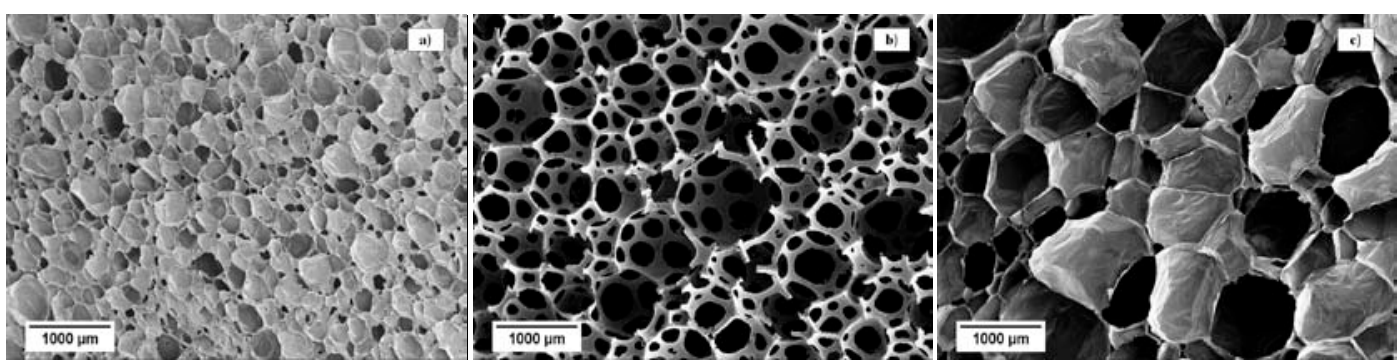

Figure 2.1. SEM micrographs corresponding to a) closed-cell foam b) open-cell foam and c) foam with an intermediate open-cell content.

Figure 2.1 a) belongs to a closed-cell polyolefin foam. The cells are not interconnected, and the presence of cell walls avoids the circulation of the gas along the structure. Figure 2.1 b) shows the typical cellular structure of an open-cell PU foam, in which the gas can move freely due to the high interconnectivity among the cells. Foams with intermediate open-cell contents display a partially interconnected structure, and only a limited number of cells are connected, as observed in Figure 2.1 c).

The level of interconnectivity is defined by the open-cell content. The open-cell content $(\%)$ is usually estimated by performing gas pycnometer measurements and is given by the following equation:

$$
C(\%)=\frac{V_{g}-V_{p}}{V_{g}\left(1-\rho_{\text {rel }}\right)} \times 100
$$

(Equation 1)

where $C$ is the open-cell content, $V_{g}$ is the geometrical volume of the sample, $V_{p}$ is the volume measured by the pycnometer and $\rho_{\text {rel }}$ is the relative density given by the ratio between the density of the foam and the density of the solid material.

Values of $C$ near to $0 \%$ correspond to closed-cell foams, whereas open-cell foams present values around $100 \%$.

Concerning open-cell foams, it is observed in Figure 2.1 b) that the high level of interconnectivity (i.e. open-cell contents around $100 \%$ ) in open-cell PU foams is a consequence of the absence of cell walls as the cells in this material are formed only by struts. However, in other foamed materials, such as open-cell polyolefin foams, the cells can be interconnected in a different way, as it is shown in Figure 2.2. While in open cell PU foams the interconnectivity is due to the absence of cell walls, in crosslinked open-cell polyolefin cellular polymers is owing to the presence of holes in the cell walls (Figure 2.2 b). 


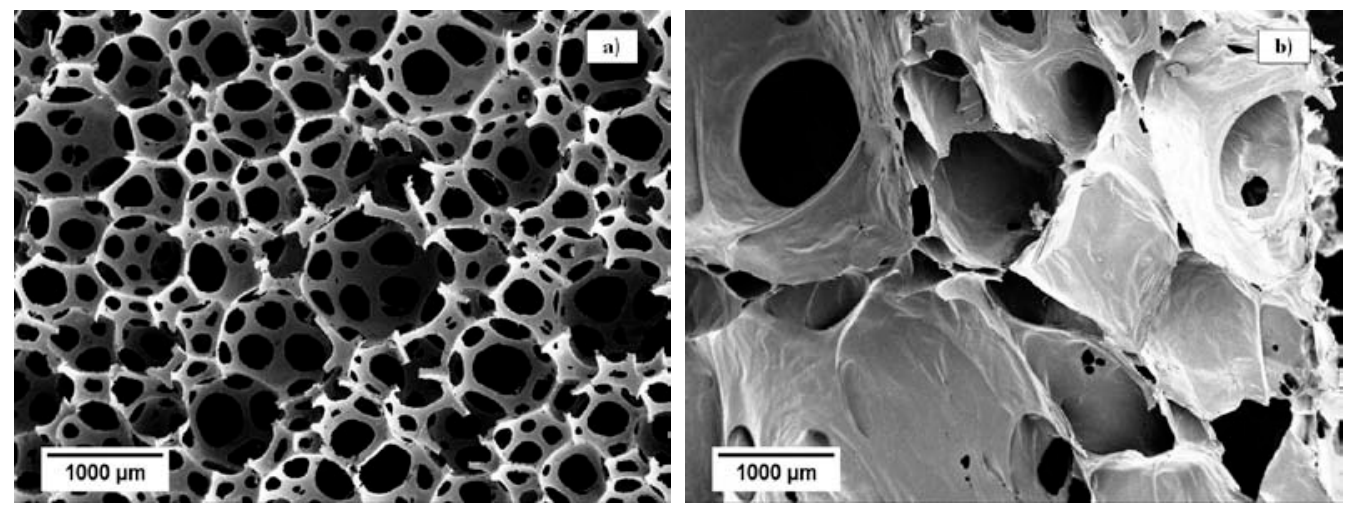

Figure 2.2. a) SEM micrograph of the cellular structure of open-cell PU foam and b) SEM micrograph of crosslinked open-cell cellular polymers based on polyolefins.

At first sight, it seems that the gas can move easier through the cellular structure of open-cell PU foams (better recovery after compression). However, depending on the number and the size of the holes created in the cell walls, materials with different behavior and properties can be produced. Thus, if the number and the size of holes are large enough, the cellular structure of this foam would resemble the one of open-cell PU foams, but if only a few and small holes are created, the cellular structure would be completely different than that of open-cell PU foams.

As a consequence, open-cell foams cannot be classified according to one single parameter as the open-cell content, because both types of interconnectivity give as a result open-cell contents of $100 \%$. It is necessary to consider an additional parameter, which would allow establishing differences among the various types of cellular structures displayed by open-cell foams. This parameter is known as tortuosity.

\subsubsection{Gas-phase tortuosity}

Tortuosity is a quite well-known concept in porous media, and it is commonly used to determine electrical or thermal conductivity [3]. J. Bear defined the tortuosity as follows: "Tortuosity is an intrinsic property of a porous material usually defined as the ratio of actual flow path length to the straight distance between the ends of the flow path" [4].

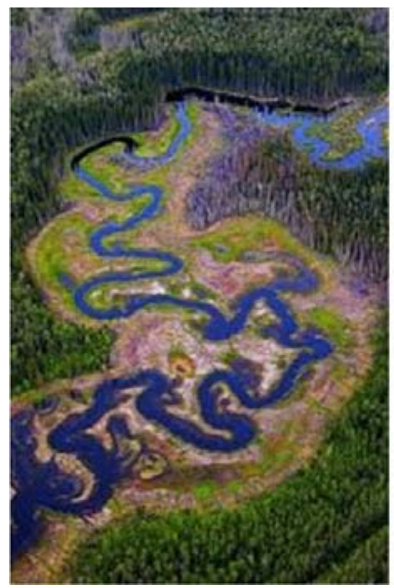

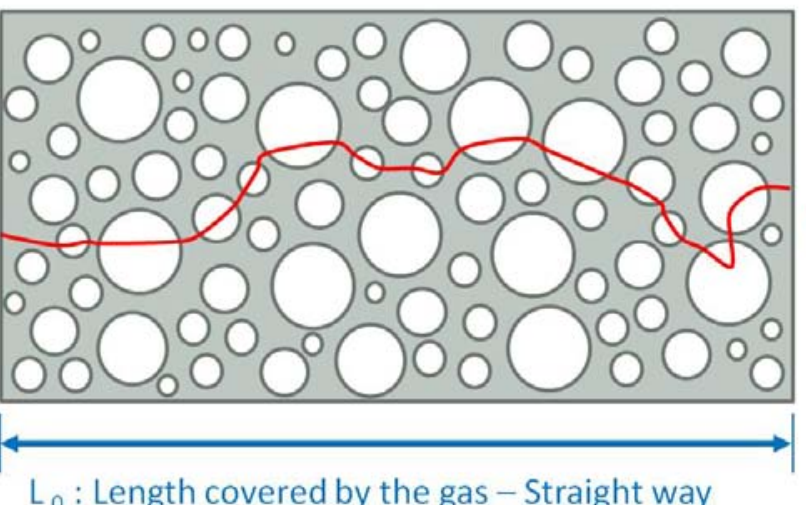

$\mathrm{L}_{0}$ : Length covered by the gas - Straight way
$\mathrm{L}:$ Real length covered by the gas

Figure 2.3. Scheme of the concept of tortuosity. 
The concept of tortuosity can also be applied to polymer foams. Within this field, tortuosity is defined as the ratio between the distance that a gas molecule has to cover from one side to another side of the sample (L) and the hypothetic shortest distance that it would cover following a straight path $\left(\mathrm{L}_{\mathrm{o}}\right)$ (Figure 2.3). Tortuosity does not depend on the type of fluid contained by the porous structure but on the type of architecture: open-cell content and number or size of the holes presented in the cell walls [5].

Tortuosity, alongside the open-cell content, allows describing accurately the cellular structure of open-cell foams. On the one hand, the cellular structure of open-cell PU foams is characterized for being low tortuous due to the presence only of struts. On the other hand, in open-cell polyolefin foams, the tortuosity is directly related to the number and the size of the holes present on the cell walls. If both the number and the size of the holes are small, the cellular structure can be defined as high tortuous, whereas if the number and the size of holes are large, a material with a tortuosity as low as that shown by the open-cell PU foams can be achieved (Figure 2.4).
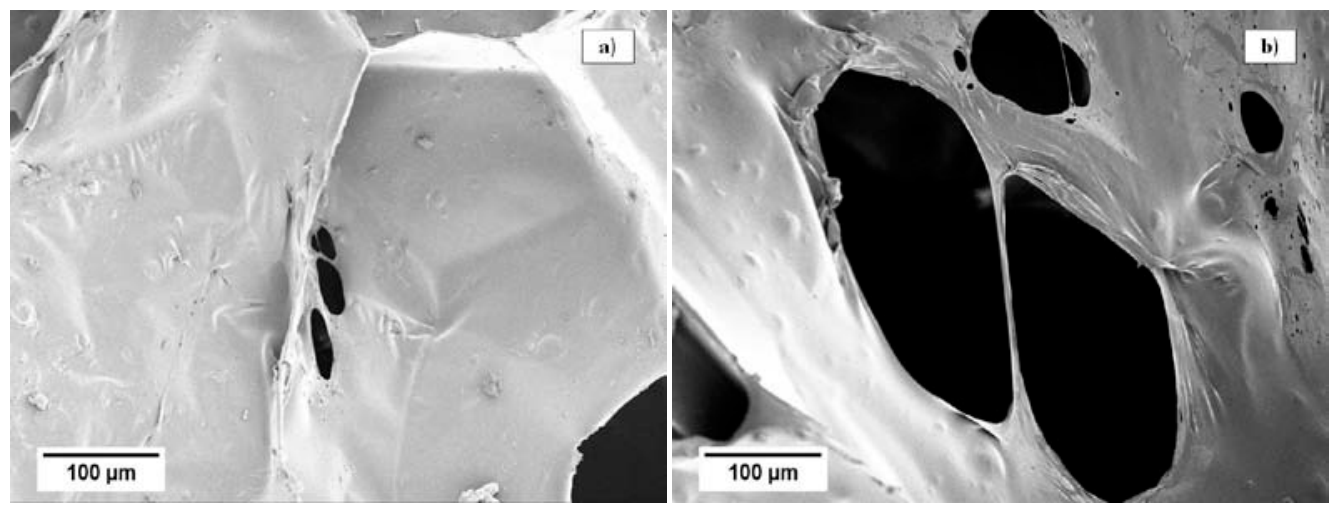

Figure 2.4. a) SEM micrograph showing the presence of small holes and b) SEM micrograph of large holes created in the cell walls of crosslinked open-cell polyolefin foams.

The tortuosity is a critical parameter for many applications, playing a very important role in the response of open-cell foams not only polymeric-based but also metallicbased ones [6-10]. The tortuosity can be estimated by using different methods such as ultrasonication or electrical conductivity measurements or theoretically using different models [5,11-14]. 

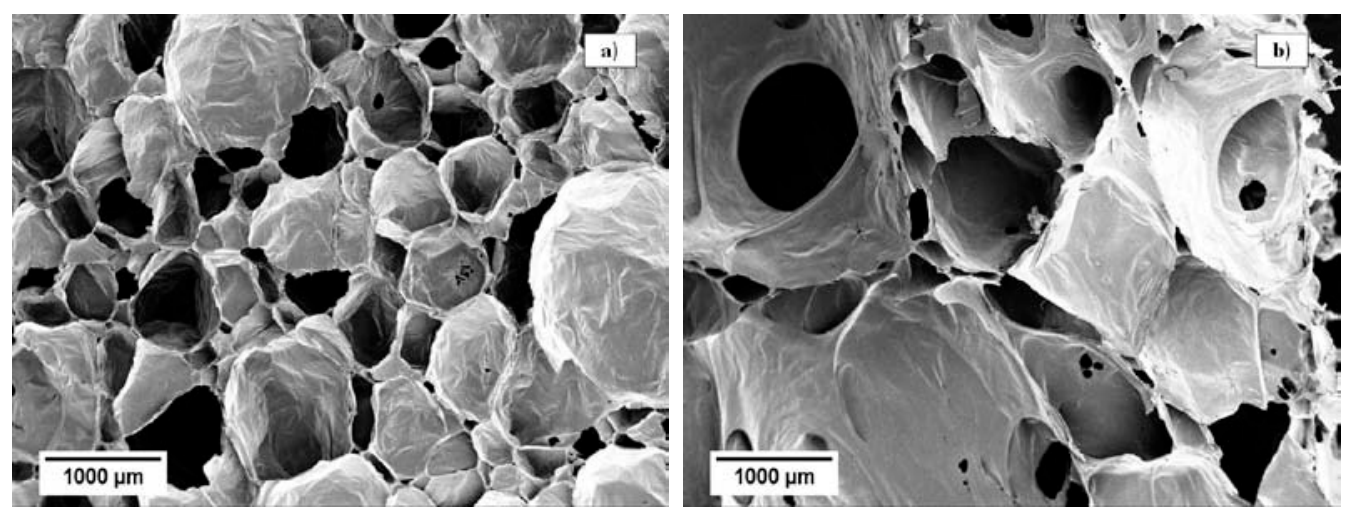

Figure 2.5. a) SEM micrograph of the cellular structure of crosslinked open-cell polyolefin cellular polymers with high tortuosity and b) SEM micrograph of the cellular structure of crosslinked open-cell polyolefin cellular polymers with low tortuosity.

Figure 2.5 corresponds to two materials produced during this research. The cellular structure is considerably different in both cases. Only a few and small holes can be observed in Figure 2.5 a). Consequently, this material will be assigned as high tortuous. However, a considerable number of large holes is present in the material displayed in Figure 2.5 b). In this case, the gas can move easily through this cellular structure, being this situation much more similar to the one appearing in open-cell PU foams. Thus, this second type of materials has been labelled as low tortuous during the thesis.

\subsection{Polyurethane (PU) foams: Basic concepts and associated problematic}

\subsubsection{Introduction. The chemistry}

Polyurethane is the polymer obtained from the blend of two chemical components: isocyanates and polyols [15-19]. Polyurethane was discovered in 1937 by Otto Bayer when he looked for an alternative to the polyamides developed by DuPont in the 1930s [20]. However, its impact in the market took place during the II World War, when polyurethane started to be used massively in several applications, such as in aircraft coating or to replace rubber [21].

Despite its name, polyurethane is not the product of the polymerization of urethane monomers. The chemistry of polyurethane is very complex because not only a single reaction takes place when the isocyanate and the polyol groups react, but at least several of them occur simultaneously [22-25].

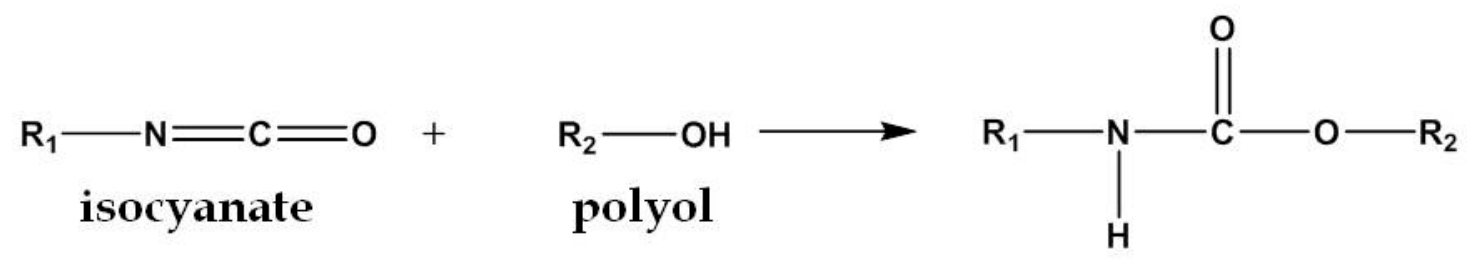

\section{urethane}

Figure 2.6. The chemical reaction of the polyol and the isocyanate groups [25]. 
The carbon of isocyanate group is characterized by a high reactivity towards nucleophiles, because the nitrogen and oxygen atoms (more electronegative than carbon) attract the electron density, remaining the carbon with a partially positive charge. As a result, nucleophile groups such as alcohol, amines, water, ureas or urethanes react with the positive carbon atom from the isocyanate group. This high reactivity makes the chemistry of the polyurethane complex [22].

As it can be observed in Figure 2.6 [25], the isocyanate reacts with the polyols to generate urethane groups. However, the isocyanate can also react with water giving an unstable carbamic acid which decomposes in an amine and $\mathrm{CO}_{2}$ (Figure 2.7 a). The $\mathrm{CO}_{2}$ generated in this reaction is the blowing agent of the system, and therefore, both the presence and concentration of water are directly connected with the final density and the properties of the foam. 
a)

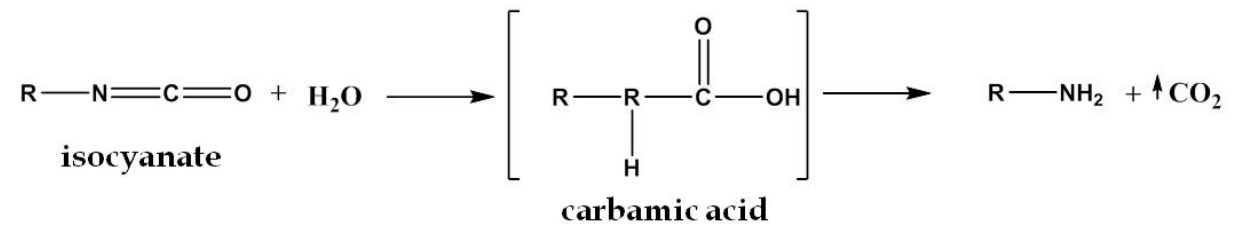

b)

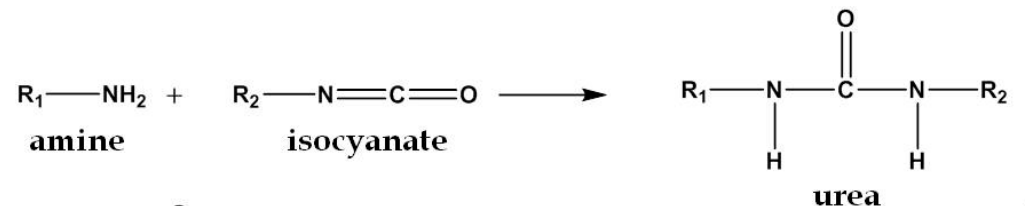

c)

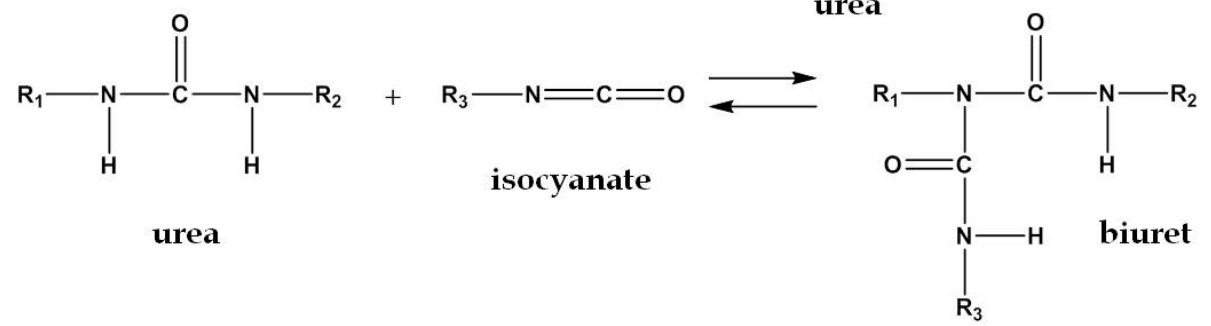

d)
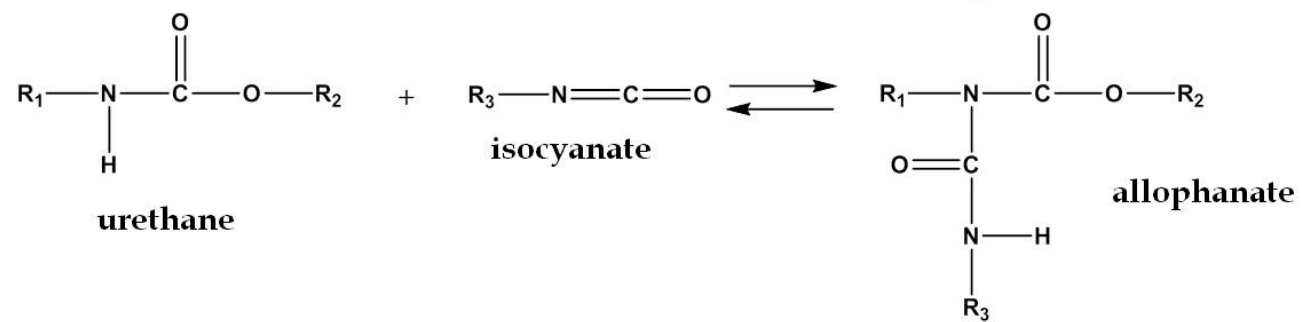

e)
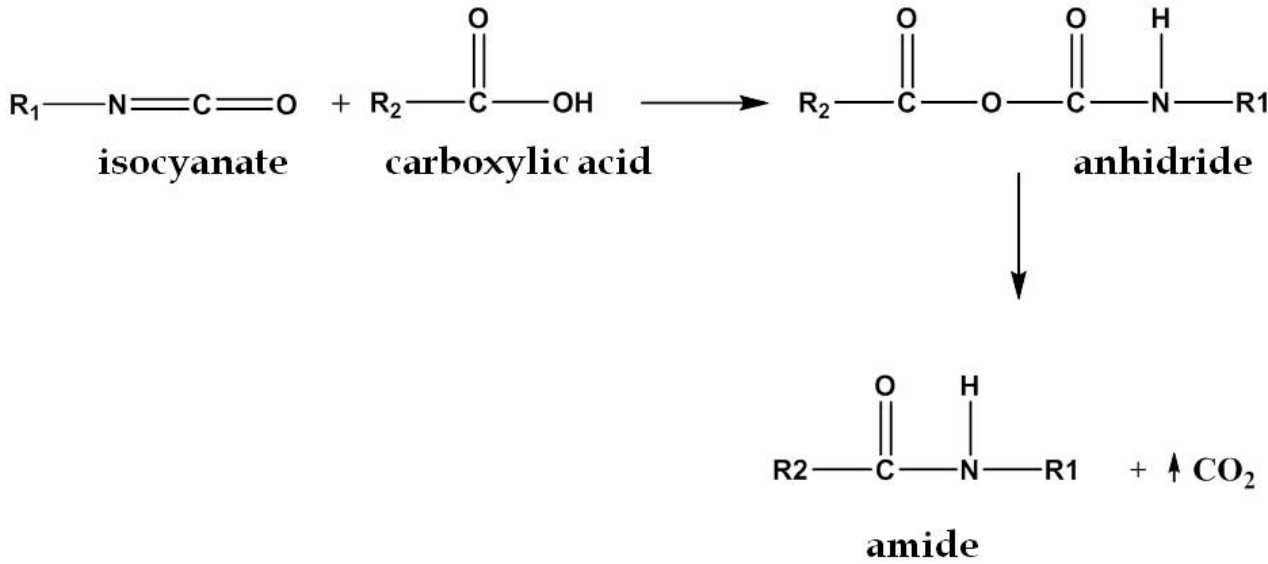

Figure 2.7. Other chemical reactions taking place during polyurethane formation.

The resulting amine group from the reaction of isocyanate and water reacts with unreacted isocyanate to produce urea groups (Figure $2.7 \mathrm{~b}$ ). The nitrogen of the urea groups is also a nucleophile, which reacts with isocyanate to generate biurets (Figure $2.7 \mathrm{c}$ ). Even the resulting urethane groups have an affinity towards the isocyanate groups forming allophanates (Figure 2.7 d) [15-17].

Furthermore, the isocyanates can dimerize forming uretidiones or even trimerize generating cyclic compounds known as isocyanurates.

All these reactions contribute to the final properties of the PU foam. Other aspects such as temperature, the presence of catalysts and the chemical structure of the $\mathrm{R}$ group 
bonded to the isocyanate groups play a key role in the structure and properties of the final material. As a result, depending on this radical, two types of PU foams can be synthesized: rigid or flexible PU foams [15-17].

Typically, two types of diisocyanates are used in the industrial production of PU foams: methylene diphenyl isocyanate (MDI) and toluene diisocyanate (TDI). Typically, MDI is used in the production of rigid PU foams, while TDI is more commonly employed in the fabrication of flexible PU foams.

Thanks to the versatility of the PU foams and the easiness of their fabrication process, these materials are widely used in daily applications. Rigid PU foams are mostly used for thermal insulation in a wide number of applications and sectors such as building and construction, appliances or in the automotive sector [26-30]. The use of flexible PU foams is mainly connected to comfort, as in the case of furniture and bedding, or to sound absorption applications [31-39].

\subsubsection{Market relevance and main properties}

Observing their vast range of applications, it can be imagined that PU foams have considerable importance inside the polymers consumption. According to the report “The Economic Benefits of the U.S. Polyurethanes Industry 2017" from the American Chemical Council, PU has an impact of $\$ 37.9$ in output and 55600 jobs depend directly on the production of polyurethane only in the United States [40].

Table 2.1 shows the percentage of total pounds of polyurethane materials consumed by each major end-use market, according to a survey published by The Centre for the Polyurethane Industry (CPI) [40].

\begin{tabular}{|cc|}
\hline MARKET & \% OF TOTAL \\
\hline Building and construction & 37.7 \\
\hline Furniture and bedding & 20.1 \\
\hline Transportation and marine & 19.4 \\
\hline Machinery and foundry & 5.9 \\
\hline Appliances & 5.2 \\
\hline Packaging & 3.7 \\
\hline Textiles, fibers and apparel & 0.7 \\
\hline Electronics & 0.6 \\
\hline Footwear & 0.3 \\
\hline Other uses & 6.4 \\
\hline Table 2.1. U.S. polyurethane consumption by end-use market (2016) [26].
\end{tabular}

Building and construction constitute by far the main end-use market for polyurethane, and it is followed by furniture and bedding. As it can be observed in Table 2.1, the number of applications of polyurethane foams is immense. Furthermore, the economic forecasts announce a continuous growth in the revenues generated by the production and commercialization of this material for the next years. 
According to the report "Global Polyurethane Foam Market 2016-2020", 52.6\% of the market share in 2016 of PU foams corresponded to flexible PU foams [41]. Furthermore, a compound annual growth rate (CAGR) of $8 \%$ is expected for flexible PU foams from 2016 to 2020, indicating that the economic impact of flexible PU foams in the market is significant nowadays and would keep an incremental trend in the coming years (Figure 2.8).

GLOBAL POLYURETHANE FOAM MARKET BY TYPE (2016)

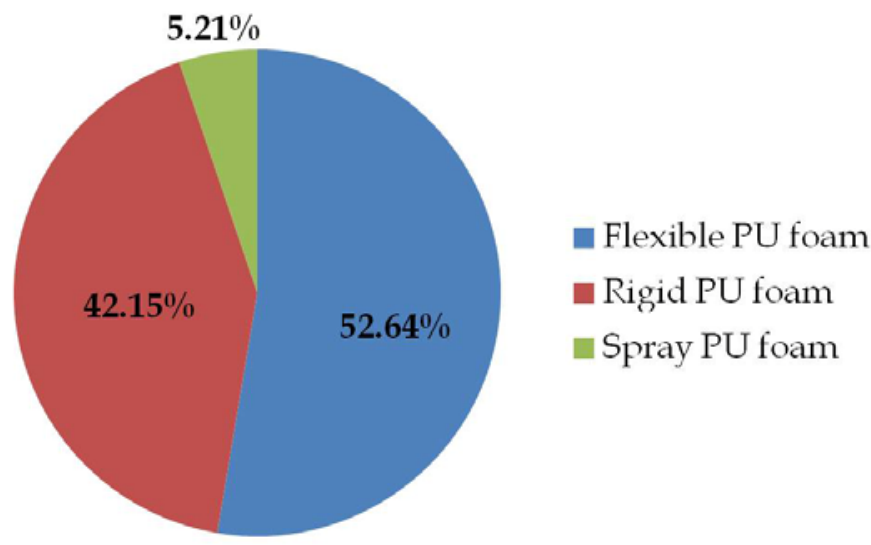

Figure 2.8. Global polyurethane foam market by type.

The largest segment of PU foams corresponds to flexible ones. These materials PU foams can be classified according to different parameters or associated aspects such as their chemistry or their production processes, as it is schematized in Figure 2.9:

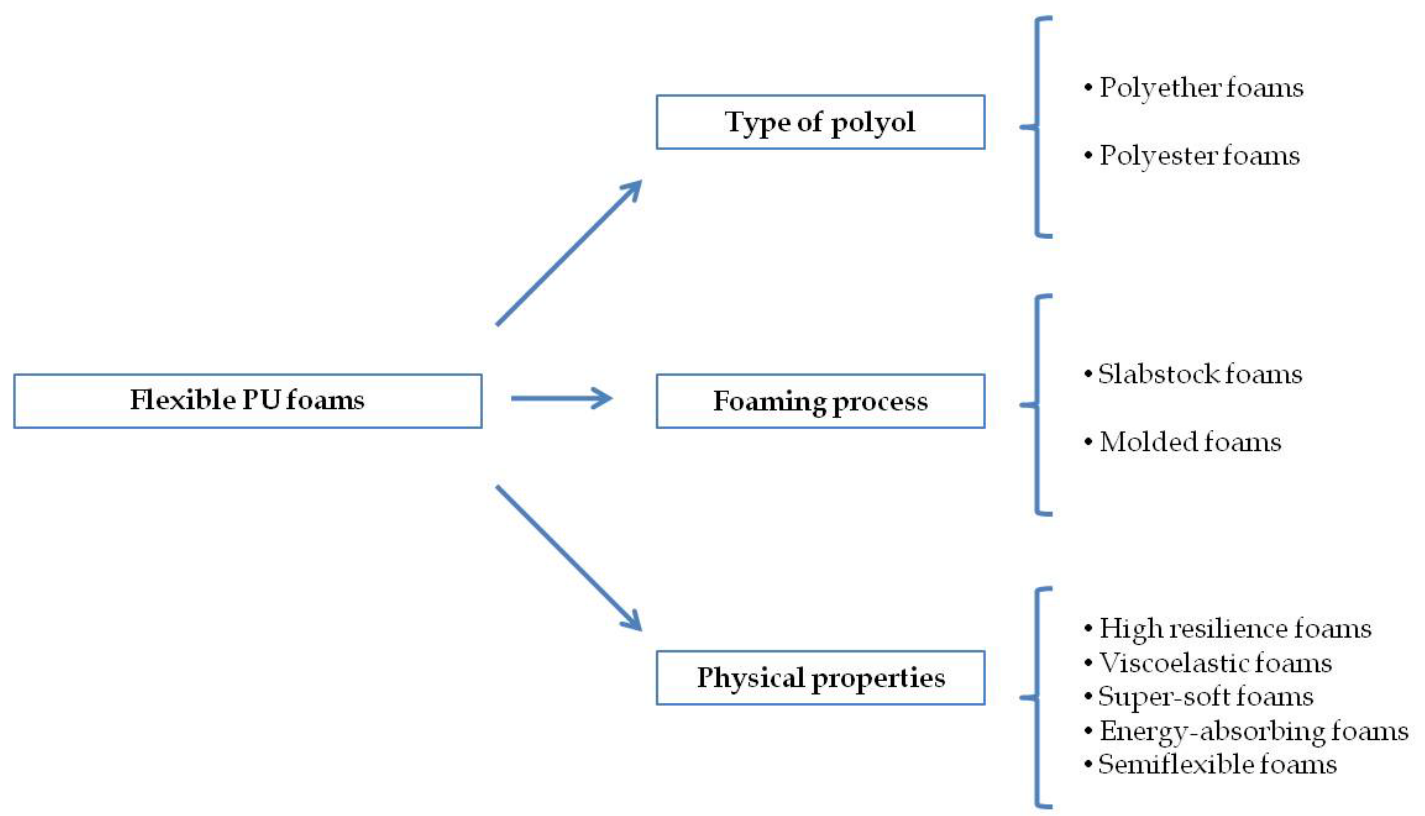

Figure 2.9. Classifications of flexible PU foams. 
The physical properties of flexible PU foams can vary considerably from one type to other types of foams, and as for other types of foamed materials, they are mostly conditioned by density, the properties of the polymeric matrix and the morphology of the cellular structure.

For example, high resilience and viscoelastic foams are mainly used in mattresses, although their physical properties are quite different. The high resilience foam has a high response after compression, whereas the viscoelastic foams, also known as memory foams, present a slow response after compression.

This is an example of the many possibilities offered by polyurethane foams. The combination of three key points: chemical composition, the morphology of the cellular structure and density can result in materials with significantly different properties able to cover a vast spectrum of potential applications.

To evidence the previous fact, the properties of both closed-cell and open-cell foams showing two different density ranges below $100 \mathrm{~kg} / \mathrm{m} 3$ (around 70-80 kg/m3 and around $30 \mathrm{~kg} / \mathrm{m} 3$ ) are displayed on the following table ( Table 2.2):

\begin{tabular}{|c|c|c|c|c|c|}
\hline FOAM & $\begin{array}{l}\text { Density } \\
\left(\mathrm{kg} / \mathrm{m}^{3}\right)\end{array}$ & $\begin{array}{l}\text { Young's } \\
\text { modulus } \\
(\mathrm{kPa})\end{array}$ & $\begin{array}{l}\text { Compressive } \\
\text { strength } \\
(\mathrm{kPa})\end{array}$ & $\begin{array}{c}\text { Compressive } \\
\text { stress (kPa) } \\
50 \% \text { strain }\end{array}$ & $\begin{array}{l}\text { Thermal } \\
\text { conductivity } \\
(\mathrm{W} / \mathrm{m} \cdot \mathbf{K})\end{array}$ \\
\hline $\begin{array}{l}\text { Closed-Cell- } \\
\text { High Density }\end{array}$ & $75-85$ & $330-400$ & $25-30$ & $31-35$ & $0.024-0.028$ \\
\hline $\begin{array}{l}\text { Open-Cell- } \\
\text { High Density }\end{array}$ & $60-70$ & $20-50$ & $1.2-2.5$ & $6.0-8.0$ & $0.027-0.032$ \\
\hline $\begin{array}{l}\text { Open-Cell- } \\
\text { Low Density }\end{array}$ & $26-32$ & $10-30$ & $2.0-3.0$ & $4.0-5.0$ & $0.025-0.028$ \\
\hline
\end{tabular}

Table 2.2. Physical properties of rigid and flexible PU foams.

But, mattresses are not the unique application of these foams. Viscoelastic foams are also used in cushions, wheelchair seats, aeroplane seats or in many sports items, such as mats, leg guards or helmets.

Semiflexible and energy-absorbing $P U$ foams are required for other types of applications due to their different properties. These foams can absorb a considerable amount of energy, being essential for structural applications in the automotive, where they are employed as bumper cores, door panels or headliners.

In addition to applications related to the mechanical response, open-cell PU foams are also excellent sound absorbers. The outstanding capacity of the open-cell PU foams to absorb sound is a strong benefit of these materials, being used in many applications related to this property, such as engine covers in the automotive or aeronautic sectors [42].

The vast number of applications covered by flexible PU foams is shown in the following scheme (Figure 2.10) [5]. 


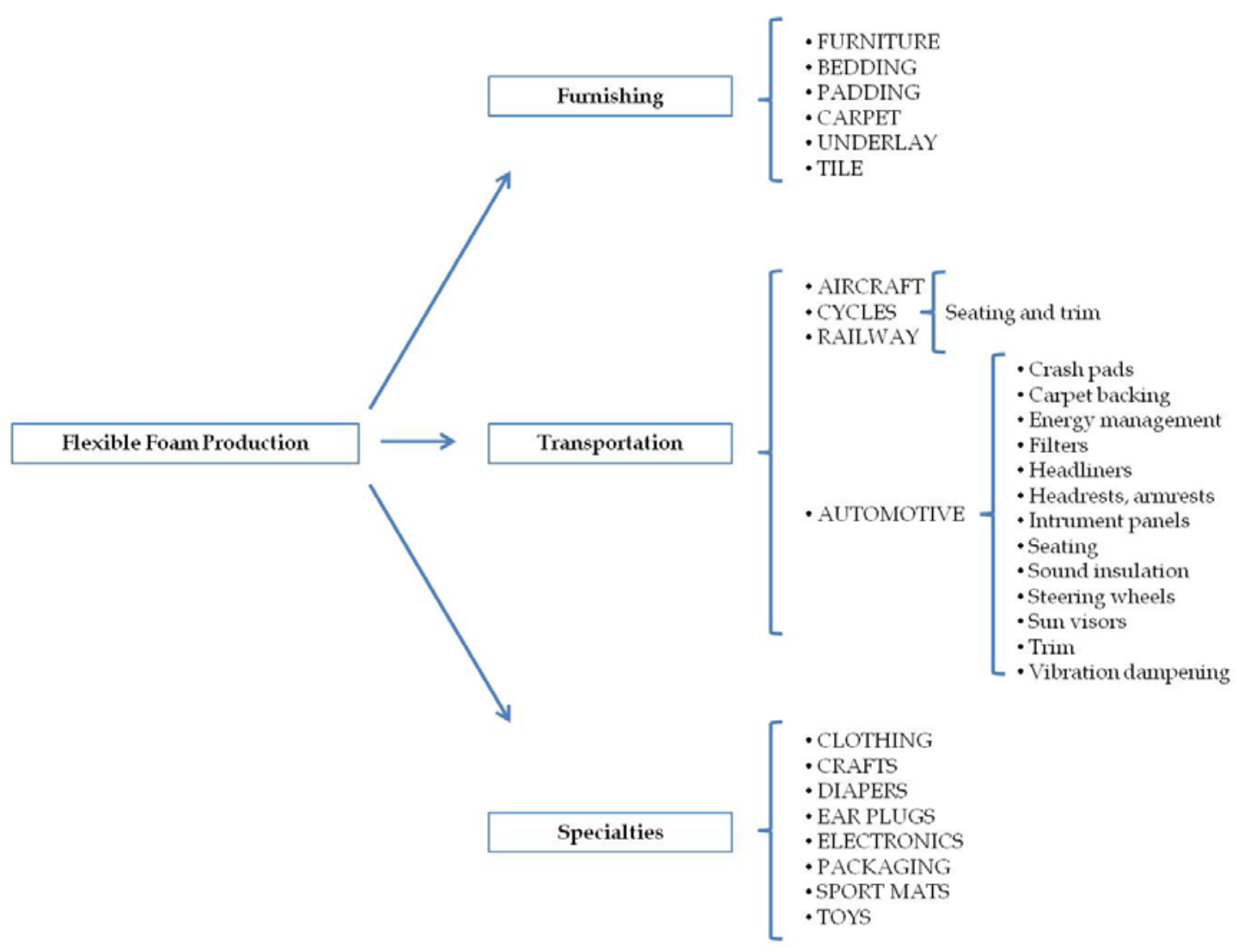

Figure 2.10. Scheme of the main applications of flexible PU foams.

This scheme helps us to understand the importance of PU foams in the field of materials. PU foams are versatile materials, which have a critical importance from economic and applicability points of view, and consequently, it is important to stand out their contribution to the society. However, PU foams also have their limitations, and this aspect is addressed in the following section.

\subsubsection{PU foams: problematic and limitation}

Polyurethane foams present many benefits from the economic and from the commercial point of views, supported by its remarkable physical properties and performance. However, polyurethane is also connected with a serious problematic: the toxicity of the isocyanates.

According to the Occupational Safety and Health Administration (OSHA): "health effects of isocyanate exposure include irritation of skin and mucous membranes, cheat tightness, and difficult breathing. Isocyanates include compounds classified as potential human carcinogens and known to cause cancer in animals. The main effects of hazardous exposures are occupational asthma and other lung problems, as well as irritation of the eyes, nose, throat and skin" [43].

Due to these hazardous effects, some policies are conducted to restrict the use of some types of isocyanates. For example, the European Chemicals Agency (ECHA) published 
a restriction proposal on diisocyanates "to prevent new cases of occupational asthma from exposure to diisocyanates among industrial workers and professionals" [44].

Not only isocyanates can be considered as a real danger for human health, but also there is a considerable risk when polyurethane foams burn. Toxic fumes are released when polyurethane is burnt, and this is a crucial aspect during a fire because the inhalation of these fumes can cause serious respiratory problems and even death [45].

Many authors have analyzed the gaseous composition of the gases released by polyurethane at several temperatures. Gharehbagh and Ahmadi studied the temperature range of decomposition of the products formed during the polyurethane reaction [46]. According to this study, biuret and allophonates are products with the lowest decomposition temperature (around 120 - $125^{\circ} \mathrm{C}$ ). Ureas and urethanes decompose in a temperature range from 160 to $200{ }^{\circ} \mathrm{C}$. Substituted ureas decompose at higher temperatures $\left(235-250^{\circ} \mathrm{C}\right.$ ), then carbodiimides (between 250 and $280{ }^{\circ} \mathrm{C}$ ) and finally the isocyanurates, whose decomposition temperature oscillates between 270 and $300^{\circ} \mathrm{C}$.

However, the critical danger starts at higher temperatures $\left(600^{\circ} \mathrm{C}\right)$ with the release of a "yellow smoke" firstly reported by Woolley in 1972 (Woolley gas) [47]. This study indicated that this smoke contained partially polymerized isocyanates and droplets of isocyanate from the foam. Furthermore, Woolley also detected low molecular weight nitrogen products, such as hydrogen cyanide, acetonitrile, acrylonitrile, pyridine and benzonitrile [48]. Subsequent studies also confirmed the presence of these products in the fumes released by polyurethane $[49,50]$. It is important to mention here, that a lethal gas such as hydrogen cyanide is formed during the decomposition of polyurethane at high temperatures. The dangers and hazardous effects of hydrogen cyanide are well-known, being this fact a critical issue for some applications of PU foams [51].

Ravey and Pearce suggested that up to $360{ }^{\circ} \mathrm{C}$ the decomposition followed first depolymerization to isocyanates and second the dissociation to a primary amine, an olefin and $\mathrm{CO}_{2}$ [52]. Allan et al. supported the mechanism proposed by Ravey and Pearce, but no amines were detected in the gaseous phase. Instead, polyureas formed part of the gaseous phase [53]. Garrido and Font also confirm the presence of isocyanates in the Wooley gas owing to the decomposition of urethane bonds with temperature [54]. They also affirmed that the degradation of alcohols started at $400{ }^{\circ} \mathrm{C}$.

One other interesting study performed by Chun et al. concluded that the chemical differences between rigid and flexible PU did not play a key role in the decomposition temperature [55]. According to this study, rigid PU foams decomposed between 200 and $410{ }^{\circ} \mathrm{C}$ whereas the temperature range of decomposition of flexible PU foams varied between 150 and $500{ }^{\circ} \mathrm{C}$. They attributed these differences to the physical form of the polyurethanes. 
Despite the outstanding properties of polyurethane foams, the problematics associated to the use of isocyanate based compounds, the release of toxic fumes in case of fire, and other disadvantages of these materials such as their high moisture uptake or their poor UV and chemical resistance has driven the interest of both academia and industry to search for potential alternatives to both closed and open-cell PU foams.

This thesis, in clear alignment with this demand, has as main technical objective: Evaluating the potential of materials, which could display the characteristics and properties exhibited by open-cell PU foams, but with noticeable improvements from an environmental point of view. As it will be explained in the next section, open-cell polyolefin foams were selected as the candidates to replace open-cell PU materials in different sectors. Among the vast range of applications of flexible PU, four different key sectors (comfort, sound absorption, oil absorption and vibration dampening) where flexible open-cell PU foams are indispensable items, have been selected to prove the viability of the novel materials developed and analyzed during this thesis.

\subsection{Crosslinked cellular polymers based on polyolefins}

\subsubsection{General concepts}

Polyolefins are the resulting polymers formed by the polymerization of olefins [56,57]. Olefins are alkanes with a chemical formula $\mathrm{C}_{n} \mathrm{H}_{2 n}$. The first reported case concerning the production of polyolefins dates from 1933 when Eric Fawcett and Reginald Gibson obtained low-density polyethylene (LDPE) from pure ethylene by applying pressure and temperature [58].

However, the major revolution in the field of polyolefins arose from the advances in the development of new catalysts for the polymerization reaction. In the 1950s, Karl Ziegler produced high-density polyethylene (HDPE) using new catalysts based on titanium [59]. In 1954, the generation of polypropylene (PP) was first reported by Giulio Natta [60]. Both Natta and Ziegler shared the Nobel Prize in 1963 due to their outstanding contributions to the field of polymers (Figure 2.11).

a)

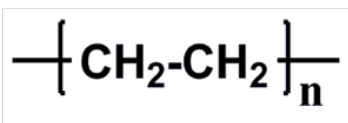

b)

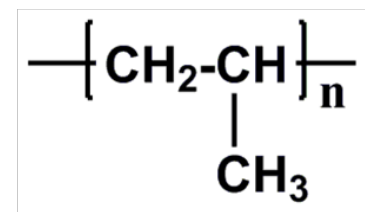

Figure 2.11. Chemical structure: a) low-density polyethylene (LDPE) and b) polypropylene (PP).

Polyolefins cover a wide range of materials, from various types of polyethylene, polypropylene, ethylene propylene diene monomer (EPDM) or different copolymers such as ethylene vinyl acetate copolymer (EVA) or ethylene butyl acrylate copolymer (EBA). Depending on the type of polyolefin, a vast range of properties is covered by these polymers [61,62]. For example, LDPE stands out for its flexibility, whereas PP has 
high stiffness. In general, polyolefins present high chemical resistance and high hydrophobicity.

The production and consumption of polyolefins are increasing year by year. The excellent properties exhibited by these polymers make them very interesting for many applications. According to the data published by PlasticsEurope, PP and LDPE were the two most demanded polymers in the year 2017 (Figure 2.12) [63].

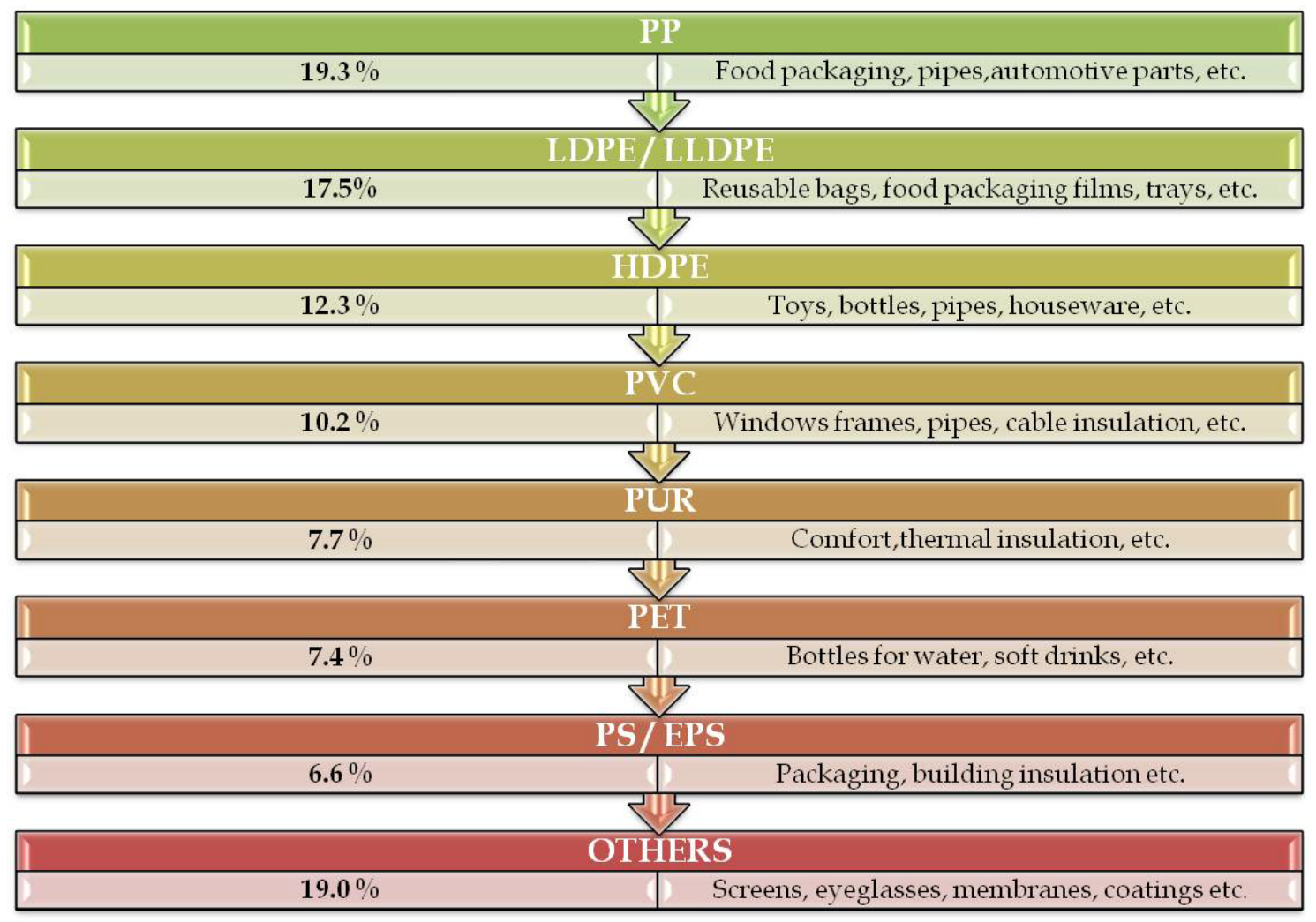

Figure 2.12. Type of resins ( $\%$ of use) and applications.

Polyolefins cover around $50 \%$ of the total plastics demand. The immense number of applications of these materials can also be observed in this figure. PP is used in automotive parts, pipes or food packaging whereas LDPE is used in reusable bags, food packaging or trays, among others.

However, many policies are conducted to reduce the consumption of plastics, and even society is becoming aware of this problematic. As a result, it is mandatory to look for alternatives to plastics, which is almost impossible in many applications, or increasing the consumption of recycled plastic. One of the most promising alternatives to reduce the plastic consumption is the substitution of solid parts by their foamed counterparts. It is possible to substitute a certain percentage of the plastic employed to fabricate a certain item by a gas introduced in the system during the manufacturing process. Due to their many advantages, including the reduction of weight and the use of raw materials, foaming has gained the attention of several relevant industrial sectors such as packaging or the automotive one. 
Despite all those facts, the main advantage associated with foaming is that it permits widening the range of application of polymers. In the case of polyolefins, the fabrication of cellular materials extends the demand of these products to applications difficult to be covered by the solid materials, such as impact protection or vibration dampening elements, shoe soles, thermal insulating materials or energy absorbing products.

Polyolefin-based foams can be classified according to their density in three groups: high-density foams (density over $500 \mathrm{~kg} / \mathrm{m}^{3}$ ), foams with intermediate densities (range between 100 and $500 \mathrm{~kg} / \mathrm{m}^{3}$ ) and low-density foams (below $100 \mathrm{~kg} / \mathrm{m}^{3}$ ). The density is a key parameter and profoundly affects the final properties of the foams. While highdensity foams are required for structural purposes or wiring, low-density foams are more suitable for other applications such as packaging or thermal insulation $[2,5,64]$.

Focusing on low-density foams, which are the types of materials produced and analyzed in this thesis, these foams can be classified considering another criteria, shape and manufacturing process, in the three groups, as it is shown in the scheme corresponding to Figure 2.13.

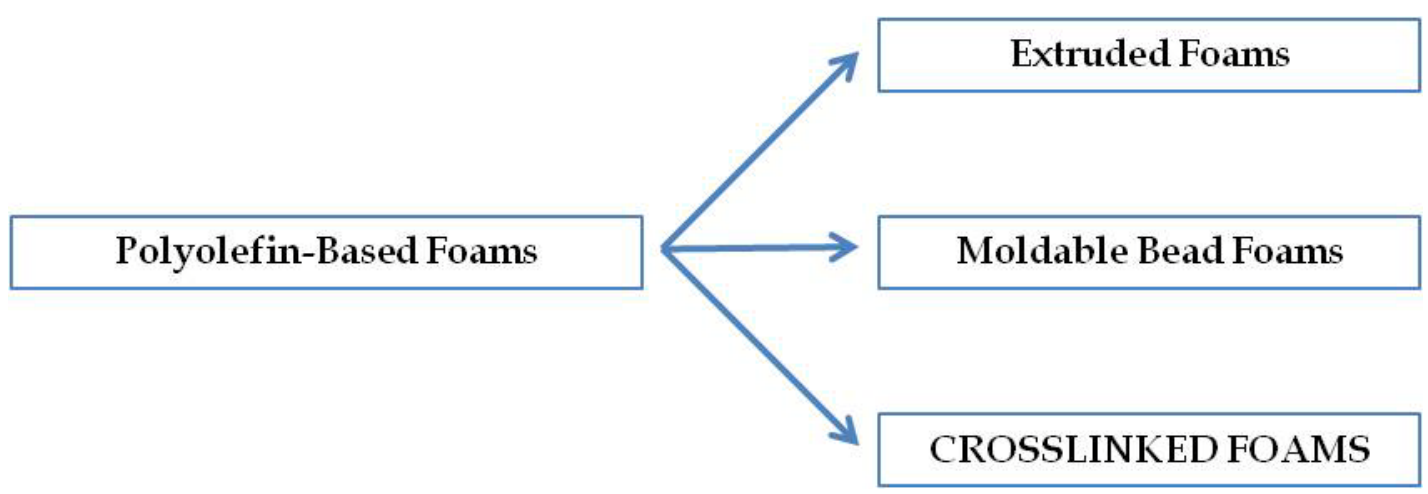

Figure 2.13. Classification of the polyolefin-based foams according to the shape and manufacturing processes.

As it is remarked in Figure 2.13, this thesis is based on the production of crosslinked polyolefin-based foams, and therefore, extrusion and bead foaming are not covered in this thesis.

In the following section, it is discussed the different alternatives currently used at industrial scale to produce crosslinked polyolefin foams, describing the different fabrication technologies and the final foamed products profoundly.

\subsubsection{Production processes}

To generate low density foams using processes implying the use of high temperatures, where chemical blowing agents are typically employed, it is necessary to modify the molecular architecture of the polymer in order to get a system displaying a behavior in the molten state that would enable the expansion of the polymer to the very stringent conditions imposed by the high expansion ratios that are necessary to be reached to achieve such low densities. 
In Figure 2.14, it can be observed how the processing window of the crosslinked PE is located in the area of optimum viscosity for producing low-density foams, whereas the steep fall in viscosity in non-crosslinked PE prevents its use for this purpose [5]. Common resins, such as LDPE or EVA, cannot withstand this pressure by themselves and an additional reaction must take place in the polymer matrix before the decomposition of the blowing agent: the crosslinking of the polymer matrix. As will be explained in the successive chapters of this thesis, crosslinking is the covalent bonding between adjacent chains of the polymers. By the crosslinking reaction, the viscosity of the polymer matrix increases, allowing the production of cellular polymers with very low densities. Branched polymers such as LDPE, EVA or EBA are easier to crosslink than linear polymers such as HDPE or PP, and this is an additional reason for using these polymer matrices (LDPE, EVA and EBA) during this research [65-67].

The crosslinking reaction, the processes available to produce this reaction and the advantages and disadvantages associated to them are explained in depth in Chapter 3 section 3.4.

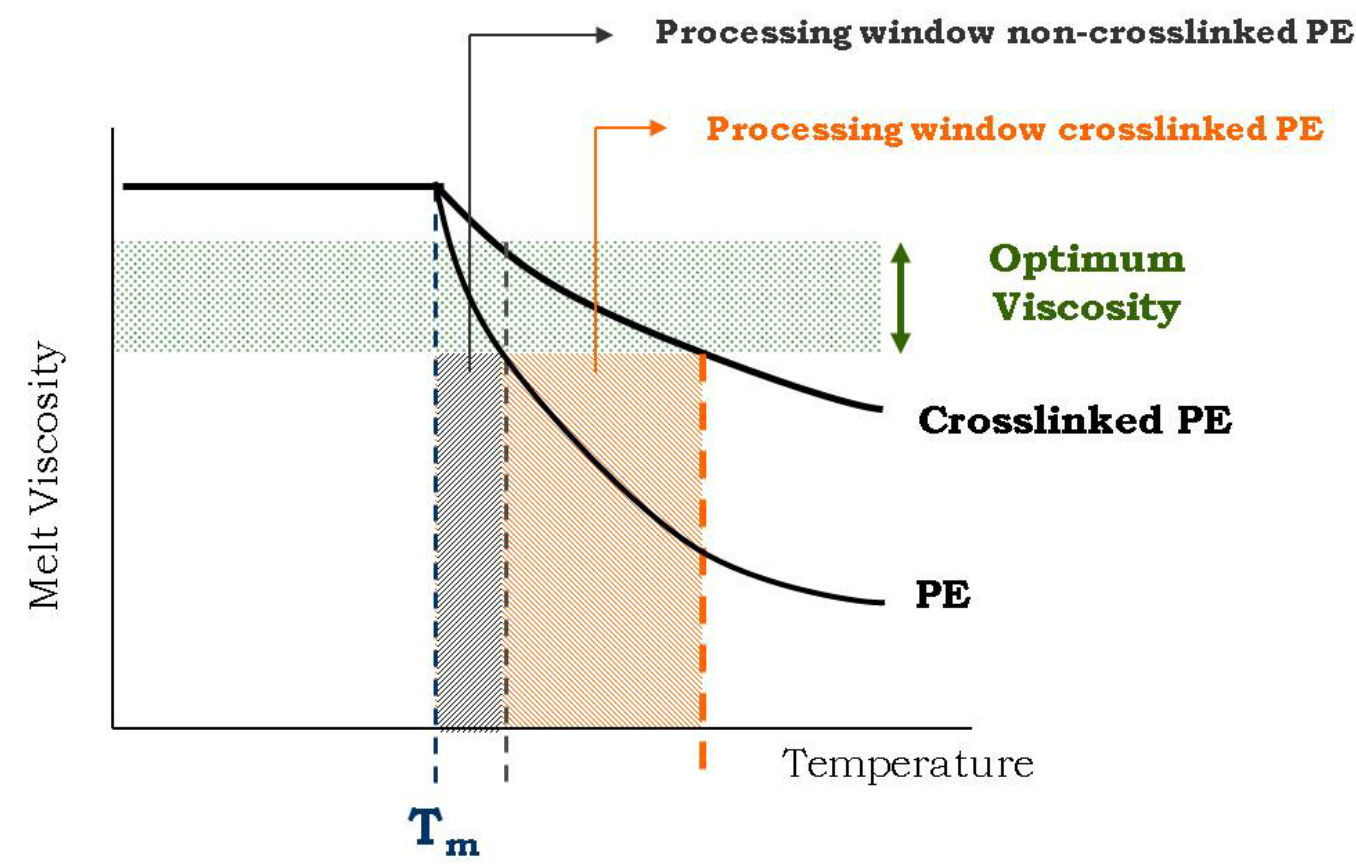

Figure 2.14. Processing windows of non-crosslinked and crosslinked PE.

Crosslinked polyolefin cellular materials can be produced by using either continuous or discontinuous processes (Figure 2.15). The main difference between them is that the continuous processes generate foamed rolls while the discontinuous ones are used to produce net-shaped parts or blocks. One the one hand, in a continuous process, the crosslinking and the blowing agent decomposition processes take place in the same oven one just after other, and it is used to produce sheets, or rolls of closed-cell foamed materials $[68,69]$. In continuous production, two processes can be distinguished depending on if the foams are physically (high energy sources such as electron irradiation) or chemically (using peroxides or silanes) crosslinked. When physical 
crosslinking is used, the thickness is limited to $10 \mathrm{~mm}$ due to the limited penetration of the beam in the plastic. Other processes are linked to the production of block foams with higher thicknesses than those obtained in the continuous processes.

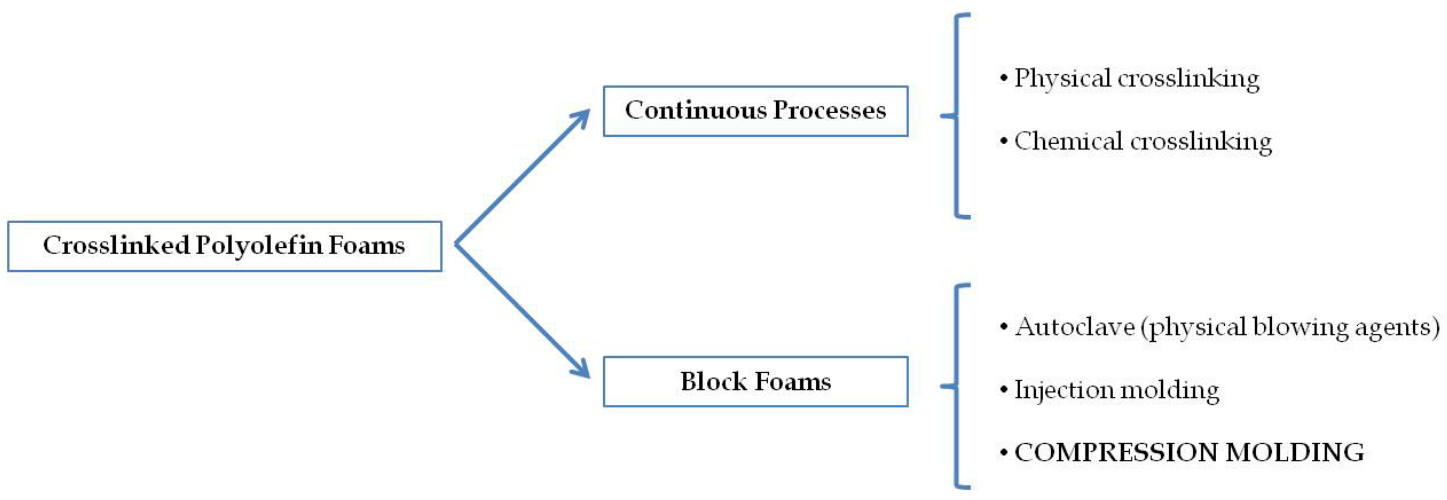

Figure 2.15. Classification of the fabrication processes used in the production of crosslinked polyolefin foams.

Those processes are described in the following sections. The particularities, advantages and disadvantages displayed by each of them are also summarized.

\subsubsection{Continuous processes}

Continuous processes are used in the production of closed-cell polyolefin sheet foamed products. This technology was developed by several Japanese companies in the 60s and 10s [69-72] of the previous century. Two different methodologies can be distinguished depending on how the polymer is crosslinked: physical crosslinking or chemical crosslinking $[5,73]$.

\section{- Physical crosslinking}

This process was designed by the Japanese companies Sekisui Chemical and Toray Industries. The process has three steps: the mixing of the polymer and blowing agent by extrusion to produce sheets, the crosslinking of the sheets and the foaming process (Figure 2.16).

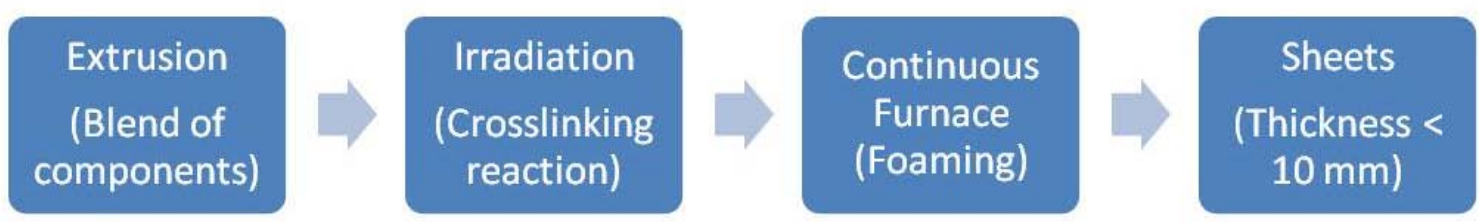

Figure 2.16. Scheme of the production of crosslinked polyolefin foams by using a continuous process: physical crosslinking.

The components of the formulation (polymer matrix, blowing agent and other additives) are blended in an extruder to produce solid sheets (Figure 2.17). The decomposition of the blowing agent must be avoided during the mixing process. Thus, it is quite important to control the temperature in the extruder and the revolutions of the screw to avoid a massive shear which could increase the temperature of the mix dramatically. In some cases, before introducing the raw materials in the extruder, they 
are previously mixed in a Banbury type mixer or in a two-roll mill to improve the homogeneity of the blend especially in the case of using powdery blowing agents. To avoid the lack of homogeneity of the blends, it is common to use blowing agents in masterbatch form to facilitate the mix with the polymer matrix. Once the extruded sheet comes out of the extruder, it is immediately cooled by using a calendering system. The thickness of the sheets is controlled by the dimensions of the die gap and by the distance between the cooling rolls.

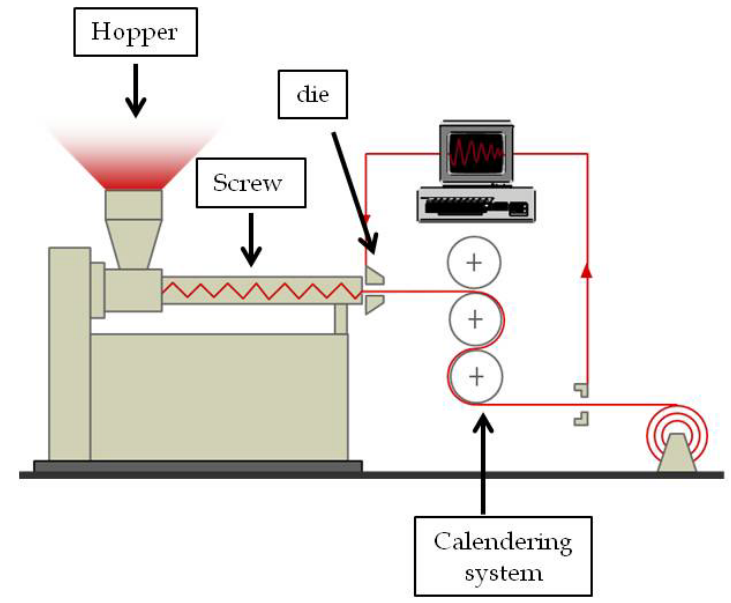

Figure 2.17. Scheme of the extrusion process used to produce the solid sheets.

During the second step, the sheet is crosslinked by using electron beam irradiation (see Chapter 3, section 3.4) (Figure 2.18). High energy radiations are able to cleave the strong $\mathrm{C}-\mathrm{H}$ chemical bond generating energetically unstable radicals in the polymer chain. The active sites react bonding the polymer chains covalently.

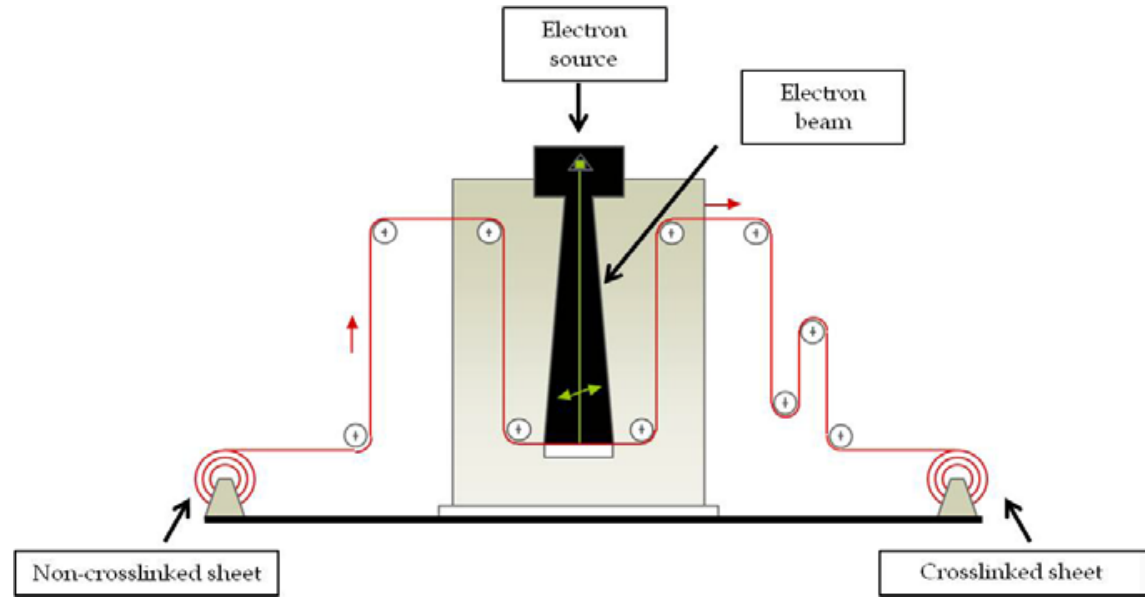

Figure 2.18. Scheme of the physical crosslinking process using high energy sources (electron beam irradiation).

In the third and last step, the solid crosslinked sheet is introduced in a furnace which can be either horizontally or vertically configured (Figure 2.19). The sheets go through the oven on coated (to avoid sticking of the polymer) conveyor belts. The furnace is comprised of different zones. The first one is a preheating chamber, where the crosslinked sheet is heated to about $150-160{ }^{\circ} \mathrm{C}$. Then, the sheets start to expand when 
they enter in the foaming chamber (higher temperature), where the foaming process is performed.
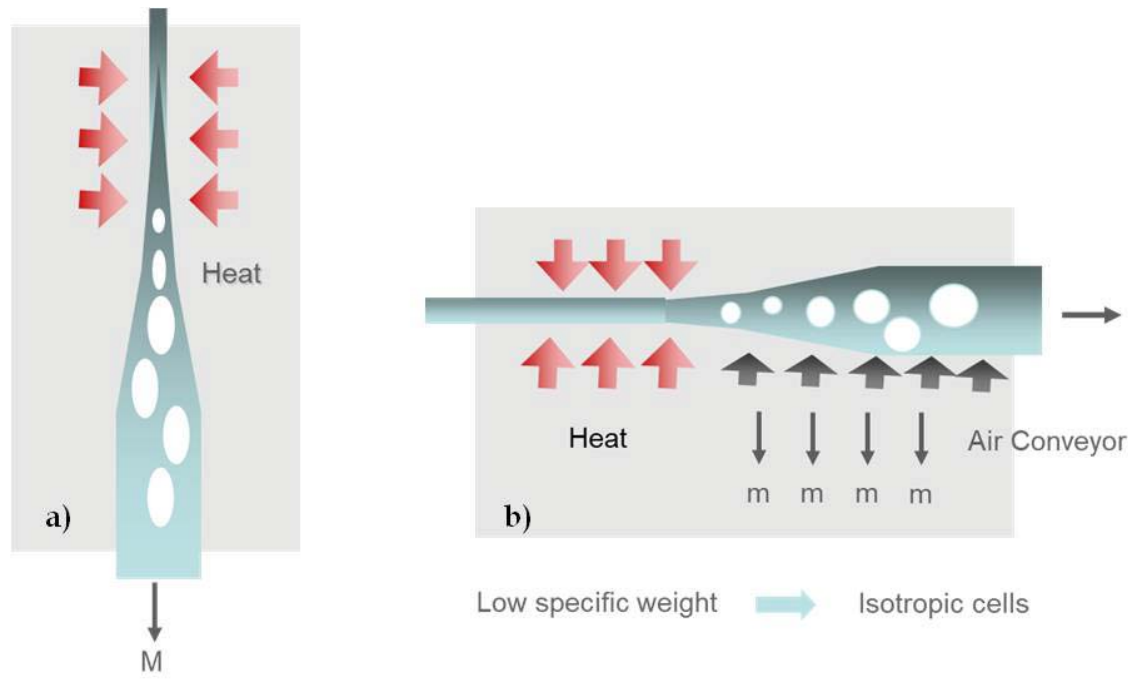

Low specific weight $\Rightarrow$ Isotropic cells

Figure 2.19. Scheme of the foaming process: a) vertical oven and b) horizontal oven.

The main advantages of this process are the absence of residues coming from the crosslinking process since the physical crosslinking is a clean process and the production of homogeneous foams with a narrow cell size distribution. However, this process presents also some disadvantages, such as the high investments needed for the installation of high energy sources and the limitation in thickness. The thickness of the rolls is limited to less than $10 \mathrm{~mm}$ due to the limited penetration of the beam. Higher thickness than $10 \mathrm{~mm}$ would be quite complex to crosslink homogeneously by using this methodology.

\section{- Chemical crosslinking}

Like the previous one, this process is commonly used nowadays in the production of crosslinked polyolefin foamed sheets. The scheme of the process is shown in Figure 2.20:
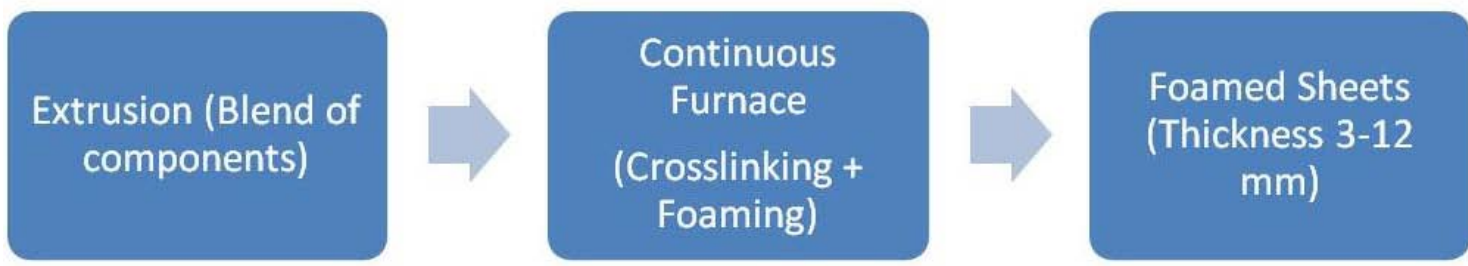

Figure 2.20. Scheme of the production of crosslinked polyolefin foams by using a continuous process: chemical crosslinking.

The initial step is similar to the one described for the physical crosslinking. However, it must be taken into account that the formulation also contains the chemical crosslinking agent. Previously, it was discussed about the accurate control of the temperature process to avoid the blowing agent decomposition. Here, this becomes more critical, 
since the chemical crosslinking agent (typically an organic peroxide) decomposes at lower temperatures than the blowing agent.

Once the sheets are produced, they are introduced in a horizontal furnace (the vertical version cannot be used since the sheet is not already crosslinked when it is introduced in the oven), which is divided in two parts: the preheating area at $180{ }^{\circ} \mathrm{C}$, where the sheets are partially crosslinked, and the foaming chamber $\left(240{ }^{\circ} \mathrm{C}\right)$, where the sheets are completely crosslinked and foamed (Figure 2.21).

The positive points of this process are the low cost, the easiness of the installation and the possibility of producing foams with higher thicknesses than those obtained with physical crosslinking. The main drawbacks are the presence of residues in the foam coming from the organic peroxides and depending on the final application, the large cell size obtained.

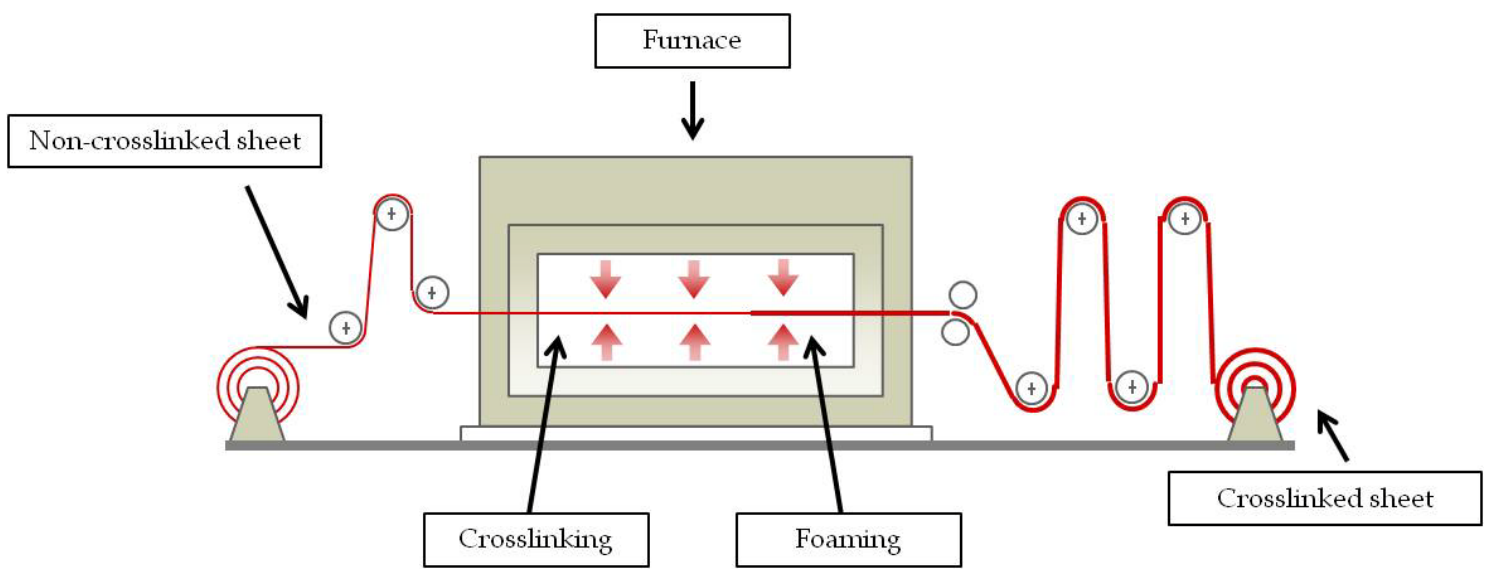

Figure 2.21. Scheme of the chemical crosslinking process using crosslinking agents (peroxides or silanes).

\subsubsection{Discontinuous processes}

The discontinuous processes are typically employed to produce net-shaped parts or blocks with sizes ranging around $2 \mathrm{~m} \times 2 \mathrm{~m}$ in section and between $0.1-0.2 \mathrm{~m}$ in thickness. Block foams are produced by batch processes in which the blowing agent used can be either a chemical blowing agent, like in the continuous process, or a physical blowing agent, mainly nitrogen.

Batch processes allow the production of thicker closed-cell polyolefin foams than those obtained in the continuous processes, extending the possibilities of the foamed products.

The production of block foams can be performed by using three different processes: autoclave, injection molding and compression molding (Figure 2.15).

Each process is explained below, paying special attention to the compression molding process, since it is the one that has been used in the production of the materials developed during this study $[5,73]$. 


\section{- Autoclave}

The autoclave process was developed by the British company Zotefoams Plc. In this process, a gas (nitrogen) is dissolved in the polymer matrix [74]. The process consists of several steps, some of them identical to the ones described in the previous section.

The scheme of the process is displayed in Figure 2.22:

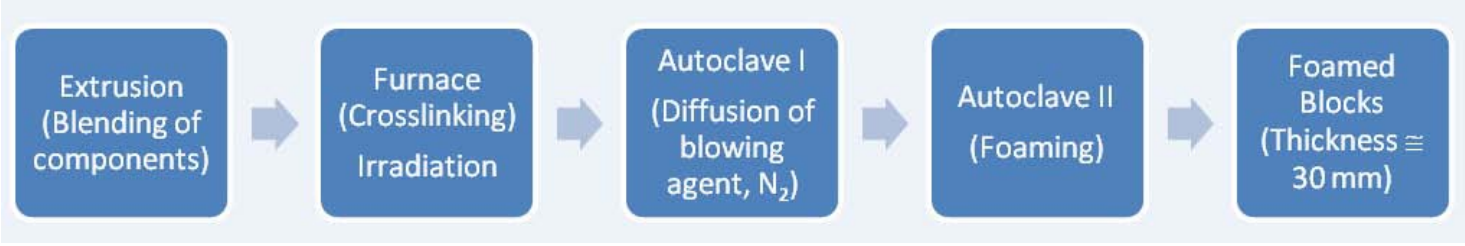

Figure 2.22. Scheme of the production of crosslinked polyolefin foams by using a batch process: autoclave.

First, the components of the formulation are blended in an extruder to produce sheets. The formulation consists of the polymer matrix and other additives. Both physical and chemical crosslinking processes are used in this technology. The choice of the crosslinking process depends on the type of polymeric matrix. Chemical crosslinking is performed when polymers with low melting points are used (EVA or LDPE). However, physical crosslinking is required when the melting point of the polymeric matrix is high (HDPE) and near to the decomposition temperature of the crosslinking agent, which could promote the premature decomposition of it in the extruder.

After the extrusion blending, the crosslinking process is performed, and depending on the polymeric matrix, this process can be carried out in a furnace under temperature if chemical crosslinking agents are included in the formulation or at room temperature by irradiating the sheet with electrons.

Samples of desirable dimensions of the crosslinked sheets are introduced in a pressure vessel, and the nitrogen is dissolved in the polymer matrix by applying high pressures, up to $70 \mathrm{MPa}$ at temperatures close to the melting point of each particular polymeric matrix (Figure 2.23). Nitrogen is used since the diffusion rate of it, and the air is identical, whereas if other physical blowing agents, such as carbon dioxide, are employed, the foam can suffer from shrinkage due to the different diffusion rates of air and carbon dioxide [75]. 


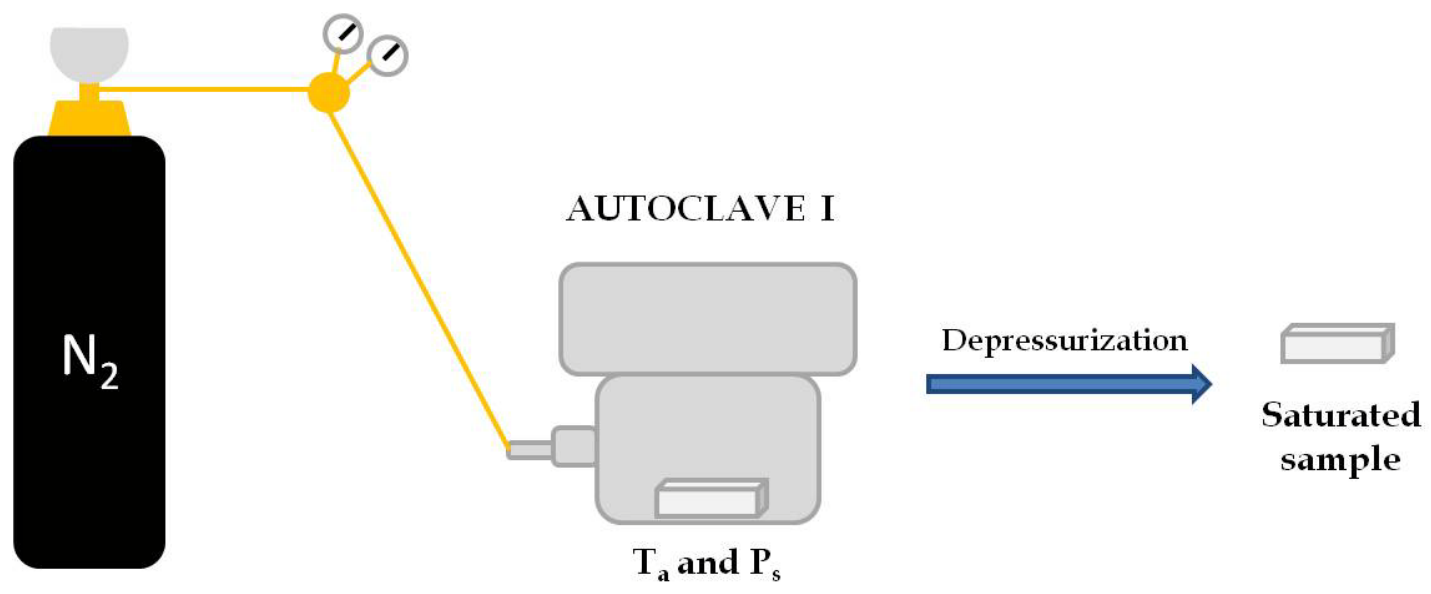

Figure 2.23. Scheme of the saturation of the sheet with physical blowing agents (nitrogen).

A rapid pressure drop induces nucleation and the materials partially expand. The partially foamed materials are introduced in a second autoclave (temperature above the melting point of the polymeric matrix), where they expand completely to generate blocks with thicknesses of around $30 \mathrm{~mm}$ (Figure 2.24).

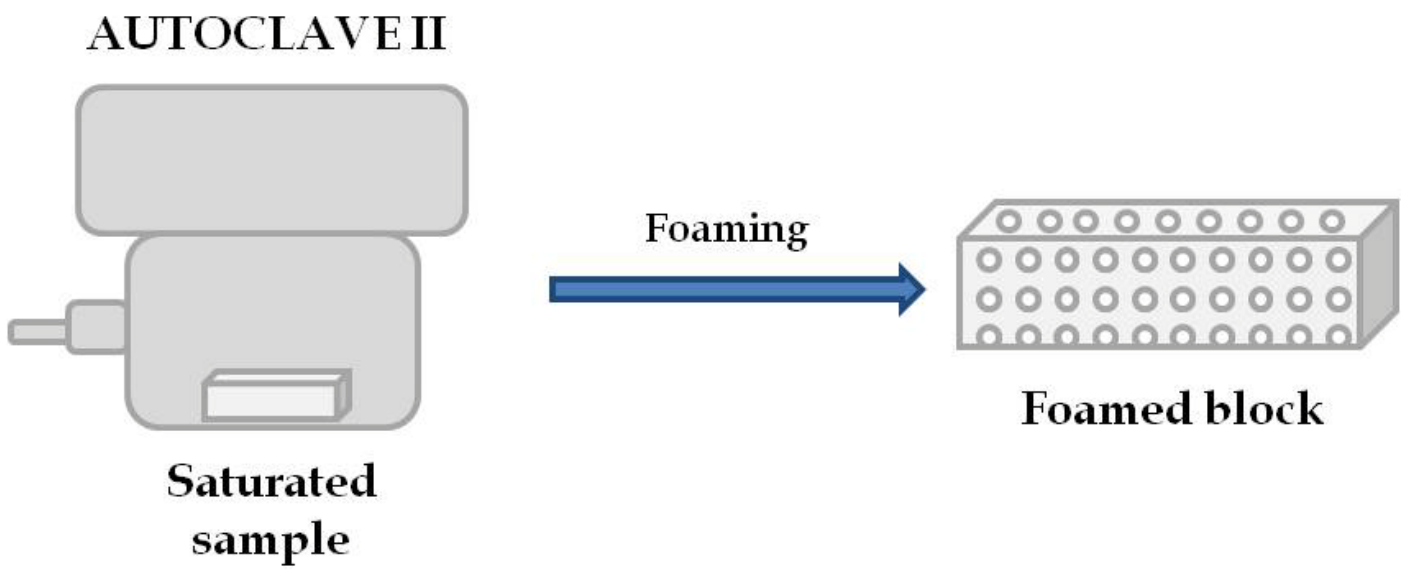

Figure 2.24. Scheme of the foaming process of a nitrogen-saturated sheet in an autoclave.

The clean is the strong point of this process since no chemical blowing agents are used, avoiding the presence of residues in the foamed product. As a result, these foams can be used for medical applications. Another benefit derived from the absence of the residues released by chemical blowing agents is the reduction in the emission of volatiles by these foams, being these particular foams quite interesting options for huge markets, such as the automotive or the aeronautics ones.

Furthermore, foams produced from different polymeric matrices, with very homogeneous cellular structures and with fine cell sizes are achieved by using this technology.

However, the installation of high energy sources combined with the use of highpressure vessels initially makes the technology quite expensive. In addition, it must be also be considered that the fabrication time is longer than in other processes, increasing the price of the product. 


\section{- Injection molding}

The injection molding is an alternative process that is mainly used to produce netshaped foams. In Figure 2.25, it is schematized the basis of the process:

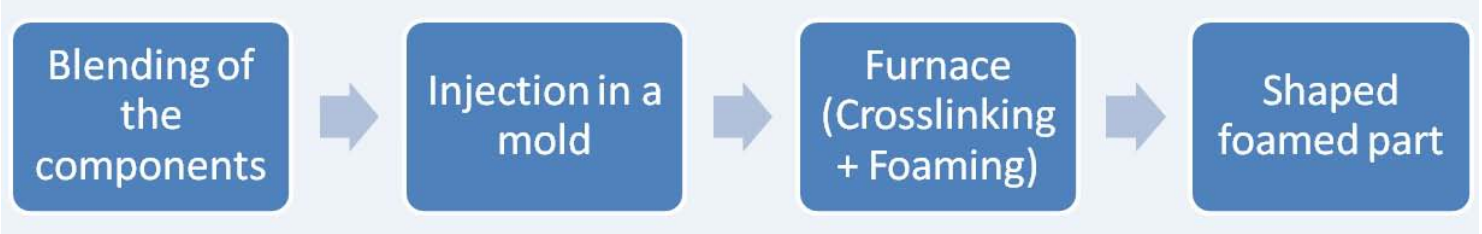

Figure 2.25. Scheme of the production of crosslinked polyolefin foams by using injection molding.

As in previous processes, the components (polymer, crosslinking agent, blowing agent and additives) of the formulation are blended before injecting the blend in a mold with the desired shape.

The molten blend is injected in a mold, which is placed in a hot-plates press until it is completely filled. Both crosslinking and blowing agents decompose applying temperature and pressure to the system. After a certain time, the pressure is released, and the material expands jumping out of the mold. As the material is reticulated under pressure inside the mold, the final foam inherits the shape of the mold.

This process is used to produce foams with higher densities (relative densities around $0.11-0.33)$ [64].

\section{- Compression molding}

This thesis is focused on the production of cellular polymers based on polyolefins using the compression molding as the fabrication process. Compression molding can be classified depending on the number of steps involved in the process in: one-step or two-steps compression molding process $[73,76]$. The critical difference between both of them is that the two-steps process allows achieving lower densities. Compression molding is commonly used at industrial scale for the production of closed-cell cellular polymers with a wide range of densities.

One-step compression molding process

The one-step process is used at industrial scale in the production of crosslinked closedcell foams with high densities (relative densities above 0.27). One example of the applications in which this type of foams are used is in the footwear industry (sole, midsoles and insole) (Figure 2.26). 

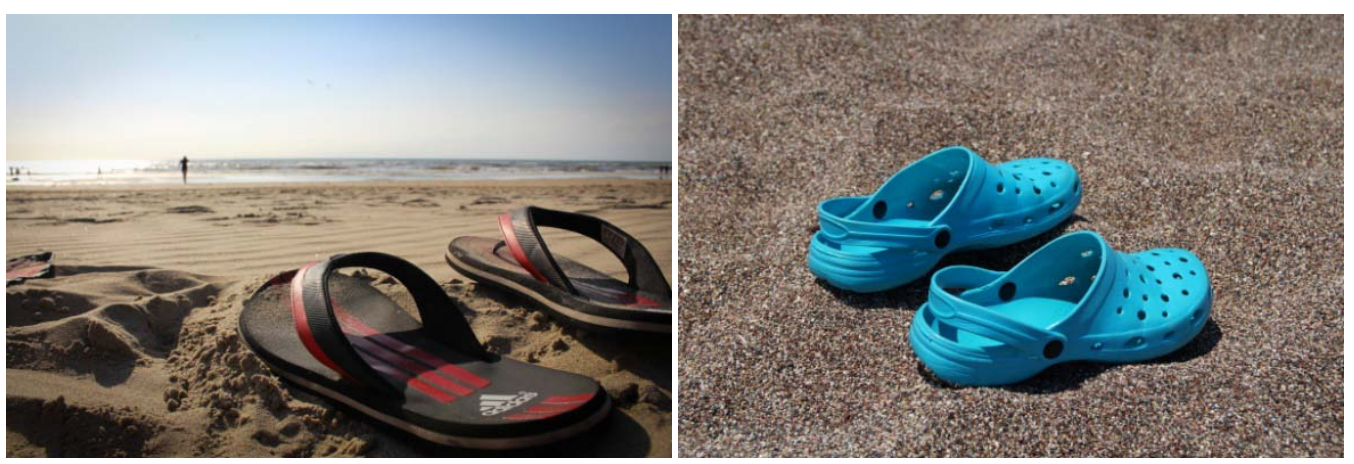

Figure 2.26. Applications of crosslinked closed-cell foams produced by using a one-step compression molding process.

Initially, the components of the formulation (polymeric matrix, crosslinking agent, blowing agent and other additives) are blended by using mixers, such as two-roll mills or Banbury-type ones (Figure 2.27). To get homogeneous blends, the polymeric matrix must be molten, so the temperature must be higher than the melting temperature of the polymer. However, it must be avoided the premature decomposition of the crosslinking and blowing agents, and thus the mixing temperature must be lower than both decomposition temperatures.
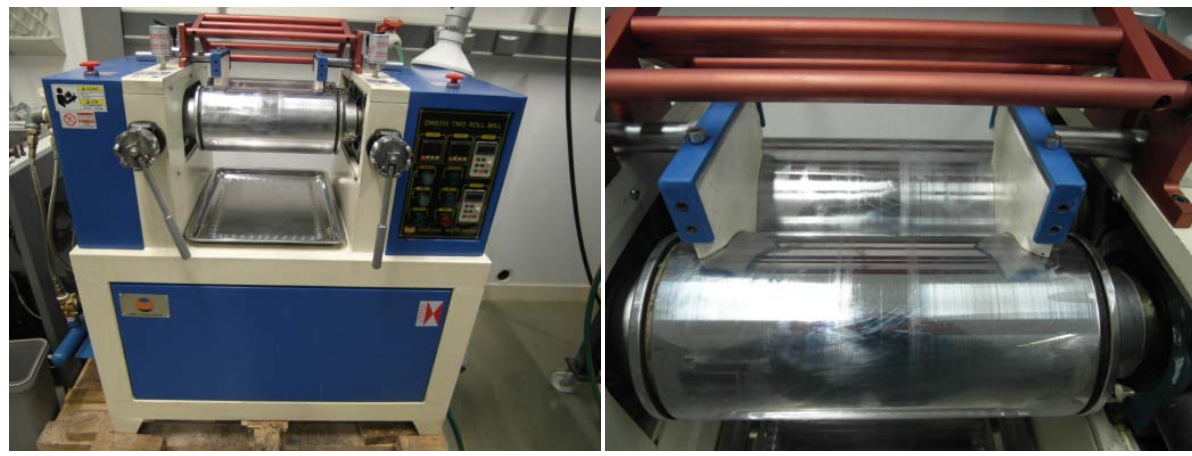

Figure 2.27. Two-roll mill used during this study.

Once the chemical components are properly blended, the obtained solid (so-called "precursor") is placed in a pre-heated mold to carry out the unique step of the process (Figure 2.28).

This step is performed at a temperature high enough to decompose both the crosslinking agent particles to promote the crosslinking of the polymer matrix and the blowing agent particles to allow the foaming of the material. This step is carried out while applying certain pressure to the mold cavity filled with the precursor. After a fixed time, this pressure is released, and a foamed material is obtained. The desired shape of the foam is achieved by using a suitable mold. 


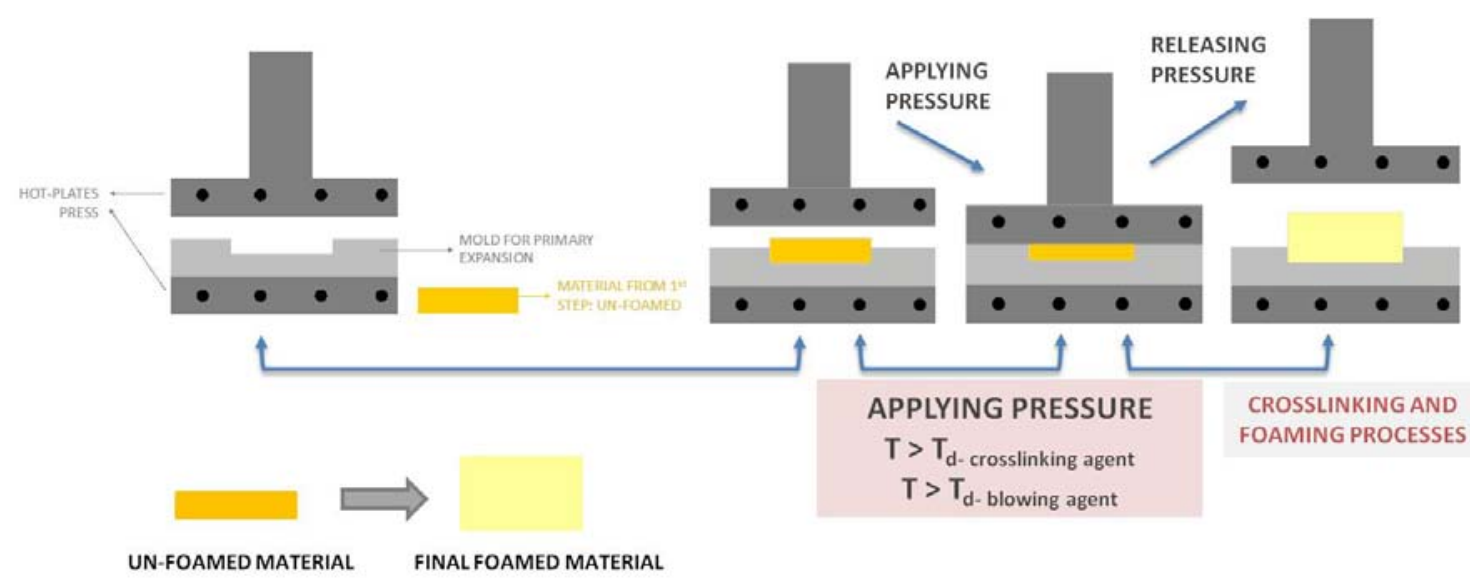

Figure 2.28.Scheme of the one-step compression molding process.

The temperature of the process depends on the type of crosslinking agent and blowing agent used in the production. Typically, dicumyl peroxide, as the crosslinking agent, and azodicarbonamide, as blowing agents, are employed to produce these materials. For this particular case, temperatures of around $180^{\circ} \mathrm{C}$ are used as long as activators of the decomposition of the azodicarbonamide are included in the formulation. This activation in the decomposition temperature of the azodicarbonamide is explained in depth in Chapter 3, section 3.5.

This process has the advantage of being very fast, and big amount of materials can be produced in short periods of time. However, the impossibility of producing lowdensity foams constitutes the critical limitation of the process.

Two-steps compression molding process

The two-steps compression molding process is used at industrial scale to produce lowdensity crosslinked closed-cell foams (relative density below 0.1). These foams are widely used in several applications such as packaging, sport or toys (Figure 2.29).
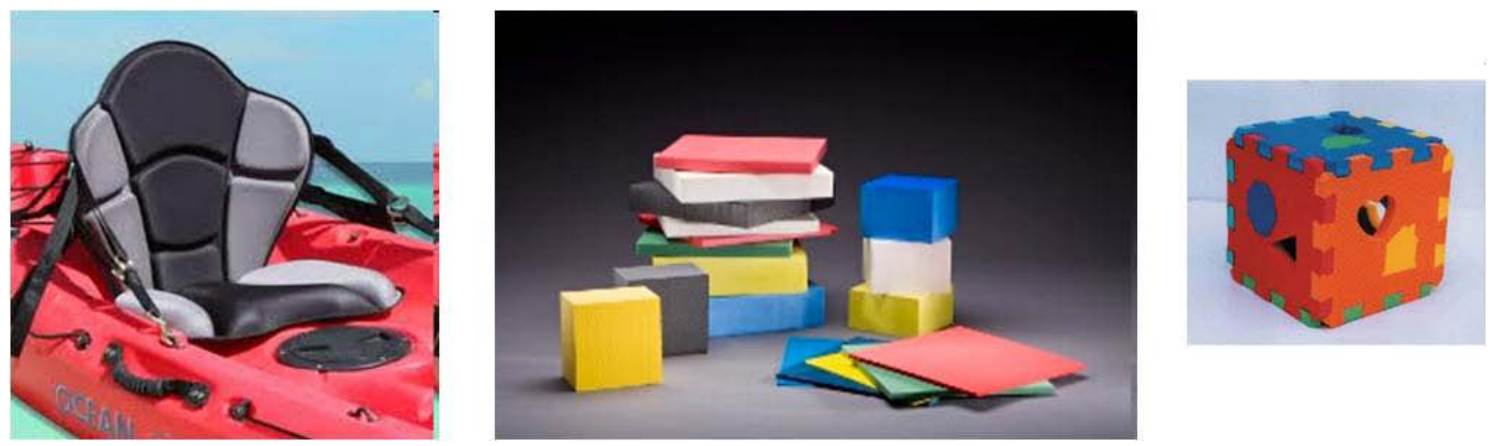

Figure 2.29. Commercial products made of crosslinked polyolefin foams produced by using the two-steps compression molding process.

As in the case of the one-step process, the components of the formulation are initially blended using the same technologies mentioned previously. 
After homogeneously blending, the so-called "precursor" is placed in the cavity of a pre-heated mold to carry out the first step of the process. This process is carried out under pressure and temperature similar to the one-step process (Figure 2.30). However, contrary to the one-step version, the aim of the first step in the two-steps process is only to crosslink the polymer matrix avoiding as much as possible the decomposition of the blowing agent particles. Therefore, lower temperatures than in the one-step process are necessary in this case. The temperatures commonly employed oscillate in a range between 145 to $155^{\circ} \mathrm{C}$. After a fixed time, the applied pressure is released, and a partially foamed material is obtained (primary foam). It was mentioned before, that the purpose of this step is to crosslink the polymeric matrix without decomposing blowing agent particles. However, as the formulations included activators of the decomposition of the blowing agent particles (like in the one-step process, dicumyl peroxide and azodicarbonamide are commonly used as crosslinking and blowing agents) some of the blowing agent particles decompose leading to a partially foamed material, so-called primary foam. Nevertheless, the expansion ratio achieved in the first step oscillates around 2 and 3, remaining the majority of the blowing agent particles without decomposing.

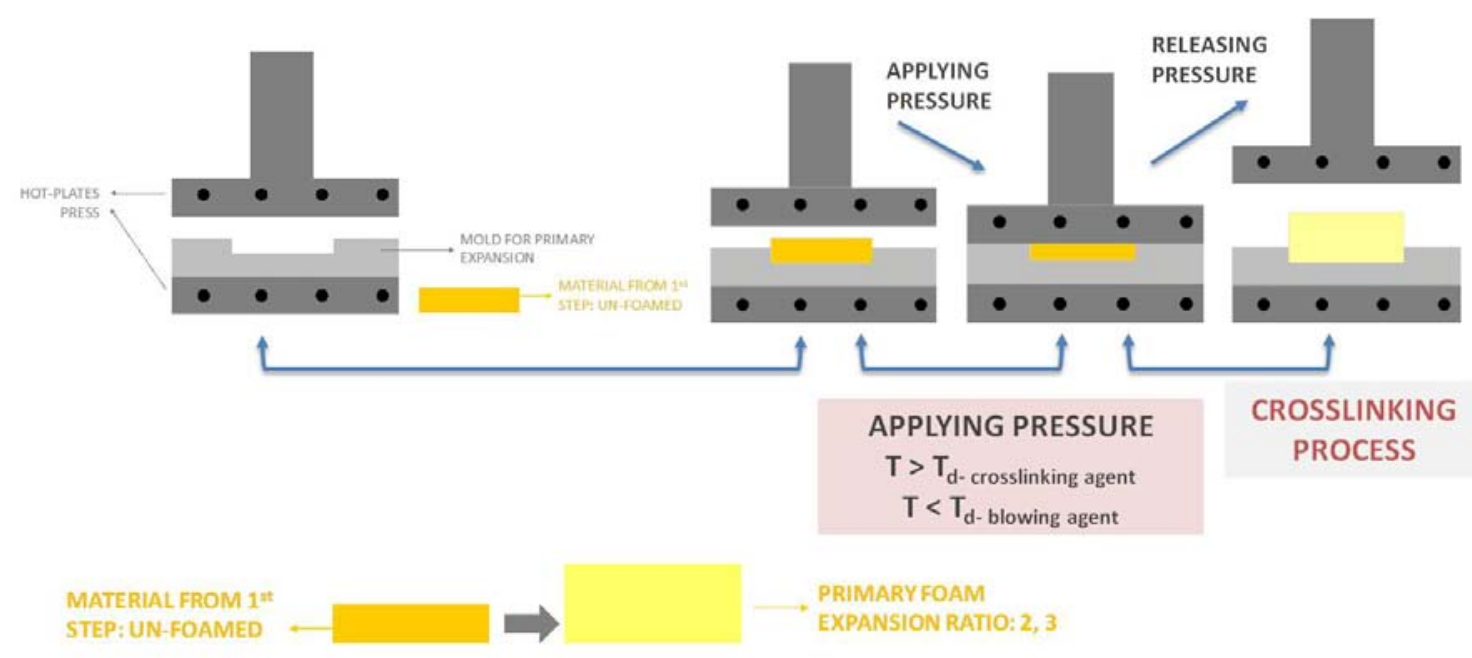

Figure 2.30. First step of the two-steps compression molding process.

As it was previously mentioned, this partially foamed material still contains many blowing agent particles, which have not decomposed at such low temperatures. Therefore, it is necessary to carry out a second step, which enables the fully decomposition of the blowing agent particles and consequently reaching the final desired density.

Thus, the primary foam is introduced in a second pre-heated mold. The mold is placed in an oven at a temperature high enough to fully decompose the blowing agent. Unlike the previous step, this final foaming step is carried out at atmospheric pressure ("free foaming process") (Figure 2.31). In the particular case of using azodicarbonamide as the blowing agent, the addition of activator of its decomposition allows reducing the temperature of the second step. At industrial scale, a range of temperature between 170 and $190^{\circ} \mathrm{C}$ is used for performing this step. 


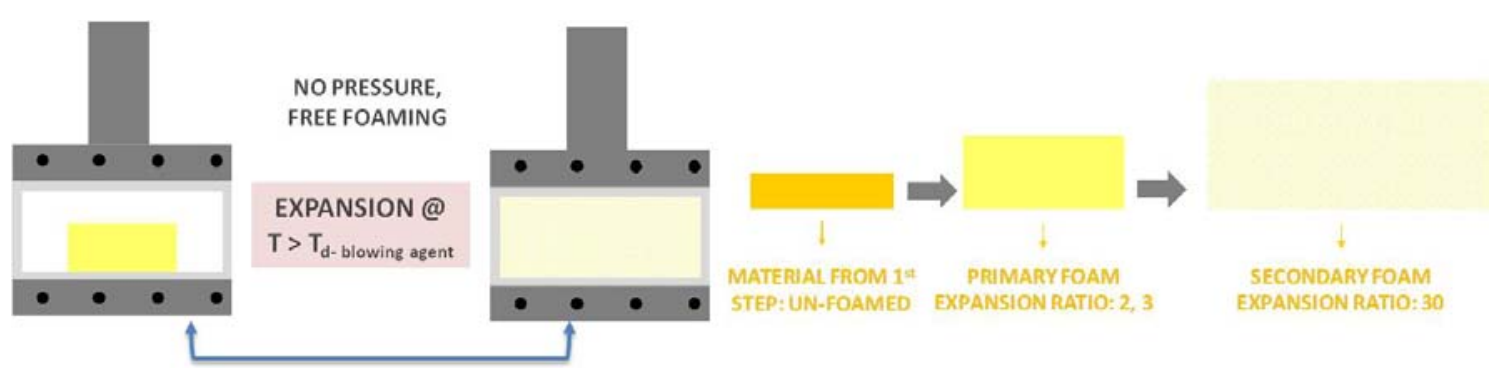

Figure 2.31. Second step of the two-steps compression molding process.

The principal advantage of the two-steps compression molding process is linked to the production of low-density foams. However, this process requires longer times than the one-step one and the installation of more than one press since two processes must be performed.

By using this technology, thick foamed blocks can be produced. The thickness of the blocks produced in this thesis was $10 \mathrm{~cm}$ (Figure 2.32). However, foamed blocks with higher thicknesses (up to $15 \mathrm{~cm}$ ) can be produced at industrial scale.

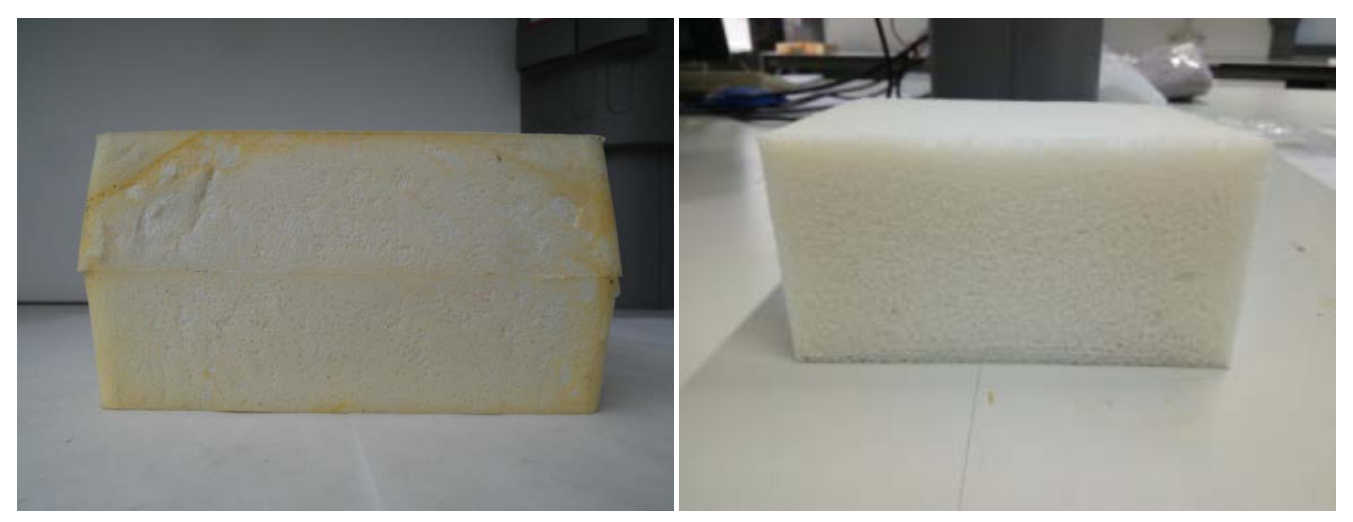

Figure 2.32. Crosslinked closed-cell polyolefin foams produced by using the two-steps compression molding process.

There are many international companies, such as Palziv Group, Sekisui Chemical Co., LTD, Berkosan, OK Company, which commercialize foamed materials produced by using the two-steps compression molding process. At industrial scale, nowadays, in the case of polyolefins, this process is almost solely dedicated to the production of closed-cell foams.

Closed-cell materials are easy and inexpensive to produce by using a two-steps compression molding process. After being founded in the late 1990s, one of the main research topics covered by CellMat Laboratory was to establish the structureproperties relationship of closed-cell polyolefin foams produced by using a two-steps compression molding process. The relationship of the morphology of the cellular structure and physical properties such as thermal, mechanical or acoustic properties was evaluated for various systems and materials [77-93]. 

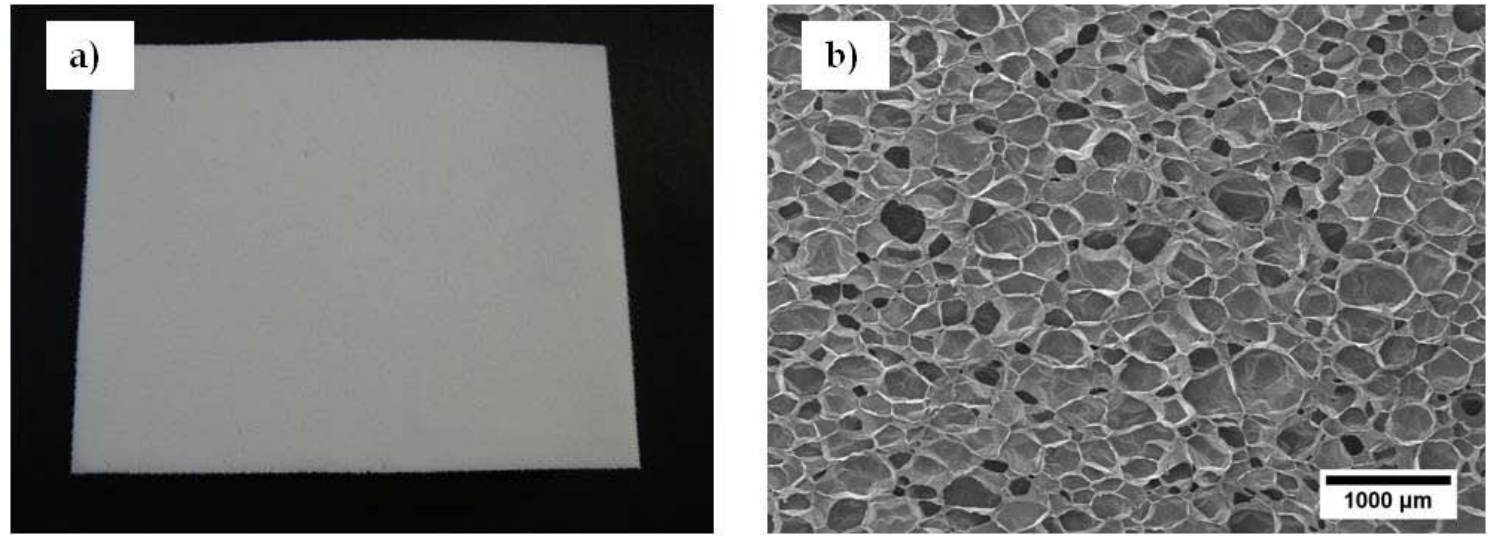

Figure 2.33. a) Commercial crosslinked closed-cell polyolefin cellular polymer and b) SEM micrograph of a typical closed cellular structure (right).

During the last years, most of the companies dealing with the production of these materials have developed new grades of products to give response to the increasing demand for these materials mainly motivated by their outstanding properties. However, until now, most of them have not succeeded in producing an open-cell product that would widen in a significant extend the range of application and the market share covered by crosslinked polyolefin foams.

As it was mentioned, the development of crosslinked open-cell polyolefin foams is not as advanced as in the case of closed-cell materials, and currently, it is only possible to find a company producing and commercializing them. The Japanese company Sanwa Kako Co., LTD. commercializes two models of crosslinked open-cell polyolefin foams: OPCELL $®$ and SUPEROPCELL ${ }^{\circledR}$ [94]. M. Alvarez-Lainez developed a work in CellMat Laboratory based on the analysis of the structure-properties relationship of crosslinked open-cell cellular polymers provided by Sanwa Kako [95]. This work was focused on the analysis of the thermal, mechanical and acoustic properties of these open-cell materials. They present interesting properties such as no deterioration due to chemicals, excellent sound absorption, fire retardancy and some special advantages over PU: no poisonous gases are released during burning, hydrophobicity, lower emissions of volatiles or non-hazardous chemicals involved in the production. To fabricate these materials that are based on blends of EVA and LDPE, Sanwa Kako uses a patented method based on applying a mechanical deformation to create the interconnection between the cells [96].

Up to now, there is not any reported work based on the development of crosslinked open-cell polyolefin foams directly during the foaming process. Sanwa Kako claims in his patent the use of mechanical deformation of foams already produced without having interconnectivity among the cells.

CellMat Technologies S.L. and CellMat Laboratory patented in 2015 a method to produce crosslinked open-cell polyolefin foams directly during the fabrication process [97]. This fact is the critical difference between the technology employed by CellMat Technologies and that used by Sanwa Kako. Based on this methodology, several 
crosslinked open-cell polyolefin foams with different grades of cellular structure tortuosity have been fabricated and characterized during the developed of this thesis. The main objective has been the evaluation of the effect of the cellular structure and in particular of gas-phase tortuosity on several physical properties. The methodology applied on the past for closed-cell materials has been followed to evaluate these novel materials. During this work, it has been considered as a critical issue in the motivation of this work the technical objective of the thesis that was to determine if the crosslinked open-cell foams based on polyolefins could be used as a replacement for open-cell PU foams in several applications.

\subsection{Physical properties of low-density flexible foams}

Tortuosity is the central element of this work. In this thesis, it has been studied how the tortuosity affects the physical properties of crosslinked open-cell foams. For this purpose, the mechanical properties, the acoustic absorption, the oil uptake, the damping of mechanical vibrations, the thermal stability and thermal conductivity of a collection of open-cell foams based on different types of polyolefins and with different tortuosity levels have been analyzed in depth (Figure 2.34).

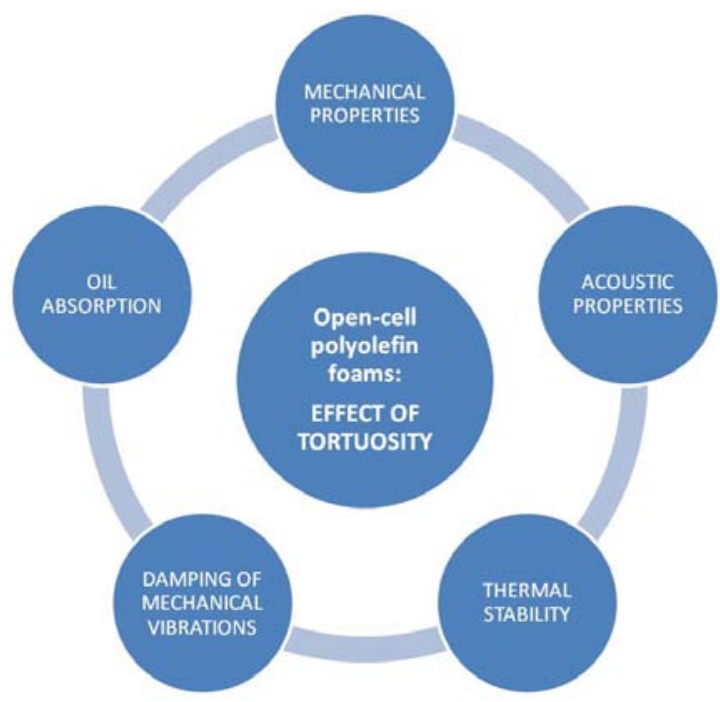

Figure 2.34. Scheme of the physical properties characterized in this thesis and the effect of tortuosity.

Therefore, it is essential to review previous works, in which the mechanical, acoustic, oil-absorption, dynamic mechanical and thermal properties of polymer foams have been evaluated. The following sub-sections of this chapter aim at summarizing what it has been studied concerning the properties mentioned before.

\subsubsection{Mechanical properties}

There are many examples of cellular materials in nature: bones, wood, sponges, coral etc. As M.F. Ashby mentioned in his article "The Mechanical Properties of Cellular Solids": "When modern man builds large load-bearing structures, he uses dense solids: steel, concrete, glass. When nature does the same, she generally uses cellular materials" [98]. 
The understanding of the mechanisms involved in cellular materials during mechanical tests has awakened interest over the years [1,99], and many authors have focused their works on studying the mechanical properties of both closed and opencell cellular polymers [100-108]. Mechanical properties can be characterized either in compression or in tension, although this section is focused only on the compressive behavior of foams.

The mechanical properties under compression are highly dependent on whether the cells are open or closed, the relative density, the viscosity of the fluid contained inside the cellular structure, the cell size, the anisotropy of the cells or the stiffness of the polymeric matrix. Focusing on the last aspect, the deformation mechanisms under load-compression are different depending on whether the matrix is rigid or flexible [109-111]. However, this revision is focused only on the deformation mechanisms of flexible foams, since the stiffness of polymer matrices used in this thesis is quite low.

Three different regimens can be distinguished in the stress-strain curves of both flexible closed and open-cell foams (Figure 2.35). The shape of the stress-strain curves depends on the level interconnectivity of the cellular structure:
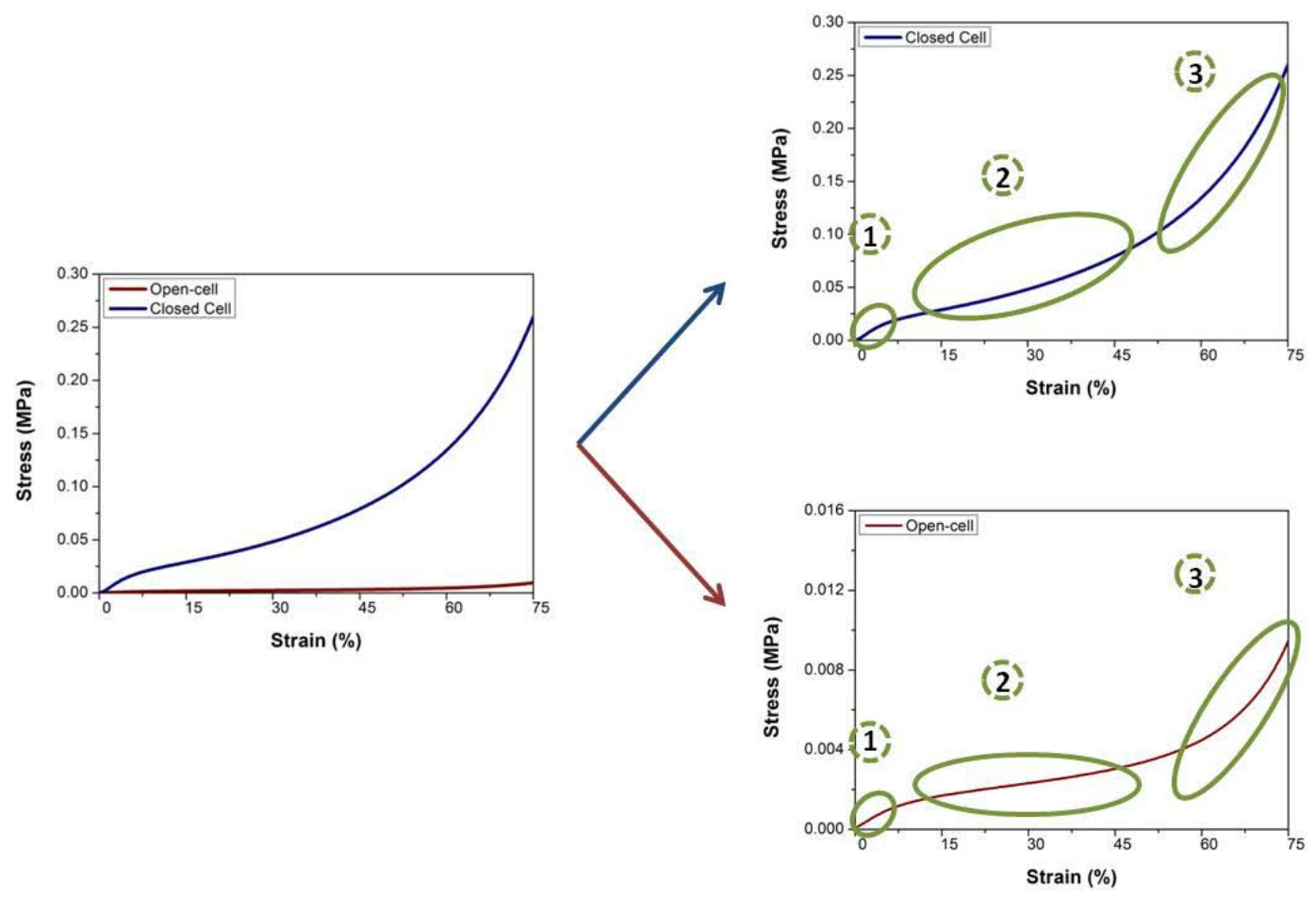

Figure 2.35. Stress-strain curves of crosslinked LDPE closed-cell (grey) and LDPE open-cell (red) foams.

1) Up to a strain of around a 5\%, the stress increases linearly (linear elasticity). As it can be observed in Figure 2.36, the stress increases for both types of materials, but the stress value is one order of magnitude higher in closed-cell cellular polymers than in open-cell ones.

According to Gibson and Ashby [1], there is a difference in the mechanisms involved in the linear elasticity region. In closed-cell foams, the deformation 
mechanisms are linked to the bending of cell edges, and the stretching of the cell faces, whereas, in open-cell foams, the mechanism controlling this region is solely the cell wall bending [112-116].
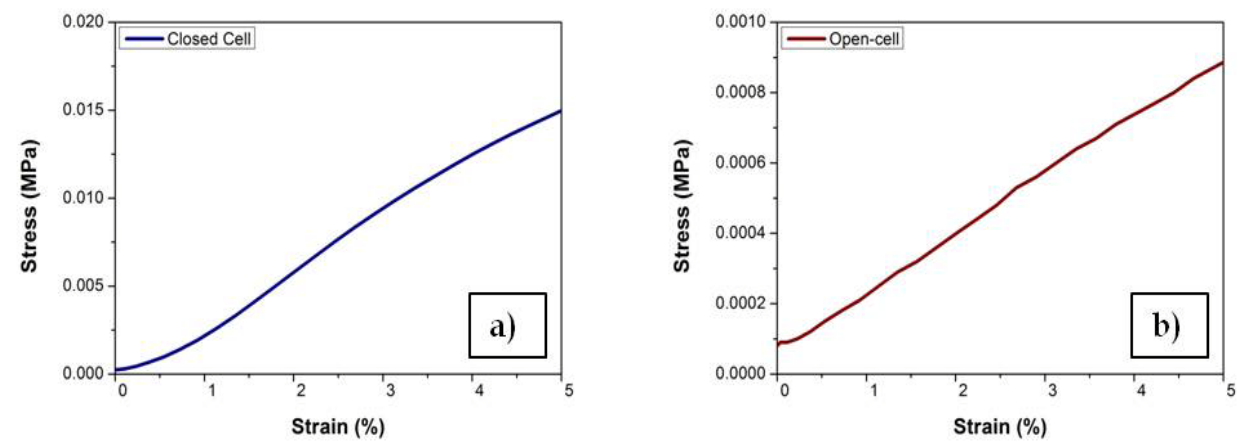

Figure 2.36. Linear region of the stress-strain curves: a) closed-cell (density of $27 \mathrm{~kg} / \mathrm{m}^{3}$ ) and b) open-cell (density of $16 \mathrm{~kg} / \mathrm{m}^{3}$ ) LDPE foams.

2) At higher strains (above 5\%), the materials start to collapse due to the buckling of the cell walls and struts. In this region, there is a non-linear dependency between stress and strain. The type of cellular structure interconnectivity plays a key role in the elastic collapse and the post-collapse behavior. The shape of the curve is clearly different depending on the type of interconnectivity, as it is observed in Figure 2.37. One the one hand, in closed-cell materials, the stress increases as the strain does, due to the presence of gas inside the cells. Zhang and Ashby determined that this increment was caused by gas pressure; being the contribution of the membrane stresses less important [117].

On the other hand, as the gas escapes out of the foam in open-cell materials during the compression test, there is no contribution of the gas, and this region is characterized by the presence of a plateau. Figure 2.37 shows perfectly the different behavior displayed by closed and open-cell materials.
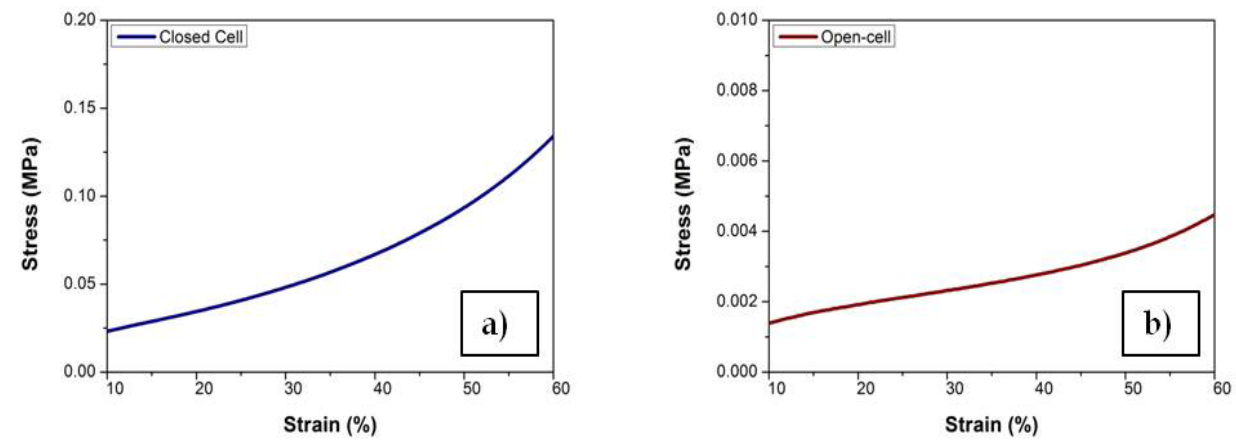

Figure 2.37. Stress-strain curves from 10 to $60 \%$ strain: a) closed-cell and b) open-cell LDPE foams.

Gent and Thomas developed a model considering that the compression of the gas occurred isothermally [118]. Successive modifications of this model have led to the following equation $[64,119,120]$ : 


$$
\sigma=\sigma_{c}+\frac{p_{a}(1-2 v) \varepsilon}{\left(1-\varepsilon-\frac{\rho_{f}}{\rho_{s}}\right)}(1-C)
$$

where $\sigma_{c}$ is the collapse stress, $p_{a}$ is the atmospheric pressure, $v$ is the Poisson's ratio, $\varepsilon$ is the strain, $\rho_{f}$ is the foam density, $\rho_{s}$ is the solid density (its ratio is the relative density), and $\mathrm{C}$ is the open-cell content. The term $p_{a}(1-2 v) \varepsilon$ has been denominated as effective gas pressure in this work.

Using this modified model, the collapse stress and the effective gas pressure can also be measured during a compression test.

3) At very high strains, the opposing walls of the cells come into contact, and this is reflected in the curve as an abrupt increase in the stress (Figure 2.38) $[1,121,122]$. This area is known as the densification region. The strain limit up to the densification regime is given by the following equation:

$$
\varepsilon_{D}=1-1.4\left(\frac{\rho_{f}}{\rho_{s}}\right)
$$

where $\varepsilon_{D}$ is the densification strain.
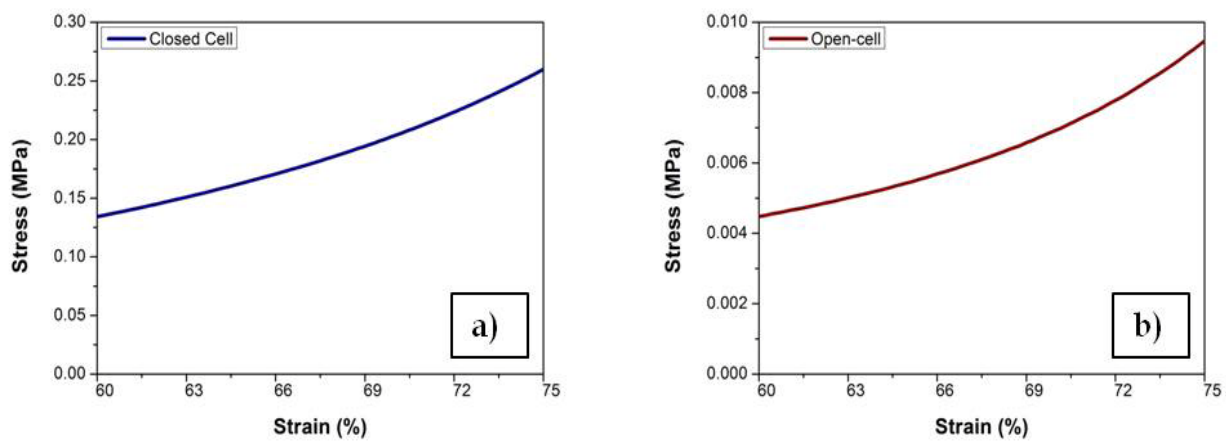

Figure 2.38. Densification region: a) closed-cell and b) open-cell LDPE foams.

In the particular case of flexible PU foams, the mechanical properties have been evaluated considering both molded and slabstock foams.

Patten and Seefried analyzed the mechanical properties of molded high resiliency urethane foams for automotive seating applications. They detected that variations in the amount of water in the formulations affected not only the final density of the foam but also the elastic modulus. Formulations with lower water levels displayed higher load-bearing properties [123]. Moreland et al. analyzed the dependence of relative humidity and temperature on the viscoelastic behavior of flexible slabstock PU foams, finding that an increase of the temperature in the range of $25-100{ }^{\circ} \mathrm{C}$ induced a decay in the viscoelasticity [124]. Concerning the relative humidity, a similar trend was obtained: the viscoelasticity decayed as the relative humidity increased. 
Dounis and Wilkes determined the viscoelastic and compression set behavior of molded foams with formulations with different water/TDI ratios. They also compared these results with those obtained for slabstock foams, coming to the conclusion that the difference between them owed to a major difference in the formulation components [125]. Gong et al. analyzed the compressive response of open-cell PU anisotropic foams in two research articles aiming at understanding the mechanisms involved in the deformation of open-cell foams in compression tests $[107,126]$.

Rampf et al. analyzed the structural and mechanical properties of flexible PU foams cured under pressure. According to this research, an overpressure of 2 bars applied during foaming and curing can affect both structural and mechanical properties [127]. By applying this overpressure process, they achieved to control the shrinkage producing closed-cell foams with no effective shrinkage.

According to these studies, the mechanical properties of open-cell PU foams depend mostly on the chemistry behind the foams and the density of the foam. The influence of the cellular structure parameters is less important in the mechanical response, being more complex to improve the mechanical properties by varying these parameters.

One alternative aiming at improving the mechanical properties of PU foams is the addition of fillers [30]. Goods et al. studied the mechanical behavior of PU foams reinforced by the addition of aluminum powder. They observed that the modulus increased as the proportion of aluminum powder was higher. However, the high content of aluminum may provoke the cracking of the foam due to the poor adhesion between particles and the polyurethane matrix [128]. Saint-Michel et al. studied and modelled the effect of the particle size $(1$ and $30 \mu \mathrm{m})$ on the mechanical properties when calcium carbonate and crystallized silica are used as fillers [129]. They concluded that if the particle size of the filler is larger than the bubble size; there is no effect of the reinforcement on the mechanical properties in the non-linear regime. Bandarian et al. incorporated multi-walled carbon nanotubes in open-cell flexible PU foams [37]. The nanoparticles increased both compressive modulus and strength. Yan et al. found similar tendencies as the one observed by Bandarian when carbon nanotubes are incorporated in rigid PU foams [130]. Santiago-Calvo et al. incorporated graphene oxide to rigid PU foams and analyzed its effect on thermal and mechanical properties [131]. An improvement of 59\% in the relative Young's modulus and 54\% in the relative collapse stress was reported in comparison to the unfilled foam.

One interesting topic is the analysis of the mechanical properties of green or bio-based PU foams [132,133]. Lately, many works can be found in the literature based on the enhancement of the mechanical properties of these foams by incorporating fillers. Kadam et al. added bentonite nanoclays to bio-based PU foams obtaining a significant improvement of compressive strength [134]. Luo et al. performed a similar study but adding hydroxyl-functionalized multiwalled carbon nanotubes to a soy oil-based rigid PU biofoam [135]. 
Concerning crosslinked low-density polyolefin foams, Rodriguez-Perez is his thesis, analyzed the mechanical properties under compression of several closed-cell foams [77]. He observed that for the same polymer matrix, Young's modulus is highly dependent on the density, being the elastic modulus higher for materials with higher densities. Furthermore, the type of polymer matrix also played a key role being the Young's modulus of closed-cell LDPE foams completely different from that of the EVA based ones. He also determined the effect of the cellular structure parameters such as cell size, the fraction of mass in the struts, cell wall thickness and the orientation of the cells on the compressive response observing their influence on the mechanical properties. Hidalgo analyzed how mechanical parameters such as the collapse stress or the Poisson's coefficient varied in different zones of blocks of closed-cell LDPE foams. One interesting conclusion of this analysis is that the collapse stress depends on the density of the foam and the gas pressure inside the cells [76]. Davari et al. also determined that the density was the main parameter controlling the mechanical properties of crosslinked closed-cell LDPE foams, although cell size and cell size distribution also played a key role on it [136]. Jeong and Jeong also found an improvement in the mechanical properties when clay nanocomposites were added to crosslinked EVA/olefin block copolymer foams [137].

However, the mechanical properties of crosslinked open-cell polyolefin foams have been scarcely characterized due to the complexity inherent to their production process, not widespread up to now. Rodriguez-Perez et al. analyzed the mechanical properties of open-cell foams based on LDPE/EVA blends with different densities provided by Sanwa Kako and compared them with those exhibited by closed-cell foams based on polyolefins or with those corresponding to open-cell PU foams. They observed significant differences among the stress-strain curves of the open-cell LDPE/EVAbased foams and the PU foam. As the tortuosity of the open-cell LDPE/EVA foam increased, there was a certain level of contribution of the gas phase in the post-collapse region (Figure 2.33, area 2) whereas a plateau was obtained for the open-cell PU foam due to the non-contribution of the gas to the mechanical properties. Furthermore, it was also concluded that both density and cellular structure interconnectivity affected the mechanical properties, obtaining higher modulus and higher collapse stress values for closed-cell foams and foams with higher densities [138].

Another critical mechanical parameter to be considered is the amount of absorbed energy. Closed-cell cellular polymers are commonly used in packaging or body protection applications where high energy absorption is required. Therefore, it is necessary to determine the energy that a material can absorb to guarantee its use for this type of applications. Regardless of the strain rate, the absorbed energy is given by the area under the load stress-strain curve.

The energy absorption is directly associated with impact at high strain rates, and thus, it is common to estimate this parameter by using impact tests. Rusch analyzed the load-compression behavior of flexible foams concluding that the compressive stress can be factored into the product of two terms: The first one a dimensionless function of 
the compressive strain and the second a factor dependent on the compressive strain and the apparent Young's modulus [139]. Velasco et al. characterized mechanically thermoplastic foams by performing falling dart impact tests. The results indicated a dependence of the failure strength, toughness and the elastic modulus on the foam density, the foaming process and the chemical composition [140]. Ruiz-Herrero et al. determined the mechanical properties of closed-cell LDPE foams under compressive impact loading and concluded that the optimum behavior depended upon static stress and strain rate [141]. Jeong et al. presented a constitutive model for PU foams with strain rate sensitivity [142]. The model had seven parameters, and two of them were affected by the magnitude of the strain rate. The comparative of the results obtained by using their model and the experimental results showed good results at low strain rates that it did not approximate the results accurately in impact tests due to the ringing of the system caused by the impact.

Focusing on open-cell foams, Mills analyzed the mechanisms involved in the deformation of open-cell foams in compression tests at high strain rates using for this purpose open-cell PU foams [143,144]. However, as far as the author knows, the evaluation of the mechanical properties of crosslinked open-cell polyolefin foams at high strain rates has not been reported yet in open literature.

Before concluding this section, and in order to summarize the review of the state of the art corresponding to the mechanical performance of flexible foams, Figure 2.39 presents the compressive stress at $50 \%$ of the strain as a function of density for different types of flexible foams that would serve as reference during the whole thesis: commercial crosslinked closed-cell foams, flexible closed-cell polyurethane foams and flexible open-cell polyurethane foams. Commercial crosslinked closed-cell LDPE foams present higher compressive stress values than the flexible polyurethane foams ( 5 times higher in comparison to open-cell foams with a similar density). The compressive stress values of the flexible closed-cell PU foams are higher than those displayed by the flexible open-cell foams. However, it must be taken into account that the density is not the same in both cases. In the case of flexible open-cell PU foams, the compressive stress values are slightly dependent on the density, being the values of foams with densities of, for instance, 30 and $65 \mathrm{~kg} / \mathrm{m}^{3}$, quite similar

This figure will serve in Chapter 4 as an indicator to determine where the crosslinked open-cell foams under consideration are located: 


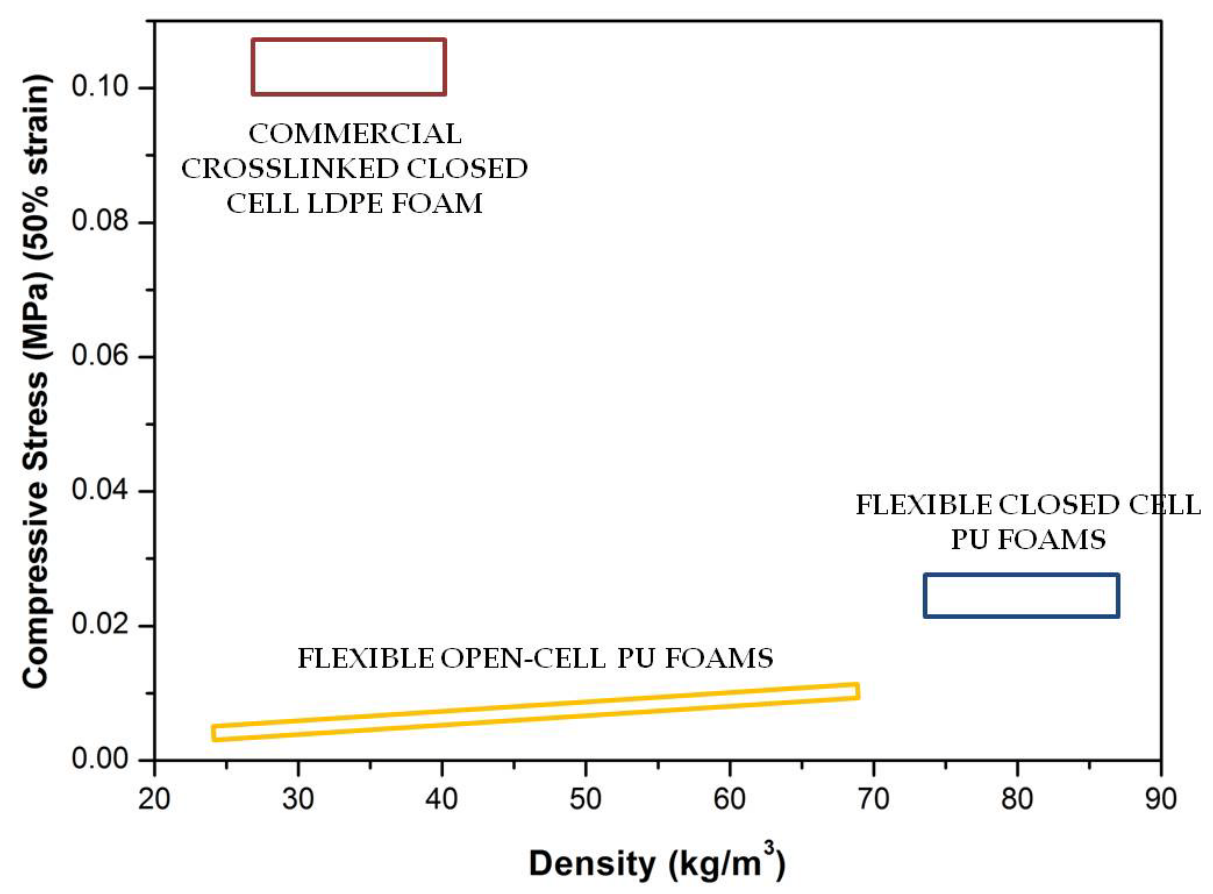

Figure 2.39. Compressive stress (MPa) at 50\% strain for commercial flexible PU and closed-cell LDPE foams with different densities.

In this thesis, the results regarding the mechanical properties of the materials developed during this research are illustrated in Chapter 4.

\subsubsection{Acoustic properties}

Noise pollution is a major worldwide problem. The European Environmental Agency (EEA) warns about the consequences of noise pollution in a public report [145]. According to this institution, 16600 cases of premature death are estimated each year due to high noise exposure. Thirty-two millions of European citizens feel annoyed about it, and 13 million suffer from sleep problems.

According to the European Union (EU) communication, about $40 \%$ of the population in EU countries is exposed to road traffic noises higher than $55 \mathrm{~dB}$. Furthermore, $20 \%$ of the population is exposed to noise levels higher than $65 \mathrm{~dB}$ during the daytime, and $30 \%$ are exposed to noises exceeding $55 \mathrm{~dB}$ at night. To have a better understanding of the last value, the World Health Organization (WHO) considers that the "annual average night exposure should not exceed $40 \mathrm{~dB}$ corresponding to the sound from a quiet street in a residential area"[146]. 


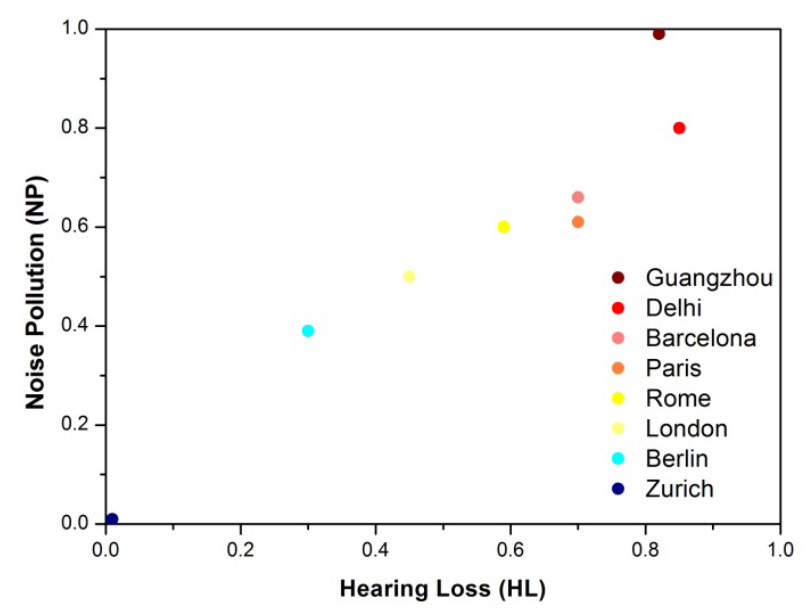

Figure 2.40. Noise pollution levels of several cities.

In Figure 2.40, it is shown the cities with the highest levels of noise pollution. The study used the average hearing loss index and found that it showed a $64 \%$ positive correlation with noise pollution levels in each city, indicating that hearing loss may be an outcome of living in these cities. The results of the hearing loss index of each city and the noise pollution data were mapped to range between 0 and 1 . The sum of these two rankings was combined to give an overall combined hearing loss rank. Guangzhou (1.82) and Delhi (1.72) both located in Asia, show the highest levels of noise pollution. In Europe, Barcelona (1.36) leads the statistic followed by Paris (1.31) and Rome (1.19). Therefore, this problem does not only concern cities located in Asia but also the ones located in Europe and America [147].

The World Health Organization (WHO) informs about this issue, indicating that noise may cause, apart from sleep disturbance, cardiovascular and psychophysiological effects [148].

Taking into account the considerations of global institutions, noise pollution should be considered as potential damage for human beings. As a consequence, many types of research are aimed at developing new or better materials with improved sound absorption capacities.

Open-cell porous materials are, in general, excellent sound absorbers. The wave sounds are dissipated inside the cellular structure and with a very little reflection. Porous fibrous materials, both natural and synthetic, are used as sound absorbers [149151]. Cellular polymers are located inside the group of porous materials.

The theory of the propagation of sound waves in elastic porous materials was presented by Biot [152-154], and successive modifications have led to new models in which parameters such as air flow resistivity, porosity and tortuosity play a critical role $[6,155,156]$. 
Open-cell foams are excellent sound absorbers due to their ability to dissipate energy. The attenuation of sound by foams is explained by the conversion of sound energy to heat due to relaxing processes occurring in the material. Four mechanisms are associated with energy dissipation in open-cell materials:

- Friction losses caused by the interaction of the fluid (air) and the solid phase.

- Losses by heat transfer caused by the compressions and expansions of the fluid when the sound energy is transported.

- Losses by relaxations of the polymeric chains. The sound energy is converted to heat due to the molecular relaxations of the polymer matrix.

- The vibration of the sample

One option to estimate the sound absorption capability of a certain material is based on the use of impedance tubes (Figure 2.41). There are other alternatives, such as free field methods under (semi) anechoic conditions or the reverberant field method [157]. However, this revision of concepts is focused only on the transfer-function technique employed in an impedance tube with two microphones. A loudspeaker produces an acoustic wave which travels through the tube. Two microphones are located between the loudspeaker and the sample. The material absorbs the sound energy partially, and the remaining sound energy is reflected to form the standing wave pattern. By using a transfer-function relation between the acoustic pressure measured in the two microphones, the complex reflection coefficient can be determined and therefore, the acoustic impedance, the transmission loss and the sound absorption coefficient can also be estimated [158].

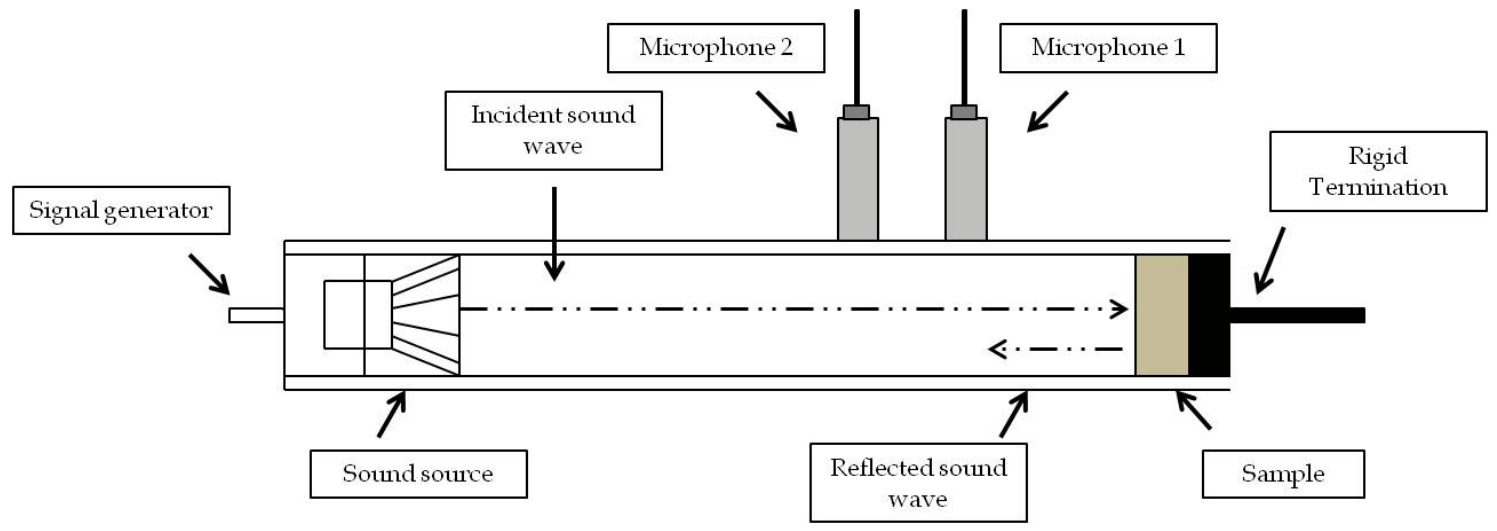

Figure 2.41. Scheme of an impedance tube.

The reflection coefficient $(R)$ complex and the acoustic impedance $(Z)$ can be estimated by using Equation 4 and Equation 5, respectively:

$$
\begin{gathered}
R=\left(\frac{H_{12}-H_{i}}{H_{r}-H_{12}}\right) e^{j 2 k(l+x)} \\
\frac{Z}{\rho c}=\frac{1+R}{1-R}
\end{gathered}
$$


where $H_{12}$ is the transfer function from the first to the second microphone, $H_{i}$ is the transfer function of the incident wave detected by the second microphone, $H_{r}$ is the transfer function of the reflected wave detected by the first microphone, and $\rho c$ is the characteristic impedance of air.

The sound absorption coefficient (a) is given by Equation 6:

$$
\alpha=1-|R|^{2}
$$

Open-cell PU foams are commonly used for sound absorption applications [159-161]. Adachi et al. found a close relationship between cell size and sound absorption in open-cell flexible PU foams [162]. Zhang et al. correlated the sound absorption with the level of the interconnectivity of PU foams [163]. They obtained an expected result according to previous studies, open-cell foams are better sound absorbers than closedcell foams. Gwon et al. determined the sound absorption of several open-cell PU foams with different densities and cellular structures. They concluded that the presence of a high number of small cavities in the cell walls improved the sound absorption [164]. Sung et al. performed a study based on the effect of isocyanate molecular structure on the sound absorption paying attention to the concentration of uretonimine groups [165]. They determined the suitable concentration of uretonimine groups to obtain the highest sound absorption.

Many authors have studied the sound absorption of open-cell PU foams modified by the addition of different types of particles. Verdejo et al. improved in a $30 \%$ the acoustical damping of flexible PU foams by adding $0.1 \%$ of carbon nanotubes [166]. Sung et al. incorporated magnesium hydroxide to PU formulations, obtaining an improvement in the noise reduction up to $70 \%$ in comparison to the unfilled foamed [167]. Sung and Kim analyzed the influence of several inorganic fillers (talc, zinc borate and aluminium hydroxide) on the acoustic properties of PU foams [168]. They obtained better absorptions in the samples, including talc as filler. Furthermore, it was observed that the higher the amount of talc added to the materials, the higher the sound absorption capacity.

Ryu et al. investigated the effect of carbon nanotubes, perfluoroalkane, dimethylsiloxane and carbon nanotubes/perfluoroalkane on the sound absorption properties of PU foams [169]. Improvements up to $34.1 \%$ in the sound absorption were obtained when 1.25 PHR of perfluoroalkane was added and an improvement of $22.1 \%$ when 0.5 PHR of carbon nanotubes were incorporated into the formulation. Khanouki and Ohadi enhanced the sound absorption of PU foams by incorporating silicon dioxide nanoparticles [170]. Lee and Jung presented a work in which the sound absorption could be tuned by adding graphene oxide [171].

Due to the lack of alternatives to open-cell PU foams, only a few examples evaluating the sound absorption capacity of other types of open-cell cellular polymers can be found in the literature. Liu et al. estimated the absorption coefficient at room and high temperature of several open-cell polyimide foams with different densities and cell sizes 
[172]. They concluded that as the cell size decreases, the interfacial area between the solid frame and the fluid resistance increases, increasing the dissipation of the sound waves. Li, in his thesis studied the use of melamine foams for acoustic applications [173].

Concerning polyolefins, the sound absorption of open-cell PE and PP foams produced by extrusion was tested by several authors, giving promising results [174,175]. Focusing on polyolefin foams produced by a two-steps compression molding process, Alvarez et al. analyzed the sound absorption performance of crosslinked open-cell polyolefin cellular polymers provided by Sanwa Kako Co., LTD $[95,176]$. They analyzed the sound absorption of several open-cell polyolefin foams, finding excellent values at low frequencies $(1000-2000 \mathrm{~Hz})$. One drawback of the open-cell PU foams used for this particular application is the low absorption at frequencies lower than 2000 $\mathrm{Hz}$. This is an important aspect to take into consideration because as it was discussed at the beginning of this sub-section, road traffic is one of the main noise sources. Many parts of the vehicles are recovered with sound absorbers materials to reduce noise emission. However, many sounds are located in frequency ranges below $2000 \mathrm{~Hz}$, and therefore, open-cell PU is not able to eliminate the sound created by these elements completely. However, the crosslinked open-cell polyolefin cellular polymers evaluated in this paper presented excellent sound absorptions in a low-frequency range, appearing maximums of the acoustic absorption coefficient at frequencies below 2000 $\mathrm{Hz}$. Although the results are very good at low frequencies, it is also true, that open-cell PU foams present better absorptions at higher frequencies (above $2000 \mathrm{~Hz}$ ). Therefore, a combination of both types of materials could be an excellent solution to diminish the noise levels considerably. Furthermore, Alvarez et al. demonstrated that the theory of Biot-Allard alongside Johnson's approach could be used to predict the acoustic behavior not only of PU foams but also the one displayed by open-cell polyolefin foams $[153,177]$.

As in the case of the compressive stress, Figure $\mathbf{2 . 4 2}$ gives a global vision of the acoustic response of commercial foams. The absorption coefficient $(a)$ is plotted against density for flexible open-cell polyurethane foams and commercial closed-cell LDPE foams: 


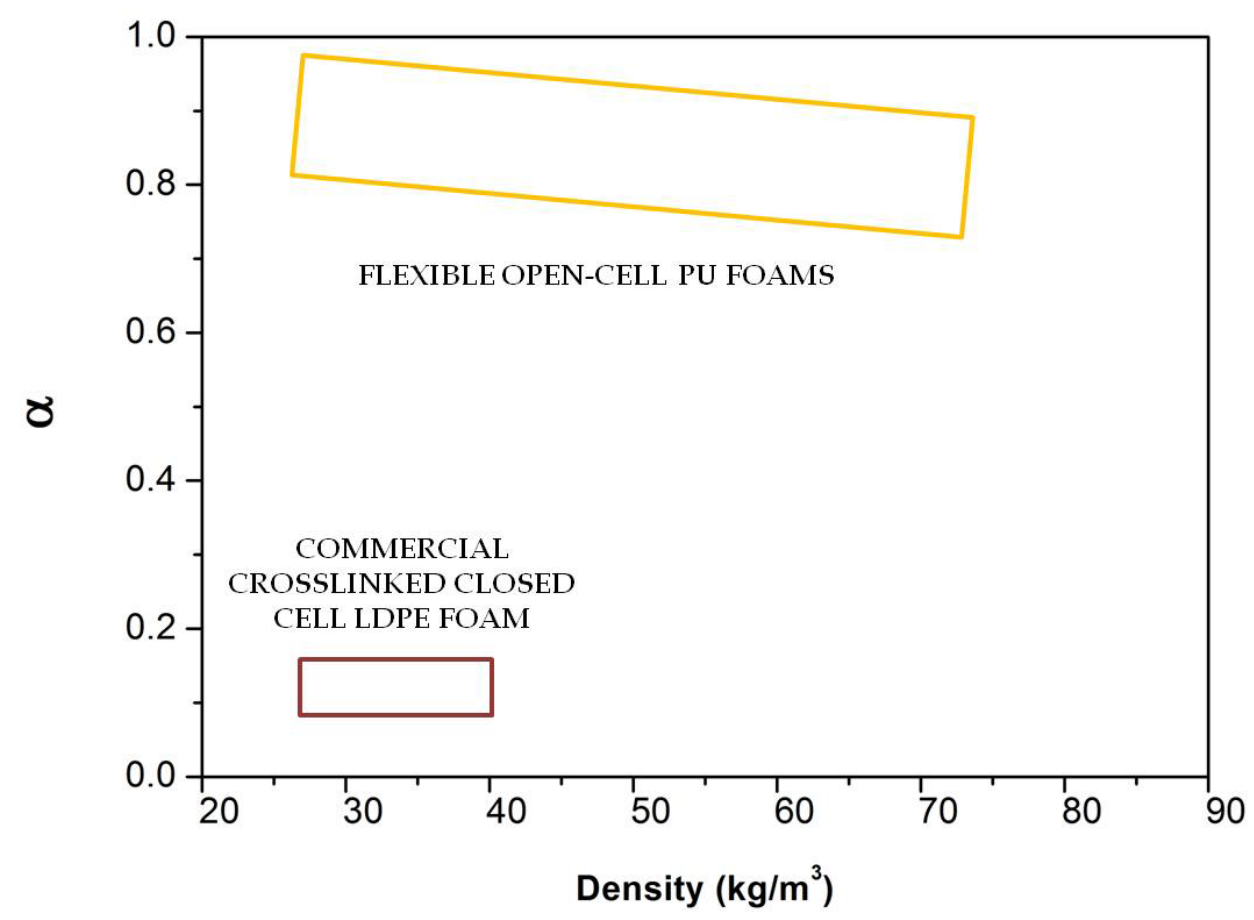

Figure 2.42. Sound absorption coefficient (a) for commercial flexible PU and closed-cell LDPE foams with different densities.

Concerning the PU-based foams, the absorption coefficient depends on the density of the foam, presenting low-density foams better absorptions than the high-density ones. This dependence does not appear in the commercial crosslinked closed-cell LDPE foams, but it must be considered that their absorptions are considerably smaller than those displayed by the flexible open-cell PU foams.

The sound absorptions capacity of the materials developed during this thesis were analysed using an impedance tube, and the results were compared to the ones obtained for the reference open-cell PU foam. The goals of this analysis were first to determine if these new materials could absorb more sound than the commercial opencell flexible PU foam, secondly to evaluate the behavior of these foams at low frequencies and finally to determine the effect of the cellular structure tortuosity on the sound absorption. Chapter 5 gathers all the results obtained during the sound absorption characterization.

\subsubsection{Oil-absorption properties}

Oil spills have a harmful long-term effect on the marine and terrestrial ecosystem [178181]. According to the data published by the International Tanker Owners Pollution Federation (ITOPF), approximately 116000 tons of oils were released to the environment in 2018, being the MT SANCHI oil spill in the East China Sea the largest one recorded in 24 years [182]. 
There are many examples of large oil spills in the last 40 years; for example, the Castillo de Bellver tank released 252000 tons of oil near to South Africa in 1981, the Exxon Valdez spilt 37000 tons in Alaska in 1989. In Spain, the Prestige oil tank sank in 2002, causing an oil spill of 63000 tons, being this case one of the most harmful environmental accidents in our country. The Deepwater Horizon oil spill in the Gulf of Mexico in 2010 was one of the largest oil-spill ever reported. However, it is not necessary to go so far away in time to report a considerable oil spill. As it was mentioned before, in January 2018, the MT SANCHI and the CF Crystal tankers collided causing the death of 32 crewmen and the releasing of 113000 tons of condensed gas.

It must also be mentioned that not only large spills but also medium and small spills are rather relevant for the environment. Around $70 \%$ of the total number of oil spills corresponds to medium or small ones.

A fast response is critical to minimize the damaging effects of oils spills. Furthermore, it is also very important to avoid the arrival of oil to the coast, because the harmful effects increase in a very large extent.

The current techniques employed to eliminate the oil are based on the use of dispersants and skimmers. Dispersants are added to the oil spill to reduce the surface tension, creating more and smaller oil droplets. Once the small droplets are formed, biodegradation by bacterial colonies takes place. However, there are some limitations in this process: there must be suitable sea conditions, oils with high viscosity are difficult to disperse, and in some cases, there is a risk of toxicity due to the chemical nature of the employed dispersants [178,183-185].

The mechanical recovery is usually the first measure adopted by the governments to deal with this problem. Skimmers are included in this approach. First, bombs are used to concentrate the oil, allowing the skimmers to collect it. However, there are also some limitations in the use of skimmers: their efficiency is reduced with bad weather, the oil viscosity also has a clear influence because some heavy crudes don't flow easily and finally the movement of currents and waves can limit the oil collection [186].

Another undesirable option is the in-situ burning, a technique based on the burning of the spill. This process is limited because toxic fumes are released and furthermore some toxic particles can stay in suspension after burning, resulting in air contamination. Due to these limitations, this method can be only applied offshore $[187,188]$.

One very interesting option is the use of absorbent materials. Teas et al. classified these materials into three groups $[189,190]$ : inorganic mineral products (such as zeolites or clays) [191-197], organic vegetable products (cotton fibers, wool, kenaf, kapok fibers, etc...) [198-205] and synthetic organic products (graphene, carbon nanotubes, gels, polymers, etc...) [206-213]. 
To be considered suitable for oil spill remediation, an absorbent material must fulfil some physical-chemical requirements that are summarized in Figure 2.43.

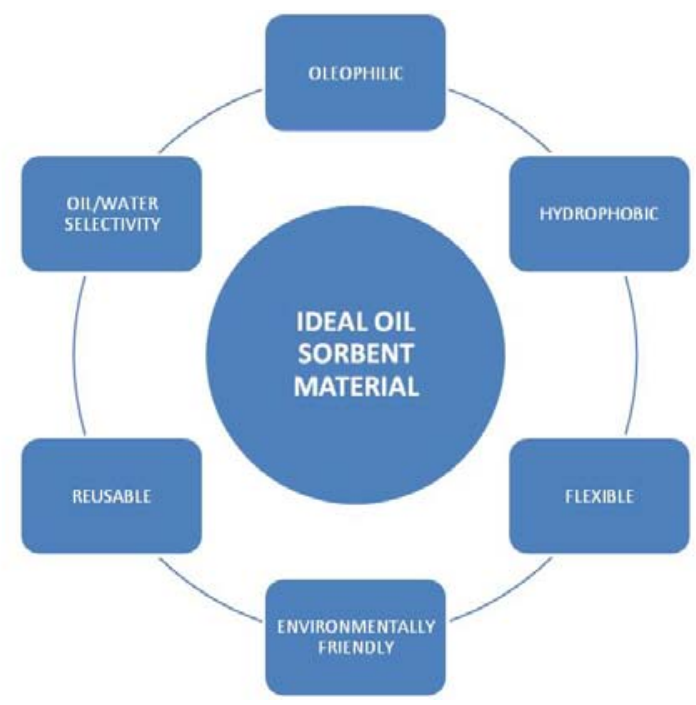

Figure 2.43. Properties required for a material to be used in oil spill remediation.

An absorbent must present affinity towards oils (oleophilicity) without absorbing water (hydrophobicity), which means that the materials must absorb oil selectively.

The flexibility is a key aspect since the oil must be extracted from the material, behaving as an oil sponge. Furthermore, the material must be reusable, allowing the collection and the extraction of the oil from the materials as many times as possible. Finally, the absorbent material must be environmentally friendl, limiting its impact as much as possible.

Organic vegetable products should be the best solution for this issue from an environmental point of view. As it was previously enounced, many groups are researching about this topic looking for a suitable natural material for oil spills remediation. One approximation is the use of natural fibers, such as cotton or kapok fibers. However, organic vegetable products present several limitations which hinder their use. Firstly, the oil absorption is far from that obtained for the synthetic materials. Secondly, it is very difficult to scale up the production of the products employed in several research works. Finally, these materials also show low hydrophobicity. Due to these drawbacks, it is mandatory to look for alternatives, which can be excellent oil absorbers by themselves or materials whose blends with natural sorbents allow overcoming the limitations of natural sorbents [214].

Organic synthetic products are gaining interest in the last years. Various allotropes of carbon have been evaluated, obtaining excellent oil absorptions, such as the carbon nanotubes reported by Gui et al. [207] or the spongy graphene with very high hydrophobicity reported by $\mathrm{Bi}$ et al. [208]. However, it is complex to scale up these materials, and the production costs would be disproportionate. 
Polymers and consequently, cellular polymers can also be found inside the group of organic synthetic materials. It has been seen that the materials must fulfil some chemical and environmental requirements to use them for oil spill remediation. The cellular polymer must also fulfil other requirements related to some physical properties:

- Low density: the lower the density, the higher the amount of oil that can be absorbed. The porosity $(\Phi)$ of the material is a key parameter to take into account in the analysis of the oil absorption capacity. Porosity is defined in Equation 7:

$$
\Phi=1-\frac{\rho_{f}}{\rho_{s}}
$$

where $\rho_{f}$ is the foam density, $\rho_{s}$ is the solid density, and its ratio is the relative density.

- High open-cell content: the cellular polymers must be open-cell to allow the penetration of oil inside the cellular structure.

At this point, nowadays, the only possible cellular polymer which fulfils these requirements is open-cell PU.

Due to this, open-cell PU foams have been deeply studied as oil sorbent materials. Doung and Burford analyzed the effect of the density, the oil viscosity and the temperature on the oil absorption capacity of several open-cell PU foams [215]. The oil absorption increased as the density of the foam decreased. However, the oil absorption was only slightly dependent on the oil viscosity. Absorptions up to 100 grams of oil per gram of foam were obtained when naphthenic oil was used. Pinto et al. studied the effect of the morphology of the porous structure of open-cell PU foams on the oil absorption, concluding that the better oil absorptions were obtained for PU foams with very high interconnectivity and cell sizes around or below 500 microns [216]. However, open-cell PU foams present a critical limitation: their low hydrophobicity. The presence of polar groups in the products formed in the reactions shown in Figure 2.7 is responsible for water absorption. To overcome this limitation, recent works have been focused on carrying out different types of surface treatments aimed at making the foams superhydrophobic. Li et al. improved the oleophilic/hydrophobic properties of PU foams by adding an oleophilic monomer, lauryl methacrylate [217]. Wang and Lin coated carbon nanotube/poly(dimethylsiloxane) to a PU sponge obtaining absorptions of hexane up to 35000 times its weight [218]. Liu et al. developed a PU foam coated with graphene oxide with very high oil and solvent absorption levels [219]. Nikkhah et al. published a study in which nanoclays were added to the open-cell PU foams, and this led to an improvement of the oil absorption capacity of up to a $16 \%$ [220]. The same authors also coated foams with multi-walled carbon nanotubes in a parallel study, increasing the oil absorption capacity up to a $22 \%$ [221]. Pinto et al. analyzed the effect of surface modification with silicon oxide nanoparticles and 
polydimethylsiloxane [222]. An oil absorption of up to 60 grams of oil per gram of foam was obtained being, in addition, the foams reusable.

The surface modification induces not only high hydrophilic behavior but also promotes oil absorption. Another example is the addition of super-paramagnetic iron oxide particles to facilitate the collection of the samples from the surface of the sea or the ocean [223]. The variety of particles which can be used to coat the surface of the PU foams is immense. However, on the one hand, the addition of particles affects the costs, and on the other hand, the viability of scaling up the materials is highly reduced.

As previously discussed with other properties, the limitation lies in the lack of alternatives to open-cell PU foams. Focusing on the related physical criteria, polyolefins could be an excellent alternative due to the non-polar nature of the C--C chains, which fosters the oil/water selectivity. Furthermore, polyolefins such as LDPE or EVA are flexible enough to allow the removal of the oil from the structure, and in addition, they are non-toxic.

Despite all these facts, there are few studies evaluating the oil absorption capacity of open-cell polyolefin polymers due to the complexity associated with the production of this type of open-cell materials. Rizvi et al. produced PP/polytetrafluoroethylene (PTFE)-based cellular materials by extrusion [224]. These cellular polymers were able to absorb up to 24 grams of gasoline per gram of foam. They also analyzed the reusability of the foams by measuring the non-recovered deformation using low strain rate compression tests, concluding that it was necessary to add a PP copolymer to improve the reusability of the materials. Wang et al. prepared blends of polypropylene (PP) and a thermoplastic polyolefin elastomer (POE) and foamed them also by using a continuous extrusion process. The materials were able to absorb around 20 grams of motor oil per gram of foam, and the addition of the elastomeric phase resulted in an improvement in the reusability level [225].

The production of crosslinked open-cell polyolefin cellular polymers by using a twosteps compression molding process opens a new path in the viability of using polyolefin cellular materials for oil absorption. Up to now, there are no works in the literature dealing with the evaluation of the oil absorption capability of these materials. As a result, a systematic analysis of the oil absorptive properties of the materials developed during this thesis has been performed. Two key aspects were taken into consideration: first, the effect of the tortuosity on the oil absorption and second, how much oil could be absorbed by these materials. Besides, the reusability of the materials was also characterized by using the methodology suggested by Rizvi et al. [224] and by performing several oil recollections, removing the oil and measuring the oil absorption of the same material (up to 50 times) again.

Chapter 6 of this thesis explains in depth the results related to the oil absorption levels displayed by all the different open-cell materials and their level of reusability. 


\subsubsection{Other properties}

After reviewing the mechanical, acoustic and oil absorption properties, the last section of this second chapter briefly summarizes some concepts and previous works related to two additional physical properties of critical importance in flexible foams: vibration dampening and thermal stability.

\subsubsection{Vibration dampening}

It is well-known that polymers are viscoelastic materials. Foams can be produced using different polymeric matrices, and therefore, polymer foams can inherit such viscoelastic character.

The viscoelastic behavior of a certain material can be evaluated using dynamic mechanical analysis (DMA). DMA consists of applying a sinusoidal strain to a material at a fixed frequency. This strain creates in the material a sinusoidal stress, which is out of phase with respect to the applied strain. The difference in phase indicates whether the viscous or the elastic component predominates in a material. An ideal viscous material would have a phase difference of $90^{\circ}$, whereas an ideal elastic material would recover instantaneously being both sinusoidal waves in phase $\left(0^{\circ}\right)$. Polymers present a behavior between these two ideal cases (viscoelastic-like character).

In the field of polymers, DMA is a quite interesting tool, since the relaxation processes of the polymeric chains can be detected. A clear example is the evaluation of $\alpha, \beta$ and $\gamma$ relaxations of the polyethylene chains $[226,227]$.

Three main parameters are estimated using DMA: the storage modulus $(E)$, the loss modulus $\left(E^{\prime \prime}\right)$ and the loss tangent $(\tan \delta)$ (Equations 8-10):

$$
\begin{gathered}
E^{\prime}=\frac{\sigma_{0}}{\varepsilon_{0}} \cdot \cos \delta \\
E^{\prime \prime}=\frac{\sigma_{0}}{\varepsilon_{0}} \cdot \sin \delta \\
\tan \delta=\frac{E^{\prime \prime}}{E^{\prime}}
\end{gathered}
$$

(Equation 8)

where $\sigma_{0}$ is the stress, $\varepsilon_{0}$ is the strain and $\delta$ is the angle phase.

$\tan \delta$ is a very interesting parameter, and it is used for the determination of the ability of a particular material to damp mechanical vibrations. This is critical, for example, in the automotive or the aeronautic sectors since the motors produce annoying vibrations. Materials with high $\tan \delta$ are excellent candidates to be used for this particular application due to their high capability of damping vibrations.

Dynamic mechanical analysis has been widely applied to unfoamed polymers or reinforced polymers [228-232]. Similarly, the dynamic mechanical response of foamed polymers has also been covered by several authors. Rodriguez-Perez et al. analyzed the 
dynamic mechanical properties of several foams based on different polymeric matrices (LDPE, LDPE/HDPE, LDPE/LLDPE, LDPE/EVA, PP and PP/HDPE) and different densities (from 30 to $310 \mathrm{~kg} / \mathrm{m}^{3}$ ) in the low-frequency range. They found that under these conditions, the viscoelasticity was ruled by the nature of the polymeric matrix and not by the morphology of the cellular structure [233]. Rodriguez-Perez et al. also characterized low-density closed-cell polyolefin foams [234]. They were able to detect the a relaxation only in foams based on LDPE (the relaxation was not detected in foams based on HDPE). They also observed that different crystalline structures led to different values of storage modulus and $\tan \delta$ and thus to different a viscoelastic behavior.

Concerning flexible PU foams, there are not many studies in the bibliography in which these materials have been characterized by using DMA $[235,236]$. Wolska et al. studied the mechanical behavior of flexible PU foams reinforced with graphite and phosphorous based fillers, concluding that the storage modulus increased due to the incorporation of fillers [237].

The dynamic mechanical properties of crosslinked open-cell polyolefins were analyzed by Rodriguez-Perez et al. in an article which covers the analysis of the physical properties of the open-cell foams fabricated by Sanwa Kako [138]. When it comes to the characterization using DMA, it was observed that the storage modulus of the open-cell foams was much lower than the storage modulus of closed-cell foams, and this parameter was highly dependent on the temperature (decreased as the temperature increased) for both closed and open-cell polyolefin foams. However, this behavior was not found in an open-cell PU foam, being the storage modulus constant with temperature mostly due to the thermoset character of the polymeric matrix. Furthermore, one of the most interesting results was the high value of $\tan \delta$ displayed by the open-cell polyolefin foams, which indicates the high capability of these materials to dissipate energy and damp vibrations.

The collection of materials produced and evaluated during this thesis was also characterized by using dynamic mechanical analysis. This topic is covered in the Chapter 7 of the document.

\subsubsection{Thermal stability}

The thermal properties of polymers are critical to determine accurately the range of temperatures in which they can be employed. By using thermomechanical analysis, it is possible to measure the changes in the dimensions of a sample within a certain range of temperatures.

In the case of polymers, internal structural changes such as the glass transition temperature $\left(T_{g}\right)$ or the relaxations of the polymer chains are bonded to variations in the thermal expansion coefficient (a). This coefficient can be estimated using Equation 11: 


$$
\alpha=\frac{l}{l_{0}}\left(\frac{d l}{d T}\right)
$$

where $l_{0}$ is the initial height of the sample and $l$ is the height of the sample at a certain temperature $(T)$.

The thermomechanical properties of crosslinked closed-cell foams were studied in detail by Rodriguez-Perez et al., observing a critical effect of the density, and thus of the gas enclosed inside of the cells, on the thermal expansion coefficient. According to this research, the effect of gas expansion with temperature and the cell wall thickness must be taken into account to understand the different thermal behavior of polymeric foams [238].

The open-cell crosslinked polyolefin foams fabricated by Sanwa Kako were also characterized by using TMA [138]. The closed-cell foams have a higher thermal expansion coefficient below $45{ }^{\circ} \mathrm{C}$ due to the contribution of the gas enclosed in the cells in the expansion. It was also observed that the open-cell foams started collapsing at lower temperatures than the closed-cell ones.

The thermal stability of the materials under consideration has also been measured by using TMA, and the results are gathered in Chapter 7 alongside with the DMA characterization.

\subsubsection{Thermal conductivity}

One of the main fields of application of polymeric foams is as thermal insulating materials. When it comes to the thermal conductivity of a polymeric foam, it is known that four main factors should be considered in the mechanism of heat transfer: the convection of the gas phase $\left(\lambda_{c}\right)$, the conduction of both solid and gaseous phases $\left(\lambda_{s}\right.$ and $\left.\lambda_{g}\right)$ and the radiation $\left(\lambda_{r}\right)$.

$$
\lambda=\lambda_{s}+\lambda_{g}+\lambda_{c}+\lambda_{r}
$$

Closed-cell foams present lower thermal conductivity than the solid polymer due to the lower thermal conductivity of the air enclosed in the cells than the solid polymer. Gibson and Ashby described (by using as an example a closed-cell polystyrene foam with relative density 0.025 and thermal conductivity of $0.04 \mathrm{~W} / \mathrm{m} \cdot \mathrm{K}$ ) the contribution of each term in the thermal conductivity. While the conduction of the solid face contributed only $7.5 \%$ of the total value, the conductivity of the enclosed gas played a critical role, being this contribution as remarkable as $67.5 \%$ [1]. The contribution of the radiation and convection was around $25 \%$. However, according to the same authors, the convection is important only when the Grashof number exceeds a value of 1000 [239]. The Grashof number $\left(G_{r}\right)$ is given by Equation 12:

$$
G_{r}=\frac{g \beta \Delta T_{c} l^{3} \rho^{2}}{\mu^{2}}
$$


where $g$ is the acceleration due to gravity $\left(9.81 \mathrm{~m} / \mathrm{s}^{2}\right), \beta$ is the volume coefficient of expansion for the gas, $\Delta T_{c}$ is the temperature difference across one cell, $l$ is the cell size, and $\rho$ and $\mu$ are the density and dynamic viscosity of the gas, respectively.

Furthermore, it is also accepted that the convection term has a negligible contribution in closed-cell foams as long as the cells are less than $4 \mathrm{~mm}$ in diameter [239].

The density plays a key role in this parameter. By lowering the density, the volume of gas increases and the fraction of solid is reduced. Furthermore, as it was previously discussed, the contribution of the gas phase in the thermal conductivity is quite relevant, and therefore, the gas enclosed inside the cells has a critical influence on this property.

Halogenated gas, specifically chlorofluorocarbon (CFC) blowing agents presented very low values of thermal conductivity and were used as blowing agents in the production of polystyrene-based foams for thermal insulation. However, after Montreal's Protocol, the use of CFC was restricted to avoid the depletion of the Ozone Layer. One interesting alternative to CFC's-based blowing agents is HCFC-based blowing agents. Shankland analyzed the effect of HCFC-123 and HCFC-141 in comparison to CFC 11 and HCFC-124 and HCFC-142 in comparison to CFC-12 on the thermal conductivity, concluding that although CFC-based foams presented lower thermal conductivity values, these alternatives were environmentally acceptable, less toxic and flammable [240]. Concerning the study of the thermal conductivity of the gas phase, one critical parameter is gas diffusion. The gas enclosed in the cells tends to diffuse out of the foam, penetrating air inside the cells. As air is characterized by presenting higher thermal conductivity values than current gases used as blowing agents, for instance, $\mathrm{CO}_{2}$, the ageing of the foams has been analyzed by several authors [241-245].

The current studies about thermal conductivity are conducted to reduce the cell size to obtain lower thermal conductivity values (Knudsen effect) [246]. The Knudsen effect implies that diffusion occurs when the cell size is comparable or smaller than the free path of the particles involved. According to this effect, if the cell size range is changed from the micrometric to the nanometric scale, the thermal conductivity would decrease abruptly [247-249].

The thermal conductivity of the materials under study has also been evaluated although a not very deep analysis was performed since this thesis is focused on opencell foams, which present poorer insulating abilities than their closed-cell counterparts and to the complexity of the cellular structure of the open-cell foams considered for the study.

The thermal conductivity of the collection of materials evaluated during this thesis has been measured by using a thermal conductivimeter, which measures the heat flow per area between two plates. Heat flow through the test sample results from having a temperature gradient across the sample as it is defined according to Fourier's equation (Equation 12): 


$$
q_{T} \quad=-\lambda_{T}\left(\frac{d T}{d x}\right)
$$

where $q_{T}$ is the heat flow per area is total thermal conductivity, $\lambda_{T}$ is the thermal conductivity of the material under analysis and $(d T / d x)$ is the gradient of temperature.

The analysis of the thermal conductivity properties of closed-cell PU foams has been extensively studied by many authors since this foam is widely used as thermal insulators [250-253].

Concerning crosslinked polyolefin foams, several studies have been performed on this topic. Rodriguez-Perez et al. analyzed the thermal properties of closed-cell foams physically crosslinked, concluding that the most important mechanism contributing to the thermal conductivity of those materials was the conduction of the gaseous phase. In addition, they observed that the radiation term decreased when the density increased [254]. Almanza et al. predicted the radiation term of the thermal conductivity of crosslinked closed-cell polyolefin foams [255]. They presented an equation with adjustable parameters that permits to estimate the thermal conductivity of these materials with a good level precision. The parameters that are considered for the model are: the relative density, conductivity of gas and solid phases, fraction of mass in the struts, cell size, thickness and the chemical composition and morphology of the polymeric matrix. Hasanzadeh et at. presented a recent study, in which the effect of the density, cell size and cell wall thickness was evaluated for LDPE foams. They obtained a thermal conductivity as low as $30 \mathrm{~mW} / \mathrm{mK}$ for a foam with a density of $37 \mathrm{~kg} / \mathrm{m}^{3}$, a cell size of 100 microns and a cell wall thickness of 6 microns [256].

Alvarez-Lainez et al. evaluated the thermal properties of crosslinked open-cell polyolefin foams manufactured by Sanwa Kako. The thermal conductivity was measured in a temperature range between 24 and $50{ }^{\circ} \mathrm{C}$. At low temperatures, the thermal conductivity of the open-cell samples was slightly higher than that exhibited by their closed-cell counterparts with similar density and chemical composition. The different mechanisms accounting for the overall thermal conductivity of those materials were also studied, concluding that convention mechanism was negligible and the differences regarding the radiation term were responsible for the explained the differences exhibited by materials with different cellular structures [257].

Figure 2.44 represents the same fact previously discussed for the mechanical and the acoustical properties. This figure shows the thermal conductivity of several commercial foams as a function of the density. In Chapter 7, it will be displayed the thermal conductivities of the foams under consideration to give a global comparative with these commercial products: 


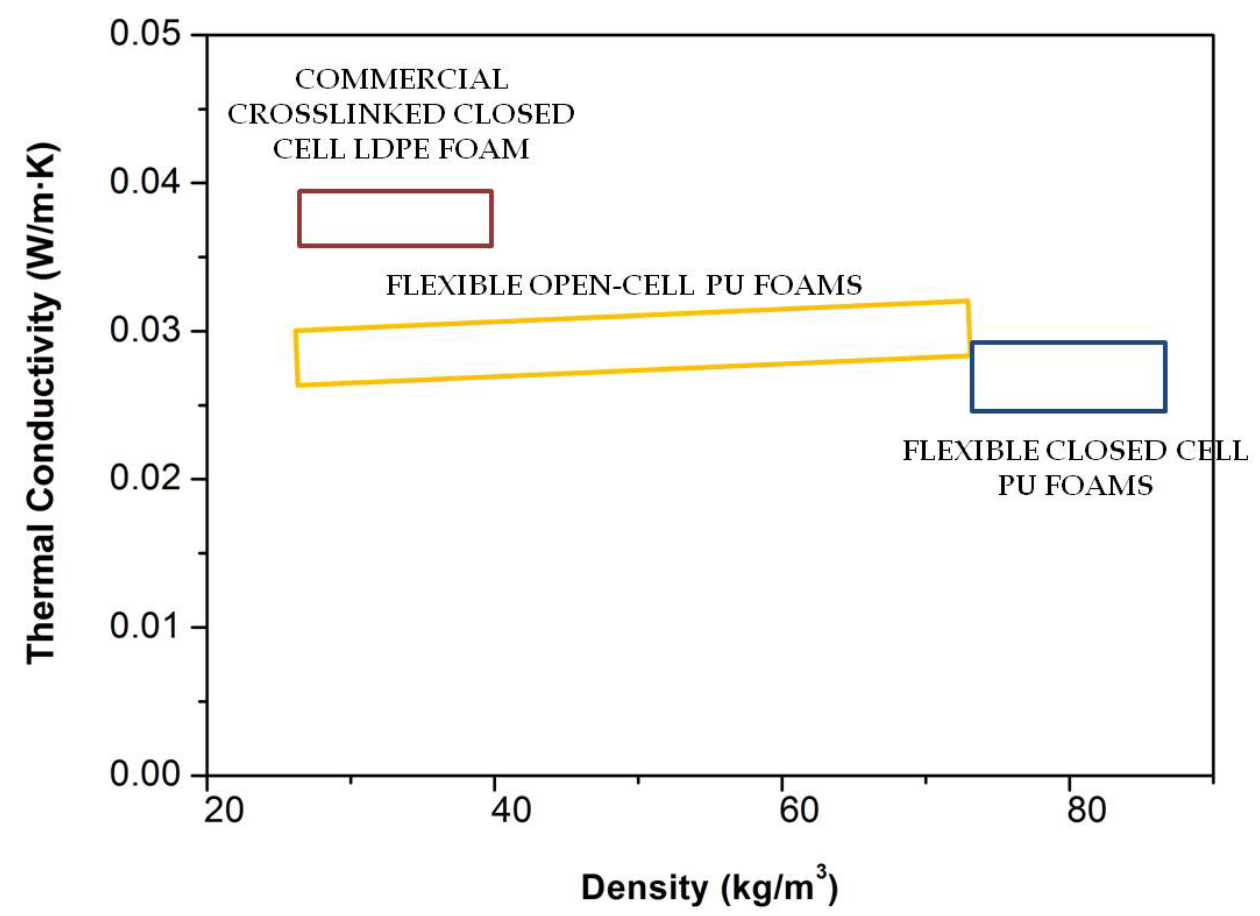

Figure 2.44. Thermal conductivity (W/m K) for commercial flexible PU and closed-cell LDPE foams with different densities.

Regardless of the level of interconnectivity and the density, PU foams have lower values of the thermal conductivity than the commercial crosslinked closed-cell LDPE foams.

Concerning PU foams, despite comparing foams with different densities, the closedcell PU foams present better thermal insulation properties than the open-cell counterparts. The thermal conductivity of the open-cell PU foams slightly increases when the density also increases, due to the reasons previously discussed (less gas phase and more contribution of the solid).

\subsubsection{Summary}

The last section of this second chapter summarizes schematically which parameters affect in a large extent each of the physical properties previously described for the different types of foams mentioned up to now (the effect of the polymer matrix is not accounted). In Table 2.3, it is indicated with arrows the contribution of each parameter to each physical property, depending on the cellular structure interconnectivity, for polyolefin and polyurethane foams. CC is referred to crosslinked closed-cell polyolefin foams, OC is referred to crosslinked open-cell polyolefin foams, and PU is assigned to flexible open-cell PU foams 


\begin{tabular}{|c|c|c|c|c|c|}
\hline \multicolumn{6}{|c|}{ MECHANICAL PROPERTIES } \\
\hline Sample & Density & Cell Size & Anisotropy & $\begin{array}{c}\text { Open-cell } \\
\text { content }\end{array}$ & Tortuosity \\
\hline $\mathrm{CC}$ & $\uparrow \uparrow$ & - & $\uparrow$ & $\uparrow \uparrow$ & - \\
\hline $\mathrm{OC}$ & $\uparrow \uparrow$ & - & $\uparrow$ & $\uparrow \uparrow$ & $\uparrow \uparrow$ \\
\hline PU & $\uparrow \uparrow$ & - & $\uparrow$ & $\uparrow \uparrow$ & $\uparrow \uparrow$ \\
\hline \multicolumn{6}{|c|}{ ACOUSTIC PROPERTIES } \\
\hline Sample & Density & Cell Size & Anisotropy & $\begin{array}{c}\text { Open-cell } \\
\text { content }\end{array}$ & Tortuosity \\
\hline $\mathrm{CC}$ & $\uparrow$ & - & - & $\uparrow \uparrow$ & - \\
\hline $\mathrm{OC}$ & $\uparrow$ & - & - & $\uparrow \uparrow$ & $\uparrow \uparrow$ \\
\hline PU & $\uparrow$ & - & - & $\uparrow \uparrow$ & $\uparrow \uparrow$ \\
\hline \multicolumn{6}{|c|}{ OIL ABSORPTION } \\
\hline Sample & Density & Cell Size & Anisotropy & $\begin{array}{c}\text { Open-cell } \\
\text { content }\end{array}$ & Tortuosity \\
\hline $\mathrm{CC}$ & $\uparrow \uparrow$ & - & - & $\uparrow \uparrow$ & - \\
\hline OC & $\uparrow \uparrow$ & $\uparrow$ & - & $\uparrow \uparrow$ & $\uparrow \uparrow$ \\
\hline PU & $\uparrow \uparrow$ & $\uparrow$ & - & $\uparrow \uparrow$ & $\uparrow \uparrow$ \\
\hline \multicolumn{6}{|c|}{ VIBRATION DAMPENING } \\
\hline Sample & Density & Cell Size & Anisotropy & $\begin{array}{c}\text { Open-cell } \\
\text { content }\end{array}$ & Tortuosity \\
\hline $\mathrm{CC}$ & $\uparrow$ & - & - & $\uparrow \uparrow$ & - \\
\hline OC & $\uparrow$ & - & - & $\uparrow \uparrow$ & - \\
\hline PU & $\uparrow$ & - & - & $\uparrow \uparrow$ & - \\
\hline \multicolumn{6}{|c|}{ THERMAL STABILITY } \\
\hline Sample & Density & Cell Size & Anisotropy & $\begin{array}{c}\text { Open-cell } \\
\text { content }\end{array}$ & Tortuosity \\
\hline $\mathrm{CC}$ & $\uparrow$ & $\uparrow$ & $\uparrow$ & $\uparrow \uparrow$ & - \\
\hline $\mathrm{OC}$ & $\uparrow$ & $\uparrow$ & $\uparrow$ & $\uparrow \uparrow$ & $\uparrow$ \\
\hline PU & $\uparrow$ & $\uparrow$ & $\uparrow$ & $\uparrow \uparrow$ & $\uparrow$ \\
\hline \multicolumn{6}{|c|}{ THERMAL CONDUCTIVITY } \\
\hline Sample & Density & Cell Size & Anisotropy & $\begin{array}{c}\text { Open-cell } \\
\text { content }\end{array}$ & Tortuosity \\
\hline $\mathrm{CC}$ & $\uparrow \uparrow$ & $\uparrow \uparrow$ & $\uparrow$ & $\uparrow \uparrow$ & - \\
\hline OC & $\uparrow \uparrow$ & $\uparrow \uparrow$ & $\uparrow$ & $\uparrow \uparrow$ & - \\
\hline PU & $\uparrow \uparrow$ & $\uparrow \uparrow$ & $\uparrow$ & $\uparrow \uparrow$ & - \\
\hline
\end{tabular}

Table 2.3. Contribution of the foam parameters to the physical properties. Legend: - not relevant, $\uparrow$ relevant contribution and $\uparrow \uparrow$ very relevant contribution. 


\subsection{References}

[1]. L.J. Gibson, M.F. Ashby. Cellular Solids: Structure and Properties, $2^{\text {ndedn. }}$ Pergamon., Oxford, 1998.

[2]. M.A. Rodriguez-Perez. Advances in Polymer Science, 184, 97-126, 2005.

[3]. B. Ghanbarian, A.G. Hunt, R.P. Ewing, M. Sahimi. Soil Science Society of America Journal, 77, 1461-1477, 2013.

[4]. J. Bear. Dynamic of Fluids in Porous Media. Dover Publications., New York, 1972.

[5]. D. Klempner, K.C. Frisch. Handbook of Polymeric Foams and Foam Technology. Hanser Publishers., Munich, 1991.

[6]. J.F. Allard, B. Castagnede, M. Henry. Review of Scientific Instruments, 65, 754-755, 1995.

[7]. M. Melonand, B. Castagnede. The Journal of the Acoustical Society of America, 98, 1228-1230, 1995.

[8]. M. Melon, E. Mariez, C. Ayrault, S. Sahraoui. The Journal of the Acoustical Society of America, 104, 2622-2627, 1998.

[9]. T.E. Gomez Alvarez Arenas, S. de la Fuente, I. Gonzalez Gomez. Applied Physics Letter, 88, 221910, 2006.

[10]. L.H. Le, C. Zhang, D. Ta, E. Lou. Ultrasonics, 50, 1-5, 2010.

[11]. A. Moussatov, C. Ayrault, B. Castagnede. Ultrasonics, 39, 195-202, 2001.

[12]. Z.E. Fellah, S. Berger, W. Lauriks, C. Depollier, C. Aristegui, N.Y. Chapelon. The Journal of the Acoustical Society of America, 113, 2424-2433, 2003.

[13]. H. Saomoto, J. Katagiri. Theoretical and Applied Mechanics Letters, 5, 177-180, 2015.

[14]. W. Sobieski. Granular Materials, 18, 72-81, 2016.

[15]. G. Oertel. Polyurethane Handbook 2nd Edition. Hanser Publishers., Munich, 1985.

[16]. D. Randall, S. Lee. The Polyurethanes Book. John Wiley \& Sons., Hoboken, 2003.

[17]. M. Szycher. Szycher's Handbook of Polyurethanes, CRC Taylor \& Francis., Boca Raton, 2013.

[18]. M.F. Sonnenschein. Polyurethanes: Science, Technology, Markets and Trends. John Wiley \& Sons., Hoboken, 2014.

[19]. I.G. Farbenindustrie AG. In Frankfurt, Main. Verfahren zur Herstellung von Polyurethanen bzw. Polyharnstoffen. Patent, DE728981.

[20]. S. Thomas, A.V. Rane, K. Kanny, V.K. Abitha, M.G. Thomas. Recycling of Polyurethane Foams, Elsevier., Amsterdam, 2018. 
[21]. K. Ashida. Polyurethane and Related Foams, CRC Taylor \& Francis., Boca Raton, 2006.

[22]. K.J. Saunders. Organic Polymer Chemistry, Chapman \& Hall., London, 1988.

[23]. R.B. Seymour, G.B. Kauffman. Journal of Chemical Education, 69, 909-910, 1992.

[24]. H.W. Engels, H.G. Pirkl, R. Albers, R.W. Albach, J. Krause, A. Hoffmann, H. Casselmann, J. Dormish. Angewandte Chemical International Edition, 52, 9422-9441, 2013.

[25]. J. Bernardini, D. Licursi, I. Anguillesi, P. Cinelli, M.B. Coltelli, C. Antonetti, A.M. Raspolli-Galletti, A. Lazzeri. BioResources, 12, 3630-3655, 2017.

[26]. A. Demharter. Cryogenics. 38, 113-117, 1998.

[27]. O. Volkert. Process for the Preparation of Polyurethane Rigid Foams Having a Low Thermal Conductivity and their Use. Patent, US5096933A.

[28]. C. Tomasi. Rigid Polyurethane Foam and Heat Insulating Construction Element Comprising the Same. Patent, US6808800B2.

[29]. T. Widya, C.W. Macosko. Journal of Macromolecular Science, Part B, 44, 897-908, 2005.

[30]. M.C. Saha, M.E. Kabir, S. Jeelani. Materials Science and Engineering: A. 479, 213$222,2008$.

[31]. H. Maucher. Mattresses and Chaise Longue Cushions Having a Core Made of Flexible Polyurethane Foam. Patent, US5491852A.

[32]. H. Mattesky. Flexible, Substantially Open Celled Polyurethane Foam and Method of Making Same. Patent, US6391933B1.

[33]. A. Di Stasio, L. Lavelle, G. Borgart, B. Lucas, S. Barger. Mattress Having Reticulated Viscoelastic Foam. Patent, US20050210595A1.

[34]. I.S. Lin, M.P. Yao. Modified Hydrophilic Polyurethane Memory Foam, Application and Manufacturing Method Thereof. Patent, US20070032561A1.

[35]. Y. Imai, T. Asano. Journal of Applied Polymer Science, 27, 183-195, 1982.

[36]. C.H. Sung, K.S. Lee, K.S. Lee, S.M. Oh, J.H. Kim, M.S. Kim, H.M. Jeong. Macromolecular Research, 15, 443-448, 2007.

[37]. M. Bandarian, A. Shojaei, A.M. Rashidi. Polymer International, 60, 475-482, 2010.

[38]. C. Zhang, J. Li, Z. Hu, F. Zhu, Y. Huang. Materials \& Design, 41, 319-325, 2012.

[39]. J.G. Gwon, S.K. Kim, J.H. Kim. Materials \& Design, 89, 448-454, 2016.

[40]. American Chemistry Council. "The Economic Benefits of the U.S. Polyurethanes Industry 2017".

[41].https://www.businesswire.com/news/home/20161214005038/en/High-

Demand-Emerging-Economies-Boost-Global-Polyurethane. 
[42].https://www.plasticstoday.com/content/engine-cover-molded-polyurethaneintegral-foam-single-shot/18002255521981.

[43]. https://www.osha.gov/SLTC/isocyanates/.

[44].https:// echa.europa.eu/-/restriction-proposal-on-diisocyanates-and-severalauthorisation-applications-agreed-by-rac-and-seac.

[45]. S.T. McKenna, T.R. Hull. Fire Science Reviews, 5:3, 2016.

[46]. A. Gharehbagh, Z. Ahmadi. "Polyurethane Flexible Foam Fire Behavior". 2012.

[47]. W.D. Woolley, A.I. Wadley, P. Field. Fire Research Notes, 951, 1-17, 1972.

[48]. W.D. Woolley, P.J. Fardell, I.G. Buckland. Fire Research Notes, 1039, 1-17, 1975.

[49]. J. Chambers, J. Jiricny, C.B. Reese. Fire and Materials, 5, 133-141, 1981.

[50]. B.C. Levin, M. Paabo, M.L. Fultz, C.S. Bailey. Fire and Materials, 9, 125-134, 1985.

[51].https://www.atsdr.cdc.gov/MMG/MMG.asp?id=1141\&tid=249.

[52]. M. Ravey, E.M. Pearce. Journal of Applied Polymer Science, 63, 47-74, 1997.

[53]. D. Allan, J. Daly, J.J. Liggat. Polymer Degradation and Stability, 98, 535-541, 2013.

[54]. M.A. Garrido, R. Font. Journal of Analytical and Applied Pyrolysis. 113, 202-215, 2015.

[55]. B.H. Chun, X. Li, E.J. Im, K.H. Lee, S.H. Kim. Fire and Materials. 5, 133-141, 2007.

[56]. C. Vasile. Handbook of Polyolefins. Marcel Dekker., New York, 2000.

[57]. M. Al-Ali AlMa'adeed, I. Krupa. Polyolefin Compounds and Materials. Springer., Berlin, 2016.

[58]. D.W. Sauter, M. Taoufik, C. Boisson. Polymers, 9, 185-198, 2017.

[59]. R.B. Seymour. Pioneers in Polymer Science. Kluwer Academic Publishers., Boston, 1989.

[60]. S. Sivaram. Resonance, 22, 1007-1023, 2017.

[61]. R.B. Seymour, T. Cheng. Advances in Polyolefins: The World's Most Widely Used Polymers. Springer., Berlin, 1987.

[62]. A. C. Albertsson. Long-Term Properties of Polyolefins. Springer., Berlin, 2004.

[63]. Plastics - the Facts 2018. PlasticsEurope, Association of Plastics Manufacturers.

[64]. N.J. Mills. Polyolefin Foams. Rapra Technology Limited., Shawbury, 2003.

[65]. J. Sharif, S. Hanisah Syed Abdul Aziz, K. Hashim. Radiation Physics and Chemistry, 58, 191-195, 2000.

[66]. T. Kang, C. Ha. Polymer Testing, 19, 773-783, 2000. 
[67]. D. Gheysari, A. Behjat. European Polymer Journal, 37, 2011-2016, 2001.

[68]. http://www.palziv.com/foam_in_rolls_galfoam.html.

[69]. https://www.sekisuichemical.com/product/prd_04.html.

[70]. https://www.furukawakk.co.jp/e_index.htm

[71]. https://www.toray.com/.

[72]. https://www.hitachi-chem.co.jp/english/.

[73]. D. Eaves. Handbook of Polymer Foams. Rapra Technology Limited., Shawbury, 2004.

[74]. https://www.zotefoams.com/product/azote/plastazote/.

[75]. P. Grathwohl. Diffusion in Natural Porous Media. Kluwer Academic Publishers., Dordrecht, 1998.

[76]. F. Hidalgo. Design and Optimization of Process Parameters in the Production of Crosslinked Polyolefin Foams by Compression Molding. PhD Thesis, University of Valladolid, 2008.

[77]. M.A. Rodriguez-Perez. Thermal and Mechanical Properties of Polyolefin Foams. PhD Thesis, University of Valladolid, 1999.

[78]. O. A. Almanza. Modelling of Thermal and Mechanical Properties of Polyolefin Foams. PhD Thesis, University of Valladolid, 2000.

[79]. L.O. Arcos. Thermal and Mechanical Properties of Polyolefin Foams Produced by Compression Molding. PhD Thesis, University of Valladolid, 2002.

[80]. J.L. Herrero. Impact and Creep Behavior of Polyethylene Based Foams. PhD Thesis, University of Valladolid, 2004.

[81]. J.I. Peña. Effect of Thermal Treatments in Low-Density Polyethylene Foamed Blocks Produced by Compression Molding. PhD Thesis, University of Valladolid, 2006.

[82]. R. A. Campo-Arnaiz. Application of Spectroscopic Techniques for Studying the Morphology and the Thermal and Emission Properties of Low Density Polyolefin Foams. PhD Thesis, University of Valladolid, 2011.

[83J.A. Martinez-Diez, M.A. Rodriguez-Perez, J.A. de Saja, L.O. Arcos y Rabago, O. Almanza. Journal of Cellular Plastics, 37, 21-42, 2001.

[84]. M.A. Rodriguez-Perez, O. Almanza, J.L. del Valle, A. Gonzalez, J.A. de Saja. Polymer Testing, 20, 253-267, 2001.

[85]. M.A. Rodriguez-Perez. Cellular Polymers, 21, 117-136, 2002.

[86]. R.A. Campo-Arnaiz, M.A. Rodriguez-Perez, B. Calvo, J.A. de Saja. Journal of Polymer Science, Part B: Polymer Physics, 43, 1608-1617, 2005.

[87]. J.L. Herrero, M.A. Rodriguez-Perez, J.A. de Saja. Cellular Polymers, 24, 329-346, 2005. 
[88]. M.A. Rodriguez-Perez, J.L. Herrero, E. Solorzano, J.A. de Saja. Cellular Polymers, 25, 221-236, 2006.

[89]. J.L. Herrero, M.A. Rodriguez-Perez, J.A. de Saja. Journal of Applied Polymer Science, 99, 2204-2210, 2006.

[90]. J.L. Herrero, M.A. Rodriguez-Perez, J.A. de Saja. Cellular Polymers, 35, 159-176, 2006.

[91]. M.A. Rodriguez-Perez, J.I. Gonzalez-Peña, J.A. de Saja. European Polymer Journal, 43, 4474-4485, 2007.

[92]. M.A. Rodriguez-Perez, O. Almanza, J.L. Herrero, J.A. de Saja. Cellular Polymers, 27, 179-200, 2008.

[93]. M.A. Rodriguez-Perez, J.I. Gonzalez-Peña, J.A. de Saja. Polymer International, 58, 620-629, 2009.

[94]. https://en.sanwa-chemi.co.jp/.

[95]. M. Alvarez-Lainez. Thermal, Mechanical and Acoustic Properties of Open Cell Polyolefin Foams. PhD Thesis, University of Valladolid, 2007.

[96]. K. Matsumoto, N. Kotani, N. Ida, Y. Miyano. Method of Producing Open-Cell Foams of Cross-Linked Polyolefins. Patent, US5242634A.

[97]. M.A. Rodriguez-Perez, C. Saiz-Arroyo, J. Tirado-Mediavilla. Process to Produce a Highly Expanded Open Cell Cross-Linked Polyolefin Foam. Patent, WO 2015/140374 A1.

[98]. M.F. Ashby. Metallurgical Transactions A, 14, 1755-1769, 1983.

[99]. N.A. Fleck. Cellular Metals and Polymers, 1-4, 2004.

[100]. R. Chan, M. Nakamura. Journal of Cellular Plastics, 5, 112-118, 1969.

[101]. P.J. Phillips, N.R. Waterman. Polymer Engineering \& Science, 14, 67-71, 1974.

[102]. M. Wilsea, K.L. Johnson, M.F. Ashby. International Journal of Mechanical Sciences, 17, 457-460, 1975.

[103]. H.X. Zhu, J.F. Knott, N.J. Mills. Journal of the Mechanics and Physics of Solids, 45, 319-325 327-343, 1997.

[104]. N.J. Mills, H.X. Zhu. Journal of the Mechanics and Physics of Solids, 47, 669-695, 1999.

[105]. N. Reichelt, M. Stadlbauer, R. Folland, C.B. Park, J. Wang. Cellular Polymers, 22, 315-327, 2003.

[106]. R. Verdejo, N.J. Mills. Journal of Biomechanics, 37, 1379-1386, 2004.

[107]. L Gong, S. Kyriakides, W.Y. Jang. International Journal of Solids and Structures, 42, 1355-1379, 2005. 
[108]. M.C. Saha, H. Mahfuz, U.K. Chakravarty, M. Uddin, M.E. Kabir, S. Jeelani. Materials Science and Engineering:A, 406, 328-336, 2005.

[109]. G. Menges, F. Knipschild. Polymer Engineering \& Science, 15, 623-627, 1975.

[110]. K.C. Rusch. Journal of Applied Polymer Science, 14, 1263-1276, 1970.

[111]. Z.H. Tu, V.P.M. Shim, C.T. Lim. International Journal of Solids and Structures, 38, 9267-9279, 2001.

[112]. W.L. Ko. Journal of Cellular Plastics, 1, 45-50, 1965.

[113]. J.M. Lederman. Journal of Applied Polymer Science, 15, 693-703, 1971.

[114]. W.E. Warren, A.M. Kraynik. Journal of Applied Mechanics, 55, 341-346, 1988.

[115]. M. Fatima Vaz, M.A. Fortes. Journal of Materials Science Letters, 12, 408-410, 1993.

[116]. L.D. Wegner, L.J. Gibson. Acta Metallurgica et Materialia, 43, 1651-1667, 1995.

[117]. J. Zhang. PhD Thesis, University of Cambridge, 1989.

[118]. A.N. Gent, A.G. Thomas. Rubber Chemistry and Technology, 36, 597-611, 1963.

[119]. N.J. Mills, M.A. Rodriguez-Perez. Cellular Polymers, 20, 79-100, 2001.

[120]. J.L. Herrero, M.A. Rodriguez-Perez, J.A. de Saja. Polymer, 46, 3105-3110, 2005.

[121]. S.G. Bardenhagen, A.D. Brydon, J.E. Guilkey. Journal of the Mechanics and Physics Solids, 53, 597-617, 2005.

[122]. Q.M. Li, I. Magkiriadis, J.J. Harrigan. Journal of Cellular Plastics, 42, 371-392, 2006.

[123]. W. Patten, C. G. Seefried. Journal of Cellular Plastics, 12, 41-48, 1976.

[124]. J.C. Moreland, G. L. Wilkes, R.B. Turner. Journal of Applied Polymer Science, 52, 549-568, 1994.

[125]. D.V. Dounis, G. L. Wilkes. Polymer, 38, 2819-2828, 1997.

[126]. L Gong, S. Kyriakides. International Journal of Solids and Structures, 42, 13811399, 2005.

[127]. M. Rampf, O. Speck, T. Speck, R.H. Luchsinger. Journal of Cellular Plastics, 48, 53-69, 2011. 
[128]. S.H. Goods, C.L. Neuschwanger, L.L. Whinnery, W.D. Nix. Journal of Applied Polymer Science, 74, 2724-2736, 1999.

[129]. F. Saint-Michel, L. Chazeau, J. Cavaille. Composites Science and Technology, 66, 2709-2718, 2006.

[130]. D. Yan, K. Dai, Z. Xiang, Z. Li, X. Ji, W. Zhang. Journal of Applied Polymer Science, 120, 3014-3019, 2011.

[131]. M. Santiago-Calvo, V. Blasco, C. Ruiz, R. Paris, F. Villafane, M.A. RodriguezPerez. Journal of Applied Polymer Science, 136, 47474, 2019.

[132]. S. Cho, J. Il So, J. Jung, S. Hwang, S. Baeck, S.E. Shim. Macromolecular Research, 27, 153-163, 2019.

[133]. J. Konieczny, K. Loos. Polymer, 11, 256, 2019.

[134]. H. Kadam, S. Bandyopadhyay-Ghosh, N. Malik, S.B. Ghosh. Macromolecular Research, 136, 47063, 2019.

[135]. X.G. Luo, Y.X. Cai, L.M. Liu, F.Q. Zhang, Q.X. Wu, J. Zeng. Journal of the American Oil Chemists Society, 96, 319-328, 2019.

[136]. M. Davari, M.K. Razavi Aghjeh, S.M. Seraji. Journal of Applied Polymer Science, 124, 2789-2797, 2012.

[137]. E.J. Jeong, H.M. Jeong. Polymer-Korea, 41, 926-934, 2017.

[138]. M.A. Rodriguez-Perez, M. Alvarez, J. de Saja. Journal of Applied Polymer Science, 114, 1176-1186, 2009.

[139]. K.C. Rusch. Journal of Applied Polymer Science, 13, 2297-2311, 1969.

[140]. J.I. Velasco, A.B. Martinez, D. Arencon, M.A. Rodriguez-Perez, J. de Saja. Journal of Materials Science, 34, 431-438, 1999.

[141]. doi.org/10.4028/www.scientific.net/MSF.480-481.513

[142]. K.W. Jeong, S.S. Cheon, M.B. Munshi. Journal of Mechanical Science and Technology, 26, 2033-2038, 2012.

[143]. H.X. Zhu, N.J. Mills, J.F. Knott. Journal of the Mechanics and Physics of Solids, $45,1875-1904,1997$.

[144]. N.J. Mills. Cellular Polymers, 25, 293-316, 2006.

[145]. https://www.eea.europa.eu/themes/human/noise.

[146].http://www.euro.who.int/en/health-topics/environment-andhealth/noise/policy/who-night-noise-guidelines-for-europe. 
[147]. https://www.mimi.io/.

[148]. http://www.euro.who.int/en/health-topics/environment-and-health/noise.

[149]. R.F. Lambert. The Journal of the Acoustical Society of America, 72, 879-887, 1982.

[150]. W. Yang, Y. Li. Science China Technological Sciences, 55, 2278-2283, 2012.

[151]. U. Berardi, G. Iannace. Building and Environment, 94, 840-852, 2015.

[152]. M.A. Biot. The Journal of the Acoustical Society of America, 28, 168-178, 1956.

[153]. M.A. Biot. Journal of Applied Physics, 33, 1482-1498, 1961.

[154]. M.A. Biot. The Journal of the Acoustical Society of America, 34, 1254-1264, 1956.

[155]. C.W. Kosten, J.H. Janssen. Acta Acustica, 7, 372-378, 1957.

[156]. D.L. Johnson, J. Koplik, R. Dashen. Journal of Fluid Mechanics, 176, 379-402, 1987.

[157]. http://pcfarina.eng.unipr.it/Public/Standing-Wave/ebook_6_impedance.pdf.

[158]. J.Y. Chung, D.A. Blasser. The Journal of the Acoustical Society of America, 68, 907-913, 1980.

[159]. I. P. Dunn, W. A. Davern. Applied Acoustics, 19, 321-334, 1986.

[160]. W. Lauriks, A. Cops, C. Verhaegen. Journal of Sound and Vibration, 131, 143-156, 1989.

[161]. J. Lee, G.H. Kim, C.S. Ha. Journal of Applied Polymer Science, 123, 2384-2390, 2012.

[162]. H. Adachi, T. Hasewaga, T. Asano. Journal of Sound and Vibration, 131, 143-156, 1989. Journal of Applied Polymer Science, 65, 1395-1402, 1997.

[163]. C. Zhang, J. Li, Z. Hu, F. Zhu, Y. Huang. Materials \& Design, 41, 319-325, 2012.

[164]. J.G. Gwon, S.K. Kim, J.W. Kim, J.H. Kim. Materials \& Design, 89, 448-454, 2016.

[165]. G. Sung, S.K. Kim, J.W. Kim, J.H. Kim. Polymer Testing, 53, 156-164, 2016.

[166]. R. Verdejo, R. Stämpfli, M. Alvarez-Lainez, S. Mourad, M.A. Rodriguez-Perez, P.A. Brühwiler, M. Schaffer. Composites Science and Technology, 69, 1564-1569, 2009.

[167]. G. Sung, J.W. Kim, J.H. Kim. Journal of Industrial and Engineering Chemistry, 44, 99-104, 2016.

[168]. G. Sung, J.H. Kim. Composites Science and Technology, 146, 147-154, 2017. 
[169]. S.C. Ryu, D.H. Kim, J. Kim, J.W. Lee, W.N. Kim. Polymer Composites, 39, 10871098, 2018.

[170]. M.A. Khanouki, A. Ohadi. Advances in Polymer Technology, 37, 2799-2810, 2018.

[171]. J. Lee, I. Jung. Applied Acoustics, 151, 10-21, 2019.

[172]. X. Liu, M. Zhan, K. Wang. High Performance Polymers, 24, 646-653, 2012.

[173]. W. Li. Experimental Studies on the Determination of Acoustic Bulk Material Properties and Transfer Impedance. PhD Thesis, University of Kentucky, 2014.

[174]. S. Subramonian, L. Remy, D. Schoer. Cellular Polymers, 23, 349-367, 2004.

[175]. C.P. Park, M.J. Brucker, G. Eschenlauer, M.E. Schaller, J. Koening. Polyolefin Foam for Sound and Thermal Insulation. Patent, WO2001070861A2.

[176]. M. Alvarez-Lainez, M.A. Rodriguez-Perez, J.A. de Saja. Materials Letters, 121, 2630, 2014.

[177]. J.F. Allard, N. Atalla. Propagation of Sound in Porous Media. John Wiley \& Sons., Chichester, 2009.

[178]. M. Swedmark, A. Granmo, S. Kollberg. Water Research, 7, 1649-1672, 1973.

[179]. S.F. Moore, R.L. Dwyer. Water Research, 8, 819-827, 1974.

[180]. B.M. Jenssen. Environmental Pollution, 86, 207-215, 1994.

[181]. P.F. Kingston. Spill Science \& Technology Bulletin, 7, 53-61, 2002.

[182]. https://www.itopf.org/knowledge-resources/data-statistics/statistics/.

[183]. A.H. Knap, T.D. Sleeter, R.E. Dodge, S.C. Wyers, H.R. Frith, S.R. Smith. Oil and Petrochemical Pollution, 1, 157-169, 1983.

[184]. H. Chapman, K. Purnell, R.J. Law, M.F. Kirby. Marine Pollution Bulletin, 54, 388396, 2015.

[185]. S. Kleindienst, J.H. Paul, S.B. Joye. Nature Reviews: Microbiology, 13, 388-396, 2015.

[186]. M. Fingas. The Basics of Oil Spill Cleanup. CRC Press., Boca Raton, 2012.

[187]. D.D. Evans, G.W. Mulholland, H.R. Baum, W.D. Walton, K.B. McGrattan. Journal of Research of the National Institute of Standards and Technology, 106, 231-278, 2001.

[188]. J.V. Mullin, M.A. Champ. Spill Science \& Technology Bulletin, 8, 323-330, 2003.

[189]. C. Teas, S. Kalligeros, F. Zanikos, S. Stournas, E. Lois, G. Anastopoulos. Desalination, 140, 259-264, 2001.

[190]. M.O. Adebajo, R.L. Frost, J.T. Kloprogge, O. Carmody, S. Kokot. Journal of Porous Materials, 10, 159-170, 2003. 
[191]. M.R. Johnson, J.J. Smith. Method for Removing Oil from Water. Patent, US6409924B1.

[192]. M.M.G. Ramos-Vianna, J.H.R. Franco, C.A. Pinto, F.R. Valenzuela-Diaz, P.M. Büchler. Brazilian Journal of Chemical Engineering, 21, 239-245, 2004.

[193]. C. Tsai, C. Liao, H. Wang, Y. Chien, C. Jou. Marine Pollution Bulletin, 57, 895$898,2008$.

[194]. O.K. Karakasi, A. Moutsatsou. Fuel, 89, 3966-3970, 2010.

[195]. Q. Wen, J. Di, L. Jiang, J. Yu, R. Xu. Chemical Science, 4, 591-595, 2013.

[196]. T. Sakthivel, D.L. Reid, I. Goldstein, L. Hench, S. Seal. Environmental Science \& Technology, 47, 5843-5850, 2013.

[197]. L. Bandura, M. Franus, G. Józefaciuk, W. Franus. Fuel, 147, 100-107, 2015.

[198]. W.S. Anthony. Applied Engineering and Agriculture, 10, 357-361, 1994.

[199]. K. Hori, M.E. Flavier, S. Kuga, T. Lam, K. Iiyama. Journal of Wood Science, 46, 401-404, 2000.

[200]. M.M. Radetić, D.M. Jocić, P.M. Jovančić, Z.L. Petrović, H.F. Thomas. Environmental Science \& Technology, 37, 1008-1012, 2003.

[201]. M.A. Abdullah, A.U. Rahmah, Z. Man. Journal of Hazardous Materials, 177, 683691, 2010.

[202]. R.S. Rengasamy, D. Das, C.P. Karan. Journal of Hazardous Materials, 186, 526532, 2011.

[203]. J. Wang, Y. Zheng, A.Wang. Chemical Engineering Journal, 213, 1-7, 2012.

[204]. X. Zhou, Z. Zhang, X. Xu, F. Guo, X. Zhu, X. Men, B. Ge. ACS Applied Materials \& Interfaces, 5, 7208-7214, 2013.

[205]. N. Lv, X. Wang, S. Peng, L. Luo, R. Zhou. RSC Advances, 8, 30257-30264, 2018.

[206]. A. Bayat, S.F. Aghamiri, A. Moheb, G.R. Vakili-Nezhaad. Chemical Engineering \& Technology, 28, 1525-1528, 2005.

[207]. X. Gui, J. Wei, K. Wang, A. Cao, H. Zhu, Y. Jia, Q. Shu, D. Wu. Advanced Materials, 22, 617-621, 2010.

[208]. H. Bi, X. Xie, K. Yin, Y. Zhou, S. Wan, L. He, F. Xu, F. Banhart, L. Sun, R.S. Ruoff. Advanced Functional Materials, 22, 4421-4425, 2012.

[209]. D. Wang, E. McLaughlin, R. Pfeffer, Y.S. Lin. Separation and Purification Technology, 99, 28-35, 2012.

[210]. Y. He, Y. Liu, T. Wu, J. Ma, X. Wang, Q. Gong, W. Kong, F. Xing, Y. Liu, J. Gao. Journal of Hazardous Materials, 260, 796-805, 2013.

[211]. A. Pavia-Sanders, S. Zhang, J.A. Flores, J.E. Sanders, J.E. Raymond, K.L. Wooley. ACS Nano, 7, 7552-7561, 2013. 
[212]. S. Kizil, K. Karadag, G. Ozan-Aydin, H. Bulbul-Sonmez. Journal of Environmental Management, 149, 57-64, 2015.

[213]. R. Sarbatly, D. Krishnaiah, Z. Kamin. Marine Pollution Bulletin, 106, 8-16, 2016.

[214]. H. Chol. Environmental Science \& Technology, 26, 772-776, 1992.

[215]. H.T.T. Duong, R.P. Burford. Journal of Applied Polymer Science, 99, 360-367, 2005.

[216]. J. Pinto, A. Athanassiou, D. Fragouli. Journal of Physics D: Applied Physics, 49, 145601, 2016.

[217]. H. Li, L. Liu, F. Yang. Marine Pollution Bulletin, 64, 1648-1653, 2012.

[218]. C. Wang, S. Lin. ACS Applied Materials \& Interfaces, 5, 8861-8864, 2013.

[219]. Y. Liu, J. Ma, T. Wu, X. Wang, G. Huang, Y. Liu, H. Qiu, Y. Li, W. Wang, J. Gao. ACS Applied Materials \& Interfaces, 5, 10018-10026, 2013.

[220]. A.A. Nikkhah, H. Zilouei, A. Asadinezhad, A. Keshavarz. Chemical Engineering Journal, 262, 278-285, 2015.

[221]. A. Keshavarz, H. Zilouei, A. Abdolmaleki, A. Asadinezhad. Journal of Environmental Management, 157, 279-286, 2015.

[222]. J. Pinto, J.A. Heredia-Guerrero, A. Athanassiou, D. Fragouli. International Journal of Environmental Science and Technology, 14, 2055-2066, 2017.

[223]. P. Calcagnile, D. Fragouli, I.S. Bayer, G.C. Anyfantis, L. Martiradonna, P.D. Cozzoli, R. Cingolani, A. Athanassiou. ACS Nano, 6, 5413-5419, 2012.

[224]. A. Rizvi, R. K. M. Chu, J.H. Lee, C.B. Park. ACS Applied Materials \& Interfaces, 6, 21131-21140, 2014.

[225]. S. Wang, K. Wang, Y. Pang, Y. Li, F. Wu, S. Wang, W. Zheng. Journal of Applied Polymer Science, 133, 43812, 2016.

[226]. L. Mandelkern, M. Glotin, R. Popli, R.S. Benson. Journal of Polymer Science Part C: Polymer Letters, 19, 435-441, 1981.

[227]. N. Alberola, J.Y. Cavaille, J. Perez. European Polymer Journal, 28, 935-948, 1992.

[228]. R. Schledjewski, J. Karger-Kocsis. Journal of Thermoplastic Composite Materials, 7, 270-277, 1994.

[229]. B. John, K.T. Varughese, Z. Oommen, P. Poetschke, S. Thomas. Journal of Applied Polymer Science, 87, 2083-2099, 2003.

[230]. H.A. Khonakdar, U. Wagenknecht, S.H. Jafari, R. Hassler, H. Eslami. Advances in Polymer Technology, 23, 307-315, 2004.

[231]. W. Stark, M. Jaunich. Polymer Testing, 30, 236-242, 2011.

[232].X.B. Xu, C. Koomson, M. Doddamani, R.K. Behera, N. Gupta. Composites Part B: Engineering, 159, 346-354, 2019. 
[233]. M.A. Rodriguez-Perez, S. Rodriguez-Llorente, J. de Saja. Advances in Polymer Technology, 23, 307-315, 2004. Polymer Engineering and Science, 37, 959-965, 1997.

[234]. M.A. Rodriguez-Perez, J.I. Velasco, D. Arencon, O. Almanza, J.A. de Saja. Journal of Applied Polymer Science, 75, 156-166, 2000.

[235]. N.C. Hilyard, A. Cunningham. Low Density Cellular Plastics: Physical Basis of Behavior. Chapman and Hall., London, 1994.

[236]. http://perceptionenhancement.com/docs/papers/sgbb2006dba.pdf.

[237]. A. Wolska, M. Gozdzikiewicz, J. Ryszkowska. Journal of Material Science, 47, 5627-5634, 2012.

[238]. M.A. Rodriguez-Perez, O. Alonso, A. Duijsens, J. de Saja. Journal of Polymer Science Part B: Polymer Physics, 36, 2587-2596, 1998.

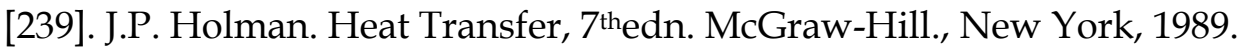

[240]. I.R. Shankland. International Journal of Refrigeration, 13, 113-121, 1990.

[241]. A.G. Ostrogorsky, L.R. Glicksmann, D.W. Reitz. International Journal of Heat and Mass Transfer, 29, 1169-1176, 1986.

[242]. J.W. Wu, W.F. Sung, H.S. Chu. International Journal of Heat and Mass Transfer, 42, 2211-2217, 1999.

[243]. A. Prociak, J. Pielichowski, T. Sterzynski. Polymer Testing, 19, 705-712, 2000.

[244]. C.V. Vo, A.N. Paquet. Journal of Cellular Plastics, 40, 205-228, 2004.

[245]. A. Galakhova, M. Santiago-Calvo, J. Tirado-Mediavilla, F. Villafañe, M.A. Rodriguez-Perez, G. Riess. Polymers, 11, 1192-2002, 2019

[246]. X. Lu, R. Caps, J. Fricke, C.T. Alviso, R.W. Pekala. Journal of non-crystalline solids, 188, 226-234, 1995.

[247]. J. Pinto. Fabrication and Characterization of Nanocellular Polymeric Materials from Nanostructured Polymers, PhD Thesis, University of Valladolid, 2014.

[248]. B. Notario. Fabrication and Characterization of the Physical Properties of Nanocellular Polymers: the Transition from the Micro to the Nanoscale, PhD Thesis, University of Valladolid, 2016.

[249]. B. Notario, J. Pinto, E. Solorzano, J.A. de Saja, M. Dumon, M.A. Rodriguez-Perez. Polymer, 56, 57-67, 2015

[250]. C. Tseng, M. Yamaguchi, T. Ohmori. Cryogenics, 37, 305-312, 1997.

[251]. J.W. Wu, W.F. Sung, H.S. Chu. International Journal of Heat and Mass Transfer, 42, 2211-2117, 1999.

[252]. M. Thirumal, D. Khastgir, N.K. Singha, B.S. Manjunath, Y.P. Naik. Journal of Applied Polymer Science, 108, 1810-1817, 2008. 
[253]. H. Zhang, W.Z. Fang, Y.M. Li, W.Q. Tao. Applied Thermal Engineering, 115, 528$538,2017$.

[254]. M.A. Rodriguez-Perez, O. Alonso, J. Souto, J.A. de Saja. Polymer Testing, 16, 287298, 1997.

[255]. O.A. Almanza, M.A. Rodriguez-Perez, J.A. de Saja. Journal of Polymer Science Part B: Polymer Physics. 38, 993-1004, 2000.

[256]. R. Hasanzadeh, T. Azdast, A. Doniavi, R.E. Lee. Polyolefins Journal, DOI: 10.22063/poj.2018.2185.1113.

[257]. M. Alvarez-Lainez, M.A. Rodriguez-Perez, J.A. de Saja. Journal of Polymer Science Part B: Polymer Physics. 46, 212-221, 2007. 


\section{MATERIALS AND FABRICATION PROCESS}





\section{INDEX}

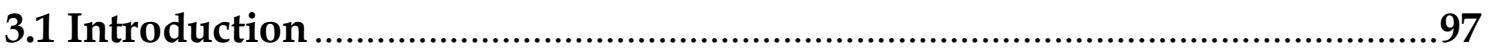

3.2 Polymeric matrices, blowing and crosslinking agents..............................97

3.3 Formulation, fabrication process and materials ......................................99

3.3.1 Preparation of the solid precursors .............................................101

3.3.2 Two-steps compression molding process: first step ….................102

3.3.3 Two-steps compression molding process: second step ................103

3.3.4 Description of the foamed materials............................................104

3.3.5 Crystalline morphology of the foamed materials ......................107

3.3.6 Analysis of the morphology of the cellular structure ...................111

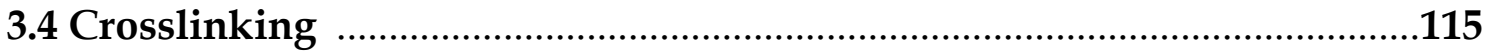

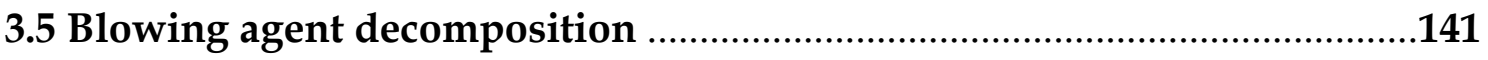

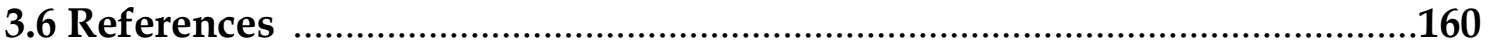




\subsection{Introduction}

The experimental part associated with this thesis is described in this chapter. Initially, the main properties of the polymer matrices used in this research are listed to follow, the fabrication process is explained in detail. The chemical formulations and the cellular materials will be itemized. Next, a subsection focused on the crosslinking process, where both chemical and physical crosslinking processes are also included is also introduced in this chapter.

This section also contains two articles based on the use of electron irradiation for different purposes. The first one is focused on the effect of the electron irradiation dose on the foaming mechanisms and the cellular structure of several physically crosslinked high-density polyethylene (HDPE) foams. The advantages and disadvantages associated with physical crosslinking will be discussed in detail, emphasizing the reasons which explain why we opted for chemical crosslinking instead of using this alternative for the production of the open cell crosslinked polyolefin foams object of this thesis. The second article addresses the effect of the irradiation on another key component of the formulation: the blowing agent. Very interesting results were observed when azodicarbonamide was irradiated with different doses and the explanation behind these results is described in detail in this chapter.

\subsection{Polymeric matrices, blowing and crosslinking agents}

In previous chapters, it has been discussed the suitability of using polyolefins in the production of open-cell foams. The excellent properties of these polymers make them very interesting materials to be used in the complex objective of producing open-cell foams [1-7]. In addition, it must also be considered the technical objective which is connected to the scientific one: the idea of replacing flexible open-cell PU foams, materials with excellent properties, with open-cell foams based on polyolefins.

During this research, four different polymeric matrices were employed: low-density polyethylene (LDPE), ethylene vinyl acetate copolymer (EVA) with vinyl acetate (VA) content of $12.5 \%$, ethylene vinyl acetate copolymer (EVA) with vinyl acetate (VA) content of $18 \%$ and, ethylene butyl acrylate copolymer (EBA) with a butyl acrylate content of $17 \%$. The main properties of the four polymers are listed in Table 3.1: 


\begin{tabular}{|c|c|}
\hline \multicolumn{2}{|c|}{ LOW-DENSITY POLYETHYLENE (LDPE) } \\
\hline COMMERCIAL REFERENCE & PROPERTIES \\
\hline LDPE REPSOL ALCUDIA PE003 & $\begin{array}{ll}\text { - } & \text { Melt Flow Index }(M F I)=2.4 \\
& \mathrm{~g} / 10 \mathrm{~min}\left(190{ }^{\circ} \mathrm{C}, 2.16 \mathrm{~kg}\right) \\
\text { - } & \text { Density }=920 \mathrm{~kg} / \mathrm{m}^{3} \\
\text { - } & \text { Crustallinity }=40.2 \%\end{array}$ \\
\hline \multicolumn{2}{|c|}{ ETHYLENE VINYL ACETATE COPOLYMER (EVA 12) } \\
\hline COMMERCIAL REFERENCE & PROPERTIES \\
\hline EVA REPSOL ALCUDIA® PA-554 & $\begin{array}{ll}\text { - } & \text { Melt Flow Index }(M F I)=4.0 \\
& \mathrm{~g} / 10 \mathrm{~min}\left(190^{\circ} \mathrm{C}, 2.16 \mathrm{~kg}\right) \\
\text { - } & \text { Density }=931 \mathrm{~kg} / \mathrm{m}^{3} \\
\text { - } & \text { VA content }=12.5 \% \\
\text { - } & \text { Crystallinity }=23.7 \%\end{array}$ \\
\hline \multicolumn{2}{|c|}{ ETHYLENE VINYL ACETATE COPOLYMER (EVA 18) } \\
\hline COMMERCIAL REFERENCE & PROPERTIES \\
\hline EVA REPSOL ALCUDIA® PA-538 & $\begin{array}{ll}\text { - } & \text { Melt Flow Index }(M F I)=2.0 \\
& \mathrm{~g} / 10 \mathrm{~min}\left(190^{\circ} \mathrm{C}, 2.16 \mathrm{~kg}\right) \\
\text { - } & \text { Density }=937 \mathrm{~kg} / \mathrm{m}^{3} \\
\text { - } & \text { VA content }=18.0 \% \\
\text { - } & \text { Crystallinity }=16.7 \%\end{array}$ \\
\hline \multicolumn{2}{|c|}{ ETHYLENE BUTYL ACRYLATE COPOLYMER (EBA) } \\
\hline COMMERCIAL REFERENCE & PROPERTIES \\
\hline EBA REPSOL EBANTIX® E1715 & $\begin{array}{ll}\text { - } & \text { Melt Flow Index }(M F I)=1.5 \\
& \mathrm{~g} / 10 \mathrm{~min}\left(190^{\circ} \mathrm{C}, 2.16 \mathrm{~kg}\right) \\
\text { - } & \text { Density }=926 \mathrm{~kg} / \mathrm{m}^{3} \\
\text { - } & \text { BA content }=17.0 \% \\
\text { - } & \text { Crystallinity }=30.7 \%\end{array}$ \\
\hline
\end{tabular}

Table 3.1. Main properties of the polymeric matrices used in this work.

Furthermore, it is necessary to incorporate in the formulations other additives such as blowing agents, which are the source of gas, or crosslinking agents, necessary to produce foams with low densities. Their main properties are displayed in Table 3.2: 


\begin{tabular}{|c|c|}
\hline \multicolumn{2}{|c|}{ AZODICARBONAMIDE (ADCA) } \\
\hline COMMERCIAL REFERENCE & PROPERTIES \\
\hline DONGJIN UNICELL ${ }^{\circledR}$ D 800 & 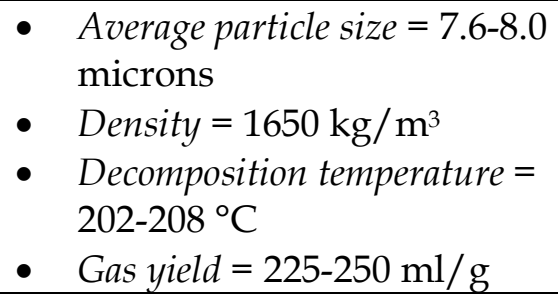 \\
\hline \multicolumn{2}{|c|}{ DICUMYL PEROXIDE (DCP) } \\
\hline COMMERCIAL REFERENCE & PROPERTIES \\
\hline ARKEMA LUPEROX® ${ }^{\circledR}$ DC40P & $\begin{array}{l}\text { - } \quad \text { Density }=784.9 \mathrm{~kg} / \mathrm{m}^{3} \\
\text { - } \\
40 \% \text { of } \mathrm{CaCO}_{3} \text { (filler) }\end{array}$ \\
\hline
\end{tabular}

Table 3.2. Main properties of the blowing and crosslinking agents used in the production of the foams.

\subsection{Formulation, materials and fabrication process}

This thesis is focused on the production and characterization of polyolefin cellular polymers with low densities (relative densities below 0.1) [8-13]. For this purpose, the two-steps compression molding process was selected as the foaming process to produce the materials [14].

Before going into details with the fabrication technology, it is important to describe the chemical formulations and the materials developed during this work in order to facilitate the understanding of the production process.

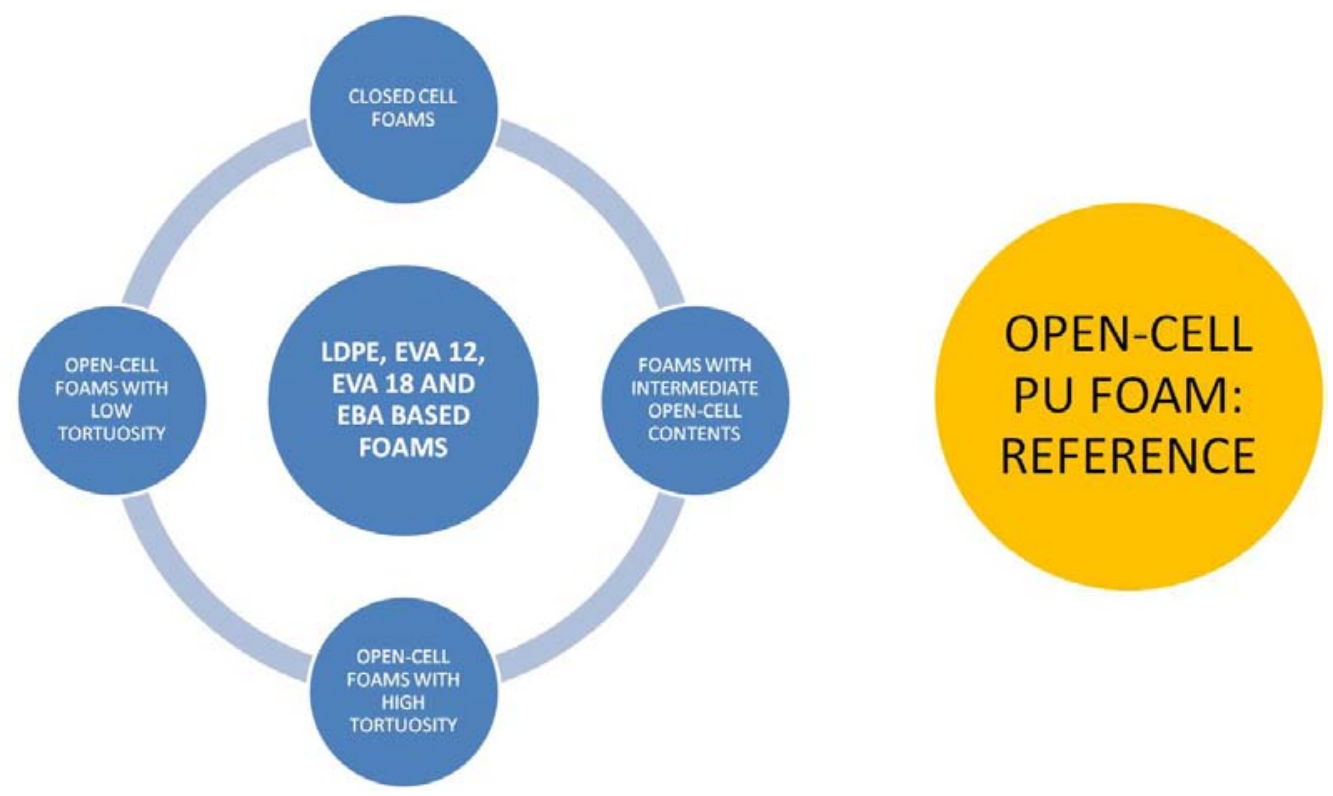

Figure 3.1. Scheme of the different materials considered for this thesis.

As it was previously mentioned, four different polymeric matrices were used during this research. For each polymeric matrix, four types of cellular polymers (different levels of cellular structure interconnectivity and cellular structure tortuosity) were 
produced: a closed-cell material (CC), a cellular polymer with intermediate open-cell content (MO) and two types of open-cell materials (OC), with high tortuosity (OC HT) and with low tortuosity (OC LT). As a result, sixteen different materials were fabricated and evaluated during this work with the target of establishing in a clear way, their composition-structure-properties relationship. To complete this study, a flexible open-cell PU foam was used as reference (Figure 3.1) for comparative purposes.

Regarding the polyolefin-based cellular polymers, even though different materials have been produced, the chemical formulations always include the same components. The different types of cellular structure interconnectivity and cellular structure tortuosities were achieved by adjusting the concentration of each component and by modifying the processing parameters. Thus, regardless of the type of polymeric matrix, the formulations included the following five components (Table 3.3):

\begin{tabular}{l} 
CHEMICAL FORMULATION \\
\hline POLYMER MATRIX: LDPE, EVA 12, EVA 18 AND EBA \\
\hline BLOWING AGENT: AZODICARBONAMIDE (ADCA) \\
\hline CROSSLINKING AGENT: DICUMYL PEROXIDE (DCP) \\
\hline ACTIVATOR OF ADCA DECOMPOSITION: ZINC \\
STEARATE \\
\hline PROCESSING AID: STEARIC ACID \\
\hline
\end{tabular}

As it is done traditionally at industrial scale when using the two-steps compression molding process, an exothermic blowing agent, ADCA, has been used. ADCA is a yellow powder that decomposes above $200-215{ }^{\circ} \mathrm{C}$. ADCA is widely used due to the high amount of gas released during its decomposition [15] and to other associated advantages such as the nature of the released gas (nitrogen) and its low price compared with other chemical blowing agents. As it will be discussed in the following subsections of this chapter, the decomposition process is quite complex, being the chemical route of decomposition still not fully clear.

The high decomposition temperature of ADCA is beneficial for polymeric matrices whose melting points are relatively high, such as polypropylene. However, this temperature is excessive for producing LDPE or EVA-based foams with good quality. The decomposition temperature of ADCA can be easily lowered by using metal catalysts, such as zinc oxide $(\mathrm{ZnO})$ or cadmium oxide $(\mathrm{CdO})$, polyols, alcohol amines or some organic acids [16-19]. The formulations employed in this work include zinc stearate, as the activator of the decomposition reaction of the ADCA. Zinc stearate allows foaming using a working temperature of around $180{ }^{\circ} \mathrm{C}$, similar to that employed at industrial scale.

DCP is also added to the formulation to promote the crosslinking of the polymeric matrix. DCP is an organic peroxide which decomposes at temperatures above $140{ }^{\circ} \mathrm{C}$ 
generating radicals during its decomposition. Further details of the crosslinking process are included in section 3.4 of this chapter.

Finally, the formulations also contain stearic acid, which acts as processing aid. The stearic acid reduces the friction during the blending process, avoiding an undesirable temperature increase that could induce a premature decomposition of either the crosslinking or the blowing agents.
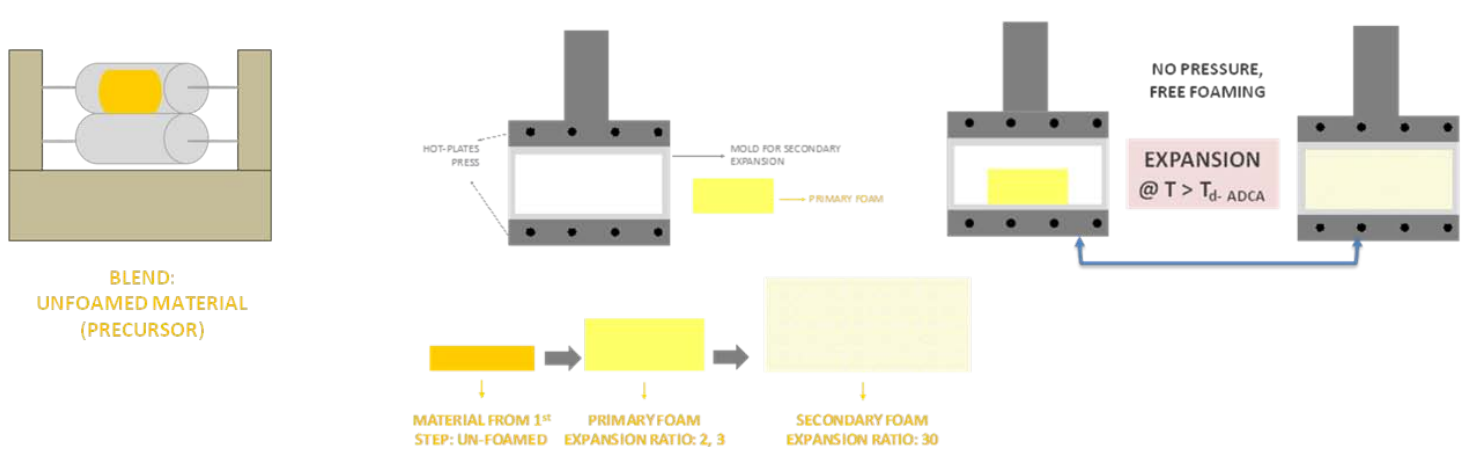

Figure 3.2. Scheme of the whole process.

Figure 3.2 shows the scheme of the foaming process used in this thesis. The two-steps compression process was described in Chapter 2, section 2.4.2.2. Therefore, in the following subsections, only specific details about each part of the process are described more in depth.

\subsubsection{Preparation of the solid precursors}

All precursors or unfoamed solid materials were produced using a two-roll mill. Initially, the polymer is molten in an oven before its incorporation in the two-roll mill. Once the polymer is molten, it is introduced in the rolls together with the rest of the additives of the formulation to blend them. The processing temperature must permit an adequate blending of the components, and therefore, it must be higher than the melting point of the polymeric matrix. However, not very high temperatures can be used since the crosslinking or blowing agents could start prematurely decomposing. Therefore, the processing temperature must be located between the melting temperature of the polymer matrix and the decomposition temperature of the crosslinking agent since the decomposition temperature of the DCP is much lower than the decomposition temperature of the ADCA. The temperature in the front roll was set at $118^{\circ} \mathrm{C}$ and in the back roll at $123^{\circ} \mathrm{C}$ for both LDPE and EBA, and these temperatures were lower when EVA was used $\left(100{ }^{\circ} \mathrm{C}\right.$ in the front roll and $105^{\circ} \mathrm{C}$ in the back roll respectively). The speed of the rolls was kept constant for all the polymeric matrices: 13 rpm in the back roll and $16 \mathrm{rpm}$ in the front roll.

One critical aspect of the preparation of the precursors is the order in which the components are incorporated into the rolls. In our case, the stearic acid was the first additive incorporated to the polymeric matrix as it reduces the friction between the polymer and the rolls. Next, the kicker and the blowing agent were added and the last 
additive to be incorporated was the crosslinking agent. The reason behind this particular order is that we wanted to avoid the premature decomposition of the DCP. If $\mathrm{DCP}$ is added at the beginning of the blending process, there is a considerable risk of decomposing some DCP particles during the mixing process.

The components were homogenously blended, obtaining a yellowish precursor as the one depicted in Figure 3.3:
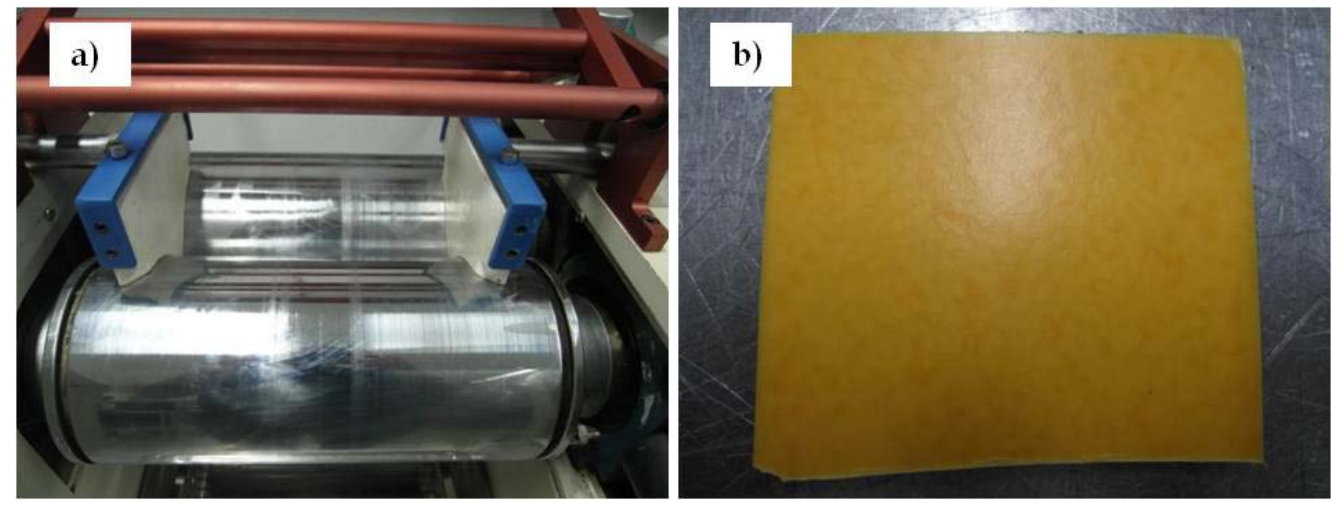

Figure 3.3. a) Two-roll mill and b) solid precursor obtained after blending the components of the formulations.

\subsubsection{Two-steps compression molding process: first step}

The first step of the two-steps compression molding process is performed by applying both temperature and pressure. As it was explained in Chapter 2, section 2.4.2.2, the crosslinking process of the polymer matrix occurs during this step. In addition, a partial decomposition of the blowing agent also takes place during this step.

A fixed mass of the precursor is placed in the cavity of a pre-heated mold. The volume of the cavity is $79 \times 79 \times 25 \mathrm{~mm}^{3}$ (length $\times$ width $\times$ thickness) (Figure 3.4). The processing temperature was set in all experiments at $152{ }^{\circ} \mathrm{C}$, temperature enough to promote the decomposition of DCP but without decomposing a large concentration of blowing agent. The applied pressure was always 27 bars, and the processing time was established in 45 minutes. 

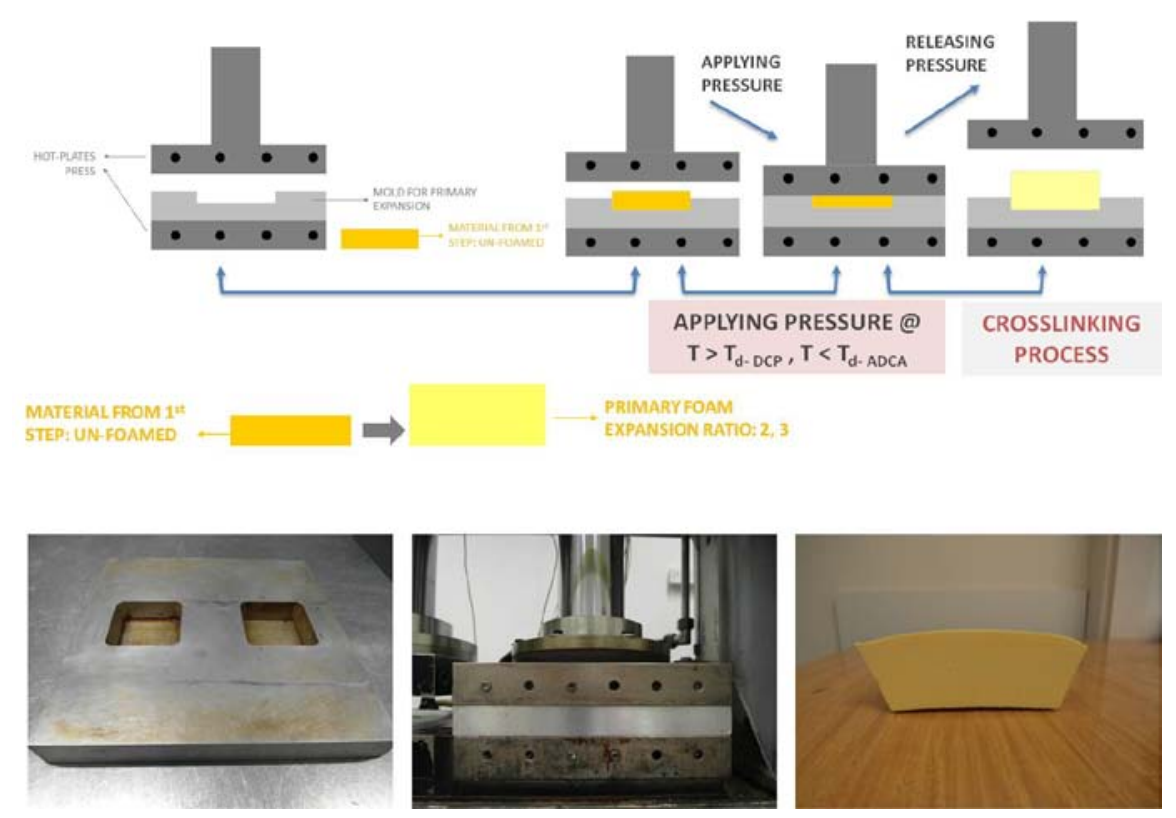

Figure 3.4. First step of the two-steps compression molding process: scheme, mold, process and primary foam.

After this time, the pressure is released, and it is obtained a slightly foamed material, known as primary foam (Figure 3.4). Despite the low processing temperature, the material is able to expand slightly due to the effect of the kicker (zinc stearate) on the decomposition temperature of ADCA. As it will be explained in section 3.5 of this chapter, kickers can reduce the decomposition temperature of the ADCA considerably, allowing working at lower temperatures than those required when using non-activated ADCA.

The expansion ratio typically reached by the primary foam is of around 3 times. However, there is still a considerable amount of ADCA, which has not decomposed yet. Consequently, it is necessary to perform a second step to decompose the blowing agent completely and to reach the final desired density.

\subsubsection{Two-steps compression molding process: second step}

The second step is necessary to fully decompose the blowing agent allowing the polymer to expand until the final desired expansion ratio. The primary foam is placed in a second pre-heated mold. The volume of the cavity of this second mold is $195 \times 195$ $x 100 \mathrm{~mm}^{3}$ (length $\mathrm{x}$ width $\mathrm{x}$ thickness) (Figure 3.5).

The objective of this process is to decompose the blowing agent particles to allow the material to grow until reaching the desired density.

As the formulations contain activator, the processing temperature is set at $180{ }^{\circ} \mathrm{C}$, and the heating process is performed in a hot-plates press instead of using an oven to foster the heat transfer and therefore to save time. The processing time is fixed in 50 minutes. After this time, the mold is removed and is cooled until room temperature is reached, obtaining the final foam. 
The expansion ratio in the second step is 12. The total expansion ratio during the whole process is 36 and, thus, a considerable reduction in density is achieved.
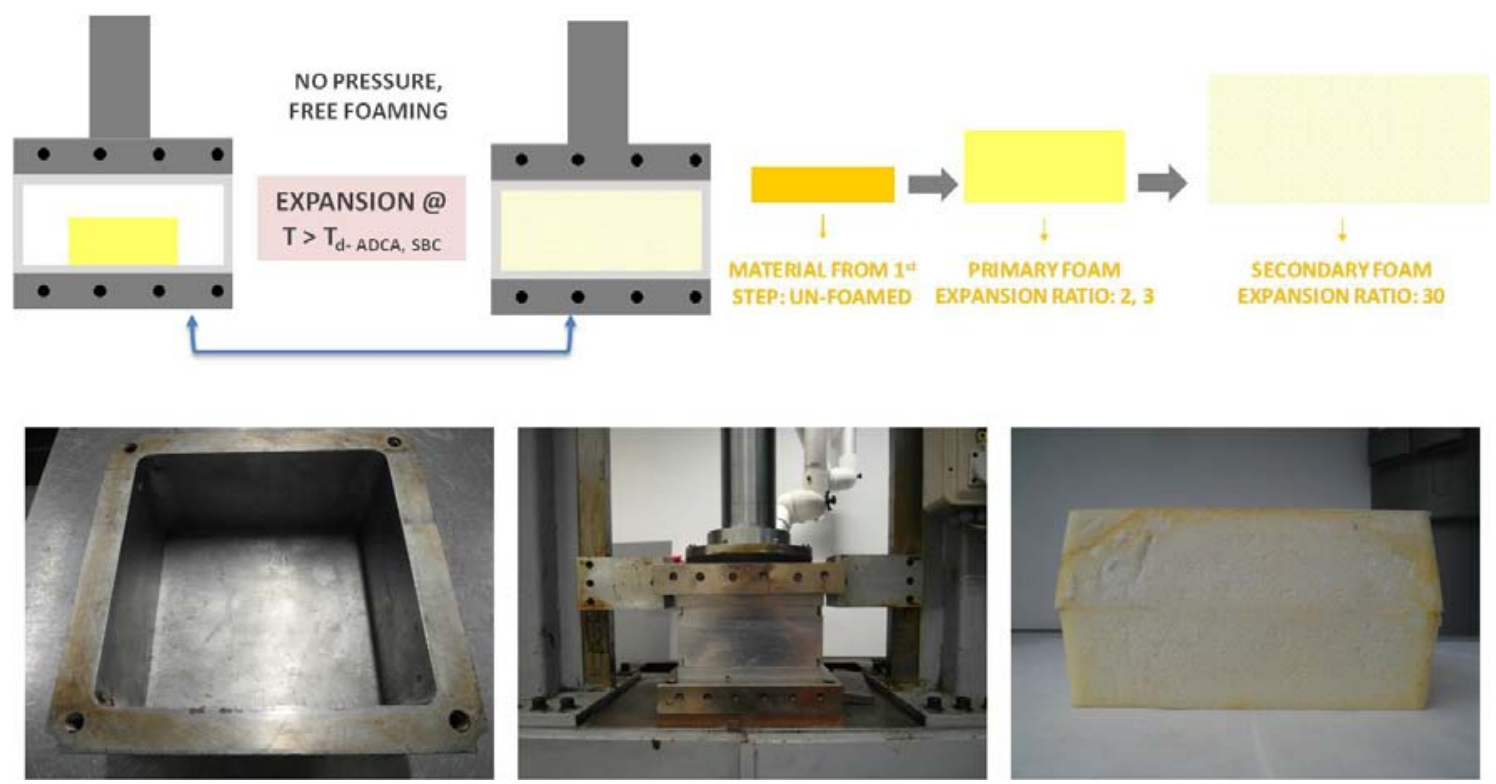

Figure 3.5. Second step of the two-steps compression molding process: scheme, mold, process and final foam.

All the foams were produced using the same processing conditions except for the open-cell foams with high tortuosity where it is necessary to include an additional step after the foaming process. The differences among the materials with different levels of interconnectivity lie on the chemical composition.

The next section describes in detail all the materials characterized in this thesis. Furthermore, it is explained how open-cell foams with high tortuosity were obtained.

\subsubsection{Description of the foamed materials}

The two-steps compression technology is typically used at industrial scale to produce low-density crosslinked closed-cell polyolefin foams. However, during this research, by using this technology, it has been possible to produce not only closed-cell (CC) but also foams with different levels of interconnectivity using four different polymer matrices: foams with intermediate open-cell content $(\mathrm{MO}$, with open-cell contents of around 65\%) and open-cell foams (OC, with open-cell contents of 100\%) (Figure 3.6).

In addition, for the open-cell foams, two additional types of foams have been developed: open-cell foams with high (OC HT) and with low tortuosity (OC LT). This research introduces a novel aspect because it is reported for the first time the production of open-cell foams with very low tortuosity directly during the fabrication process, without performing any additional step to break the cell walls. In Chapter 2 of this document, it was shown the morphology of the cellular structure of these novel open-cell foams. Their cellular structure differs completely from the one corresponding to the open-cell PU foams. The cellular structure of open-cell PU foams is only formed by struts, whereas the open-cell polyolefin foams are characterized by the presence of holes in the cell walls. 
However, in the case of the open-cell polyolefin foams with high tortuosity produced for this work, it was followed the commercial production route of breaking the cell walls after foaming (Figure 3.6) [20].

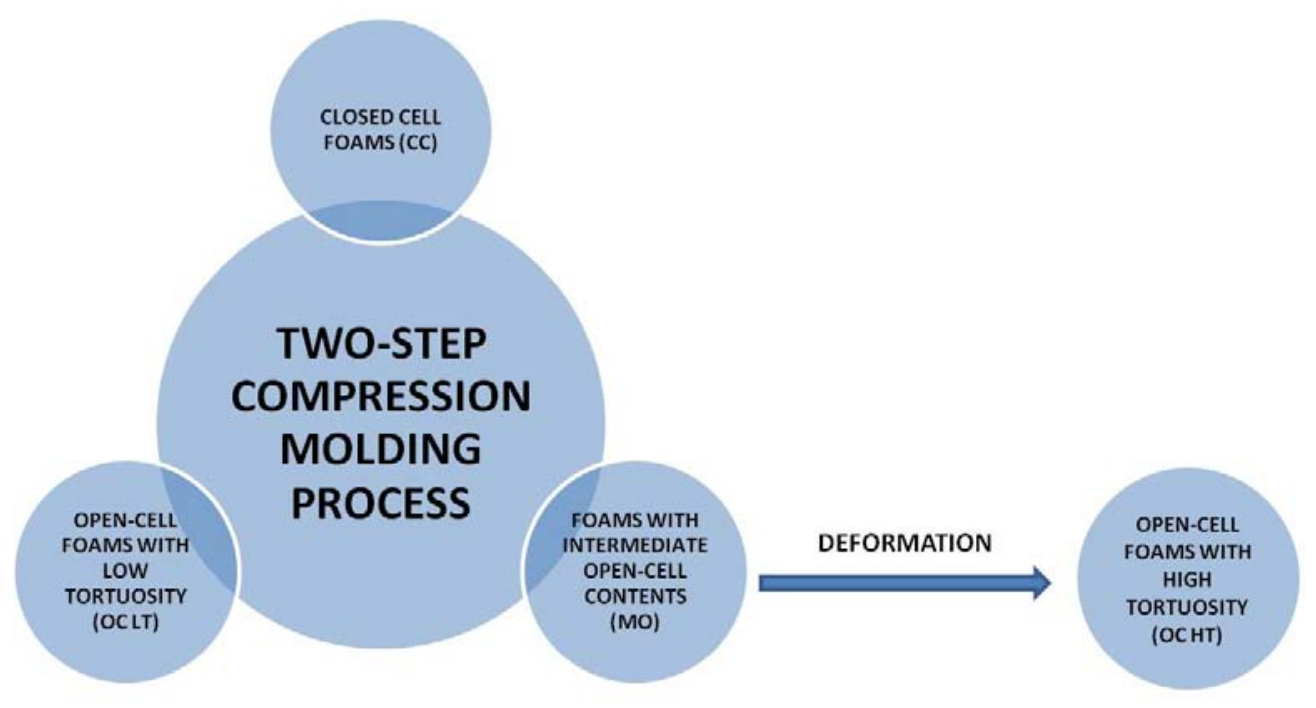

Figure 3.6. Scheme of the fabrication process and the materials developed in this thesis.

Open-cell foams with high tortuosity were produced from foams with intermediate open-cell contents by performing a mechanical compression promoting a further rupture of the cell walls, as it is shown in Figure 3.7.

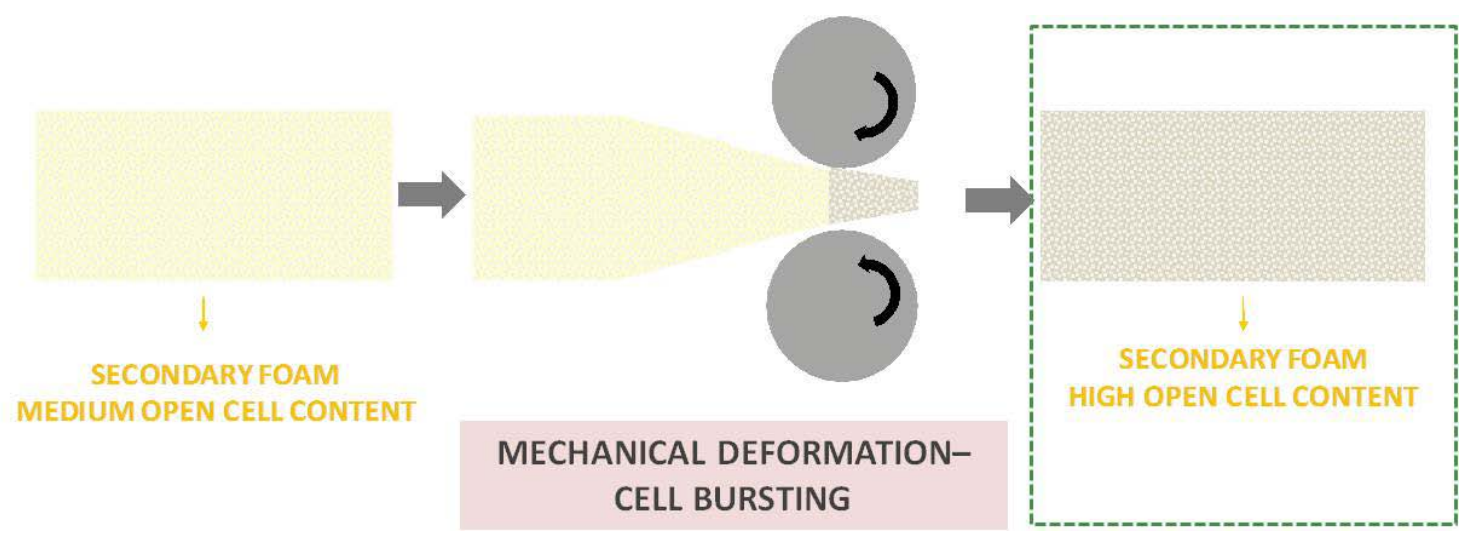

Figure 3.7. Scheme of the production route used to produce open-cell materials with high tortuosity.

This mechanical deformation allows the creation of few and small holes, characteristics of the cellular structure of a high tortuous open-cell material.

The cellular structure and several physical properties of the different types of polyolefin foams have been evaluated. The production of closed-cell foams does not include any novel aspect to this field; however, just for comparative purposes, it was essential to use them as a reference in order to determine how the cellular structure and the physical properties of the novel materials varied when they were compared to the closed-cell ones. On the grounds that closed-cell foams were used as a reference, it was mandatory to use another open-cell reference. In Chapter 1, it was pointed out that the technical objective of this work was to develop an alternative to flexible open-cell 
PU foams and therefore a commercial flexible open-cell PU foams were also used as a reference.

The reference PU foam is a molded PU foam produced for the automotive sector, specifically for seats and cushioning, providing comfort to the occupants.

The nomenclature, density $\left(\mathrm{kg} / \mathrm{m}^{3}\right)$, open-cell content $(\%)$ and tortuosity (in the case of materials with a certain level of interconnectivity) of the materials are shown in the following table (Table 3.4):

\begin{tabular}{|cccc|}
\hline Nomenclature & Density $\left(\mathbf{k g} / \mathbf{m}^{3}\right)$ & $\begin{array}{c}\text { Open-cell } \\
\text { content }(\%)\end{array}$ & Tortuosity \\
\hline LDPE CC & $27.0 \pm 0.4$ & $27 \pm 2$ & $-^{*}$ \\
\hline LDPE MO & $19.9 \pm 1.0$ & $65 \pm 6$ & $-^{*}$ \\
\hline LDPE OC HT & $20.0 \pm 1.0$ & $95 \pm 3$ & $4.0 \pm 0.4$ \\
\hline LDPE OC LT & $15.8 \pm 0.1$ & $99 \pm 1$ & $1.9 \pm 0.1$ \\
\hline EVA 12 CC & $25.2 \pm 1.1$ & $41 \pm 3$ & $-^{*}$ \\
\hline EVA 12 MO & $21.9 \pm 1.8$ & $69 \pm 3$ & $-^{*}$ \\
\hline EVA 12 OC HT & $21.9 \pm 0.7$ & $96 \pm 1$ & $4.3 \pm 0.9$ \\
\hline EVA 12 OC LT & $21.9 \pm 1.5$ & $98 \pm 0$ & $2.6 \pm 0.6$ \\
\hline EVA 18 CC & $26.9 \pm 1.5$ & $46 \pm 1$ & $-^{*}$ \\
\hline EVA 18 MO & $18.5 \pm 0.2$ & $64 \pm 5$ & $\mathbf{-}^{*}$ \\
\hline EVA 18 OC HT & $18.4 \pm 0.9$ & $97 \pm 2$ & $3.8 \pm 0.5$ \\
\hline EVA 18 OC LT & $17.3 \pm 0.6$ & $99 \pm 1$ & $1.9 \pm 0.2$ \\
\hline EBA CC & $24.3 \pm 2.1$ & $43 \pm 3$ & $\mathbf{-}^{*}$ \\
\hline EBA MO & $20.3 \pm 1.3$ & $68 \pm 1$ & $\mathbf{-}^{*}$ \\
\hline EBA OC HT & $19.7 \pm 0.3$ & $95 \pm 1$ & $4.0 \pm 0.7$ \\
\hline EBA OC LT & $20.1 \pm 2.3$ & $99 \pm 0$ & $1.9 \pm 0.2$ \\
\hline PU & $47.2 \pm 0.1$ & $98 \pm 0$ & $2.0 \pm 0.0$ \\
\hline
\end{tabular}

Table 3.4. Nomenclature, density $\left(\mathrm{kg} / \mathrm{m}^{3}\right)$, open-cell content $(\%)$ and tortuosity of the materials produced in this work.

As it was previously noted, by using a two-steps compression molding process, very low densities can be achieved. In these materials, the densities are in a range between 16 and $27 \mathrm{~kg} / \mathrm{m}^{3}$ in the case of the polyolefin-based foams. The open-cell PU foam has a density slightly higher in comparison to the polyolefin foams $\left(47 \mathrm{~kg} / \mathrm{m}^{3}\right)$.

At the beginning of this work, one of the main interesting topics related to this research was to produce foams with excellent comfort properties. Therefore, a commercial flexible open-cell PU foam employed for this purpose was selected for comparative purposes. The commercial foams used in the particular application of seats in the automotive sectors are characterized for having densities of around $50 \mathrm{~kg} / \mathrm{m}^{3}$. The densities of the foams under consideration are slightly lower than the commercial materials. However, the results obtained for these materials have been compared along the whole document. Furthermore, it is also convenient to clarify, that once the mechanical properties were analyzed, the same open-cell PU foam was used as the reference for the other physical properties considered in this work, aiming at determining the versatility of each type of material. 
Concerning the cellular structure interconnectivity, the open-cell content was measured by estimating the contribution of gas in the post-collapse region in the stresscurves at low strain rates using the Gent and Thomas model. This is explained in detail in Chapter 4 (section 4.1) of this document. The common procedure based on the standard ASTM D-2856-94 was not used because the samples are very flexible, and they can be deformed by the gas pressure in the air pycnometer.

The open-cell content in closed-cell materials is, in all cases below 50\%. There are some differences in the value depending on the polymer matrix. The LDPE CC shows the lowest open-cell content, whereas EVA 12 CC, EVA 18 CC and EBA CC present a higher value of open-cell content. This effect was also observed by Rodriguez-Perez [21], "the unexpected high value of the open-cell content presented in the CC030 foam suggests that the EVA component makes cell opening easier without the action of postprocessing mechanical compression or without special care in inverting the crosslinking reaction and the foam expansion". MO cellular materials present intermediate open-cell contents (between 64 and 69\%) and very high tortuosity due to the partial open-cell cellular structure. It can be observed that there are two types of materials with a high level of cellular structure interconnectivity (open-cell content higher than 95\%) independently of the type of polymer matrix: open-cell materials with high-tortuosity (OC HT) and with low tortuosity (OC LT) [22-26]. Finally, the reference open-cell PU foam presents a total cellular structure interconnectivity (98\% of open-cell content) and a tortuosity similar to that corresponding to the open-cell polyolefin cellular polymers with low tortuosities.

The following subsections of this chapter are focused on the descriptions of the crosslinking and the foaming processes, taking place during the different stages of the foaming process.

\subsubsection{Crystalline morphology of the polymeric matrices and the foamed materials}

One key parameter to be discussed when the physical properties of solid polymers or cellular polymers are characterized is the crystallinity of the polymeric matrix. The effect of the crystallinity on the physical properties has been studied by several authors for several polymeric matrices [27-30].

Polyolefins are semicrystalline polymers. The crystallinity of polyolefins depends on the nature of the polymeric matrix. The crystallinity and the melting point of the four polymeric matrices used in this thesis have been estimated by performing differential scanning calorimetry (DSC) experiments using the following thermal program:

1) 1 Heating from $-40{ }^{\circ} \mathrm{C}$ to $200{ }^{\circ} \mathrm{C}$ at $10 \mathrm{~K} / \mathrm{min}$.

2) A 3-minute isotherm at $200^{\circ} \mathrm{C}$.

3) Cooling from $200{ }^{\circ} \mathrm{C}$ to $-40^{\circ} \mathrm{C}$ at $-10 \mathrm{~K} / \mathrm{min}$.

4) Heating from $-40^{\circ} \mathrm{C}$ to $200^{\circ} \mathrm{C}$ at $10 \mathrm{~K} / \mathrm{min}$. 
The thermograms of the four polymeric matrices are shown in Figure 3.8:
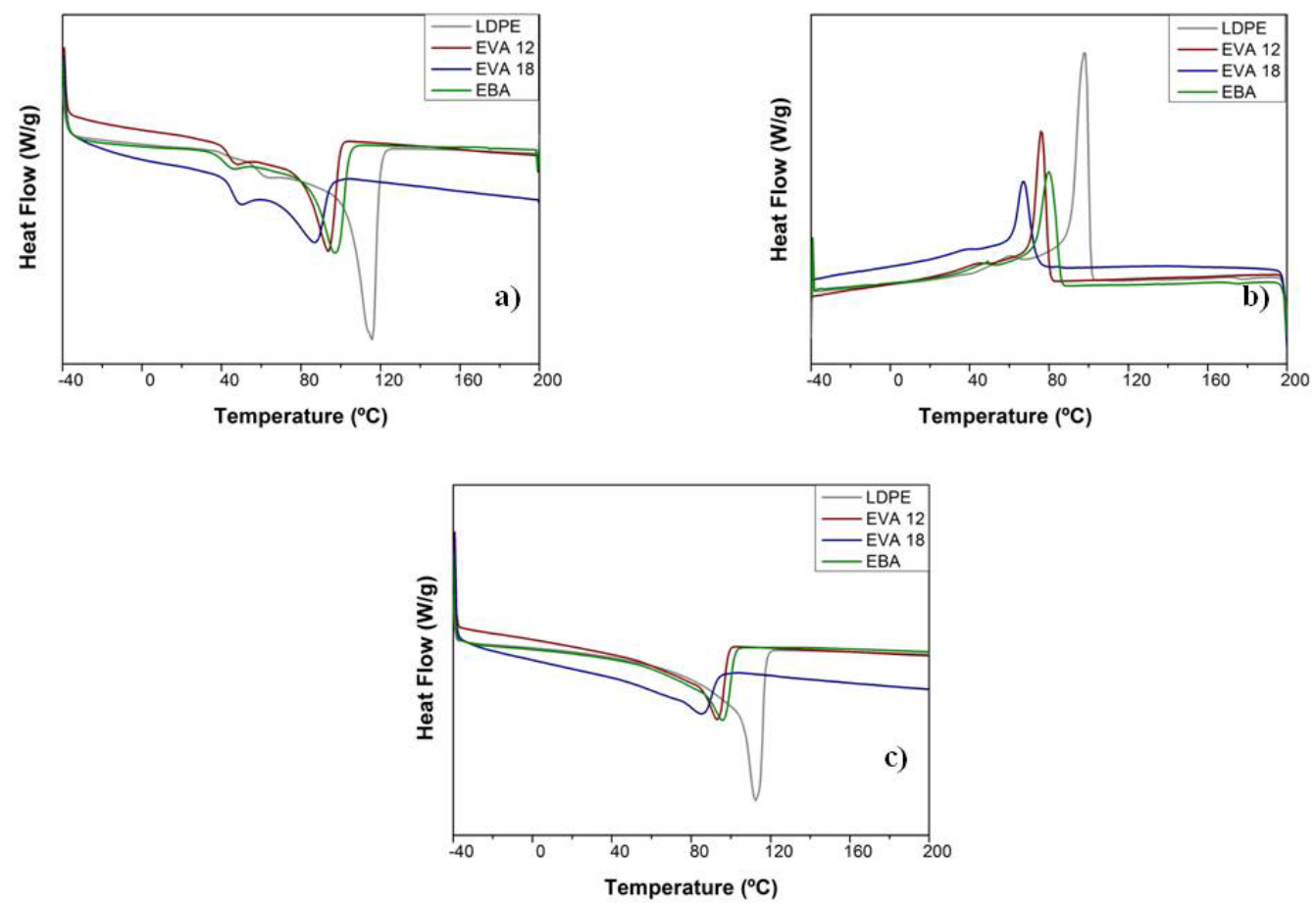

Figure 3.8. DSC thermograms of the solid polymer matrix: a) first heating step; b) cooling step and c) second heating step.

The first heating step removes the thermal history of the polymeric matrix (Figure 3.8 a). Then, the polymer is cooled down allowing the crystallization process (Figure 3.8 b), and finally, the polymer is heated again, melting the crystals, removing the effect of the thermal history of the polymer (Figure $3.8 \mathrm{c}$ ).

In the specific case of the polymeric matrices used in this study, the crystallinity of each polymer is given by the ratio of its melting enthalpy and the enthalpy of a $100 \%$ crystalline LDPE (288 J/g).

From the thermograms shown in Figure 3.8, it can be inferred that the introduction of vinyl acetate or butyl acrylate groups induced disorder in the polymeric chains, decreasing both the crystallinity of the polymeric matrix and the melting point of the polymeric matrix with respect to the LDPE.

The crystallinity $(\%)$ and the melting points $\left(T_{m}\right)$ of the polymeric matrices estimated in the first and the second heating steps are displayed in Table 3.5:

\begin{tabular}{|ccccc|}
\hline Sample & $\begin{array}{c}\text { Crystallinity }(\%) \\
1^{\mathrm{O}} \text { Heating step }\end{array}$ & $\begin{array}{c}\mathrm{T}_{\mathrm{m}}\left({ }^{\circ} \mathrm{C}\right) \\
\mathbf{1}^{\mathrm{O}} \text { Heating step }\end{array}$ & $\begin{array}{c}\text { Crystallinity }(\%) \\
2^{\mathrm{O}} \text { Heating step }\end{array}$ & $\begin{array}{c}\mathrm{T}_{\mathrm{m}}\left({ }^{\mathrm{o}} \mathrm{C}\right) \\
\text { Heating step }\end{array}$ \\
\hline LDPE CC & 45.26 & 115.30 & 46.54 & 112.13 \\
\hline EVA 12 CC & 29.89 & 93.65 & 29.15 & 92.99 \\
\hline EVA 18 CC & 25.93 & 86.50 & 23.25 & 85.01 \\
\hline EBA CC & 29.96 & 96.94 & 30.74 & 95.62 \\
\hline
\end{tabular}

Table 3.5. Crystallinity (\%) and melting points of the solid polymeric matrices estimated in the first and second heating steps. 
It can be observed in Table 3.5, that LDPE was the most crystalline (46.54\%) and the most thermal stable $\left(112.13^{\circ} \mathrm{C}\right)$ polymeric matrix of the series, whereas the high vinyl acetate content of the EVA 18 introduced disorder to the polymeric chains, giving the lowest value of crystallinity $(23.25 \%)$ and the lowest melting temperature $\left(85.01{ }^{\circ} \mathrm{C}\right)$. The crystallinity and the melting points of EVA 12 and EBA were very similar. Both values for EVA 12 and EBA were located between those displayed by LDPE and EVA 18.

DSC experiments were performed not only for the solids but also for all the foamed materials presented previously in Table 3.4, aiming at analyzing how the polymer crystals melt and crystallize in conditions completely different than those presented in the solids.

The following thermal program was performed for these experiments:

1) Heating from $0{ }^{\circ} \mathrm{C}$ to $130{ }^{\circ} \mathrm{C}$ at $10 \mathrm{~K} / \mathrm{min}$.

2) A 3-minute isotherm at $130^{\circ} \mathrm{C}$.

3) Cooling from $130{ }^{\circ} \mathrm{C}$ to $0^{\circ} \mathrm{C}$ at $-10 \mathrm{~K} / \mathrm{min}$.

4) Heating from $0{ }^{\circ} \mathrm{C}$ to $130^{\circ} \mathrm{C}$ at $10 \mathrm{~K} / \mathrm{min}$.

Figure 3.9 shows the thermograms corresponding to the closed-cell foams produced in this thesis:
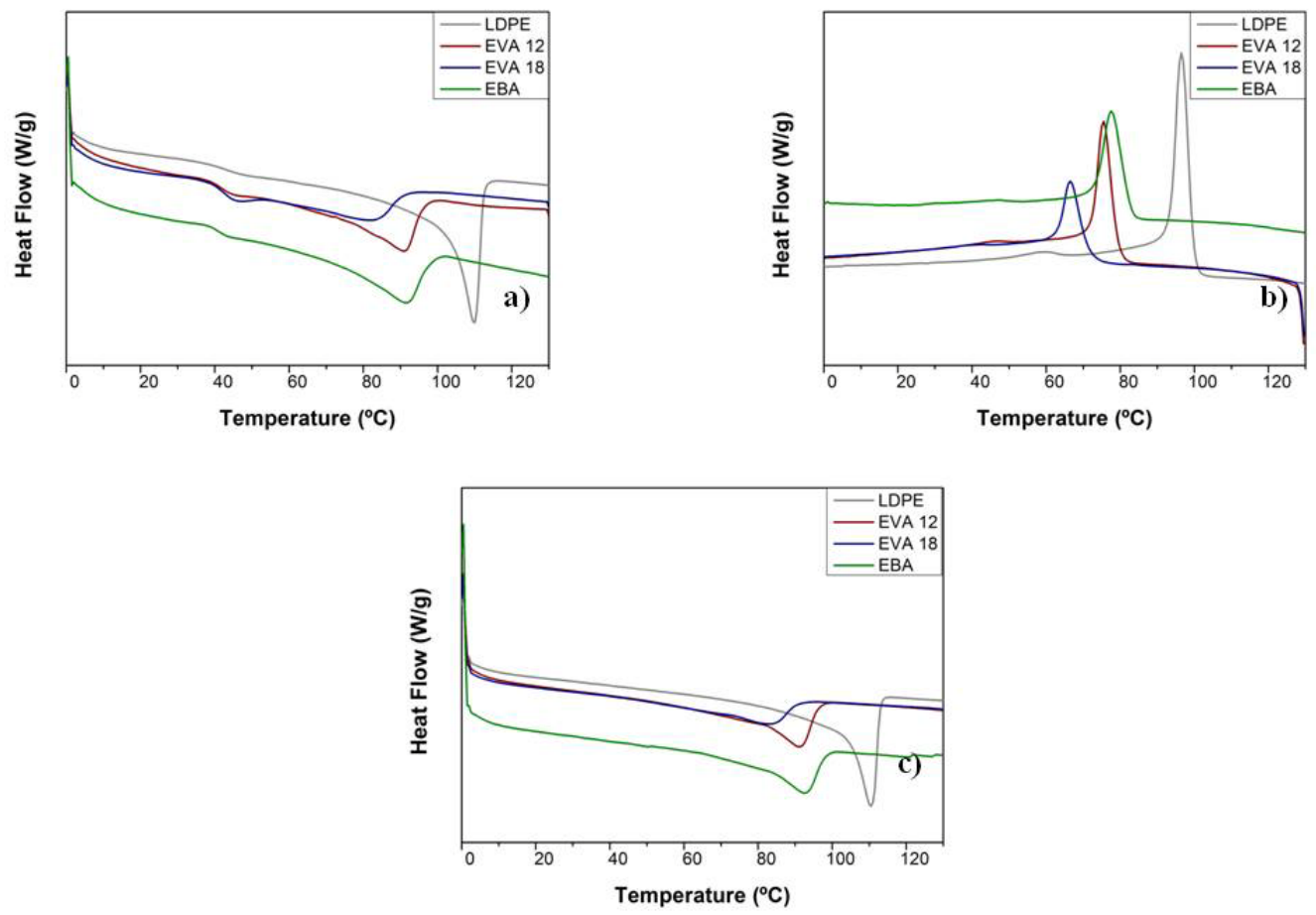

Figure 3.9. DSC thermograms of the closed-cell foams: a) first heating step; b) cooling step and c) second heating step. 
Previously, it was mentioned that the crystallinity is given by the ratio of the melting enthalpy of the material under analysis and the melting enthalpy of a $100 \%$ crystalline LDPE. This estimation is also correct for foamed materials. However, it must be taken into account that the formulations used to produce the foams consist of not only the polymeric matrix but also other additives, particularly ADCA, which leave residues in the foam after decomposition. The residues of the ADCA contribute to the melting enthalpy, and this must be extracted to isolate the contribution of the polymeric matrix to this enthalpy. As a result, a simple correction must be applied in the calculation. ADCA decomposes releasing $70 \%$ of gas and leaving 30\% of residues. According to this data, the correction to be applied is shown in Equation 1 and Equation 2:

$$
\begin{gathered}
\% \text { residue }(A D C A)=\% A D C A \times \frac{30}{100} \\
\text { Crystallinity }(\%)=\frac{\Delta H_{m}}{288} \times \frac{100}{100-\% \text { residue }(A D C A)}
\end{gathered}
$$

(Equation 1)

(Equation 2)

The crystallinity (\%) and the melting points $\left(T_{m}\right)$ of the foamed materials estimated in the first and the second heating steps are displayed in Table 3.6:

\begin{tabular}{|ccccc|}
\hline Sample & $\begin{array}{c}\text { Crystallinity }(\%) \\
\mathbf{1}^{\mathbf{0}} \text { Heating step }\end{array}$ & $\begin{array}{c}\mathrm{T}_{\mathrm{m}}\left({ }^{\circ} \mathbf{C}\right) \\
\mathbf{C}^{\mathrm{H}} \text { Heating step }\end{array}$ & $\begin{array}{c}\text { Crystallinity }(\%) \\
\mathbf{2}^{\mathbf{0}} \text { Heating step }\end{array}$ & $\begin{array}{c}\mathrm{T}_{\mathrm{m}}\left({ }^{\circ} \mathrm{C}\right) \\
\text { Heating step }\end{array}$ \\
\hline LDPE CC & 41.83 & 109.64 & 36.80 & 110.37 \\
\hline LDPE MO & 43.59 & 110.25 & 39.98 & 110.75 \\
\hline LDPE OC HT & 40.89 & 110.19 & 37.19 & 110.92 \\
\hline LDPE OC LT & 41.34 & 110.25 & 35.35 & 110.42 \\
\hline EVA 12 CC & 24.49 & 90.84 & 21.07 & 91.12 \\
\hline EVA 12 MO & 22.67 & 91.35 & 20.72 & 91.74 \\
\hline EVA 12 OC HT & 24.23 & 90.79 & 19.98 & 91.40 \\
\hline EVA 12 OC LT & 24.27 & 91.46 & 20.67 & 92.01 \\
\hline EVA 18 CC & 20.72 & 79.96 & 15.30 & 82.69 \\
\hline EVA 18 MO & 19.76 & 81.91 & 14.35 & 82.97 \\
\hline EVA 18 OC HT & 19.28 & 82.02 & 14.52 & 82.97 \\
\hline EVA 18 OC LT & 19.98 & 81.97 & 15.06 & 83.14 \\
\hline EBA CC & 29.78 & 91.89 & 23.14 & 92.72 \\
\hline EBA MO & 31.54 & 93.21 & 25.33 & 93.71 \\
\hline EBA OC HT & 28.25 & 93.45 & 21.14 & 93.67 \\
\hline EBA OC LT & 26.09 & 93.29 & 20.89 & 94.01 \\
\hline Table 3.6. Crystallinity (\%) and melting points of the foamed materials estimated in the first and second heating \\
\hline
\end{tabular}

According to the data shown in Table 3.6, similar trends, relatives to the type of polymeric matrix were found for the foamed materials. LDPE presented the highest crystallinity and the highest melting point, whereas EVA 18 showed the lowest values of both parameters.

It is important to stand out, that the crystallinity in foamed materials decreased if the foams and the solids are compared. Reductions between 3 and 10\% can be observed in the crystallinity associated with the second heating step. This can be explained considering, on the one hand, that the polymeric matrix is crosslinked in the foamed 
materials, which hinders the crystallization process, and on the other hand, that the available space that the crystals have to crystallize is limited to the cell walls. This reduction in crystallinity also caused a reduction in the melting points (around 1 and 2 $\left.{ }^{\circ} \mathrm{C}\right)$.

Concerning the effect of the cellular parameters, such as interconnectivity or tortuosity, on the crystallinity and the melting point, no specific trends have been found.

Once the crystalline morphology of the polymeric matrices has been analyzed, the following section is focused on the analysis of the morphology of the cellular structure.

\subsubsection{Analysis of the morphology of the cellular structure}

The cellular structure of the open-cell foams developed during this study is quite complex and the traditional methods used for measuring parameters, such as cell size or the anisotropy ratio, are difficult to be used in the characterization of the open-cell materials.

Figure 3.8 and Figure 3.9 show SEM micrographs of LDPE and EVA-based foams with different level of interconnectivity. The cellular structure is completely different depending on the level of interconnectivity.

The cell size of CC foams was estimated by using a methodology developed in CellMat Laboratory using the software Image J. The results are summarized in Table 3.7:

\begin{tabular}{|c|c|}
\hline Nomenclature & Cell size $(\mu \mathrm{m})$ \\
\hline LDPE CC & $173 \pm 81$ \\
\hline EVA 12 CC & $224 \pm 76$ \\
\hline EVA $18 \mathrm{CC}$ & $254 \pm 83$ \\
\hline EBA CC & $266 \pm 88$ \\
\hline
\end{tabular}

The LDPE CC foam presents the smaller cell size of the series. This can be explained, taking into account the higher stiffness of the polymeric matrix, which restricts the stretching of the cell walls giving smaller cells. Due to this reason, the EVA $12 \mathrm{CC}$ foam has a smaller cell size than the EVA 18 CC since the increase of the vinyl acetate content is bonded to an increase in the softness of the polymer. The cell size of the EBA CC foam is similar to the one displayed by the EVA 18 CC foam [31]. 

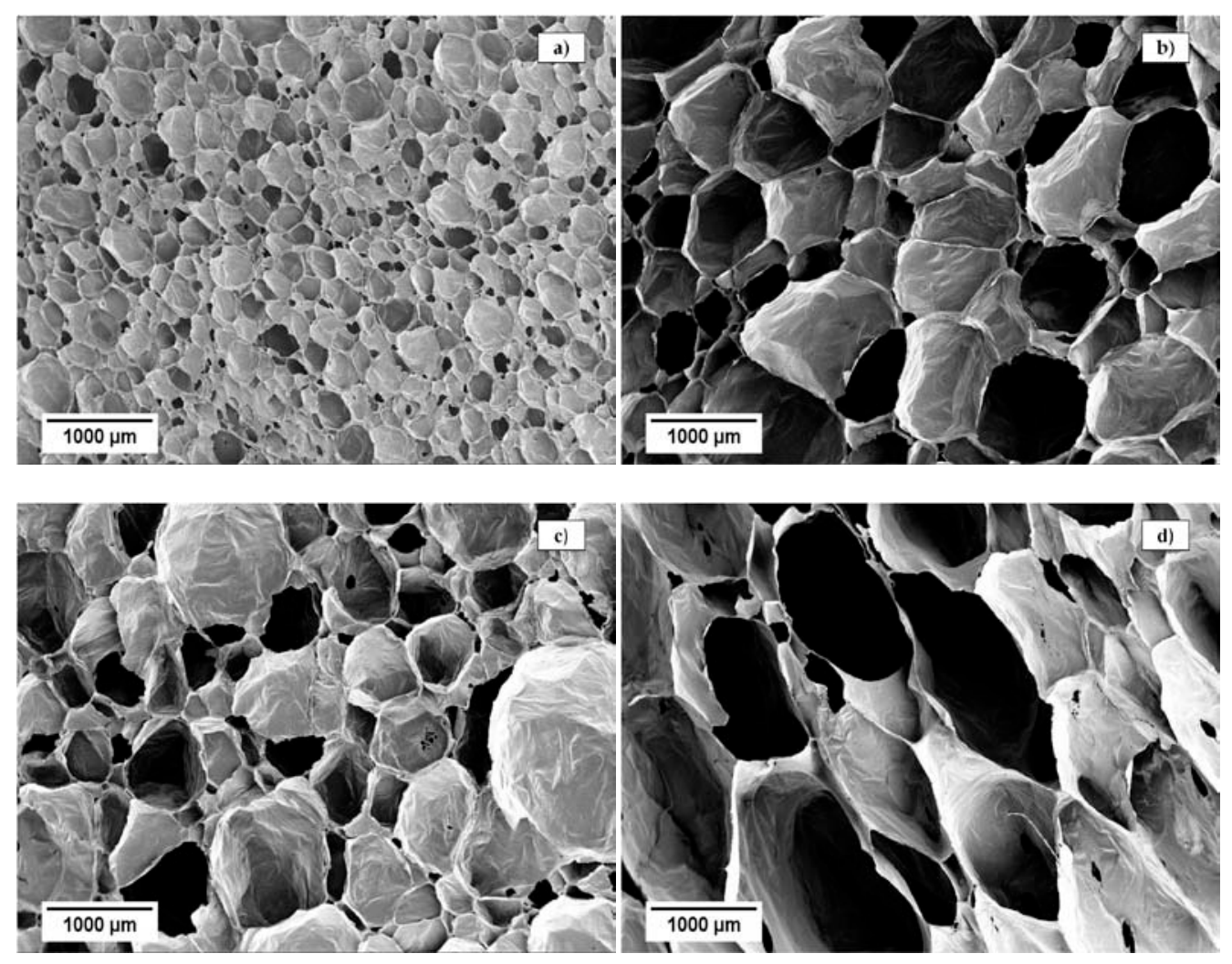

Figure 3.10. SEM micrographs of LDPE foams: a) CC; b) MO; c) OC HT and d) OC LT.
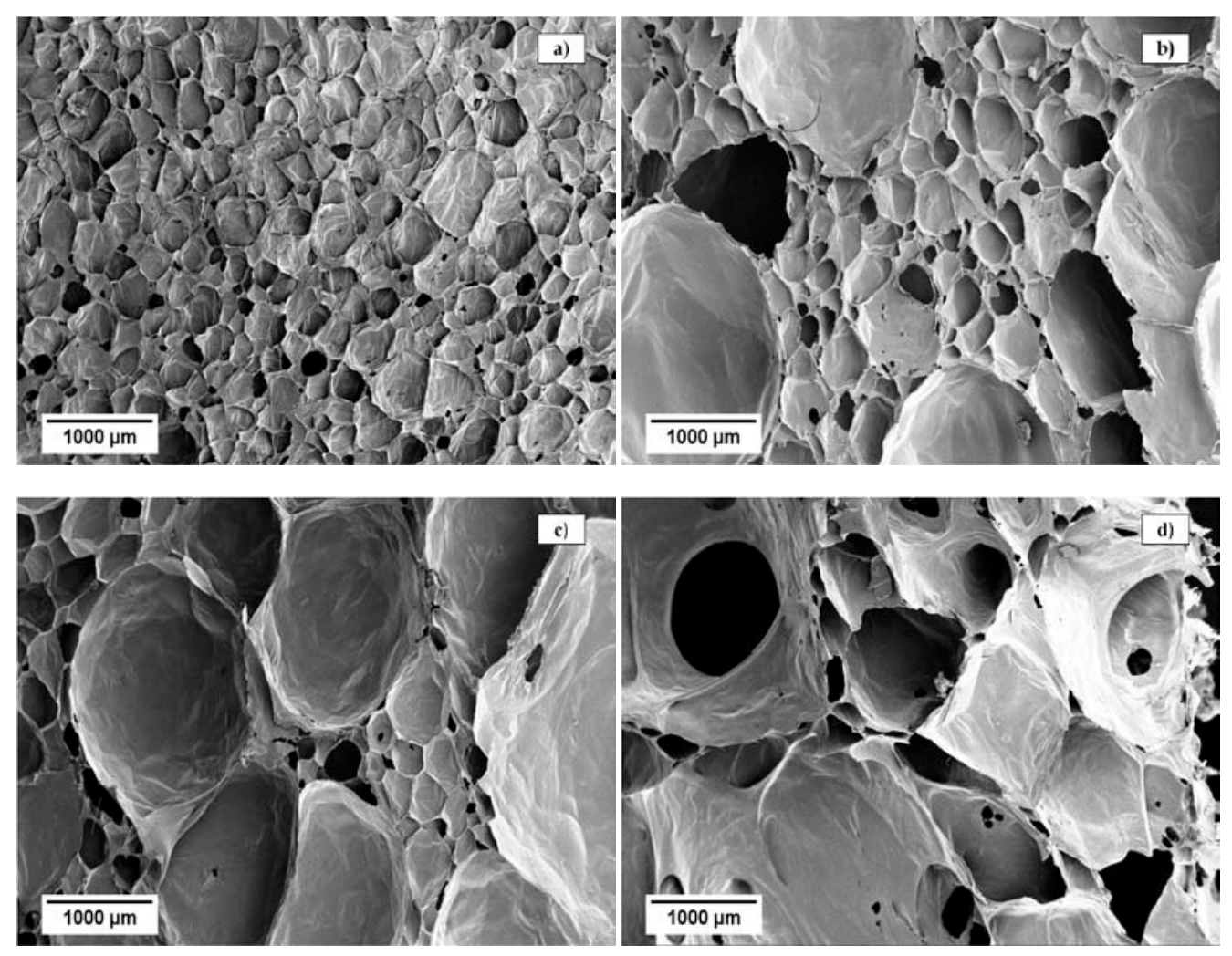

Figure 3.11. SEM micrographs of EVA 18 foams: a) CC; b) MO; c) OC HT and d) OC LT. 
However, this easy characterization technique could not be applied to MO, OC HT and OC LT foams due to the complex cellular structure of these foams (see Figure 3.10 and Figure 3.11).

Another methodology was used to characterize the complex cellular structure of these foams: X-ray tomography. This non-destructive technique provides 3D information about materials. X-ray tomography, as the well-know $\mathrm{x}$-ray radiography, is based on the attenuation of the radiation through the material. Due to the different energy absorption of each element, it is possible to distinguish the different composition of a particular material.

The critical difference between X-ray tomography and X-ray radiography is the acquisition number of radiographs. A tomography is a vast number of radiographs taken in a short period. The X-rays interact with the sample while it is rotating, acquiring hundreds of radiographs [32].

Once the radiographs are taken, and after several steps, they are reconstructed allowing obtaining slices of the scanned object.

This methodology has been used in this thesis to define the cellular structure of LDPE and EVA 18-based foams [33].

One image of the reconstruction performed in the X-ray tomography analysis for the MO, OC HT and OC LT LDPE and EVA 18-based foams are shown in Figure 3.12 and Figure 3.13:
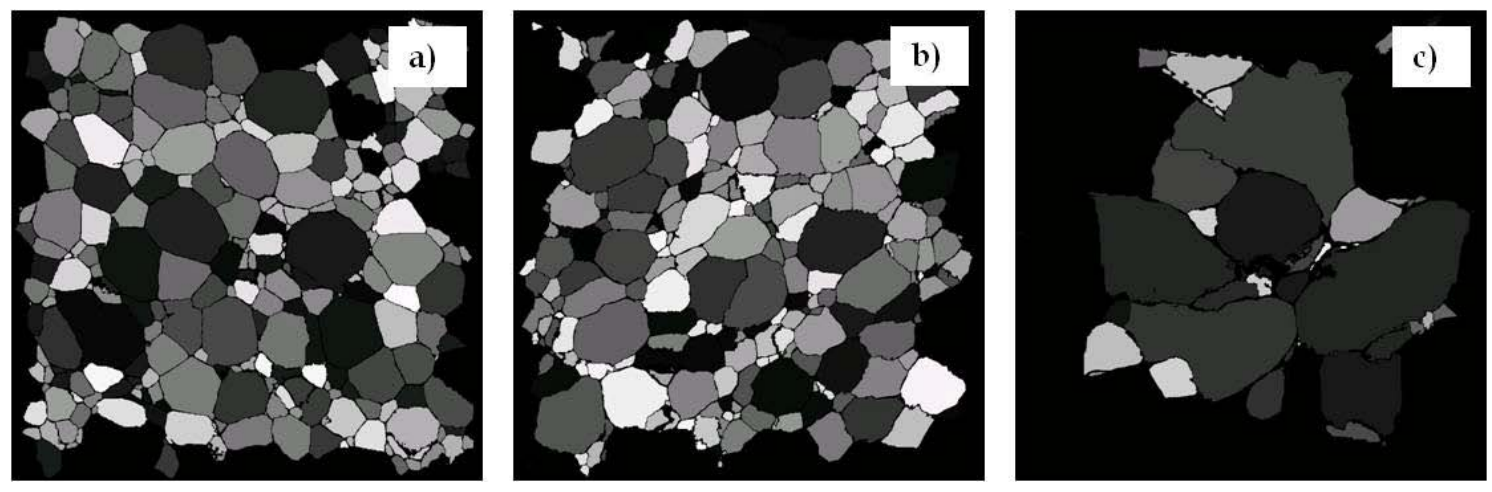

Figure 3.12. Image of the reconstruction in the X-ray tomography analysis of LDPE foams: a) MO; b) OC HT and c) OC LT. 

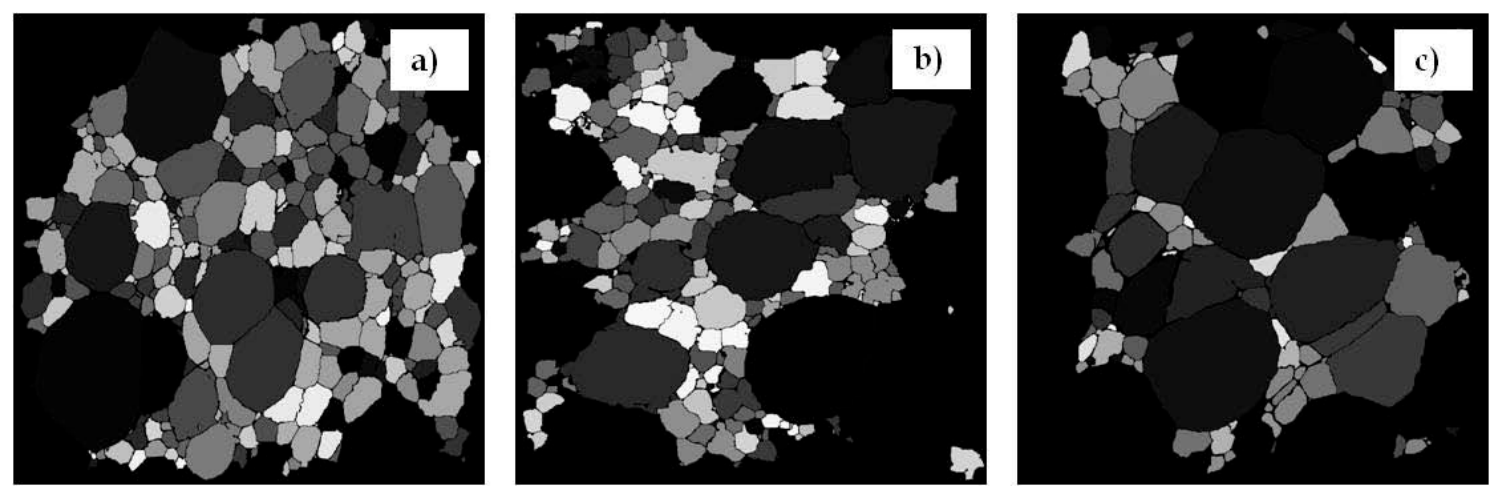

Figure 3.13. Image of the reconstruction in the X-ray tomography analysis of EVA foams: a) MO; b) OC HT and c) OC LT.

By analyzing hundreds of images like the ones shown in Figure 3.10 and Figure 3.11, the cell size can be estimated. The results related to the average cell size of these foams are summarized in Table 3.8.

\begin{tabular}{|c|c|}
\hline Nomenclature & Cell size $(\mu \mathrm{m})$ \\
\hline LDPE MO & $352 \pm 199$ \\
\hline LDPE OC HT & $331 \pm 219$ \\
\hline LDPE OC LT & $120 \pm 260$ \\
\hline EVA 18 MO & $320 \pm 192$ \\
\hline EVA 18 OC HT & $331 \pm 203$ \\
\hline EVA 18 OC LT & $226 \pm 264$ \\
\hline
\end{tabular}

The average cell size value of the $\mathrm{MO}$ and OC HT values are similar. This is expected since the OC HT foams are produced from the MO ones. These results indicate that the process is reproducible in the production of $\mathrm{MO}$ and OC HT foams.

However, according to the average cell size value presented in Table 3.6, it can be concluded that the OC LT foams are quite heterogeneous (see errors in Table 3.6). The cellular structure of these foams is quite complex, coexisting cells of numerous sizes. Figure 3.10 d) and Figure 3.11 d) shows the SEM micrographs of the OC LT foams. It would be expected to obtain very large cell sizes since the cells of these micrographs are larger than $1 \mathrm{~mm}$. However, it seems that there are many small cells, which cannot be seen at the magnification applied in Figure $3.10 \mathrm{~d}$ ) and Figure $3.11 \mathrm{~d}$ ), which contribute considerably to reducing the average cell size.

This analysis shows the complexity associated with the characterization of the cellular structure of the open-cell polyolefin-based foams. As will be discussed in the subsequent chapters, the consideration of the effect of the cellular structure on the physical properties was limited due to the notorious heterogeneity and the differences between the different foamed materials. 


\subsection{Crosslinking}

One critical issue in the production of low-density polyolefin cellular polymers is the crosslinking of the polymer matrix. It must be taken into account that, it is necessary a considerable amount of gas to reduce the density up to 36 times, as in the case of the materials produced for this study. The polymeric matrix must withstand the gas pressure generated during the decomposition of the blowing agent. Furthermore, the polymer stretches during growing, and therefore, the viscosity must be optimal to avoid the apparition of degeneration mechanisms (coalescence or coarsening) during the stabilization of the foam. Consequently, the viscosity of the polymer matrix must be adjusted to avoid undesirable degeneration mechanisms but also to be able to reach the desired expansion ratio.

Crosslinking is a process in which the polymer chains are bonded to provide stability by increasing the viscosity of the polymer matrix [8]. There are two ways of crosslinking: by using chemical crosslinking agents, such as organic peroxides or silanes, or by irradiation using high energy sources (electron beam irradiation) [34-41].

The materials developed during this work have been produced by using chemical crosslinking agents. Dicumyl peroxide (DCP) is a widely used crosslinking agent owing to its effectiveness as a chemical crosslinker, in particular in polyolefin-based materials [42-45].

The crosslinking process is schematized in Figure 3.14.

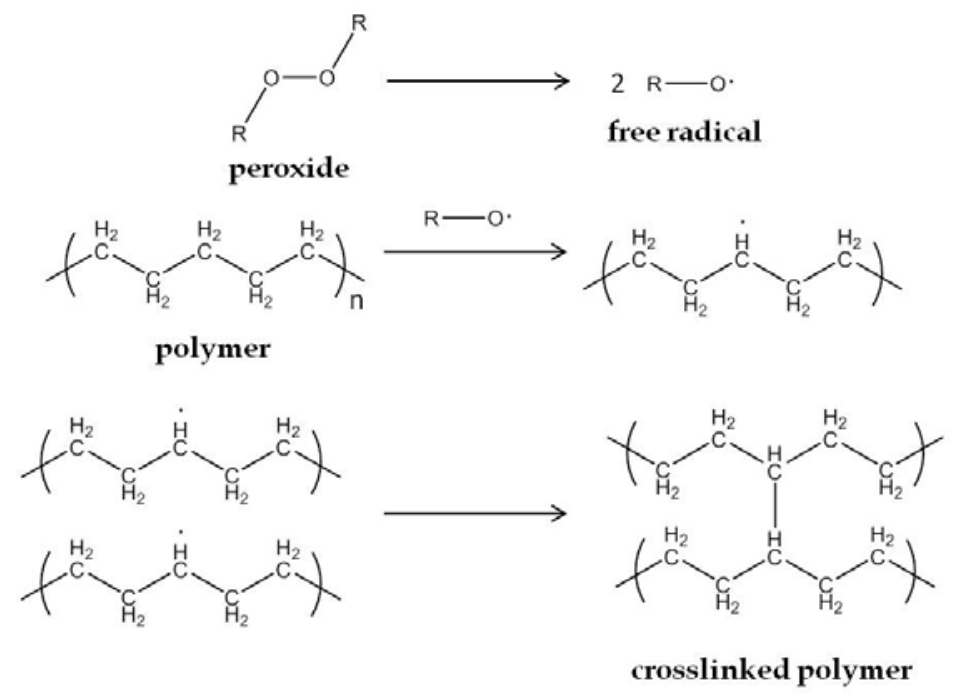

Figure 3.14. Scheme of the crosslinking process in the presence of a chemical crosslinking agent.

DCP decomposes at a certain temperature (around $140{ }^{\circ} \mathrm{C}$ ) generating radicals. The radicals formed during its decomposition are non-stable chemical specimens, and they tend to be energetically stable by taking a proton from the polymer chain, generating radicals in the polymer matrix. The presence of radicals in the polymer chain is also associated with a low-energy state and, this unstable situation is solved by the formation of covalent bonds between the polymer chains [46]. 
The use of organic peroxides is a very effective way to perform the crosslinking process. However, there are also some drawbacks associated with their use. The most critical issue is the formation of sub-products derivated from the DCP when it stabilizes after its protonation. Particularly, in the case of DCP, acetophenone is generated, and it remains in the cellular structure, which could be a limitation for some specific applications. Furthermore, it is difficult to control the gel-content level with chemical crosslinking agents because this parameter is markedly controlled by the DCP concentration. Gel-content is very sensitive to slight variations in the concentration of DCP and thus is quite complex to control the level of crosslinking with these organic compounds accurately.

Even though it has been possible to produce open-cell crosslinked polyolefin foams by using DCP, it was also considered interesting to deal with other alternatives. One option is the use of high energy sources, such as electron irradiation, to crosslink the polymer matrix $[47,48]$. In this case, the polymer matrix is irradiated with a certain dose to generate radicals directly in the polymer chains. As in the case of the chemical crosslinking agents, the unstable energetic situation is fixed by covalent-bonding. By using high energy sources, two main issues are solved: no sub-products are formed, and the irradiation dose controls more precisely the crosslinking level.

The crosslinking process performed by using electron irradiation was addressed during the initial stages of this research work. Despite using chemical crosslinking agents to produce the materials, it was considered the option of studying this alternative path. For this purpose, we analyzed the effect of the irradiation dose on the foaming mechanisms and the cellular structure of a polymer, which has not been reported in the literature, high-density polyethylene (HDPE). HDPE is a linear polymer, and the linearity of the chains makes more difficult the crosslinking of the polymeric matrix $[2,49,50]$. Blends of HDPE and ADCA were irradiated with different doses, and the effect of each irradiation dose on the foaming process and on the homogeneity of the cellular structure was determined.

This study resulted in an article published in the Journal of Applied Polymer Science (issue 22, volume 135, page 46276, 2018) with the title "Analysis of the Foaming Mechanisms of Materials Based on High-density Polyethylene (HDPE) Crosslinked with Different Irradiation Doses".

In this work, it is demonstrated that high irradiation doses (175 kGy) are necessary to crosslink HDPE effectively when the target is to obtain materials with low densities (65 $\mathrm{kg} / \mathrm{m}^{3}$ ). HDPE based cellular polymers with low cell sizes (around 50 microns) were obtained. All these results were supported by measuring the strain hardening (extensional rheological measurements) of the polymer irradiated with different doses [51-53].

All the produced foams crosslinked using electron irradiation were closed-cell materials. Considering that our motivation was to obtain open-cell materials, it was decided to continue the research by using the chemical crosslinking approach. 


\title{
Analysis of the Foaming Mechanisms of Materials based on High Density Polyethylene (HDPE) Crosslinked with Different Irradiation Doses
}

\author{
E. Lopez-Gonzalez ${ }^{1,2}$, L.O. Salmazo ${ }^{1}$, A. Lopez-Gil², E. Laguna-Gutierrez ${ }^{1 *}$, M.A. \\ Rodriguez-Perez ${ }^{1}$ \\ ${ }^{1}$ Cellular Materials Laboratory (CellMat), Condensed Matter Physics Department, University \\ of Valladolid, Paseo Belén 7, 47011, Valladolid (Spain) \\ ${ }^{2}$ CellMat Technologies S.L., Paseo de Belen 9-A (CTTA Building), 47011, Valladolid, Spain \\ * Corresponding author. Tel: +34 983423194 \\ E-mail address: ester.laguna@fmc.uva.es
}

\begin{abstract}
Different crosslinked high-density polyethylene (HDPE) based cellular polymers have been produced by a free foaming process using a chemical blowing agent. The polymer matrix was crosslinked by electron beam irradiation using different doses ranging from 25 to $175 \mathrm{kGy}$. The main aim of this work is to study the effect of the different irradiation doses on the density, cellular structure and foaming mechanisms. Results show that irradiation doses as high as $175 \mathrm{kGy}$ have to be used to obtain cellular materials with a low relative density (0.06), cell sizes of around 50 microns and cell densities of $1.6 \times 10^{7}$ cells $\mathrm{cm}^{-3}$. The strain hardening of the polymer matrix increases with the irradiation dose leading to an increase of the polymer resistance to be stretched, which helps to avoid undesirable cellular degeneration processes. Irradiation doses lower than $175 \mathrm{kGy}$ are not able to stabilize the cellular structure leading to foams with relative densities higher than 0.1 and degenerated cellular structures.
\end{abstract}

Keywords: rheology, polyolefins, foams, crosslinking, irradiation

\section{INTRODUCTION}

Polyethylene (PE) is widely used for some applications such as packaging, insulation, leisure, toys or medicine.1,2 $\mathrm{PE}$ is a semicrystalline polymer with high flexibility, toughness and stiffness, excellent chemical resistance to both oxidizing and reducing agents and good electrical insulation properties. ${ }^{3}$

In particular, high-density polyethylene (HDPE) is a linear PE that presents interesting properties such as high thermal resistance and high stiffness and strength. ${ }^{4,5}$ These properties make it a very promising polymer for the production of solid polymeric based products such as bottles, pipes, protective devices (helmets, knee and elbow pads) etc. ${ }^{6}$ However, due to the linear configuration of its molecular chains, HDPE has a low strain hardening, which is related to a low melt strength. Moreover, HDPE also presents a high crystallinity, which hampers the dissolution of gas inside the polymer matrix. These intrinsic characteristics of the polymer hinder its foamability, and hence, 
its extensive use as a cellular polymer is restricted. Although it is difficult to dissolve gas into the HDPE polymer matrix, HDPE foams are interesting materials due to the properties of the pure polymer. As a result, these foamed materials are suitable for structural applications.7,8

Due to the inherent difficulty in generating stable and low-density cellular polymers by using HDPE, crosslinking of the polymer matrix could be an effective solution to produce these foamed materials. The extensional rheological properties of a polymer matrix are improved after crosslinking. Some previous works have demonstrated that an increase in the strain hardening is observed when the crosslinking degree increases.9,10 If the strain hardening increases, the polymer system can withstand higher deformations avoiding the rupture of the cell walls and hence, hindering the collapse of the cellular structure. ${ }^{11,12}$

Crosslinking is a process in which the polymer chains are bonded due to the presence of unstable free radicals resulting in the formation of covalent $\mathrm{C}-\mathrm{C}$ bonds. At the same time, this process involves an increase in the viscosity of the polymer matrix.13,14 Moreover, crosslinking confers the whole system of some additional properties such as better mechanical and thermal properties and extends the processing window temperature in which homogeneous and stable foams can be produced.15,16 These free radicals can be generated by two different methods: chemical crosslinking by using, for example, organic peroxides or by a physical process in which high energy sources such as electron beam or $\gamma$-irradiation are employed.17-22 Once the free radicals are generated, the covalent bond between neighboring carbon atoms is produced, forming a high viscous polymer network. ${ }^{23}$

Crosslinking with high energy sources has many advantages respect to chemical crosslinking: there are no chemical residues, crosslinking can be carried out at room temperature, and the crosslinking degree can be more accurately controlled by using different irradiation doses. Furthermore, in the case of formulations prepared for foaming applications, when both a chemical blowing agent and a chemical crosslinking agent are employed, it is quite difficult to separate the crosslinking and the foaming stages adequately. However, by using irradiation, the crosslinking step takes place before the release of gas from the blowing agent. This is very important because when both stages take place simultaneously, some difficulties could be found to control the foaming process. ${ }^{24}$

Some works have been found that analyze how the crosslinking process affects the properties of solid HDPE polymer matrices. Gheysari et al. ${ }^{25}$ studied the effect of using different irradiation doses in LDPE and HDPE polymer matrices, employing for this purpose two different energy bombardments of 5 and $10 \mathrm{MeV}$. They concluded that high energy sources $(10 \mathrm{MeV})$ not only produced the crosslinking of the polymer but also induced degradation processes such as chain scission, leading to an even lower degree of crosslinking. There are also other studies focused on analyzing the crosslinking of solid HDPE using, in this case, chemical crosslinking agents. For 
example, Kang et al. ${ }^{26}$ investigated, how different parameters such as temperature, shear rate and crosslinking agent content affected the torque values, and hence the crosslinking reaction, of HDPE crosslinked by using di-ter-butyl-peroxide (DTBP). They concluded that the effect of the temperature is more notorious than the shear rate. High reaction temperatures fostered the crosslinking reaction of the polymer matrix.

However, the previous studies are focused on analyzing solid HDPE polymer matrices without any references to cellular materials. The number of works that analyze the effect of the crosslinking process on the foaming behavior of HDPE polymer matrices is not very extensive. Laguna-Gutierrez et al. ${ }^{9}$ analyzed the extensional rheological behavior and foamability of blends of a chemical crosslinking agent and HDPE. They concluded that foams with low densities and small cell sizes could be produced by tuning both the foaming time and the foaming temperature and by increasing the crosslinking degree.

Although the number of studies that analyze the effect of crosslinking on foaming is not very extensive when the polymer matrix employed is HDPE, this effect has been analyzed in more detail in other polymer matrices like LDPE and EVA.27,28

As far as the author knows, no works related to the study of the cellular structure of HDPE foams crosslinked by using high energy sources and foamed by using azodicarbonamide (ADCA) as blowing agent have been found in the literature. This paper analyzes in detail the effect of using several irradiation doses ranging from 25 to $175 \mathrm{kGy}$ on the cellular structure and foaming mechanisms of HDPE cellular materials fabricated through a free foaming process using ADCA as blowing agent.

\section{MATERIALS}

HDPE Rigidex® 5130 manufactured by Ineos with a density of $0.952 \mathrm{~g} \mathrm{~cm}^{-3}$ and melt flow index (MFI) of $2.40 \mathrm{~g} 10 \mathrm{~min}^{-1}$ measured at $230{ }^{\circ} \mathrm{C}$ and $2.16 \mathrm{~kg}$, was used as the polymer matrix. Azodicarbonamide (ADCA) Unifoam AZ VI-50 powder with an average particle size of 16-23 microns and a range of decomposition temperatures between 198 and $202{ }^{\circ} \mathrm{C}$ was employed as blowing agent. Azodicarbonamide was kindly supplied by Hebron an Otsuka Chemical Group Company.

\section{EXPERIMENTAL}

\section{Production of Solid Formulations}

HDPE and ADCA (17.7 phr) were blended by using a co-rotating twin-screw extruder (Collin Teach-Line® ZK 25T) with a L/D of 24. The temperature profile was 110-115-120$125-130{ }^{\circ} \mathrm{C}$, being $130{ }^{\circ} \mathrm{C}$ the temperature at the die of the extruder and the rotational speed was $50 \mathrm{rpm}$. The blend came out of the extruder and was immediately cooled with water and then pelletized. The pellets were dried in a vacuum oven for 24 hours at a temperature of $50{ }^{\circ} \mathrm{C}$. This formulation was extruded again to achieve better homogeneity of the blend. The working temperatures used during the extrusion 
process were below the decomposition temperature of the ADCA (approximately 200 $\left.{ }^{\circ} \mathrm{C}\right)$; therefore, the pellets are not foamed.

The extruded material was later thermoformed by a calendaring process using for this purpose a single screw extruder (Collin Teach-Line® ${ }^{\circledR}$ CR 72T). The temperature profile was $130-135-140-145-145^{\circ} \mathrm{C}$, and the rotational speed was $50 \mathrm{rpm}$. Solid sheets with a thickness of $1 \mathrm{~mm}$ were obtained.

These solid sheets were irradiated at four different doses to obtain different grades of crosslinking. The irradiation of the HDPE sheets was performed at room temperature in Mevion Technology facilities (Soria, Spain). The energy, power and intensity of the electron accelerator were $10 \mathrm{MeV}, 40 \mathrm{~kW}$ and $4 \mathrm{~mA}$ respectively. The energy applied was enough to ensure the proper penetration of the beam throughout the whole thickness of the sheets. The sheets were irradiated with different doses: 25, 75, 100 and $175 \mathrm{kGy}$. Total doses were applied in fractions of $25 \mathrm{kGy}$ to avoid excessive heating of the sample, which could lead to an unwanted early decomposition of the blowing agent.

Sheets of pure HDPE (without the blowing agent) were also produced by the method previously described. These sheets were also irradiated in order to determine the gel content and to characterize the rheological behavior of the polymer matrix.

\section{Foaming Process}

Prisms with dimensions of $(2 \times 2 \times 0.1) \mathrm{cm}$ were obtained from the solid irradiated sheets containing the blowing agent. The foaming of the samples occurred when they were immersed in a bath with silicon oil at $229^{\circ} \mathrm{C}$. A temperature as high as $229^{\circ} \mathrm{C}$ was chosen to ensure the proper decomposition of the blowing agent, whose decomposition temperature is in a range between 198 and $202{ }^{\circ} \mathrm{C}$. The time that the samples were maintained inside the bath (also known as foaming time) was varied with the aim of analyzing how the density and structure of the foamed samples depend on this parameter. The selected foaming times were: 15, 30, 37, 45, 53 and 60 seconds. Once the time has elapsed, the samples were extracted from the bath and cooled down with water to stabilize the cellular structure as fast as possible and reduce the degeneration mechanisms.

One interesting parameter to be calculated is the theoretical volume expansion ratio (VER). ${ }^{27}$ This parameter is defined as the theoretical minimum density that should be reached for a certain amount of chemical blowing agent, as it is shown in Equation 1:

$$
V E R=1+\frac{m_{A D C A}}{m_{P}} \rho_{P} \varphi
$$

where $m_{A D C A}$ is the mass of the blowing agent, $m_{P}$ is the mass of the polymer, $\rho_{P}$ is the density of the polymer and $\varphi$ is the gas yield $\left(220 \mathrm{~cm}^{3} \mathrm{~g}^{-1}\right.$ for ADCA). ${ }^{30}$ 
By comparing this parameter with the experimental expansion ratios obtained, it is possible to quantify the magnitude of the degeneration mechanisms taking place during the foaming process.

\section{CHARACTERIZATION TECHNIQUES}

\section{Crosslinking Degree}

Gel content measurements of the pure irradiated HDPEs (without ADCA) were performed following the ASTM standard D 2765-11 method. Specimens of irradiated HDPE were first weighed and then immersed in boiling xylene for 8 hours. After this time, the samples were removed from the boiling xylene and dried by using a vacuum oven. Once the material was completely dried, the samples were weighed again. Gel content was calculated using Equation 2:

$$
\text { Gel content }(\%)=\left(\frac{m_{f}}{m_{i}}\right) 100
$$

where $m_{i}$ is the initial weight and $m_{f}$ is the weight after the extraction process. The gel content degree for each material was determined as the average of three measurements.

Measurements of the percentage of penetration (\%) of an indenter in the crosslinked polymer were also performed. The indenter has a flat base, and its diameter is $3 \mathrm{~mm}$. These measurements were carried out by using a Perkin-Elmer DMA 7 dynamic mechanical analyzer. The range of temperatures was varied from 35 to $175{ }^{\circ} \mathrm{C}$ with a heating rate of $5^{\circ} \mathrm{C} \mathrm{min}-1$. The height of the sample was in a range between 1.00 and $1.10 \mathrm{~mm}$ and the static force applied was $50 \mathrm{mN}$. The percentage of penetration was calculated using Equation 3:

$$
\% \text { penetration }=\left(\frac{\mathrm{h}_{o}-\mathrm{h}_{\text {min }}}{\mathrm{h}_{o}}\right) 100
$$

where $h_{o}$ is the initial height and $h_{\min }$ is the deepest height that the indenter is able to reach during the measurement.

This additional measurement allows us to estimate the crosslinking degree of the polymer matrix quantitatively by a simple comparison of the percentage of penetration. For instance, the indenter is not able to penetrate deeply inside when the polymer is highly crosslinked.

\section{Extensional Rheological Measurements}

The extensional viscosity of the irradiated HDPE samples (without blowing agent) was measured by using a stress-controlled rheometer AR 2000 EX from TA Instruments with an extensional device fixture known as SER 2 from Xpansion Instruments. Two 
clamps hold the sample to two drums, which rotate in opposite directions to stretch the sample, at a certain Hencky strain rate.

To perform these tests, sheets with a dimension of $20 \mathrm{~mm} \times 10 \mathrm{~mm} \times 0.5 \mathrm{~mm}(\mathrm{~L} \times \mathrm{W} \times$ $\mathrm{T})$ were required. They were obtained by melting and compressing the material in a hot press at $220^{\circ} \mathrm{C}$ and 27 bars of pressure. The extensional rheological measurements were carried out at a temperature of $220^{\circ} \mathrm{C}$.

The measurement protocol consisted of firstly in a pre-stretch, to compensate for the volumetric expansion of the material when it was heated from room temperature. After that, a relaxation process was carried out when the initial pre-stretch was over. After this relaxation time, the experiments were performed. Measurements were conducted at a Hencky strain rate of $1 \mathrm{~s}^{-1}$. The maximum Hencky strain applied was 2.8 for all materials.

\section{Density and Expansion Ratio Measurements}

Density measurements of the cellular polymers $\left(\rho_{f}\right)$ were performed by using the Archimedes Principle (ASTM standard D1622-08). The relative density $\left(\rho_{r}\right)$ was estimated as the ratio between the density of the foamed sample and that of the solid polymer $\left(\rho_{s}\right)$ (Equation 4):

$$
\rho_{r}=\frac{\rho_{f}}{\rho_{s}}
$$

Expansion ratio $(E R)$ is defined as the inverse of the relative density:

$$
E R=\frac{1}{\rho_{r}}
$$

\section{Scanning Electron Microscopy (SEM)}

SEM was used to analyze in detail the cellular structure of the HDPE cellular polymers. Cell size in 3D $(\phi)$, anisotropy ratio $(R)$, normalized standard deviation coefficient $(N S D)$, asymmetry coefficient $(A C)$, cell density $\left(N_{v}\right)$ and cell nucleation density $\left(N_{o}\right)$ was determined by analyzing the SEM micrographs. The micrographs were taken with a Jeol JSM-820 scanning electron microscope, and the parameters were quantified by using a tool based on the software Fiji/Image J. ${ }^{31}$ To prepare the samples for microscopy, they were first frozen by immersion in liquid nitrogen to cut them without modifying their structure. Then, a thinner layer of gold was sputtered on the fractured surfaces to make them conductive.

Cell size in 3D $(\phi)$ is defined as the average cell size of all the cells considered in the micrograph as expressed in the following equation (Equation 6), where $n$ is the total number of cells: 


$$
\phi=\frac{\sum_{i=1}^{n} \phi_{i}}{n}
$$

Anisotropy ratio $(R)$ is determined as the ratio between the cell size in the cell growing direction $\left(\phi_{1}\right)$ and one perpendicular to it $\left(\phi_{2}\right)$ (Equation 7):

$$
R=\frac{\phi_{1}}{\phi_{2}}
$$

Normalized standard deviation coefficient (NSD) and asymmetry coefficient (AC) shows the homogeneity and shape of the cell size distribution. Low values of NSD mean narrow and therefore, homogeneous cell size distributions. AC provides information about the shape of the distribution: if the coefficient is negative, the smallest cells are more separated from the average value than the bigger ones and vice versa. NSD and $A C$ can be calculated by using the following equations (Equation 8 and Equation 9, respectively):

$$
\begin{aligned}
& N S D=\frac{\frac{\sqrt{\sum_{i}^{n}\left(\phi_{i}-\phi\right)^{2}}}{n-1}}{\phi} \\
& A C=\frac{\Sigma_{i}^{n}\left(\phi_{i}-\phi\right)^{3}}{n(S D)^{3}}
\end{aligned}
$$

Cell density $\left(N_{v}\right)$ is defined as the number of cells per unit volume of the foam. If it is assumed that cells are spherical, then Equation 10 can be used to estimate $N_{v} \cdot{ }^{32}$

$$
N_{v}=\frac{6 V_{f}}{\Pi \phi^{3}}
$$

where $V_{f}$ is the void fraction (Equation 11)

$$
V_{f}=1-\rho_{r}
$$

Finally, cell nucleation density $\left(N_{o}\right)$ defined as the number of cells per cubic centimeter of the solid material can be estimated from (Equation 12):

$$
N_{o}=\frac{N_{v}}{1-V_{f}}
$$

A HITACHI FlexSEM 100 scanning electron microscope was used to determine the volume of the ADCA particles after the extrusion process. Once again, a tool based on the software Fiji/Image J was employed to quantify this parameter by measuring the area and the thickness of the ADCA particles and by considering these particles as prisms. With the average volume of the ADCA particles, the potential nucleation density was estimated by using Equation 13:11 


$$
\frac{\text { nucleants }}{c m^{3}}=\frac{w_{A D C A} \rho_{c}}{\rho_{A D C A} V_{A D C A}}
$$

where $w_{A D C A}$ is the ADCA weigh fraction in the formulation, $\rho_{c}$ is the density of the polymer composite (HDPE + ADCA), $\rho_{A D C A}$ is the density of the ADCA particles, and finally, $V_{A D C A}$ is the average volume of the ADCA particles.

The coalescence and coarsening ratio $(C C R)$, defined as the ratio between the potential nucleation density and $N_{\mathrm{o}}$ (Equation 14), has been used to quantify the magnitude of the two main degeneration mechanisms taking place during the foaming process of these polymeric systems: coalescence and coarsening. Other degeneration mechanisms, like drainage, have not been considered due to their few possibilities to occur, taking into account the high viscosities of these polymeric systems. If $C C R$ is equal to 1 , that means that one particle generates one cell and hence, there are neither coalescence nor coarsening during the foaming process. High values of $C C R$ indicate high coalescence and coarsening mechanisms during the foaming process.

$$
C C R=\frac{\text { nucleants } / \mathrm{cm}^{3}}{N_{o}}
$$

\section{RESULTS AND DISCUSSION}

\section{Gel Content}

The gel content of irradiated HDPE samples without ADCA versus irradiation dose is plotted in Figure 1:

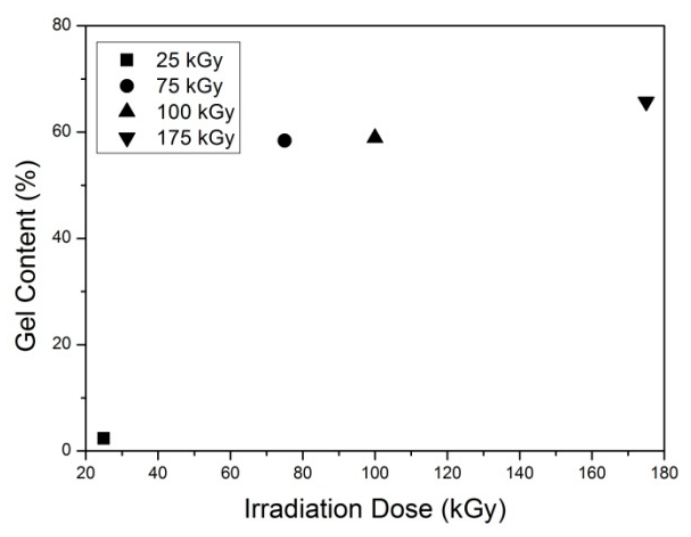

Figure 1. Gel content of the irradiated HDPE samples as a function of the irradiation dose.

The results follow an expected trend. When the irradiation dose increases the gel content also increases. At $25 \mathrm{kGy}$, the gel content value is about $2 \%$. This irradiation dose is very far from that required to crosslink the polymer matrix fully. This result is expected due to the linearity of the polymer chains. Linear polymers are more difficult to crosslink than branched polymers due to the higher distances between neighboring 
polymer chains. However, when the dose increases from 25 to $75 \mathrm{kGy}$, a steep rise is observed, from $2 \%$ to $58 \%$. Then for higher doses, the gel content rises but not so steeply. This result is in agreement with previous publications for natural rubbers. ${ }^{33-35}$ Despite increasing the irradiation dose, the gel content value does not vary because it has reached its maximum value.

An additional test to evaluate the crosslinking degree was performed by measuring the percentage of penetration (\%) of an indenter in the crosslinked polymers without blowing agent (Figure 2).

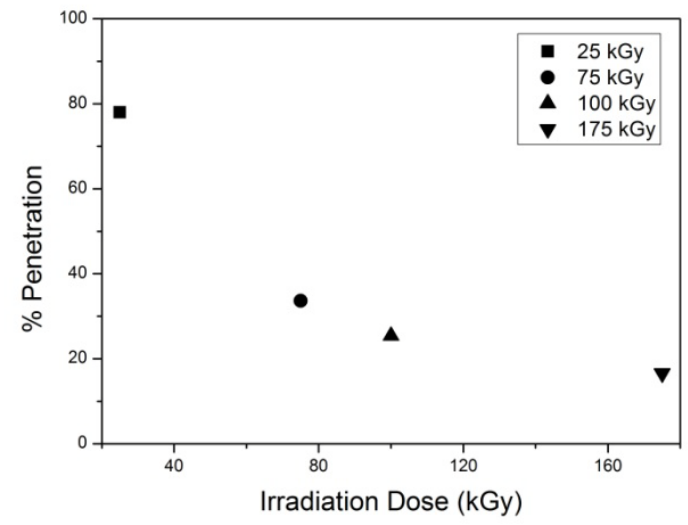

Figure 2. Dependence of the percentage of penetration (\%) of the indenter in the irradiated HDPE samples with the irradiation dose.

As can be seen in Figure 2, the penetration of the indenter decreases when the irradiation dose increases. When the crosslinking degree increases, an increase in the polymer viscosity is also obtained. As a consequence, the indenter cannot penetrate so easily inside the sample, and this value tends to be lower. These results are in agreement with the gel content measurements shown in Figure 1. An abrupt change is also observed by increasing the irradiation dose from 25 to $75 \mathrm{kGy}$ and then, for higher irradiation doses, the variations in the crosslinking degree are not so extreme. It seems that this test is more sensitive to the polymer structure after crosslinking than the gel content measurements, because the differences in penetration between the different irradiation doses are detected, even at high irradiation doses, as it is observed in Figure 2.

\section{Rheological Behavior}

Results depicted in Figure 3(a) indicate that for crosslinked HDPE samples, the extensional viscosity increases abruptly with time. This phenomenon is called strain hardening $(\mathrm{SH})$. This strain hardening is more pronounced when the crosslinking degree increases. The pure non-crosslinked HDPEs do not show this behavior due to their linear structure. ${ }^{36,37}$ 
Strain hardening can be quantified from the extensional viscosity measurements by using gel content measurements of the pure irradiated HDPEs (without ADCA) were performed following the ASTM standard D 2765-11 method. Specimens of irradiated HDPE were first weighed and then immersed in boiling xylene for 8 hours. After this time, the samples were removed from the boiling xylene and dried by using a vacuum oven. Once the material was completely dried, the samples were weighed again. Gel content was calculated using Equation 5:

$$
S H=\frac{\eta_{E}^{+}\left(t, \dot{\varepsilon_{0}}\right)}{3 \eta_{E 0}^{+}(t)}
$$

where $\eta_{E}^{+}\left(\mathrm{t}, \dot{\varepsilon}_{0}\right)$ is the transient extensional viscosity as a function of time $(t)$ and Hencky strain rate $\left(\dot{\varepsilon}_{0}\right)$ and $\eta_{E 0}^{+}(\mathrm{t})$ is the transient extensional viscosity in the linear viscoelastic regime. ${ }^{38,39}$ Strain hardening values were estimated for a time of $2.61 \mathrm{~s}$, that is, for a Hencky strain rate of $1 \mathrm{~s}^{-1}$.
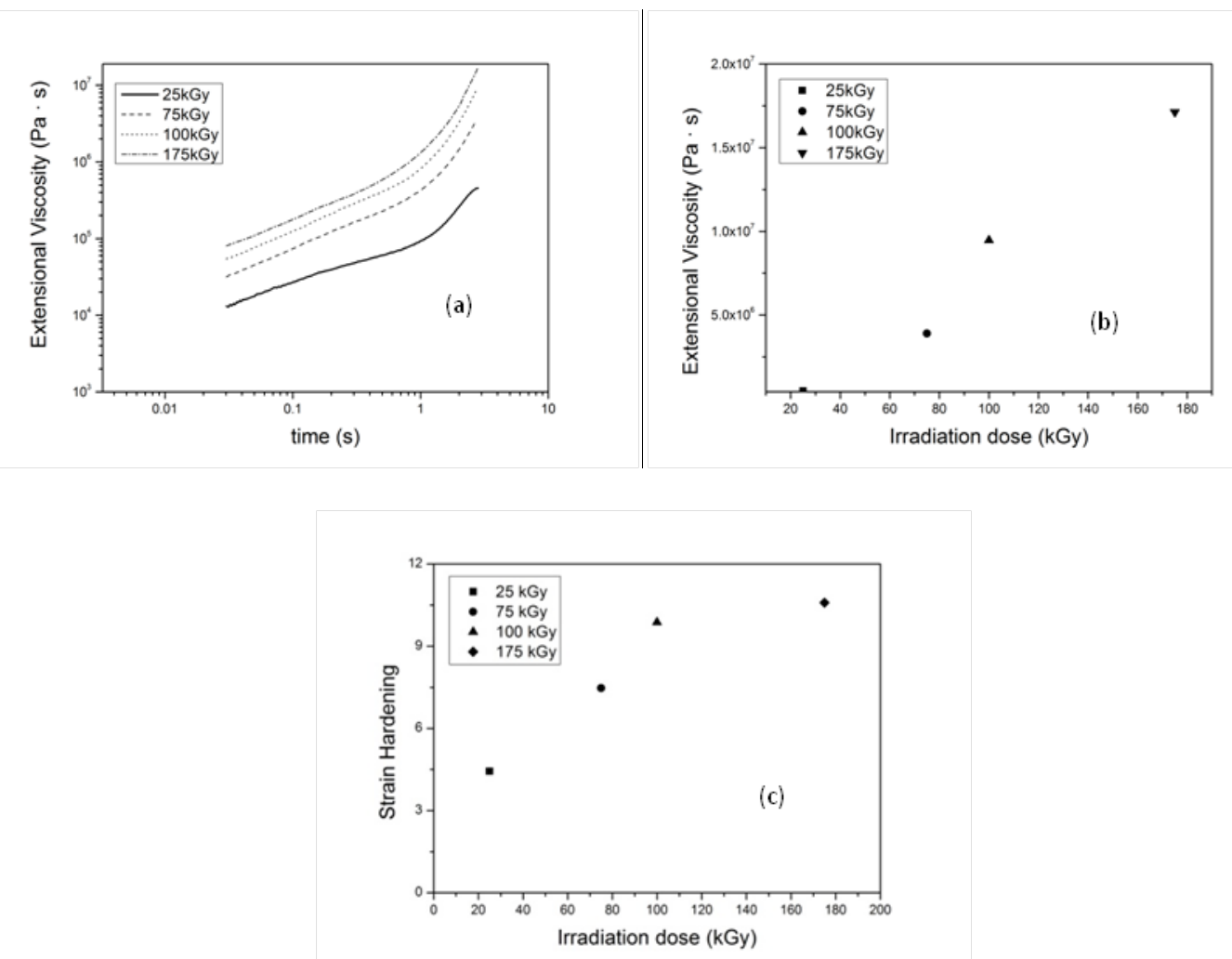

Figure 3. (a) Extensional viscosity versus time. (b) Extensional viscosity obtained at the maximum time (2.81 s) for each irradiation dose. (c) Strain hardening values of the different pure irradiated HDPEs.

Figure 3(a) shows the extensional viscosity measurements for each irradiation dose. As it is observed, the extensional viscosity increases when the dose also increases (see also Figure 3(b)). There is a huge difference in extensional viscosity between the polymer irradiated with 25 and that irradiated with $175 \mathrm{kGy}$. Moreover, the extensional viscosity deeply increases from 25 to $75 \mathrm{kGy}$. Although from 75 to $175 \mathrm{kGy}$, the extensional viscosity still increases, this increase is not so evident as before. This effect 
could be attributed to a maximum in the crosslinking degree. These results are in agreement with the ones obtained for the percentage of penetration. The difference in viscosity between each irradiation dose is observed in Figure 3(b), where the extensional viscosities determined at the maximum time $(2.81 \mathrm{~s})$ are plotted for each irradiation dose. To illustrate these differences: the extensional viscosity of the material irradiated with $175 \mathrm{kGy}$ is almost 38 times higher than that of the irradiated with 25 kGy and almost twice than that of the material irradiated with $100 \mathrm{kGy}$.

The strain hardening values of the HDPE samples irradiated with different doses are plotted in Figure 3(c). These values go up when the irradiation dose increases. The strain hardening value of the sample irradiated with $175 \mathrm{kGy}$ is 2.38 times larger than that corresponding to the sample irradiated with $25 \mathrm{kGy}$. According to the rheological measurements, it is expected that more stable and homogenous cellular structure should be obtained for the sample irradiated with $175 \mathrm{kGy}$ than for the samples irradiated with lower energies.

\section{Relative Density}

The relative density $\left(\rho_{r}\right)$ of the cellular materials was measured at different foaming times: 15, 30, 37, 45, 53 and 60 seconds. The relative density is represented versus the foaming time in Figure 4.

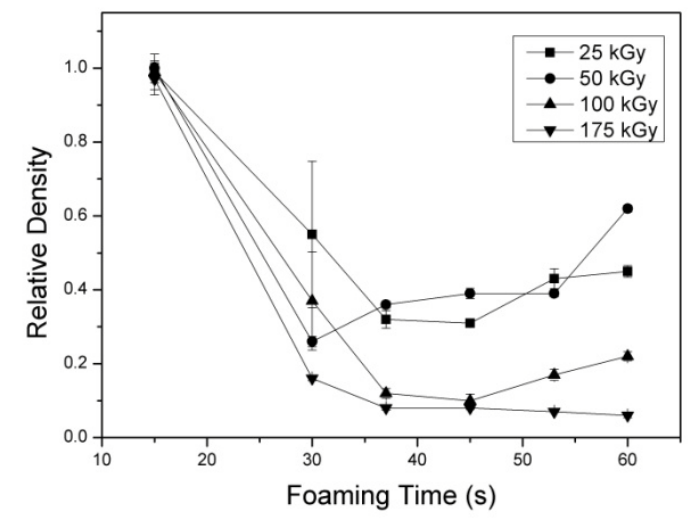

Figure 4. Relative density of the cellular polymers based on HDPEs crosslinked with different irradiation doses as a function of the foaming time.

At 15 seconds, the relative density of all samples is about 1, which indicates that the dimensions of the samples do not change at this time. This time is so low that, the beginning of the decomposition of the ADCA particles has not yet started At 30 seconds the relative density begins to decrease because the decomposition of the blowing agent has already started and the cells also have enough time to grow. For most materials, the relative density decreases up to a foaming time of 37 seconds and then, between 37 and 45 seconds, it tends to be constant with time. However, if the foaming time continues rising, an increase in the relative density is detected for all the 
materials except for the one crosslinked with the highest dose: $175 \mathrm{kGy}$. This increase in the relative density indicates that the cellular coalescence mechanisms begin to play an important role. The strain hardening of the polymer matrix is not high enough, and hence, the polymer is not able to resist the expansion during the foaming process. As a consequence, the cell walls break, and the gas escapes resulting in a collapse of the cellular structure. However, the sample irradiated with $175 \mathrm{kGy}$ can keep the gas inside at any foaming time.

The theoretical volume expansion ratio (VER) allows us to know the theoretical minimum density, or the maximum expansion ratio, which could be achieved for a fixed content of blowing agent. According to Equation 1, the maximum expansion ratio for $17.7 \mathrm{phr}$ of ADCA is 37.50, which correspond to a relative density of 0.026 . As it is observed in Figure 4, the minimum relative densities achieved for doses lower than $175 \mathrm{kGy}$ are in a range between 0.1 and 0.3 , quite far from the theoretical value. This can be explained taking into account the degeneration mechanisms which suffer the polymer matrix when the irradiation dose is not high enough. However, the minimum relative density with $175 \mathrm{kGy}$ is 0.06 , which is closer to the theoretical one (0.026). The cellular structure has been stabilized due to the suitable viscosity of the polymer matrix, and therefore, lower densities can be reached.

Figure 5 shows the effect of the strain hardening on the density of the cellular polymers foamed at the optimal foaming time, which is defined as the time required to achieve the lowest density. This optimal time is $45 \mathrm{~s}$ for the sample irradiated with 25 kGy, $30 \mathrm{~s}$ for the sample irradiated with $75 \mathrm{kGy}, 45 \mathrm{~s}$ for the sample irradiated with 100 kGy and $60 \mathrm{~s}$ for the sample irradiated with $175 \mathrm{kGy}$. The density decreases when the strain hardening value increases. When comparing the lowest relative density of the sample irradiated with $25 \mathrm{kGy}$ (obtained for a foaming time of 45 seconds) and the one of the sample irradiated with $175 \mathrm{kGy}$ (obtained for a foaming time of 60 seconds), it is possible to observe that the sample irradiated with $175 \mathrm{kGy}$ is able to expand 4.5 times more than the one irradiated with $25 \mathrm{kGy}$. This is an appreciable difference which has a direct effect on the cellular structure. 


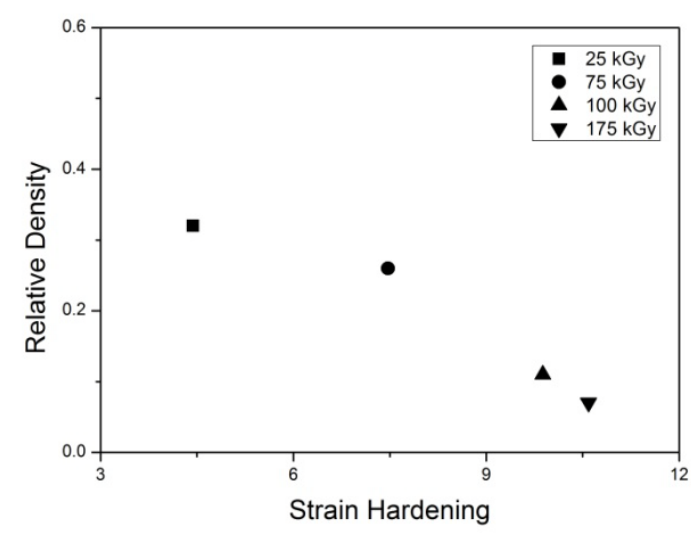

Figure 5. Relative density of the cellular polymers foamed at the optimal time versus the strain hardening values.

\section{Cellular Structure}

Two studies were carried out concerning the cellular structure of the cellular polymers. First, the influence of the irradiation dose at a fixed foaming time (the optimal one) was studied. Then, the effect of the foaming time on the cellular structure and foaming mechanisms was analyzed in two systems: samples irradiated with 100 and with 175 $\mathrm{kGy}$. These two irradiation doses were selected because, at $100 \mathrm{kGy}$, there is a threshold, in which the cellular structure is stabilized. Except for the specimen irradiated with $175 \mathrm{kGy}$, the rest of the cellular structures were similar and therefore, 100 kGy fixed a limit.

\section{Influence of the Irradiation Dose}

Figure 6 shows the SEM micrographs of HDPE cellular polymers irradiated with different doses and foamed at the optimal time to achieve the lowest density: 

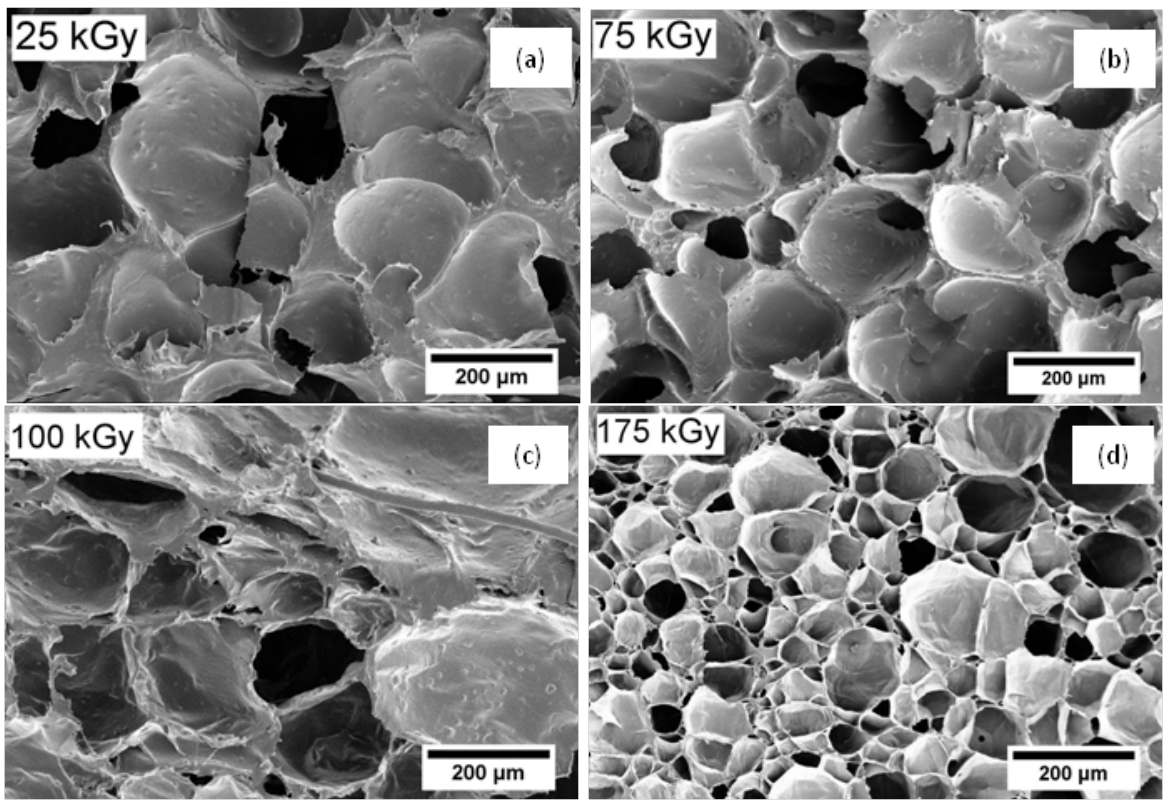

Figure 6. SEM micrographs of the HDPE cellular polymers foamed at the optimal time and irradiated with different doses: (a) $25 \mathrm{kGy}$, (b) $75 \mathrm{kGy}$, (c) $100 \mathrm{kGy}$, (d) $175 \mathrm{kGy}$.

Different cellular structures were obtained depending on the dose employed. In the case of the lowest irradiation doses ( 25 and $75 \mathrm{kGy}$ ), cellular structures with large cell sizes are observed. These structures reflect once again the degeneration mechanisms, mainly coalescence, which take place due to the low strain hardening of these polymers. The polymer matrix is not able to resist the expansion, and the cell walls break, generating larger cells. This effect is also observed when the polymer is irradiated with $100 \mathrm{kGy}$. The increase of the strain hardening allows reducing the density of the cellular materials but is not high enough to avoid the coalescence mechanisms. When the highest irradiation dose (175 kGy) is used, the most stable cellular structure is observed. Smaller cells are obtained due to the higher strain hardening of the polymer matrix. However, the cellular structure is still very heterogeneous, presenting cells with different sizes. Results indicate that irradiation doses as high as $175 \mathrm{kGy}$ should be used to obtain both low relative densities and low cell sizes.

Cellular structure parameters for the optimal time to reach the lowest foam density are summarized in Table 1.

Table 1. Cellular structure parameters of cellular polymers based on HDPE crosslinked with different irradiation doses and produced at the optimal foaming time.

\begin{tabular}{|c|c|c|c|c|}
\hline Irradiation dose $\mathbf{( k G y )}$ & 25 & 75 & 100 & 175 \\
\hline $\boldsymbol{\phi}(\boldsymbol{\mu m})$ & $167 \pm 76$ & $156 \pm 72$ & $177 \pm 91$ & $48 \pm 37$ \\
\hline $\boldsymbol{R}$ & $1.06 \pm 0.41$ & $0.91 \pm 0.27$ & $0.92 \pm 0.40$ & $0.94 \pm 0.39$ \\
\hline $\boldsymbol{N S D}$ & 0.45 & 0.46 & 0.51 & 0.77 \\
\hline$A C$ & 0.75 & 0.65 & 0.95 & 1.44 \\
\hline$N_{v} \times \mathbf{1 0}^{\mathbf{5}}\left(\mathbf{c e l l s ~ \mathbf { ~ m } ^ { - 3 } )}\right.$ & 2.83 & 3.69 & 3.08 & 157 \\
\hline $\left.\boldsymbol{N}_{\boldsymbol{o}} \times \mathbf{1 0} \mathbf{1 0 l l s ~ c m}^{-3}\right)$ & 0.91 & 1.40 & 2.91 & 237 \\
\hline
\end{tabular}


As it was also previously observed in the SEM micrographs, the cell size of the material irradiated with $175 \mathrm{kGy}$ is smaller than the others. Particularly, this value is 3.5 times lower than the one obtained in the cellular materials produced from the polymer irradiated with $25 \mathrm{kGy}$. However, it is not possible to observe any trend in cell size in the range from 25 to $100 \mathrm{kGy}$, giving similar values (between 155 and 180 microns) for all the irradiation doses. The density of the cellular materials is very different and hence, establishing a comparison between them is not a simple task.

The anisotropy coefficient in all cases is around 0.90-1.05. The anisotropy is inherently affected by the foaming process rather than by the irradiation dose. The samples were foamed by a free foaming process, in which isotropic cells (anisotropy ratio $=1$ ) are usually generated.

The normalized standard deviation coefficient (NSD) and the asymmetry coefficient $(A C)$ is used to analyze the homogeneity of the cellular structure. The estimation of these coefficients is a good and easy way of comparing results obtained with different materials. The asymmetry coefficient $(A C)$ increases when the dose also increases. As it was previously indicated, high positive values of AC mean that the cell size of the larger cells is more separated from the average cell size than the cell size of the smaller ones. Furthermore, the normalized standard deviation coefficient (NSD) also rises with the irradiation dose. Some cellular degeneration processes such as coalescence or coarsening play a key role in these parameters. In the polymer irradiated with the highest dose cellular degeneration by coarsening prevails over cell coalescence. As the ADCA particles cover a wide range of particle sizes $(6.7 \pm 3.6$ microns after the extrusion process), each cell has a different size at the beginning of the foaming process which favors cell degeneration through coarsening mechanisms. Moreover, due to the high strain hardening of this material, the cell walls do not break easily during the foaming process, and therefore, at this dose, cell coalescence is reduced. As a consequence, heterogeneous structures are formed, resulting in higher values of $A C$ and NSD than those obtained for lower irradiation doses.

Cell density $\left(N_{v}\right)$, is higher for the sample irradiated with $175 \mathrm{kGy}$. It is worth mentioning that $N_{v}$ is about 55 times higher for the cellular polymer irradiated with $175 \mathrm{kGy}$ in comparison to the material irradiated with $25 \mathrm{kGy}$. This can be explained due to the difference in cell size. The cell size for $175 \mathrm{kGy}$ is much smaller than for the other materials, and as a consequence, $N_{v}$ is higher.

Cellular degeneration mechanisms were quantified by analyzing $N_{o}$. This parameter allows comparing materials with different relative density. When no degeneration mechanisms (like coalescence or coarsening) are produced $N_{o}$ is the same for the different cellular materials because all of them are produced with the same amount of blowing agent and hence, it is possible to assume that the nucleation density does not vary from one material to another. However, when coalescence and coarsening are produced a reduction in $N_{o}$ is detected. Figure 7 shows the relationships between the strain hardening and $N_{o}$, for the samples irradiated with the different doses. 


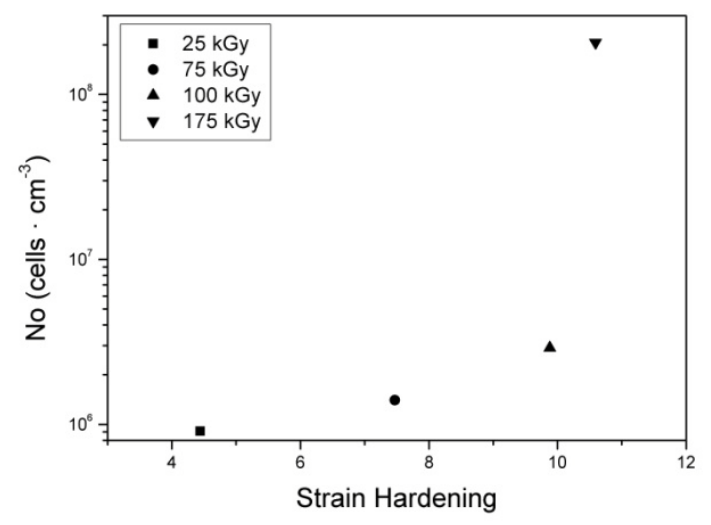

Figure 7. Cell nucleation density (No) of the crosslinked HDPE cellular polymers produced at the optimal foaming time versus strain hardening.

Results depicted in Figure 7 indicate an increase in the cell nucleation density when the strain hardening increases. This increase in $N_{o}$ is related to a reduction of the coalescence mechanisms taking place during the foaming process, due to the higher resistance of the polymer to be stretched. An abrupt increase in $N_{o}$ is also observed by increasing the irradiation dose from 100 to $175 \mathrm{kGy}$, which once again indicates that there is a critical value in the irradiation dose and hence, in the strain hardening from which stable cellular structures are obtained.

To quantify in more detail the degeneration mechanisms, the coalescence and coarsening ratio $(C C R)$ has been determined according to Equation 14. To estimate the $C C R$, the potential nucleation density must be calculated previously (see Equation 13). The weight fraction of ADCA in the formulation is 0.15 , the density of the blend (polymer/blowing agent) was $1.016 \mathrm{~g} / \mathrm{cm}^{3}$, and the density and the volume of the particles of the ADCA was $1.6 \mathrm{~g} \mathrm{~cm}^{-3}$ and $3.64 \cdot 10^{-11} \mathrm{~cm}^{3}$, respectively. Taking into account these values, the value of the potential nucleation density was $2.62 \cdot 10^{9}$ nucleants $\mathrm{cm}^{-3}$. Figure 8 shows the $C C R$ values versus the irradiation dose calculated from the potential nucleation density and $N_{o}$. 


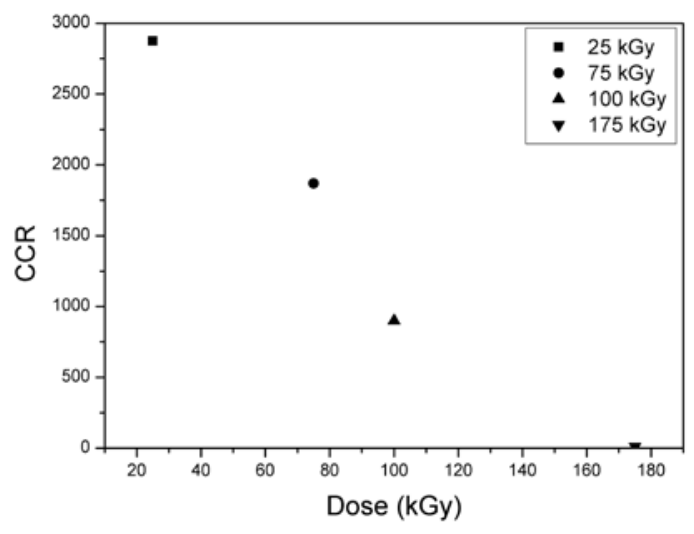

Figure 8. Coalescence and coarsening ratio (CCR) of the crosslinked HDPE cellular polymers produced at the optimal foaming

time as a function of the irradiation dose.

As it is observed in Figure 8, the CCR ratio decreases when the irradiation dose increases. This result indicates that more degeneration mechanisms (mainly coalescence) appear at low doses, which can be correlated with the low strain hardening values presented by these materials. Particularly, CCR is 260 times higher in the sample irradiated with $25 \mathrm{kGy}(C C R=2879.12)$ than in the sample irradiated with $175 \mathrm{kGy}(C C R=11.05)$. This value of $C C R=11.05$ for the sample irradiated with the highest dose (175 kGy) means that despite having a highly crosslinked material, degeneration mechanisms continue to occur, although to a lesser extent. In this case, it is expected that cellular degeneration is mainly produced by coarsening since the higher polymer strain hardening hinders ruptures of the cell walls. Nevertheless, this value is low enough to lead to stable cellular structures.

\section{Influence of the Foaming Time}

The influence of the foaming time in the cellular structure was studied for the systems irradiated with $100 \mathrm{kGy}$ and $175 \mathrm{kGy}$. Different cellular polymers were fabricated at different foaming times: 30, 37, 45, 53 and 60 seconds. The foaming time of 15 seconds was omitted because as it was already mentioned, this time is not high enough to allow the decomposition of the blowing agent.

Figure 9 and Figure 10 show the SEM micrographs of the cellular polymers irradiated with 100 and $175 \mathrm{kG}$, respectively, produced at different foaming times. 


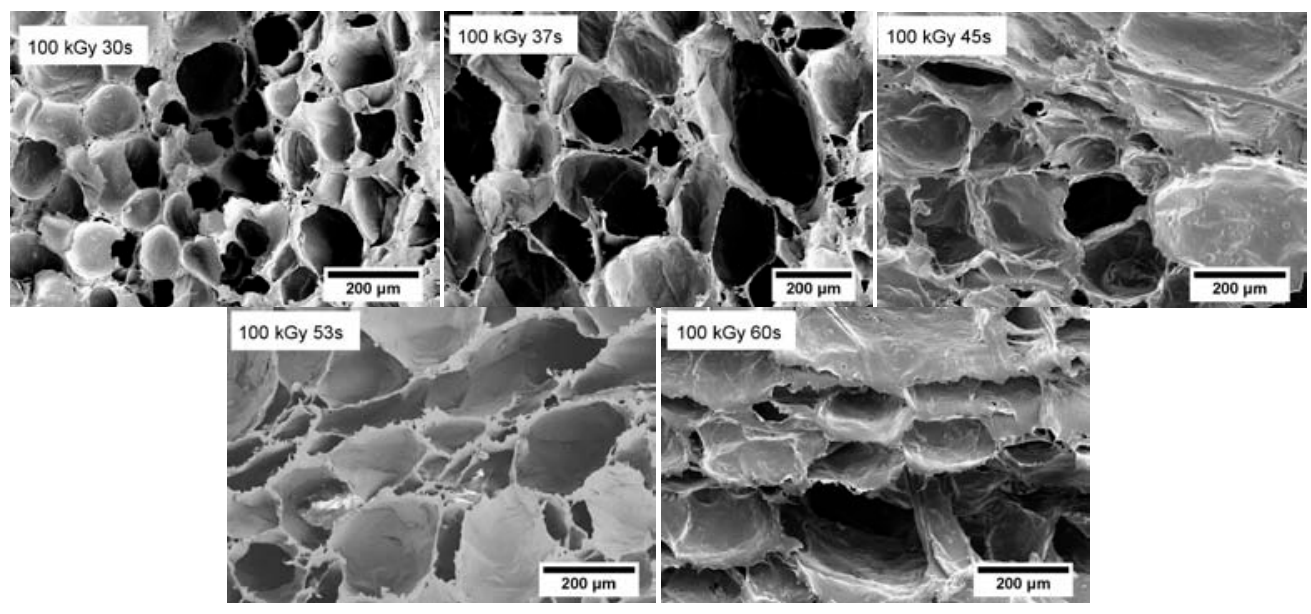

Figure 9. SEM micrographs of HDPE cellular polymers irradiated with $100 \mathrm{kGy}$ produced at different foaming times: $30,37,45,53$ and 60 seconds.

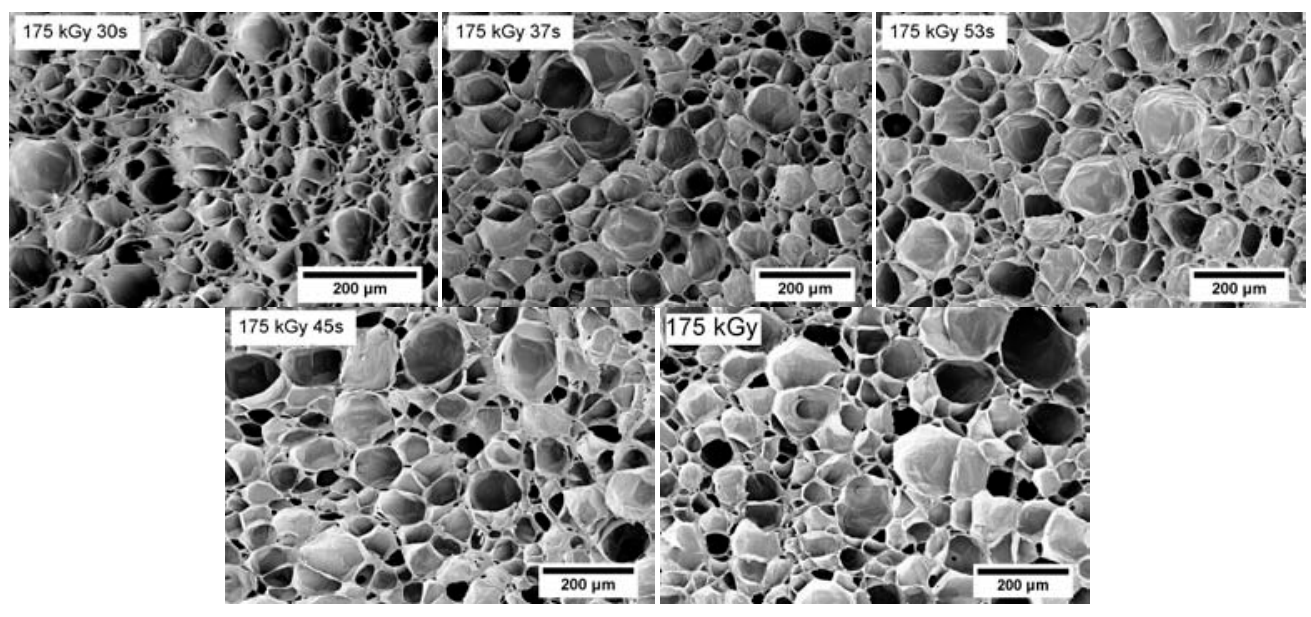

Figure 10. SEM micrographs of HDPE cellular polymers irradiated with $175 \mathrm{kGy}$ produced at different foaming times: $30,37,45,53$ and 60 seconds.

Although the polymer irradiated with $100 \mathrm{kGy}$ presents a high value of the strain hardening, this value is not high enough to obtain a stable cellular structure, as it can be observed in Figure 9. The most stable structure, with an average cell size of 94 microns, appears at 30 seconds since, at this foaming time, the cells grow only partially and hence, the degeneration mechanisms are less significant. Moreover, at this foaming time, the material also presents the highest density (Figure 4). When the foaming time increases up to 37 seconds, the cells can grow, leading to an increase of the cell size, reaching a value of 137 microns and to a reduction in the foam density. The minimum value of density is reached at 45 seconds. At this moment, as a consequence of the low thickness of the cell walls, the cellular degeneration processes are prone to occur increasing the cell size (177 microns) and the density of the cellular materials. From 45 
seconds, any important change is detected in the cellular structures, although the density of the foamed materials continues rising.

When the polymer is irradiated with $175 \mathrm{kGy}$, the highest strain hardening value is reached, and this value is suitable to achieve stable cellular structures throughout the whole foaming time range under analysis. Moreover, as it was previously indicated, the density of the cellular materials reaches a constant value at foaming times higher than 37 seconds. Although a good cellular structure is also obtained at a foaming time of 30 seconds, this time is not high enough to fully decompose the blowing agent (as in the case of $100 \mathrm{kGy}$ ), because the density is still decreasing when the foaming time increases. The cells only grow partially, and the cell size (32 microns) is very low at this foaming time. When the foaming time increases to 37 seconds, the blowing agent is fully decomposed, and the cells grow totally; therefore, an increase in the cell size is produced (46 microns). Then, this parameter reaches a constant value. Despite increasing the foaming time, degeneration processes are not observed due to the high strain hardening of the polymer matrix. As a result, the cell sizes, as well as the density, do not vary too much with the foaming time once the blowing agent is fully decomposed.

Typical cell structure parameters were estimated by analyzing the SEM micrographs. The main results of both systems are shown in Table 2.

Table. 2 Effect of the foaming time on the cellular structure parameters of crosslinked HDPE cellular polymers irradiated with two different doses: 100 and $175 \mathrm{kGy}$.

\begin{tabular}{|c|c|c|c|c|c|c|}
\hline \multicolumn{2}{|c|}{ Foaming time (s) } & 30 & 37 & 45 & 53 & 60 \\
\hline \multirow[t]{2}{*}{$\phi(\mu \mathrm{m})$} & 100 kGy & $94 \pm 51$ & $137 \pm 87$ & $177 \pm 91$ & $159 \pm 75$ & $153 \pm 82$ \\
\hline & 175 kGy & $32 \pm 23$ & $46 \pm 31$ & $48 \pm 33$ & $46 \pm 34$ & $48 \pm 37$ \\
\hline \multirow[t]{2}{*}{$R$} & 100 kGy & $0.92 \pm 0.32$ & $0.96 \pm 0.56$ & $0.92 \pm 0.40$ & $0.88 \pm 0.38$ & $0.88 \pm 0.39$ \\
\hline & 175 kGy & $0.95 \pm 0.42$ & $0.97 \pm 0.42$ & $0.85 \pm 0.35$ & $1.05 \pm 0.49$ & $0.94 \pm 0.39$ \\
\hline \multirow[t]{2}{*}{$N S D$} & $100 \mathrm{kGy}$ & 0.54 & 0.63 & 0.52 & 0.47 & 0.54 \\
\hline & 175 kGy & 0.72 & 0.044 & 0.69 & 0.74 & 0.75 \\
\hline \multirow[t]{2}{*}{$A C$} & 100 kGy & 1.51 & 1.79 & 0.95 & 1.25 & 0.84 \\
\hline & 175 kGy & 1.55 & 1.26 & 1.96 & 1.52 & 1.44 \\
\hline \multirow[t]{2}{*}{$N_{v} \times 10^{5}($ cells cm-3 $)$} & $100 \mathrm{kGy}$ & 14.4 & 6.56 & 3.08 & 3.96 & 4.18 \\
\hline & 175 kGy & 478 & 182 & 159 & 187 & 157 \\
\hline \multirow[t]{2}{*}{$N_{o} \times 10^{6}\left(\right.$ cells cm$\left.^{-3}\right)$} & 100 kGy & 3.91 & 5.41 & 2.91 & 2.29 & 1.89 \\
\hline & $175 \mathrm{kGy}$ & 299 & 226 & 206 & 272 & 237 \\
\hline
\end{tabular}

Regardless of the foaming time, the cell sizes of cellular polymers irradiated with 175 kGy are always smaller than those of the cellular polymers irradiated with $100 \mathrm{kGy}$. Furthermore, from a foaming time of 37 seconds, the cell size remains constant for 175 kGy in spite of increasing the foaming time (see Table 2). This result is also observed for the samples irradiated with $100 \mathrm{kGy}$. In this case, cell size remains constant from a foaming time of 45 seconds, although the density of these materials is not the same due to the degeneration mechanisms. In the case of $175 \mathrm{kGy}$, it can be concluded that the best foaming time is 60 seconds because the cellular structure keeps homogeneous, and 
the density reaches its minimum value. However, it is very complicated to assign the suitable foaming time for the sample irradiated with $100 \mathrm{kGy}$ due to the heterogeneous cellular structures observed at any foaming times. The only exception is the material foamed at 30 seconds; however, its relative density (0.366) is still too high.

The anisotropy is affected neither by the irradiation dose nor by the foaming times. As it was previously mentioned, when the cellular polymers are generated by a free foaming process, isotropic cells are usually created due to the absence of a physical limitation. The cells can equally grow in each direction, and the anisotropy ratio tends to be equal to one.

Both NSD and AC are in general larger for the sample irradiated with 175 than for the sample with $100 \mathrm{kGy}$. The high values of these parameters can be correlated with the heterogeneous cellular structures presenting cells with different sizes. This behavior was already analyzed in the previous section. Regarding the variation of these parameters with the foaming time, there is no a clear trend. The same type of heterogeneous structure is observed independently on the foaming time. $N_{v}$ is related to the cell size of the foamed material as it can be observed in Equation 10. The cell size is smaller for the sample irradiated with $175 \mathrm{kGy}$ than for the one irradiated with 100 kGy, independently on the foaming time. Therefore, $N_{v}$ is much higher for the materials irradiated with $175 \mathrm{kGy}$. In the same way, as with cell size, $N_{v}$ remains constant from a foaming time of $37 \mathrm{~s}$ in the sample irradiated with $175 \mathrm{kGy}$ and foaming time of $45 \mathrm{~s}$ in the sample irradiated with $100 \mathrm{kGy}$.

In Figure 11, the cell nucleation density $(\mathrm{No})$ is represented as a function of the foaming time for the materials irradiated with 100 and $175 \mathrm{kGy}$. Independently on the foaming time, No is always higher in the cellular materials based on the sample irradiated with $175 \mathrm{kGy}$ than in those based on the sample irradiated with $100 \mathrm{kGy}$. That means that the degeneration mechanisms are less intense in the highly crosslinked samples. On the other hand, the type of dependency of No with time depends on the irradiation dose. In the cellular materials based on the sample irradiated with $100 \mathrm{kGy}$, a decrease in No is obtained by increasing the foaming time (see also Table 2) due to the coalescence mechanisms, which also lead to an increase of the density of the material (as it was already observed in Figure 4). However, no important variations of No with time are detected in the sample irradiated with the highest dose (175 kGy). The strain hardening of this material is high enough to generate foamed materials with a stable cellular structure over a wide range of foaming times. 


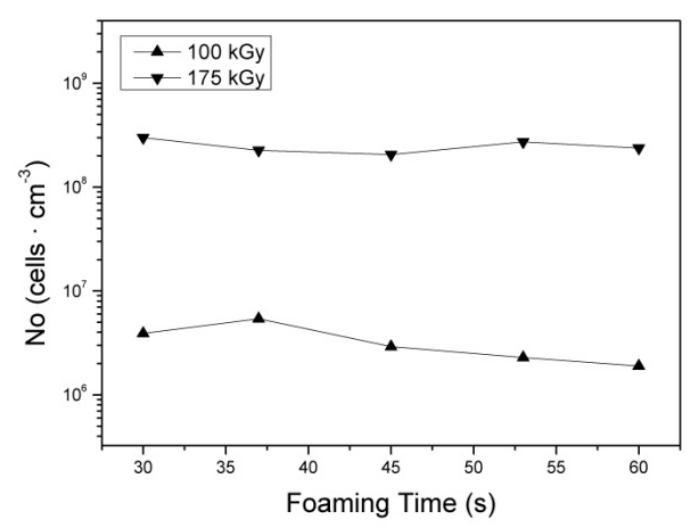

Figure 11. Cell nucleation density (No) of the HDPE cellular polymers irradiated with 100 and 175 kGy versus the foaming time.

The evolution of the degeneration mechanisms with the foaming time has also been analyzed by studying the behavior followed by the parameter CCR. Figure 12(a) shows CCR versus the foaming time for both irradiation doses (100 and $175 \mathrm{kGy}$ ).
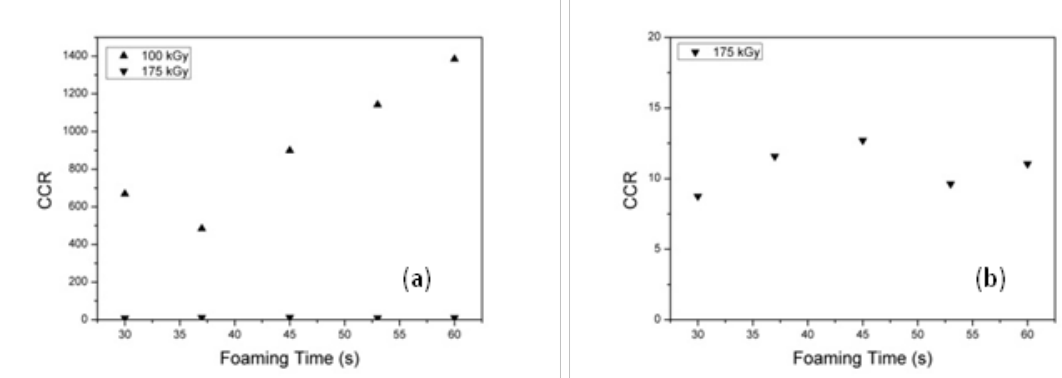

Figure 12. Coalescence and coarsening ratio (CCR) of the crosslinked HDPE cellular polymers irradiated with 100 and $175 \mathrm{kGy}$ as a function of the foaming time. (a) CCR versus time of the foams based on the HDPE irradiated with $100 \mathrm{kGy}$. (b) CCR versus time of the foams based on the HDPE irradiated with $175 \mathrm{kGy}$.

As it is observed in Figure 12(a), CCR values are much higher for the sample irradiated with $100 \mathrm{kGy}$ than for the sample irradiated with $175 \mathrm{kGy}$, at any foaming time. For example, at a foaming time of 60 seconds, the value of CCR is 125 times higher for the sample irradiated at $100 \mathrm{kGy}$ than for the other one. This result indicates that in the material irradiated at $100 \mathrm{kGy}$, cellular degeneration mechanisms are present since the beginning of the ADCA particles decomposition. Regarding the evolution of CCR with time, on the one hand, for the material irradiated with the highest dose, $C C R$ is almost constant throughout the foaming time (Figure 12(b)). This result account once again for the stability of the cellular structure. On the other hand, in the cellular materials based on the polymer irradiated at $100 \mathrm{kGy}$, an abrupt increase of CCR is observed from a foaming time of $37 \mathrm{~s}$ indicating that degeneration mechanisms intensify as the foaming time increases. 


\section{CONCLUSIONS}

Several crosslinked HDPE polymers, which were irradiated with four different doses $(25,75,100$ and $175 \mathrm{kGy})$, were foamed aiming at analyzing the effect of the irradiation dose on both density and cellular structure.

Results indicated that the lowest density was obtained for the material irradiated with the highest dose (175 kGy), which in turns presented the highest strain hardening. This material has a relative density of 0.06 , which was quite close to the minimum theoretical density that can be obtained (0.026). This sample also presents the lowest cell sizes (around $50 \mu \mathrm{m})$ and the highest cell nucleation densities $\left(1.6 \times 10^{7} \mathrm{cells} \mathrm{cm}^{-3}\right)$. The degeneration mechanisms have been quantified through the coalescence and coarsening ratio $(C C R)$. This parameter decreases as the irradiation dose increases. CCR was around 11 for the sample irradiated with $175 \mathrm{kGy}$ and about 2875 for the sample irradiated with the lowest dose (25 kGy).

The effect of the foaming time was also analyzed in the materials irradiated with 100 and $175 \mathrm{kGy}$, using for this purpose five different foaming times: 30, 37, 45, 53 and 60 seconds. When comparing the foaming kinetics of the two crosslinked materials, it was observed that the cell size and the relative density of the material irradiated with 175 kGy were stable throughout a foaming time ranging between 37 and 60 seconds. However, in the polymer irradiated with $100 \mathrm{kGy}$, an increase in cell size was detected as the foaming time increased. These values tended to stabilize beyond 45 seconds, time from which an increase of the relative density of the cellular materials was produced. Moreover, in the materials irradiated with $100 \mathrm{kGy}$, it was also found that the cellular degenerations mechanisms were present since the beginning of the ADCA particles decomposition.

\section{ACKNOWLEDGEMENTS}

Financial assistance from MINECO, FEDER, UE (MAT2015-69234-R), the Junta de Castile and Leon (VA011U16) and from DI grant DI-15-07952 (E. Lopez-Gonzalez) from the Spanish Ministry of Economy, Industry and Competitiveness are gratefully acknowledged.

\section{REFERENCES AND NOTES}

1. Deshpande, S.; Munoli, A. Indian. J. Plast. Surg. 2010, 43, 34-39.

2. Hopewell, J.; Dvorak, R.; Kosior, E. Philos. Trans. R. Soc. Lond. B. Biol. Sci. 2009, 364, 2115-2126.

3. Ziaie, F.; Borhani, M.; Mirjalili, G.; Bolourizadeh, M.A. Radiat. Phys. Chem. 2007, 76, 1684-1687.

4. Peacock, A.J. Handbook of Polyethylene: Structure, Properties and Applications; Marcel Dekker: New York-Basel, 2000. 
5. Biron, M. Thermoplastics and thermoplastic composites; Elsevier Science: Amsterdam, 2007.

6. Galli, P.; Vecellio, G. J.Polym.Sci.A. 2004, 42, 396-415.

7. Hornsby, P.R. Mater. Des. 1982, 3, 443-455

8. Tovar-Cisneros, C.; Gonzalez-Nuñez, R.; Rodrigue, D. J. Cell. Plast. 2008, 44, 223-237

9. Laguna-Gutierrez, E.; Pinto, J.; Kumar, V.; Rodriguez-Mendez, M.L.; RodriguezPerez, M.A. J. Cell. Plast. 2016, In press. DOI: 10.1177/0021955X16681454

10. Laguna-Gutierrez, E.; Escudero, J.; Kumar, V.; Rodriguez-Perez, M.A. J. Cell. Plas. 2016, 0, 1-26.

11. Laguna-Gutierrez, E.; Van Hooghten, R.; Moldenaers, P.; Rodriguez-Perez, M.A. J. Appl. Polym. Sci. 2015, 132, 42430-42444.

12. Naguib, H.E.; Park, C.B.; Panzer, U.; Reichelt, N. Polym. Eng.Sci. 2002, 42, 1481-1492.

13. Eaves, D.E. Cell. Handbook of Polymer Foams; Rapra Technology Limited: Shrewsbury, 2004.

14. Cunningham, A.; Hilyard, N.C. Low Density Cellular Plastics: Physical Basis of Behaviour; Champman \& Hall: London, UK, 1994.

15. Klempner, D.; Frisch, K.C. Handbook of Polymeric Foams and Foam Technology; Hanser Publishers: Munich, Germany, 1991; Chapter 9, pp 187-242

16. Rodríguez-Pérez, M.A. Adv.Polym. Sci. 2005, 184, 97-126.

17. Manley, T.R.; Qayyum, M.M. Polymer. 1971, 12, 176-188.

18. Manley, T.R.; Qayyum, M.M. Polymer. 1971, 13, 587-592.

19. Thomas, D.K. J. Appl. Polym. Sci. 1962, 6, 613-616.

20. Charlesby, A. Proc. Roy. Soc. (London). 1952, A215, 187-214.

21. Oster, G.; Oster, G.K.; Moroson, H. J.Polym.Sci. 1959, 34, 671-684.

22. Dole, M. Radiat. Phys. Chem. 1983, 22, 11-19.

23. Tamboli, S.M.; Mhaske, S.T.; Kale, D.D. Indian.J.Chem.Tec. 2004, 11, 853-864.

24. Bernardo, V.; Laguna-Gutierrez, E.; Lopez-Gil, A.; Rodriguez-Perez, M.A. Mater. Design. 2016, In press.

25. Gheysari, D.; Behjat, A. Eur.Polym.J. 2001, 37, 2111-2116.

26. Kang, T.; Ha, C. Polym. Test. 2000, 19, 773-783.

27. Youssef, H.A.; Senna, M.M.; Eyssa, H.M. J.Polym.Res. 2007, 14, 351-357.

28. Cardoso, E.C.L.; Lugão, A.B.; Andrade, L.G.; Silva, E. Radiat.Phy.Chem. 1998, 52, 197-200.

29. Liu, G.; Park, C.B.; Lefas, J.A. Polym. Eng. Sci. 1998, 38, 1997-2009.

30. Klempner, D.; Frisch, K.C. Handbook of Polymeric Foams and Foam Technology; Hanser Publishers: Munich, Germany, 1991.

31. Pinto, J.; Solórzano, E.; Rodríguez-Pérez, M.A. J.Cell. Plas. 2013, 49, 555-575.

32. Kumar, V. Process synthesis for manufacturing microcellular thermoplastic parts.

Ph.D. Thesis, Massachusetts Institute of Technology, Cambridge, MA, 1988.

33. Manoila, E.; Craciun, G.; Stelenescu, M.D.; Ighigeanu, D.; Ficai, M. Polym.Bull. 2014, $71,57-82$.

34. Khalid, M.; Ismail, A.F.; Ratnam, C.T.; Faridah, Y.; Rashmi, W.; Khatib, M.F.A. Radiat.Phys.Chem. 2010, 79, 1279-1285. 
35. Sharif, J.; Yunus, M.Z.W.; Hj, K.Z.; Dahlan, M.; Ahmad, M.H. Polym.Test. 2005, 24, 211-217.

36. Wagner, H.M.; Bastian, H.; Hachmann, P.; Meissner, J.; Kurzbeck, S.; Münstedt, H.; Langouche, F. Rheol. Acta. 2000, 39, 97-109.

37. Yamaguchi, M.; Suzuki, K.I. J. Appl. Polym. Sci. 2002, 86, 73-78.

38. Stange, J.; Uhl, C.; Mündstedt, H. J.Rheol. 2005, 49, 1059-1079.

39. Chaudhary, A.K.; Jayaraman, K. Polym.Eng.Sci. 2011, 51, 1749-1756. 


\subsection{Blowing agent decomposition}

Azodicarbonamide is a blowing agent widely used at industrial scale. Its massive use resides in several reasons: the high volume of gas released during its decomposition, the variety of available particle sizes, its low price or the formation mainly of $\mathrm{N}_{2}$ and $\mathrm{CO}$ during the decomposition reaction, which avoids the shrinkage of low-density cellular polymers right after production [54].

Azodicarbonamide is a yellow-orange powder that decomposes exothermically at a temperature slightly above $210^{\circ} \mathrm{C}$ (depending on the particle size) releasing gas during its decomposition. Some residues that decompose endothermically above $230{ }^{\circ} \mathrm{C}$ are formed during this reaction.

The decomposition reaction of azodicarbonamide follows a complex route with the formation of gas (nitrogen (65\%), carbon monoxide (31.5\%), isocyanic acid (less than $4 \%$ ) and ammonia (less than $4 \%$ )) and white residues (urazole, biurea, cyamelide and cyanuric acid). Although this reaction has been analyzed by several authors, there is still no a full agreement regarding all the reaction mechanisms involved during ADCA decomposition. Stevens and Lober suggested that the decomposition of the ADCA followed an exothermic reaction pathway, producing several solid residues and a gaseous mixture of nitrogen, carbon monoxide, cyanic acid and ammonia [55-59], as it is shown in the scheme presented in (Figure 3.15) [60-62].

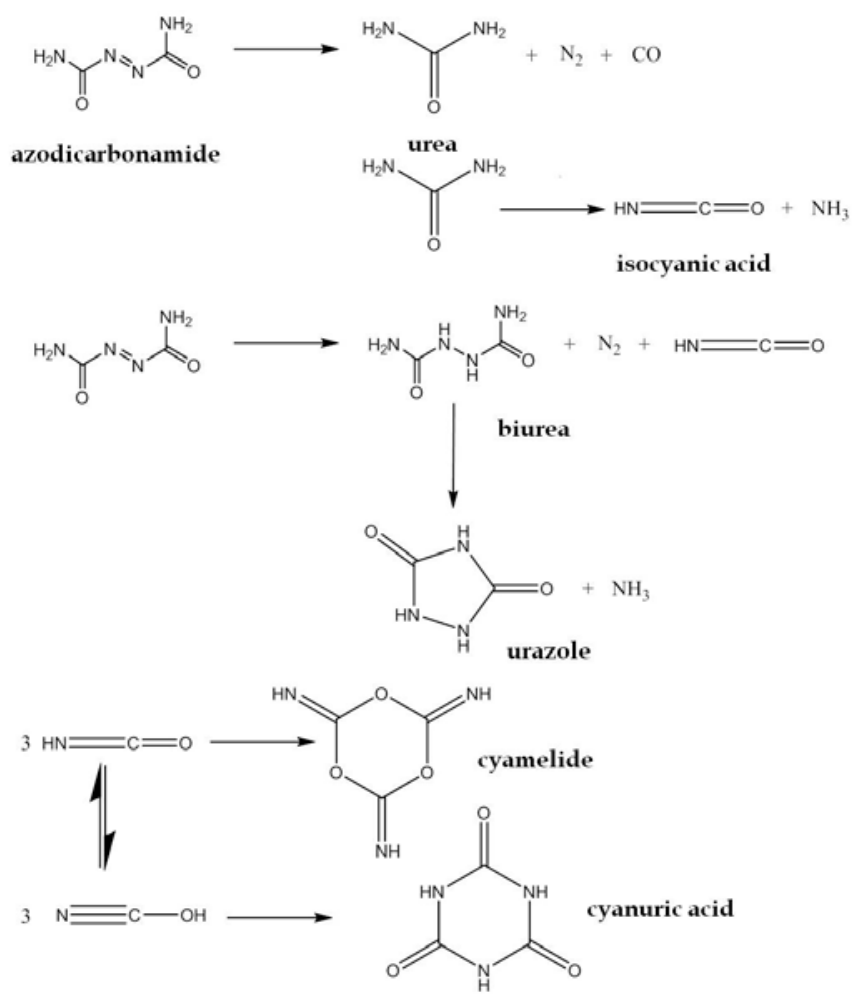

Figure 3.15. Decomposition reactions of azodicarbonamide.

From an industrial point of view and focused on the fabrication technology used in this thesis, the decomposition temperature of the azodicarbonamide is quite high, and it 
would entail unbearable costs for the companies. However, this decomposition temperature can be easily lowered due to the action of some compounds known as kickers or activators. Several authors have analyzed the effect of basic metal salts on the decomposition temperature of the azodicarbonamide, obtaining decomposition temperatures below $170^{\circ} \mathrm{C}[18,62,63]$.

Lally and Alter demonstrated that the decomposition temperature of ADCA could be lowered by using lead and tin salts, enabling their use for different polymeric matrix, such as PVC or EVA [64].

Wight analyzed the effect of lead and tin salts in the decomposition temperature of ADCA, proposing the following mechanism (Figure 3.16) [18]:

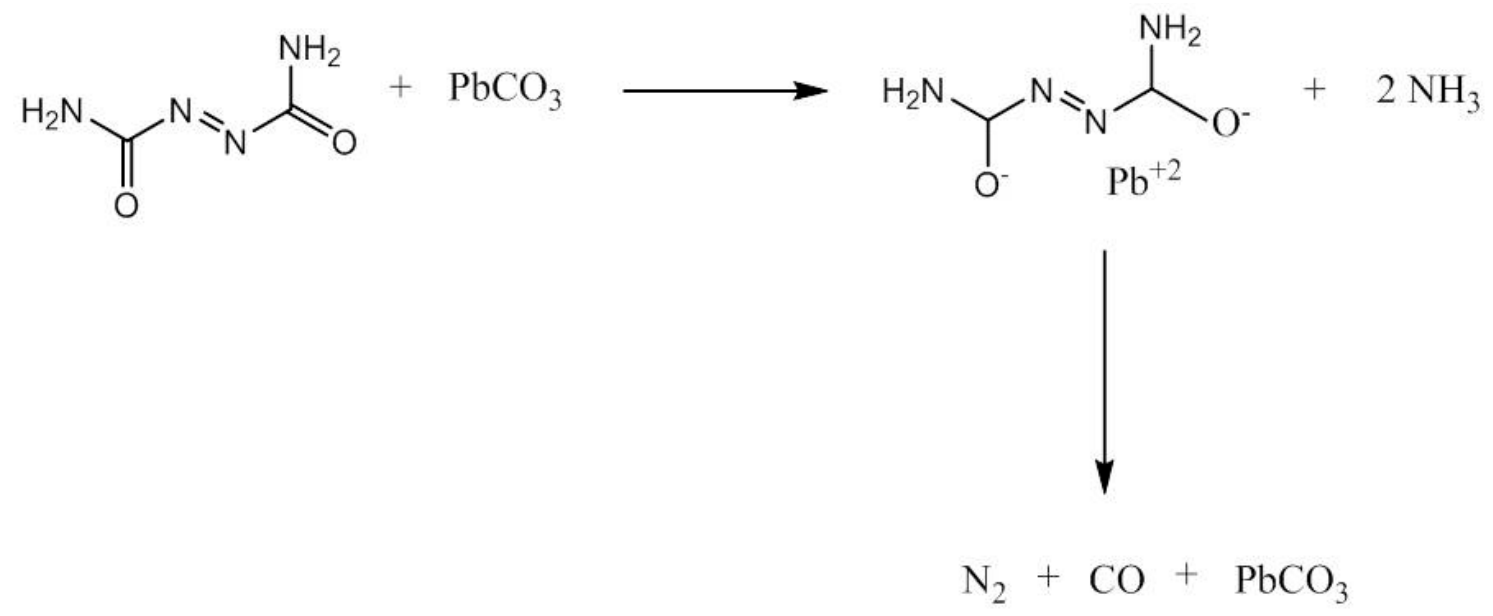

Figure 3.16. Reaction mechanism suggested by Wight in the decomposition of ADCA in the presence of lead-based activators.

Wight proposed a mechanism in which the lead is coordinated to the azodicarbonamide generating an intermediate metal complex, which decomposes next forming nitrogen and carbon monoxide as gases and the initial lead salt. It was also demonstrated that the addition of activators induces changes in the composition of the gases formed during the decomposition.

Bhatti and Dollimore analyzed the effect of activators based on zinc and cadmium. They also observed a considerable reduction in the decomposition temperature of the ADCA with respect to the non-activated one [18]. Marshall obtained reductions in the decomposition temperature of around $70^{\circ} \mathrm{C}$, incorporating an activator in plastisols formulations.

The adjustment of the decomposition temperature using activators is a topic that has been covered by academia, and that is widely used at industrial scale.

In the previous section, it was explained that high-energy electrons were successfully applied to produce low-density closed-cell foams based on HDPE. It was mentioned that blends of HDPE and azodicarbonamide were firstly crosslinked by using different irradiation doses, and finally, the foaming mechanisms were studied. In the previous 
research, the effect of the irradiation on the polymer matrix was considered. However, the effect of irradiation on the azodicarbonamide had never been isolated. To understand this possibility in more detail, a more specific research on this topic was carried out, and the effect of high-energy electrons on the ADCA decomposition kinetics was evaluated in depth.

The results from this study were gathered in an article that was published in the journal Polymer Engineering \& Science (issue 4, volume 59, page 791-798, 2019) with the title "Study of the Effect of Different Electron Irradiation Doses on the Decomposition Temperature of Azodicarbonamide".

This work shows that the decomposition temperature of the azodicarbonamide is reduced owing to the effect of the irradiation, being this effect more notorious at higher irradiation doses (150 kGy). This temperature reduction is explained by modifications of the lattice parameters of the crystalline structure observed in the XRD diffractograms.

This was an original finding that could have important consequences in the production of polyolefin foams crosslinked by irradiation. 


\title{
Study of the Effect of Different Electron Irradiation Doses on the Decomposition Temperature of Azodicarbonamide
}

\author{
E. Lopez-Gonzalez'1,2, L.O. Salmazoㄹ, A. Lopez-Gil11, M.A. Rodriguez-Perez² \\ 1.CellMat Technologies S.L. Paseo de Belen 9A, 47011 Valladolid (Spain) \\ 2.Cellular Materials Laboratory (CellMat), Condensed Matter Physics Department, University \\ of Valladolid, Paseo Belén 747011 Valladolid (Spain) \\ * Corresponding author. Tel: +34 983423194 \\ E-mail address: eduardol@fmc.uva.es
}

\begin{abstract}
Azodicarbonamide (ADCA) is a well-known chemical blowing agent used in the fabrication of polyolefin foams which decomposes into gases at temperatures above the melting temperature of the polymer. In these polymer foams, the polymer is usually crosslinked before or during the foaming process to increase its viscosity and make it capable of supporting the pressure of the gas during foaming. This crosslinking process allows producing low-density foams with homogeneous cellular structures. A typical procedure to crosslink the polymer is to irradiate it using a high energyelectron beam. When ADCA is incorporated into the polymer before the irradiation process, it is also exposed to the high energy electron beam. However, the effect of the irradiation on the decomposition process of ADCA has not been explored yet. In this research, it has been found that there is a reduction of the thermal decomposition temperature of ADCA when this material is electron irradiated with different doses ranging from 25 to $150 \mathrm{kGy}$, being this reduction higher when the irradiation dose is increased. It has also been found that the reduction of the decomposition temperature is due to a modification of the lattice parameters of the crystalline structure of ADCA.
\end{abstract}

\section{KEYWORDS}

Blowing agents; irradiation; thermal properties; foams 


\section{INTRODUCTION}

Cellular polymers also called polymer foams are two-phase materials in which a gas is dispersed in a continuous macromolecular phase [1-2]. Blowing agents are introduced in a polymer matrix to generate the gas phase necessary to produce polymer foams [3]. They can be classified as either physical or chemical blowing agents. Physical blowing agents produce cells by a phase change in the case of liquids or the diffusion of gas (mainly $\mathrm{N}_{2}$ and $\mathrm{CO}_{2}$ ) in the polymer matrix [4-5]. Chemical blowing agents (CBA) generate gas by thermal decomposition of a chemical compound. To be used with a specific polymer, the decomposition temperature of the CBA must occur in the temperature range of processing. Furthermore, the residues should be non-toxic and odorless. The blowing agent must not decompose spontaneously, and the gas yield should be as high as possible. In addition, the CBA should easily be incorporated and dispersed in the polymer matrix [6].

Azodicarbonamide (ADCA) is the most extensively used chemical blowing agent for polymer foams. ADCA is an orange-yellow powder which decomposes exothermically in a range of temperatures from $195^{\circ} \mathrm{C}$ to $235^{\circ} \mathrm{C}$. The gas yield of the ADCA is much higher than that of other typical blowing agents, such as endothermic sodium bicarbonate or exothermic 4,4'-oxydibenzenesulfonyl hydrazide (OBSH) [7]. The decomposition reaction of ADCA produces several residues, such as biurea and urazol, which decompose at higher temperatures in an endothermic process generating additional gas [8].

Cram et al. [9] reported the main chemical compounds generated during ADCA decomposition. Biurea, urazole and cyanuric acid were the main residues produced and $\mathrm{N}_{2}$ and $\mathrm{CO}$ were the main gases released. $\mathrm{CO}_{2}$ and $\mathrm{NH}_{3}$ were also formed but to a lesser extent. Particle size is a crucial factor in the production of ADCA. The release of gas depends on the size and distribution of the particles. Finer particle sizes shift the decomposition temperature of ADCA to lower temperatures. When the particle size decreases the surface area increases, and as a consequence, the particles can readily react with activators particles or even with unreacted ADCA particles. There are other parameters, such as the heating cycle (temperature and time), which has a critical effect on the decomposition rate. The decomposition process is accelerated at higher temperatures [10].

The decomposition temperature of ADCA can be decreased by using activators or promoters. Lally and Alter [11] proved that the decomposition temperature of ADCA could be lowered by the use of some salts of lead and tin. Wright analyzed the effect of silica, a lead salt, and a tin salt, using HDPE and PVC as polymer matrices [12]. Activators not only decreased the decomposition temperature of the ADCA but also increased the gas yield and induced changes in the composition of the gases produced, increasing the amount of $\mathrm{CO}_{2}$ and $\mathrm{NH}_{3}$, which is generated during the decomposition reaction. Wright proposed a mechanism in which catalytic hydrolysis of one amide of the ADCA was involved releasing $\mathrm{NH}_{3}$ and a final decarboxylation produced $\mathrm{CO}_{2}$ and 
$\mathrm{N}_{2}$. Marshall studied the effect of activators and inhibitors in plastisol formulation[13]. By using an activator, the decomposition temperature of the ADCA was as low as $150^{\circ} \mathrm{C}$. Bhatti et al. [14] studied the effect of some activators dispersed in ADCA. They concluded that the presence of an electron deficient surface favored the catalytic reactivity.

Crosslinked polyolefin foams are an essential group inside the polymeric foams market [15-17]. Crosslinking is a process in which the polymer chains are bonded to provide stability by increasing the viscosity of the polymer matrix [18]. Crosslinking can be achieved by using chemical crosslinkers, such as peroxides or silanes [19-23] or by irradiation with high energy sources [24-25]. Electron beam irradiation is a process in which high energy electrons are used to promote the crosslinking reaction of the polymer. The energy of the electrons is absorbed by the polymer producing radicals in the polymer chains. This unstable energetic situation is solved by multiple chain bonding [26-27].

The advantage of using electron irradiation for crosslinking over the use of organic peroxides is that it is possible to decouple the crosslinking and foaming process. Furthermore, no chemical residues are generated during the crosslinking process when high energy sources are employed.

In order to have a better understanding of the foaming process of irradiated polymers when ADCA is used as a chemical blowing agent, it is essential not only to understand the crosslinking reaction of the polymer matrix when electron beam irradiation is employed but also to analyze if there is an effect of the electron irradiation on the other components of the formulation and among them the impact on the decomposition kinetics of ADCA.

There are several works in the literature analyzing the effect of irradiation on different organic compounds. Tolbert and Lemmon [28] published a review about the different chemical changes produced by irradiation on different organic groups such as saturated hydrocarbons, unsaturated aliphatic and alicyclic hydrocarbons, aromatic hydrocarbons, organic halides, alcohols, amino acids, carboxylic acids and quaternary ammonium salts.

Concerning azo groups, Wojnárovits and Takács [29] analyzed the chemical reactions of different azo compounds in aqueous solution (e.g., wastewaters) with hydrated electrons (e-aq), hydroxyl radicals $(\mathrm{OH})$ and hydrogen atoms $(\mathrm{H})$ by using a pulse radiolysis technique. They presented results for compounds for azo groups such as azobenzenes and derivatives. Neta and Whillans [30] performed a study based on the effect of irradiation (2.8 MeV electrons) on azodicarbonamide but in aqueous solution. However, as far as we know, no studies related to the effect of electron irradiation on solid azodicarbonamide have been reported. Taking these ideas in mind, this paper is mainly focused on analyzing the effect of electron irradiation on the decomposition kinetics of ADCA and on determining which changes are produced in the ADCA particles. [13]. By using an activator, the decomposition temperature of the ADCA was 
as low as $150^{\circ} \mathrm{C}$. Bhatti et al. [14] studied the effect of some activators dispersed in ADCA. They concluded that the presence of an electron deficient surface favored the catalytic reactivity.

Crosslinked polyolefin foams are an essential group inside the polymeric foams market [15-17]. Crosslinking is a process in which the polymer chains are bonded to provide stability by increasing the viscosity of the polymer matrix [18]. Crosslinking can be achieved by using chemical crosslinkers, such as peroxides or silanes [19-23] or by irradiation with high energy sources [24-25]. Electron beam irradiation is a process in which high energy electrons are used to promote the crosslinking reaction of the polymer. The energy of the electrons is absorbed by the polymer producing radicals in the polymer chains. This unstable energetic situation is solved by multiple chain bonding [26-27].

The advantage of using electron irradiation for crosslinking over the use of organic peroxides is that it is possible to decouple the crosslinking and foaming process. Furthermore, no chemical residues are generated during the crosslinking process when high energy sources are employed.

In order to have a better understanding of the foaming process of irradiated polymers when ADCA is used as a chemical blowing agent, it is essential not only to understand the crosslinking reaction of the polymer matrix when electron beam irradiation is employed but also to analyze if there is an effect of the electron irradiation on the other components of the formulation and among them the impact on the decomposition kinetics of ADCA.

There are several works in the literature analyzing the effect of irradiation on different organic compounds. Tolbert and Lemmon [28] published a review about the different chemical changes produced by irradiation on different organic groups such as saturated hydrocarbons, unsaturated aliphatic and alicyclic hydrocarbons, aromatic hydrocarbons, organic halides, alcohols, amino acids, carboxylic acids and quaternary ammonium salts.

Concerning azo groups, Wojnárovits and Takács [29] analyzed the chemical reactions of different azo compounds in aqueous solution (e.g., wastewaters) with hydrated electrons (e-aq), hydroxyl radicals $(\mathrm{OH})$ and hydrogen atoms $(\cdot \mathrm{H})$ by using a pulse radiolysis technique. They presented results for compounds for azo groups such as azobenzenes and derivatives. Neta and Whillans [30] performed a study based on the effect of irradiation (2.8 MeV electrons) on azodicarbonamide but in aqueous solution. However, as far as we know, no studies related to the effect of electron irradiation on solid azodicarbonamide have been reported.

Taking these ideas in mind, this paper is mainly focused on analyzing the effect of electron irradiation on the decomposition kinetics of ADCA and on determining which changes are produced in the ADCA particles. 


\section{MATERIALS}

Azodicarbonamide Porofor ${ }^{\circledR}$ ADCA/M-C1 with an average particle size of $3.9 \pm 0.6$ microns was supplied as a powder by Lanxess AG (Leverkusen, Germany). The density of the ADCA was $1.73 \mathrm{~g} / \mathrm{cm}^{3}$. The gas yield was $228 \mathrm{~mL} / \mathrm{g}$, and the decomposition temperature starts at $210^{\circ} \mathrm{C}$.

Irradiation of the ADCA was performed at room temperature in air in Mevion Technology (Soria, Spain). The energy employed was $10 \mathrm{MeV}$. The power and the intensities were $40 \mathrm{~kW}$ and $4 \mathrm{~mA}$ respectively. Irradiation dose ranged from 25 to 150 $\mathrm{kGy}$, in steps of $25 \mathrm{kGy}$ per pass. The conveyor speed was $19 \mathrm{~m} / \mathrm{min}$. An electron paramagnetic resonance dosimetry and an alkaline type dosimetry reader were employed to control the real doses received by the samples.

\section{EXPERIMENTAL}

\section{Differential Scanning Calorimetry (DSC)}

The thermal behavior and the decomposition kinetics of both non-irradiated and irradiated ADCA were studied using a Mettler DSC 822 e differential scanning calorimeter previously calibrated with indium, zinc, and n-octane. The average weight of the samples used for these experiments was $1.22 \pm 0.07 \mathrm{mg}$.

For the purpose of studying the thermal decomposition of the ADCA, the following heating program was chosen. Samples were heated from $25{ }^{\circ} \mathrm{C}$ to $300{ }^{\circ} \mathrm{C}$ at a heating rate of $10^{\circ} \mathrm{C} / \mathrm{min}$ under nitrogen atmosphere.

The temperature of the maximum and the width at mid-height of the exothermic peak that characterizes ADCA decomposition were calculated as an average of three measurements. The maximum standard deviation obtained for the temperature of the maximum was $\pm 0.80^{\circ} \mathrm{C}$.

Thermogravimetric Analysis (TGA)

The thermal decomposition of irradiated ADCA was also studied by thermogravimetric analysis. A TGA/STDA 861 thermogravimetric analyzer model from Mettler Toledo previously calibrated was used. The weights of the samples were $2.25 \pm 0.17 \mathrm{mg}$, and the experiments were performed in a temperature range between 50 and $650{ }^{\circ} \mathrm{C}$ with a heating rate of $20^{\circ} \mathrm{C} / \mathrm{min}$ under $\mathrm{N}_{2}$ atmosphere. The onset of the decomposition step was calculated as the average of three measurements. The maximum standard deviation for this onset was $\pm 0.74{ }^{\circ} \mathrm{C}$.

Fourier Transform Infrared Spectroscopy (FTIR)

FTIR spectra in attenuated total reflectance mode (ATR) of the samples were collected using a Bruker Tensor 27 spectrometer. The spectra were obtained under a $\mathrm{N}_{2}$ purge after 32 scans with a resolution of $4 \mathrm{~cm}^{-1}$ over a wavenumber range of 4000 to $500 \mathrm{~cm}^{-1}$. 
Furthermore, a baseline correction was conducted to correct the shifts from temperature changes in each experiment.

Scanning Electron Microscopy (SEM)

SEM micrographs of the ADCA particles were taken to observe if the particle size changed when the ADCA was irradiated. For the preparation of the samples, ADCA particles were spread over an adhesive tape. After that, the sample was blown with compressed air to remove the excess of particles, which were not stuck on the tape. Finally, the adhesive tape with the adhesive-bonded particles was vacuum coated with a thin layer of gold to make them conductive. A Quanta 200 FEG microscope was used to observe the ADCA particles.

Particles from the SEM images were drawn on tracing paper. Then, the images were scanned and binarized to estimate the particle size. Particle sizes were measured by using a software tool based on Image J [31].

Density

The density of the non-irradiated and the irradiated ADCA was measured using gas pycnometry. A Micromeritics AccuPyc II 1340 pycnometer was used to perform the measurements. The measurements were conducted according to ASTM D1895.

\section{X-Ray Diffraction}

The X-ray diffraction experiments were performed in a Bruker D8 Discover A25 diffractometer using $\mathrm{Cu} \mathrm{Ka}$ radiation. Measurements were performed in a $2 \theta$ range from $10^{\circ}$ to $65^{\circ}$, the pitch angle employed was $0.02^{\circ}$, and the time of testing was 25 minutes. The interplanar spacing $(\mathrm{d})$ of the crystalline planes was calculated using the Bragg's equation:

$$
\mathrm{d}=\frac{\lambda}{2 \sin (\theta)}
$$

where $\lambda$ is the wavelength and $2 \theta$ is the diffraction angle.

\section{EXPERIMENTAL RESULTS AND DISCUSSION}

\section{Thermal Characterization}

FIG 1 shows the DSC results for the non-irradiated ADCA and the ADCA irradiated with different doses. Three different signals appear in the thermograms. The two initial ones $\left(\mathrm{T}_{1}\right.$ and $\left.\mathrm{T}_{2}\right)$ at around $210-216^{\circ} \mathrm{C}$ and $232-234{ }^{\circ} \mathrm{C}$ respectively are exothermic and are connected to the exothermic decomposition of the ADCA. The endothermic peak at approximately $252{ }^{\circ} \mathrm{C}\left(\mathrm{T}_{3}\right)$ corresponds to the endothermic decomposition of the solid residues generated during the exothermic decomposition of the ADCA [32]. In this work, the analysis is focused on the exothermic signals related to the generation of the gas phase typically employed in foaming processes. 
The collected data from the thermograms are summarized in TABLE 1. As can it be observed, in the exothermic region of the thermogram, when the ADCA is irradiated, a shoulder appears below $215{ }^{\circ} \mathrm{C}\left(\mathrm{T}_{1}\right)$. This signal is almost negligible for the nonirradiated ADCA. When the dose increases, the intensity of this shoulder also increases. Furthermore, the temperature of this first maximum tends to decrease when the irradiation dose increases. The difference in the decomposition temperature of this first peak between the ADCA irradiated with $150 \mathrm{kGy}$, and the non-irradiated is 5.70 ${ }^{\circ} \mathrm{C}$. The decomposition temperature of the second exothermic peak $\left(\mathrm{T}_{2}\right)$ is not affected by the irradiation process, being this temperature similar for irradiated and nonirradiated samples.

TABLE 1 also shows the width at mid-height of the exothermic signal. It can be inferred that the width at mid-height increases when the dose increases. The difference between the non-irradiated and the $150 \mathrm{kGy}$ irradiated ADCA is $5.63{ }^{\circ} \mathrm{C}$. When the ADCA is irradiated, the first peak in the decomposition range tends to be more intense and is shifted to lower temperatures widening the exothermic peak. Furthermore, no significant changes are observed in the endothermic peak $\left(\mathrm{T}_{3}\right)$. The temperature of this endothermic signal is almost constant for the non-irradiated and the irradiated ADCAs.

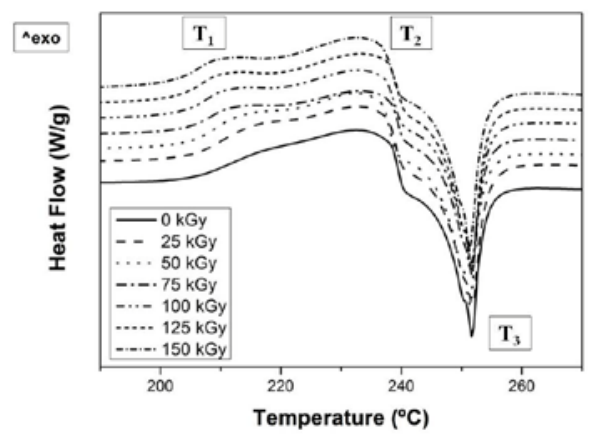

FIG 1. Experimental DSC curves of non-irradiated ADCA and irradiated ADCA.

TABLE 1. Parameters obtained from the DSC thermogram.

\begin{tabular}{|ccccc|}
\hline Sample & $\begin{array}{c}\text { Temperature 1st } \\
\text { Maximum }\left({ }^{\circ} \mathbf{C}\right)\end{array}$ & $\begin{array}{c}\text { Temperature 2 } \\
\text { Maximum }\left({ }^{\circ} \mathbf{C}\right)\end{array}$ & $\begin{array}{c}\text { Temperature 3rd } \\
\text { Minimum }\left({ }^{\circ} \mathbf{C}\right)\end{array}$ & $\begin{array}{c}\text { Full Width at } \\
\text { Half Maximum } \\
\text { (FWHM) }\end{array}$ \\
$\begin{array}{c}\text { non-irradiated } \\
\text { ADCA }\end{array}$ & 216.3 & 232.9 & 251.67 & 23.46 \\
ADCA 25 kGy & 215.3 & 233.9 & 252.00 & 26.66 \\
ADCA 50 kGy & 213.6 & 233.4 & 251.33 & 26.12 \\
ADCA 75 kGy & 212.3 & 234.2 & 251.67 & 28.80 \\
ADCA 100 kGy & 211.8 & 233.7 & 251.67 & 28.71 \\
ADCA 125 kGy & 210.9 & 234.2 & 251.67 & 29.86 \\
ADCA 150 kGy & 210.6 & 233.5 & 251.33 & 29.09 \\
\hline
\end{tabular}

The results of the TGA experiments are presented in FIG 2. FIG 2a shows the thermograms of the non-irradiated and the irradiated samples. FIG $\mathbf{2} \mathbf{b}$ shows the first derivative of the thermograms. As can it be observed in FIG 2a, the decomposition 
drop has two stages. The first one corresponds to the exothermic decomposition of the ADCA (from 220 to $245^{\circ} \mathrm{C}$ ). The second one is a small shoulder which is related to the endothermic process (from 245 to $260^{\circ} \mathrm{C}$ ) associated with the thermal decomposition of the residues of ADCA. FIG $\mathbf{2} \mathbf{b}$ shows that when the irradiation dose increases, $\mathbf{a}$ shoulder appears in the weight loss rate at around $210^{\circ} \mathrm{C}$. This behavior is similar to what was observed in the DSC curves.

The onset of the decomposition reaction for all materials was measured (TABLE 2). It is observed that there is a reduction in the onset of decomposition when the irradiation dose increases. The difference between the non-irradiated ADCA and the material irradiated with $150 \mathrm{kGy}$ is $4{ }^{\circ} \mathrm{C}$. This result is an agreement with the effect observed in the DSC curves (TABLE 1).
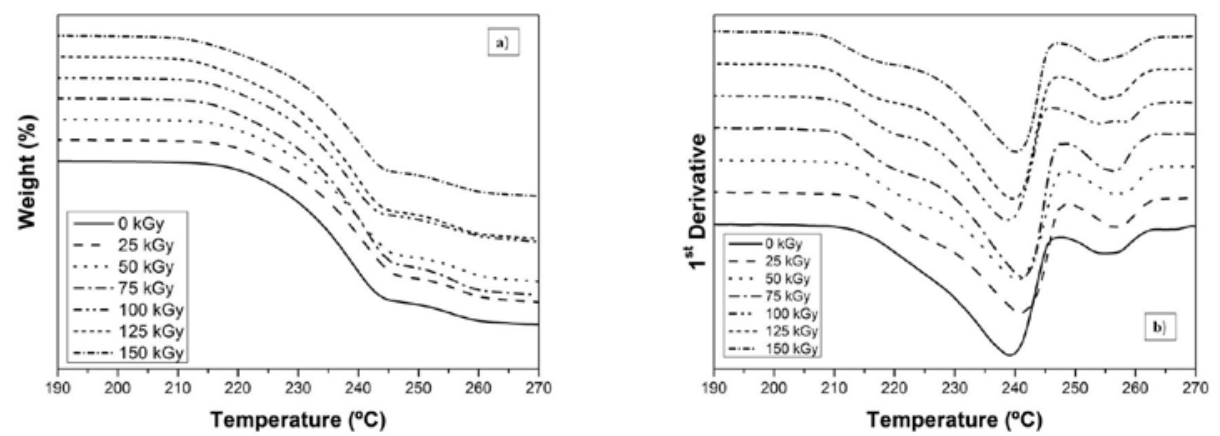

FIG 2. a)TGA thermograms and b) first derivative of the decomposition curve for the different ADCAs under study.

TABLE 2. Onset of the decomposition step from the ADCA.

\begin{tabular}{|cc|}
\hline Sample & ADCA onset $\left({ }^{\circ} \mathrm{C}\right)$ \\
\hline non-irradiated ADCA & 217.7 \\
ADCA $25 \mathrm{kGy}$ & 217.4 \\
ADCA $50 \mathrm{kGy}$ & 216.7 \\
ADCA $75 \mathrm{kGy}$ & 216.2 \\
ADCA $100 \mathrm{kGy}$ & 215.6 \\
ADCA $125 \mathrm{kGy}$ & 216.6 \\
ADCA $150 \mathrm{kGy}$ & 213.7 \\
\hline
\end{tabular}

Furthermore, the percentage of mass decomposed at several temperatures $(210,215$ and $220^{\circ} \mathrm{C}$ ) has also been estimated as it is shown in TABLE 3 :

TABLE 3. Percentage of mass decomposed at 210,215 and $220^{\circ} \mathrm{C}$.

\begin{tabular}{|c|c|c|c|}
\hline Sample & $\%$ mass $\left(210^{\circ} \mathrm{C}\right)$ & $\%$ mass $\left(215^{\circ} \mathrm{C}\right)$ & $\%$ mass $\left(220^{\circ} \mathrm{C}\right)$ \\
\hline Non-Irradiated ADCA & 0.77 & 1.73 & 4.42 \\
\hline ADCA 25 kGy & 0.58 & 1.36 & 4.03 \\
\hline ADCA 50 kGy & 0.77 & 1.82 & 5.26 \\
\hline ADCA 75 kGy & 0.78 & 2.75 & 7.64 \\
\hline ADCA 100 kGy & 1.02 & 2.99 & 7.52 \\
\hline ADCA 125 kGy & 1.20 & 4.41 & 9.56 \\
\hline ADCA 150 kGy & 1.15 & 4.13 & 8.59 \\
\hline
\end{tabular}


It is observed that more amount of gas is released for the samples irradiated with higher doses $\left(125\right.$ and $\left.150{ }^{\circ} \mathrm{C}\right)$ independently of the chosen temperature. The difference between the non-irradiated ADCA and the one irradiated with $150 \mathrm{kGy}$ is around $50 \%$ at $220^{\circ} \mathrm{C}$, and as a consequence, more gas is released under these conditions. This result is connected to the previous results shown in TABLE 1 and TABLE 2, respectively.

From the thermal analysis, it can be concluded that the irradiation produces a modification of the decomposition kinetics of the ADCA. Furthermore, this effect is more evident when the irradiation dose increases.

\section{Microstructure}

SEM images of two representative samples (non-irradiated ADCA and $150 \mathrm{kGy}$ irradiated ADCA) are shown in FIG 3. ADCA particles are observed in the images. Particle sizes were estimated by binarizing the images. The average particle sizes of both samples were calculated to analyze if there were differences in the particle size when the ADCA was irradiated.

An average value of $4.66 \pm 2.19$ microns for the non-irradiated ADCA and 4.72 \pm 1.98 microns for the $150 \mathrm{kGy}$ EB irradiated ADCA were obtained. FIG 3 shows the particle size distributions. As can be observed, the average particle size and particle size distributions were in both cases very similar. It seems that the irradiation does not affect the particle size. From this analysis, it can be concluded that the decomposition of the ADCA is not a result of changes in the average size of the ADCA particles.
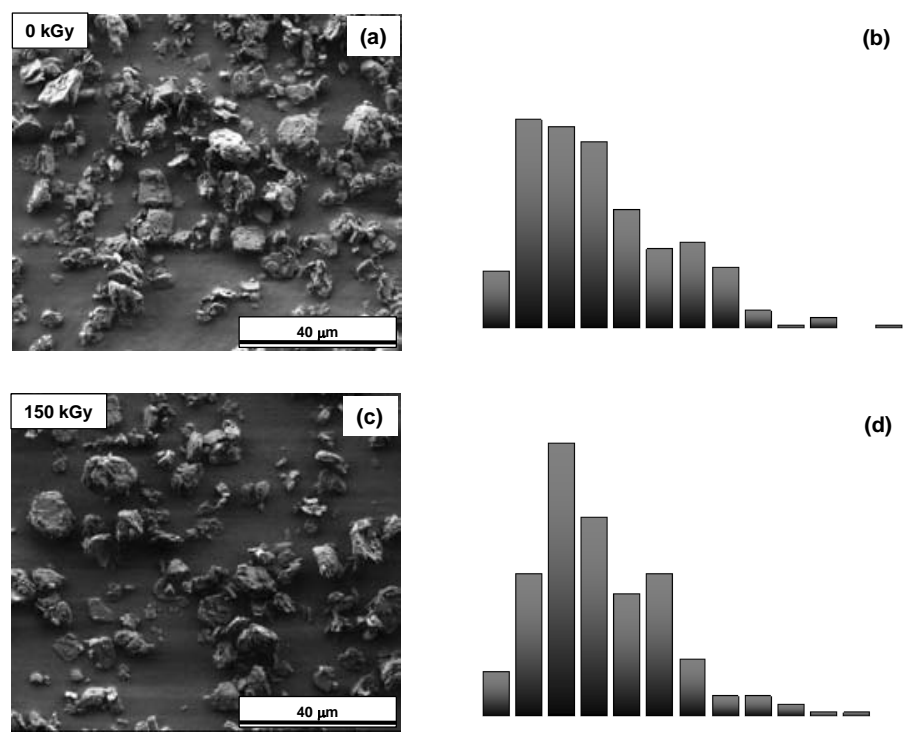

FIG 3. SEM images of two samples of ADCA: a) non-irradiated ADCA. c) ADCA EB irradiated with $150 \mathrm{kGy}$. Particle size distributions: b) non-irradiated ADCA. d) ADCA EB irradiated with $150 \mathrm{kGy}$. 


\section{FTIR spectroscopy}

Non-irradiated and irradiated ADCA was characterized by FTIR analysis to check possible modifications in the chemical nature of the ADCA induced by the irradiation process. FIG 4 shows the FTIR spectrum of these samples. Lee et al. [33] evaluated the infrared spectra of an ADCA pentamer cluster characterizing the different peaks. The frequency of the different peaks has been assigned to each vibration according to the characterization of Lee. The collected data are shown in TABLE 4:
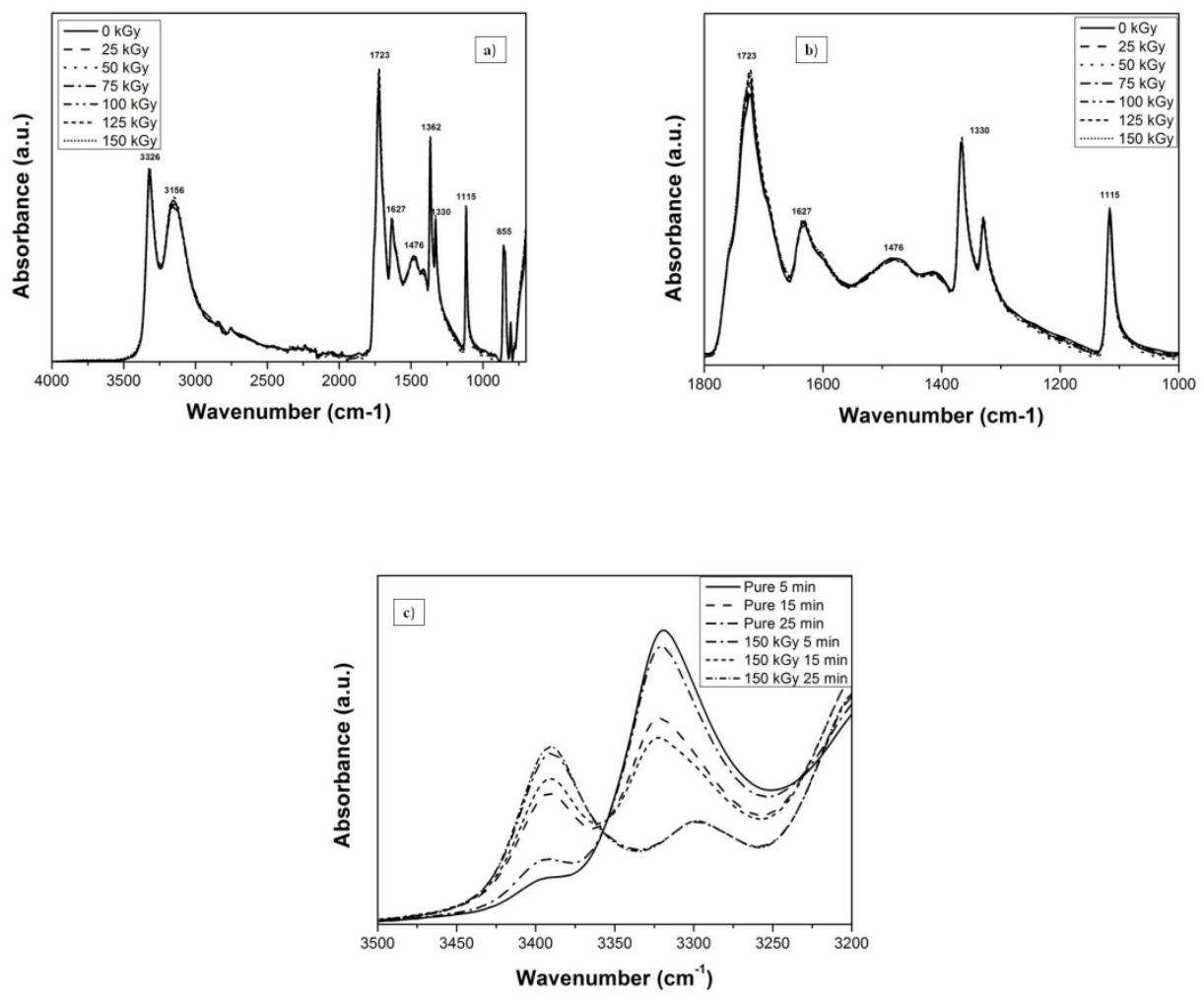

FIG 4. a) FTIR analysis for the non-irradiated ADCA and ADCA EB irradiated with different doses, b) zoom between 1800 and $1000 \mathrm{~cm}^{-1}$ and c) comparative between non-irradiated ADCA and the ADCA irradiated with 150 kGy.

TABLE 4. Assignments of ADCA vibration frequencies.

\begin{tabular}{|cc|}
\hline Wavenumber $\left(\mathbf{c m}^{-1}\right)$ & Vibration \\
\hline 3326 & N-H stretch \\
3156 & N-H stretch \\
1723 & $\mathrm{C}=\mathrm{O}$ stretch \\
1627 & $\mathrm{C}=\mathrm{O}$ stretch $+\mathrm{N}-\mathrm{H}$ scissor \\
1362 & $\mathrm{~N}-\mathrm{C}$ stretch $+\mathrm{NC}=\mathrm{O}$ bend $+\mathrm{N}-\mathrm{H}$ rock \\
1330 & $\mathrm{~N}-\mathrm{C}$ stretch $+\mathrm{NC}=\mathrm{O}$ bend $+\mathrm{N}-\mathrm{H}$ rock \\
$\mathbf{1 1 1 5}$ & $\mathrm{N}-\mathrm{H}$ rock $+\mathrm{C}=\mathrm{O}$ stretch $+\mathrm{N}-\mathrm{C}$ stretch \\
652 & $\mathrm{~N}-\mathrm{H}$ torsions \\
\hline
\end{tabular}


ADCA possesses a strong molecular symmetry. For this reason, some elements of the structure are symmetrically equivalent. The hydrogen of an amide group is equivalent to another hydrogen from the other amide group. However, the two hydrogens from the same amide group are not equivalent. This result explains why there are two stretching N-H peaks above $3000 \mathrm{~cm}^{-1}$ [34]. The two carbonyls are bonded to the same molecular moiety. Because of this, there is the only one peak in the carbonyl region, which overlaps the contribution of both carbonyls $\left(1723 \mathrm{~cm}^{-1}\right)$.

As it is observed in FIG $\mathbf{4 a}$ and FIG $\mathbf{4 b}$, there is no difference between the spectrum of the non-irradiated ADCA and the spectra of the irradiated ADCA. The position of the peaks is the same, and the absorbance does not follow any trend with the irradiation dose. It seems that the chemical structure does not vary with the irradiation.

To corroborate the previous statement, the ADCA was heated using an isothermal program was performed at $200{ }^{\circ} \mathrm{C}$. Non-irradiated and $150 \mathrm{kGy}$ irradiated ADCA powders were introduced in an oven in several crucibles at $200^{\circ} \mathrm{C}$. A crucible of each type of ADCA was taken out from the oven in steps of five minutes in a range of time of twenty-five minutes.

The isotherm study is shown in FIG 4c. The region of N-H stretch vibration $\left(3300 \mathrm{~cm}^{-1}\right)$ was selected because it illustrates well the decomposition process. When time increases from five to twenty-five minutes, the N-H stretch peak at $3326 \mathrm{~cm}^{-1}$ is reduced because of the decomposition of the ADCA. In addition, when the time increases a peak near $3400 \mathrm{~cm}^{-1}$ grows, and the intensity of this peak becomes higher when the time is increased. This effect can be explained by the formation of new subproducts in the process of the ADCA decomposition.

Focusing on the possible differences between non-irradiated and irradiated ADCA, it is observed that the same peak is formed once the ADCA decomposition takes place.

From the FTIR it is not possible to explain why the irradiated ADCA decomposes faster than the non-irradiated one. No changes in the chemical nature of the particle or changes in its surface have been detected.

X-Ray diffractometry

FIG 5 shows the XRD characterization of the non-irradiated ADCA and ADCA irradiated with different irradiation doses. The correspondent $h k l$ index for each peak has also been included. 


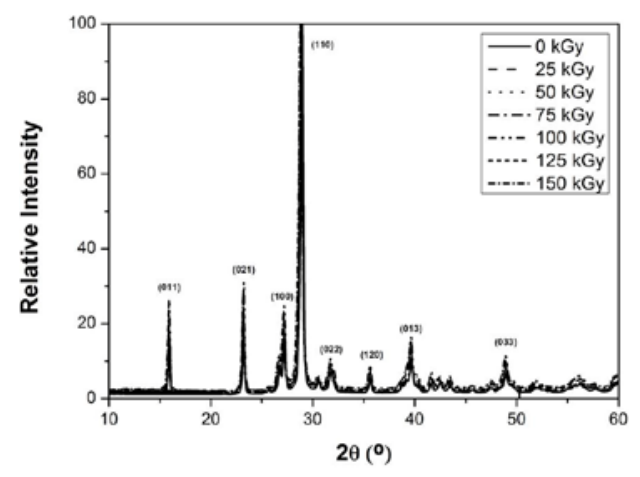

FIG 5. X-ray pattern of the non-irradiated ADCA and ADCA irradiated with different doses and the assignation of the hkl planes.

In general, the non-irradiated ADCA and ADCA irradiated with different doses present the same peaks in the analyzed range of angles. However, some diffraction lines present a slight shift, which changes depending on the irradiation dose employed. One example of these shifts is presented in FIG 6 (plane (110)) in which it is possible to appreciate in more detail how the maximum of the peak is reduced (i.e., the correspondent distance between planes is increased) when the irradiation dose increases.

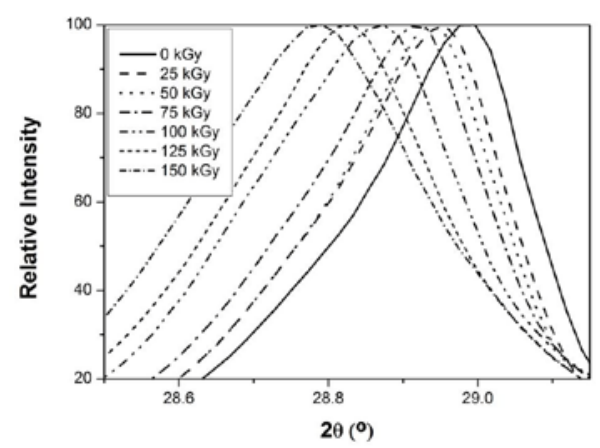

FIG 6. Examples of diffraction lines (plane 110) which are shifted with the irradiation dose.

These displacements of the diffraction lines are due to changes in the lattice parameters. With the aim of appreciating the shifts of these diffraction lines, the interplanar spacing was calculated for some $h k l$ planes according to equation 1 (FIG 7). 


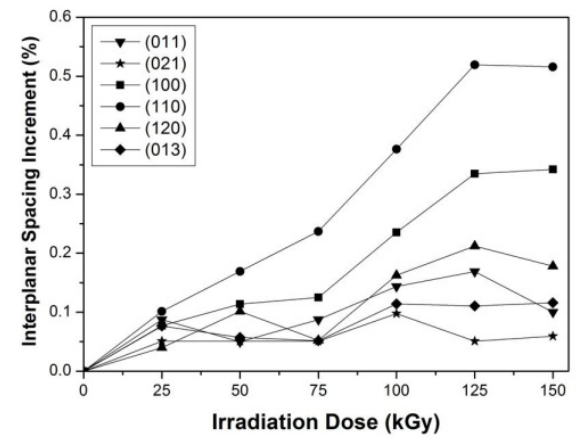

FIG 7. The increment (in percentage) of the interplanar spacing $(d)$ for different diffraction planes.

FIG 7 shows that the increment (in percentage) of the irradiation dose produces variations of the interplanar spacing in most of the $h \mathrm{kl}$ planes studied. In general, when the irradiation dose increases the interplanar spacing also increases. However, it is possible to observe that in some $h k l$ planes, the shift is more pronounced than in other planes: (110) or (100). The most affected plane is (110). These results could be the explanation of the ones obtained by thermal analysis in which the decomposition temperature of ADCA decreased with the irradiation dose (see TABLE 1). As it was reported in the work of Walker et al. [35], there is a dependency of the interlayer distance with the attractive energy associated with the Van der Waals forces. The attractive energy is reduced when the interlayer distance increases. Taking into account this effect, the changes observed in the lattice parameters are connected to variations in the attractive energy. As the irradiation dose increases, the interlayer distance also does and therefore the attractive energy between atoms of ADCA crystal drops. As a result, the decomposition temperatures are reduced.

Furthermore, the full width at half maximum (FWHM) for the more intense peak (110) was also calculated to determine differences between samples (TABLE 5).

TABLE 5. Full width at half maximum values for the diffraction peak (110).

\begin{tabular}{|cc|}
\hline Sample & $\begin{array}{c}\text { Full Width at Half Maximum } \\
\text { (FWHM) }\end{array}$ \\
non-irradiated ADCA & 0.290 \\
ADCA 25 kGy & 0.303 \\
ADCA 50 kGy & 0.292 \\
ADCA 75 kGy & 0.316 \\
ADCA 100 kGy & 0.359 \\
ADCA 125 kGy & 0.357 \\
ADCA 150 kGy & 0.401 \\
\hline
\end{tabular}

As it is observed in TABLE 5, the width increases when the irradiation dose increases, indicating a crystalline structure with more defects. 


\section{Density}

As it has been proved in the previous section, irradiating ADCA promotes an increment of the interlayer distance. This should be detected macroscopically in a density reduction of the particles. The values of the densities for each sample as a function of the irradiation dose are plotted in FIG 8.

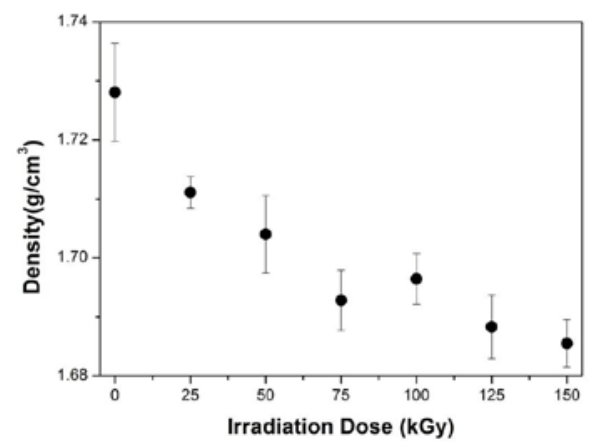

FIG 8. Density of the ADCA powder versus the irradiation dose

As expected, the density of the ADCA decreases as the irradiation dose increases. A difference of around $2.5 \%$ is observed in the extreme cases (the non-irradiated powder and the one irradiated with $150 \mathrm{kGy}$ ) which is of the same order of magnitude than the changes of interplanar spacings detected previously (FIG 7). This result confirms that the changes in the decomposition kinetics are due to changes in the crystalline structure of the ADCA.

\section{CONCLUSIONS}

ADCA powder samples were irradiated with different doses ranging from 25 to 150 kGy. A modification of the decomposition kinetics of the ADCA was observed in the DSC and TGA thermograms when the powder is irradiated. A significant reduction of $5{ }^{\circ} \mathrm{C}$ in the decomposition temperature has been detected.

To explain this effect, several studies were carried out to determine if modifications on the average particle size or in the chemical structure of the irradiated samples contributed to modify the decomposition pattern of the ADCA. However, both parameters were not affected by the irradiation.

The results obtained using X-ray diffractometry showed that the increment in the irradiation dose produced variations in the interplanar spacing for several hkl planes. These variations in the interplanar spacing seem to be the origin of the reduced decomposition temperatures of ADCA when this material is irradiated. There is an increase in the distance between atoms that is translated into a reduction in the binding energy. This result is confirmed by a clear density reduction of the particles when they are irradiated. 


\section{ACKNOWLEDGMENTS}

This work performed with the financial support from DI grant DI-15-07952 (E. LopezGonzalez) from the Spanish Ministry of Economy, Industry, and Competitiveness, CNPq (Conselho Nacional de Desenvolvimento Científico e Tecnológico - Brasil), and FPI grant Ref: BES-2010-038746 (Alberto Lopez-Gil). Financial assistance from MINECO, FEDER, UE (MAT2015-69234-R) and the Junta de Castile and Leon (VA011U16) are gratefully acknowledged

\section{REFERENCES}

1. L.J. Gibson and M.F. Ashby, Cellular Solids: Structure and Properties, Oxford, Pergamon (1998).

2. D. Klempner and V. Sendijarevic, Polymeric Foams and Foam Technology, Munich, Hanser Publishers (2004)..

3. H.F. Mark, Encyclopedia of Polymer Science and Technology 4ed, New Jersey, John Wiley \& Sons (2014).

4. J.W.S. Lee, and C.B. Park, Macromol. Mater. Eng., 291, 1233 (2006).

5. R. Pantani, V. Volpe, and G. Titomanlio, J. Mater. Process. Tech., 214, 3098 (2014).

6. G. Wypych, Handbook of Foaming and Blowing Agents, Ontario, ChemTec Publishing (2017).

7. R.H. Heck, J. Vinyl. Addit. Techn., 4, 113 (1998).

8. N.L Thomas and R.P Eastup, Blowing Agent Systems: Formulations and Processing, Shawbury, Rapra Technology (1998).

9. D.J. Cram, C.M. Lavender, R.A. Reed, and A. Schofield, Br. Plastics., 468, 24 (1961).

10. S. Quinn, Plastic Additives \& Compounding., 3, 16 (2001).

11. R. Lally, and L. Alter, SPE Journal., 23, 69 (1967).

12. F. Wright, Indus. Eng. Chem. Fund., 16, 481 (1977).

13. R. Marshall, J. Vynil. Technol., 13, 144 (1991).

14. A.S. Bhatti, D. Dollimore, R.J. Goddard, and G. O'Donnell, Thermochim. Acta., 76, 273 (1984).

15. M.A. Rodriguez-Perez, Adv. Polym. Sci.,184, 97 (2005).

16. J.I. Velasco, M. Antunes, O. Ayvad, C. Saiz-Arroyo, M.A. Rodriguez-Perez, F. Hidalgo, and J.A. de Saja. J. Appl. Polym. Sci. 105, 1658 (2007)

17. M. Alvarez-Lainez, M.A. Rodriguez-Perez, and J.A. de Saja. J. Polym. Sci. Pol. Phys. 46, 212 (2008).

18. A. Cunningham, and N.C. Hilyard, Low-Density Cellular Plastics. Physical Behaviour of Polymeric Foams. Chapman \& Hall (1994). London.

19. T. Kang, and C. Ha, Polym. Test., 19, 773 (2000).

20. T.R. Manley, and M.M. Qayyum, Polymer., 13, 587 (1972).

21. H. Liao, and C. Wu, Polym-Plas. Technol., 42, 1 (2003).

22. R. Pereira de Melo, V. de Oliveira Aguiar, and M. Vieira Marques, Mater. Res., 18, 313 (2015).

23. K. Sirisinha, and B. Sungmanee, J. Chem. Eng. Chem. Res., 1, 365 (2014). 
24. E.C.L. Cardoso, A.B. Lugão, E. Andrade, and L.G. Silva, Radiat. Phy. Chem., 52, 197 (1998).

25. M. Khalid, A.F. Ismail, C.T. Ratnam, Y. Faridah, W. Rashmi, and M.F.A. Khatib, Radiat. Phy. Chem., 79, 1279 (2010).

26. D.W. Clegg and A.A. Collyer, Irradiation Effects on Polymers. Springer (1991).

27. D.W. Kim, and K.S. Kim, J. Cell. Plas., 38, 471 (2002).

28. B.M. Tolbert, and R.M. Lemmon, Radiat. Res., 3, 52 (1955).

29. L. Wojnárovits, and E. Takács, Radiat. Phys. Chem., 77, 225 (2007).

30. P. Neta, and D.W. Whillans, Radiat. Res., 70, 325 (1977).

31. J. Pinto, E. Solórzano, and M.A. Rodríguez-Pérez, J. Cell. Plas., 49, 555 (2013).

32. J.A. Reyes-Labarta, M.M. Olaya, and A. Marcilla, J. Appl. Polym. Sci., 102, 2015 (2006).

33. C. Lee, S.K. Park, K.C. Min, Y. Kim, and N.S. Lee, B. Kor. Chem. Soc., 29, 1951 (2008).

34. G. Socrates, Infrared and Raman Characteristic Group Frequencies, New Jersey, John Wiley \& Sons (2001).

35. P.L Walker, H.A. McKinstry, and C.C Wright, Ing. Eng. Chem., 45, 1711 (1953). 


\subsection{References}

[1]. C. Vasile. Handbook of Polyolefins. Marcel Dekker., New York, 2000.

[2]. A. Peacock. Handbook of Polyethylene. CRC Press., Boca Raton, 2000.

[3]. T.R. Crompton. Polymer Reference Book. Rapra Technology Limited., Shawbury, 2006.

[4]. J.M.G. Cowie, V. Arrighi. Polymers: Chemistry and Physics of Modern Materials, CRC Press., Boca Raton, 2007.

[5]. M. Al-Ali AlMa'adeed, I. Krupa. Polyolefin Compounds and Materials, Springer., Berlin, 2015.

[6]. G. Wypych. 2nd Edition Handbook of Polymers, ChemTec Publishing., Toronto, 2016.

[7]. H.R. Kricheldorf, O. Nuyken, G. Swift. Handbook of Polymer Synthesis: Second Edition, Marcel Dekker., New York, 2005.

[8]. M.A. Rodriguez-Perez. Thermal and Mechanical Properties of Polyolefin Foams. PhD Thesis, University of Valladolid, 1999.

[9]. L.O. Arcos. Thermal and Mechanical Properties of Polyolefin Foams Produced by Compression Molding. PhD Thesis, University of Valladolid, 2002.

[10]. J.I. Peña. Effect of Thermal Treatments in Low-Density Polyethylene Foamed Blocks Produced by Compression Molding. PhD Thesis, University of Valladolid, 2006.

[11]. N.J. Mills. Polyolefin Foams. Rapra Technology Limited., Shawbury, 2003.

[12]. W.M. Allen. Journal of Cellular Plastics, 20, 69-72, 1984.

[13]. M.A. Rodriguez-Perez. Advances in Polymer Science, 184, 97-126, 2005.

[14]. D. Eaves. Handbook of Polymer Foams. Rapra Technology Limited., Shawbury, 2004.

[15]. M. Niaounakis. Biopolymers: Processing and Products. Elsevier., Amsterdam, 2015.

[16]. Blowing Agents. Encyclopedia of Polymer Science and Technology. John Wiley \& Sons., Hoboken, 2011.

[17]. G. Wypych. Handbook of Foaming and Blowing Agents. ChemTec Publishing., Toronto, 2017.

[18]. A.S. Bhatti, D. Dollimore. Thermochimica Acta, 76, 273-286, 1984.

[19]. F. Wight. Industrial and Engineering Chemical Fundamentals, 16, 481-482, 1977.

[20]. K. Matsumoto, N. Kotani, N. Ida, Y. Miyano. Method of Producing Open-Cell Foams of Cross-Linked Polyolefins. Patent, US5242634A. 
[21]. M.A. Rodriguez-Perez, M. Alvarez-Lainez, J.A. de Saja. Journal of Applied Polymer Science, 114, 1176-1186, 2009.

[22]. N.C. Hilyard, A. Cunningham. Low Density Cellular Plastics: Physical Basis of Behavior. Chapman and Hall., London, 1994.

[23]. J. Bear. Dynamic of Fluids in Porous Media. Elsevier., Amsterdam, 1972.

[24]. R. Rodriguez-Montejano, J. Pfretzschner. Polymer Testing, 18, 81-92, 1999.

[25]. A. Moussatov, C. Ayrault, B. Castagnede. Ultrasonics, 39, 195-202, 2001.

[26]. Z.E. Fellah, S. Berger, W. Lauriks, C. Depollier, C. Aristegui, N.Y. Chapelon. Journal of Acoustical Society of America, 113, 2424-2433, 2003.

[27]. C.A. Sperati, W.A. Franta, H.W. Starkweather Jr. Journal of American Chemical Society, 76, 6127-6133, 1953.

[28]. H.W. Starkweather Jr, G.E. Moore, J.E. Hansen, T.M. Roder, R.E. Brooks. Journal of Polymer Science Part A: General Papers, 21, 189-204, 1956.

[29]. D.G. Brady. Journal of Applied Polymer Science, 20, 2541-2551, 1976.

[30]. D.G.M. Wright, R. Dunk, D. Bouvart, M. Autran. Polymer, 29, 793-796, 1988.

[31]. J. Pinto, E. Solorzano, M.A. Rodriguez-Perez, J.A. de Saja. Journal of Cellular Plastics, 49, 555-575, 2013.

[32]. L. Salvo, P. Cloetens, E. Maire, S. Zabler, J.J. Blandin, J.Y. Buffiere, W. Ludwig, E. Boller, D. Bellet, C. Josserond. Nuclear Instruments and Methods in Physics Research Section B, 200, 273-286, 2000.

[33]. S. Perez-Tamarit. Structural Characterization of Solid Cellular Polymers by X-Ray Tomography and Light Scattering. PhD Thesis, University of Valladolid, 2019.

[34]. T. Kang, C.Ha. Polymer Testing, 19, 773-783, 2000.

[35]. T.R. Manley, M.M Qayyum. Polymer, 12, 176-188, 1971.

[36]. T.R. Manley, M.M Qayyum. Polymer, 13, 587-592, 1972.

[37]. H. Liao, C. Wu. Polymer-Plastic Technology \& Engineering, 42, 1-16, 2003.

[38]. C. Charlesby. Proceedings of the Royal Society, A215, 187-214, 1952.

[39]. G. Oster, G.K. Oster, H. Moroson. Journal of Polymer Science, 34, 671-684. 1959.

[40]. M. Dole. Radiation Physics and Chemistry, 22, 11-19, 1983.

[41]. L.O. Salmazo, A. Lopez-Gil, Z.M. Ariff, M. Rodriguez-Mendez, A.E. Job, M.A. Rodriguez-Perez. Macromolecular Chemistry and Physics. Doi: 10.1002/macp.201800295.

[42]. L.D. Loan. Journal of Applied Polymer Science, 2, 2259-2268, 1963.

[43]. L.D. Loan. Journal of Polymer Science Part A, 2, 3053-3066, 1964. 
[44]. S. Suyama, H. Ishigaki, Y. Watanabe, T. Nakamura. Polymer Journal, 27, 371-375, 1995.

[45]. R. Pereira de Melo, V. de Oliveira-Aguiar, M. Vieira-Marques. Materials Research, 18, 313-319, 2015.

[46]. G. Moad, D.H. Solomon. The Chemistry of Radical Polymerization. 2nd Edition. Elsevier., Amsterdam, 2005.

[47]. J.G. Drobny. Ionizing Radiation and Polymers. Elsevier., Amsterdam, 2013.

[48]. V. Kumar, B. Chaudhary, V. Sharma, K. Verma. Radiation Effects in Polymeric Materials. Springer., Switzerland, 2019.

[49]. M.A. Spalding, A.M. Chatterjee. Handbook of Industrial Polyethylene and Technology. John Wiley \& Sons., Hoboken, 2017.

[50]. E. Laguna-Gutierrez, J. Pinto, V. Kumar, M.L. Rodriguez-Mendez, M.A. Rodriguez-Perez. Journal of Cellular Plastics, DOI: 10.1177/0021955X16681454.

[51]. E. Laguna-Gutierrez. Understanding the Foamability of Complex Polymeric Systems by Using Extensional Rheology. PhD Thesis, University of Valladolid, 2016.

[52]. E. Laguna-Gutierrez, R. Van Hooghten, P. Moldenaers, M.A. Rodriguez-Perez. Journal of Applied Polymer Science, 132, 42430-42444, 2015.

[53]. E. Laguna-Gutierrez, A. Lopez-Gil, C. Saiz-Arroyo, R. Van Hooghten, P. Moldenaers, M.A. Rodriguez-Perez. Journal of Polymer Research, 23, 251-267, 2016.

[54]. R.L. Heck III, W.J. Peascoe. Blowing Agents. Uniroyal Chemical Group

[55]. H.P. Stevens, H.G. Emblem. Industrial Chemistry, 27, 391, 1951.

[56]. F. Lober. Angewandte Chemie, 64, 65-76, 1952

[57]. R.A. Reed. British Plastics, 33, 468, 1960.

[58]. D.J. Cram, C.M. Lavender, R.A. Reed, A. Schofield. British Plastics, 468, 24, 1961.

[59]. A.S. Prakash, W.A. Swann, A.N. Strachan. Journal of the Chemical Society, Perkin Transactions 2, 2, 46-50, 1975.

[60]. F. Hidalgo. Design and Optimization of Process Parameters in the Production of Crosslinked Polyolefin Foams by Compression Molding. PhD Thesis, University of Valladolid, 2008.

[61]. J.A. Reyes-Labarta, M.M. Olaya, A. Marcilla. Journal of Applied Polymer Science, 102, 2015-2026, 2006.

[62]. N. Mantaranon, S. Chirachanchai. Polymer, 96, 54-62, 2016.

[63]. R. Lally, and L. Alter. SPE Journal, 23, 69, 1967.

[64]. R. Marshall. Journal of Vinyl Technology, 13, 144-147, 1991. 


\section{MECHANICAL PROPERTIES}





\section{INDEX}

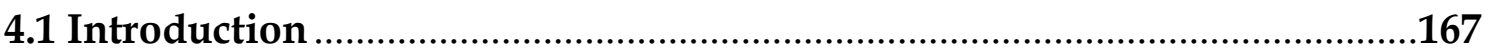

4.2 Mechanical properties: Foams based on LDPE and EVA 18 ……………...169

4.3 Mechanical properties: Foams based on EVA 12 and EBA.........................190

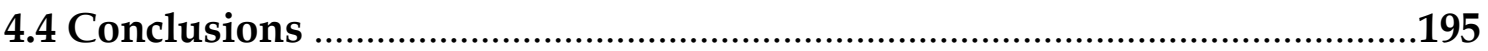

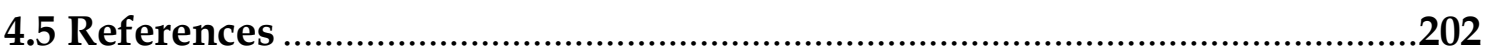




\subsection{Introduction}

One of the most studied properties in the field of cellular polymers is mechanical properties. In this thesis, the compressive response of the crosslinked polyolefin foams has been studied.

As it was mentioned in Chapter 2, the cellular structure interconnectivity (open-cell content) plays a critical role in the response of the materials to a deformation [1]. This effect has been widely characterized, establishing differences in the stress-strain curves of the materials depending on the grade of interconnectivity [2]. Furthermore, the deformation mechanisms which describe the shape of the stress-strain curve in each region are also completely different in a closed-cell or in an open-cell foam [3-5].

The analysis of the mechanical properties provides useful information relative to the possible final application of a material. Thanks to mechanical analysis parameters such as the collapse stress $\left(\sigma_{c}\right)$, the energy absorbed by the materials in the compression test or the recovery of the material after the mechanical test can be measured.

On the one hand, flexible closed-cell foams are used for applications in which high energy absorptions are required, for instance, in packaging or body protection. Thus, the mechanical response of closed-cell foams has been widely analyzed [6-15]. On the other hand, there is also an important need in characterizing the mechanical properties of open-cell foams, considering that these foams are used for comfort applications (seats, mattresses among others) [16-21].

Although the analysis of the mechanical properties of closed and open-cell foams has been widely studied, the effect of the cellular structure tortuosity on the mechanical response of open-cell foams had not been covered yet. Our hypothesis was that the size and the number of the holes created in the cell walls should be critical in the compressive response of the materials. However, not only the cellular structure but also the strain rate of deformation should play a relevant role, because the velocity of the gas molecules depends on the velocity of the test and thus, the time that the gas needs to escape out of the foam varies when the strain rate is modified. Therefore, the mechanical properties were analyzed at low and high strain rates of deformation. The velocity of the test at high strain rates has been up to 500 times higher than the one used at low strain rates.

As the materials described in this thesis encompass different levels of interconnectivity and tortuosity, different mechanical parameters were estimated and used for comparative purposes. Our analysis was focused on analyzing three mechanical parameters (see section 2.5.1. for additional details):

1. The collapse stress, $\sigma_{c}(\mathrm{MPa})$, which gives the stress necessary to buckle the cell walls and the struts of the foam.

2. The effective gas pressure (MPa) which accounts for the contribution of the gas in the post-collapse region (between $20 \%$ and $60 \%$ of the initial deformation). 
This parameter is an indirect measurement of the open-cell content: high values of effective gas pressure are linked to a considerable presence of gas inside the cells and thus to a closed-cell foam, whereas negligible gas pressure means that the gas escapes out of the foam during the tests, and thus is associated with the response of open-cell foams. Both collapse stress and the effective gas pressure were estimated by using the modified model of Gent and Thomas [22]:

$$
\sigma=\sigma_{c}+\frac{p_{a}(1-2 v) \varepsilon}{\left(1-\varepsilon-\frac{\rho_{f}}{\rho_{s}}\right)}(1-C)
$$

By representing $\sigma$ versus $\varepsilon /\left(1-\varepsilon-\frac{\rho_{f}}{\rho_{s}}\right)$ the effective gas pressure is given by the slope and the collapse stress as the zero intercept (Figure 4.1).

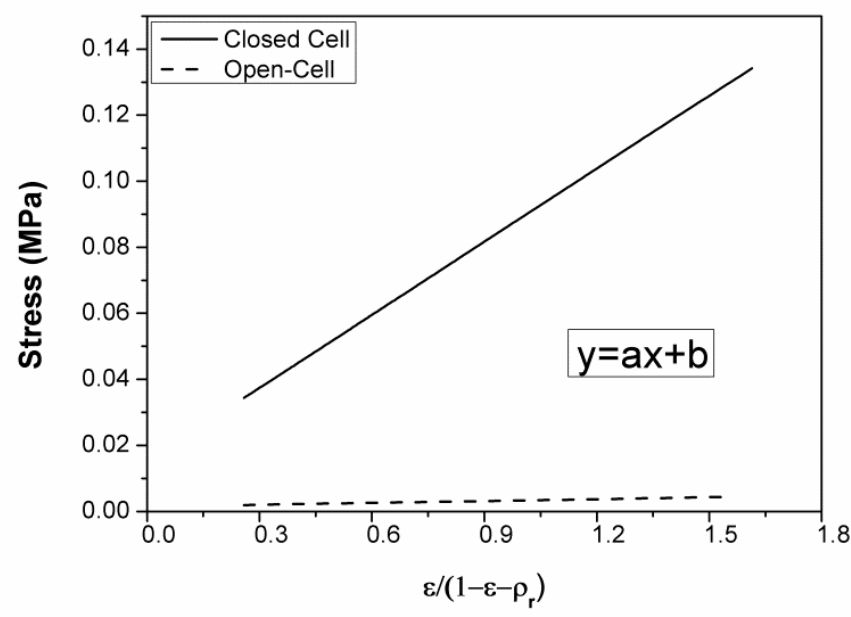

Figure 4.1. The representation used to estimate the effective gas pressure (MPa) and the collapse stress (MPa).

3. The density of absorbed energy $\left(\mathrm{J} / \mathrm{cm}^{3}\right)$, which is estimated as the area under the stress-strain curves.

These three mechanical parameters were estimated at low and high strain rates of deformation for all the materials studied in this research.

To sum up, the two main objectives concerning the study of the mechanical properties were:

1) To analyze the effect of the tortuosity on the mechanical behavior depending on the strain rate of deformation

2) To determine the mechanical response of the crosslinked open-cell polyolefin foams comparing it with the one displayed by an open-cell PU foam, used for comfort in the automotive sector. 


\subsection{Mechanical properties: Foams based on LDPE and EVA 18}

The foams based on LDPE and EVA 18 were the first materials produced in this research. Thus, initially, the mechanical properties at low and high strain rates of these materials were analyzed.

Due to the remarkable results, it was decided to write a publication about these results. The mechanical properties of the foams based on EVA 12 and EBA were characterized afterwards, and their results are described in section 4.3 .

As it was previously mentioned, the mechanical properties of the LDPE and EVA 18 foams were analyzed at low and high strain rates of deformation. The tests at low strains rates were performed in a universal testing machine (INSTRON Mod. 5500R6025) at a velocity of $270 \mathrm{~mm} / \mathrm{min}$, whereas the tests at high strain rates were carried out by using an instrumented falling weight impact tester designed by CellMat Laboratory and built by the company Microtest S.A [23]. The velocity of this test was $1.38 \cdot 10^{5} \mathrm{~mm} / \mathrm{min}$, up to 500 times higher than that performed at low strain rates.

The collapse stress, the effective gas pressure and the density of absorbed energy were measured at both strain rates. Not only the effect of the strain rate but also the effect of the polymer matrix was analyzed. Furthermore, the effect of the tortuosity on the response of the open-cell materials as a function of the strain rate was also covered.

The detailed analysis of these results is included in the following paper: "Effect of the Gas Phase Tortuosity on the Mechanical Properties of Low-Density Polyolefin Open-Cell Foams at Low and High Strain Rates", accepted in the Journal of Applied of Polymer Science. 


\title{
EFFECT OF GAS PHASE TORTUOSITY ON THE MECHANICAL PROPERTIES OF LOW-DENSITY POLYOLEFIN OPEN-CELL FOAMS AT LOW AND HIGH STRAIN RATES
}

\author{
E. Lopez-Gonzalez ${ }^{* 1,2}$, S. Muñoz-Pascual1, C. Saiz-Arroyo², M.A. Rodriguez-Perez ${ }^{1,3}$ \\ ${ }^{1}$ Cellular Materials Laboratory (CellMat), Condensed Matter Physics Department, University \\ of Valladolid, Paseo Belén 747011 Valladolid (Spain)
}

2 CellMat Technologies S.L., Paseo de Belen 9-A (CTTA Building), 47011, Valladolid, Spain

3Instituto BIOECOUVA, Universidad de Valladolid, Valladolid, Spain

* Corresponding author. Tel: +34 983423194

E-mail address: eduardol@fmc.uva.es

\begin{abstract}
This paper describes the mechanical behavior in compression, at both low and high strain rates, of several low-density open-cell polyolefin-based foams with different gasphase interconnectivity and different levels of gas-phase tortuosity. The mechanical properties of the open-cell polyolefin foams have been compared with two different references: an open-cell low tortuous foam based on flexible polyurethane and closedcell polyolefin foams. One the one hand, at low strain rates, it has been observed that the mechanical performance is controlled by the open-cell content and the properties of the polymeric matrix, being the influence of tortuosity small. On the other hand, the influence of the level of tortuosity is critical at high strain rates. In fact, it has been demonstrated that open-cell polyolefin foams with high tortuosity present an unexpected mechanical behavior, showing excellent mechanical properties, that are even similar to that of closed-cell polyolefin materials with the same chemical composition. Therefore, low-density polyolefin foams with high tortuosity have a unique mechanical performance strongly influenced by the strain rate.
\end{abstract}

\section{INTRODUCTION}

Cellular polymers are two-phase materials in which a gas is dispersed in a polymer matrix ${ }^{1}$. Due to the reduction in density and to their outstanding properties, polymer foams have become essential items for several sectors such as packaging, construction, automotive or sports ${ }^{2-4}$. In fact, during the last decades, both academia and industry have made important efforts to generate ad-hoc products with high levels of specialization for targeted sectors and markets.

Polymer foams can be classified attending to different criteria: the density of the foam, the stiffness of the polymeric matrix and the morphology of the cellular structure. 
Focusing on the density, polymer foams can be classified into three groups: highdensity foams, medium-density foams, and low-density foams. Typically, relative density, which is the ratio between the density of the foamed material and the density of the corresponding solid material, is the parameter used to classify the materials. High-density foams present relative densities higher than 0.6 , low-density foams have relative densities below 0.3 , and finally, medium-density foams are in the range of densities between both. Density is the main parameter governing the properties, and hence the applications of a certain polymer foam ${ }^{5}$.

Low-density foams are also divided into two groups depending on the stiffness of the polymeric matrix: rigid or flexible foams. The rigid foams group is essentially dominated by polyurethane (PU) ${ }^{6,7}$ and polystyrene (PS) foams that are mainly employed as thermal insulators and in the core of sandwich panels. Polyolefin-based foams produced using low-density polyethylene (LDPE) or ethylene vinyl acetate copolymer (EVA) as polymeric matrices as well as flexible PU foams are considered flexible foams. Due to their softness and depending on the type of cellular structure morphology, these materials are used in energy absorption applications such as packaging, sports, shoes, comfort-related applications, gaskets, acoustic absorption, liquids absorption, filters, etc ${ }^{8-12}$.

Furthermore, polymer foams can also be classified, taking into account the morphology of the cellular structure. According to this criterion, foams are divided into three main groups: closed-cell foams, foams with intermediate open-cell contents and open-cell foams. In closed-cell materials, the gas is enclosed inside the cells that are comprised of struts and cell walls, and consequently, the gas phase cannot move freely through the cellular structure. Open-cell materials are characterized by a full level of interconnection between the cells (i.e. an open-cell content of $100 \%$ ), and therefore, the gas can move through the whole cellular structure. Foams with intermediate open-cell contents can be considered as hybrids between closed and open-cell foams, being their cellular structure partially interconnected.

But this is a general classification which is not always enough to characterize the materials. When speaking about open-cell foams, it is possible to find different scenarios regarding the ability of the gas to move along the cellular structure. Figure 1 shows two different types of open-cell foams. Figure 1 (a) corresponds to a flexible PU foam whose cellular structure is only formed by struts. The total absence of cell walls in the structure allows the gas molecules to move easily through the cellular structure. Figure 1 (b) shows the cellular structure of low-density open-cell polyolefin foam. This material also has a fully interconnected cellular structure, but in this case, the interconnectivity between cells is due to the holes located in the cell walls. In this type of structure, the movement of the gas molecules through the structure is more difficult and more energy is needed to promote it. Furthermore, depending on the size and the number of holes in the cell walls, the movement of the gas will be restricted to different levels. 
Therefore, it is clear that open-cell content is not enough to describe the cellular structure of such complex open-cell materials where the movement of the gas molecules is somehow restricted by the morphology of the cells. An additional parameter is needed to account for the easiness of gas movement. This parameter is the gas phase tortuosity.
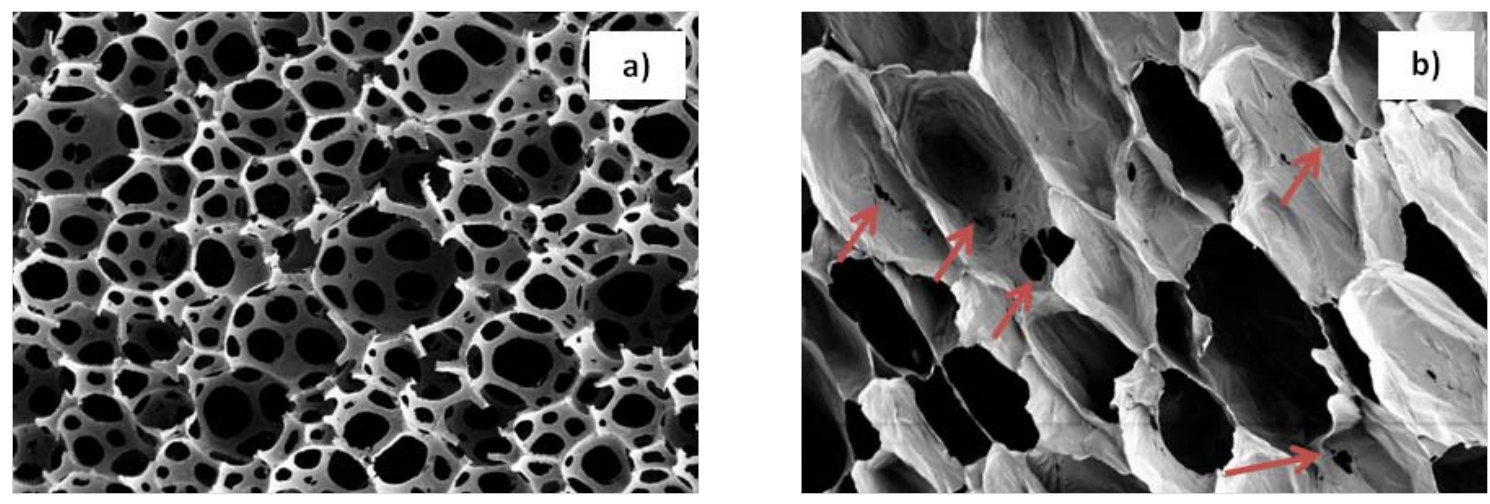

Figure 1. Open-cell low-density flexible cellular polymers: (a) cellular polymer comprised of struts and (b) cellular polymer with holes in the cell walls (indicated with arrows).

It measures the real distance that a gas molecule has to cover to move from one side to the other side of the foam ${ }^{13,14}$. Tortuosity can be measured using different methods such as ultrasonic measurements ${ }^{15,16}$, electrical conductivity measurements ${ }^{1}$ or can be theoretically estimated using several models ${ }^{17,18}$. Thus, taking into account the cellular structure tortuosity, it is possible to divide open-cell polymer foams into two groups: low and high tortuous foams. The range of typical tortuosity values varies from values near 2 (low tortuous materials) to values higher than 3.5 (high tortuous materials) ${ }^{1}$.

The influence of the open-cell content on the mechanical performance of flexible foams has been reported by several authors ${ }^{19-21}$. In general, it has been concluded that for foams with the same chemical composition and relative density, an increase in the open-cell content, reduces the stiffness and strength of the foams. Gong et al.20 analyzed the compressive response of polyester urethane open-cell foams with relative densities of around 0.025. They observed a clear effect of the anisotropy in the mechanical properties depending on the compressive tests were performed in the rise or the transverse direction. Zhu et al. ${ }^{21}$ modelled the elastic constants of open-cell foams. For this analysis, they considered the edge cross section and the foam density to estimate the mechanical parameters (Young modulus, shear modulus and Poisson's ratio) considering the bending, twisting and stretching of the cell edges.

However, the influence of tortuosity in the mechanical response (evaluated either at low or high strain rates) of low-density foams is a topic that has not been covered in the literature mainly because of the inherent difficulty of producing foams with different tortuosity levels, the same density, the same chemical composition and the same open-cell content The understanding of its influence on the overall performance of open-cell foams might be a critical issue for their use in some applications ${ }^{22}$. 
Thus, the objective of this work is to carry out a comparative study to determine the effect of the gas phase tortuosity level on the mechanical performance of several materials at low and high strain rates. For this purpose, the materials that are included in the study are low-density open-cell LDPE and EVA based foams with fully interconnected cellular structure and different tortuosity levels. In addition, a flexible open-cell PU foam with low tortuosity, closed-cell foams and foams with an intermediate open-cell content based on LDPE and EVA have been employed as references for comparative purposes.

\section{EXPERIMENTAL}

\section{Compressive properties: background.}

In this section, some basic concepts on the mechanical performance of low-density flexible foams are introduced, because they are needed to define the key mechanical parameters used during the paper to characterize the foams.

The mechanical performance of open-cell foams is different from that of closed-cell foams, especially when considering compressive tests. One of the main reasons behind such differences is the contribution of the gas phase to the mechanical properties in flexible foams.

Compression tests can be carried out either at low or at high strain rates. Figure 2 depicts stress-strain curves obtained at a low strain rates and corresponding to PECC (closed-cell foam) and PEOC LT (open-cell foam) foams (cubic samples of $45 \times 45 \times 45$ $\mathrm{cm}^{3} ; 270 \mathrm{~mm} / \mathrm{min}$; strain $75 \%$; 5 load-unload cycles).

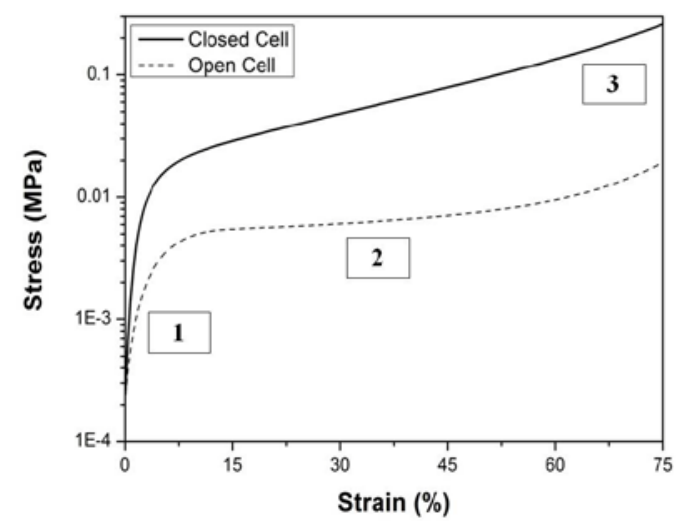

Figure 2. Typical stress-strain curve for closed (PECC) and open-cell foams (PEOC LT) at low strain rates (270 $\mathrm{mm} / \mathrm{min} ; 75 \%$ strain).

Three regions can be defined in the stress-strain curves regardless of the type of cellular structure morphology 23 :

1) At low strains (below 5\%), the materials present a linear behavior. There are two mechanisms controlling the response of the materials in this region: the bending of the cell edges and the stretching of the cell walls. In this region, the 
contribution of the gas inside the cells can be considered negligible, and therefore, this linear dependence is observed for all the materials regardless of their cellular structure morphology 24,25 .

2) This area is usually called the post-collapse region. In this region, the gas phase is playing a critical role. On the one hand, the stress increases in closed-cell foams due to the contribution of the gas enclosed in the cells. On the other hand, for open-cell foams, the gas is leaving the foam during the mechanical tests due to the macroscopic deformation, and the primary mechanism of deformation in the post-collapse area is the buckling of the cell walls which derives into constant stress values (plateau). Gent and Thomas ${ }^{23}$ developed a model considering that the compression occurs isothermally. Subsequent modifications of this model have led to the following equation (1) $26-28$ :

$$
\sigma=\sigma_{c}+\frac{p_{a}(1-2 v) \varepsilon}{\left(1-\varepsilon-\frac{\rho_{f}}{\rho_{s}}\right)}(1-C)
$$

where $\sigma$ is the stress, $\sigma_{c}$ is the collapse stress, $p_{a}(1-2 v)$ is the effective pressure of the gas in the sample, being $p_{a}$ the atmospheric pressure and $v$ the Poisson ratio, $\varepsilon$ is the strain, $\rho_{f}$ is the foam density $\left(\mathrm{kg} / \mathrm{m}^{3}\right), \rho_{s}$ is the density of the solid $\left(\mathrm{kg} / \mathrm{m}^{3}\right)$, and its ratio $\left(\rho_{f} / \rho_{s}\right)$ is known as relative density $\left(\rho_{r}\right)$, and finally $C$ is the open-cell content. This equation considers the contribution of the gas (effective gas pressure $\left.=p_{a}(1-2 v)(1-C)\right)$ in the deformation reached in the post-collapse region.

By representing $\sigma$ versus $\varepsilon /\left(1-\varepsilon^{-}-\rho_{r}\right)$, plots as the one shown in Figure 3 are obtained. $\sigma_{c}$ and the effective gas pressure in the post-collapse region can be calculated by carrying out a linear fit to the experimental data. The slope ( $\mathrm{a}$ in the figure) would correspond to the effective gas pressure and the constant term ( $b$ in the figure) to the collapse stress (see Figure 3 ). 


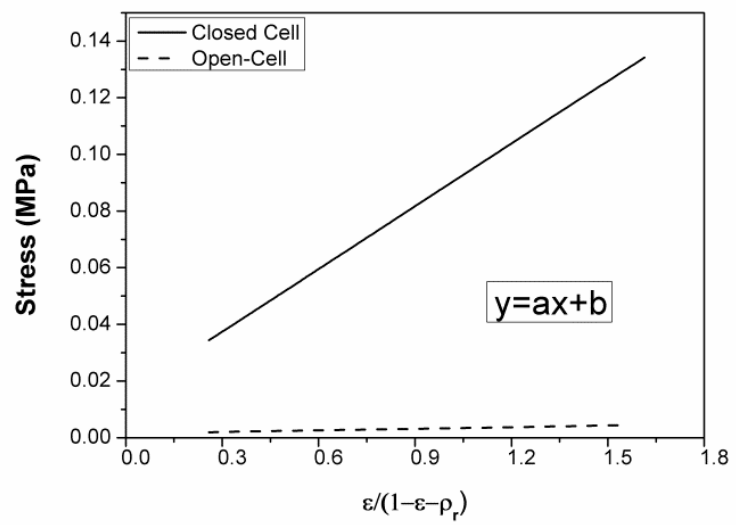

Figure 3. $\sigma$ versus $\varepsilon /\left(1-\varepsilon-\rho_{r}\right)$ for the PECC and PEOC LT foams based on the Gent and Thomas model: determination of the $\sigma_{c}(\mathrm{~b})$ and the effective gas pressure (a).

1) The final area is the densification region, in which the cellular structure is fully collapsed, and the upper and lower faces of the foam are in contact. This is detected in the stress-strain curve as an increase in the stress values ${ }^{29}$.

Due to some technical requirements, mainly related to the final applications of some materials, it is also helpful to evaluate the mechanical response at high strain rates ${ }^{1,30}$. It is logical to think, that there could be some variations in the mechanical response at high strain rates in comparison to the response at low strain rates because the strain rate of the test is several orders of magnitude higher. Therefore, not only the morphology of the cellular structure but also the cellular structure tortuosity and the viscoelastic properties of the polymer matrix could play a key role in the modification of the mechanical behavior at high strain rates.

Figure 4 shows the stress-strain curve of PECC and PEOC LT foams at high strain rates (1.38 $10^{5} \mathrm{~mm} / \mathrm{min}$; cubic samples $\left.45 \times 45 \times 45 \mathrm{~cm}^{3}\right)$. As in the previous case, it is also possible to define the same three regions: the linear region (1), the post-collapse region (2) and finally, the densification (3). The same mechanisms as the ones explained before are determining the response of the foams at high strain rates, and therefore the same parameters defined for the low strain rate experiments can be used to characterize these curves. 


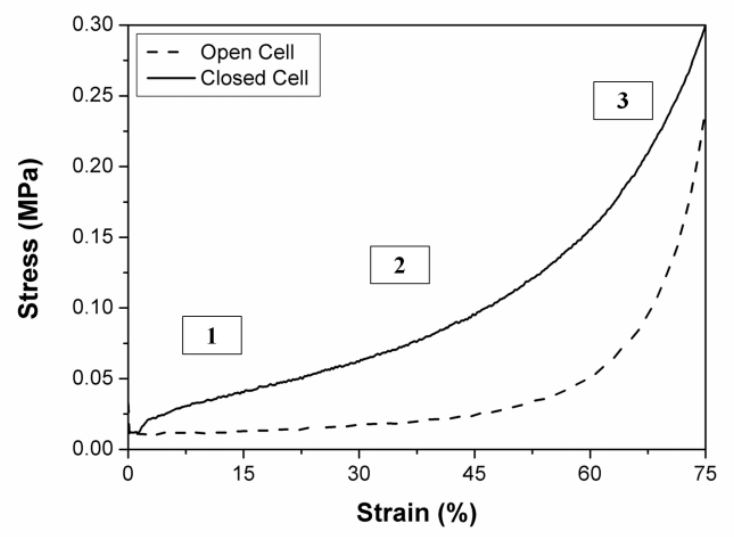

Figure 4. Stress-strain curve of the PECC and PEOC LT foams at high strain rates. Strain rate: $1.38 \cdot 10^{5} \mathrm{~mm} / \mathrm{min}$.

\section{Materials}

Two types of polyolefins were employed for the productions of the foams with different cellular structure morphologies. Low-density polyethylene LDPE Alcudia ${ }^{\circledR}$ 003 manufactured by Repsol (Spain) with a density of $0.920 \mathrm{~g} / \mathrm{cm}^{3}$ and a melt flow index (MFI) of $2.00 \mathrm{~g} / 10 \mathrm{~min}$ measured at $230{ }^{\circ} \mathrm{C}$ and $2.16 \mathrm{~kg}$ and ethylene vinyl acetate copolymer EVA Alcudia ${ }^{\circledR}$ PA-538 manufactured by Repsol (Spain) with a VA content of 18 , a density of $0.937 \mathrm{~g} / \mathrm{cm}^{3}$ and a melt flow index (MFI) of $2.00 \mathrm{~g} / 10 \mathrm{~min}$ measured at $230{ }^{\circ} \mathrm{C}$ and $2.16 \mathrm{~kg}$ were employed as polymeric matrices.

Azodicarbonamide (ADCA) Unicell D800 CB powder with an average particle size of 7.6-8.0 microns and a range of decomposition temperatures between 202 and $208{ }^{\circ} \mathrm{C}$ was employed as the blowing agent. Azodicarbonamide was kindly supplied by Dongjin Semichem CO.LTD (South Korea). Dicumyl peroxide (DCP) Luperox® DC40 supplied by Arkema (France) was used as the crosslinking agent. Other additives such as zinc stearate acting as an activator of the decomposition temperature of the blowing agent and stearic acid acting as processing aid were also added to the formulations.

Several LDPE and EVA foams with different cellular structure interconnectivity and tortuosity were provided by CellMat Technologies S.L. (Valladolid, Spain). The materials were produced using a two-steps compression molding process ${ }^{31}$. The main differences between the cellular polymers produced for this work lie in the different levels of interconnectivity reached during the fabrication process. As a result, foams with a low level of interconnectivity (PECC and EVCC), foam with an intermediate open-cell content (PEMC and EVMC) and two types of open-cell foams: with high tortuosity (PEOC HT and EVOC HT) and with low tortuosity (PEOC LT and EVOC LT). The open-cell content was close to $100 \%$ for these open-cell foams regardless of the level of tortuosity. The main characteristics of these materials are summarized in Table 1. 
Table 1. Nomenclature, density, open-cell content and tortuosity of the materials under study.

\begin{tabular}{|c|c|c|c|c|}
\hline Nomenclature & Density $\mathbf{( k g / \mathbf { m } ^ { 3 } )}$ & $\begin{array}{c}\text { Relative } \\
\text { density }\end{array}$ & $\begin{array}{c}\text { Open-cell } \\
\text { content }(\%)\end{array}$ & Tortuosity \\
\hline EVCC & $26.9 \pm 1.5$ & 0.0287 & $46.0 \pm 0.6$ & -* $^{*}$ \\
\hline PECC & $27.0 \pm 0.4$ & 0.0293 & $27.2 \pm 1.8$ & -* $^{*}$ \\
\hline EVMC & $18.5 \pm 0.2$ & 0.0198 & $64.0 \pm 5.0$ & -* $^{*}$ \\
\hline PEMC & $19.9 \pm 1.0$ & 0.0216 & $64.6 \pm 6.4$ & * $^{*}$ \\
\hline EVOC LT & $17.3 \pm 0.6$ & 0.0185 & $99.3 \pm 0.6$ & $1.9 \pm 0.2$ \\
\hline PEOC LT & $15.8 \pm 0.1$ & 0.0172 & $99.0 \pm 0.0$ & $1.9 \pm 0.1$ \\
\hline EVOC HT & $18.4 \pm 0.9$ & 0.0196 & $97.0 \pm 1.5$ & $3.8 \pm 0.5$ \\
\hline PEOC HT & $20.0 \pm 1.0$ & 0.0217 & $95.0 \pm 3.0$ & $4.0 \pm 0.4$ \\
\hline PU & $47.2 \pm 0.1$ & 0.0407 & $98.0 \pm 0.0$ & $2.0 \pm 0.0$ \\
\hline
\end{tabular}

-* tortuosity not measured because they were materials with a significant closed-cell content.

\section{Differential scanning calorimetry (DSC)}

The crystallinity of both polymer matrices was estimated by performing differential scanning calorimetry (DSC) measurements (Mettler DSC 822e). The following thermal program was selected:

1) Heating from $-40{ }^{\circ} \mathrm{C}$ to $200{ }^{\circ} \mathrm{C}$ at $10 \mathrm{~K} \mathrm{~min}^{-1}$.

2) A 3-minute isotherm at $200^{\circ} \mathrm{C}$.

3) Cooling from $200{ }^{\circ} \mathrm{C}$ to $-40^{\circ} \mathrm{C}$ at $-10 \mathrm{~K} \mathrm{~min}^{-1}$.

4) Heating from $-40{ }^{\circ} \mathrm{C}$ to $200{ }^{\circ} \mathrm{C}$ at $10 \mathrm{~K} \mathrm{~min}^{-1}$.

The crystallinity was calculated as the ratio of the heat of fusion in the last heating step and the heat of fusion of a $100 \%$ crystalline material $(288 \mathrm{~J} / \mathrm{g}$ for $100 \%$ crystalline polyethylene). The crystallinity was estimated as the average of three measurements. The crystallinity of the LDPE was $35.07 \pm 1.75 \%$ whereas EVA presented a lower crystallinity $(14.74 \pm 0.70 \%)$ due to the disorder caused by the VA chains.

The density of the open-cell foams is inside a range between 15 and $20 \mathrm{~kg} / \mathrm{m}^{3}$. The relative density was also presented in the table, being these values for the open-cell foams very similar. Therefore all open-cell polyolefin foams had similar densities regardless of the type of polymer matrix. The open-cell PU foam used in this study had a density of $47.2 \mathrm{~kg} / \mathrm{m}^{3}$. This density is slightly higher than the open-cell polyolefin foams. However, these differences are reduced if the relative density is taken into account.

\section{Mechanical properties}

The mechanical properties were evaluated performing compression tests at low and high strain rates:

The performance of the foams at low strain rates was characterized, carrying out compression tests in a universal testing machine (Instron Mod. 5500R6025). 
Tests were performed at room temperature at a strain rate of $270 \mathrm{~mm} / \mathrm{min}$. The maximum static strain was $75 \%$ for all samples.

The measured specimens were cubes of $45 \times 45 \times 45 \mathrm{~mm}^{3}$, and they were conditioned at $23{ }^{\circ} \mathrm{C}$ for 24 hours before performing the experiments. Five samples of each material were tested to obtain the average response.

The effective gas pressure in a strain range between 20 and 60\% (post-collapse region) was estimated as the slope of the linear equation obtaining in the $\sigma \mathrm{vs} \varepsilon /\left(1-\varepsilon-\left(\rho_{f} / \rho_{s}\right)\right.$ plot. Furthermore, the collapse stress $\left(\sigma_{c}\right)$ was determined as the constant term in the same equation (see Figure 3).

Moreover, the density of absorbed energy $\left(\mathrm{J} / \mathrm{cm}^{3}\right)$ was also estimated as the area under the loading curve in the whole considered strain range.

To perform the compression tests at high strain rates, an instrumented falling weight impact tester designed by CellMat Laboratory and built by the company Microtest SA (Spain) was used ${ }^{32}$. The striker was flat with a diameter $(\varphi)$ of $80 \mathrm{~mm}$. The force transducer (KISTLER type 9333A) was located in the upper part of the striker, and the force data acquisition frequency was $55.3 \mathrm{kHz}$. The displacement of the striker was measured using a laser triangulation sensor, LDS90/40, from LMI Sensors-95. The incident energy was $15.21 \mathrm{~J}(\mathrm{~m}=5.75 \mathrm{~kg}, \mathrm{v}=2.3 \mathrm{~m} / \mathrm{s})$.

The selected strain rate for these tests was $1.38 \times 10^{5} \mathrm{~mm} / \mathrm{min}$, which is more than 500 times higher than that employed for the compression tests. Similarly, the evaluated specimens were cubes of $45 \times 45 \times 45 \mathrm{~mm}^{3}$, and they were also conditioned at $23{ }^{\circ} \mathrm{C}$ for 24 hours before carrying out the experiments. Three samples of each type of foam were tested to obtain the average response.

Stress-strain curves were built from the data provided by the impact testing machine. To compare the mechanical response at low and high strain rates, the effective gas pressure was also calculated in the same strain range (20-60\%) The collapse stress $\left(\sigma_{c}\right)$ was also determined using the same procedure as that employed in the low strain rate experiments (Figure 3). Finally, the density of absorbed energy was calculated in a strain range between $0 \%$ and $75 \%$ as the area under the loading part of the stress-strain curve.

\section{Density}

The density of the samples was estimated by measuring geometrically the cubic samples used for this study.

\section{Open-Cell Content Estimation}

The open-cell content of the foams was estimated from the effective gas pressure measured in the stress-strain curves at low strain rates. As it was previously explained, this region is influenced by the contribution of the gas enclosed inside the cells (1). By 
representing $\sigma$ vs $\varepsilon /\left(1-\varepsilon-\rho_{r}\right)$, a linear trend is obtained. Thus, the effective gas pressure can be determined by fitting those data to a linear equation (Figure 3). Once this effective pressure is obtained, the value of the open-cell content (1-C) was estimated. In all these estimations, the Poisson's ratio, $v$, was assumed to be negligible for this type of materials 8,33 . This method was used because the most conventional approach based on using a gas pycnometer to obtain the open-cell content, was difficult to apply in these materials due to its low stiffness which promotes a deformation of the foams due to the pressure applied by the gas pycnometer.

\section{Determination of the tortuosity}

The tortuosity of the foams was determined by using an electrical measurement. A setup as the one schematized in Figure 5 was employed.

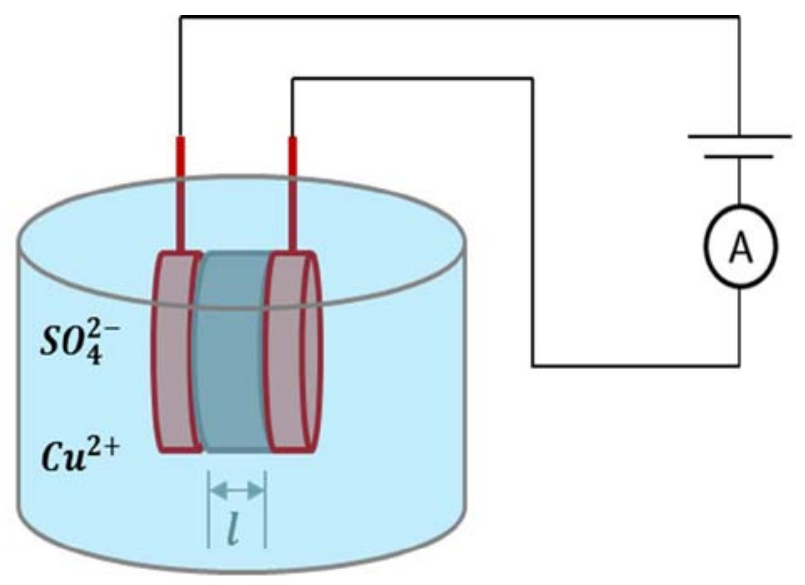

Figure 5. Scheme of the set up employed for the determination of the tortuosity.

A solution $0.4 \mathrm{M}$ of $\mathrm{CuSO}_{4} \cdot 5 \mathrm{H}_{2} \mathrm{O}$ was used as the auxiliary liquid. Two copper discs (15 mm diameter) were employed as electrodes. The copper electrodes were connected to a source providing alternating current (EA-3048B Elektro-Automatik GmbH, Germany).

First, the electrical conductivity of the solution without the foamed sample between the electrodes was measured in a fixed voltage range. The resistance of the solution without a sample between the electrodes $\left(R_{o}\right)$ was determined by applying Ohm's law. The measurements were performed in a range of voltages varying from 3 to $6 \mathrm{~V}$ in steps of $0.5 \mathrm{~V}$. A gap of 2 minutes was established between each measurement.

Once the resistance of the solution without the sample was measured, the electrical conductivity of the solution containing the foamed sample placed between the two copper electrodes was also determined. For this purpose, cylindrical specimens with 25 $\mathrm{mm}$ in thickness and $30 \mathrm{~mm}$ in diameter were immersed for 14 hours in the solution before measuring to assess a proper and complete penetration of the auxiliary liquid inside the cellular structure. After this time, the samples were placed between the two copper electrodes and the electrical conductivity was measured in the same voltage 
range as the one used before. The resistance of the solution with the sample between the electrodes was also determined $\left(R_{f}\right)$.

The tortuosity is defined as the ratio between the resistance with the foamed sample between the copper electrodes $\left(R_{f}\right)$ and the resistance of the solution without foamed sample between the electrodes $\left(R_{o}\right)$, as it is indicated in (2):

$$
\mathrm{T}=\frac{\mathrm{R}_{\mathrm{f}}}{\mathrm{R}_{\mathrm{o}}}
$$

This parameter was only measured for the foams with a fully interconnected cellular structure (i.e. an open-cell content higher than 95\%).

\section{Analysis of the morphology of the cellular structure}

Scanning electron microscopy (SEM) was used to analyze the cellular structure of the foams under study qualitatively. The SEM micrographs were taken using a Jeol JSM820 scanning electron microscope. The samples were cut at room temperature using a razor blade. Then, a thin layer of gold was sputtered on the exposed surface to make it conductive.

\section{RESULTS AND DISCUSSION}

\section{Cellular structure and tortuosity}

The cellular structure of the materials under study is shown in Figure 6: 

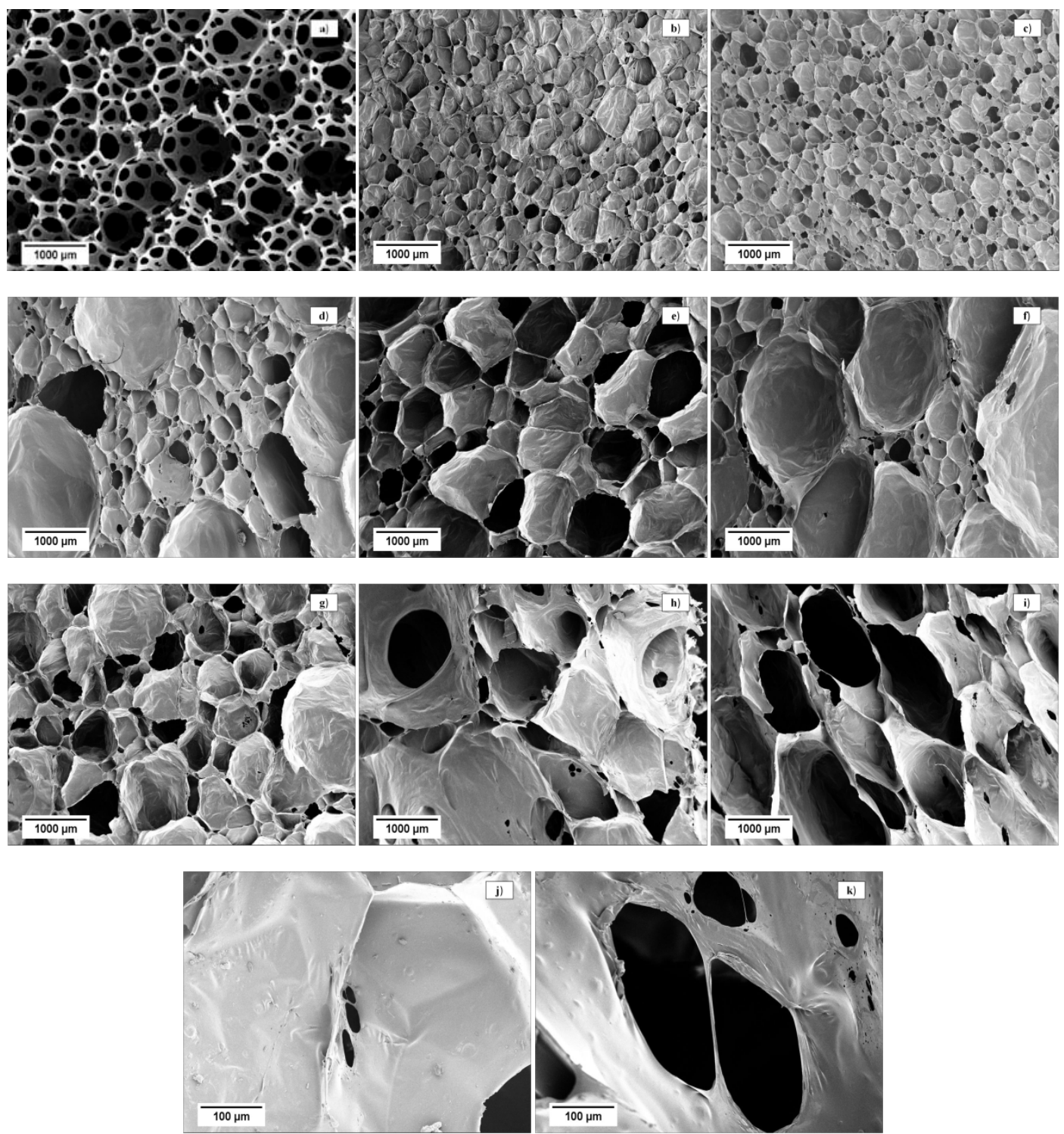

Figure 6. SEM micrographs: (a) PU; (b) EVCC; (c) PECC; (d) EVMC; (e) PEMC; (f) EVOC HT; (g) PEOC HT; (h) EVOC LT and (i) PEOC LT; (j) EVOC HT foam: holes in cell walls and (k) EVOC LT foam: holes in the cell walls.

Figure 6 (a) shows the cellular structure of the open-cell PU used as a reference. The high level of interconnectivity in this material is due to a cellular structure including only struts and a total absence of cell walls. Figure 6 (b) and (c) show the cellular structure of the crosslinked closed-cell EVA and LDPE foams used as references. These two materials present homogeneous cellular structures where cells are comprised by struts and cell walls, and that consequently present a very low level of interconnectivity between the cells (open-cell contents for these materials are 47 and $26 \%$ respectively). Figure 6 (d) and (e) are referred to foams with intermediate opencell contents (MC) in which the open-cell content is 64\%. Figure 6 (f-i) correspond to fully interconnected open-cell EVA and LDPE foams (open-cell content higher than 95\%). In the particular case of open-cell materials, two types of structures can be distinguished: Figure 6 (f) and (g) show materials with high tortuosity (HT) while Figure $6(\mathrm{~h})$ and (i) are referred to open-cell foams with low tortuosity (LT). 
The differences between open-cell samples displaying low and high tortuosity levels can be better appreciated in the high-magnification micrographs depicted in Figure 6 (j) and Figure $6(\mathrm{k})$. High tortuous open-cell polyolefin foams are characterized by the presence of few and small holes in the cell walls (Figure $6 \mathrm{j}$ ) while the number and the size of the holes of low tortuous open-cell polyolefin foams are considerably larger (Figure $6 \mathrm{k}$ ). These clear differences in the cellular structure are also detected when the gas phase tortuosity is measured. In fact, the fully interconnected foams with low tortuosity present values of this parameter of 1.9 for both LDPE and EVA foams. However, the materials with high tortuosity have values between 3.8 (EVA) and 4.0 (LDPE), i.e. values two times higher than those of low tortuous materials and also two times higher than the value of the PU foam used as a reference.

\section{Mechanical performance measured at low strain rates}

The effective gas pressure, the collapse stress $\left(\sigma_{c}\right)$ and the density of absorbed energy were calculated for the materials described in Table 1 . The experimental results are summarized in Figure 7:
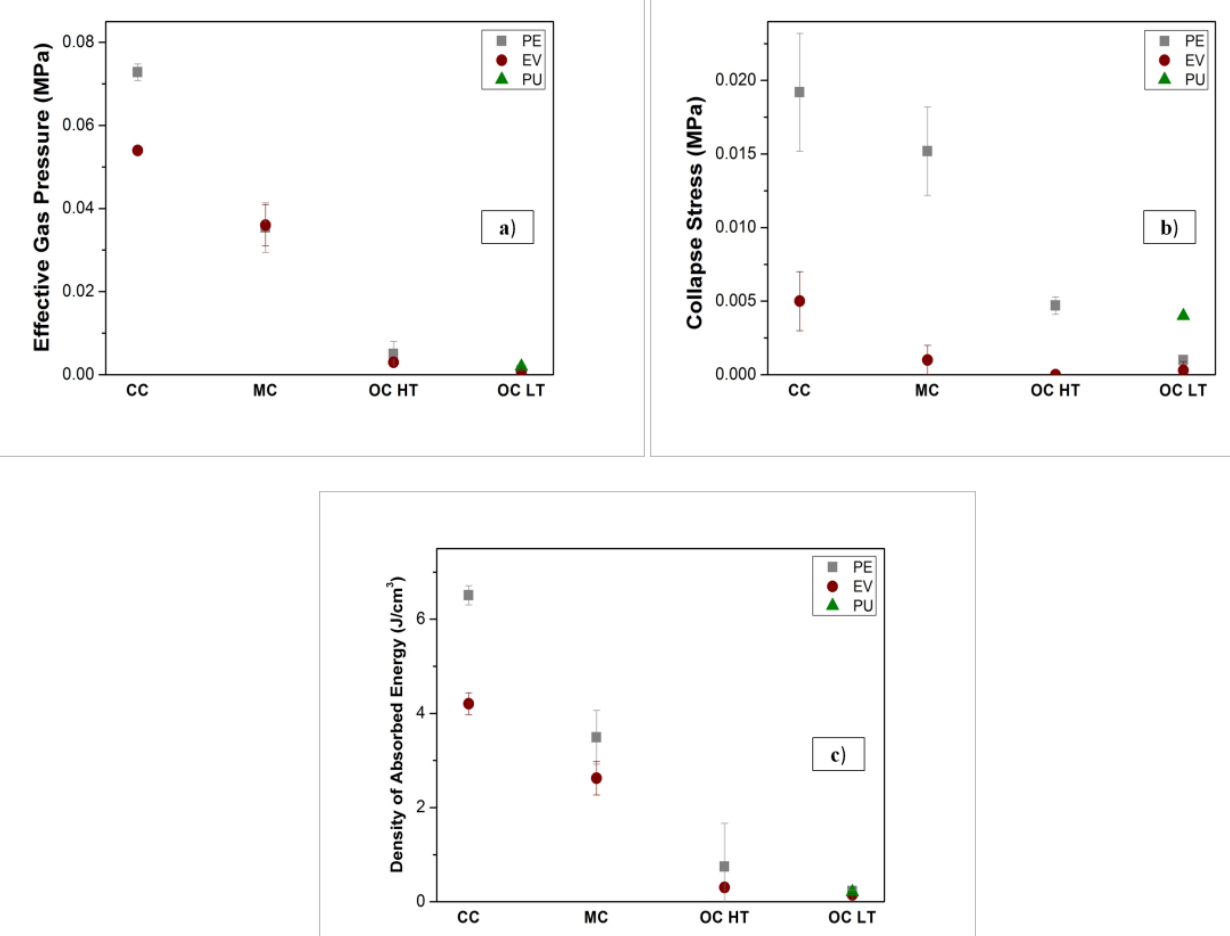

Figure 7. Mechanical parameters at low strain rates: (a) effective gas pressure (MPa); (b) collapse stress (MPa) and (c) density of absorbed energy $\left(\mathrm{J} / \mathrm{cm}^{3}\right)$ for LDPE and EVA foams under study.

Figure 7 (a) describes the contribution of the gas in the post-collapse region for LDPE and EVA based foams. The contribution of the gas phase becomes smaller as the opencell content increases. In closed-cell foams, the gas is enclosed inside the cells (no interconnection) and therefore its contribution to the mechanical performance is considerable in the post-collapse region. However, as the open-cell content increases, more cells are interconnected, and the gas can diffuse out through the whole cellular 
structure when the materials are compressed. In fact, when these foams are compressed, a substantial part of the gas has already escaped out from the material before reaching the post-collapse region and, as a consequence, the contribution of the gas is almost negligible for open-cell foams in the post-collapse zone. Furthermore, it can be observed that the different tortuosity levels do not have a significant effect on the effective gas pressure (open-cell foams with high tortuosity shows only slightly higher values) in comparison with that of the open-cell content, being the effective gas pressures of high tortuous and low tortuous fully interconnected open-cell polyolefin foams similar but also close to that of the reference open-cell PU foam, despite the differences in the type of polymer matrix and density.

The collapse stress $\left(\sigma_{c}\right)$ also depends on the cellular structure morphology. The collapse stress values of closed-cell polyolefin foams are higher than those obtained for polyolefin foams with intermediate open-cell contents and the open-cell ones (Figure 7 b). As it occurred with the effective pressure, the tortuosity of the structure does not seem to have a significant influence. Similar collapse stress values are achieved for high and low tortuous open-cell polyolefin foams. However, the type of polymer matrix has a critical influence on this parameter. Collapse stress is related to the stiffness of the cell walls and struts. Due to this effect, remarkable differences have been found between the values corresponding to LDPE foams and those corresponding to EVA foams. EVA is softer and more flexible than LDPE due to its low crystallinity (14.74 \% for EVA against $35.07 \%$ for LDPE), and consequently, the collapse stress values of EVA based foams are lower regardless of the type of microstructure. For example, in closed-foams, the collapse stress value of LDPE based foam is 3.8 times higher than that of the EVA based one.

Figure 7 (c) shows the values of the density of absorbed energy. Similar tendencies as the ones observed for the effective gas pressure and the collapse stress are observed for this parameter. Closed-cell polyolefin foams can absorb more energy than partially or fully interconnected foams when they are evaluated using compression tests at low strain rates. The energy absorption capability of open-cell polyolefin foams is similar regardless of the differences in the cellular structure tortuosity, there is only a small difference in favor of foams with high tortuosity, but these differences are much smaller than those due to variations in the open-cell content. The density of absorbed energy also shows the difference between LDPE and EVA foams, showing the LDPE foams a better performance. In addition to this, the behavior of the flexible PU foam used as a reference is similar to that of the open-cell foams with low tortuosity.

To sum up, this section shows that at low strain rates, the main parameters affecting the mechanical behavior of the materials are the open-cell content and the nature of the polymeric matrix. The tortuosity is not playing any significant role when the foams are compressed at these low strain rates. 


\section{Mechanical performance measured at high strain rates}

The experimental results obtained from the stress-strain curves measured at high strain rates are summarized in Figure 8:
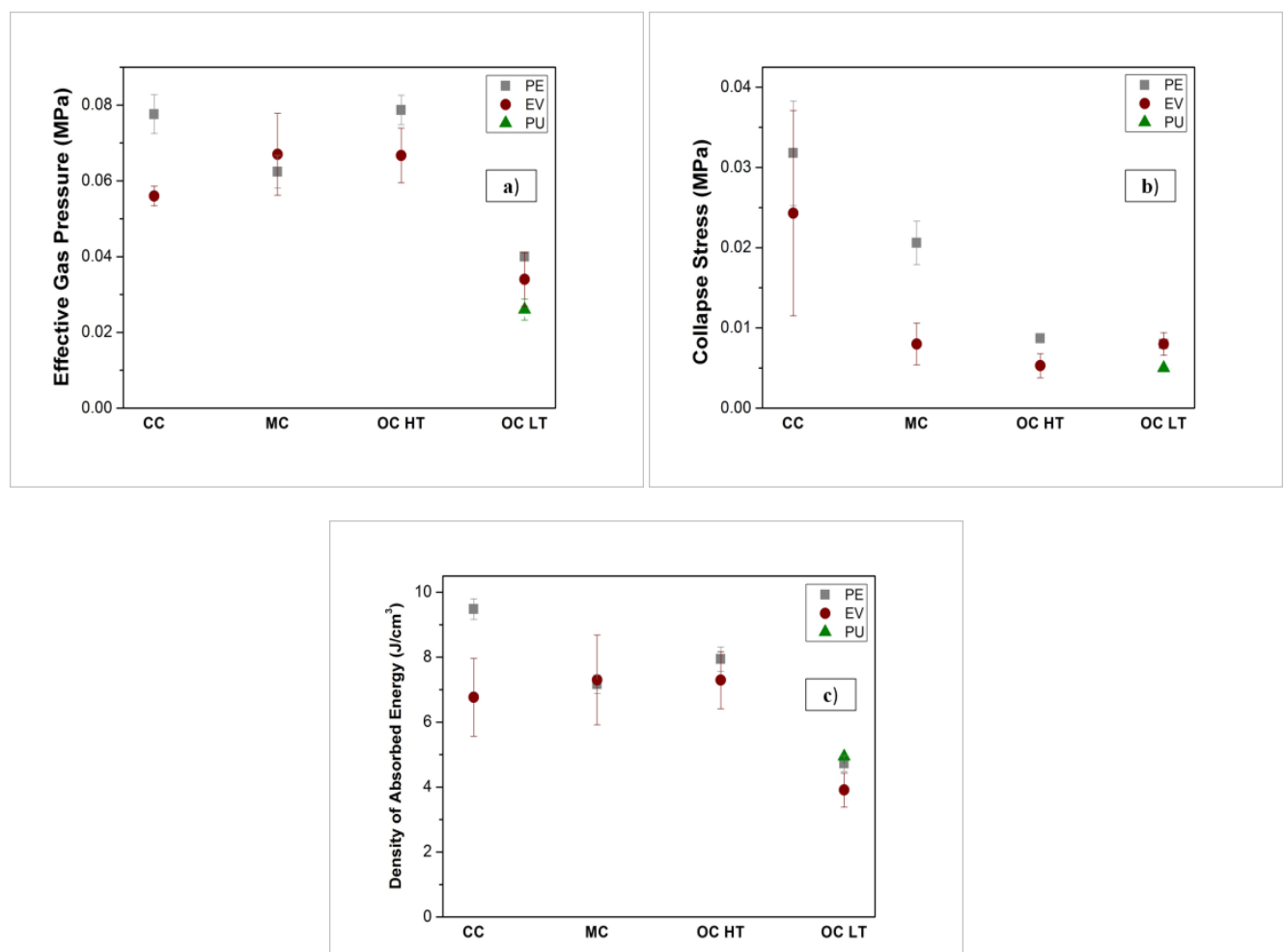

Figure 8. Mechanical parameters at high strain rates: (a) effective gas pressure (MPa); (b) collapse stress (MPa) and (c) density of absorbed energy (J/cm3) for LDPE and EVA foams under study.

On the one hand, the collapse stress follows the same trend as when it is measured at low strain rates. It decreases when the open-cell content increases and there is also a critical contribution of the type of polymer matrix. Besides that, and due to the differences in strain rate, the obtained values of collapse stress are higher in comparison to the ones estimated at low strains.

On the other hand, it is clear that regardless of the type of polymer matrix, the gas contribution in the post-collapse region has increased in a great extent for the fully interconnected open-cell polyolefin foams with high tortuosity when the tests are performed at high strain rates (Figure 8 a). In fact, the effective gas pressure values obtained for these materials, are similar to those achieved obtained for closed-cell foams. The results indicate that, at high strain rates, there is a significant contribution of the gas in the post-collapse region in open-cell foams with high tortuosity. This effect is not observed in open-cell foams with low tortuosity. Although the effective gas pressure also raises for open-cell polyolefin foams with low tortuosity at high strain rates, this increment is not as pronounced as the one observed in foams with high tortuosity and in fact, the values obtained are clearly below those of the high tortuosity materials The material based on PU behaves in a similar way to the polyolefin foams 
with low tortuosity, which is logical taking into account the low tortuosity of this material.

This effect is also observed in the density of absorbed energy (Figure $8 \mathrm{c}$ ). At high strain rates, as the contribution of the gas in open-cell polyolefin foams with high tortuosity is very high, these foams can absorb energy levels not far from those absorbed by closed-cell foams.

In order to show these effects in a clearer way, figures including a comparative analysis between the effective gas pressure and the density of absorbed energy of the foams evaluated at low and high strain rates are presented in Figure 9:
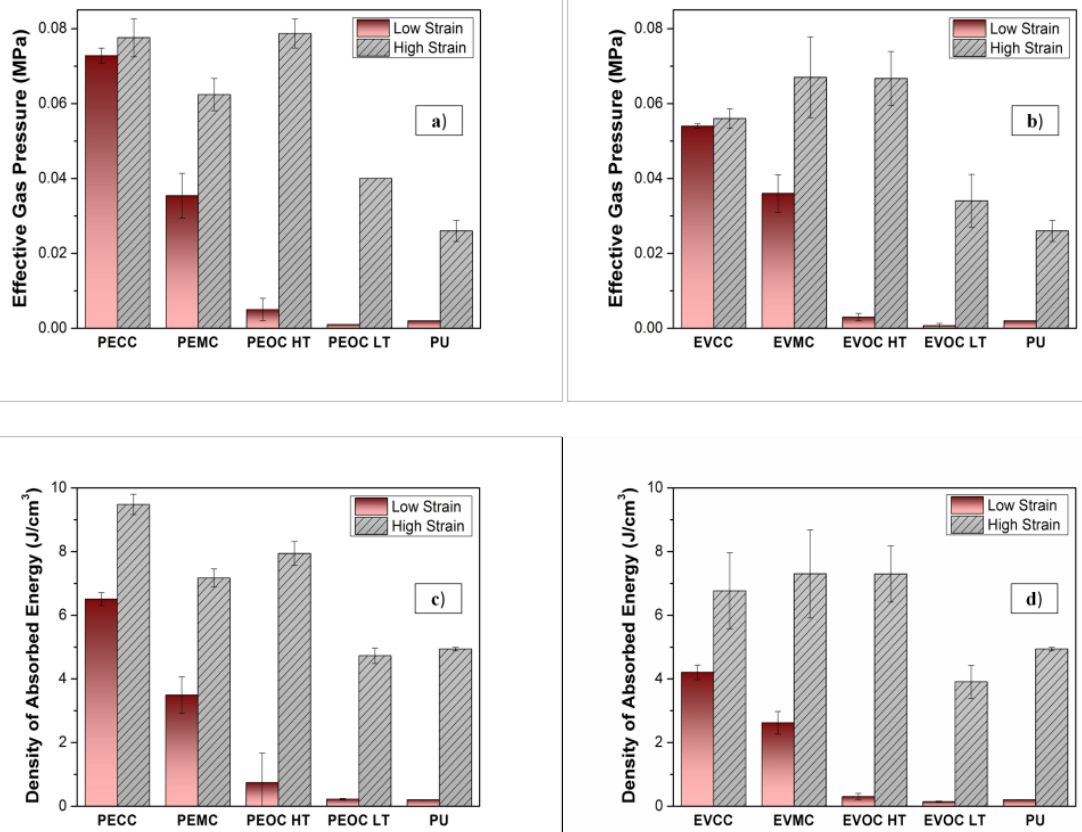

Figure 9. Comparative between the effective gas pressure (a-b) and the density of absorbed energy and (c-d) for all materials under study at low and high strain rates.

The results show that all the materials increase their values of effective gas pressure and density of energy absorbed when the experiments are performed at high strain rates. However, this increase is much more pronounced in the fully interconnected foams with a high tortuosity. In fact, these foams can reach values of the effective gas pressure and density of absorbed energy as high as that of the closed-cell foams with the same chemical composition.

There are two main contributions that could increase the values of these parameters when the strain rate increases. On the one hand, the viscoelasticity of the polymers from which the foams are produced. All the materials have been tested above its $T_{g}$, and therefore the mechanical behavior is strain rate dependent. On the other hand, another effect that could be important is related to the amount of gas that remains in the foams during the mechanical tests. 
When the experiments are performed at low strain rates, the gas has enough time to escape from the fully interconnected cellular structures comprising the foams regardless of their tortuosity. As a result, the effective gas pressure and the density of absorbed energy values are very similar for open-cell polyolefin foams with high and low tortuosity.

However, as the strain rate at which the mechanical test is performed increases, the time allowed to the gas to leave the sample is reduced, and consequently, the cellular structure tortuosity plays a key role in this aspect. As it was previously shown in the SEM micrographs, open-cell polyolefin foams are characterized by the presence of holes in the cell walls. The number and the size of the holes in the cell walls are critical regarding the contribution of the gas phase to the mechanical properties when the materials are deformed at high strain rates. Open-cell polyolefin foams with high tortuosity are characterized by the presence of few and small holes in the cell walls. The escape of the gas is hindered due to the intricate path that a gas molecule has to cover to leave the material. Therefore, at high strain rates, only a small portion of the gas entrapped in the cellular structure has enough time to leave the foam during the time that the experiment lasts. As the number and the size of the holes increases in open-cell polyolefin foams with low tortuosity, a higher amount of gas can escape, and as a result, the gas contribution is not as pronounced as in high tortuous foams. This concept is schematically represented in Figure 10.

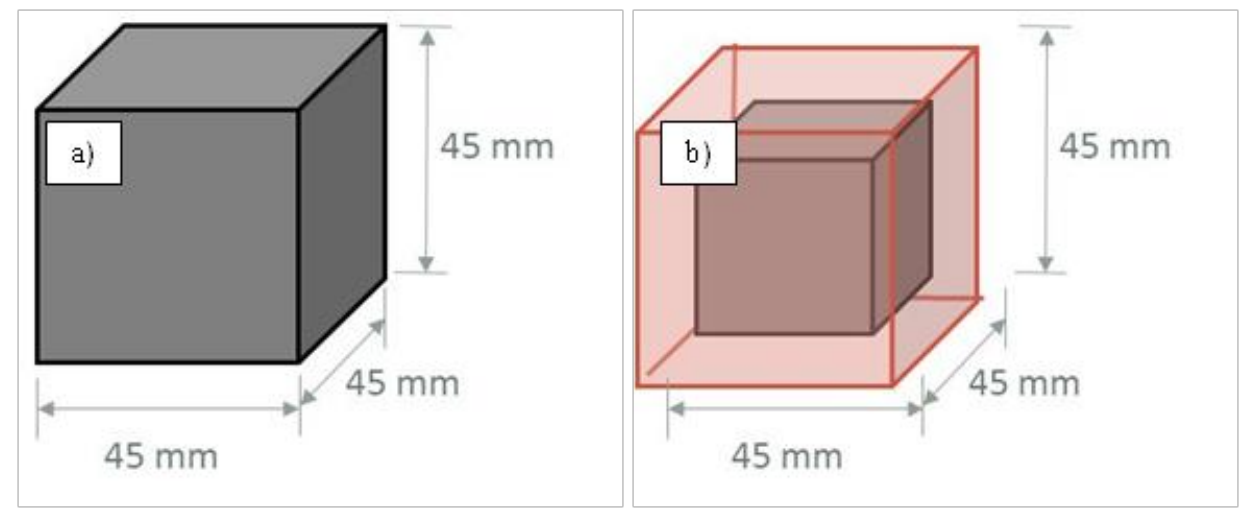

Figure 10. Scheme of the gas contribution in the cubic samples used for this study: a) initial situation and b) contribution of the gas (grey cube) after compression at high strain rates for open-cell polyolefin foams with high tortuosity.

Figure 10 (a) shows the initial situation of the foamed samples before carrying out the compressive tests at either low or high strain rates. At this time, the same amount of gas is entrapped inside the cellular structure of the materials independently of the level of interconnectivity or tortuosity. As the foams are compressed at high strain rates, some of the gas phase remains inside the foam during the compression test. This amount of gas can be estimated using a simple approach.

If it is considered that the velocity of the gas molecules is the velocity of the impact tests $(2.3 \mathrm{~m} / \mathrm{s})$ and the test takes place in $12 \mathrm{~ms}$, the distance which the gas molecules can go across can be estimated $\left(d_{1}=27.6 \mathrm{~mm}\right)$. Considering that the length of the cubic 
samples is $45 \mathrm{~mm}$, a gas molecule which stays in the middle of the sample must go across $22.5 \mathrm{~mm}(L)$ to leave the sample. However, these $22.5 \mathrm{~mm}$ is the ideal value, but taking into account the tortuosity of the cellular structure, this distance increases depending on the tortuosity value (3).

$$
\mathrm{d}_{2}=\mathrm{L} \cdot \mathrm{T}
$$

where $L$ is half of the length $(22.5 \mathrm{~mm})$ of the cubes used for the mechanical tests (shortest distance), and $T$ is the tortuosity.

The relation between both distances $\left(d_{1}\right.$ and $\left.d_{2}\right)$ indicates the percentage of gas which remains inside the sample (Table 2).

Table 2. Percentage of gas which remains in the sample in the high strain compression tests.

\begin{tabular}{|c|c|c|}
\hline Sample & Tortuosity & \% gas inside the sample \\
\hline EVOC HT & 3.8 & 67.4 \\
\hline PEOC HT & 4.0 & 69.5 \\
\hline EVOC LT & 1.9 & 36.4 \\
\hline PEOC LT & 1.9 & 36.1 \\
\hline PU & 1.9 & 37.1 \\
\hline
\end{tabular}

The results of Table 2 indicate that around $70 \%$ of the gas phase is contributing to the compressive response of high tortuosity foams at high strain rates. In other words, the samples with high tortuosity behave as samples with a closed-cell content of around a $70 \%$ as it is represented by the grey cube inserted inside the red one in the scheme of Figure $10(b)$.

This is an interesting behavior that would depend on several factors. For instance, an increase of the strain rate would promote that a higher amount of gas is not able to diffuse from the foam during the tests, and therefore, an improved mechanical behavior should be expected. Moreover, testing samples with higher dimensions would also have an effect on the mechanical performance, because the proportion of gas retained in the structure would be higher. Therefore, better performance should be expected.

\section{CONCLUSIONS}

The mechanical behavior in compression, at both low and high strain rates, of several low-density open-cell polyolefin-based cellular materials with different gas-phase interconnectivity and different level of tortuosity has been studied.

At both strain rates, the collapse stress is mainly influenced by the chemical composition (is higher when the polymer used to produce the foam is stiffer) and by the of level cellular structure interconnectivity rather than by the tortuosity. 
Experimental values decrease as open-cell content increases, and they are slightly affected by the foams tortuosity.

Concerning the effective gas pressure and the density of the absorbed energy, not only the cellular structure interconnectivity but also the tortuosity plays a key role in these parameters. It has been found that at low strain rates, both open-cell polyolefin foams with high and low tortuosity behave similarly to an open-cell PU foam used as a reference. However, this behavior changes completely at high strain rates. Since the open-cell polyolefin foams with high tortuosity present small holes in the cell walls, the gas are not able to escape at high strain rates and therefore the contribution of gas increases abruptly in comparison to the one achieved at low strain rates. As a result, open-cell polyolefin foams with high tortuosity present, at high strain rates, a similar mechanical behavior as the one showed by closed-cell foams. This effect is not observed in the case of open-cell polyolefin foams with low tortuosity, because these materials are characterized by the presence of larger holes in the cell walls, and thus a larger percentage of the gas can escape from the foam during the mechanical tests even at high strain rates.

It is then concluded that fully interconnected low-density foams with high tortuosity present an unexpected strong strain rate dependent mechanical performance, being very soft at low strain rates and showing a high energy absorption at high strain rates. It is also expected that this behavior is not limited to polyolefin-based foams. Any other type of low-density flexible foam with a high tortuosity will show a similar mechanical performance.

\section{ACKNOWLEDGMENTS}

Financial support from DI grant DI-15-07952 (E._Lopez) from the Spanish Ministry of Economy, Industry, and Competitiveness and from MINECO, FEDER, UE (MAT201569234-R) is gratefully acknowledged.

\section{REFERENCES}

1. Low density cellular plastics. Physical basis of behavior; Hilyard, N.C; Cunningham , A. Eds.;, Chapman and Hall, London, 1994.

2. Handbook of Polymeric Foams and Foam Technology; Klempner, D.; Frisch, K.C. Eds.; Hanser Publishers: Munich, 1991.

3. Polymer Foams Handbook; Mills, N. Eds.; Elsevier Science Publishers: Amsterdam, 2007.

4. Rodriguez-Perez, M.A. Adv. Polym. Sci. 2005, 184, 97-126.

5. Handbook of Polymeric Foams and Foam Technology, second ed ; Klempner, D.; Sendijarevic, V. Eds.; Hanser Publishers, Munich, 2004.

6. Demharter, A. Cryogenics. 1998, 37, 305-312.

7. Tseng, C.; Yamaguchi, M.; Ohmori, T. Cryogenics. 1997, 37, 305-312.

8. Mills, N.J.; Fitzgerald, C.; Gilchrist, A.; Verdejo, R. Compos. Sci. Technol. 2003, 63, 2389-2400. 
9. Verdejo, R.; Mills, N.J. J. Biomech. 2004, 37, 1379-1386.

10. Avalle, M.; Belingardi, G.; Montanini, R. Int. J. Impact. Eng. 2001, 25, 455-472.

11. Patten, W.N.; Sha, S.; Mo, C. J. Sound. Vib. 1998, 217, 145-161.

12. Ouassim, H.; Mighri, F.; Rodrigue, D. Cell. Polym. 2018, 37, 153-168.

13. Dynamics of fluids in porous media; Bear, J. Elsevier Science Publishers: Amsterdam, 1972.

14. Pfretzschner, J.; Rodriguez, R.M. Polym. Test. 1999, 18, 81-92.

15. Moussatov, A.; Ayrault, C.; Castagnède, B. Ultrasonics. 2001, 39, 195-202.

16. Fellah, Z.E.; Berger, S.; Lauriks, W.; Depollier, C.; Aristegui, C.; Chapelon, N.Y. J. Acoust. Soc. Am. 2003, 113, 2424-2433.

17. Sobieski, W. Granul. Matt. 2016, 18, 72-81.

18. Saomoto, H.; Katagiri, J. Theor. Appl. Mech. Lett. 2015, 5, 177-180.

19. Cellular Solid: Structure and Properties, 2ndedn; Gibson, L.J.; Ashby, M.F. Eds.; Pergamon, Oxford, 1998.

20. Gong, L.; Kyriakides, S.; Jang, W.Y. Int. J. Solids. Struct. 2005, 42, 1355-1379.

21. Zhu, X.H.; Knott, J.F.; Mills, N.J. J. Mech. Phys. Solids. 1997, 45, 319-343.

22. Rodriguez-Perez, M.A.; Alvarez-Lainez, M.; de Saja, J.A. J. Appl. Polym. Sci. 2009, 114, 1176-1186.

23. Gent, A.N.; Thomas, A.G. Rubber. Chem. Technol. 1963, 36, 597-611.

24. Wegner, L.D.; Gibson, L.J. Acta. Metall. Mater. 1995, 43, 1651-1667.

25. Fatima Vaz, M.; Fortes, M.A. J. Mater. Sci. Lett. 1993, 12, 1408-1410.

26. Polyolefin Foams; Mills, N.J. Rapra Review Reports, vol. 14, 2003.

27. Ruiz-Herrero, J.L.; Rodriguez-Perez, M.A.; de Saja, J.A. Polymer, 2005, 46, 31053110.

28. Mills, N.J.; Rodriguez-Perez, M.A. Cell. Polym. 2001, 20, 79-100.

29. Weaire, D.; Fortes, M.A. Adv. Phys. 1994, 43, 685-738

30. Ruiz-Herrero, J.L.; Rodriguez-Perez, M.A.; de Saja, J.A. Material Science Forum, 2005, 480-481, 513-518.

31. Handbook of Polymer Foams; Eaves, D. Eds.; Rapra Technology, Shawbury, 2004.

32. Ruiz-Herrero, J.L.; Rodriguez-Perez, M.A.; de Saja, J.A. Polym. Test. 2005, 24, 641-647.

33. Rodriguez-Perez, M.A.; Hidalgo, F.; Solorzano, E.; de Saja J.A. Polym. Test. 2009, 28, 188-195. 


\subsection{Mechanical properties: Foams based on EVA 12 and EBA}

The mechanical properties of EVA 12 and EBA foams were also characterized by performing mechanical tests at low and high strain rates. The samples used were also cubes of $45 \times 45 \times 45 \mathrm{~mm}^{3}$, and a strain of $75 \%$ was reached.

As it was previously mentioned, three mechanical parameters were analyzed: the collapse stress $(\mathrm{MPa})$, the effective gas pressure $(\mathrm{MPa})$ and the density of absorbed energy $\left(\mathrm{J} / \mathrm{cm}^{3}\right)$.

In the previous section, it was determined, the different mechanical behavior of the LDPE and EVA 18 foams, depending on the interconnectivity and tortuosity of the cellular structure and the strain rate of deformation. A similar study was performed with EVA 12 and EBA in order to determine if similar tendencies were found for these two different polymer matrices.

Firstly, the results corresponding to the tests at low strain rates will be described, and the last part of the section will cover the results obtained at high strain rates.

\section{- Low strain rates}

The effective gas pressure, the collapse stress and the density of absorbed energy are shown below in Figure 4.2:
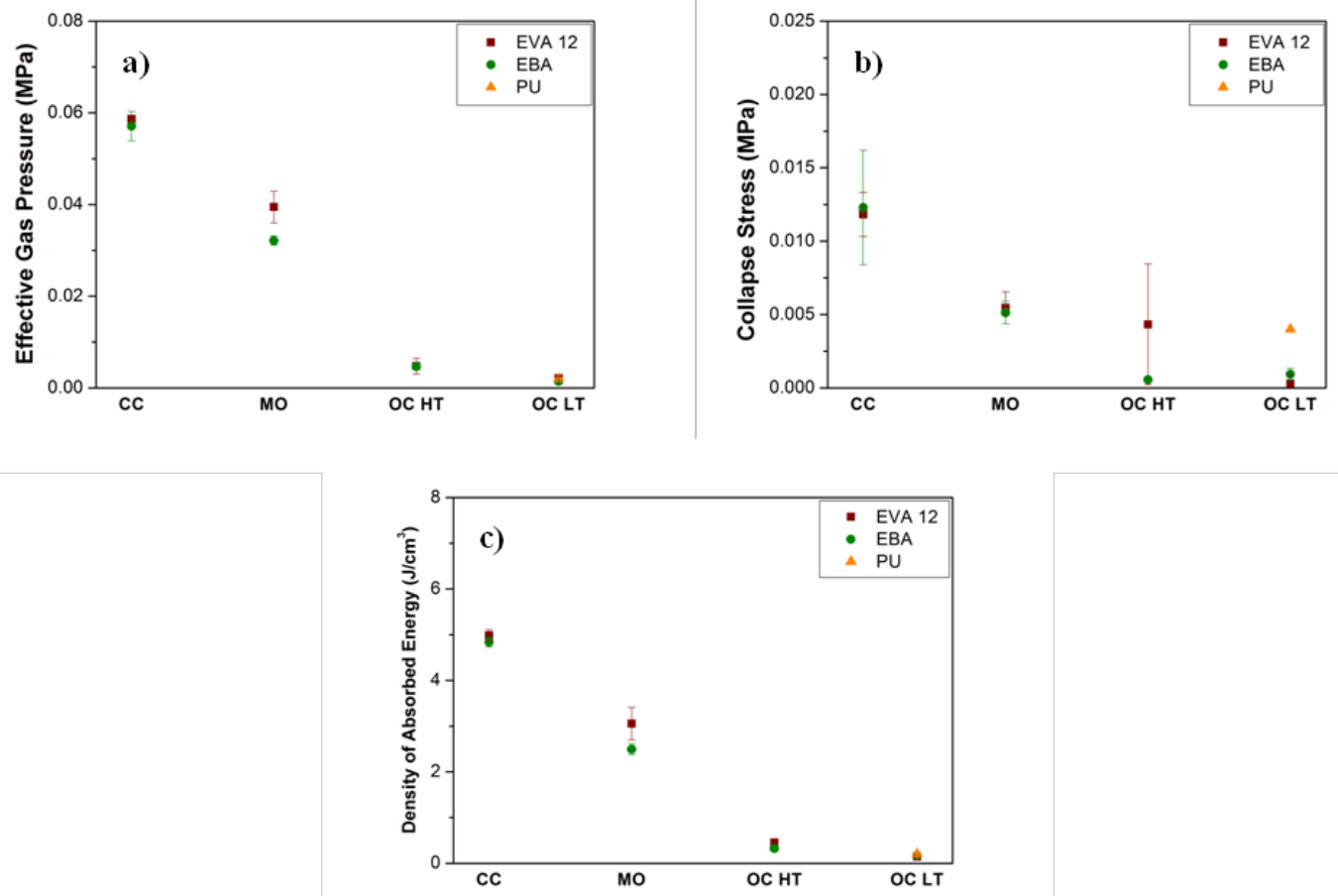

Figure 4.2. Mechanical parameters at low strain rates: a) effective gas pressure (MPa); b) collapse stress (MPa) and c) density of absorbed energy $\left(\mathrm{J} / \mathrm{cm}^{3}\right)$ for EVA 12, EBA and the reference PU foam. 
The effective gas pressure $(\mathrm{MPa})$ accounts for the contribution of gas in the postcollapse region, where the shape of the curve is completely different depending on the interconnectivity of the cellular structure. In closed-cell foams, the stress increases due to the gas contribution, whereas in open-cell foams the curve is characterized by the presence of a plateau (no gas contribution). In Figure 4.2 a), it is observed, how the contribution of the gas depends on the cellular structure interconnectivity, as it was already seen in LDPE and EVA 18 foams (section 4.2). The gas contribution of the closed-cell foams is the highest, reducing this contribution as the level of interconnectivity increases. Furthermore, this statement does not depend on the type of polymer matrix, since the same tendency was found for the four polymer matrices under study. Besides, the tortuosity is not playing any considerable role in this parameter, since the gas contribution in both types of open-cell foams is negligible, behaving them similarly to the open-cell PU foam.

To establish differences among polymer matrices, the collapse stress (MPa) is a parameter which gives essential information about it. Figure $4.2 \mathrm{~b}$ ) shows the collapse stress values of the foams, and it can be inferred, that open-cell foams collapse at lower stresses than the foams with lack of interconnectivity. Besides, if EVA 12 and EBA foams are compared, no notorious differences between both polymer matrices were found, except for the open-cell foam with high tortuosity, in which the gas contribution of the EVA 12 OC HT is higher than the EBA OC HT. This can be explained, taking into account that the level of tortuosity of the EVA 12 OC HT (4.3) is slightly higher than the tortuosity value of the EBA OC HT foam (4.0).

The density of absorbed energy $\left(\mathrm{J} / \mathrm{cm}^{3}\right)$ is displayed in Figure $4.2 \mathrm{c}$ ). The energy absorption is a quite interesting parameter, from which useful information can be extracted about materials. Furthermore, in our research, this parameter helped us to corroborate the results obtained for the effective gas pressure since the energy absorption must be higher when the cellular structure is scarcely interconnected. What is observed in Figure $4.2 \mathrm{c}$ ) is the expected behavior, the highest density of absorbed energy is corresponded to the closed-cell foams, whereas the open-cell foams, regardless of the tortuosity, presented the lowest absorptions. The density of absorbed energy of MO foams is located in between that of the closed and the open-cell ones.

Concerning the mechanical tests at low strain rates, it can be concluded that the EVA 12 and EBA foams present similar trends to the ones already observed for LDPE and EVA 18. The cellular structure parameter which markedly affects the mechanical properties is the level of interconnectivity, whereas the effect of the tortuosity is not so critical. In addition, these two polymeric matrices present a similar degree of crystallinity and mechanical properties, and due to this, the corresponding foams also show similar characteristics.

\section{- High strain rates}

Once the mechanical properties at low strain rates were analyzed, the study was extended to characterize the mechanical behavior of EVA 12 and EBA foams at high 
strain rates. In the research article included in the previous section, it was proven that the tortuosity has a critical effect on the mechanical properties depending on the strain rate. One the one hand, it was observed, that the gas contribution of LDPE OC HT and EVA 18 OC HT foams steeply increased at high strain rates, behaving these foams like closed-cell foams. On the other hand, the LDPE OC LT and EVA OC LT foams resembled the mechanical behavior of the open-cell PU foam at both strain rates of deformation.

In order to determine if this double mechanical behavior of the open-cell foams with high tortuosity also appeared in EVA 12 and EBA foams, impact tests were performed by using an instrumented falling weight impact tester at velocity 500 times higher than the one established at low strain rates (see article, experimental section, mechanical properties). Cubic samples with similar dimensions to the ones employed at low strain rates were also used.

The same mechanical parameters were studied: the effective gas pressure, the collapse stress and the density of absorbed energy

One load-unload cycle was performed, reaching strains higher than $75 \%$, which was the strain limit used at low strain rates. However, for comparative purposes, the effective gas pressure and the collapse stress were estimated in the same strain range (from $20 \%$ to $60 \%$ ) than in the estimations at low strain rates. Furthermore, the density of absorbed energy was calculated as the area under the curve from $0 \%$ to $75 \%$, establishing equal integration limits at both low and high strain rates.

The results obtained for EVA 12 and EBA foams are disclosed in Figure 4.3: 

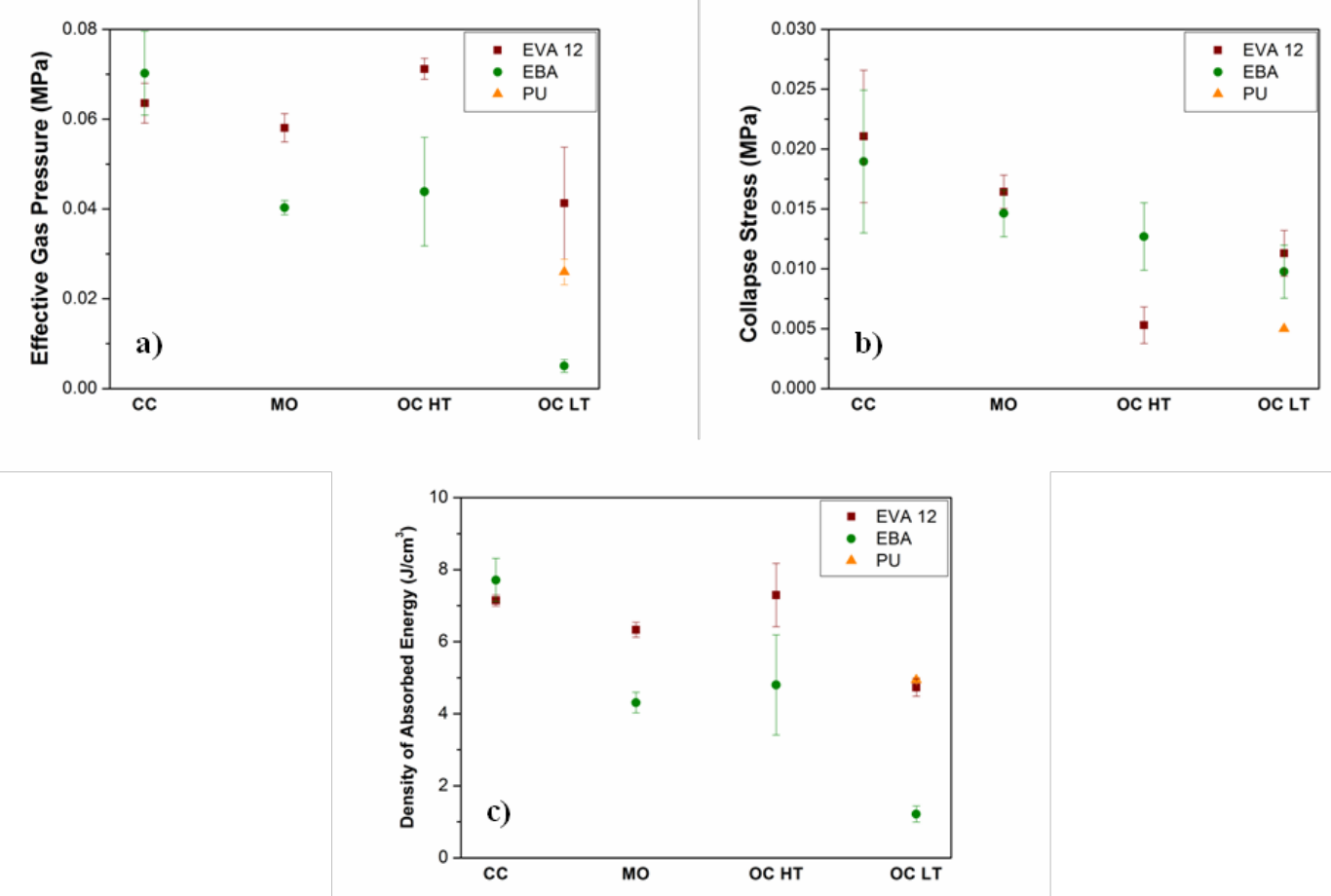

Figure 4.3. Mechanical parameters at high strain rates: a) effective gas pressure (MPa); b) collapse stress (MPa) and c) density of absorbed energy $\left(\mathrm{J} / \mathrm{cm}^{3}\right)$ for EVA 12 and EBA foams and the reference PU foam.

Figure 4.3 a) shows the contribution of gas at high strain rates. In spite of increasing the strain rate of deformation, the gas contribution in CC and MO foams is not affected, and thus, the gas is contributing to the mechanical response of these foams. However, regardless of the type of polymer matrix, the EVA12 and EBA OC HT foams present the same behavior as their counterparts based on LDPE and EVA 18. At high strain rates, a considerable amount of gas remains inside the open-cell foams with high tortuosity, since the gas does not have enough time to escape out. The small size of the holes in OC HT foams hinders the escape of the gas, and thus, the gas is contributing to the mechanical response, increasing the stress in the post-collapse region rather than presenting a plateau.

If we pay attention to the OC LT foams, different mechanical responses are obtained for EVA 12 and EBA OC LT foams. It could be affirmed that the gas contribution is quite elevated for the EVA 12 OC LT foam, whereas EBA OC LT shows the opposite result. The presence of gas in EVA 12 OC LT foam could be explained taking into account that the tortuosity of this particular foam is slightly higher than the rest of OC LT foams, 2.6 for EVA 12 OC LT against 1.9 for the rest of the OC LT foams (see Chapter 3, Table 3.4). It is probably that the EVA 12 OC LT foam has smaller holes which limit the movement of the gas. However, it is quite challenging to explain why the EBA OC LT foam presents negligible gas contributions (even this parameter increases for open-cell PU foam when the results at low and high strain rates are compared). One hypothetical explanation could be bonded to the heterogeneity of the cellular structure of the foams. It could have happened that the EBA OC LT samples 
used for mechanical characterizations had very large holes which allowed the gas escape. Considering that the size of many cells of these OC LT foams is larger than the cells of the open-cell PU foam, holes larger than the size of the PU foam cells can be created. This could explain why the gas contribution in the EBA OC LT foam is so low, whereas the values for the open-cell PU foam are higher.

To exemplify better the differences in the gas contributions at high and low strain rates of deformation, Figure 4.4 shows a comparison between the effective gas pressure at both strain rates. Both for EVA 12 (Figure 4.4 a) and EBA (Figure 4.4 b) the mechanical response of the OC HT foams are strain-rate dependent, behaving these foams as opencell foams at low strain rates and as closed-cell foams at high strain rates.
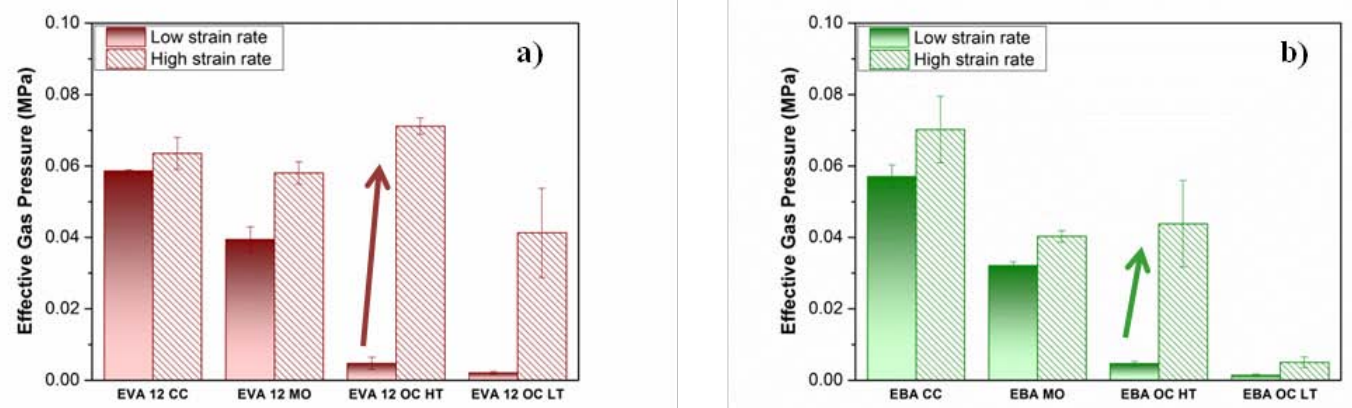

Figure 4.4. Comparative of the effective gas pressure at low and high strain rates for a) EVA 12 and b) EBA foams.

The effect of the tortuosity on the effective gas pressure is not reflected in the collapse stress (Figure $4.3 \mathrm{~b}$ ). The same trend as the one found at low strain rates was found. The closed-cell foams collapse at higher stress than the other foams with different interconnectivity, whereas lower stresses are necessary to collapse the open-cell foams regardless of the type of polymer matrix.

As it was previously explained, the presence or the absence of gas inside the cells affects the energy absorption. As the effective gas pressure steeply increases in the OC HT foams at high strain rates, these materials are able to absorb as much energy as the closed-cell foams, particularly in the case of the EVA 12 OC HT foam. The capability of absorbing energy of the EBA OC HT also raises, but not in the same extent as the EBA $\mathrm{CC}$ foam (Figure $4.3 \mathrm{~b}$ ).

Focusing on the open-cell foams with low tortuosity, since a larger amount of gas remains inside the cellular structure of these foams at high strain rates, the density of absorbed energy increases for the EVA 12 OC LT and the open-cell PU foams. However, the EBA OC LT does not present this response because the gas is able to escape as it was previously explained. These results are in agreement with the ones concerning the effective gas pressures. 


\subsection{Conclusions}

The mechanical characterization allowed us to come to some interesting conclusions about the mechanical behavior of crosslinked polyolefin foams with different interconnectivity and tortuosity, which can be extrapolated to other flexible open-cell foams.

Concerning open-cell foams, the contribution of the gas does not depend on the tortuosity at low strain rates, behaving OC HT and OC LT materials like open-cell foams, as in the case of the open-cell PU foam. However, the tortuosity has a critical effect at high strain rates. The gas has a considerable contribution in OC HT foams, whereas this contribution of gas is not relevant in OC LT foams. The relationship between effective gas pressure and the open-cell content is shown in Figure 4.5:
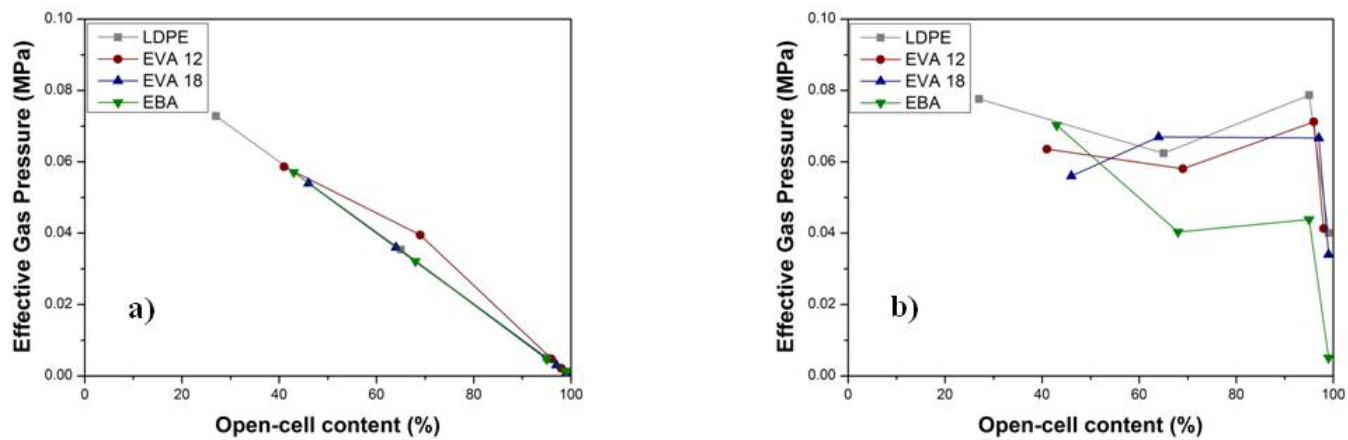

Figure 4.5. Effective gas pressure versus open-cell content a) low strain rates and b) high strain rates.

It is observed in Figure 4.5 a) that the level of interconnectivity (open-cell content) has a significant contribution on the effective gas pressure, as it has been discussed in the previous sections of this chapter. However, at high strain rates, both the interconnectivity and the tortuosity are contributing to the effective gas pressure (Figure 4.5 b).

It is also important to mention that the average values are higher at high strain rates than at low strain rates. It has been discussed that the contribution of the gas at high strain rates was high for almost all types of foams due to the high velocity of this test, reducing the time, that the gas needs for escaping out of the sample, considerably.

For the same data, the collapse stress was also estimated. Figure 4.6 shows how the collapse stress varies with the open-cell content at low and high strain rates for the four polymers considered in this research. 

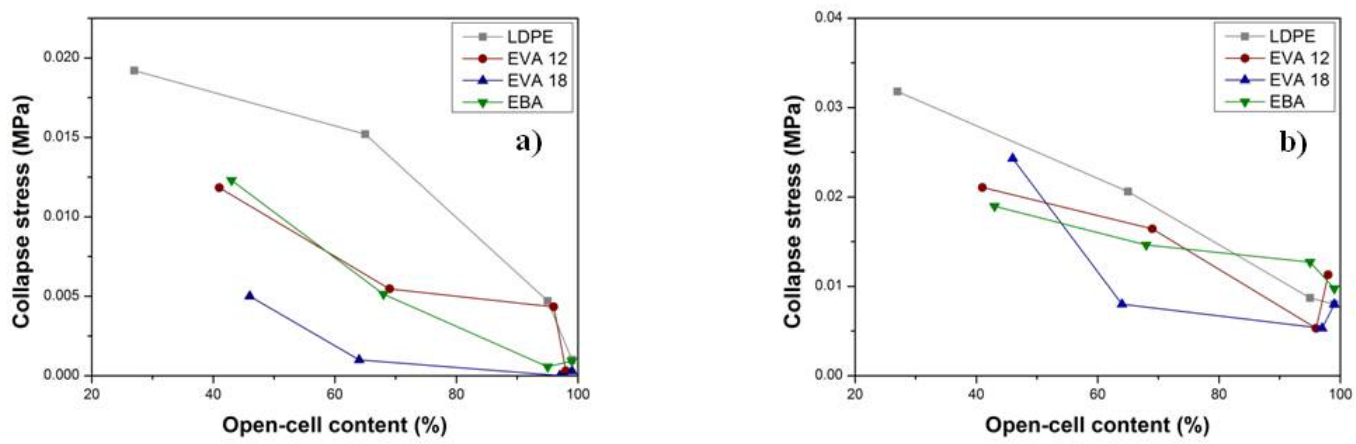

Figure 4.6. Collapse stress versus open-cell content a) low strain rates and b) high strain rates.

It can be observed that the stress necessary to collapse the foam decreases as the opencell content increases. The level of interconnectivity has a critical influence on this parameter. However, not only the interconnectivity but also the composition of the polymer matrix affects the collapse stress. Bearing in mind the crystallinity of the polymer matrix (see Chapter 3, Table 3.1) the most crystalline polymer (LDPE) presents the highest collapse stress values for $\mathrm{CC}$ and $\mathrm{MO}$ foams (Figure $4.7 \mathrm{a}$ ). The collapse stress values decrease as the crystallinity of the polymers also does at low strain rates. At high strain rates, it is also fulfilled that LDPE presents the highest values of collapse stress. This is reflected in Figure 4.7 (low strain rates) and Figure 4.8 (high strain rates), in which the collapse stress values of the four types of foams of each polymer matrix is plotted against the crystallinity at both strain rates.
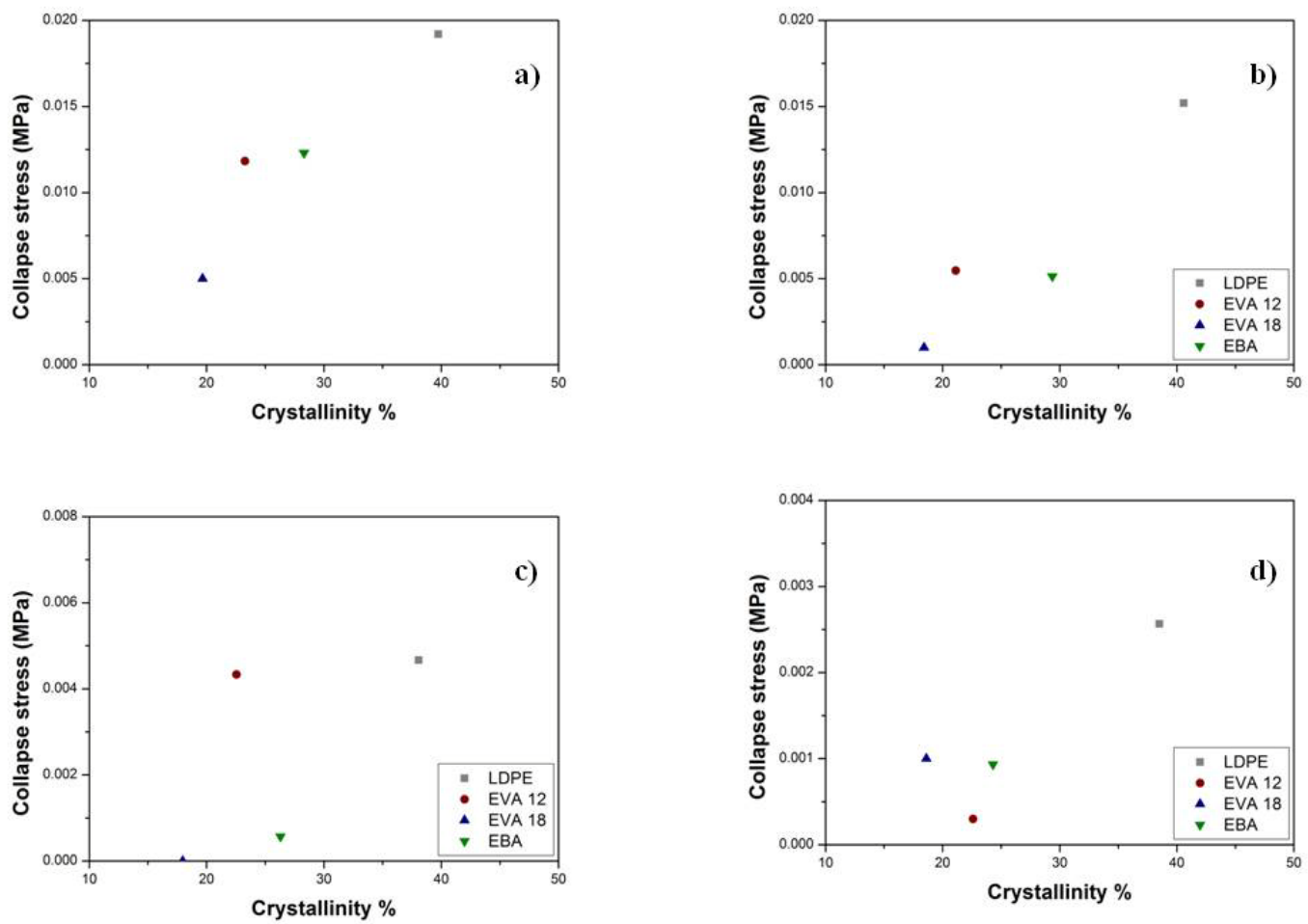

Figure 4.7. Collapse stress values at low strain rates versus crystallinity: a) CC foams; b) MO foams; c) OC HT foams and d) OC LT foams. 
The results at low strain rates are presented in Figure 4.7. A clear trend between the collapse stress versus crystallinity is observed in the foams with a low level of interconnectivity. The collapse stress decreases as the crystalline also does for CC (Figure $4.7 \mathrm{a}$ ) and $\mathrm{MO}$ foams (Figure $4.7 \mathrm{~b}$ ). The effect of the vinyl acetate content is observed for EVA-based materials, being the collapse stress lower for the EVA with the highest vinyl acetate content. However, these trends are not so clear for materials with a high level of interconnectivity. It is fulfilled that the collapse stress for LDPE (the most crystalline polymeric matrix) is the highest, but there is not any trend for the other polymeric matrices (Figure $4.7 \mathrm{c}$ ) and Figure $4.7 \mathrm{~d}$ ).
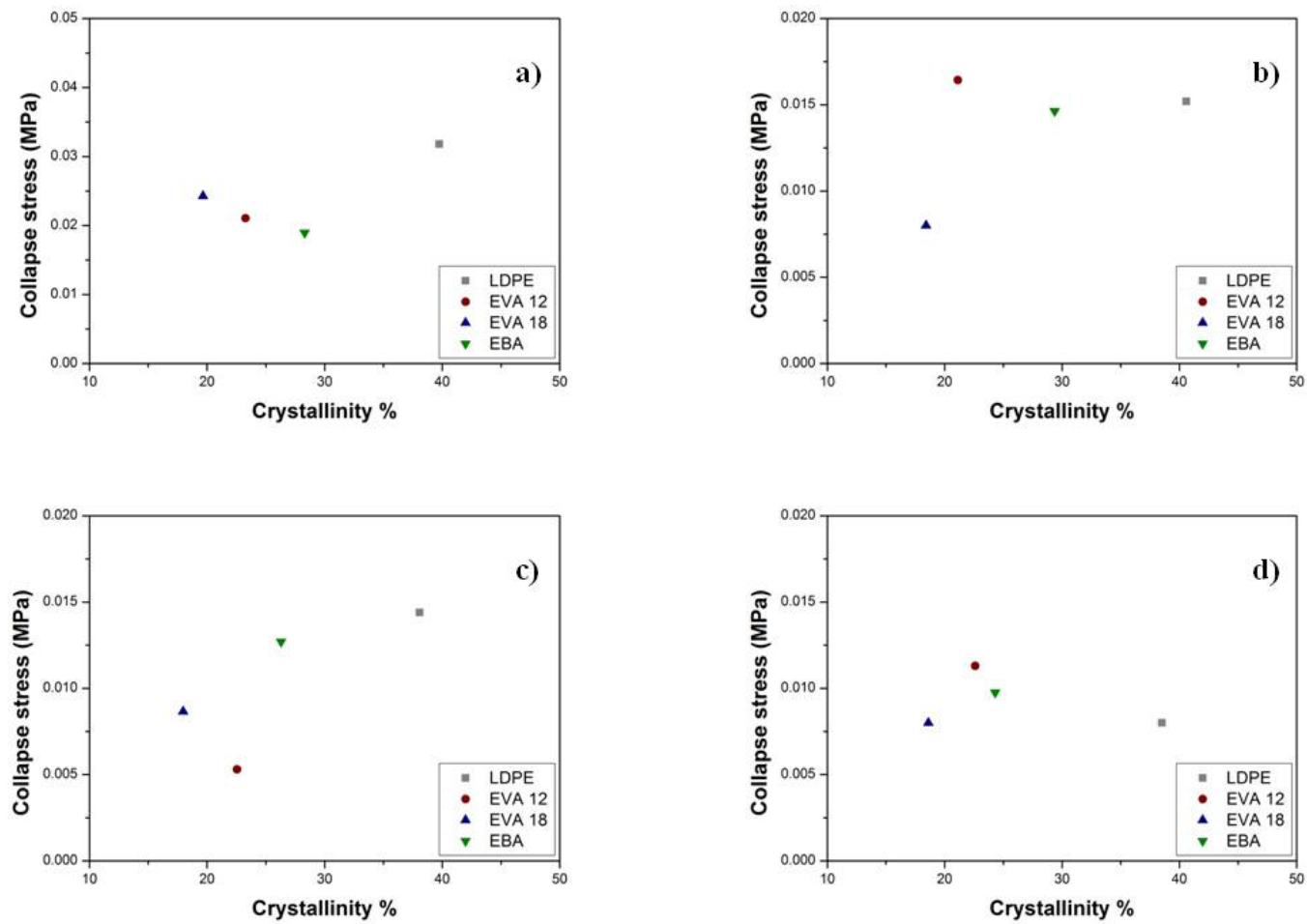

Figure 4.8. Collapse stress values at high strain rates versus crystallinity: a) CC foams; b) MO foams; c) OC HT foams and d) OC LT foams.

Figure 4.8 shows the results of the collapse stress versus crystallinity at high strain rates. In CC foams, the LDPE CC foam presents the highest value of collapse stress, which is in agreement with the results observed at low strain rates (Figure 4.8 a). EVA $18 \mathrm{MO}$ foam has the lowest collapse stress values of the series, and therefore for CC and $\mathrm{MO}$ foams, it can be concluded that at high strain rates there is also a slight dependency of the collapse stress with crystallinity for foams with a low or intermediate level of interconnectivity. For open-cell foams, it is also observed at high strain rates, that there is not any relationship between both parameters (Figure $4.8 \mathrm{c}$ ) and Figure $4.8 \mathrm{~d}$ ).

Figure 4.7 and Figure 4.8 allow us to conclude that the effect of crystallinity on the collapse stress is connected with the cellular structure interconnectivity. One the one hand, for CC and MO, foams the collapse stress depends on the level of 
interconnectivity. On the other hand, for OC foams, it seems that the cellular structure tortuosity is the parameter, which highly affects the results.

The density of absorbed energy has also been estimated at both strain rates. Figure 4.9 shows a similar comparison as in Figure 4.5 or Figure 4.6, but representing the density of absorbed energy.
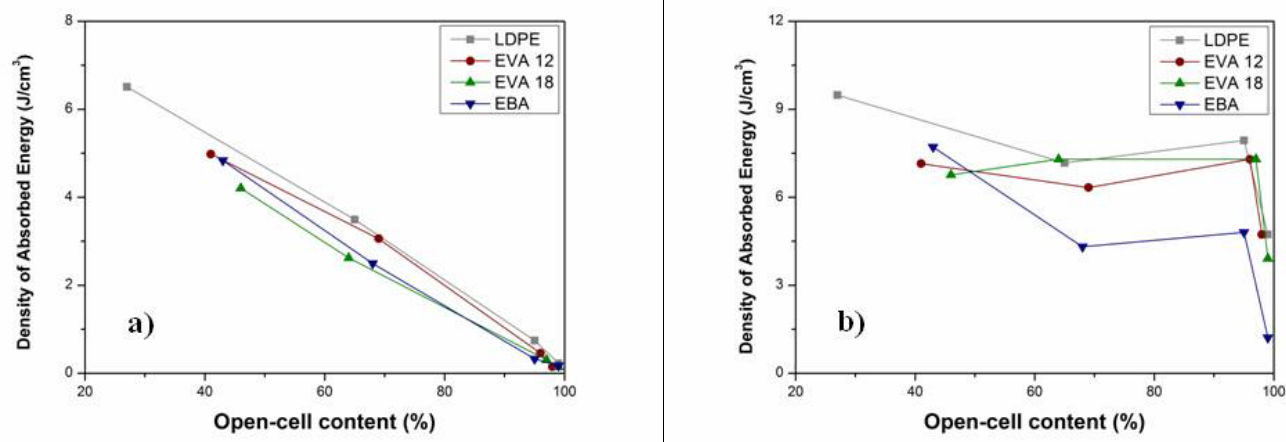

Figure 4.9. Density of absorbed energy versus open-cell content a) low strain rates and b) high strain rates.

The results for the density of absorbed energy shows a similar trend to the one observed for the effective gas pressure. At low strain rates, this parameter is dependent on the interconnectivity (open-cell content) whereas, at high strain rates, it depends both on the interconnectivity and tortuosity.

Figure 4.10 (low strain rates) and Figure 4.11 (high strain rates) shows the relationship between the average values of the density of absorbed energy of the four types of foams and the crystallinity of the materials. 

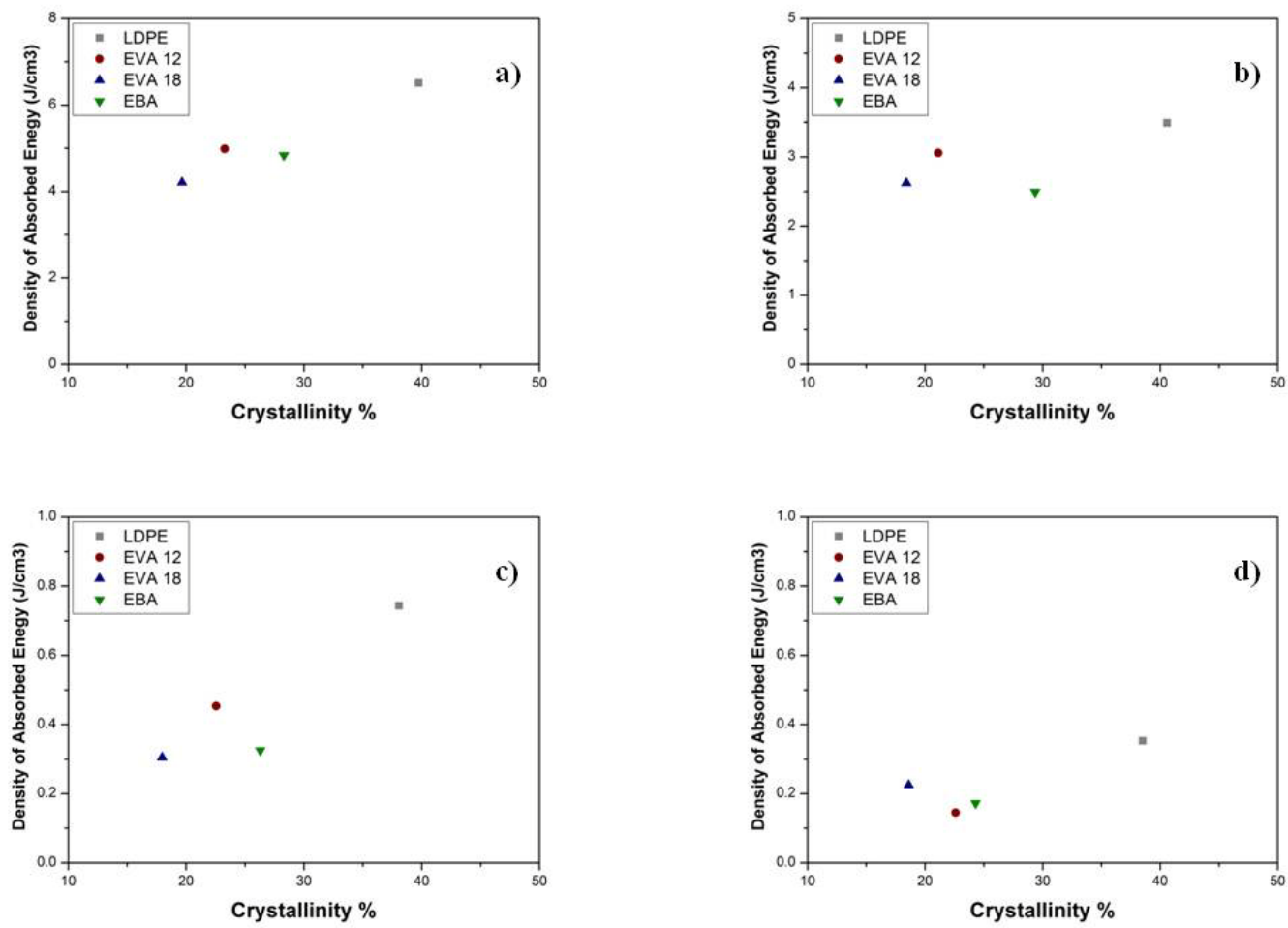

Figure 4.10. Density of absorbed energy at low strain rates versus crystallinity: a) CC foams; b) MO foams; c) OC HT foams and d) OC LT foams.

It is observed in Figure 4.10 that regardless of the cellular structure interconnectivity, the foams based on the most crystalline polymeric matrix (LDPE) are able to absorb more energy than the counterparts. The tendency between crystallinity and density of absorbed energy is not so clear for the other polymeric matrices. It is fulfilled that the EVA 18-based foams (the most amorphous polymeric matrices) present the lowest absorbed energies for CC and OC HT foams (Figure 4.10 a) and Figure $4.10 \mathrm{c}$ ). However, the differences in the absorbed energy values are not so relevant for EVA 12, EVA 18 and EBA, behaving the foams based on these polymeric matrices similarly. At low strain rates, it can be concluded that the effect of crystalline on the density of absorbed energy is clear for the LDPE with respect to the other polymeric matrices. For this parameter, the level of cellular interconnectivity is not contributing.

Figure 4.11 shows the results of the density of absorbed energy versus crystallinity at high strain rates. 

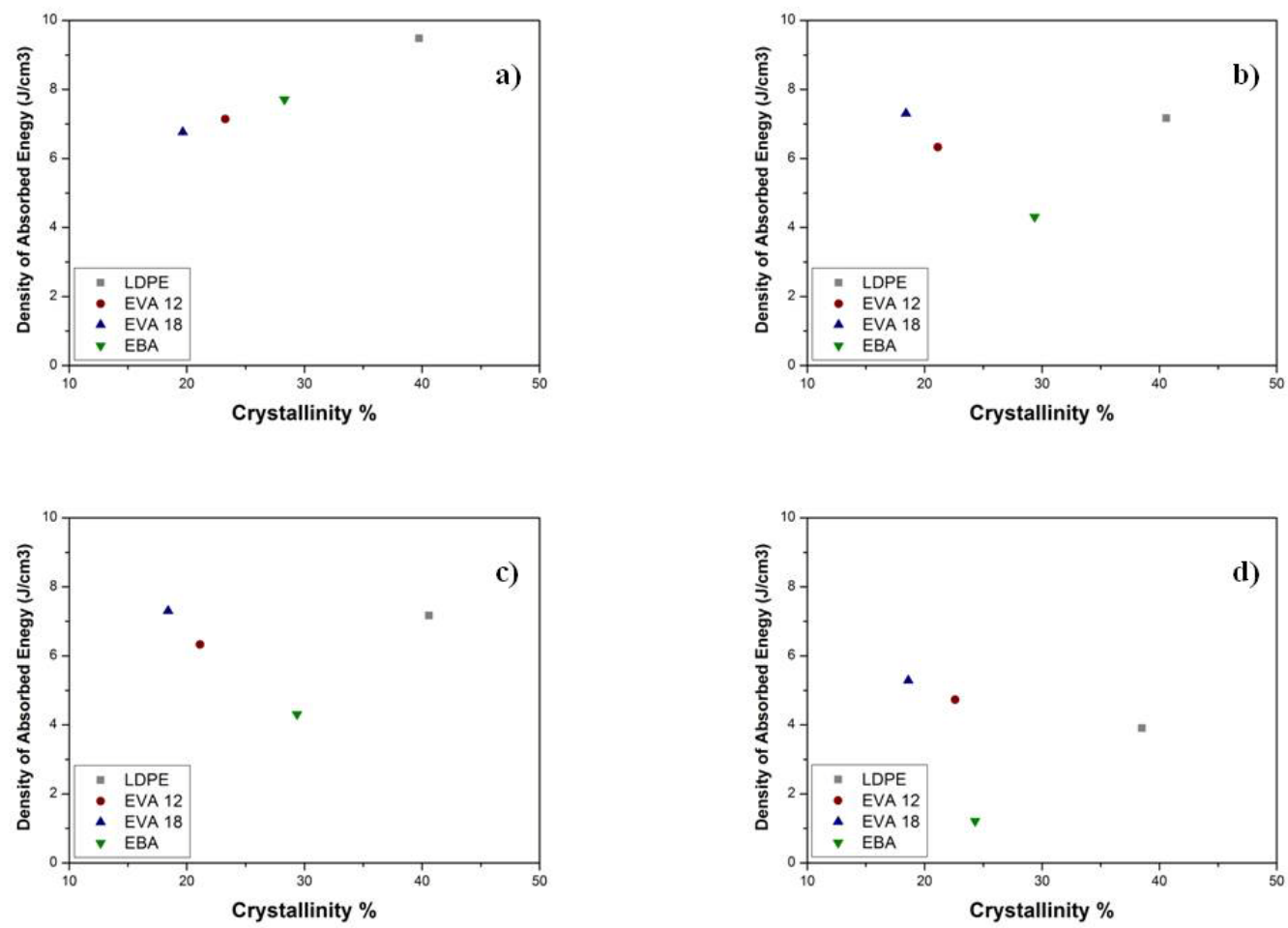

Figure 4.11. Density of absorbed energy at high strain rates versus crystallinity: a) CC foams; b) MO foams; c) OC HT foams and d) OC LT foams.

At high strain rates, the effect of crystallinity on the density of absorbed energy is observed for CC foams (Figure 4.11 a). The density of absorbed energy decreases as the crystallinity also does. However, for the other levels of interconnectivity, there is not any evident tendency between crystallinity and the density of absorbed energy (Figure 4.11 b) and Figure 4.11 c) and Figure 4.11 d).

It can be concluded that the effect of crystallinity is relevant in closed-cell foams. For open-cell foams, as explained for the collapse stress, it seems that the tortuosity is playing a critical role instead of the nature of the polymeric matrix.

To conclude this chapter, in Chapter 2, section 2.5.1, the compressive stress at $50 \%$ of strain was plotted against the density for several commercial foams (commercial crosslinked closed-cell LDPE foams, flexible closed-cell PU foams and flexible open-cell PU foams) at low strain rates. Figure 4.12 compares the results obtained from literature data with those measured in our materials. 


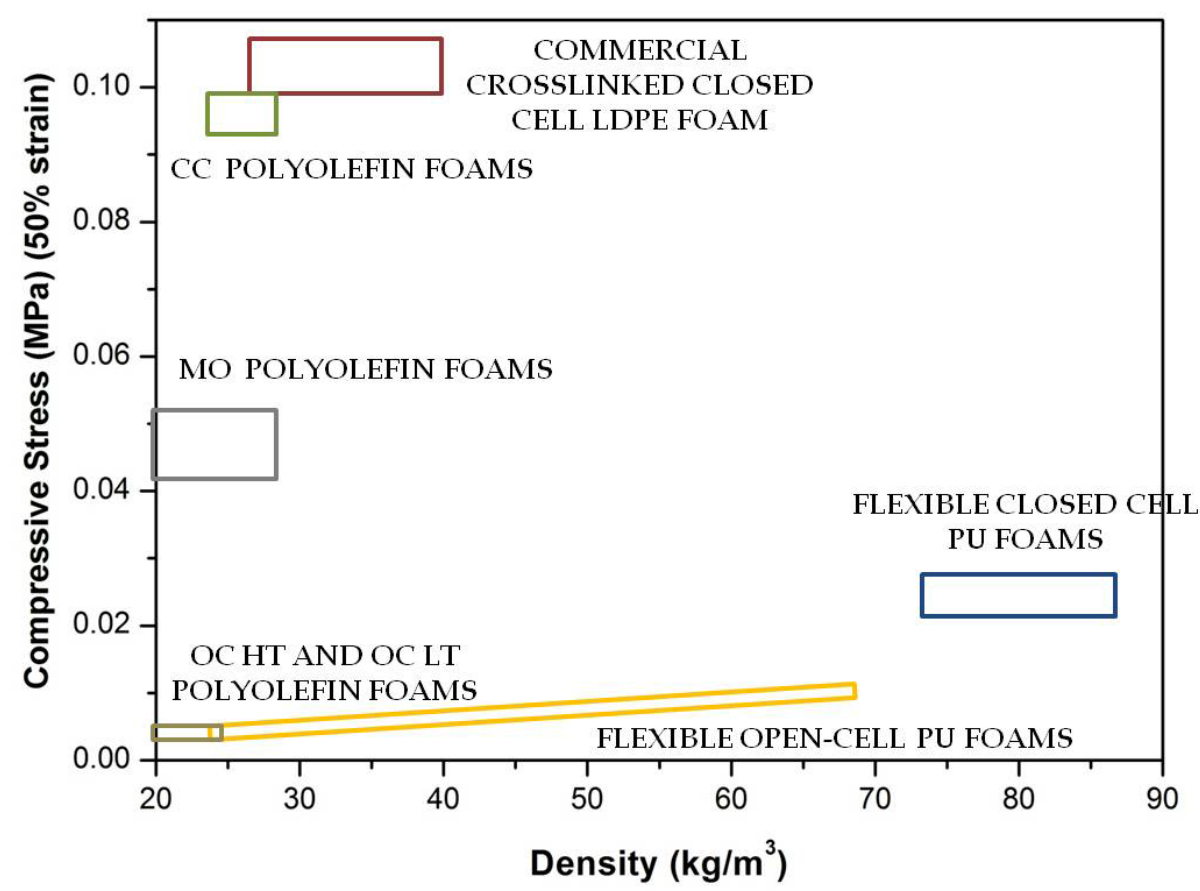

Figure 4.12. Compressive stress (MPa) at 50\% for several commercial foams and the foam under study (CC, MO, OC HT and OC LT).

The results of the foams under consideration cover the range obtained for the four polymeric matrices. For closed-cell foams, as in the results we have included soft polymeric matrices, such as EVA 12, EVA 18 and EBA, the values are slightly lower than the value of the commercial crosslinked closed-cell LDPE foams, although this difference is not large.

The compressive stress values for the $\mathrm{MO}$ foams are placed in a range between the typical values of the closed-cell and the open-cell foams. This result is expected since these materials present an intermediate level of interconnectivity.

Figure 4.12 graphically summarizes the mechanical behavior of the open-cell polyolefin foams, already described in this chapter. At low strain rates, both OC HT and OC LT foams display a similar mechanical response as the open-cell flexible PU foams of the literature. 


\subsection{References}

[1]. L.J. Gibson, M.F. Ashby. Cellular Solids: Structure and Properties, 2nd edn. Pergamon., Oxford, 1998.

[2]. W.L. Ko. Journal of Cellular Plastics, 1, 45-50, 1965.

[3]. G. Menges, F. Knipschild. Polymer Engineering \& Science, 15, 623-627, 1975.

[4]. F.K. Abd El-Sayed, R. Jones, I.W. Burgess. Composites, 10, 209-214, 1979

[5]. M.F. Ashby. Metallurgical Transactions A, 14, 1755-1769, 1983.

[6]. N.J. Mills. Polymer Foams Handbook. Elsevier, Amsterdam, 2007.

[7]. J. Miltz, O. Ramon. Polymer Science \& Technology, 30, 129-133, 1990.

[8]. N.J. Mills, H.X. Zhu. Journal of the Mechanics and Physics Solid, 47, 669-695, 1999.

[9]. G. Lyn, N.J. Mills. Sport Engineering Banner, 4, 153-163, 2001.

[10]. N.J. Mills, C. Fitzgerald, A. Gilchrist, R. Verdejo. Composites and Science Technology, 63, 2389-2400, 2003.

[11]. R. Verdejo. Gas Loss and Durability of EVA Foams Used in Running Shoes. PhD Thesis, University of Birmingham, 2003.

[12]. J.L. Ruiz-Herrero, M.A. Rodriguez-Perez, J.A. de Saja. Materials Science Forum, 480-481, 513-518, 2005.

[13]. J.L. Ruiz-Herrero, M.A. Rodriguez-Perez, J.A. de Saja. Cellular Polymers, 24, 329346, 2005.

[14] M.A. Rodriguez-Perez, J.L. Ruiz-Herrero, E. Solorzano, J.A. de Saja. Cellular Polymers, 25, 221-236, 2006.

[15]. J.L. Ruiz-Herrero, M.A. Rodriguez-Perez, J.A. de Saja. Cellular Polymers, 35, 159176, 2006.

[16]. W.E. Warren, A.M. Kraynik. Journal of Applied Mechanics, 55, 341.346, 1988.

[17]. H.X. Zhu, J.R. Hobdell, A.H. Windle. Acta Materialia, 48, 4893-4900, 2000.

[18]. L. Gong, S. Kyriakides, W.Y. Jang. International Journal of Solids and Structures, 42, 1355-1379, 2005.

[19]. L. Gong, S. Kyriakides. International Journal of Solids and Structures, 42, 13811399, 2005.

[20]. Y.X. Gan, C. Chen, Y.P. Shen. International Journal of Solids and Structures, 42, 6628-6642, 2005. 
[21]. N.J. Mills. International Journal of Solids and Structures, 44, 51-65, 2007.

[22]. A.N. Gent, A.G. Thomas. Rubber Chemistry and Technology, 36, 597-611, 1963.

[23]. J.L. Ruiz-Herrero, M.A. Rodriguez-Perez, J.A. de Saja. Polymer Testing, 24, 641647, 2005. 
5. ACOUSTIC PROPERTIES 



\section{INDEX}

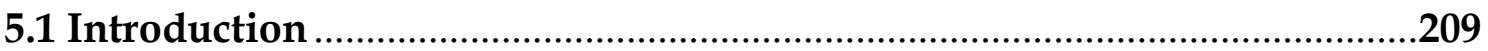

5.2 Acoustic absorption: Foams based on LDPE and EVA 18 .........................210

5.3 Acoustic absorption: Foams based on EVA 12 and EBA ...........................218

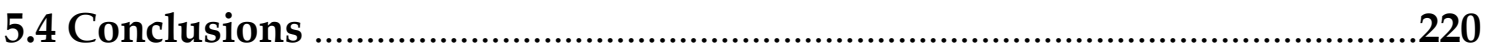

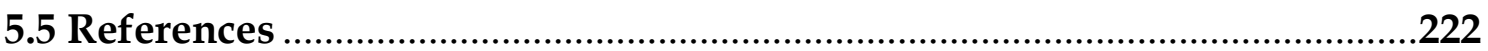




\subsection{Introduction}

As it was mentioned in Chapter 2, noise pollution is becoming a critical issue for the

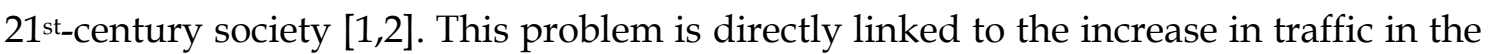
cities, which is raising the noise levels dramatically [3,4]. Motors are one of the noisiest elements in vehicles [5]. As a result, motor parts are covered by high sound absorptive porous materials, typically open-cell PU foams, to diminish the amount of noise released outside.

Open-cell PU foams for sound absorption are currently available in the market. They are widely used in several items thanks to their excellent normalized absorptions coefficients. For sound absorption, the cell must be interconnected to allow the propagation of sound waves through the cellular structure. The mechanisms of sound absorption in cellular materials are as follows:

- Friction losses caused by the interaction of the fluid (air) and the solid phase.

- Losses by heat transfer caused by the compressions and expansions of the fluid when the sound energy is transported.

- Losses by relaxations of the polymeric chains. The sound energy is converted to heat due to the molecular relaxations of the polymer matrix.

- The vibration of the sample

Thus, the mechanisms of damping of sound waves are connected to the cellular structure interconnectivity and the tortuosity [6-8].

It has been discussed the problematic of PU foams from a health point of view, but focusing on the acoustic performance, PU foams present limited sound absorptions at frequencies below $2000 \mathrm{~Hz}$. It is important to point out here, that many noises generated inside a vehicle are located in the low-frequency range, and open-cell PU foams are not able to give an appropriate response to this problematic. Therefore, it is important to develop open-cell porous materials, which not only absorb sound at high but also in the low range of frequencies.

As a consequence, it was decided to characterize the sound absorption of the open-cell polyolefin cellular materials described in this work. One of the targets of this study was determining the effect of tortuosity on acoustic absorption.

The results are presented in two sections. First, the results for LDPE and EVA 18 foams are presented in the form of a short communication entitled: "Influence of the Cellular Structure Tortuosity on the Acoustic Absorption of Open-Cell Polyolefin Foams" under review when this thesis is being written. In addition, in section 5.3, the results for the other two polymeric matrices under study, EVA 12 and EBA, are also discussed. 


\subsection{Acoustic absorption: Foams based on LDPE and EVA 18}

The acoustic performance of the materials was characterized in an impedance tube following the standard ISO 10534-2. This method is based on the measurement of the pressure of two microphones located in fixed positions when the source generates the sound waves. By measuring these pressures, the impedance tube estimates how much sound has been absorbed and how much has been reflected for each frequency.

The analysis is focused on the estimation of the normalized absorption coefficient (Equation 1):

$$
\tilde{\alpha}=\frac{\int_{f_{1}}^{f_{2}} \alpha(f) d f}{f_{2}-f_{1}}
$$

where $f_{1}$ and $f_{2}$ are the frequency limits and $a$ is the absorption coefficient.

Normalized absorption coefficients near to 1 indicate high sound absorptions and low values of the coefficient is connected to the poor sound absorption performance.

The normalized absorption coefficient was estimated in two frequency ranges:

1) From 500 to $6400 \mathrm{~Hz}$ (whole frequency range)

2) From 500 to $2000 \mathrm{~Hz}$ (low-frequency range)

The normalized absorption coefficient of the open-cell PU used in this thesis as reference was also measured in both frequency ranges, and the results were compared to the ones obtained for the open-cell polyolefin foams. It is important to mention here, that the same open-cell PU foam was used for the analysis of the physical properties. As mentioned before, although there are specific grades of open-cell PU foams for acoustic absorption, the open-cell PU foam used as a reference in this thesis showed excellent sound absorptions, and thus, it was used for comparative purposes. 


\title{
Influence of the Cellular Structure Tortuosity on the Acoustic Absorption of Open-
} Cell Polyolefin Foams

\author{
E. Lopez-Gonzalez ${ }^{1,2 *}$, C. Saiz-Arroyo ${ }^{2}$, M.A. Rodriguez-Perez ${ }^{1}$ \\ ${ }^{1}$ Cellular Materials Laboratory (CellMat), Condensed Matter Physics Department, University \\ of Valladolid, Paseo Belen 747011 Valladolid (Spain) \\ 2 CellMat Technologies S.L., Paseo de Belen 9-A (CTTA Building), 47011, Valladolid, Spain \\ * Corresponding author. Tel: +34 983423194 \\ E-mail address: eduardol@fmc.uva.es
}

\begin{abstract}
The effect of the cellular structure tortuosity on the sound absorption for two types of novel open-cell crosslinked foams based on ethylene vinyl acetate copolymer (EVA) and low-density polyethyelene (LDPE) with high and low tortuosities has been analyzed. Furthermore, the acoustic performance has also been compared to the one obtained for a commercial open-cell polyurethane (PU) foam. The results confirm the critical influence of the cellular structure tortuosity on this physical property, being the open-cell foams with low tortuosity better sound absorbers than that the materials with high tortuosity. Besides, it has also been proved, that this open-cell polyolefin foams with low tortuosity present similar normalized absorption coefficients to those of the open-cell PU foam in the whole frequency range $(500-6400 \mathrm{~Hz})$, being remarkable the excellent sound absorptions at low frequencies $(500-2500 \mathrm{~Hz})$ in a region where the open-cell PU foam presents a poorer performance.
\end{abstract}

\section{KEYWORDS}

POLYOLEFINS, OPEN-CELL FOAMS, ACOUSTIC ABSORPTION, TORTUOSITY

\section{Introduction}

Noise pollution has become a growing issue to be diminished in the coming years. According to the environmental noise guidelines divulged by the World Health Organization (WHO), the noise levels coming from road traffic should be less than 53 decibels $(\mathrm{dB})$ and less than $45 \mathrm{~dB}$ for night noise exposure [1]. However, the statistics disclosed by the WHO showed that more than $40 \%$ of the population in the EU is exposed to road traffic noise level exceeding $55 \mathrm{~dB}$. As a consequence, high noise level exposure may cause major health problems [2].

Open-cell polymer foams are considered as excellent sound absorbers due to the ability of these materials to damp the sound waves [3-4]. Several authors have widely characterized the acoustic behavior of open-cell polyurethane (PU) foams [5-6]. But not only raw open-cell PU foams have been acoustically analyzed but also modified opencell PU foams. The effect of the addition of several organic and inorganic fillers on the 
acoustic performance of open-cell PU has been reported by several authors, aiming at improving the acoustical characteristics of these materials [7-11]. However, it is also interesting to look for new materials that could replace PU foams due to the drawbacks of these type of materials such as the isocyanates used in their production, the low chemical and water resistance and the toxic fumes released by these materials during burning [12].

Open-cell polyolefin foams have emerged as an interesting candidate to replace opencell PU foams in several applications [13]. Alvarez-Lainez et al. determined the acoustic behavior of some commercial open-cell polyolefin foams based on blends of lowdensity polyethylene (LDPE) and ethylene vinyl acetate copolymer (EVA), being the high tortuosity of these open-cell foams a clear limitation in the sound absorption [14]. In fact, as far as the authors know, there are not any previous papers analyzing the acoustic properties of open-cell polyolefin foams with a low tortuosity. This work presents the acoustical properties of novel crosslinked open-cell EVA and LDPE foams with low tortuosity produced by a two-steps compression molding process [15]. Two main aspects have been analyzed: a) the effect of the cellular structure tortuosity on the sound absorption by comparing these materials with open-cell EVA and LDPE high tortuous foams and, b) the suitability of the open-cell polyolefin foams with a low tortuosity for acoustical applications by comparing its sound absorption with the ones obtained for an open-cell PU foam.

\section{Experimental}

Materials: several EVA and LDPE foams with different cellular structure morphology and interconnectivity were provided by CellMat Technologies S.L (Spain). The materials were produced using a two-steps compression molding process.

The density, open-cell content and the tortuosity values of the materials used in this work are summarized in (Table. 1).

Table 1.

Density $\left(\mathrm{kg} / \mathrm{m}^{3}\right)$, open-cell content $(\%)$ and tortuosity of the materials under study.

\begin{tabular}{|c|c|c|c|}
\hline Sample & Density $\left(\mathrm{kg} / \mathrm{m}^{3}\right)$ & Open-cell content $(\%)$ & Tortuosity \\
\hline EVA 18 OC HT & $17.6 \pm 0.7$ & $97 \pm 1$ & $3.8 \pm 0.5$ \\
\hline EVA 18 OC LT & $15.1 \pm 0.4$ & $99 \pm 1$ & $1.9 \pm 0.2$ \\
\hline LDPE OC HT & $20.0 \pm 1.0$ & $95 \pm 3$ & $4.0 \pm 0.4$ \\
\hline LDPE OC LT & $15.8 \pm 0.1$ & $99 \pm 1$ & $1.9 \pm 0.1$ \\
\hline PU & $47.2 \pm 0.1$ & $98 \pm 0$ & $1.9 \pm 0.0$ \\
\hline
\end{tabular}


The densities of the polyolefin based materials are in a range between 15 and $20 \mathrm{~kg} / \mathrm{m}^{3}$; being the open-cell content is close to $100 \%$ in all cases. However, there is a considerable difference in the tortuosities values. The tortuosity of both open-cell polyolefin OC HT foams is up to 2.10 times higher than the ones with low tortuosity. Furthermore, the tortuosity of the open-cell PU foam is similar to both polyolefin OC LT foams, and thus, it can also be considered as low tortuous material.

As it is observed in (Fig. 1), the type of cellular structure interconnectivity is completely different in the open-cell polyolefin foams compared to the open-cell PU foam. On the one hand, the cellular structure of the open-cell PU foam consists of struts (Fig 1.c), which confers excellent properties to these materials regarding recovery and it is closely linked with a low tortuosity. On the other hand, the open-cell polyolefin foams present holes in the cell walls. Depending on the size and the number of holes, open-cell polyolefin foams with two levels of cellular structure tortuosity can be achieved: small sizes and a low number of the holes are related to open-cell foams with high tortuosities (Fig. 1a) whereas open-cell foams with low tortuosities are characterized by the presence of large and a considerable number of holes (Fig. 1b).
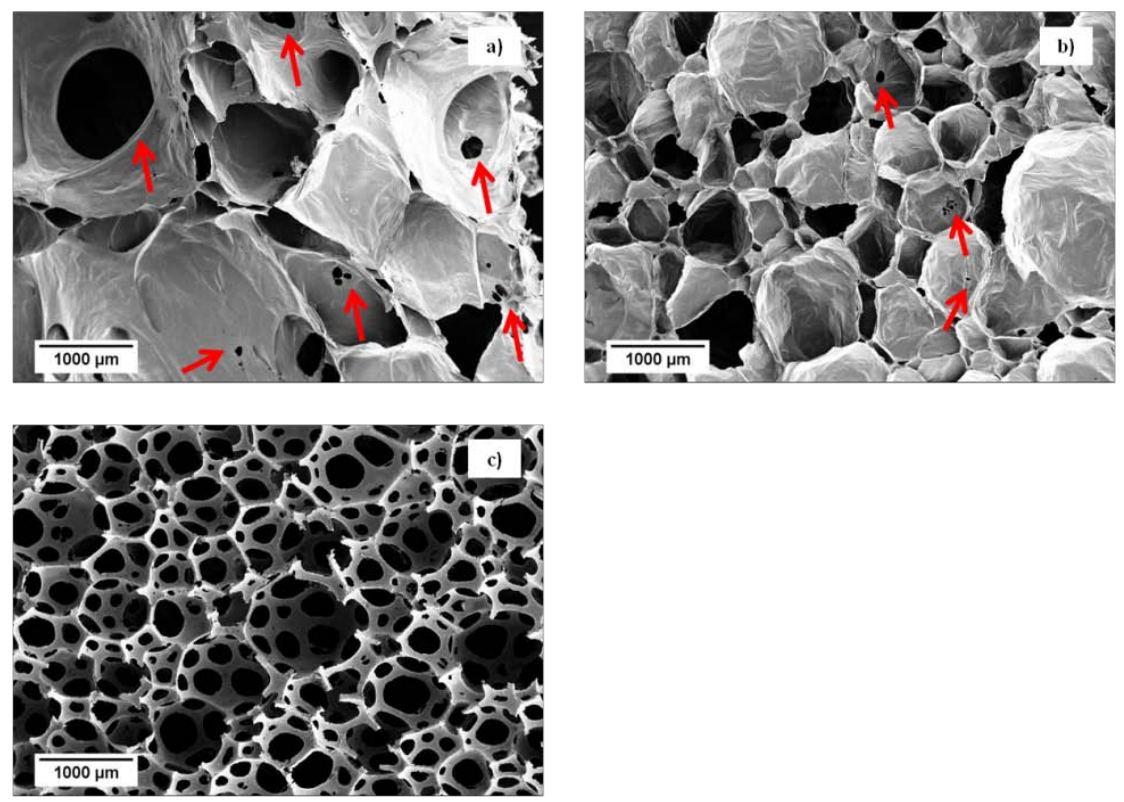

Fig. 1. (a) SEM micrographs of EVA OC LT, (b) EVA OC HT and (c) reference open-cell PU foams. The cellular structure of the LDPE based foams was similar to that of the EVA foams. Some of the holes in the cell walls in the open cell polyolefin foams are indicated with an arrow.

Density: the density of the materials was calculated as the average value of five cylindrical specimens measured geometrically.

Open Cell: the open-cell content (\%) was measured according to the ASTM D-2856-94 method.

Tortuosity: the tortuosity was measured by performing electrical conductivity measurements [16-17]. A solution $0.5 \mathrm{M}$ of $\mathrm{CuSO}_{4} \cdot 5 \mathrm{H}_{2} \mathrm{O}$ was used as the auxiliary liquid. Initially, the electrical conductivity (alternating current) of the solution without 
a sample between two copper electrodes was measured in a fixed voltage range. By using Ohm's Law, the resistance can be estimated $\left(R_{0}\right)$. Afterwards, the foamed samples are immersed in the solution overnight to ensure the proper penetration of the liquid inside the foamed materials. Finally, the electrical conductivity of the solution with the foamed sample between the electrodes is measured in the same voltage range, and thus, the resistance $\left(R_{f}\right)$ is obtained. The tortuosity is given by the following equation (equation (1)):

$$
T=f\left(\frac{R_{f}}{R_{0}}\right)
$$

Sound absorption: the acoustic absorption curves were obtained by using the transfer function method according to ISO 10534-2 by performing sound absorption tests in an impedance tube (Brüel \& Kjaer, Nǣrum, Denmark). The frequency range was 500-6400 Hz. Six cylinder samples with a diameter of $29 \mathrm{~mm}$ and $20 \mathrm{~mm}$ in thickness were used for these tests. The normalized acoustic coefficient $(\tilde{\alpha})$ was estimated by using (equation (2)):

$$
\tilde{\alpha}=\frac{\int_{f_{1}}^{f_{2}} \alpha(f) d f}{f_{2}-f_{1}}
$$

\section{Results}

The sound absorption curves in the whole frequency $(500-6400 \mathrm{~Hz})$ and the lowfrequency ranges $(500-2000 \mathrm{~Hz})$ of the materials under study are shown in (Fig. 2).
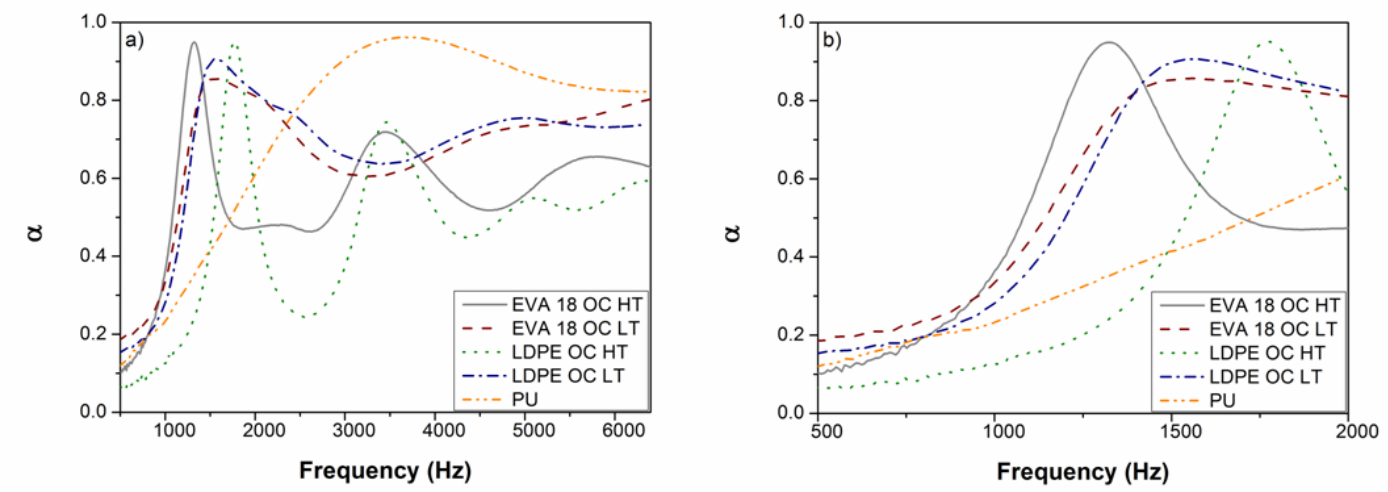

Fig. 2. Sound absorption curves of the materials under study (a) whole frequency range and (b) low frequencies.

It can be observed (Fig. 2a) that there is a critical influence of the cellular structure tortuosity on the sound absorption, being the acoustic performance of the OC LT foams much better than the OC HT ones, regardless of the polymer matrix. The open-cell PU 
exhibits an excellent sound absorption behavior at frequencies beyond $2000 \mathrm{~Hz}$. However, its absorption at low frequency is small (Fig. 2b). It is remarkable that both open-cell polyolefin foams have their maximum absorption at low frequencies (between 1000 and $1500 \mathrm{~Hz}$ ) in the region where the open-cell PU has low performance. Furthermore, the OC LT foams present high absorptions not only at low but also at higher frequencies.

The normalized absorption coefficient $(\tilde{\alpha})$ was estimated in the whole range and at low frequencies to establish a comparative between the sound absorptions of the materials (Fig. 3).

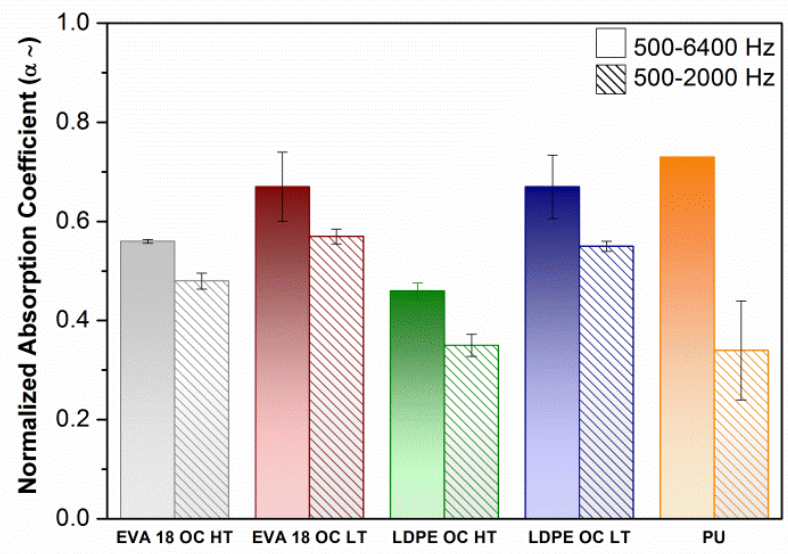

Fig. 3. Normalized absorption coefficients of the materials under study in the whole frequency range $(500-6400 \mathrm{~Hz})$ and at low frequencies $(500-2000 \mathrm{~Hz})$.

On the one hand, the EVA OC LT and the LDPE OC LT foams present similar sound absorptions in the whole range of frequencies, slightly lower than the one obtained for the open-cell PU foam. On the other hand, the LDPE OC HT foam has the lowest performance in the two ranges of frequencies under study. The EVA OC HT also presents lower absorptions than the materials with low tortuosity. As the tortuosity is very high due to the presence of small holes, the sound waves cannot be appropriately damped by the OC HT foams. However, in the OC LT foams, the holes are very large, and the sound waves penetrate through them being dissipated inside the cellular structure. Concerning low frequencies, it can be outlined the excellent sound absorption of the OC LT foams, being its absorption much higher than that of the opencell PU foam. Taking into account that some applications in the automotive and in aeronautics sectors require absorptions at low frequencies (roofs for instance), this new open-cell polyolefin foams with low tortuosity can be considered as a potential alternative to the commercial open-cell PU foam used in this type of applications. 


\section{Conclusions}

The sound absorption of novel crosslinked open-cell polyolefin-based foams with high and low tortuosities has been characterized and compared with the one obtained for a commercial open-cell PU foam. The effect of the cellular structure tortuosity on the acoustic behaviour has been proved, increasing the sound absorptions as the tortuosity decreases. The OC LT foams present slightly lower sound absorptions than the opencell PU in the whole range of frequencies. However, it is remarkable their excellent sound absorptions at low frequencies $(500-2000 \mathrm{~Hz})$ in a region where the open-cell PU foam exhibits a low performance. It can be concluded that this novel open-cell polyolefin-based foams with low tortuosity can emerge as a real candidate to replace open-cell PU in sound absorption applications.

\section{Acknowledgements}

Funding: This work was supported by the Spanish Ministry of Economy, Industry, and Competitiveness (DI grant DI-15-07952); from MINECO, FEDER, UE (MAT2015-69234R) and the Junta de Castile and Leon (VA275P18)

\section{References}

[1] Environmental noise guidelines for the European Region, World Health Organization.

[2] L. Goines, L. Hagler, Southern. Med. J. 100 (2007) 287-294.

[3] M.A. Biot, J. Acoust. Soc. Am. 28 (1956) 168-191.

[4] J. Allard, P. Herzog, D. Lafarge, M. Tamura, Appl. Acoust. 39 (1993) 3-21.

[5] R.F. Lambert, J. Acoust. Soc. Am. 72 (1982) 879-887.

[6] W. Lauriks, A. Cops, C.Verhaegen, J. Sound. Vib. 131 (1989) 143-156.

[7] G. Sung, J.W. Kim, J.H. Kim, J. Ind. Eng. Chem. 44 (2016) 99-104.

[8] G. Sung, J.H. Kim, Compos. Sci. Technol. Chem. 146 (2017) 147-154.

[9] J. Lee, G.H. Kim, C.S. Ha, J. Appl. Polym. Sci. 123 (2012) 2384-2390.

[10] S.A. Baghban, M. Khorasani, G.M.M. Sadeghi, J. Appl. Polym. Sci. 135 (2018) 4674446756.

[11] S.C. Ryu, D.H. Kim, J. Kim, J.W. Lee, W.N. Kim, Polym. Composite. 39 (2018) 10871098.

[12] Y. Alarie, M.F. Stock, M.M. Schaper, M.M. Birky, Fund. Appl. Toxicol. 3 (1983) 619626. 
[13] M.A. Rodriguez-Perez, M.A. Lainez, J.A. de Saja, J. Appl. Polym. Sci. 114 (2009) 1176-1186.

[14] M.A. Lainez, M.A. Rodriguez-Perez, J.A. de Saja, Mater. Lett. 121 (2014) 26-30.

[15] D. Eaves. Handbook of Polymer Foams. Shawbury: Rapra Technology; 2004.

[16] D. Klempner, V. Sendijarevic, Handbook of Polymeric Foams and Foam Technology. 2nded. Munich: Hanser Publishers; 2004.

[17] R. Rodriguez-Montejano, R. Pfretzschner, Polym. Test. 18 (2003) 81-92. 


\subsection{Acoustic absorption: Foams based on EVA 12 and EBA}

As it was previously discussed, the short communication displays the sound absorption of the materials based on LDPE and EVA 18. Despite not being included in the short communication, the sound absorption of the partially or fully interconnected materials based on EVA 12 and EBA were also measured.

The same procedure was followed: the sound absorption was measured in the whole range and at low frequencies. The two objectives of these measurements were to prove that the tortuosity has a critical influence regardless of the polymer matrix and also to confirm that the open-cell materials with low tortuosity exhibit a better sound absorption performance at low frequencies than the open-cell PU foam.

The sound absorption curves for both polymer matrices in the whole range of frequencies are shown in Figure 5.1.
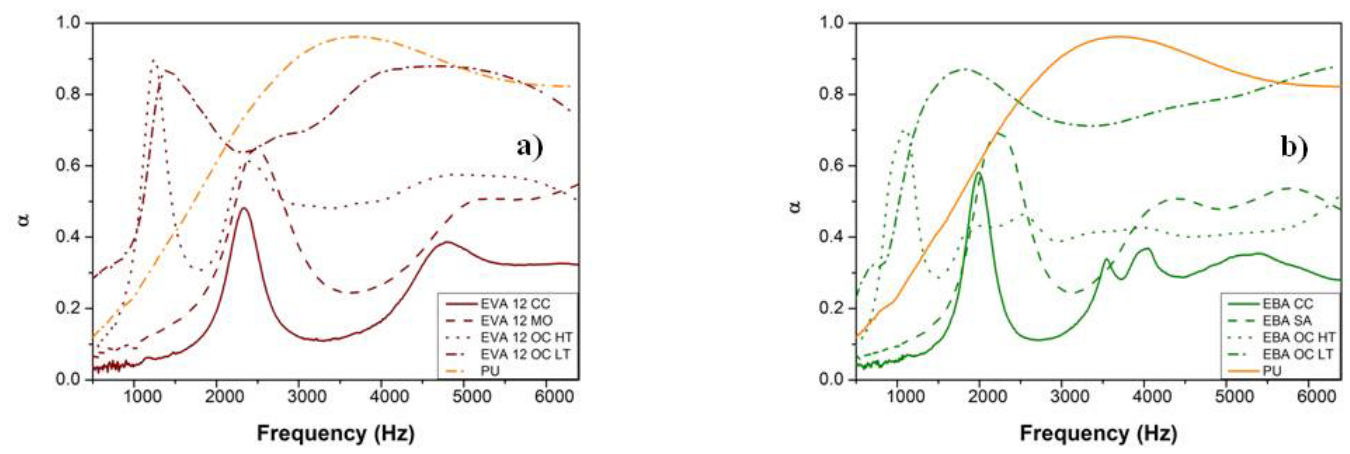

Figure 5.1. Sound absorption curves of the materials in the whole range of frequencies: (a) EVA 12 and (b) EBA.

The results show that the interconnectivity of the cellular structure affects how the sound waves are dissipated in the cellular materials, being the sound absorptions of the open-cell materials much higher than that of closed-cell and the partially interconnected materials. Furthermore, the contribution of the tortuosity is also critical for these two polymer matrices. The acoustic absorption of open-cell materials with low tortuosity is superior to the ones displayed by the materials with high tortuosity. This statement was a conclusion of the short communication (section 5.2), and again, the same result is found for these materials.

The remarkable sound absorptions at low frequencies of the open-cell polyolefin foams are also observed for these two polymer matrices, appearing the maximums below $2000 \mathrm{~Hz}$, frequencies much lower than those obtained for the open-cell PU foam (Figure 5.2). 

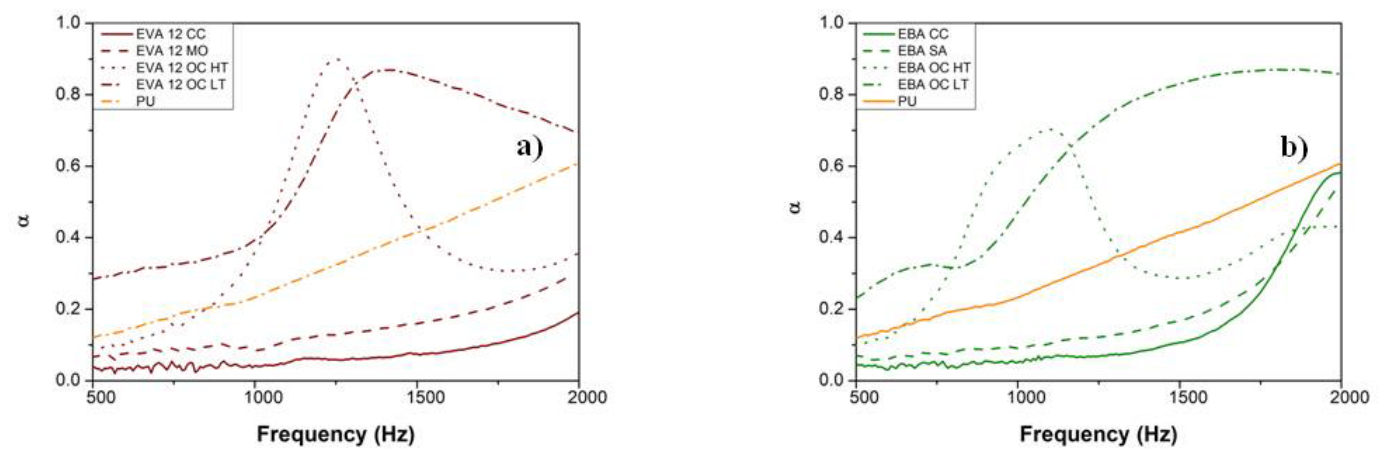

Figure 5.2. Sound absorption curves of the materials at low frequencies (500-2000 Hz): (a) EVA 12 and (b) EBA.

Regardless of the tortuosity, open-cell materials present the maximum in the acoustic absorption curves at low frequencies, whereas the sound absorption of the open-cell PU foam in this range is quite low.

The normalized absorption coefficients of all the materials in the whole range and at low frequencies are collected in the following table (Table 5.1):

\begin{tabular}{|ccc|}
\hline Sample & $\begin{array}{c}\mathrm{a}_{\mathrm{n}} \\
(500-6400 \mathrm{~Hz})\end{array}$ & $\begin{array}{c}\mathrm{a}_{\mathrm{n}} \\
(500-2000 \mathrm{~Hz})\end{array}$ \\
\hline LDPE CC & $0.13 \pm 0.01$ & $0.03 \pm 0.00$ \\
\hline LDPE MO & $0.39 \pm 0.05$ & $0.13 \pm 0.03$ \\
\hline LDPE OC HT & $0.46 \pm 0.02$ & $0.35 \pm 0.02$ \\
\hline LDPE OC LT & $0.67 \pm 0.07$ & $0.55 \pm 0.01$ \\
\hline EVA 12 CC & $0.23 \pm 0.03$ & $0.10 \pm 0.02$ \\
\hline EVA 12 MO & $0.35 \pm 0.03$ & $0.14 \pm 0.02$ \\
\hline EVA 12 OC HT & $0.50 \pm 0.05$ & $0.39 \pm 0.04$ \\
\hline EVA 12 OC LT & $0.71 \pm 0.08$ & $0.60 \pm 0.02$ \\
\hline EVA 18 CC & $0.25 \pm 0.01$ & $0.12 \pm 0.07$ \\
\hline EVA 18 MO & $0.46 \pm 0.04$ & $0.29 \pm 0.06$ \\
\hline EVA 18 OC HT & $0.56 \pm 0.01$ & $0.48 \pm 0.02$ \\
\hline EVA 18 OC LT & $0.67 \pm 0.07$ & $0.57 \pm 0.01$ \\
\hline EBA CC & $0.24 \pm 0.02$ & $0.14 \pm 0.02$ \\
\hline EBA MO & $0.39 \pm 0.03$ & $0.17 \pm 0.05$ \\
\hline EBA OC HT & $0.41 \pm 0.07$ & $0.38 \pm 0.07$ \\
\hline EBA OC LT & $0.74 \pm 0.07$ & $0.68 \pm 0.06$ \\
\hline PU & $0.73 \pm 0.00$ & $0.34 \pm 0.10$ \\
\hline
\end{tabular}

Table 5.1. Normalized absorption coefficient in the whole range and at low frequencies.

This table also includes the data of closed cell LDPE and EVA 18 foams, which do not appear in the short communication (section 5.2). It is observed in Table 5.1 the significant difference between the sound absorption of CC and OC LT foams, being this difference in the whole and the low-frequency range as high as 0.54 in the case of LDPE.

As it was stated before, concerning polyolefin cellular polymers, the highest sound absorptions are reached by the low tortuous materials, being their value similar to 
those exhibited by the open-cell PU foam in the whole range of frequencies. The difference between the low tortuous and high tortuous materials in the normalized absorption coefficient is 0.11 for EVA 18, 0.21 for LDPE and EVA 12, whereas, for EBA, this value is higher, 0.33 .

A remarkable result is again connected to sound absorption at low frequencies. The open-cell materials with low tortuosity, regardless of the polymer matrix, present excellent sound absorptions at low frequencies ( 0.60 for EVA 12 and 0.68 for EBA), much higher than the value of the PU foam (0.34).

\subsection{Conclusions}

The study presented in this chapter contributes to extend the knowledge about the acoustic properties of polymer foams. It is well-known that open-cell porous materials are better sound absorbers than closed-cell materials due to the effective attenuation of the sound waves by these cellular structures. However, open-cell foams can have different cellular structures with different type of interconnectivity.

This study has allowed us determining how different levels of tortuosity affect the sound absorption in open-cell polyolefin foams (Figure 5.3). It has been concluded that the open-cell foams with low tortuosity presented better sound absorptions than the open-cell foams with high tortuosity regardless of the polymer matrix. The effective attenuation of the sound waves in open-cell foams with low tortuosity is achieved by the presence of large holes, which allowed the penetration of the waves and their attenuation. Despite having holes in the cell walls, open-cell foams with high tortuosity displayed lower sound absorptions due to the small size of the holes and the small number of them. The small number of holes played a critical role since the sound wave is reflected instead of being attenuated by the polymer matrix, behaving these opencell foams as hybrids between closed-cell and open-cell foams. In fact, the OC HT foams slightly improve the results obtained for the MO foams.
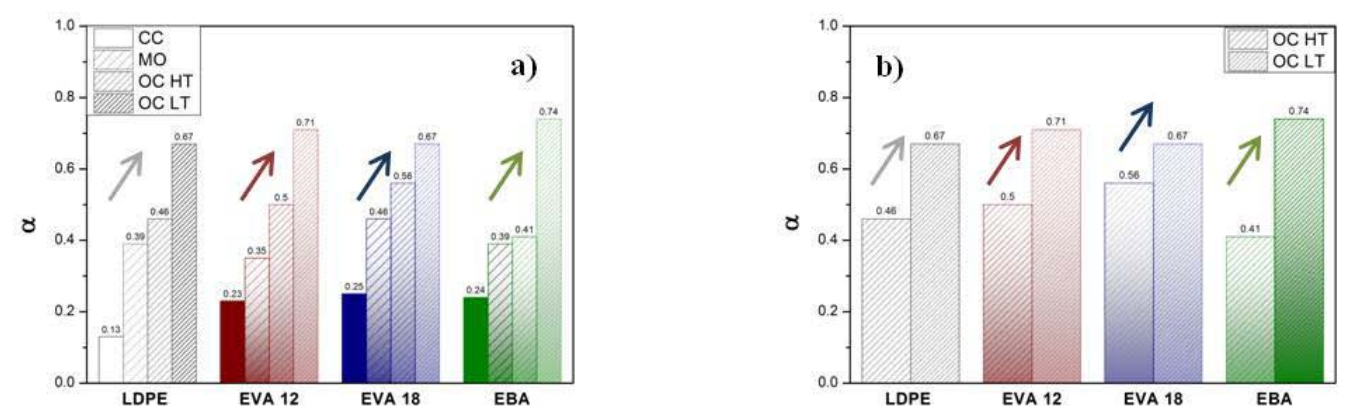

Figure 5.3. Normalized absorption coefficient of the materials in the whole range of frequencies: effect of the (a) interconnectivity and $(b)$ tortuosity.

Finally, it is also important to indicate, that even though the open-cell PU foam presented higher sound absorptions in the whole range of frequencies (except for the EBA OC LT foam, whose normalized absorption coefficient is slightly higher), these 
open-cell foams based on polyolefins were much better sound absorbers than the opencell PU foam used as a reference at frequencies below $2500 \mathrm{~Hz}$, extending the versatility and the range of applicability of these open-cell foams.

Figure 5.4 summarizes the results described in this chapter and comparing the results with data of the literature (in the whole frequency range) for flexible open cell PU foams and crosslinked closed cell LDPE foams. Despite having slightly lower sound absorption, OC LT foams can be considered acceptable sound absorbers, standing out their fantastic absorptions in the low-frequency range.

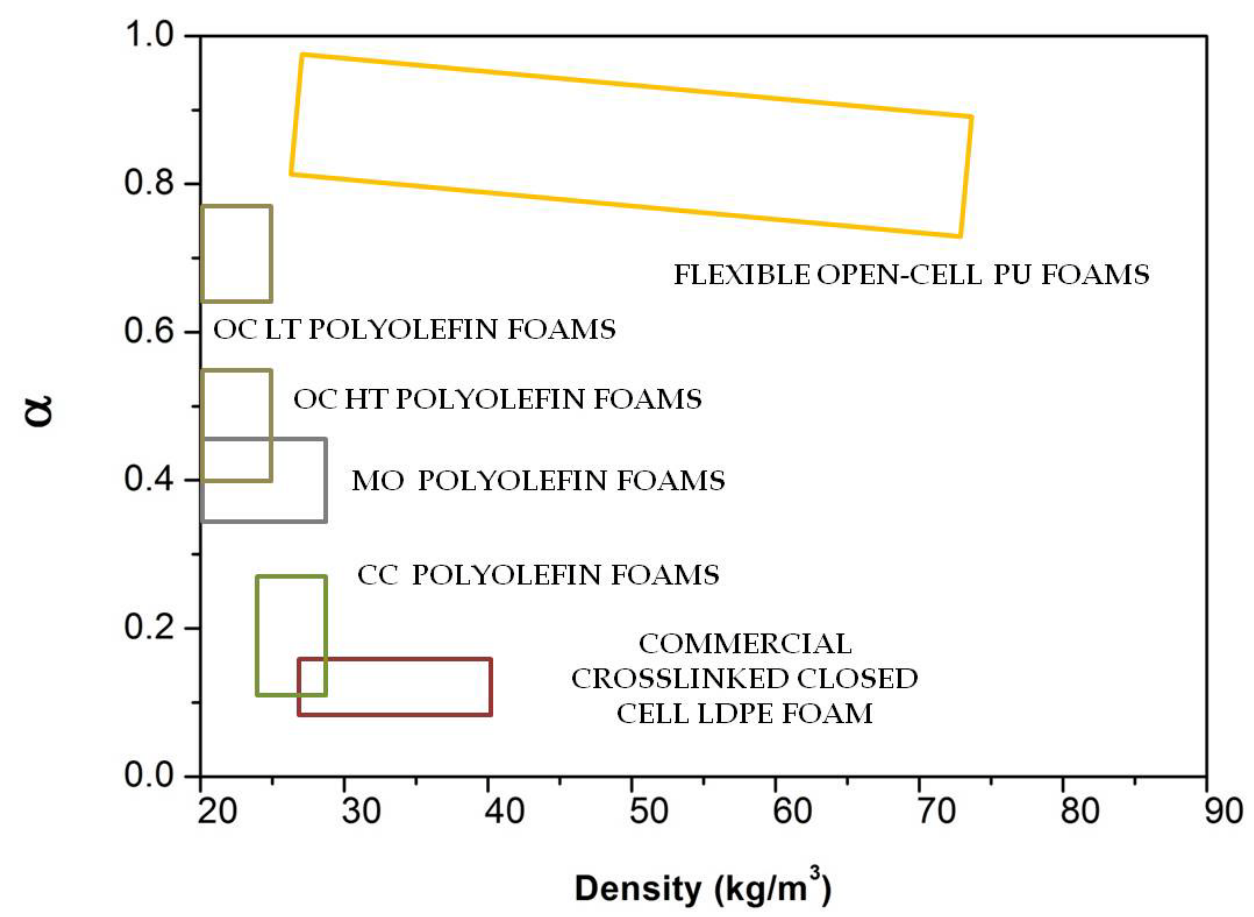

Figure 5.4. Sound absorption coefficient in the whole frequency range (a) for several commercial foams and the foams under study (CC, MO, OC HT and OC LT). 


\subsection{References}

[1]. https://www.eea.europa.eu/themes/human/noise.

[2]. S.A. Stansfeld, M.P. Matheson. British Medical Bulletin, 68, 243-257, 2003.

[3]. W. Babisch. Noise \& Health, 13, 201-204, 2011.

[4]. J. Khan, M. Ketzel, K. Kakosimos, M. Sørensen, S.S. Jensen. Science of the Total Environment, 634, 661-676, 2018.

[5]. P. Vijayraghavan, R. Krishnan. IEEE Transactions on Industry Applications, 35, 1007-1013, 1999.

[6]. M.A. Biot. The Journal of the Acoustical Society of America, 28, 168-178, 1956.

[7]. C.W. Kosten, J.H. Janssen. Acta Acustica, 7, 372-378, 1957.

[8]. W. Lauriks, A. Cops, C. Verhaegen. Journal of Sound and Vibration, 131, 143-156, 1989. 
6. OIL ABSORPTION 



\section{INDEX}

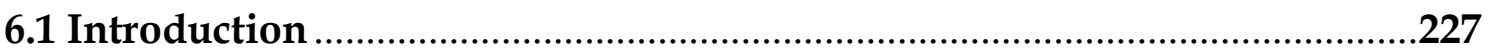

6.2 Oil Absorption: Foams based on LDPE and EVA 18 …...........................229

6.3 Oil Absorption: Foams based on EVA 12 and EBA …..............................250

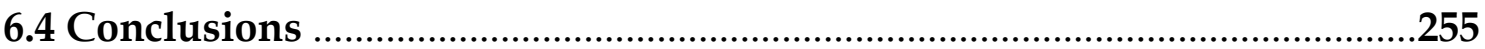

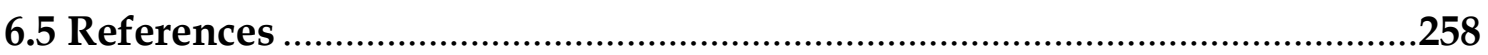




\subsection{Introduction}

Oil spills are tremendous environmental disasters. The disastrous ecological effects can persist years or decades depending on if the crude oil is removed or if no cleaning processes are performed [1-3].

There are studies which show the catastrophically effects of oil spills on different elements. Focusing on seabirds, according to the published data, around 35000 seabirds were found dead after the Exxon Valdez oil spill, whereas around 1500 mortal species were counted after the Shetland oil spill [4]. This data is quite singular because more than twice tones of oil were released in the Shetland oil spill in comparison to the Exxon Valdez one, so it is quite complex to establish relationships between the oil spilt and the environmental effects, more elements play a role in this aspect.

In Chapter 2, some of the largest and most recent oil spills have been listed, and the attention was paid on the environmental effects. However, it must be taken into account that the economy can also be affected by these disasters. Garza-Gil et al. estimated the short-term economic damages from the Prestige oil spill in Galicia (Spain) [5]. This analysis was focused on two elements: the fishing and the tourism sectors. Concerning the fishing sector, it was estimated a loss of $10 \%$ in the tones produced and a loss of $17 \%$ in sales. Additionally, to the fishing sector, in the tourist sector, the income decreased by $134 €$ million. Furthermore, if the costs of oil removal are included, it can be concluded that the expenses are out of proportion.

Of course, the main steps must be led to reducing these (in the majority of the cases) avoidable accidents. However, once the spill takes place, fast and rigorous policies must be taken to diminish the disastrous effects.

In Chapter 2, the drawbacks of the current methods of recovery were addressed, and it was also pointed out, that cellular polymers are starting to be considered as a real alternative to the current strategies.

Most of the studies based on the oil absorption of cellular polymers are connected to open-cell PU foams [6-14]. However, polyolefins are polymers derivatives of petrol, and as a consequence, they present a high affinity towards oil. The complexity of producing open-cell polyolefins materials has limited the applicability of these foams in this field. Up to now, there are only two studies, in which the oil absorptive properties of open-cell foams produced by extrusion foaming have been tested $[15,16]$.

The development of the open-cell polyolefins foams with low density and tortuosity allowed us to determine if these types of materials can be considered as oil sponges. For this purpose, the oil absorptions of the open-cell materials both with high and low tortuosity were measured using 15W40 motor oil, 80W90 motor oil and sunflower oil as the oily fluids. The methodology followed to perform these measurements were based on the work of Pinto et al. [13], in which samples of $2 \times 2 \times 1$ (length $\times$ width $x$ thickness) $\mathrm{cm}^{3}$ were employed. The samples were initially weighted and then were 
placed superficially on the oil without forcing them to absorb it. The samples stayed for 10 minutes on the oil and after this time were removed and were weighed again without removing the superficial oil.

Oil absorption is estimated by using the following equation (Equation 1):

$$
\text { Oil absorption }\left(\frac{g}{g}\right)=\frac{\left(w_{1}-w_{0}\right)}{w_{o}}
$$

where $w_{0}$ is the weight of the sample before absorbing oil and $w_{1}$ is the weight of the sample after absorbing oil.

Equation 1 gives an idea of the capacity for absorbing oil. However, this equation is not suitable for comparing purposes, because the density of the foams (and as a consequence the porosity) is not considered in this equation. Thus, it is also necessary to introduce a new equation, which takes into account the effect of density.

The oil absorption efficiency (OAE) allows the comparison between foams of different densities. This parameter indicates which materials present better performance regarding effectiveness in the oil recovery. This parameter is estimated by using Equation 2:

$$
O A E=\frac{\frac{\left(w_{1}-w_{0}\right)}{w_{0}}}{V_{f} \cdot \frac{w_{0}}{\rho_{f}} \cdot \rho_{\text {oil }}}
$$

where $V_{f}$ is the void fraction (porosity), $\rho_{f}$ is the foam density and $\rho_{\text {oil }}$ is the oil density. Values near to 0 mean low efficiency and near to 1 lead to high efficiencies in oil absorption.

It must be taken into account that the results are strongly influenced by the viscosity of the oil used in the tests [17]. There are many works in which the absorption of liquid solvents, such as hexane, is measured obtaining outstanding absorptions. However, the viscosity of the oils is considerably higher than the one corresponding to organic solvents, and the absorption of oils is somehow restricted by their viscosity. Due to this, three different oils with three different densities and viscosities were used in order to determine the effect of this property.

Another requirement that the materials must fulfill to be used in this application is having negligible water absorptions. The materials must absorb oil selectively without taking water. This property is referred to clean separations of the oil from the water, allowing the reuse of the absorbed oil. The water absorption is estimated by using the same equation as the oil absorption (Equation 1), but performing the tests using water.

One other critical aspect is the possibility of reusing the materials several times without losing performance. This property was also studied by using two approximations: 
compression tests at low strain rates and testing the material several times, i.e. carrying out reabsorption cycles.

The first methodology was reported by Rizvi et al. [15], and it is based on the estimation of the non-recovered deformation over several load-unload cycles when the material is compressed ( $75 \%$ of strain). The non-recovered deformation accounts for the percentage of material which is not able to recover after compression. This value must be as low as possible and constant through the successive load-unload cycles to consider a material as reusable. The second methodology tries to resemble a real situation, in which the material absorbs oil, the oil is removed from the structure by squeezing the foam, and the foam is used again to absorb the fluid. This approximation based on reabsorption cycles was employed in our study, by performing absorption tests along 50 cycles. The materials must absorb a similar amount of oil after each cycle and thus, they must not lose their performance throughout the successive cycles to consider them as reusable.

On the one hand, the analysis of the oil absorption capacity and the reusability of the LDPE and EVA 18 foams was performed. The high oil absorption and in the case of the EVA foams, their excellent reusability, allowed us to write a paper on this topic which has been submitted to the journal International Journal of Environmental Science and Technology. On the other hand, the oil absorptive behavior and the reusability of the EVA 12 and EBA foams were also addressed. The results concerning these two polymer matrices are included in section 6.3 of this chapter.

\subsection{Oil absorption: Foams based on LDPE and EVA 18}

The oil absorption capacity and the reusability of LDPE and EVA 18 open-cell foams were characterized. As it was previously mentioned (section 2.5.3), when open-cell PU foams are employed for this purpose, generally a superficial treatment is performed to increase the hydrophobicity of these foams. As oil-water selectivity is a key requirement for oil absorption, in the case of PU foams, a superficial treatment is necessary to fulfil it. However, these superficial treatments induce several restrictions, for instance, they hinder the industrial scalability of the material, and they increase the final cost of the product.

These limitations are not presented in the crosslinked open-cell polyolefin foams, due to the high hydrophobicity of these foams without performing any additional surface treatment. Furthermore, in some cases, thanks to the nature of the polymer matrix, these foams also fulfil other physical and chemical requirements (already introduced in Chapter 2) mandatory for this particular application: oleophilicity, flexibility, oil-water selectivity, low-density, open-cell and no toxicity.

On the base of these properties, it was considered as an interesting topic to determine if these open-cell foams could absorb a relevant amount of oil, and it was also necessary to determine if the materials could fulfil another critical requirement: the reusability. 
Keeping in mind all these issues, the oil absorption capacity of the LDPE and the EVA 18 open-cell foams was measured using three different types of oils: motor oil 15W40, motor oil $80 \mathrm{~W} 90$ and sunflower oil. The objectives of this work were the following ones:

- To determine the absorption capability of these polyolefin open-cell foams towards oil (grams of oil absorbed per gram of foam).

- To analyze the effect of the tortuosity on oil absorption.

- To analyze the effect of the oil properties on the oil uptake.

- To study the oil-water selectivity of the open-cell foams.

- To characterize the reusability of the open-cell polyolefin foams.

An analysis in depth of these issues was performed allowing us to submit these innovative results to the journal Marine Pollution Bulletin in a research article entitled: "Low-Density Open-Cell Flexible Polyolefin Foams as Efficient Materials for Oil Absorption: Influence of Tortuosity on Oil Absorption", that is included in the following pages. 


\title{
Low-Density Open-Cell Flexible Polyolefin Foams as Efficient Materials for Oil Absorption: Influence of Tortuosity on Oil Absorption
}

\author{
E. Lopez-Gonzalez ${ }^{1,2}$, C.Saiz-Arroyo ${ }^{2}$, M.A. Rodriguez-Perez ${ }^{1}$ \\ ${ }^{1}$ Cellular Materials Laboratory (CellMat), Condensed Matter Physics Department, \\ University of Valladolid, Paseo Belen 7, 47011, Valladolid (Spain) \\ ${ }^{2}$ CellMat Technologies S.L., Paseo de Belen 9-A (CTTA Building), 47011, Valladolid, \\ Spain
}

\begin{abstract}
Polymer foams have consolidated in the last years as materials for the remediation of oil spills in open waters. Open-cell polyurethane foams (PU) foams have been thoroughly studied to be used for this application. However, due to their low hydrophobicity, superficial treatments become compulsory to increase it. Open-cell polyolefin foams show, as flexible open-cell PU foams, an interconnected structure and some interesting properties that could make them ideal candidates to replace PU foams in several applications including oil uptake.
\end{abstract}

This work is focused on low-density open-cell flexible cellular materials based on lowdensity polyethylene (LDPE) and ethylene vinyl acetate copolymer (EVA). Besides that, cellular polymers with low and high tortuosities have been produced using these two polymeric matrices. The materials have been characterized to evaluate the effect of the cellular structure tortuosity on the oil-absorption efficiency. Low tortuous open-cell polyolefin foams were able to absorb up to 3 times more oil than high tortuous opencell polyolefin foams regardless of the type of polymer matrix. Furthermore, the affinity of the open-cell polyolefin foams towards water has also been analyzed, resulting in negligible water absorptions both for low and high tortuous open-cell polyolefin foams without including any chemical surface treatment to become them superhydrophobic. The reusability of the low tortuous open-cell polyolefin foams has also been discussed using cyclic compression tests and reabsorption measurements, showing excellent results. The oil-absorption capacity of low tortuous open-cell polyolefin foams has been compared to the oil absorption of a commercial open-cell flexible PU foam giving promising results.

\section{INTRODUCTION}

Around 7000 tonnes of oil were released into open waters in 2017 (https://www.itopf.org/fileadmin/data/Photos/Statistics/Oil_Spill_Stats_2017_web. pdf). Despite the decreasing trend in the number of oil spills in water from the 1970s until now, it is still an important issue when oil is accidentally released into open waters. These oil spills such as the ones from the Deepwater Horizon (627.000 tonnes in 
the Gulf of Mexico in 2010) or the one from Prestige (63.000 tonnes in Spain in 2002) hurt the ecosystem of the surrounding areas, whose recovery can take many decades or even a whole century (Montagna et al. 2013).

There are several techniques to separate oil from water, being some of them based on the employment of skimmers, vacuum pumps, dispersants or membranes (Lessard and DeMarco 2000; Kota et al. 2013; Zhang et al. 2013; Zhu et. 2014). In-situ oil burning is also employed to remove oil from water. However, this aggressive technique produces toxic smokes, which are injurious for human health and for this reason, this method is only applied offshore (Allen and Ferek 1993).

The use of absorbent materials is also a common approach used to recover oil from water. According to (Teas et al. 2001) oil absorbents can be classified into three groups: inorganic mineral products (Wen et al. 2013; Xue et al. 2014), organic products, and organic vegetable based products (Choi and Cloud 1992; Rengasamy et al. 2011; Pintor et al. 2012; Wang et al. 2013; Zhou et al. 2013). To consider a material as an absorbent for this particular application, it should fulfill a series of requirements: oil affinity, hydrophobicity, low density, flexibility, environmental friendliness, and reusability (Adebajo et al. 2003).

Polymeric foams belong to the group of organic products according to the previous classification and have emerged as promising absorbent materials to be employed for remediation of oil spills due to their hydrophobic and oleophilic behavior, suitable oilwater selectivity, high oil-absorption capacity, low cost and in some cases their reusability.

Polymeric foams can be defined as two-phase materials, in which a gas phase is dispersed in a polymeric matrix (Klempner and Frisch 1992; Cunningham and Hilyard 1994; Eaves 2004; Klempner and Sendijarevic 2004; Hamdi et al. 2018). They can be classified regarding the level of cell interconnectivity into two groups: closed and open-cell materials. In closed-cell materials, the gas phase is discontinuous, and consequently, the gas is enclosed inside the cells and cannot move freely through the cellular structure. On the other hand, in open-cell materials, both polymeric and gas phases are continuous, and hence, the gas can move through the cellular structure. The level of the interconnectivity of the cells is a critical parameter that determines the properties and the final application of the foam. In the case of oil absorption, the cells must be interconnected to allow the penetration of the oil into the cellular structure. However, different degrees of interconnectivity can be generated in open-cell materials by varying the nature of the polymeric matrix or the fabrication process, as observed in Figure 1. 

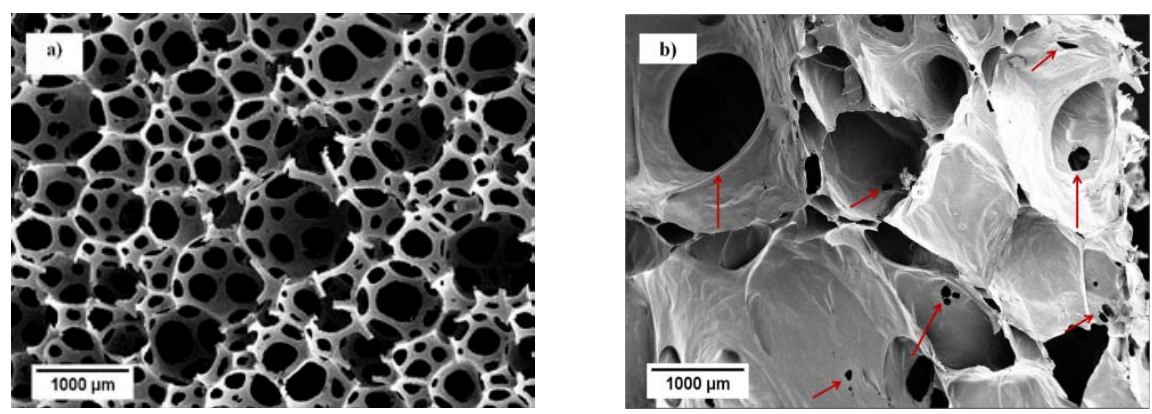

Figure 1. Open-cell low-density flexible cellular polymers: a) cellular polymer comprised of struts b) cellular polymer with holes in the cell walls (indicated with arrows).

Figure 1 displays micrographs corresponding to two different types of open-cell materials. Figure 1a) corresponds to a flexible PU foam typically characterized by presenting a cellular structure only comprised by struts. As a result, it can be said that the cells present a high level of interconnectivity. Figure $\mathbf{1 b}$ ) corresponds to an opencell foam based on polyolefins but in this case, the interconnection between the cells is based on the presence of holes in the cell walls, so for this particular case, the level of interconnectivity is lower than that in the previous case. To quantify the level of cell interconnectivity, it is necessary to introduce a parameter able to account for it. This parameter is the tortuosity (Cunningham and Hilyard 1994). Tortuosity can be defined as the ratio between the real distance that a gas molecule has to cover from one side to the other of the foam and the straight, and the shortest distance that this gas molecule would have to cover in a hypothetical case. Taking this into account, open-cell cellular materials can be classified as low (as in the case of PU foam in Figure 1a) and high tortuous materials (see Figure 1b). In the case of open-cell materials where the interconnectivity of the structure is based on the presence of holes in the cell walls, it is possible to create materials with low or high tortuosity by varying the size and the number of holes appearing in the cell walls.

The applicability of flexible open-cell PU foams as oil-absorbent materials has been widely studied by several authors (Wang et al. 2012; Calcagnile et al. 2012; Pinto et al. 2017). The chemical nature of PU foams makes compulsory subjecting them to a surface treatment aimed at increasing their hydrophobicity to enable their use for this particular application (Wang and Lin 2013; Zhu et al. 2013; Li et al. 2013; Liu et al. 2013; Pinto et al. 2018). The need for the introduction of this secondary process introduces important additional costs and limits the industrial scalability of these materials.

Some examples describing the use of polyolefin-based foams as oil-absorbent materials can also be found in the literature. Rizvi et al. (2014) evaluated the efficiency of opencell polypropylene/polytetrafluoroethylene (PP/PTFE 97:3) foams produced by a continuous extrusion process. These foams were able to absorb up to 24 grams of gasoline per gram of foam. They also analyzed the reusability of the foams by measuring the non-recovered deformation using low strain rate compression tests, concluding, that it was necessary to add a PP copolymer to improve the reusability of the foams. Wang et al. (2016) prepared blends of polypropylene (PP) and a thermoplastic polyolefin elastomer (POE) and produced open-cell foams also using a 
continuous extrusion process. In this case, the foams were able to absorb around 20 grams of motor oil per gram of foam, and the addition of the elastomeric phase resulted in an improvement in the reusability level.

Open-cell polyolefin foams could be potential alternatives to be used for oil spill remediation due to, among other reasons, their chemical nature. Polyolefin foams can be produced using different fabrication methods: nitrogen gas solution process, injection molding, a continuous or semi-continuous process involving either chemical or physical crosslinking processes or the one or the two-steps compression molding process (Eaves 2004; Rodriguez-Perez 2005).

Compression molding is a well-known and widely employed method to produce polyolefin foams at industrial scale (Klempner and Frisch 1992). Depending on the final density of the foam, either the one-step (relative density higher than 0.1) or the two-steps process (relative density lower than 0.1) are employed. In both cases, it is necessary to subject the polymeric matrix to a crosslinking process to increase its viscosity. Thus it will be able to withstand the high stretching ratios at which it is subjected during the foam formation (Gibson and Ashby 1995).

As far as the authors know, there are no previous reports in the literature related to the evaluation of the oil-absorption capacity of low-density open-cell polyolefin foams produced by a two-steps compression molding process. Herein, we present a study focused on the effect of the tortuosity of the cellular structure on the oil absorption of several low-density open-cell polyolefin foams produced from low-density polyethylene (LDPE) and an ethylene vinyl acetate copolymer (EVA) produced by a two-steps compression molding process. Furthermore, other critical requirements, such as hydrophobicity or reusability, have also been evaluated. It has been proved that the tortuosity level displayed by the cellular structure plays a key role in this application, being more effective the low tortuous structures than the high tortuous ones for this particular application.

\section{MATERIALS AND METHODS}

Two types of polymeric matrices are considered: low-density polyethylene (LDPE Alcudia ${ }^{\circledR} 003$ manufactured by Repsol (Spain)) with a density of $0.920 \mathrm{~g} / \mathrm{cm}^{3}$ and a melt flow index (MFI) of $2.40 \mathrm{~g} / 10 \mathrm{~min}$ (measured at $190^{\circ} \mathrm{C}$ and $2.16 \mathrm{~kg}$ ) and an ethylene vinyl acetate copolymer (EVA Alcudia ${ }^{\circledR}$ PA-538 manufactured by Repsol) with a VA content of $18 \mathrm{wt} \%$, a density of $0.937 \mathrm{~g} / \mathrm{cm}^{3}$ and a melt flow index (MFI) of $2.00 \mathrm{~g} / 10 \mathrm{~min}$ (measured at $190^{\circ} \mathrm{C}$ and $2.16 \mathrm{~kg}$ ). Azodicarbonamide (ADCA), Unicell D800 CB powder, with an average particle size of 7.6-8.0 microns and a range of decomposition temperature varying from 202 to $208{ }^{\circ} \mathrm{C}$ has been employed as the blowing agent. Azodicarbonamide was kindly supplied by Dongjin Semichem CO.LTD (South Korea). Dicumyl peroxide (DCP) Luperox® DC40 from Arkema (France) has been used as the crosslinking agent. Oil Red $O$, a biological stain was supplied by Acros Organics was used to stain the oil in the presence of water to determine the oilwater selectivity. 
Several crosslinked LDPE and EVA foams with similar densities (in the range between 15 and $20 \mathrm{~kg} / \mathrm{m}^{3}$ ) and different cellular structure interconnectivity and tortuosity were provided by CellMat Technologies S.L. (Valladolid, Spain). The materials were produced using a two-steps compression molding process. The main differences between the cellular polymers produced for this work lie in the different levels of interconnectivity reached during the fabrication process. Foams with an intermediate open-cell content (EVA MO and PE MO) and two types of open-cell foams; with high tortuosity (EVA HT and PE HT) and with low tortuosity (EVA LT and PE LT) have been characterized. The open-cell content was close to $100 \%$ for these open-cell foams regardless of the level of tortuosity. The main characteristics of these materials are summarized in Table 1.

Table 1. Nomenclature, density, open-cell content and tortuosity of the foams. ${ }^{*}$ - the tortuosity was not measured for MO foams due to its intermediate open-cell content.

\begin{tabular}{|c|c|c|c|c|}
\hline Description & Nomenclature & $\begin{array}{c}\text { Density } \\
\mathbf{( k g / \mathbf { m } ^ { 3 } )}\end{array}$ & $\begin{array}{c}\text { Open-cell } \\
\text { content } \mathbf{( \% )}\end{array}$ & Tortuosity \\
\hline $\begin{array}{c}\text { MEDIUM-OPEN } \\
\text { CELL } \\
\text { CONTENT }\end{array}$ & EVA MO & $18.6 \pm 0.2$ & $64 \pm 5.0$ & ${ }^{*_{-}}$ \\
\cline { 2 - 5 } & PE MO & $19.9 \pm 1.0$ & $65 \pm 6.4$ & ${ }_{-}$ \\
\hline $\begin{array}{c}\text { OPEN-CELL } \\
\text { HIGH } \\
\text { TORTUOSITY }\end{array}$ & EVA HT & $18.4 \pm 0.9$ & $97 \pm 1.5$ & $3.8 \pm 0.5$ \\
\hline $\begin{array}{c}\text { OPEN-CELL } \\
\text { LOW } \\
\text { TORTUOSITY }\end{array}$ & EVA LT & $20.0 \pm 1.0$ & $95 \pm 3.0$ & $4.0 \pm 0.4$ \\
\cline { 2 - 5 } & PE LT & $17.3 \pm 0.6$ & $99 \pm 0.6$ & $1.9 \pm 0.2$ \\
\hline & PU & $47.2 \pm 0.1$ & $98 \pm 0.2$ & $2.0 \pm 0.0$ \\
\hline
\end{tabular}

In addition to the open cell polyolefin foams, an open-cell polyurethane foam with a density of $47 \mathrm{~kg} / \mathrm{m}^{3}$ and a low tortuosity (2.0) similar to the ones of the EVA and PE foams with low tortuosities (1.9) was used as reference material for comparative purposes.

Oil-absorption measurements were carried out by using three types of oils with different densities and viscosities: motor oil 15W40, motor oil $80 \mathrm{~W} 90$ and commercial sunflower oil. The main properties of the oils are summarized in Table 2 :

Table 2. Density and kinematic viscosity values of the oils at 20 and $40{ }^{\circ} \mathrm{C}$. Data obtained from the technical data sheets of the oils used.

\begin{tabular}{|c|c|c|}
\hline Oil & Density at $20^{\circ} \mathbf{C ~} \mathbf{( k g / \mathbf { m } ^ { 3 } )}$ & $\begin{array}{c}\text { Kinematic Viscosity at } \mathbf{4 0} \\
{ }^{\circ} \mathbf{C ~}\left(\mathbf{m m}^{2} / \mathbf{s}\right)\end{array}$ \\
\hline $\mathbf{1 5 W 4 0}$ & 878.70 & 105.10 \\
\hline $\mathbf{8 0 W 9 0}$ & 883.30 & 136.90 \\
\hline Sunflower & 918.80 & 28.00 \\
\hline
\end{tabular}

\section{Density}

The density of the samples was estimated by measuring geometrically the cubic samples used for this study. 


\section{Tortuosity Measurements}

The tortuosity of the open-cell foams considered for the study was estimated by measuring the electrical conductivity of an ionic solution with and without foamed sample immersed in it. A set-up as the one in the scheme depicted in Figure 2 was employed.

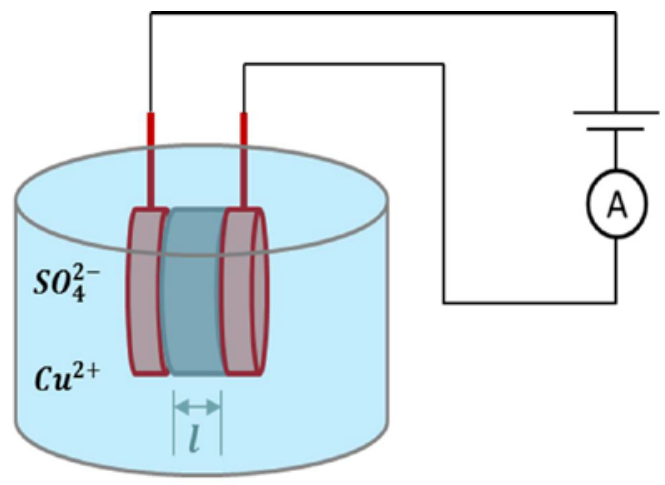

Figure 2. Scheme of the set-up used to measure the electrical conductivity of a $\mathrm{CuSO} 4 \cdot 5 \mathrm{H} 2 \mathrm{O}$ solution.

A solution $0.4 \mathrm{M}$ of $\mathrm{CuSO}_{4} \cdot 5 \mathrm{H}_{2} \mathrm{O}$ was used as the auxiliary liquid. Two copper cylinders (with $15 \mathrm{~mm}$ in diameter and $0.70 \mathrm{~mm}$ in thickness) were employed as electrodes. Alternating current (EA-3048B Elektro-Automatik GmbH, Germany) was employed for the measurements.

The measurements were performed in a range of voltages varying between 3 and $6 \mathrm{~V}$ in steps of $0.5 \mathrm{~V}$. First, the electrical conductivity of the auxiliary liquid was measured without placing a -foamed sample between the electrodes. Then, the electrical conductivity of the auxiliary liquid, including a foamed sample between the electrodes was measured. The samples were soaked for several hours to assure proper penetration of the solution through the cellular structure. At least three repetitions were carried out for each type of material.

Then, tortuosity was estimated by using Equation 1:

$$
T=\frac{R_{f}}{R_{o}}
$$

where $R_{o}$ was the resistance of the solution without the foamed sample and $R_{f}$ was the resistance of the solution when the foam was placed in between the two copper electrodes.

\section{Oil-Absorption Experiments}

Samples with dimensions of $2 \mathrm{~cm} \times 2 \mathrm{~cm} \times 1 \mathrm{~cm}$ were employed for the oil-absorption tests. The samples were placed smoothly over the surface without immersing them in the oil or squeezed the sample to favor the oil absorption. The tests were performed at room temperature, and the foamed samples remained superficially on the oil for 10 minutes. Before the measurement, the foams were weighed $\left(w_{0}\right)$ and then after 10 
minutes in the oil; they were extracted and weighed $\left(w_{1}\right)$ directly. The oil-absorption capacity was estimated by using Equation 2:

$$
\text { Oil absorption }(g / g)=\frac{\left(w_{1}-w_{0}\right)}{w_{o}}
$$

where $w_{1}$ is the weight of the sample after being placed on the oil and $w_{0}$ is the weight before it. The average value of three measurements was the value considered for the analysis of the foams behavior.

Equation 2 does not take into account the density of the oil used for the experiments (see Table 2). For this reason, to compare the absorption performance of the foams for different oils, the volumetric absorption ratio was also estimated (Equation 3):

$$
v_{\text {oil }} / v_{\text {foam }}=\frac{\frac{w_{\text {oil }}}{\rho_{\text {oil }}}}{\frac{w_{\text {foam }}}{\rho_{s}}}
$$

where $w_{\text {oil }}$ is defined as $\left(w_{1}-w_{0}\right) \cdot \rho_{\text {oil }}$ and $\rho_{s}$ are the density of the oil and the solid polymer, respectively.

The oil-absorption efficiency (OAE) allows the comparison between foams of different densities. This parameter indicates which materials present better performance regarding effectiveness in the oil recovery. The OAE is defined as the ratio between the oil absorption and the maximum reachable oil absorption for a given material (Equation 4).

$$
O A E=\frac{\frac{\left(w_{1}-w_{0}\right)}{w_{0}}}{V_{f} \cdot \frac{\rho_{o i l}}{\rho_{f}}}
$$

where $V_{f}$ is the void fraction and $\rho_{f}$ is the foam density. Values near to 0 mean low efficiency and near to 1 indicate a high efficiency.

\section{Water-Absorption Experiments}

To evaluate the selectivity level of the considered materials, the water absorption tests were measured following a methodology similar to the one explained before for oil absorption. The water absorption was estimated using Equation 5.

$$
\text { water absorption }(g / g)=\frac{\left(w_{1}-w_{0}\right)}{w_{o}}
$$

where $w_{1}$ is the weight of the sample after the water absorption and $w_{0}$ is the weight before performing the test. The average value of three measurements was calculated. 


\section{Reusability}

The reusability of the foams was characterized by using two different methods:

- Method \#1: this method involves carrying out compression tests at low strain rates. Compressive stress-strain curves at low rates of deformation ( $270 \mathrm{~mm} / \mathrm{min}$ ) were obtained at room temperature using a universal testing machine (Instron model 5500R6025). The maximum static stress was 75\%. Cubic specimens of $45 \times 45 \times 45 \mathrm{~mm}^{3}$ were used for the tests. The samples were first conditioned at $23{ }^{\circ} \mathrm{C}$ for 24 hours. Twenty (20) consecutive loadunload cycles without delay time between the load and unload cycles were performed to simulate the squeezing process. The reusability of the foams was estimated by comparing the non-recovered deformation induced in the sample after the subsequent load-unload cycles. This parameter is calculated as the intersection between the stress-strain curve in the unload curve and the abscissa axis ( 0 stress). To assure a full reusability of the foam, the values of the non-recovered deformation must be constant throughout the successive load-unload cycles.

- Method \#2: This method implies performing subsequent oil-absorption tests. Thus, after carrying out the initial oil-absorption test, the sample is squeezed; place again over the oil and the oil uptake is measured again. The process is repeated 50 times. Hence, the reusability of the foams can be determined by comparing the oil absorption measured in the 50 considered cycles.

\section{RESULTS AND DISCUSSION}

\section{Cellular Structure and Tortuosity}

The cellular structure of the reference PU, EVA and LDPE based foams with low and high tortuosity is shown in (Figure 3): 

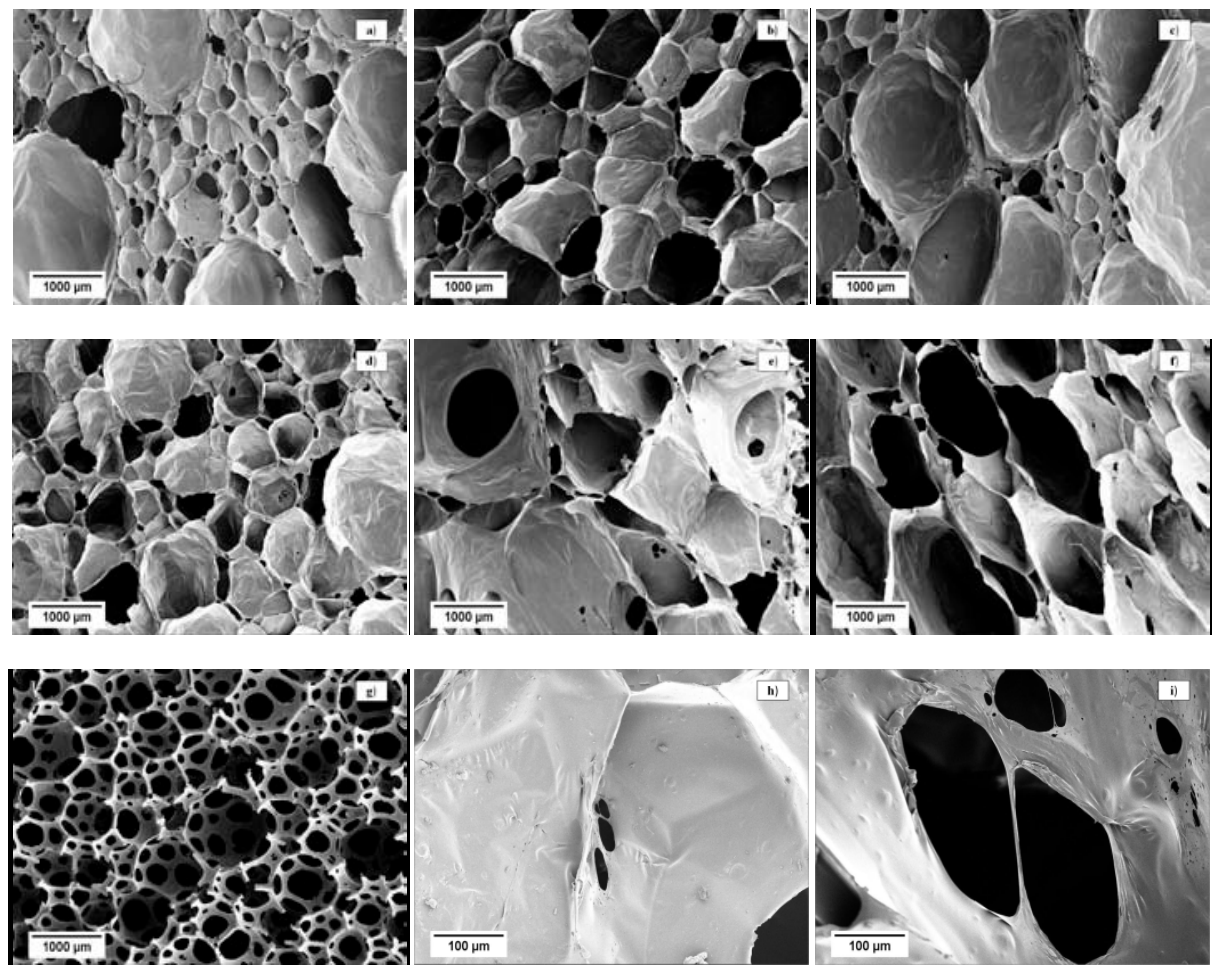

Figure 3. SEM micrographs: a) EVA MO; b) PE MO; c) EVA HT; d) PE HT; e) EVA LT; f) PE LT; g) PU; h) EVA HT foam: holes in cell walls and i) EVA LT foam: holes in the cell walls.

Foams with intermediate open-cell contents (Figure 3a) and 3b), present a low level of interconnection between the cells as there is only a limited number of small holes in the cell walls. On the one hand, open-cell high tortuous foams present a reduced number of small holes in the cell walls (Figure 3c) and 3d). Moreover, open-cell foams with low tortuosity (Figure $\mathbf{3 e}$ ) and $\mathbf{3 f}$ ) are characterized by the presence of an elevated number of large holes in the cell walls. As the holes are very large, the gas phase could diffuse easily and similarly to what happens in open-cell PU foams. Therefore, and as it could be expected, the tortuosity values displayed by LT foams is similar to that shown by PU foams. Figure $3 \mathrm{~g}$ ) shows the cellular structure of the open-cell PU used as a reference. The high level of interconnectivity in this material is due to a cellular structure including only struts and a total absence of cell walls.

The differences between open-cell samples displaying low and high tortuosity levels can be better appreciated in the high-magnification micrographs depicted in Figure 3h) and Figure 3i). High tortuous open-cell polyolefin foams are characterized by the presence of few and small holes in the cell walls (Figure 3h) while the number and the size of the holes of low tortuous open-cell polyolefin foams are considerably larger (Figure 3i).

The numerical results obtained in the tortuosity measurements (Table 1) account for the differences in the morphology of the cellular structure of the different considered foams. The tortuosity of the open-cell PU foam was very low (2.0) as the ions of the auxiliary liquid cover a shorter distance to reach the electrodes in the tortuosity measurements. For the polyolefin foams, low tortuous materials present values of this 
parameter (around 1.9) similar to that of flexible PU foam while in the case of high tortuous foams the values (around 4.0) are twofold than that of PU or LT type foams.

\section{Oil-Absorption Measurements}

The oil-absorption performance of LDPE and EVA LT, HT and MO foams was analyzed and compared with that of the open-cell PU foam. Figure 4 summarizes the results of the oil absorption in grams of oil per grams of foam:

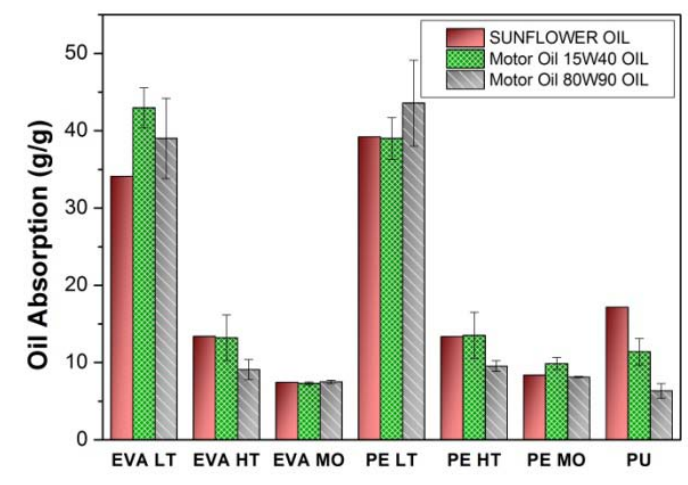

Figure 4. Oil-absorption results for LDPE and EVA foams.

It is clear from Figure 4 that both LT and HT type foams display a better oil-absorption capacity than $\mathrm{MO}$ type foams. $\mathrm{MO}$ foams present a high tortuosity but also a cellular structure with a lower level of interconnection (lower open-cell content, $65 \%$ ) that hinders the penetration of the oil inside the material, only $65 \%$ of the internal volume can be reached by the oil.

When HT and LT foams are compared, it is observed, that LT foams (either based on LDPE or EVA) presented higher oil-uptake values than HT foams regardless of the type of oil. Focusing just on one type of oil, e.g., 15W40 oil, EVA LT foam absorbed up to 3.26 times more oil than EVA HT one, and in the case of LDPE, PE LT foam absorbed 2.89 times more oil than the PE HT one. These results are directly connected with the different tortuosity levels displayed by HT and LT type samples. The presence of a higher number of large holes in the cell walls of LT foams facilitates the penetration of oil inside the structure. However, in HT foams, the oil-absorption was hindered by the presence of a limited number of holes with smaller sizes.

LT foams absorbed up to 43 grams of motor oil 15W40 per gram of foam in the case of EVA and 39 grams in the case of LDPE. Considering the other two types of oil, EVA LT foams were able to absorb 39 and 34 grams of oil per gram of foam for motor oil 80W90 and sunflower oil respectively, and in the case of LDPE foams, those values were 43 and 39 grams per gram of foam. The oil-uptake values displayed by open-cell polyolefin foams with low tortuosity are clearly higher than those reported in the literature for open-cell polyolefin foams ${ }^{33,35}$. 
As it was previously mentioned a commercial open-cell not superficially treated PU flexible foam had been included in the study for comparative purposes. Both LT (3.76 times higher) and HT (1.16 times higher) foams were able to absorb more oil than the open-cell PU foam. PU foams include polar groups in their backbone structure that reduce the chemical affinity towards non-polar molecules. On the other hand, polyolefins such as LDPE and EVA mainly consist of alkyl chains which clearly show a greater affinity towards non-polar groups. Such differences translate into a clear different performance of polyurethane and polyolefin open-cell foams being possible also for the latter to avoid the use of complex and sometimes expensive surface treatments. In addition, it is also observed that samples based on EVA and LDPE present similar values of the oil absorption.

To account for the effect of the characteristics of the type of oil, the volumetric absorption ratio was also determined (see Figure 5):

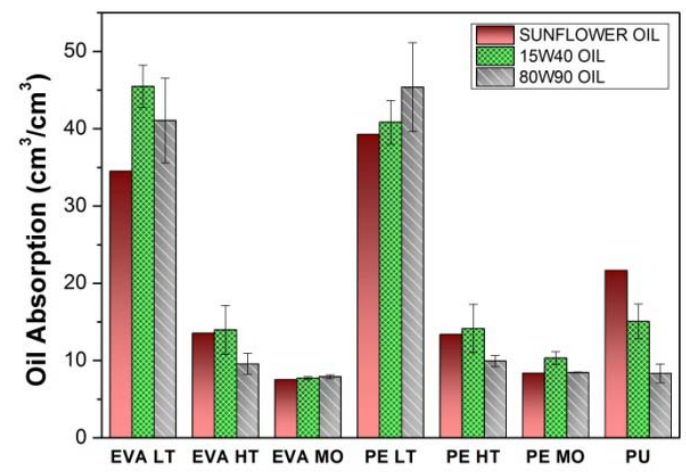

Figure 5. Volumetric oil-absorption results for LDPE and EVA foams.

It is observed in Figure 5 that LT type samples absorb a higher amount of high-viscous oils (motor oils) than low-viscous oils (sunflower oil). During the testing process, right after extracting the soaked samples from the oil, they were directly weighed without removing the superficial oil. The presence of superficial oil lying on the surface of the samples after extracting the foam from the oil could be behind the accounted differences. In LT foams, a thin film of the highly viscous oil was retained in the surface of the foam, and therefore higher amounts of oil were quantified.

Moreover, there was an effect of the characteristics of the cellular structure on the oil uptake. The cell size distribution in LT type foams is very wide, and as a consequence, there are cells of significantly different sizes, as it can be observed in Figure 3. There is a significant population of cells with cell sizes larger than $2 \mathrm{~mm}$, and thus the size of the holes is also large allowing the easy penetration of oil. However, in HT foams, the cell size distribution is also wide, but there are not so many cells with cell sizes larger than $2 \mathrm{~mm}$. The cells sizes are more uniform, and also the holes are much smaller in size in HT foams than in LT foams. As a result, the absorption is not as high as in LT foams. 
The oil density and viscosity had not any influence on the oil-absorption capacity of MO foams. Herein, the absorption was limited by its lower open-cell content regardless of the nature and characteristics of the oil, resulting in similar levels of uptake for all of them.

Concerning the PU foam, its absorption capacity was affected by the viscosity of the oil. Low-viscous oils were absorbed better than high-viscous ones, which was in agreement with some of the examples that can be found in the literature ${ }^{30}$.

The values of the oil-absorption efficiency (OAE) are presented in Table 3:

Table 3. Oil-absorption efficiencies (OAE) of the materials for each oil.

\begin{tabular}{|c|c|c|c|}
\hline Sample & OAE Sunflower & $\begin{array}{c}\text { OAE motor } \\
\text { oil 15W40 }\end{array}$ & $\begin{array}{c}\text { OAE motor } \\
\text { oil 80W90 }\end{array}$ \\
\hline EVA MO & $0.14 \pm 0.02$ & $0.16 \pm 0.00$ & $0.14 \pm 0.00$ \\
\hline PE MO & $0.17 \pm 0.00$ & $0.23 \pm 0.02$ & $0.17 \pm 0.00$ \\
\hline EVA HT & $0.30 \pm 0.04$ & $0.27 \pm 0.06$ & $0.16 \pm 0.02$ \\
\hline PE HT & $0.27 \pm 0.07$ & $0.31 \pm 0.07$ & $0.19 \pm 0.01$ \\
\hline EVA LT & $0.60 \pm 0.06$ & $0.86 \pm 0.05$ & $0.69 \pm 0.09$ \\
\hline PE LT & $0.63 \pm 0.06$ & $0.71 \pm 0.05$ & $0.70 \pm 0.09$ \\
\hline PU & $0.80 \pm 0.22$ & $0.61 \pm 0.09$ & $0.30 \pm 0.04$ \\
\hline
\end{tabular}

When the density of the foam is taken into account, it can be observed that the differences between the open-cell PU foam and the LT foams in the absorptive behavior are reduced. The efficiency in oil absorption of the open-cell PU foams is higher for low-viscous oils, whereas the open-cell polyolefin foams with low tortuosity have a better performance for high-viscous oils.

It can be inferred both from the previous figures and from the data in Table 3, that the main parameters affecting the absorptive capacity are the tortuosity, the density and the viscosity of the oil.

\section{Water Measurements}

Figure 6 displays the water-absorption levels for the different materials and a comparison between the oil absorption of the foams, (with sunflower oil) and their water absorption: 

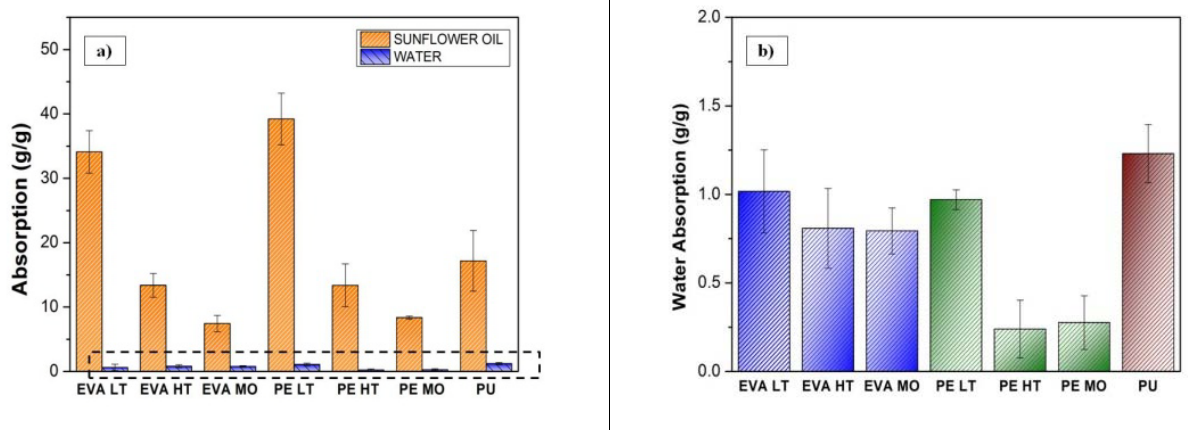

Figure 6. a) Comparative between sunflower oil and water absorptions and b) water absorptions of the materials under study.

As it is observed in Figure 6, the water absorption was practically negligible in comparison to the oil absorption. PE LT foam absorbed 36 times more sunflower oil than water without performing any superficial treatment aimed at making the foam superhydrophobic. Besides, these, polyolefin open-cell foams presented a more hydrophobic character than the PU foam as this material absorbed about twice more water than, for example, the EVA LT foam.
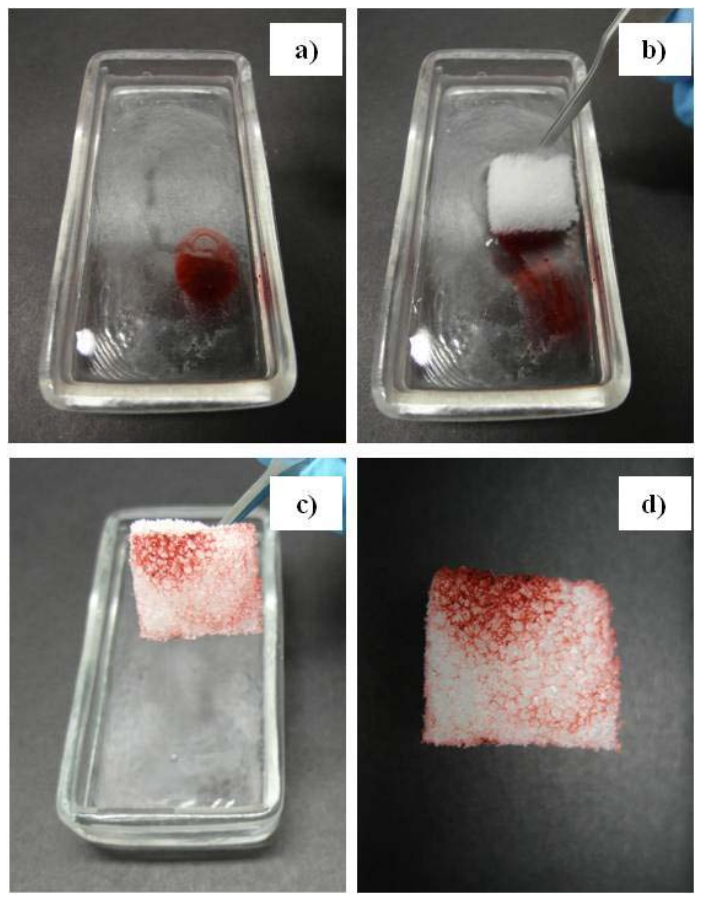

Figure 7. An experimental test of oil absorption in an oil/water mix.

Figure 7 shows the selectivity of the LT open-cell polyolefin foams in an oil/water mix. The oil was stained in red by using Oil Red O. As it is observed, the foam was able to absorb almost all the oil without collecting water. 


\section{Reusability}

To evaluate the viability of the LT open-cell polyolefin foams to be used as oilabsorption materials, it was necessary to analyze their reusability. As it was explained in the section Materials, two different methods were applied for this purpose.

\section{- Compression tests at low strain rates. Determination of the non-recovered} deformation

The reusability of the LT open-cell polyolefin foams and the PU foam was characterized using for this purpose compression tests at low strain rates (270 $\mathrm{mm} / \mathrm{min}$ ). 20 load-unload cycles were performed. HT open-cell polyolefin foams have not been considered for this part of the study because the oil absorption of these materials was not very high.

By using compression tests, the reusability was analyzed by determining the nonrecovered deformation in the unload part of the stress-strain curves.
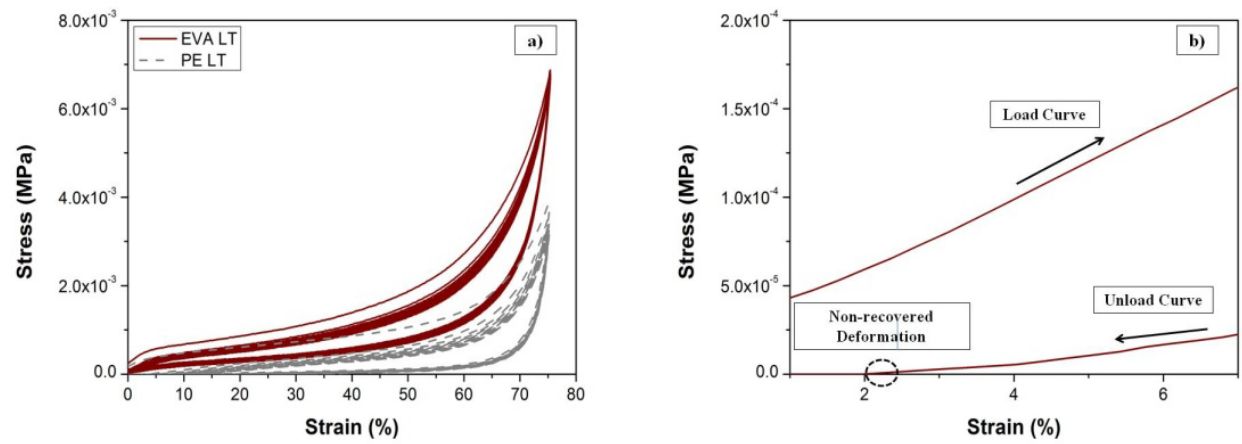

Figure 8. a) Strain-stress curves for the EVA LT and PE LT foams (20 cycles) and b) \% of non-recovered deformation for one of the cycles.

Figure 8a) shows the strain-stress curve of the EVA LT and PE LT foams for 20 loadunload cycles. These curves present the typical shape obtained when considering opencell flexible foams. In the load cycle, the stress increases (linear elasticity) at low strains (below $10 \%$ of strain). Then, the stress is almost constant as the strain increases (plateau) due to the absence of gas inside the cells, and finally, the stress increases at high strains (densification). In the unload cycle, the non-recovered deformation was determined by measuring the \% strain in which the unload curve intersected the abscissa axis (no stress), as it is described in Fig $\mathbf{8 b}$ ). Non-recovered deformation values near to $0 \%$ indicate that the foam fully recovers after the removal of the applied load. High non-recovered deformation \% means a poor recovery performance of the material.

Table 4 summarizes the non-recovered deformation values measured after several cycles for the considered materials: 
Table 4. Non-recovered deformation (\%) of the foams under study.

\begin{tabular}{|c|c|c|c|c|c|}
\hline \multirow{2}{*}{ Sample } & \multicolumn{5}{|c|}{ Non-recovered Deformation (\%) } \\
\cline { 2 - 6 } & Cycle 1 & Cycle 5 & Cycle 10 & Cycle 15 & Cycle 20 \\
\hline EVA LT & 0.62 & 2.22 & 3.21 & 3.59 & 4.20 \\
\hline PE LT & 13.11 & 26.04 & 29.02 & 31.02 & 32.02 \\
\hline PU & 0.20 & 1.14 & 1.98 & 1.96 & 1.86 \\
\hline
\end{tabular}

PU displayed the lowest non-recovered deformation, and almost constant values of this parameter during the subsequent load-unload cycles. EVA LT exhibited similar non-recovered strains to those achieved for PU foams. In both materials, the nonrecovered strain increased slightly between the first and the fifth cycle, but it could be said that the values are small and remained approximately constant throughout the whole series of load-unload cycles. However, non-recovered strains were quite high for PE LT in comparison to the other two materials. This different behavior between EVA LT and PE LT foams is explained, taking into account the rubbery nature of the polymeric matrix (EVA), which facilitated the recovery of the foam. The non-recovered strain of PE LT slightly increased from the first to the fifth cycle (around 29\%) and then also remained constant.

\section{- Behavior as a function of the number of absorption tests}

To complement the results obtained from the mechanical compression tests at low strain rates and to have a more realistic picture of the performance of the materials, reabsorption measurements of the foams under study were also carried out. In this case, the foams were extracted from the oil after 10 minutes, weighed and squeezed to remove almost all the oil inside the cellular structure. After removing the oil, the foams were placed in the oil again and were left there for other 10 minutes. This process was repeated for 50 times.

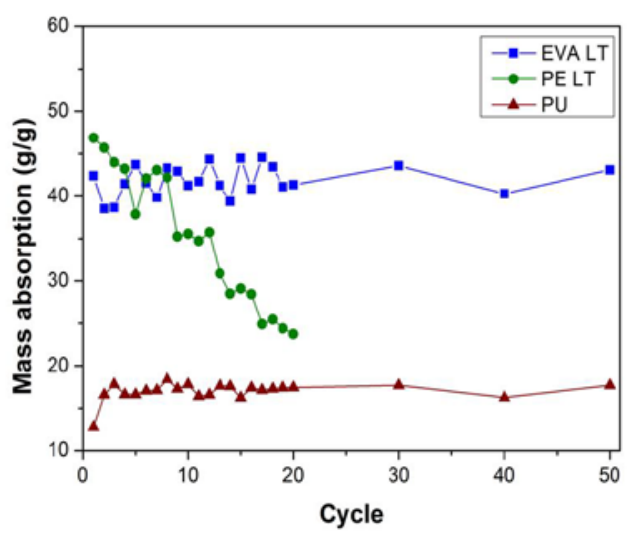

Figure 9. Oil absorption of the foams under study in the successive immersion-squeezing cycles (15W40 oil).

Figure 9 shows the oil absorption for 15W40 oil of the LT open-cell polyolefin foams and the PU foam throughout the successive reabsorption cycles. 
As it is observed in Figure 9, the oil absorption was almost constant for EVA LT and PU throughout the subsequent reabsorption cycles. The slight increase of oil absorption was explained by taking into account that in each cycle, different volumes of oil remained in the foam surface, but in general, the values were almost constant.

With regard to PE LT foams, it is observed that the oil absorption decreases as the number of cycles increases. The poorer recovery capacity of PE LT foams was observed by using the previous method, and it is again displayed with this second one. This effect can be explained, taking into account the rubbery character of the polymer matrix. As the PE LT was squeezed, a densification of the material was observed restricting the oil absorption. When this process was repeated for 20 times, the foam was collapsed, and as a result, the tests could not be performed 50 times. However, EVA is more flexible than LDPE and, therefore, this material was able to recover completely after the mechanical squeezing during at least 50 cycles. This is in agreement with the results obtained by the method based on performing low strain rates compression tests.

Both methods provided useful information regarding the level of reusability of the different foams. Herein, it is concluded that EVA LT open-cell polyolefin foams, were able to keep constant their oil-absorption capacity throughout 50 consecutive reabsorption cycles. On the other hand, the results indicate that PE LT foams present a worse capacity of reabsorbing oil due to the lower recovery levels of the foam after a mechanical deformation.

\section{CONCLUSIONS}

The oil-absorption capacity of crosslinked EVA and LDPE low-density open-cell flexible polyolefin foams with different cellular interconnectivity levels was evaluated considering different types of oils with different densities and viscosities. A commercial superficial untreated PU foam was used as a reference.

Regarding oil-absorption measurements, open-cell foams with low tortuosity proved to be able to absorb up to 3 times more oil than the open-cell materials with high tortuosity and also showed significantly high oil-absorption capabilities (43 grams of motor oil 15W40 per gram of foam). Furthermore, both types of open-cell polyolefin foams showed better oil-absorption capacity than the PU foam due to their chemical affinity towards the oils. When it comes to the influence of the type of oil, on the one hand, larger volumes of oil with higher viscosities remained superficially in the LT foams, resulting in higher weights. On the other hand, and in agreement with other publications, the viscosity of the oil had a direct effect on the oil absorption of the PU foams, being the absorption of low-viscous oils higher than the absorption of highviscous oils.

The water absorption of both types of polyolefin open-cell foams was very low. It was also remarkable that these results were obtained without carrying out any superficial treatment to increase the hydrophobicity of the foams. Moreover, the water absorption 
of both LT and HT open-cell polyolefin foams was lower than that of the PU foam. Finally, the reusability of the LT open-cell foams was also evaluated firstly by estimating the non-recovered deformation in compression tests at low strain rates and secondly by measuring the oil-reabsorption capacity. The non-recovered deformation of EVA LT foams was similar to the one shown by the PU foam.

Moreover, this value was almost constant throughout 20 load-unload cycles. This behavior was also observed in the reabsorption measurements. On the other hand, PE LT foams present a worse recovery and a poor performance in the reabsorption tests due to the lower elasticity of the polymer matrix. The results showed that EVA LT foams did not lose their ability to recover throughout the subsequent absorption cycles, and similar amounts of oil were absorbed. As a conclusion, it can be affirmed that EVA LT foams fulfil the requirements to be reused.

In this work, it has been demonstrated, that low-density open-cell flexible EVA foams with low tortuosity could be a promising alternative to be used for oil spill remediation.

\section{ACKNOWLEDGEMENTS}

Financial support from DI grant DI-15-07952 (E. Lopez-Gonzalez) from the Spanish Ministry of Economy, Industry, and Competitiveness and MINECO, FEDER, UE (MAT2015-69234-R) is gratefully acknowledged.

\section{REFERENCES} Adebajo MO, Frost RL, Kloprogge JT, Carmody O, Kokot S (2003) Porous materials for oil spill cleanup: A review of
synthesis and absorbing properties. J Porous Mater 10:159-170. https:/ / doi.org/10.1023/ A:1027484117065

Allen AA, Ferek RJ (1993) Advantages and disadvantages of burning spilled oil. International Oil Spill Proceedings 1:765-772. https://doi.org/10.7901/2169-3358-1993-1-765

Calcagnile P, Fragouli D, Bayer IS, Anyfantis GC, Martiradonna L, Cozzoli PD, Cingolani R, Athanassiou A. (2012) Magnetically driven floating foams for the removal of oil contaminants from water. ACS Nano 6:5413-5419. https://doi.org/10.1021/nn3012948

Choi HM, Cloud RM (1992) Natural sorbents in oil spill cleanup. Environ Sci Technol 26:772-776. https://doi.org/10.1021/es00028a016

Cunningham A, Hilyard NC (1994) Low Density Cellular Plastics: Physical Basis of Behavior. Chapman and Hall, London.

Eaves D (2004) Handbook of Polymer Foams. Rapra Technology Limited, Shrewsbury.

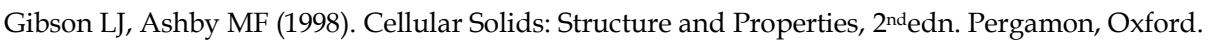

Hamdi O, Mighri F, Rodrigue D (2018) Optimization of the cellular morphology of biaxially stretched thin polyethylene foams produced by extrusion film blowing. Cell Polym 13:153-168. https://doi.org/10.1177/0262489318797517

ITOPF Ltd: “Oil Tanker Spill Statistics 2017” (London, United Kingdom).

https://www.itopf.org/fileadmin/data/Photos/Statistics/Oil_Spill_Stats_2017_web.pdf.

Klempner D, Frisch KC (1992) Handbook of Polymeric Foams and Foam Technology. Hanser Publishers, Munich. 
Klempner D, Sendijarevic V (2004). Handbook of Polymeric Foams and Foam Technology $2^{\text {nd }}$ Edition. Hanser Publishers, Munich.

Kota KA, Kwon G, Choi W, Mabry JM, Tuteja A (2012) Hygro-responsive membranes for effective oil-water separation. Nat Commun 3:1025. https:// doi.org/10.1038/ncomm2027

Lessard RR, DeMarco G (2000) The Significance of oil spill dispersants. Spill Sci Technol B 6:59-68. https://doi.org/10.1016/S1353-2561(99)00061-4

Li H, Liu L, Yang F (2013) Oleophilic polyurethane foams for oil spill cleanup. Procedia Environ Sci 18:528-533. https:// doi.org/10.1016/j.proenv.2013.04.071

Liu Y, Ma J, Wu T, Wang X, Huang G, Liu Y, Qiu H, Li Y, Wang W, Gao J (2013) Cost effective reduced graphene oxide coated polyurethane sponge as a highly efficient and reusable oil-absorbent. ACS Appl Mater Inter 5:10018-10026. https:// doi.org/10.1021/am4024252

Montagna PA, Baguley JG, Cooksey C, Hartwell I, Hyde LJ, Hyland JL, Kalke RD, Kracker LM, Reuscher, Rhodes ACE (2013) Deep-Sea benthic footprint of the Deepwater Horizon blowout. Plos One 8:e70540.

https://doi.org/10.1371/journal.pone.0070540

Pinto J, Athanassiou A, Fragouli D (2016) Effect of the porous structure of polymer foams on the remediation of oil spills. J Phys D: Appl Phys 49:145601. https://doi.org/10.1088/0022-3727/49/14/145601

Pinto J, Heredia-Guerrero JA, Athanassiou A, Fragouli D (2017) Reusable nanocomposite-coated polyurethane foams for the remediation of oil spills. Int J Environ Sci Technol 14:2055-2066. https:/ / doi.org/10.1007/s13762-017-1310-6

Pintor AMA, Ferreira CIA, Pereira JC, Correia P, Silva SP, Vilar VJP, Botelho CMS, Boaventura RAR (2012) Use of cork powder and granules for adsorption of pollutants: A review. Water Res 46: 3152-3166. .

https:// doi.org/10.1016/j.watres.2012.03.048

Rengasamy RS, Das D, Praba Karan C (2011) Study of oil sorption behavior of filled and structured fiber assemblies made from polypropylene, kapok and milkweed fibers. J Hazad Mater 186:526-532.

https:// doi.org/10.1016/j.jhazmat.2010.11.031

Rizvi A, Chu RKM, Lee JH, Park CB (2014) Superhydrophobic and oleophilic open-cell foams from fibrillar blends of polypropylene and polytetrafluoroehtylene. ACS Appl Mater Inter 6:21131-21140. https://doi.org/10.1021/am506006v

Rodriguez-Perez MA (2005) Crosslinked polyolefin foams: production, structure, properties and applications. Adv Polym Sci 184:97-126. https:/ / doi.org/10.1007/b136244

Teas C, Kalligeros S, Zanikos F, Stournas S, Lois E, Anastopoulos G (2001) Investigation of the effectiveness of absorbent materials in oil spill clean up. Desalination 140:259-264. https:/ / doi.org/10.1016/S0011-9164(01)00375-7

Xue Z, Cao Y, Liu N, Feng L, Jiang L (2014) Special wettable materials for oil/water separation. J Mater Chem A 2:24452460. https://doi.org/10.1039/C3TA13397D

Wang P, Zou C, Zhong H (2012) The study of highly oil absorption polyurethane foam material and its application in the emergency disposal of hazardous chemicals. Adv Mat Res 518-523:847-853.

https://doi.org/10.4028/www.scientific.net/AMR.518-523.847

Wang CF, Lin SJ (2013) Robust superhydrophobic/superolephilic sponge for effective continuous absorption and expulsion of oil pollutants from water. ACS Appl Mater Inter 5:8861-8864. https://doi.org/10.1021/am403266v

Wang J, Zheng Y, Wang A (2013) Coated kapok fiber for removal of spilled oil. Mar Pollut Bull 69: 91-96. https:// doi.org/10.1016/j.marpolbul.2013.01.007

Wang S, Wang K, Pang Y, Li Y, Wu F, Wang S, Zheng W (2016) Open-cell propylene/polyolefin elastomer blend foams fabricated for reusable oil-sorption materials. J Appl Polym Sci 133:43812-43821. https://doi.org/10.1002/app.43812

Wen Q, Di J, Jiang L, Yu J, Xu R (2013) Zeolite-coated mesh film for efficient oil-water separation. Chem Sci 4:591-595. https://doi.org/10.1039/C2SC21772D 
Zhang F, Zhang WB, Shi Z, Wang D, Jin J, Jiang L (2013) Nanowire-haired inorganic membranes with superhydrophilicity and underwater ultralow adhesive superolephobicity for high efficiency oil/water separation. Adv Mater 25:4192-4198. https:// doi.org/10.1002/adma.201301480

Zhou X, Zhang Z, Xu X, Guo F, Zhu X, Men X, Ge B (2013) Robust and durable superhydrophobic cotton fabrics for oil/water separation. ACS Appl Mater Inter 5:7208-7214. https://doi.org/10.1021/am4015346

Zhu Q, Chu Y, Wang Z, Chen N, Lin L, Liu F, Pan Q (2013) Robust superhydrophobic polyurethane sponge as a highly reusable oil-absorption material. J Mater Chem A 1:5386-5393. https://doi.org/10.1039/C3TA00125C

Zhu Y, Wang D, Jiang L and Jin J (2014) Recent progress in developing advanced membranes for emulsified oil/water separation. NPG Asia Mater 6:e101. https://doi.org/10.1038/am.2014.23 


\subsection{Oil absorption: Foams based on EVA 12 and EBA}

The previous section is referred to the results obtained for the oil absorption, oil absorption efficiencies, water absorption and the reusability of open-cell foams based on LDPE and EVA 18. However, all these parameters were also characterized in the open-cell foams based on EVA 12 and EBA.

This section is focused on summarizing the main results obtained for these polymer matrices, following the same methodology explained in the research article of section 6.2 .

To simplify the results, in the analysis of the EVA 12 and EBA foams, the results of the MO foams are not shown; only the ones corresponding to open-cell foams are described in this section. The results for the MO foams were similar to the ones explained in the previous section, showing these materials low values of oil absorption.

Figure 6.1 shows the oil absorptions of the EVA 12 and EBA open-cell foams and also the absorption of the open-cell PU foam used as a reference.
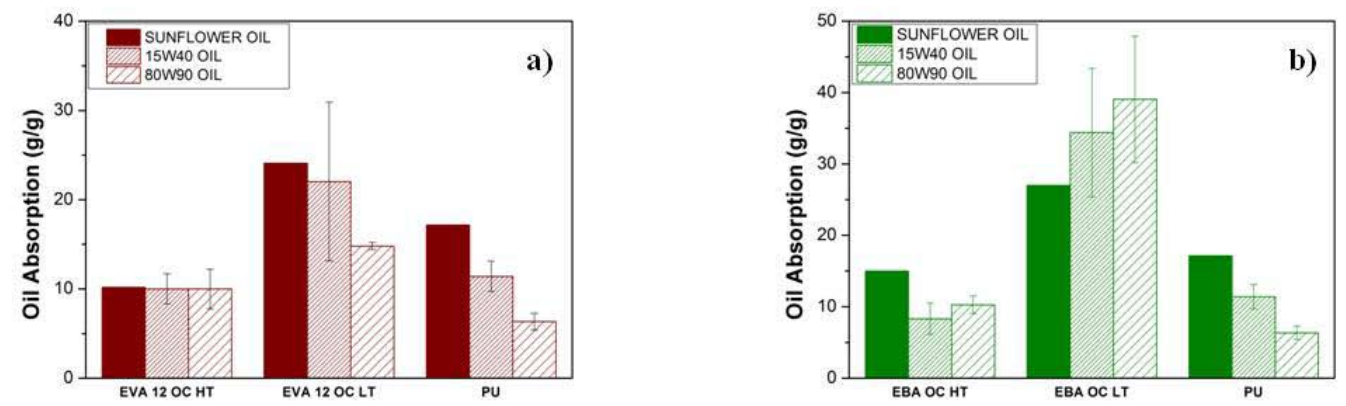

Figure 6.1. Motor 15W40, motor 80 W90 and sunflower oil absorptions of the materials: (a) EVA 12 and (b) EBA.

For both polymer matrices and regardless of the type of oil, the low tortuous foams are able to absorb a larger amount of oil than the high tortuous materials. This tendency was also found in LDPE and EVA 18. As it was pointed out in the previous research article, the explanation behind this result is connected to the different size of the holes. Oil can penetrate more easily through the large holes of the low tortuous foams. However, this penetration is hindered when the holes are small, situation which is found in the open-cell materials with high tortuosity.

Concerning EVA 12 (Figure 6.1 a), it can be observed, that the EVA OC LT foam absorbs more oil than the open-cell PU foam regardless of the type of oil. However, its oil absorptions are considerably lower than the ones displayed by the LDPE or EVA 18 OC LT foams. These foams absorbed over 40 grams of oil per gram of foam, whereas the maximum absorption obtained for EVA 12 OC LT is 22 grams of oil per gram of foam. This can be explained, taking into account the higher tortuosity value of the EVA 12 OC LT in comparison to its counterparts (see Chapter 3, section 3.3.4). The holes in the EVA 12 OC LT foams are not as large as in other materials, and thus, there is a 
limitation in the oil absorption. Furthermore, the heterogeneity of the cellular structure also plays an important role, as it can be inferred from the large error bars in the EVA 12 OC LT.

Another interesting result is the influence of the type of oil on the absorption. Focusing on the EVA 12 OC LT foam, the oil capacity is related to the oil viscosity. The less viscous oil (sunflower oil) is the one which is easily to absorb, whereas the absorption of the most viscous oil (motor oil 80W90) is restricted. This tendency was also observed in the open-cell PU foam. However, this logical effect has not been observed in all cases, and for example, in EBA OC LT, the opposite tendency was found.

In the case of EBA open-cell foams, the EBA OC LT foam is also able to absorb more oil than the open-cell PU foams. In this case, higher absorptions (up to 39 grams of oil per gram of foam) were obtained. As in EVA 12, the large error bars account for the lack of homogeneity in the cellular structure and considering the small size of the sample used for this characterization; this error is magnified. Furthermore, concerning the type of oil, an unexpected tendency was found, being the oil absorption of the most viscous oil the highest one. This illogical result was also obtained for the LDPE and EVA 18 foams. In the research article of previous section (section 6.2), it was explained that the measurement methodology used plays a critical role on this aspect, because the superficial oil is not removed, and thus it is quite complicated to evaluate the effect of the oil viscosity on the oil uptake because the highly viscous oils have a higher tendency to stay in the surface.

There is not any standard which describes how to perform these measurements and as many factors are contributing to the oil absorption, it is quite difficult to isolate the contribution of each factor.

Even though the tortuosity values are quite similar for the open-cell foams with low tortuosity, the cellular structure of the foams is different (different cell size, number of holes and holes size) and therefore it is not possible to analyze the effect of the polymer matrix on the oil absorption. It would be quite interesting to produce open-cell foams with analogous cellular structures to establish differences between them. In this hypothetical case, it would be expected, that the less polar polymer matrix (LDPE) could absorb a larger amount of oil, followed by EBA since the butyl acrylate groups are less polar than the vinyl acetate ones. Even, it would be possible to determine the differences between EVA 12 and EVA 18 due to the different vinyl acetate content. Since the vinyl acetate groups contribute to the polarity of the matrix, EVA 18 should present the lowest oil absorptions. However, these trends were not observed because cellular structure parameters are playing a more important role on this property.

The oil absorption depends critically on the density of the foam. The number of grams per gram of foam does not take into account the density of the material. As a consequence, and for comparative purposes, the oil absorption efficiency (OAE) was also estimated for the EVA 12 and EBA open-cell foams. 
The results of the OAE for each type of oil are displayed in Table 6.1.

\begin{tabular}{|cccc|}
\hline Sample & $\begin{array}{c}\text { Oil Absorption } \\
\text { Efficiency } \\
\text { Sunflower oil }\end{array}$ & $\begin{array}{c}\text { Oil Absorption } \\
\text { Efficiency } \\
15 W 40 \text { oil }\end{array}$ & $\begin{array}{c}\text { Oil Absorption } \\
\text { Efficiency } \\
80 W 90 \text { oil }\end{array}$ \\
\hline EVA 12 OC HT & $0.28 \pm 0.09$ & $0.28 \pm 0.05$ & $0.30 \pm 0.07$ \\
\hline EVA 12 OC LT & $0.66 \pm 0.26$ & $0.63 \pm 0.25$ & $0.44 \pm 0.01$ \\
\hline EBA OC HT & $0.33 \pm 0.03$ & $0.19 \pm 0.05$ & $0.25 \pm 0.03$ \\
\hline EBA OC LT & $0.60 \pm 0.12$ & $0.80 \pm 0.21$ & $0.96 \pm 0.22$ \\
\hline PU & $0.80 \pm 0.22$ & $0.61 \pm 0.09$ & $0.30 \pm 0.04$ \\
\hline
\end{tabular}

For LDPE and EVA 18 OC LT foams, the OAE values were above 0.60 independently of the type of oil. However, the EVA OC 12 LT foam presents lower values and thus poorer efficiencies. Moreover, the OAE values of the EVA 12 OC LT are lower in some cases than that of the open-cell PU foam, despite having higher oil absorptions (Figure 6.1 a). This is explained taking into account the higher density of the open-cell PU foam $\left(47 \mathrm{~kg} / \mathrm{m}^{3}\right)$ in comparison to the EVA 12 OC LT foam $\left(21.9 \mathrm{~kg} / \mathrm{m}^{3}\right)$. The low density of the open-cell polyolefin foams allows them to take a considerable amount of oil, whereas the open-cell PU foam cannot absorb as much as the polyolefin foams due to the high density (less space to store the oil).

The OAE values for the EBA OC LT are excellent. This foam is able to absorb oil efficiently. The high OAE for the $80 \mathrm{~W} 90$ is based on the presence of superficial oil. When the sample is extracted from the oil, the oils with higher viscosities remained superficially whereas the sunflower oil tended to drop from the foam (except for EVA OC LT 12).

The hydrophobicity of the materials was also tested using the same procedure but with water as the fluid. It must be taken into account, that in a real situation, for instance, in an ocean, the recovery methods must absorb the oil selectively avoiding the water uptake. In this aspect, it was proved that the oil-water selectivity of the LDPE and EVA 18 open-cell foams was excellent, presenting these two materials (section 6.2) water absorptions below 1 gram of water per gram of foam.

The results of the water absorption of EVA 12 and EBA open-cell foams are included in Figure 6.2. 

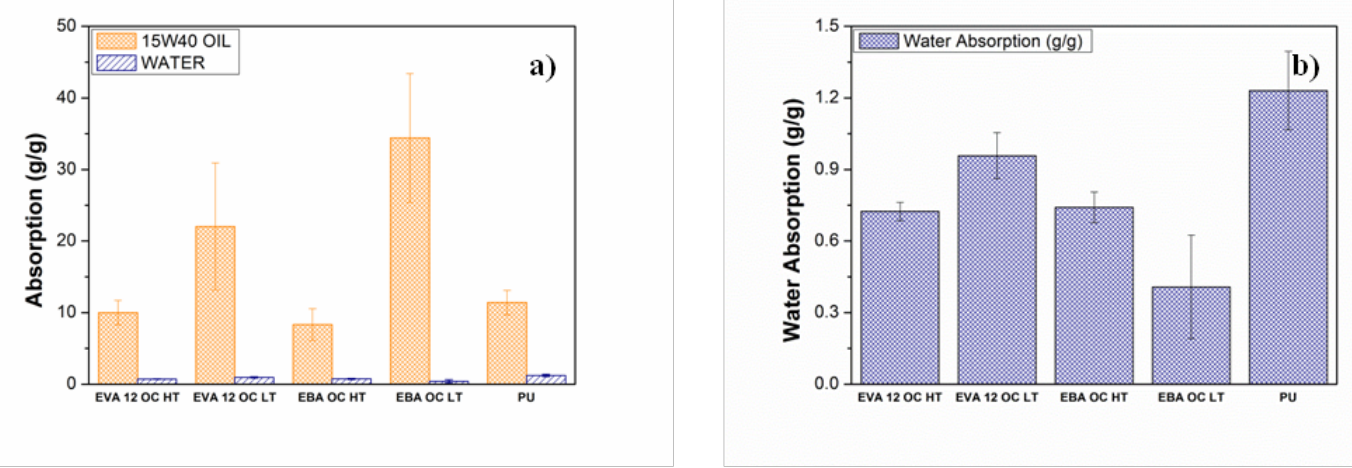

Figure 6.2. (a) Comparison between motor oil $15 W 40$ and water absorptions and (b) water absorptions.

Figure 6.2 a) shows a comparison between the motor oil $15 \mathrm{~W} 40$ and the water absorptions. As in the case of LDPE and EVA 18, the water absorptions of the EVA 12 and EBA open-cell foams can be neglected. All the water absorptions are below 1 gram of water of foam, which is connected to the low polarity of the polyolefin chains. In Figure $6.2 \mathrm{~b}$ ), it can be inferred that the open-cell PU foam is more hydrophilic, absorbing more than 1 gram of water per gram of foam $(1.23 \mathrm{~g} / \mathrm{g})$. In chapter 2 , this limitation of open-cell PU foams was discussed. This limitation is typically overcome by treating the surface of the foams with the aim of making it superhydrophobic. In the hypothetical case of comparing open-cell polyolefin foams with the same cellular structures, it would be observed the opposite tendency as the one explained for oil absorption. Concerning water absorptions, EVA 18 would show the highest affinity towards water, whereas the lower water absorption would be obtained for LDPE. Even more "real" differences could be distinguished between polyolefins and polyurethane.

As a summary, it has also been proven with these polymer matrices the critical effect of the tortuosity on the oil absorptions, being the low tortuous materials the most adequate for this property. Furthermore, the EBA OC LT presents excellent results concerning oil absorptions and oil-water selectivity, whereas the EVA 12 has a poorer performance due to the slight difference in tortuosity between this material and its counterparts.

Finally, the last parameter that has been analyzed was the reusability. The two approximations (compression tests at low strain rates and reabsorption cycles) followed in the research articles were also applied for EVA 12 OC LT and EBA OC LT.

Concerning compression tests at low strain rates $(270 \mathrm{~mm} / \mathrm{min} ; 20$ load-unload cycles, $75 \%$ stain), the non-recovered deformation (NRD) were estimated for both open-cell materials. The results (cycles: 1, 5, 10, 15 and 20) are collected in Table 6.2: 


\begin{tabular}{|cccccc|}
\hline Sample & $\begin{array}{c}\text { NRD (\%) } \\
\text { Cycle 1 }\end{array}$ & $\begin{array}{c}\text { NRD (\%) } \\
\text { Cycle 5 }\end{array}$ & $\begin{array}{c}\text { NRD (\%) } \\
\text { Cycle 10 }\end{array}$ & $\begin{array}{c}\text { NRD (\%) } \\
\text { Cycle 15 }\end{array}$ & $\begin{array}{c}\text { NRD (\%) } \\
\text { Cycle 20 }\end{array}$ \\
\hline EVA 12 OC LT & 2.47 & 3.45 & 5.45 & 6.46 & 5.43 \\
\hline EBA OC LT & 0.10 & 2.08 & 3.07 & 3.07 & 4.08 \\
\hline PU & 0.20 & 1.14 & 1.98 & 1.96 & 1.86 \\
\hline
\end{tabular}

The non-recovered deformation accounts for the percentage of the material which is not able to recover after being deformed. Thus, this value must be as low as possible for considering a material as reusable. The open-cell PU is a material which is used in seats in the automotive sector, and it was expected that it could recover totally after deforming it. As a result, it can be observed in Table 6.2, the very low NRD values displayed by this foam. Although both open-cell polyolefin foams present higher values, it is also important to stand out that the values are low, recovering the material almost completely after the deformation process. Only LDPE presented poorer values in this test showing values above $20 \%$ (see section 6.2).

Therefore, we can conclude that the values of the non-recovered deformation are almost constant throughout the successive load-unload cycles, and thus, the materials do not lose their performance after being deformed up to 20 times. This result is positive, and at least according to this methodology the open-cell polyolefin foams with low tortuosity (except for LDPE) fulfill this strict requirement.

The second methodology is based on reabsorption tests. This process is widely used to characterize the reusability of foams [15-17,19]. In our research, the process of collecting oil, squeezing the foam to remove the oil and collection again of oil was repeated up to 50 times, a considerable number of cycles which give an accurate idea about the capacity of the materials of being reused.

The results of the oil absorption throughout the subsequent reabsorption cycles (motor oil 15W40) are shown in Figure 6.3:

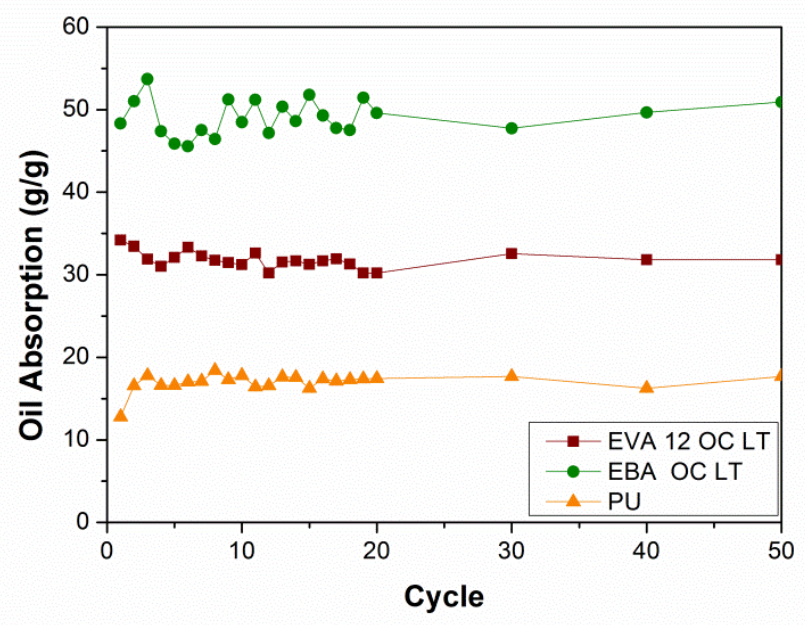

Figure 6.3. Oil absorption as a function of the reabsorption cycle for motor oil 15W40. 
Before describing each material in detail, the main conclusion which can be extracted from Figure 6.3, is that the open-cell materials considered in this figure do not lose their performance after 50 cycles. This result is in agreement with the results obtained for the compression tests.

On the one hand, the difference between the $1^{\text {st }}$ and the $50^{\text {th }}$ cycle in the EVA 12 OC LT foam is 2.36 grams of oil per gram of foam, a low value in comparison to the total absorption of this material. On the other hand, for EBA OC LT, the values are quite constant between 45 and 55 grams of oil per gram of foam.

Looking at Figure 6.1, the EBA OC LT foam was able to absorb over 35 grams of motor oil 15W40 per gram of foam. However, in Figure 6.3, up to 53 grams of motor oil $15 \mathrm{~W} 40$ per gram of foam were absorbed. This is a consequence of the heterogeneity in the results obtained for the EBA LT foams, due to the small size of the samples used in these tests and the variation of the tortuosity among samples.

To conclude this section, we can say that EVA and EBA open-cell foams with low tortuosity are very promising materials for this particular application. High oil absorptions were obtained, also presenting excellent oil-water selectivity without inducing superhydrophobicity to the materials. It is also remarkable that these opencell materials can be reused at least 50 times.

\subsection{Conclusions}

In this chapter, it has been demonstrated that crosslinked open-cell foams with low tortuosity based on polyolefin are excellent candidates to be used for oil absorption.

Figure 6.4 compares the oil absorptive behavior (motor oil 15W40) of the OC LT foams of this study with some examples in the literature aiming at referencing where these foams are located. 


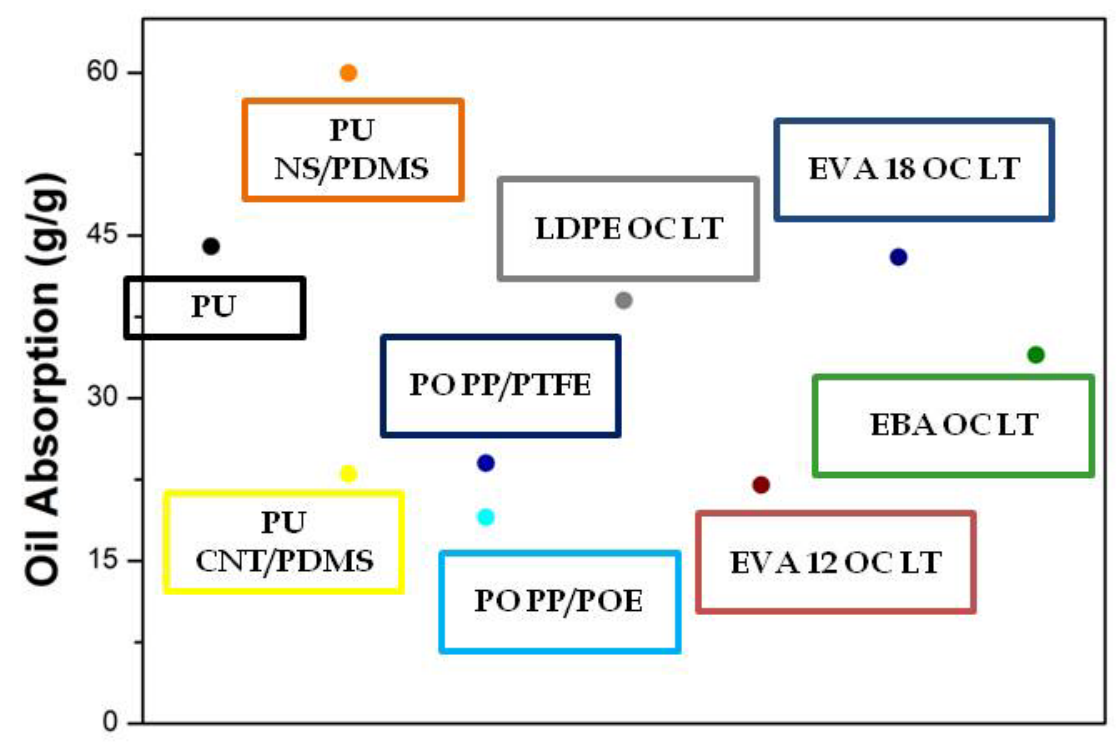

Figure 6.4. Comparative of the oil absorption between OC LT foams and some examples in the literature. PU: nontreated open-cell PU foam [18]; PU NS/PDMS PU treated with nanosilica and polydimethylsiloxane [13]; PU

CNT/PDMS PU treated with carbon nanotubes and polydimethylsiloxane [9]; PO (polyolefin) PP/PTFE polypropylene/polytetrafluoroethylene foams [15] and PO (polyolefin) PP/POE polypropylene/polyolefin elastomer foams [16].

In comparison to the different PU foams, it is observed that the OC LT foams are quite competitive being their absorptions similar to non-treated PU foams [18]. In fact, in some examples, the OC LT foams are able to absorb more oil than the treated PU foams, as in the case of PU foams treated with carbon nanotubes and polydimethylsiloxane [9]. However, in other examples, treated PU foams show higher oil absorptions than the OC LT foams [13]. Taking into account, the excellent oil-water selectivity of the OC LT foams without applying any surface treatment, the results can be considered positive.

Concerning polyolefin foams, the OC LT foams of this study present higher absorption than those exhibited by the foams produced by Rizvi et al. [15] and Wang et al. [16]. It is true that density is not the same in these examples, but reaching low-densities entail a considerable challenge. Up to now, the OC LT foams presented in this chapter display the highest oil absorption reported up to now in the literature for open-cell foams based on polyolefins. 


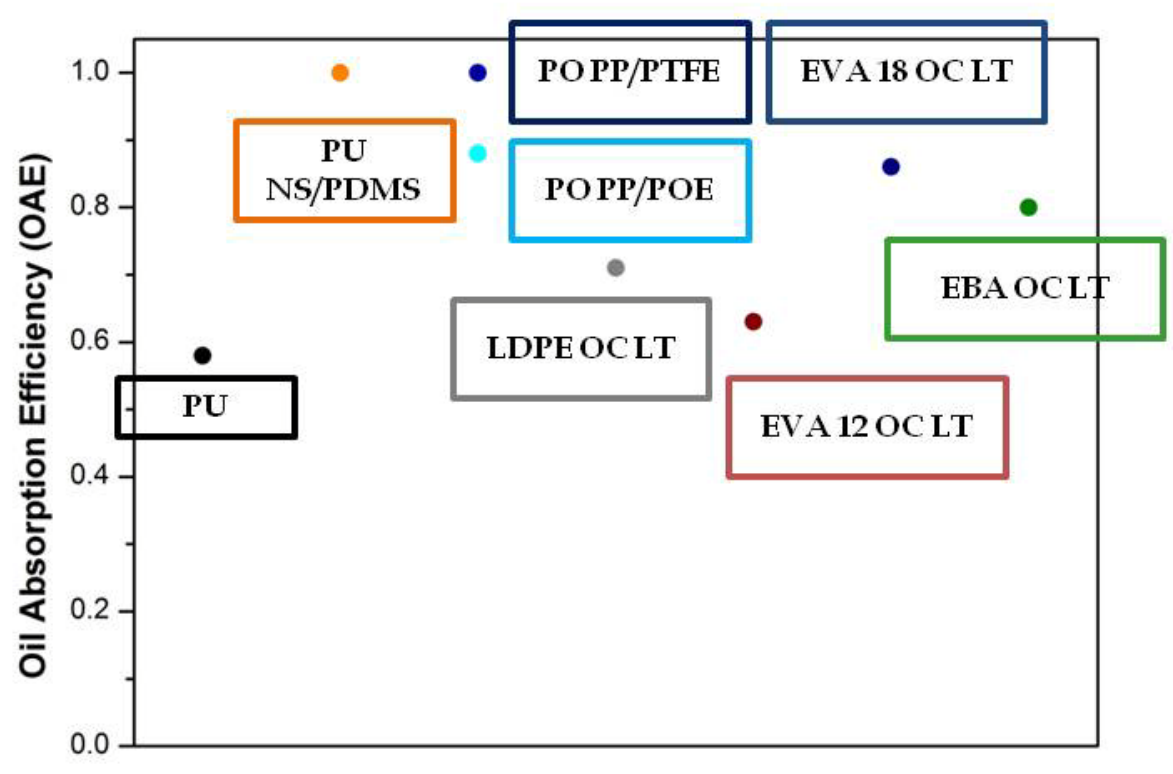

Figure 6.5. Comparative of the oil absorption efficiency (OAE) between OC LT foams and some examples in the literature. PU: non-treated open-cell PU foam [18]; PU NS/PDMS PU treated with nanosilica and polydimethylsiloxane [13]; PO (polyolefin) PP/PTFE polypropylene/polytetrafluoroethylene foams [15] and PO (polyolefin) PP/POE polypropylene/polyolefin elastomer foams [16].* the OAE for the PU CNT/PDMS PU treated with carbon nanotubes and polydimethylsiloxane foam was not estimated due to the lack of data [9].

Figure 6.5 shows the results related to the OAE values. All the open-cell polyolefin foams present OAE values above 0.5 , indicating the extraordinary efficiency of the materials to absorb oil. The values are comparable to those obtained for the open-cell foams reported in the literature.

Finally, a value added of these foams is the excellent reusability exhibited in both tests, (except for the LDPE OC LT foam).

As a result, EVA and EBA OC LT foams are promising materials for oil spill remediation thanks to the high oil absorptions, very low densities, excellent oil-water selectivity, flexibility and reusability exhibited by these foams. 


\subsection{References}

[1]. J.E. Lindstrom, R.P. Barry, J.F. Braddock. Soil Biology and Biochemistry, 31, 1677$1689,1999$.

[2]. D.H. Monson, D.F. Doak, B.E. Ballachey, A. Johnson, J.L. Bodkin. Proceeding of the National Academy of Sciences of the United States of America, 12, 6562-6567, 2000.

[3]. C.H. Peterson, S.D. Rice, J.W. Short, D. Esler, J.L. Bodkin, B.E. Ballachey, D.B. Irons. Science, 302, 2082-2086, 2003.

[4]. P.F. Kingston. Spill Science \& Technology Bulletin, 7, 53-61, 2002.

[5]. M. Garza-Gil, J.C. Suris-Regueiro, M.M. Valera-Lafuente. Marine Policy, 30, 544551, 2006.

[6]. H.T.T. Duong, R.P. Burford. Journal of Applied Polymer Science, 99, 360-367, 2005.

[7]. J. Pinto, A. Athanassiou, D. Fragouli. Journal of Physics D: Applied Physics, 49, 145601, 2016.

[8]. H. Li, L. Liu, F. Yang. Marine Pollution Bulletin, 64, 1648-1653, 2012.

[9]. C. F. Wang, S.J. Lin. ACS Applied Materials \& Interfaces, 5, 8861-8864, 2013.

[10]. Y. Liu, J. Ma, T. Wu, X. Wang, G. Huang, Y. Liu, H. Qiu, Y. Li, W. Wang, J. Gao. ACS Applied Materials \& Interfaces, 5, 10018-10026, 2013.

[11]. A.A. Nikkhah, H. Zilouei, A. Asadinezhad, A. Keshavarz. Chemical Engineering Journal, 262, 278-285, 2015.

[12]. A. Keshavarz, H. Zilouei, A. Abdolmaleki, A. Asadinezhad. Journal of Environmental Management, 157, 279-286, 2015.

[13]. J. Pinto, J.A. Heredia-Guerrero, A. Athanassiou, D. Fragouli. International Journal of Environmental Science and Technology, 14, 2055-2066, 2017.

[14]. P. Calcagnile, D. Fragouli, I.S. Bayer, G.C. Anyfantis, L. Martiradonna, P.D. Cozzoli, R. Cingolani, A. Athanassiou. ACS Nano, 6, 5413-5419, 2012.

[15]. A. Rizvi, R. K. M. Chu, J.H. Lee, C.B. Park. ACS Applied Materials \& Interfaces, 6, 21131-21140, 2014.

[16]. S. Wang, K. Wang, Y. Pang, Y. Li, F. Wu, S. Wang, W. Zheng. Journal of Applied Polymer Science, 133, 43812, 2016.

[17]. Q. Zhu, Y. Chu, Z. Wang, N. Chen, L. Lin, F. Lui, Q. Pan. Journal of Materials Chemistry A, 1, 5386-5393, 2013.

[18]. P. Wang, C. Zou, H. Zhong. Advanced Materials Research, 518-523, 847-853, 2012.

[19]. Q. Zhu, Q. Pan, F. Liu. The Journal of Physical Chemistry C, 115, 17464-17470, 2011. 


\section{GENERAL PROPERTIES}





\section{INDEX}

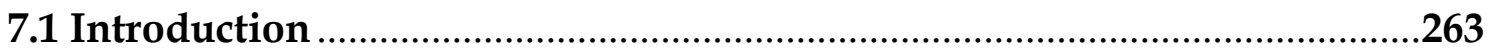

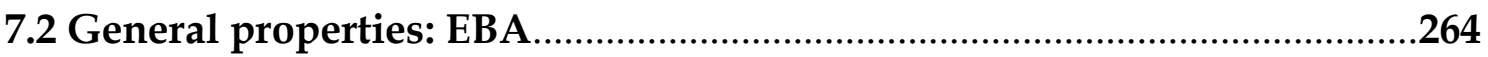

7.3 DMA analysis and thermal stability: LDPE, EVA 12 and EVA 18 foams.287

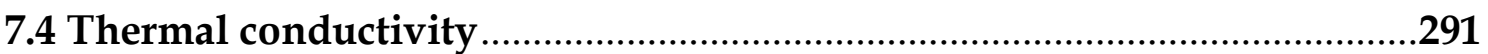

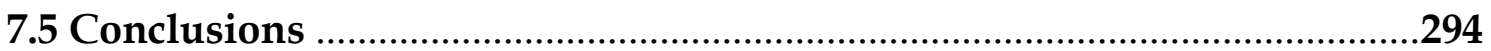

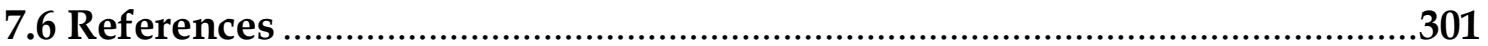




\subsection{Introduction}

EBA is perhaps the less known polyolefin used in this research. EBA is a copolymer of ethylene and butyl acrylate [1]. The butyl acrylate groups confer disorder (similar to the vinyl acetate groups in EVA) to the ethylene chains, and therefore the crystallinity is lower than that of LDPE. Despite not being widely used, EBA presents some properties, such as flexibility, chemical resistance, hydrophobicity, which makes it promising for foaming purposes.

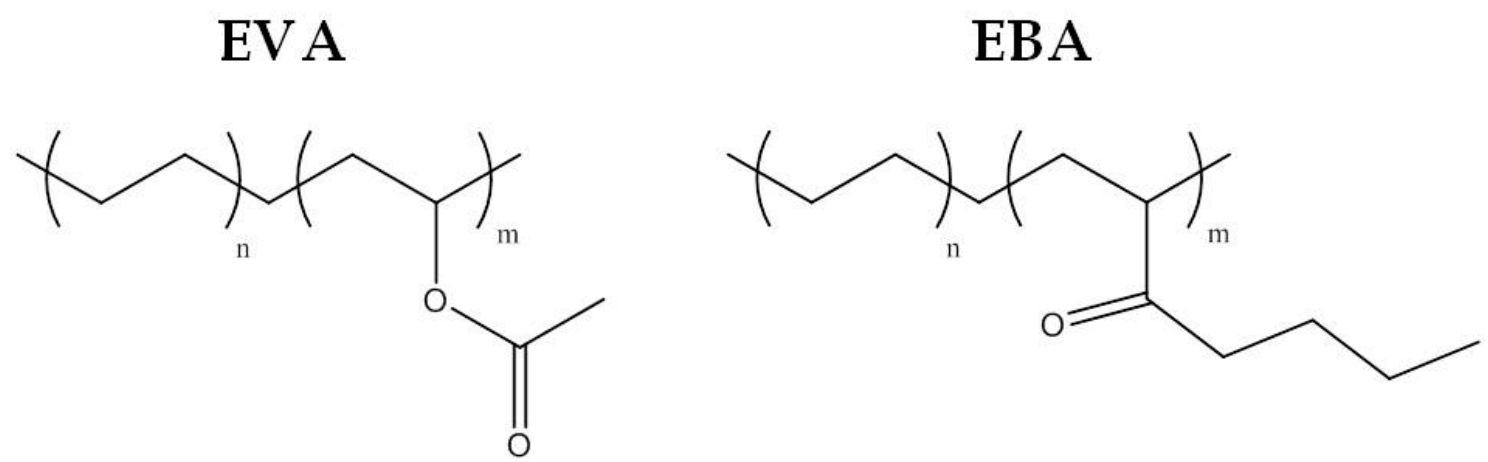

Figure 7.1. Chemical structure: a) ethylene vinyl acetate (EVA) and b) ethylene butyl acrylate (EBA) copolymers.

There are few works in the literature, in which EBA have been used. Perhaps, the most common application of EBA is limited to modification of bitumens [2-6]. However, as there are no previous reports in the literature based on the foaming of EBA. This aspect, together with the interesting properties of EBA, aimed our research at producing and characterizing open-cell polyolefin foams based on EBA.

The first aspect to take into account was if EBA crosslinked properly by using organic peroxides. Due to the lack of studies, a prior analysis was necessary to determine that EBA was susceptible to be crosslinked $[7,8]$. Once this aspect was proven, a similar procedure as the one used for LDPE and the two EVA considered in this research was followed, also obtaining materials with different cellular structure interconnectivity and tortuosity.

The mechanical, acoustic and oil absorption properties of these materials were discussed in previous chapters and are included again in this one. However, the dynamic mechanical properties, thermal stability and thermal conductivity were also measured. The thermal stability allowed determining if the materials were able to withstand high temperatures or the temperature, at which the materials started collapsing.

Dynamic mechanical analysis (DMA) is used to characterize the viscoelastic properties of a material [9-11]. This technique is based on applying sinusoidal stress at a fixed frequency in a range of temperatures. As a result, a strain (due to the applied stress) is produced in the material, but out of phase. This difference in phase provides useful information about the viscoelastic behavior material. In our specific case, the analysis 
was focused on two parameters: the modulus of the complex modulus $\left(E^{*}\right)$ and loss factor $(\tan \delta)$.

One interesting result, which can be extracted from the DMA analysis, is the ability of a material to damp mechanical vibrations. This ability is related to $\tan \delta$. High values of $\tan \delta$ lead to damping of the vibrations, whereas low values of $\tan \delta$ mean the opposite.

The characterization of all these properties and the results derived from the analysis were published in a research article in the Journal of Applied Polymer Science (section 7.2). However, it was also considered interesting to analyze the dynamic mechanical properties, the thermal stability and the thermal conductivity of the materials based on LDPE, EVA 12 and EVA 18. Thus, these results are also included in a subsequent section (section 7.3).

\subsection{General properties: EBA}

A deep characterization of different EBA cellular polymers with different cellular structure interconnectivity and tortuosity is described in this section. Mechanical, acoustic, thermal, dynamic mechanical and oil absorption properties were analyzed. Two new characterizations are included in this chapter: thermal and dynamic mechanical properties.

The thermal stability of the materials was studied by using thermo mechanical analysis. For this purpose, it was determined the temperature at which the thickness is reduced by $10 \%$. This temperature provides relevant information about when the material starts collapsing and the maximum temperature which can withstand.

The dynamic mechanical characterization was focused on determining the $\mathrm{E}^{*}$ and tan $\delta$. $E^{*}$ is given by Equation 1:

$$
E^{*}=\sqrt{E^{\prime}+E^{\prime \prime}}
$$

(Equation 1)

where $E$ 'is the storage modulus and $E^{\prime \prime}$ is the loss modulus. E'and $E^{\prime \prime}$ are defined by Equation 2 and Equation 3:

$$
\begin{aligned}
& E^{\prime}=\frac{\sigma}{\varepsilon} \cos \delta \\
& E^{\prime \prime}=\frac{\sigma}{\varepsilon} \sin \delta
\end{aligned}
$$

where $\sigma$ is the amplitude of the stress, $\varepsilon$ is the amplitude of the strain and $\delta$ is the phase angle between the stress and the strain. $\tan \delta$ is given by the ratio between the loss and storage modulus (Equation 4).

$$
\tan \delta=\frac{E^{\prime \prime}}{E^{\prime}}
$$


The effect of the cellular structure interconnectivity and tortuosity on all these properties has been determined, and this work and the results are explained in detail in a research article entitled "Crosslinked Ethylene Butyl Acrylate Copolymer Foams with Different Cellular Structure Interconnectivity and Tortuosity: Microstructure and Physical Properties" published in Journal of Applied Polymer Science (doi.org/10.1002/app.48161). 


\title{
Crosslinked ethylene butyl acrylate copolymer (EBA) foams with different cellular structure interconnectivity and tortuosity: microstructure and physical properties
}

\author{
E. Lopez-Gonzalez ${ }^{1,2 *}$, S.Muñoz-Pascual1 ${ }^{1}$, C. Saiz-Arroyo ${ }^{2}$, M.A. Rodriguez-Perez ${ }^{1}$ \\ ${ }^{1}$ Cellular Materials Laboratory (CellMat), Condensed Matter Physics Department, University \\ of Valladolid, Paseo Belén 747011 Valladolid (Spain) \\ ${ }^{2}$ CellMat Technologies S.L., Paseo de Belen 9-A (CTTA Building), 47011, Valladolid, Spain \\ * Correspondence to E. Lopez-Gonzalez
}

\begin{abstract}
In this work, the cellular structure, physical properties and the structure-property relationship of several novel crosslinked ethylene butyl acrylate (EBA) foams with different cellular structure interconnectivity (low tortuosity and high tortuosity) have been analyzed and compared to that of closed-cell EBA foams and to that of an opencell PU foam. The results have shown that these materials present interesting properties highly dependent on the tortuosity of the cellular structure. In particular, it has been proved that reducing the tortuosity allows enhancing the acoustic absorption, the oil uptake, and the cushioning behaviour. On the other hand, increasing tortuosity allows improving the impact behaviour. In addition, the new open-cell materials present an enhanced damping factor for low-frequency vibrations.
\end{abstract}

\section{INTRODUCTION}

The current global policies are conducted to reduce the consumption of plastic in the coming years ${ }^{1}$. As a consequence, alternative routes to reduce the environmental impact must be considered due to the importance of plastic in our society. Cellular polymers, a two-phase material in which a gas is dispersed in the polymer matrix, contribute to solving this challenge because these materials allow reducing the amount of material needed to produce a specific item ${ }^{2-4}$.

Cellular polymers have been introduced in numerous markets (construction, packaging, automotive, sport or acoustic insulation) in the last decades due to their excellent properties ${ }^{5-11}$.

These materials can be divided into different groups considering cellular parameters such as density, anisotropy or cells interconnectivity. Focusing on the last parameter, cellular polymers can be classified as closed-cell, open-cell and cellular polymers with intermediate open-cell contents ${ }^{12}$. One the one hand, closed-cell materials present a negligible level of interconnectivity due to the confinement of the gas inside the cells ${ }^{13}$. On the other hand, the gas can move through the cellular structure in open-cell cellular polymers $^{14}$.

The market of flexible open-cell cellular polymers is dominated by flexible open-cell polyurethane (PU) foams ${ }^{15-17}$. PU foams present a cellular structure formed by cells 
mainly composed of struts, and due to its outstanding properties, these materials are employed in a wide range of applications. Some of them are lead to improve our quality of life, for example in comfort applications helping us to rest correctly or by acting as sound absorbers reducing the high noise levels in cities avoiding major health problems 18,19 .

In addition, other emerging applications for open-cell flexible foams are focused on preserving the environment. Oil spill remediation is nowadays a challenging issue when crude oil is released in open waters. Not only the large but also the small but numerous oil spills are the cause of the destruction of the environment, and they are also responsible for the death of valuable fauna and flora ${ }^{20,21}$. Flexible open-cell PU foams have emerged in the last years as potential alternatives to the current methods of oil recovery $22-25$.

However, PU foams also display several drawbacks, such as the use of isocyanate as raw material or the toxicity of the fumes released in their burning, which can restrict their use in the near future. Furthermore, the poor resistance to water limits their use in oil absorption applications, since a high oil-water selectivity is required ${ }^{26}$. To overcome this critical issue, there are several studies in the literature focused on making the PU foamsuperhydrophobic by using surface treatments ${ }^{27-29}$. However, this process raises the price of the final product and hinders industrial scalability. As a consequence, the search for potential substitutes to flexible open-cell PU foams is gaining interest.

One interesting alternative is the use of open-cell cellular polymers based on polyolefins ${ }^{30-34}$. The type of cellular structure interconnectivity in crosslinked open-cell polyolefin cellular polymers is different from that of open-cell PU foams. In the case of crosslinked open-cell polyolefin materials, the gas can move through the cellular structure due to the presence of holes of different sizes in the cell walls. Both the number and the size of the holes are critical parameters to describe the cellular structure of this type of materials accurately. Thus, not only the open-cell content but also the cellular structure tortuosity is an important parameter necessary to understand the physical properties of these materials properly ${ }^{35,36}$.

Typically, low-density polyethylene (LDPE) and ethylene vinyl acetate copolymer (EVA) are used as polymer matrices to produce crosslinked polyolefin foams ${ }^{37-39}$. The open-cell polyolefin cellular polymers described in previous papers ${ }^{30,31}$ were produced by compressing foams with intermediate open-cell content generating holes in the cell walls, which typically results in materials with high tortuosities. However, as far as the authors know, there are not academic works based on the characterization and analysis of the structure-property relationship of open-cell polyolefin cellular polymers with different levels of interconnection between the cells, i.e. different levels of tortuosity. In this work, novel open-cell polyolefin foams, which different levels of cells interconnections (i.e. different levels of tortuosity) have been studied ${ }^{40}$.

In addition, it is important to comment that this is the first time that EBA polymer is used to produce crosslinked polyolefin cellular polymers. EBA was chosen owing to its 
excellent properties regarding flexibility, which makes these copolymers excellent candidates to replace open-cell PU materials.

\section{EXPERIMENTAL}

\section{Materials}

Several EBA foams with different cellular structure interconnectivity and tortuosity were provided by CellMat Technologies S.L. (Valladolid, Spain). The materials were produced using a two-steps compression molding process ${ }^{40}$. EBA EBANTIX® E1715 manufactured by Repsol (Spain) with a butyl acrylate content of $17 \%$, a density of 0.926 $\mathrm{g} / \mathrm{cm}^{3}$ and a melt flow index (MFI) of $1.50 \mathrm{~g} / 10$ min measured at $230{ }^{\circ} \mathrm{C}$ and $2.16 \mathrm{~kg}$ was employed as the polymer matrix in the production of the foams.

The main differences between the cellular polymers produced for this work lie in the different levels of interconnectivity reached during the fabrication process. As a result, a foam with a low level of interconnectivity (EBA CC), a foam with an intermediate open-cell content (EBA MO) and two types of open-cell foams (EBA OC HT and EBA OC LT), with an open-cell content close to $100 \%$ were produced. The main characteristics of these materials are summarized in Table 1.

A commercial flexible polyurethane (PU) foam with a density of $47 \mathrm{~kg} \mathrm{~m}^{-3}$ and typically used in seats in the automotive sector was used to compare its behavior with that of the EBA foams analyzed in the paper.

Typical open-cell flexible PU foams present high interconnectivity due to the absence of cell walls; the cells are mainly comprised of struts. However, both EBA OC HT and EBA OC LT foams are characterized by a different type of cellular structure interconnectivity in comparison to the open-cell PU foams. In this particular case, the interconnections between cells are produced by the presence of holes in the cell walls. The level of interconnection is related to the number and size of the holes, and thus, the tortuosity of the cellular structure.

On the one hand, EBA OC HT presents small holes in the cell walls, hindering the path that the gas needs to move through the cellular structure (HT; high tortuosity). On the other hand, EBA OC LT foams are characterized by a high number and a large size of the holes (LT; low tortuosity). The holes are so large that the level of interconnectivity is similar to that of open-cell PU foams (Table 1). This is explained in more detail in the section results and discussion.

As it has been mentioned in previous paragraphs, the open-cell polyolefin foams reported in previous research works were produced using the two-steps compression molding process by performing an additional step to the process in which the material is compressed to create some holes in the cell walls. In our research, this procedure was followed to produce the EBA OC HT foams. This material was produced by compressing in a two-roll mill the EBA MO foam five times, fixing the distance between the roles in $80 \mathrm{~mm}$. However, EBA OC LT foams were obtained directly 
during the foaming process without deforming the material after foaming. This was achieved by modifications in the formulation and process parameters.

\section{Differential scanning calorimetry (DSC)}

The thermal behavior of the EBA foams was analyzed by using a Mettler DSC 822e differential scanning calorimeter previously calibrated with indium, zinc, and n-octane. The average weight of the samples used for these experiments was $1.24 \pm 0.07 \mathrm{mg}$. The following temperature program was selected:

1) Heating from $-40{ }^{\circ} \mathrm{C}$ to $200{ }^{\circ} \mathrm{C}$ at $10 \mathrm{~K} \mathrm{~min}^{-1}$.

2) A 3-minute isotherm at $200^{\circ} \mathrm{C}$.

3) Cooling from $200{ }^{\circ} \mathrm{C}$ to $-40^{\circ} \mathrm{C}$ at $-10 \mathrm{~K} \mathrm{~min}^{-1}$.

4) Heating from $-40{ }^{\circ} \mathrm{C}$ to $200{ }^{\circ} \mathrm{C}$ at $10 \mathrm{~K} \mathrm{~min}^{-1}$.

The crystallinity was calculated as the ratio of the melting enthalpy in the last heating step and the melting enthalpy of a 100\% crystalline material (288 J g-1 for $100 \%$ crystalline polyethylene). The crystallinity was estimated as the average of three measurements.

\section{Gel content}

The gel content was measured according to ASTM D2765-16 standard procedure. Three measurements were performed for each type of material, estimating the average value. Xylene was used as the solvent. After extraction, the samples were vacuum dried overnight and then its weight was measured and compared with the initial weight of the sample before the xylene extraction.

\section{Scanning electron microscopy (SEM)}

SEM was used to observe the differences in the cellular structure of the EBA foams with different cellular structure morphology and interconnectivity. The micrographs were taken with a Hitachi FlexSEM 1000 (Tokyo, Japan) microscope. The samples were cut with a sharp razor at room temperature. A thin gold layer was sputtered on the fractured surface of the samples to make them conductive.

SEM was also used to estimate the cell size in 3D $(\phi)$ of the EBA foams. The cell size was quantified by using a tool based on the software Fiji/Image J41.

\section{Tortuosity}

The tortuosity of the EBA foams under study was estimated measuring the electrical conductivity of an ionic solution with and without the sample immersed in it ${ }^{12}$. The experimental setup used for the estimation of the tortuosity is schematized in Figure 1: 


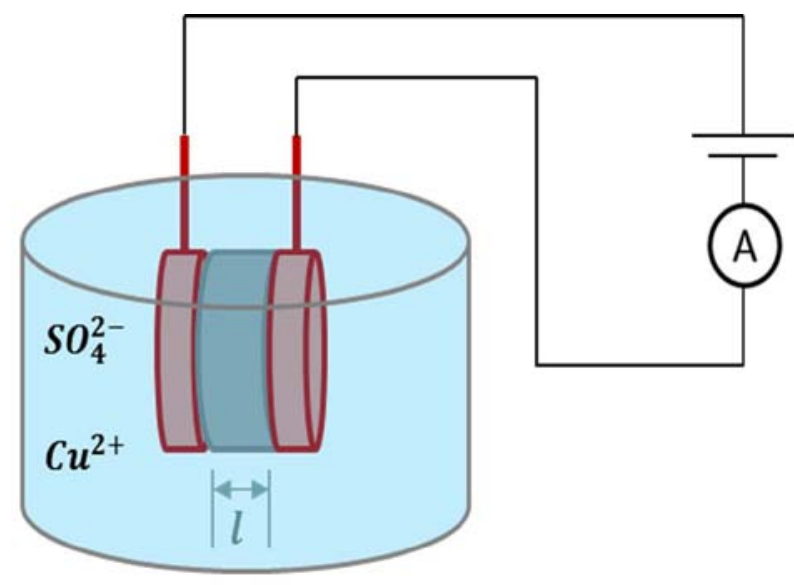

Figure 1. Scheme of the experimental setup of the tortuosity measurement.

A $0.4 \mathrm{M}$ of $\mathrm{CuSO}_{4} \cdot 5 \mathrm{H}_{2} \mathrm{O}$ ionic solution was used as the auxiliary liquid. Alternating current (EA-3048B Elektro-Automatik GmbH, Germany) was used in the measurements. The voltage range varied between 3 and $6 \mathrm{~V}$ in steps of $0.5 \mathrm{~V}$. First, the electrical conductivity of the auxiliary liquid was measured without placing a sample between the electrodes, and according to Ohm's Law, the resistance was calculated $\left(R_{0}\right)$. Finally, the electrical conductivity of the auxiliary liquid, including the sample between the electrodes was measured, and thus, the electrical resistance $\left(R_{f}\right)$. The samples were soaked overnight to ensure the proper penetration of the solution through the cellular structure before performing the measurement. The tortuosity is given by the ratio between $R_{f}$ and $R_{0}(1)$. Three measurements of each material were performed, and the average values are reported.

$$
T=\frac{R_{f}}{R_{o}}
$$

\section{Mechanical properties at low and high strain rates}

The mechanical properties of the materials were characterized at low and high strain rates of deformation. For both tests, cubic samples of $45 \times 45 \times 45 \mathrm{~mm}^{3}$ were employed. The samples were conditioned at $23{ }^{\circ} \mathrm{C}$ for 24 hours before performing the tests. Three samples of each material were tested.

The mechanical tests at low strain rates were carried out using a universal testing machine (Instron Mod. 5500R6025). The strain rate was $270 \mathrm{~mm} \mathrm{~min}^{-1}$, and five loadunload cycles were performed. The maximum strain was approximately $75 \%$ for all samples independently of the type of cellular structure.

The mechanical tests at high strain rates (impact tests) were performed using an instrumented falling weight impact tester designed by CellMat Laboratory and built by the company Microtest SA (Spain) ${ }^{42}$. The strain rate was $1.38 \times 10^{5} \mathrm{~mm} \mathrm{~min}^{-1}$, approximately 500 times higher than for the tests at low strain rates.

Three following mechanical parameters were estimated from these tests: the collapse stress $(\mathrm{MPa})$, the effective gas pressure $(\mathrm{MPa})$ and the density of absorbed energy $\left(\mathrm{J} \mathrm{cm}^{-}\right.$ 
3). The collapse stress and the effective gas pressure were calculated in the postcollapse region (between $20 \%$ and $60 \%$ strain) according to the modified model of Gent and Thomas ${ }^{43}(2)$.

$$
\sigma=\sigma_{c}+\frac{p_{a}(1-2 v) \varepsilon}{\left(1-\varepsilon-\frac{\rho_{\mathrm{f}}}{\rho_{\mathrm{s}}}\right)}(1-C)
$$

where $\sigma$ is the stress, $\sigma_{c}$ is the collapse stress, $p_{a}(1-2 v)(1-C)$ is the effective pressure of the gas in the sample, being $p_{a}$ the atmospheric pressure and $v$ the Poisson ratio, $\varepsilon$ is the strain, $\rho_{f}$ is the foam density $\left(\mathrm{kg} \mathrm{m}^{-3}\right), \rho_{s}$ is the density of the solid $\left(\mathrm{kg} \mathrm{m}^{-3}\right)$, and its ratio $\left(\rho_{f} / \rho_{s}\right)$ is known as the relative density $\left(\rho_{r}\right)$, and finally $C$ is the open-cell content.

The effective gas pressure accounts for the contribution of gas in the sample in the post-collapse region. As the samples are very flexible, it is intricate to measure the open-cell content using the ASTM D 2856-94 standard method in an air pycnometer because the samples deform under pressure if they have a high open-cell content. Due to this, we have used the effective gas pressure as an indirect method to measure the open-cell content. High values in the effective gas pressure indicate a lack of interconnectivity of the cellular structure, and thus, low values of open-cell content (closed-cell). On the contrary, low values in the effective gas pressure mean no contribution of gas in the post-collapse region (plateau) and as a result, high open-cell contents (open-cell). The effective gas pressure can be obtained calculating the slope of the curve $\sigma$ versus $\varepsilon /\left(1-\varepsilon-\rho_{f} / \rho_{s}\right)$. Based on the works of Mills et al. ${ }^{8}$ and Rodriguez-Perez et al. ${ }^{44}$, it was assumed a Poisson ratio value of 0.05 in the calculations of the effective gas pressure for the materials under study.

The density of absorbed energy is calculated as the area under the stress-strain curve. The strain limit to make the calculations was $75 \%$. In the case of high strain rates, despite deforming the samples to values even higher than $75 \%$, this value was also chosen as the strain to obtain the density of absorbed energy during impact.

\section{Thermal stability}

The thermal stability was analyzed using a PerkinElmer TMA7 (Waltham, USA) testing apparatus. The temperature program selected for the analysis was from -20 to $150{ }^{\circ} \mathrm{C}$ at $5{ }^{\circ} \mathrm{C} \mathrm{min}-1$. Samples with cylindrical shape and diameter of $10 \pm 0.1 \mathrm{~mm}$ and a thickness of $10 \pm 0.7 \mathrm{~mm}$ were employed. The stress applied during testing was around $12 \mathrm{~Pa}$. Three measurements were conducted for each material.

The required temperature to reduce the thickness of the foam by $10 \%$ was determined. This temperature also provides useful information about the beginning of the collapse suffered by the samples with temperature. The temperature necessary to reduce the thickness of the samples by $10 \%$ was calculated as the average of three measurements. 


\section{Dynamic mechanical properties}

A PerkinElmer DMA 7 testing equipment with a parallel-plate mechanism was used to perform the tests. Cylindrical specimens of $10 \pm 0.1 \mathrm{~mm}$ in diameter and $10 \pm 0.8 \mathrm{~mm}$ in thickness were used. The measurements were carried out as a function of temperature between -40 and $150{ }^{\circ} \mathrm{C}$ at a heating rate of $5{ }^{\circ} \mathrm{C} \mathrm{min}-1$. All materials were tested at a frequency of $1 \mathrm{~Hz}$ and with deformations in the linear viscoelastic regime. The modulus of the complex modulus $\left(\mathrm{E}^{*}\right)$ and $\tan$ delta $(\tan \delta)$ was calculated as a function of temperature. Three measurements of each material were performed.

\section{Acoustic properties}

The acoustic behavior of the foams was characterized employing a Brüel \& Kjaer (Nærum, Denmark) model 4206 impedance tube according to ASTM E1050 and ISO 10534-2. The acoustic measurements were performed in a frequency range between 500 and $6400 \mathrm{~Hz}$. Cylindrical samples of $29 \mathrm{~mm}$ in diameter and $25 \mathrm{~mm}$ in thickness were used for these tests. Six measurements were performed for each material, obtaining the average value.

\section{Oil absorption measurements}

The oil absorption capacity of the materials under study was also analyzed using for this purpose $15 \mathrm{~W} 40$ commercial motor oil. Specimens with dimensions of $20 \mathrm{~mm} \times 20$ $\mathrm{mm} \times 10 \mathrm{~mm}(\mathrm{~L} \times \mathrm{W} \times \mathrm{T})$ were cut and weighed initially before placing them in the oil $\left(w_{0}\right)$. Then, the samples were placed superficially on a beaker full of motor oil without squeezing or immersing them to favor the oil absorption. After 10 minutes, the specimens were extracted from the oil and were weighed again $\left(w_{1}\right)$. The oil absorption capacity was measured using (3):

$$
\text { Oil absorption }(g / g)=\frac{\left(w_{1}-w_{0}\right)}{w_{o}}
$$

where $w_{0}$ was the initial weight of the sample before introducing in the oil and $w_{1}$ was the weight after the oil uptake. The average value of three measurements was considered for all samples.

The same methodology was followed to determine the hydrophobicity of the foams. Samples with the same dimensions as in oil absorption tests were weighed and placed superficially on a beaker full of distilled water for 10 minutes. The samples were extracted from the water and weighed again. Equation (3) was also used for the estimation of the water absorption.

The reusability of the materials was estimated by performing 20 compressive cycles at low strain rates $\left(270 \mathrm{~mm} \mathrm{~min}^{-1}\right)$. The maximum strain applied was $75 \%$. The reusability was analyzed by estimating the non-recovered deformation given by the intersection between the unload curve and the abscissa in the stress-strain curve. 


\section{RESULTS AND DISCUSSION}

\section{Structural characterization}

The main characteristics of each type of material are displayed in Table 1.

Table 1. Nomenclature, density, open-cell content, tortuosity, gel content and crystallinity of the materials under study. -* tests not performed because it is not possible to measure the tortuosity of this sample due to its low opencell content, ${ }^{* *}$ The polymer matrix is a PU and therefore crystallinity was not measured.

\begin{tabular}{|ccccccc|} 
Nomenclature & $\begin{array}{c}\text { Density } \\
\left(\mathrm{kg} \mathrm{m}^{-3}\right)\end{array}$ & $\begin{array}{c}\text { Open-cell } \\
\text { content } \\
(\%)\end{array}$ & Tortuosity & $\begin{array}{c}\text { Gel } \\
\text { content } \\
(\%)\end{array}$ & $\begin{array}{c}\text { Crystallinity } \\
(\%)\end{array}$ & $\begin{array}{c}\text { Cell size } \\
(\mu \mathrm{m})\end{array}$ \\
\hline EBA CC & $24.3 \pm 2.1$ & $42.9 \pm 3.2$ & $-*$ & $69 \pm 4$ & $15.3 \pm 1.5$ & $266.4 \pm 88.9$ \\
\hline EBA MO & $20.3 \pm 1.3$ & $67.9 \pm 1.0$ & $4.3 \pm 0.2$ & $59 \pm 16$ & $14.6 \pm 0.9$ & $501.4 \pm 241.4$ \\
\hline EBA OC HT & $19.7 \pm 0.3$ & $95.3 \pm 0.7$ & $4.0 \pm 0.7$ & $50 \pm 9$ & $13.6 \pm 0.8$ & $502.3 \pm 255.5$ \\
\hline EBA OC LT & $20.1 \pm 2.3$ & $98.6 \pm 0.3$ & $1.9 \pm 0.2$ & $27 \pm 2$ & $14.3 \pm 1.6$ & $1339.6 \pm 723.3$ \\
\hline PU & $47.2 \pm 0.1$ & $98.0 \pm 0.1$ & $1.9 \pm 0.1$ & $-* *$ & $-* *$ & $638.7 \pm 222.3$ \\
\hline
\end{tabular}

As can be observed in Table 1, four types of EBA foams were produced. As previously mentioned, the open-cell content was estimated considering the contribution of the gas in the post-collapse region of the stress-strain curves (effective gas pressure). EBA CC corresponds to foams with low interconnectivity of the cellular structure (around 40\%), EBA MO presents an intermediate open-cell content (68\%), and finally, there are two types of open-cell foams, EBA OC HT and EBA OC LT both with open-cell contents higher than 95\%. The difference between EBA OC HT and EBA OC LT is the level of interconnection in the cellular structure. As the holes in the cell walls are larger in EBA OC LT foams, this open-cell material presents a similar level of interconnection than that of the open-cell PU foam used as a reference. However, as the EBA OC HT foam is produced deforming EBA MO foams, small holes are created in the cell walls restricting the movement of the gas through the cellular structure. As a result, the tortuosity of the EBA OC HT foams is slightly lower than that of EBA MO foams due to the effect of these small holes but much higher than that of EBA OC LT or the PU foams owing to the small size of the holes. These differences in the level of the interconnectivity of the cellular structure can be observed in the SEM micrographs displayed in Figure 2: 

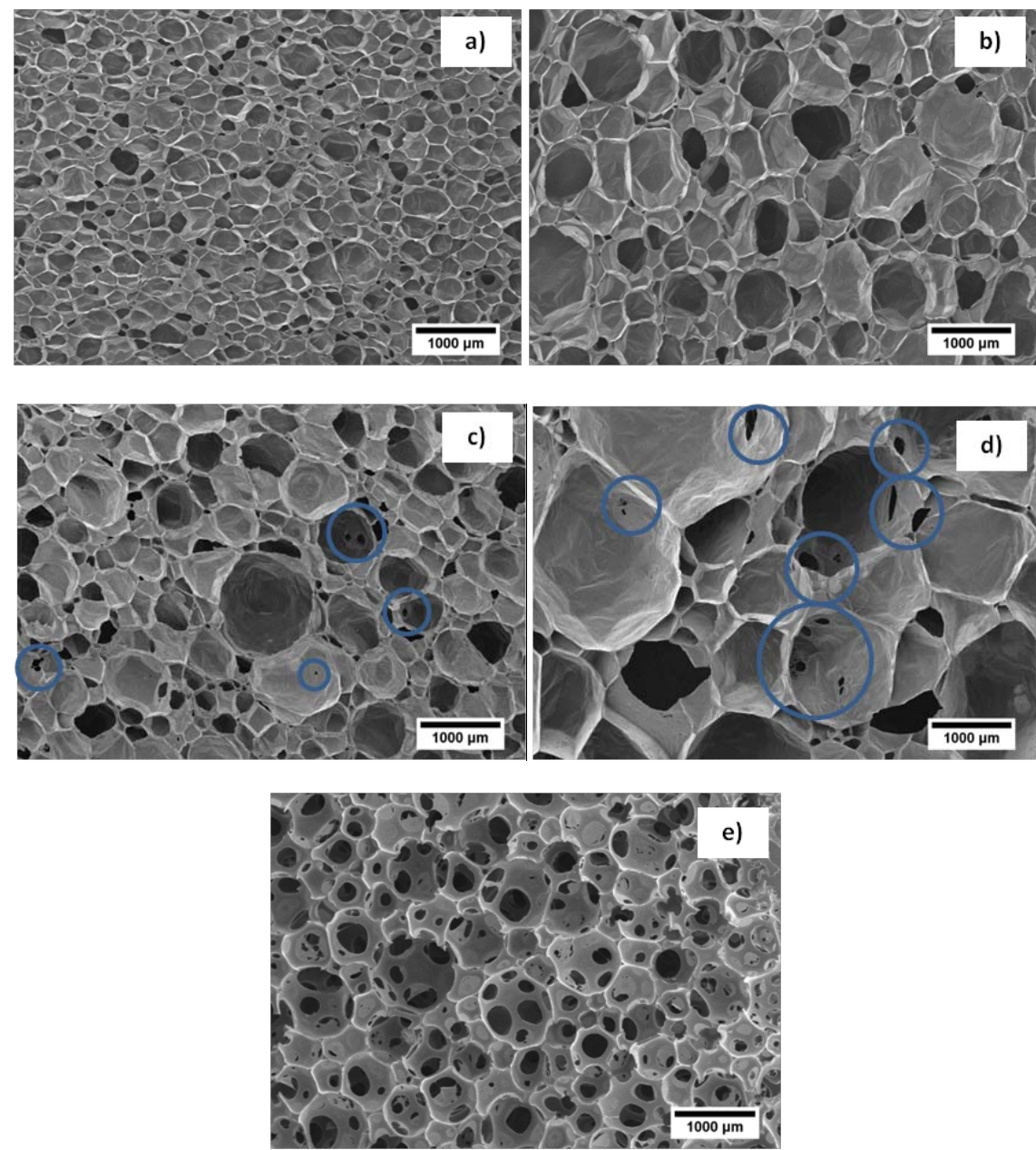

Figure 2. SEM micrographs of the materials under study: a) EBA CC; b) EBA MO; c) EBA OC HT; d) EBA OC LT and e) PU used as a reference.

Figure 2 (a) shows the cellular structure of the closed-cell material. As it was explained previously, the level of the interconnectivity of the cellular structure in EBA CC is very low, and in the majority of the cells, the gas is enclosed inside them. Furthermore, the cell size of this material is much lower $(266 \mu \mathrm{m})$ than that the rest of the foams. This can be explained, taking into account the nucleation effect and the degeneration mechanisms of the cellular structure. The effect of the degeneration processes on the cellular structure can be correlated to the gel-content. High gel-content values are indicative of high viscosity of the polymer matrix. If the viscosity is high, the degeneration processes are restricted, and thus, cells with lower cell sizes are created. The results show a clear correlation between cell size and gel content; a higher gelcontent promotes smaller cell sizes.

The EBA MO foam presents higher cellular structure interconnectivity (68\% open-cell content) but far from that observed for both OC HT and OC LT foams (Figure 2b). It is remarkable the effect of the mechanical process performed, aiming at breaking the cell walls. Considering that EBA OC HT foams (Figure 2c) with an open-cell content of 95\% are obtained from the EBA MO ones, it is clear that the deformation process is very effective to generate open-cell materials. 
EBA OC LT foams are characterized by the presence of huge holes in the cell walls. Furthermore, the average cell size of this material is much larger than, for example, the EBA OC HT one (up to 2.67 times larger). As it was mentioned before, EBA OC LT (Figure $2 \mathrm{~d}$ ) foams are produced directly in the fabrication process. For this purpose, the gas pressure must be able to break the walls during expansion and thus, the viscosity should be low. This low viscosity leads to a side effect, the large cell size. As the viscosity after the crosslinking process is low, the cell walls can be stretched to a higher level resulting in a cellular structure mainly formed by large cells. This is consistent with the low value of the gel content of the OC LT. EBA CC presents the highest gel content level (69\%) whereas EBA MO and EBA OC HT have a similar gel content level (between 50 and 60\%). In spite of the different level of interconnectivity in $\mathrm{MO}$ and OC HT foams, it was expected that both values were similar if it is considered that the EBA OC HT foams were produced from the EBA MO ones. As the foam is already crosslinked before the deformation process necessary to break the cell walls, the crosslinked phase is not affected by this mechanical rupture. Finally, the gel content level of the EBA OC LT is very low $(27 \%)$.

Another aspect to take into account to explain the difference in cell size, as it was discussed before, is the degeneration mechanisms of the cellular structure. OC LT materials are prone to suffer from coalescence due to its low viscosity, and this could lead to larger cell sizes.

The densities of the EBA foams are ranged between 20 and $24 \mathrm{~kg} \mathrm{~m}^{-3}$. The materials expanded around 47 times, considering the initial density of the polymer matrix. This density is smaller than that of the PU foam used as a reference. It is also remarkable, the low crystallinity (between 13 and 15\%) of the foams regardless of the type of material. The butyl acrylate groups induce a considerable disorder in the ethylene chains, and as a result, the crystallinity is much lower than that of a LDPE polymer.

\section{Physical properties}

\section{Mechanical properties}

The mechanical properties of the foamed materials were tested at low and high strain rates. The strain-stress curves of foamed materials have been deeply analyzed by several authors $5,9,14,45,46,47$. The typical stress-strain curve can be divided into three different regions. In the first region, there is a linear dependency between the stress and the strain. Two different mechanisms define this linear region depending on the level of the interconnectivity of the cellular structure: cell edges bending in open-cell materials and cell edges bending and cell walls stretching in closed-cell ones. This linear behavior finishes when the stress reaches the collapse stress at a certain strain. At higher strains, a new region, also dependent on the type of cellular structure interconnectivity, starts. In the case of open-cell materials, this region is characterized by the presence of a plateau. However, the contribution of gas inside the cells plays a key role in this region for closed-cell materials produced from flexible polymers such as polyolefins. The stress tends to increase due to the compression of the gas inside the 
cells. Due to this effect, the open-cell content can be extracted from these stress-strain curves according to the Gent and Thomas model in this region (strain range between $20 \%$ and $60 \%$ ) (2). Considering this model, a high value of the effective gas pressure (slope) is related to the presence of gas inside the cells (closed-cell materials). For opencell foams, as the gas can escape out of the material at these strains, the value of the effective gas pressure is negligible. Finally, the last region of the stress-strain curves is defined at higher strains (> 65\%), when the foam is collapsed, and the upper and lower faces of cells are in contact (densification region). In this region, the stress greatly increases when strain rises.

Three mechanical parameters have been analyzed at both strain rates: the effective gas pressure, the collapse stress and the density of absorbed energy. This analysis aims at determining if the cellular structure tortuosity affects the stress-strain curve in the postcollapse region depending on the strain rate.

The main results obtained at both strain rates are compared in Figure 3:
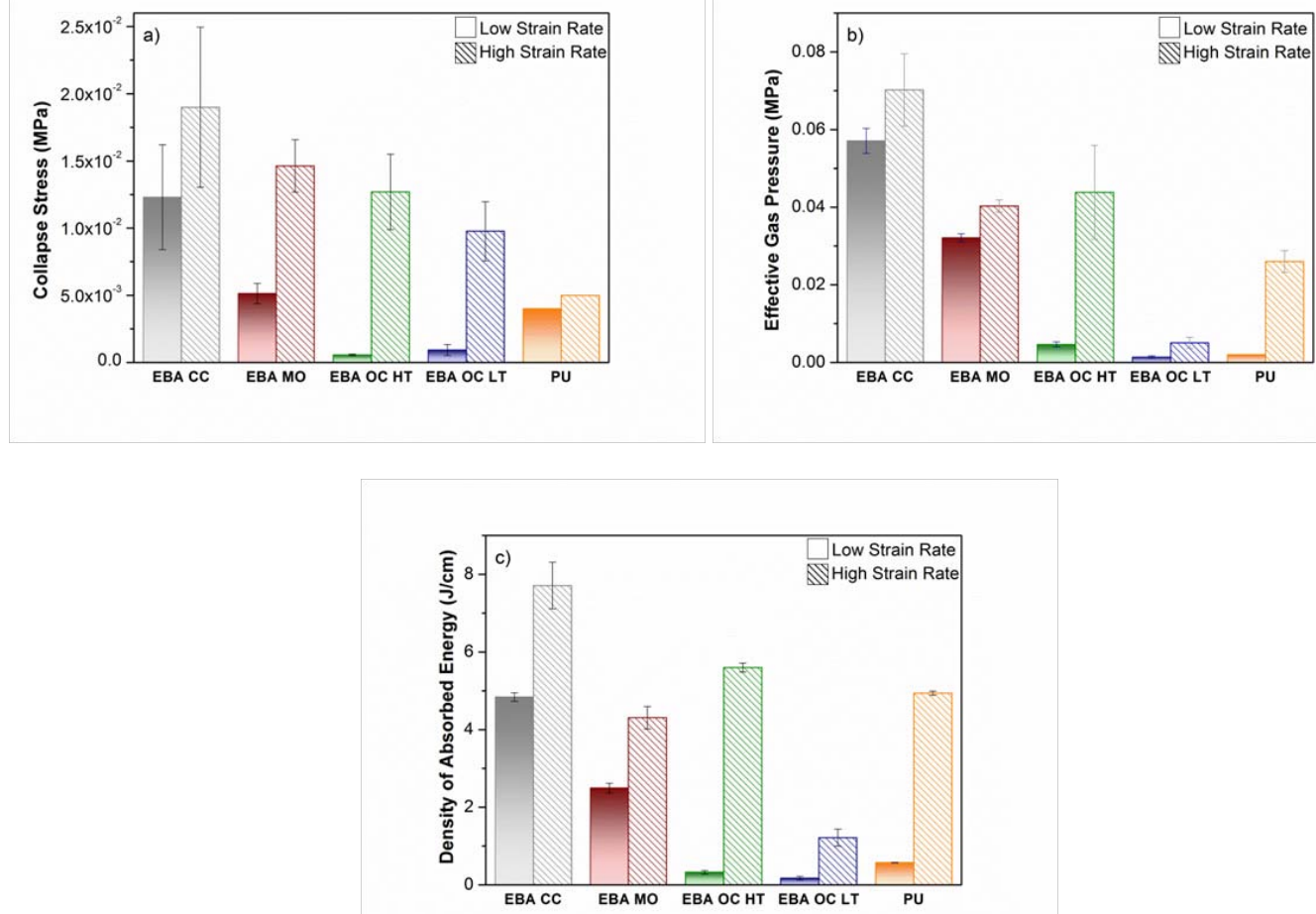

Figure 3. Comparative of the mechanical properties of the different EBA foams and the reference PU at low and high strain rates. a) Effective gas pressure (MPa); b) collapse stress (MPa) and c) density of absorbed energy (J/cm³).

The collapse stress (Figure 3a) is clearly influenced by the level of the interconnectivity. This parameter decreases when the level of interconnectivity increases at both low and high strain rates. In all cases, the obtained values at high strain rates are higher than those measured at low strain rates; this is due to the viscoelastic behavior of the polymeric matrix of these foams. 
Concerning the effective gas pressure (Figure $3 b$ ), it can be observed that the contribution of gas is very high for $\mathrm{CC}$ and $\mathrm{MO}$ regardless of the strain rate. As it was observed previously in the SEM micrographs (Figure 2a and b) the level of the interconnectivity of the cellular structure is very low, and thus, it is expected that the gas remains inside the cellular structure in the post-collapse region. Focusing on opencell foams, both OC HT and OC LT foams behave similarly as the reference open-cell PU foam at low strain rates. The gas has enough time to leave the foam during the compression test, and the curves are characterized by the presence of a plateau at these strains (i.e. a very small slope in the stress-strain curve). Therefore, at low strain rates, the open-cell EBA foams present a similar behavior to that of PU foams.

However, it is remarkable the effect of the strain rate for the OC HT foam. At high strain rates, there is a large contribution of the gas in OC HT foams in the post-collapse region. The effective gas pressure of EBA OC HT foam is very similar to the EBA MO foam. This surprising effect can be explained, taking into account the cellular structure tortuosity.

The mechanical test at high strain rates is up to 500 times faster than at low strain rates. As a consequence, the time that the gas phase has to escape out of the sample is much lower. If the structure is very tortuous, the gas cannot leave the sample in the short time of the impact event (around $12 \mathrm{~ms}$ ) and therefore remains inside contributing to the detected stress. However, in the case of the EBA OC LT and PU foams, as the tortuosity is half less than that of EBA OC HT foam, a significant amount of gas can escape during the impact test. As a result, EBA OC LT and PU behave as an open-cell foam at both strain rates showing a very small slope in the stress-strain curve in the post-collapse region.

If it is considered that the speed of the gas molecules is the speed of the impact tests $(2.3 \mathrm{~m} / \mathrm{s})$ and the test takes place in $12 \mathrm{~ms}$, the distance which the gas molecules can go across can be estimated $\left(d_{1}=27.6 \mathrm{~mm}\right)$. Considering that the length of the cubic samples is $45 \mathrm{~mm}$, a gas molecule which stays in the middle of the sample must go across $22.5 \mathrm{~mm}$ to leave the sample. However, these $22.5 \mathrm{~mm}$ is the ideal value, but taking into account the tortuosity of the cellular structure, this distance increases depending on the tortuosity value (4).

$$
d_{2}=L \cdot T
$$

where $L$ is half of the length $(22.5 \mathrm{~mm})$ of the cubes used for the mechanical tests (shortest distance), and $T$ is the tortuosity.

The relation between both distances $\left(d_{1}\right.$ and $\left.d_{2}\right)$ indicates the percentage of gas which remains inside the sample (Table 2). 
Table 2. Percentage of gas which remains in the sample in the high strain compression tests.

\begin{tabular}{|ccc|}
\hline Sample & Tortuosity & \% gas inside the sample \\
\hline EBA MO & $4.3 \pm 0.2$ & 71.4 \\
\hline EBA OC HT & $4.0 \pm 0.7$ & 69.3 \\
\hline EBA OC LT & $1.9 \pm 0.2$ & 35.4 \\
\hline PU & $1.9 \pm 0.1$ & 35.4 \\
\hline
\end{tabular}

Up to $70 \%$ of the total gas remains inside the foam in EBA MO and EBA OC HT. This is a considerable gas contribution behaving these materials as almost closed-cell materials at high strain rates. However, this gas contribution is considerably lower (35\%) for the EBA OC LT and the PU materials.

To corroborate the previous statement, the density of absorbed energy was also calculated. Closed-cell materials are used for several applications in which high energy absorptions are required (packaging of different type of items and body protection elements). It is expected that the absorbed energy increases as the level of interconnectivity is reduced. Figure 3(c) displays the main results obtained for the energy absorptions. At low strain rates, it is observed this clear relationship between energy absorption and the level of interconnectivity. The CC and the MO present higher energy absorptions than the open-cell foams. However, it is also confirmed here how the EBA OC HT foam presents a noticeable dependency on the strain rate. At high strain rates, this material can absorb a large amount of energy, very similar to EBA CC and much higher than EBA OC LT. This result is in agreement with that obtained for the effective gas pressure, and therefore, the cellular structure interconnectivity and the tortuosity affects the mechanical properties markedly.

EBA OC HT foams present a defined double behavior depending on the strain rate: they behave as an open-cell foam at low strain rates and as a closed-cell foam at high strain rates. This remarkable effect makes these materials very interesting for applications where comfort and protection are required because this material shows both effects in just one material. 


\section{Dynamic mechanical behavior and thermal expansion}

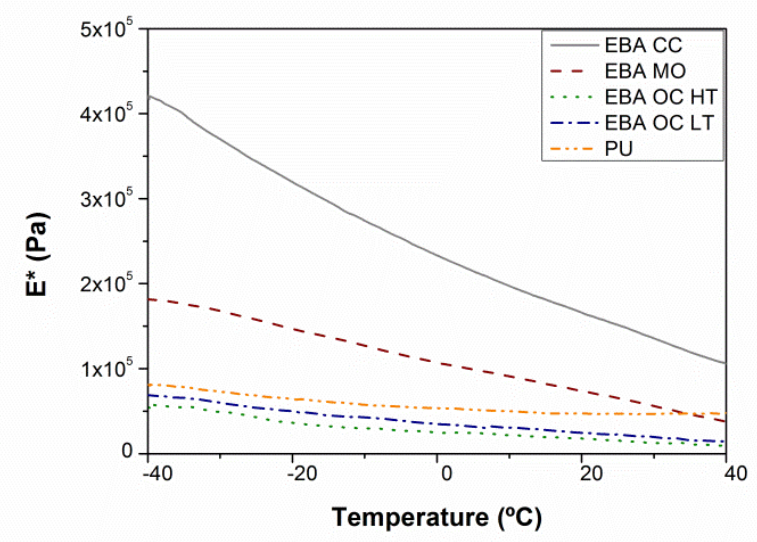

Figure 4. Modulus of the complex modulus ( $\left.E^{\prime}\right)$ versus temperature for the materials under study.

Figure 4 shows the modulus of the complex modulus as a function of temperature for the materials under study. For all the materials, the stiffness decreases when the temperature rises. As it was expected, there is a clear influence of the cellular structure interconnectivity on this parameter. The EBA CC foam presents the highest modulus of the complex modulus in the temperature range between -40 and $40{ }^{\circ} \mathrm{C}$. In these materials, both cells edge bending, and cell faces stretching contribute to the stiffness of the materials, and due to this, the material presents higher storage modulus.

Furthermore, the relationship between the modulus and the cellular structure interconnectivity is also fulfilled for EBA MO, whose modulus is found between the values of the material with low cellular structure interconnectivity (EBA CC) and the open-cell materials. Open-cell materials have the lowest modulus. The values for both EBA OC HT and EBA OC LT foams are lower than those obtained for the open-cell PU foam at any temperature, which is probably due to the lower density and as consequence higher porosity of the polyolefin-based foams.

Tan $\delta$ is used to determine the ability of a material to damp vibrations. High values of $\tan \delta$ indicate better behavior for damping mechanical vibrations. The results are presented in Figure 5 for temperatures between -40 and $40{ }^{\circ} \mathrm{C}$. In the range of temperatures under study, no relaxations of the matrix polymer were detected in the $\tan \delta$ curve. For all the materials the damping factor was almost constant, except for the EBA OC HT that showed an increase. 


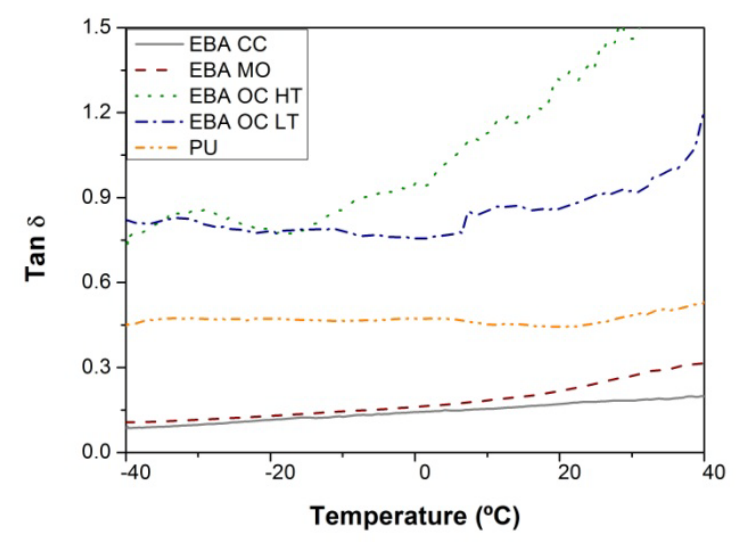

Figure 5. $\tan \delta$ versus temperature for the materials under study.

Comparing both EBA CC, EBA MO and open-cell foams, it is observed that $\tan \delta$ is higher for open-cell foams than for the ones with lower cellular structure interconnectivity. Besides, both EBA OC HT and EBA OC LT present higher tan $\delta$ than the open-cell PU foam. Therefore, these open-cell EBA foams present a better behavior than the PU foam for damping vibrations. This is a remarkable result, showing that apart from the viscoelastic damping coming from the base material, that is the main reason for the values of $\tan \delta$ found in the EBA CC and EBA MO materials ${ }^{48,49}$, there is an additional damping mechanism in the open-cell polyolefin foams that allows increasing tan $\delta$ values from around 0.2 for the materials with low open-cell contents to 0.9 for the open-cell foam with low tortuosity and to even higher values for the opencell high tortuous material. This additional damping mechanism should be connected with the energy dissipated by the gas phase when moves outside and inside the sample during the mechanical cycle. From a practical point of view, this new behavior opens the possibility of using these new foams as very efficient materials for damping ef mechanical vibrations.

Once the viscoelastic behavior has been characterized, the thermal stability of the materials was also considered.

To quantify this property, the temperature to reduce the thickness of the foam by $10 \%$ was measured. The values are displayed in Table 3:

Table 3. Temperature to reduce the thickness of the foam by $10 \%$. -* The thickness of the PU foam is not reduced in this temperature range.

\begin{tabular}{|cc|}
\hline Sample & Temperature $\left({ }^{\circ} \mathrm{C}\right)$ \\
\hline EBA CC & $83.6 \pm 5.2$ \\
\hline EBA MO & $80.5 \pm 0.6$ \\
\hline EBA OC HT & $68.7 \pm 1.3$ \\
\hline EBA OC LT & $68.2 \pm 2.8$ \\
\hline PU & $-*$ \\
\hline
\end{tabular}


It is observed in Table 3, that this temperature decreases as the level of interconnectivity increases, being the EBA CC the most thermally stable material, whereas the collapse of the open-cell foams starts at a temperature below $70{ }^{\circ} \mathrm{C}$.

\section{Acoustic properties}

The acoustic absorption of the materials under study is shown in Figure 6:

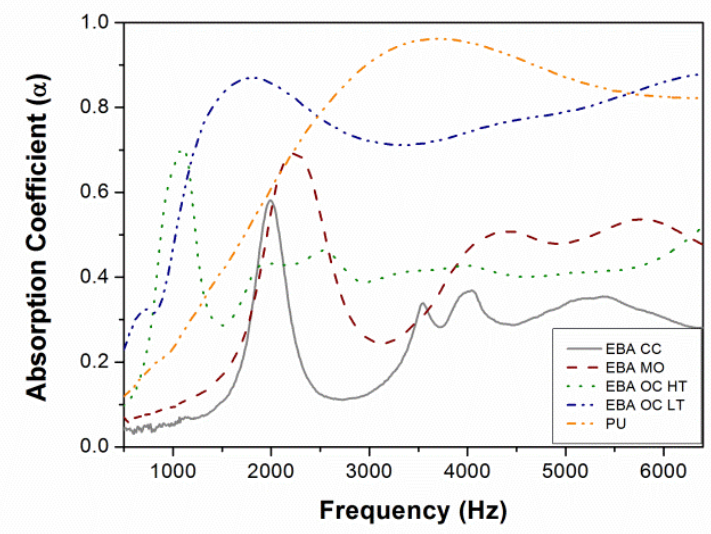

Figure 6. Absorption coefficient versus frequency of the materials under study.

It can be observed a clear influence of the cellular structure interconnectivity on the absorption coefficient (a). The EBA CC foam displays the lower absorptions far from those obtained for any of the open-cell foams. The EBA OC LT presents higher absorptions than that obtained for the EBA OC HT one in all frequency range. A possible explanation of this result can be based on how the sound waves are propagated through the cellular structure. As the holes are larger in EBA OC LT foams, the waves can propagate more easily than through tiny holes. As a result, it can be stated that EBA OC LT foams are more suitable for acoustic absorption than the EBA OC HT ones. It can also be outlined that the EBA OC LT foam shows high values of the acoustic absorption, in the same range than those found for the open-cell PU foam, typically used for acoustic absorption.

Setting aside the cellular structure interconnectivity, all EBA foams display an interesting feature: the maximum absorptions for the EBA cellular polymers appear at lower frequencies than those of the PU foam. Aiming at understanding better these results, the normalized absorption coefficient $\left(a_{n}\right)$ has been calculated by using the following equation (5):

$$
\alpha_{n}=\frac{\int_{f_{1}}^{f_{2}} \alpha(f) d f}{f_{2}-f_{1}}
$$

where $f_{2}$ and $f_{1}$ are the frequencies used as limits in the integration.

The results are summarized in Table 4, where the frequency of the peak in the acoustic absorption curve, the normalized absorption coefficient in the whole frequency ranges 
(500-6400 Hz) and the normalized absorption coefficient at low frequencies (500-2500 $\mathrm{Hz}$ ) are collected:

Table 4. Frequency of the maximum in the acoustic absorption curve, normalized absorption coefficients in the whole frequency range and normalized absorption coefficients at low frequencies.

\begin{tabular}{|cccc|}
\hline Sample & $\begin{array}{c}\text { Frequency } \\
\text { Maximum }(\mathrm{Hz})\end{array}$ & $\begin{array}{c}\mathrm{a}_{\mathrm{n}} \\
(500-6400 \mathrm{~Hz})\end{array}$ & $\begin{array}{c}\mathrm{a}_{\mathrm{n}} \\
(500-2500 \mathrm{~Hz})\end{array}$ \\
\hline EBA CC & $1992 \pm 60$ & $0.24 \pm 0.03$ & $0.18 \pm 0.01$ \\
\hline EBA MO & $2240 \pm 169$ & $0.39 \pm 0.03$ & $0.29 \pm 0.04$ \\
\hline EBA OC HT & $1048 \pm 112$ & $0.41 \pm 0.07$ & $0.40 \pm 0.07$ \\
\hline EBA OC LT & $1684 \pm 275$ & $0.74 \pm 0.07$ & $0.68 \pm 0.12$ \\
\hline PU & $3715 \pm 106$ & $0.73 \pm 0.00$ & $0.43 \pm 0.01$ \\
\hline
\end{tabular}

As it was emphasized before, there is a considerable difference in the frequency of the maximum peaks for the EBA-based foams (below $2500 \mathrm{~Hz}$ ) and the PU foam used as a reference (above $3500 \mathrm{~Hz}$ ).

Concerning the normalized absorption coefficient, it can be observed how this parameter is affected by the tortuosity. As it was expected, the EBA CC foam has the poorest acoustic absorption. It is remarkable the slight difference (0.02) in absorption between the MO and OC HT foam. Despite creating holes in the cell walls, it seems that this fact has not any considerable effect on the acoustic absorption if the acoustic absorption is evaluated in the whole frequency range. However, this difference is wider at low frequencies (0.11). Focusing the analysis on the tortuosity, it can be inferred from the data of Table 4, that the tortuosity plays a key role on this property, being the absorption of the EBA OC LT much higher than that of EBA OC HT foam. It is also remarkable that the EBA OC LT (0.74) presents similar acoustic absorptions to the open-cell PU foam (0.73). Particularly, EBA OC LT shows the highest absorption coefficient $(0.68)$ at low frequencies, whereas the $\mathrm{PU}$ foam has a poorer performance in this range $(0.43)$.

These results indicate the extremely good acoustic absorption of the EBA OC LT foam, standing out the excellent absorptions at low frequencies, which makes this material a potential alternative to the current materials used for acoustic absorption.

\section{Oil absorption}

The oil (commercial motor oil 15W40) and the water absorption capacities of the opencell EBA foams have been measured and have been compared to the reference PU foam. The oil absorption of the EBA CC and the EBA MO foams was not measured. The oil cannot penetrate in the cellular structure of these materials due to the lack of interconnectivity of the cellular structure.

The oil and water absorptions of the foams under study are shown and compared in Figure 7: 

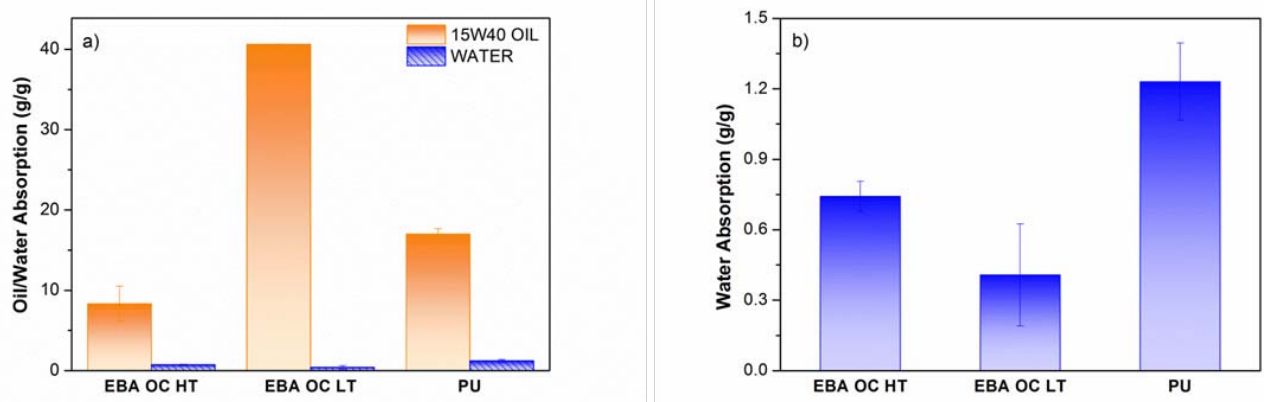

Figure 7. a) Comparative between oil (motor oil 15W40) and water absorptions and b) water absorptions of the opencell foams under study.

From Figure 7, it can be inferred, that the affinity towards oil in all the materials is much higher than the hydrophilic behavior. Furthermore, the cellular structure tortuosity plays once again a critical role. The oil absorption of the EBA OC LT foam is nearly five times higher than that of the EBA OC HT one. It is also noteworthy that the EBA OC LT presents better oil absorptions than the PU foam characterized in this paper. Here, it is convenient to clarify, that there are other examples in the literature based on studies of oil absorption of open-cell PU foams, which have oil absorptions up to 60 grams of oil per gram of foam ${ }^{37}$. Nevertheless, considering that any additional surface treatments have been performed in the EBA foams, 40 grams of oil per gram of foam can be considered a significant oil uptake.

Concerning the water absorptions, both open-cell EBA foams are more hydrophobic than the PU foam. Water absorptions, as low as 0.40 grams of water per gram of foam, were obtained without performing any surface treatment. This result constitutes a relevant benefit in comparison with PU foams.

Another aspect of being considered is the reusability of the materials, which is a critical requirement for a material to be used for this application. As a consequence, the material must be employed as many times as necessary without losing performance. For this purpose, the EBA OC LT foam and the open-cell PU foam were subjected to 20 compressive cycles ${ }^{50}$. The parameter to be analyzed in the reusability tests is called the non-recovered deformation (NRD). This parameter should be as low as possible and constant along the consecutive cycles to consider a material as reusable.

The non-recovered deformations values for the two analyzed materials are exposed in Table 5:

Table 5. Non-recovered deformation (NRD) values of EBA OC LT and the PU foam as a function of the compressive cycle.

\begin{tabular}{|cccccc|}
\hline Sample & $\begin{array}{c}\text { NRD } \% \\
\left(1^{\text {st }} \text { cycle }\right)\end{array}$ & $\begin{array}{c}\text { NRD } \% \\
\left(5^{\text {th }} \text { cycle }\right)\end{array}$ & $\begin{array}{c}\text { NRD } \% \\
\left(10^{\text {th }} \text { cycle }\right)\end{array}$ & $\begin{array}{c}\text { NRD } \% \\
\left(15^{\text {th }} \text { cycle }\right)\end{array}$ & $\begin{array}{c}\text { NRD \% } \\
\left(20^{\text {th }} \text { cycle }\right)\end{array}$ \\
\hline EBA OC LT & 0.1 & 2.1 & 3.1 & 3.1 & 4.1 \\
\hline PU & 0.2 & 1.1 & 2.0 & 2.0 & 2.0 \\
\hline
\end{tabular}


Both materials present an almost constant behavior along the cycles. The nonrecovered deformation slightly increases from the first to the last cycle in both materials.

Furthermore, both materials have non-recovered deformation values under 5\%, which means that these materials recover almost completely after compression. This result was expected for the PU since it is used for applications in which the total recovery of the material is required (comfort). Thus, it can be observed in Table 5, that the EBA OC LT foam nearly reproduces the performance of open-cell PU foams.

\section{CONCLUSIONS}

The physical properties of novel crosslinked EBA foams with different cellular structure interconnectivity and tortuosities have been analyzed and compared to those obtained for an open-cell PU foam used as a reference.

Concerning the mechanical properties, it has been determined that the cellular structure tortuosity has a critical influence depending on the strain rate of deformation. On the one hand, the low tortuous foams behave as an open-cell foam at both low and high strain rates. On the other hand, the contribution of gas increases dramatically at high strain rates for the high tortuous foam, behaving this foam similarly to a closedcell foam at high strains. The small size and the small amount of the holes in the high tortuous foams allow the escape of the gas at low strain rates, but at high strain rates, the gas does not have enough time to escape through the tiny holes. As a result, there is a marked dependence of the foam behavior with the strain rate.

The low tortuous foams present excellent sound absorptions in the whole range of frequencies, but it is remarkable its superior absorption at low frequencies in a region where the open-cell PU foam has a poorer performance. In addition, the cellular structure tortuosity plays a critical role on the sound absorption, being low tortuous foams much better absorbers than the high tortuous ones, because the sound waves can penetrate easily through larger holes.

The effect of the cellular structure tortuosity on the oil absorption has been analyzed, concluding that the oil can penetrate easily through the large holes of the low tortuous foams. It is also noteworthy that these EBA-based foams can be reused at least 20 times.

Furthermore, these open-cell EBA foams are suitable for damping vibrations due to its high $\tan \delta$ value.

As a summary of this research, we can conclude that these novel open-cell EBA foams can be considered as a potential alternative to open-cell PU foams for several applications. 


\section{ACKNOWLEDGMENTS}

This work performed with the financial support from DI grant DI-15-07952 (E. LopezGonzalez) from the Spanish Ministry of Economy, Industry, and Competitiveness. Financial assistance from MINECO, FEDER, UE (MAT2015-69234-R) and the Junte of Castile and Leon (VA275P18) are gratefully acknowledged.

\section{REFERENCES}

1. Reducing Marine Litter: action on single-use plastics and fishing gear. European Commission

2. Mills, N. Polymer Foams Handbook; Elsevier Science Publishers: Amsterdam, 2007.

3. Polymeric Foams: Mechanisms and Materials; Lee, S.T.; Ramesh, N.S., Eds.; CRC Press Taylor \& Francis Group: Boca Raton, 2004.

4. Gibson, L.J.; Ashby, M.F. Cellular Solid: Structure and Properties, 2nded; Clarke, D.R.; Suresh, S.; Ward, I.M., Eds.; Cambridge University Press, 1997.

5. Rodriguez-Perez, M.A. Adv. Polym. Sci. 2005, 184, 97-126.

6. Nagy, A.; Ko, W.L.; Lindholm, U.S. J. Cell. Plas. 1974, 10, 127-134.

7. Avella, M.; Cocca, M.; Errico, M.E.; Gentile, G. J. Cell. Plas. 2011, 47, 271-281.

8. Mills, N.J.; Fitzgerald, C.; Gilchrist, A.; Verdejo, R. Compos. Sci. Technol. 2003, 63, 2389-2400.

9. Verdejo, R.; Mills, N.J. J. Biomech. 2004, 37, 1379-1386.

10. Mosanenzadeh, S.G.; Naguib, H.E.; Park, C.B.; Atalla, N. Polym. Eng. Sci. 2013, 53, 1979-1989.

11. Chen, S.M.; Jiang, Y. Polym. Composite. 2018, 39, 1370-1381.

12. Handbook of Polymeric Foams and Foam Technology; Klempner, D.; Sendijarevic, V. Eds.; Hanser Publishers: Munich, 1991.

13. Rodriguez-Perez, M.A.; Velasco, J.I.; Arencon, D.; Almanza, O.; de Saja, J.A. J. Appl. Polym. Sci. 1999, 75, 156-166.

14. Zhu, H.X.; Knott, J.F.; Mills, N.J. J. Mech. Phys. Solids. 1997, 45, 319-325,327-343.

15. DesMarais, T.A. Flexible polyurethane foam. US Patent 4067832A, 1978.

16. Radovich, D.A.; Lowery, M.K. Flexible polyurethane foams. US Patent 4546122A, 1985.

17. Leenslag, J.W.; Cunningham, A.; Eling, B. Flexible polyurethane foams. US Patent 5900442A, 1999.

18. Scarpa, F.; Pastorino, P.; Garelli, A.; Patsias, S.; Ruzzene, M. Phys. Stat. Sol. (b) 2005, 242, 681-694.

19. Design. 2016, 53, 448-454.Gwon, J.G.; Kim, S.K.; Kim, J.H. Mater.

20. Peterson, C.H. Adv. Mar. Biol. 2001, 39, 1-103.

21. Skalski, J.R.; Coats, D.A.; Fukuyama, A.K. Environ. Manage. 2001,28, 9-18.

22. Adebajo, M.O.; Frost, R.L.; Kloprogge, J.T.; Carmody, O.; Kokot, S. J. Porous. Mater. 2003, 10, 159-170.

23. Calcagnile, P.; Fragouli, D.; Bayer, I.S.; Anyfantis, G.C.; Martiradonn, L.; Cozzoli, P.D.; Cingolani, R.; Athanassiou, A. ACS Nano. 2012, 6, 5413-5419. 
24. Pinto, J.; Athanassiou, A.; Fragouli, D. J. Phys. D: Appl. Phys. 2016, 49, 145601.

25. Wang, P.; Zou, C.; Zhong, H. Adv. Mat. Res. 2012, 518, 847-853.

26. Thakur, S.; Jahid, M.A.; Hu, J. Polym. Int. 2018, 67, 1386-1392.

27. Pinto, J.; Heredia-Guerrero, J.A.; Athanassiou, A.; Fragouli, D. Int. J. Environ. Sci. Technol. doi:10.1007/s13762-017-1310-6.

28. Wang, C.F.; Lin, S.J. ACS Appl. Mater. Inter. 2013, 5, 8861-8864.

29. Zhu, Q.; Chu, Y.; Wang, Z.; Chen, N.; Lin, L.; Liu, F.; Pan, Q. J. Mater. Chem. A. 2013, 1, 5386-5393.

30. Alvarez-Lainez, M.; Rodriguez-Perez, M.A.; de Saja, J.A. Mat. Lett. 2014, 121, 2630.

31. Alvarez-Lainez, M.; Rodriguez-Perez, M.A.; de Saja, J.A. J. Polym. Sci. Pol. Phys. 2008, 46, 212-221.

32. Almanza, O.; Rodriguez-Perez, M.A.; de Saja, J.A. Polym. Int. 2004, 53, 20382044.

33. Zhou, H.; Wang, Z.; Xu, G.; Wang, X.; Wen, B.; Jin, S. Cell. Polym. 2017, 37, 167182.

34. Ouassim, H.; Mighri, F.; Rodrigue, D. Cell. Polym. 2018, 37, 153-168.

35. Bear, J. Dynamics of fluids in porous media; American Elsevier Pub. Co: New York, 1972.

36. Pfretzschner, J.; Rodriguez, R.M. Polym. Test. 1999, 18, 81-92.

37. Mills, N.J.; Zhu, H.X. J. Mech. Phys. Solids. 1999, 47, 669-695.

38. Mills, N.J.; Rodriguez-Perez, M.A. Cell. Polym. 2001, 20, 79-100.

39. Wang, B.; Wang, M.; Xing, Z.; Zeng, H.; Wu, G. J. Appl. Polym. Sci. 2013, 127, 912-918.

40. Handbook of Polymer Foams; Eaves, D., Eds.; Rapra Technology Limited: Shawbury, 2004.

41. Pinto, J.; Solorzano, E.; Rodriguez-Perez, M.A. J. Cell. Plas. 2013, 49, 555-575.

42. Ruiz-Herrero, J.L.; Rodriguez-Perez, M.A.; de Saja, J.A. Polym. Test. 2005, 24, 641-647.

43. Gent, A.N.; Thomas, A.G. Rubber. Chem. Technol. 1963, 36, 597-611.

44. Rodriguez-Perez, M.A.; Hidalgo, F.; Solorzano, E.; de Saja J.A. Polym. Test. 2009, 28, 188-195.

45. Menges, G.; Knipschild, F. Polym. Eng. Sci. 1975, 15, 623-627.

46. Maiti, S.K.; Gibson, L.J.; Ashby, M.F. Acta. Metall. Mater. 1984. 32, 1963-1975.

47. Iannace, F.; Iannace, S.; Caprino, G.; Nicolais, L. Polym. Test. 2001, 20, 643-647.

48. Rodriguez-Perez, M.A.; de Saja, J.A. Polym. Test. 1999, 19, 831-848.

49. Rodriguez-Perez, M.A.; Rodriguez-Llorente, S.; de Saja, J.A. Polym. Eng. Sci. 1997, 39, 959-966.

50. Rizvi, A.; Chu, R.K.M.; Lee, J.H.; Park, C.B. ACS Appl. Mater. Inter. 2014, 6, 21131-21140. 


\subsection{DMA analysis and thermal stability: LDPE, EVA 12 and EVA 18 foams}

This chapter of the thesis covers the remaining physical properties, which have been measured over the research. Since there were no articles in the bibliography based on the production of cellular polymer based on EBA, we believed that it could be interesting to present the results of the characterization of all the physical properties of the EBA foams in just one article (previous section).

On the other hand, in the previous chapters, the mechanical, acoustic and oil absorptive properties of all materials have been described. However, the dynamic mechanical properties, the thermal stability were not discussed for LDPE, EVA 12 and EVA 18. This section includes the results obtained for these materials.

The characterization of these materials has followed the same experimental procedure as the one described in section 7.2.

Concerning the dynamic mechanical properties, the shape of the samples, the dimensions, the heating rate, the range of temperatures and the frequency were maintained constant. The modulus of the complex modulus $\left(\mathrm{E}^{*}\right)$ and $\tan$ delta $(\tan \delta)$ were measured as a function of temperature.

The main results are summarized in Figure 7.2:
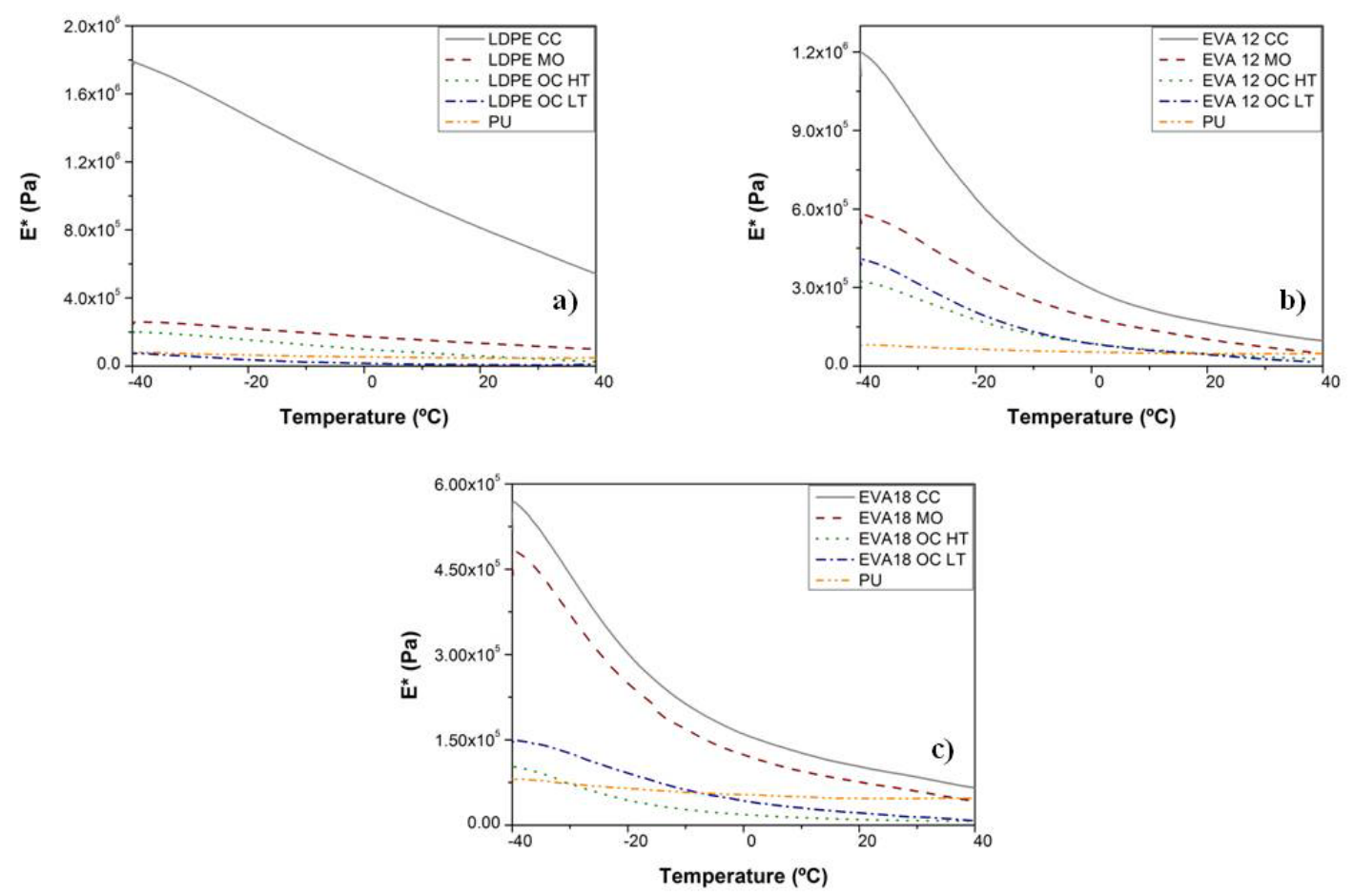

Figure 7.2. Complex modulus: a) LDPE; b) EVA 12 and c) EVA 18 foams. 
Similar results than those described for EBA foams were obtained for all materials regardless of the polymer matrix. There is a trend between the complex modulus and the interconnectivity, the lowest the interconnectivity of the cellular structure the highest the complex modulus.

Concerning open-cell materials, in some examples, it is observed an effect of the tortuosity on the complex modulus, but it cannot be stated, that there is a relevant effect. Based on the characterization of the previous physical properties, it should be expected that open-cell foams with low tortuosity would present a lower complex modulus than the high tortuous foams. However, it must be taken into account that the sample size for these tests is very small, and these samples are not representative of the whole foam. Furthermore, considering that these foams are not as homogeneous as the open-cell PU foams in terms of cellular structure, some unexpected results can be obtained. Despite not having a clear tendency with the tortuosity, the complex modulus values of the open-cell foams are always much smaller than those obtained for $\mathrm{CC}$ and $\mathrm{MO}$ materials.

Not only the complex modulus but also tan $\delta$ has been measured. The $\tan \delta$ curves are presented in Figure 7.3:
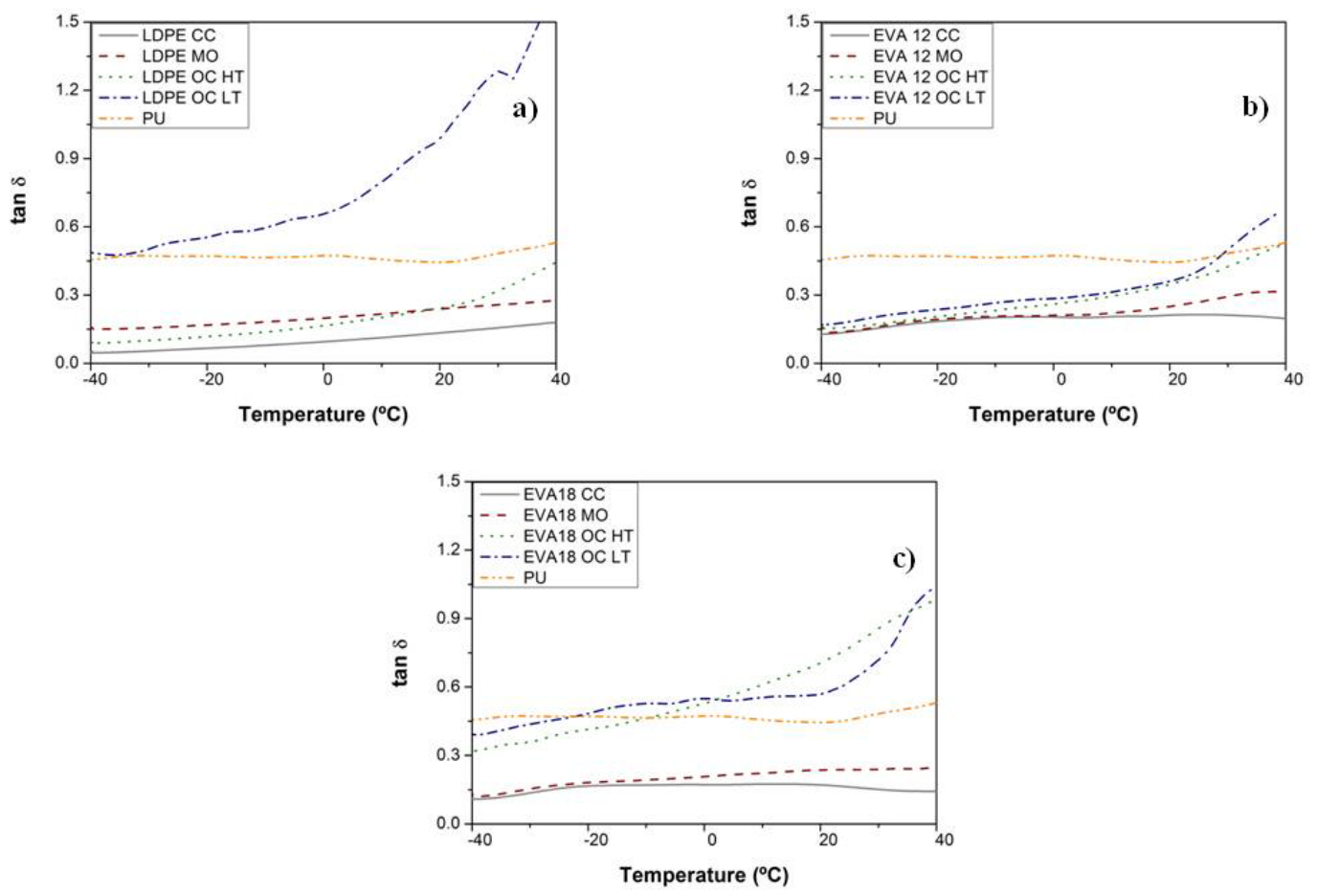

Figure 7.3. $\tan \delta:$ a) LDPE; b) EVA 12 and c) EVA 18 foams.

For EBA foams, it was observed that the open-cell foams displayed high value of $\tan \delta$ in the range of temperature under study (from -40 to $40{ }^{\circ} \mathrm{C}$ ). For the other polymers, similar tendencies were obtained, standing out the high values of $\tan \delta$ of the foams with low tortuosity. Except for EVA 12, the open-cell materials show higher tan $\delta$ than the open-cell PU foam used in this study. However, as the interconnectivity of the 
cellular structure decreases, the values of $\tan \delta$ also go down, restricting the use of CC and $\mathrm{MO}$ as absorbers of mechanical vibrations.

One other critical aspect to be considered is the thermal stability of the materials. In the previous article, the temperature to reduce the thickness of the EBA foams by $10 \%$ (start of the collapse) was quantified, showing dependency between thermal stability and cellular structure interconnectivity. The results for LDPE, EVA 12 and EVA 18 foams are summarized in Figure 7.4 and in Table 7.1, where the temperature needed to reduce the thickness by $10 \%$ has been included.
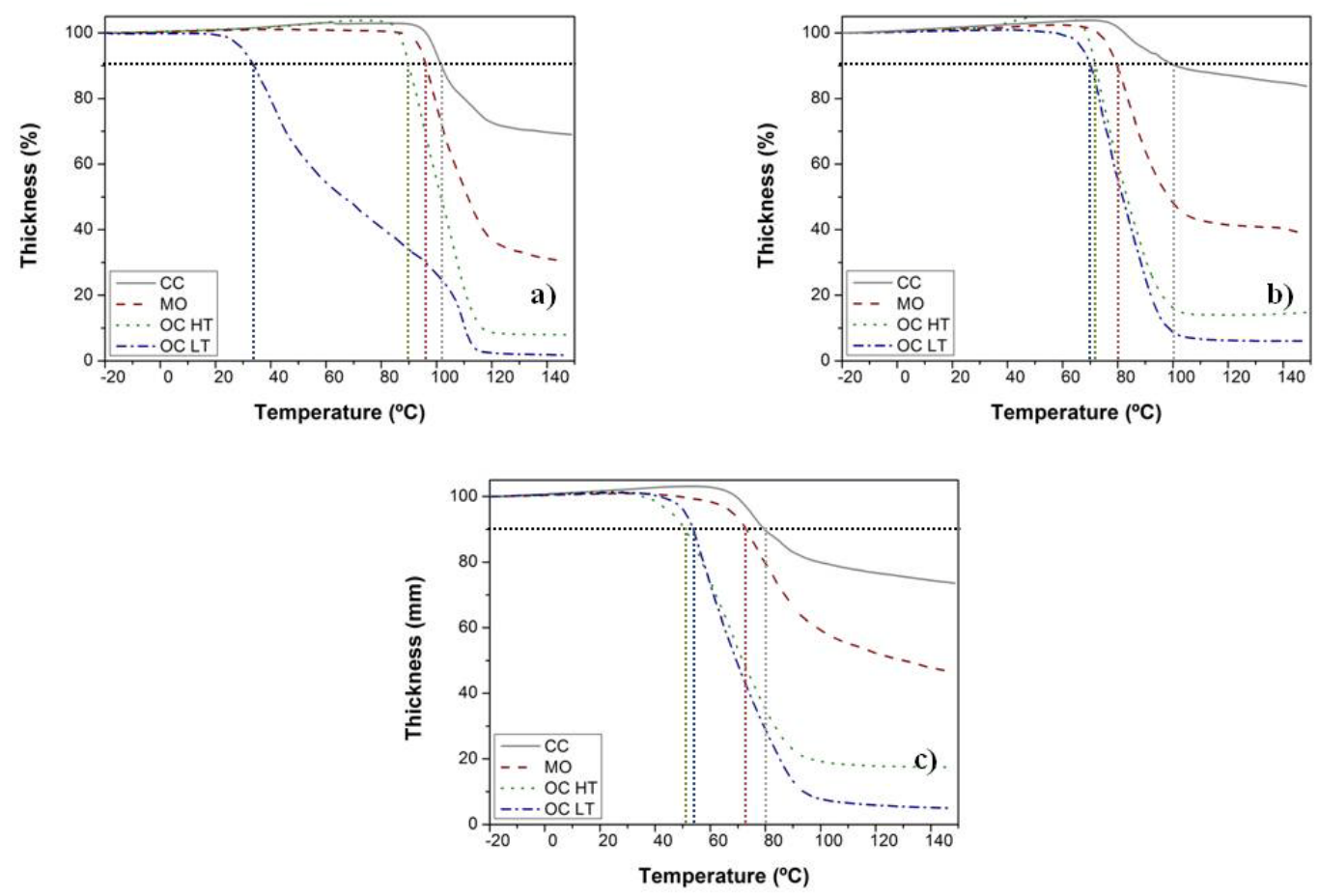

Figure 7.4. Thickness (\%) versus temperature. Thickness reduction by $10 \%$ : a) LDPE; b) EVA 12 and c) EVA 18 foams. 


\begin{tabular}{|cc|}
\hline Sample & $\begin{array}{c}\text { Temperature } \\
\left({ }^{\circ} \mathrm{C}\right)\end{array}$ \\
\hline LDPE CC & $101.89 \pm 1.64$ \\
\hline LDPE MO & $96.02 \pm 0.36$ \\
\hline LDPE OC HT & $90.17 \pm 1.98$ \\
\hline LDPE OC LT & $34.50 \pm 2.96$ \\
\hline EVA 12 CC & $100.42 \pm 7.02$ \\
\hline EVA 12 MO & $79.69 \pm 0.20$ \\
\hline EVA 12 OC HT & $71.95 \pm 0.35$ \\
\hline EVA 12 OC LT & $70.24 \pm 3.84$ \\
\hline EVA 18 CC & $79.64 \pm 0.08$ \\
\hline EVA 18 MO & $73.02 \pm 0.87$ \\
\hline EVA 18 OC HT & $50.91 \pm 1.83$ \\
\hline EVA 18 OC LT & $54.04 \pm 2.13$ \\
\hline PU & $>150$ \\
\hline Table 7.1. Temperature to reduce the thickness of the foam by 10\%.
\end{tabular}

For all polymer matrices, the closed-cell materials are the most thermally stable ones, being their collapse temperature considerably higher than the ones obtained for opencell materials. MO foams are located in between closed and open-cell materials. Finally, open-cell materials present the poorest thermal stability, being their values quite low, even as low as $35^{\circ} \mathrm{C}$ for LDPE OC LT. For almost all polymer matrices, open-cell high tortuous foams display better thermal stability than the materials with low tortuosity.

Furthermore, it is also observed the effect of the polymer matrix on this collapse temperature. Except for the LT materials, the expected trend is observed, with higher values for the LDPE materials and lower values for the EVA copolymers. It was expected that EVA based materials collapsed at lower temperatures than LDPE, considering that the melting temperature of LDPE is higher than the melting temperature of EVA. Focusing on EVA, even the content of vinyl acetate affects this temperature. EVA 12 presents lower vinyl acetate content than EVA 18, and due to this, EVA 12 has higher crystallinity and higher melting temperature. As a consequence, its thermal resistance is higher.

Concerning open-cell foams with low tortuosity, the thermal stability of the EVA $12 \mathrm{O}$ LT is much higher than the rest of OC LT foams. This non-expected result could be explained, taking into account the higher tortuosity value of this foam in comparison to the others (see Chapter 3 section 3.3.4). EVA 12 OC LT is the most tortuous foams inside the group of the open-cell foams with low tortuosity, and thus, its collapse temperature is more similar to that of the EVA 12 OC HT foam. Another aspect to consider is the lack of homogeneity of the open-cell foams with low tortuosity. It is possible that some samples may contain large holes and other samples may have smaller ones. As the samples used for this characterization are quite small and many cells of the OC LT foams are above $1 \mathrm{~mm}$, there is a heterogeneity caused by the reduced number of cells present in the samples. 


\subsection{Thermal conductivity}

This section includes the results concerning the thermal conductivity measurements of all the foams characterized in this thesis.

A Thermal Conductivity Instrument from LaserComp@ (TA Instruments) was used for these thermal measurements. Heat flow through the test sample $(q)$ results from having a temperature gradient $(\Delta T)$ across the material. The thermal conductivity $(\lambda)$ is defined according to Fourier's equation (Equation 5):

$$
q_{T}=\lambda A\left(\frac{\Delta T}{d}\right)
$$

where $A$ is the cross-sectional area of the sample and $d$ is the thickness of the sample.

For the characterization of the thermal conductivity, samples of $15 \times 15 \times 2 \mathrm{~cm}^{3}$ were used, and the measurements were performed at four different temperatures: $0,10,20$ and $30^{\circ} \mathrm{C}$.
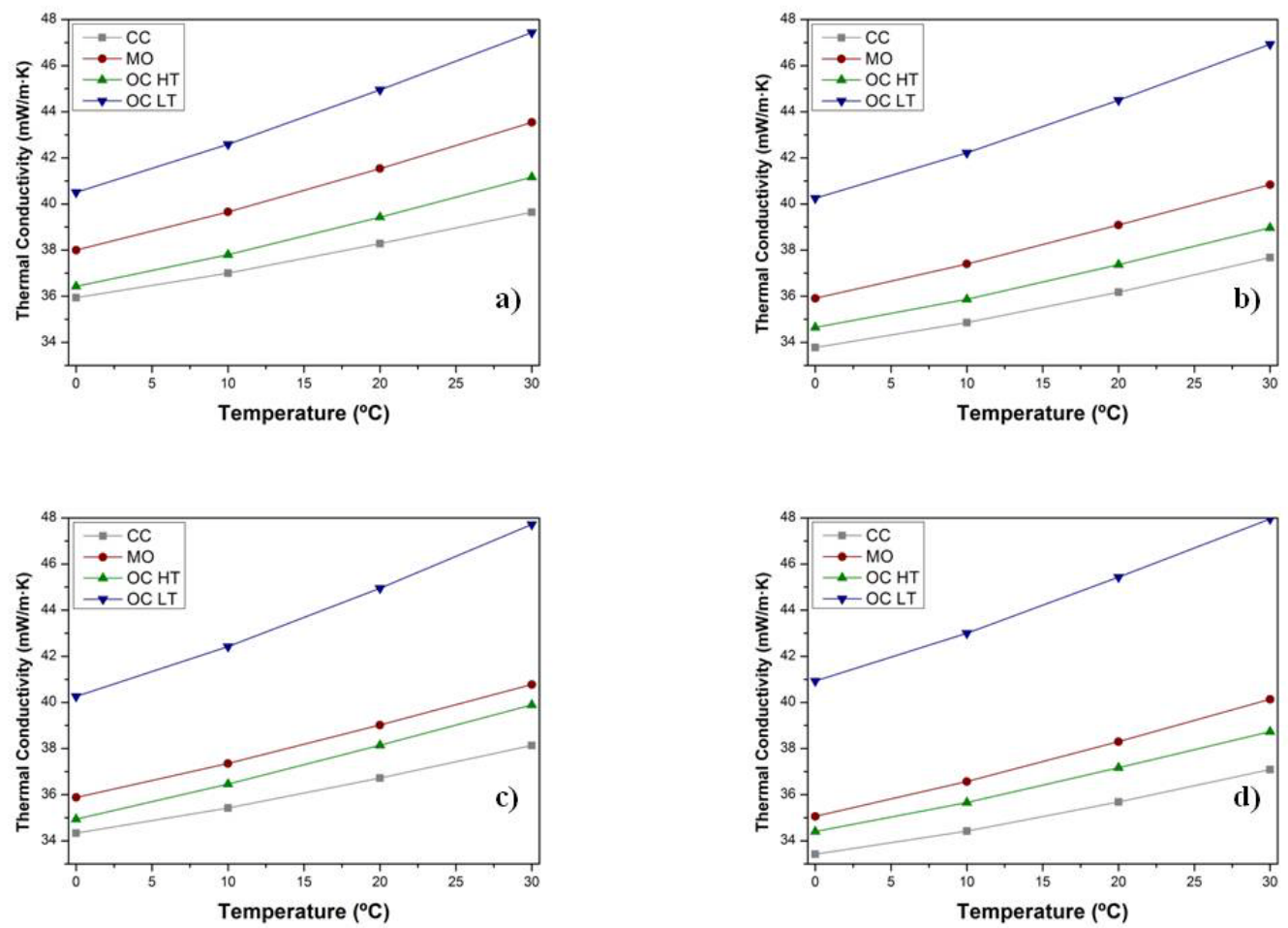

Figure 7.5. Thermal conductivity $(\mathrm{mW} / \mathrm{m} \cdot \mathrm{K}$.) versus temperature: a) LDPE; b) EVA 12; c) EVA 18 and d) EBA foams.

Figure 7.5 shows the thermal conductivity values for each collection of foams as a function of the temperature. The thermal conductivity increases as the temperature also does. As it is explained by Zhao et al. in a study of thermal conductivity of opencell steel alloy foams, there are two contributions in this increase: the rise of solid conductivity with temperature and the influence of thermal radiation [12]. Regardless 
of the polymeric matrix, it seems that the OC LT foams are more dependent on the temperature since the slope of the line is steeper than that observed for the rest of the materials. The results of the linear fit (thermal conductivity versus temperature) for all materials are summarized in Table 7.2.

\begin{tabular}{|cccc|}
\hline Sample & Slope & Intercept & $\mathrm{R}^{2}$ linear \\
\hline LDPE CC & 0.124 & 35.856 & 0.997 \\
\hline LDPE MO & 0.185 & 37.910 & 0.998 \\
\hline LDPE OC HT & 0.158 & 36.330 & 0.997 \\
\hline LDPE OC LT & 0.231 & 40.400 & 0.998 \\
\hline EVA 12 CC & 0.130 & 33.672 & 0.995 \\
\hline EVA 12 MO & 0.165 & 35.838 & 0.999 \\
\hline EVA 12 OC HT & 0.145 & 34.546 & 0.996 \\
\hline EVA 12 OC LT & 0.223 & 40.127 & 0.998 \\
\hline EVA 18 CC & 0.127 & 34.245 & 0.997 \\
\hline EVA 18 MO & 0.164 & 35.802 & 0.998 \\
\hline EVA 18 OC HT & 0.165 & 34.878 & 0.999 \\
\hline EVA 18 OC LT & 0.249 & 40.101 & 0.997 \\
\hline EBA CC & 0.123 & 33.312 & 0.994 \\
\hline EBA MO & 0.170 & 34.972 & 0.998 \\
\hline EBA OC HT & 0.145 & 34.315 & 0.998 \\
\hline EBA OC LT & 0.238 & 40.786 & 0.997 \\
\hline PU & 0.148 & 32.744 & 0.997 \\
\hline
\end{tabular}

Table 7.2. Linear fit parameters (thermal conductivity versus temperature) for the materials under study.

It can be observed in Table 7.2, that the slope of the OC LT materials is higher than the ones corresponding to the $\mathrm{CC}, \mathrm{MO}$ and OC HT foams. The thermal conductivity of the OC LT foams depends markedly on the temperature. The lowest slopes are obtained for CC foams, and therefore, the thermal conductivity is less sensitive to the temperature. The open-cell PU foam stands out not only for its low thermal conductivity but also for its very low slope, being the dependence of the thermal conductivity with the temperature very low.

Another result to take into consideration is the effect of the cellular structure interconnectivity on the thermal conductivity. OC LT foams presented the highest thermal conductivity values for all polymeric matrices. If both CC and OC LT foams are compared (most extreme cases), it can be concluded that the lower the open-cell content, the lower the thermal conductivity. However, the previous statement is not fulfilled when MO and OC HT foams are compared. Despite having higher interconnectivity, OC HT foams presented lower thermal conductivity values than the MO foams, even though it is true that the differences in thermal conductivity are small.

The thermal conductivity of foams depends on many parameters and in the particular case of these foams, the cells interconnections could favor the presence of some convection in the open cell foams with low tortuosity. In addition, in these foams, the 
presence of large cells and large holes in the cells walls should increase the radiation contribution and as a consequence, the total thermal conductivity. On the other hand, the difference between MO foams and OC HT foams could be due to a different cellular structure orientation due to the high compression that the OC HT suffers during its production. Regarding the CC foam, it is expected that these materials have a lower conductivity due to the reduced radiation because of the small cell size and the absence of large cell holes in the walls that should increase the extinction coefficient and as a consequence reduce the radiation contribution.

Figure 7.6 allows isolating the effect of the polymeric matrix on the thermal conductivity. It is also included the thermal conductivity of the open-cell PU foam used as a reference (Figure $\mathbf{7 . 6} \mathrm{d}$ ):
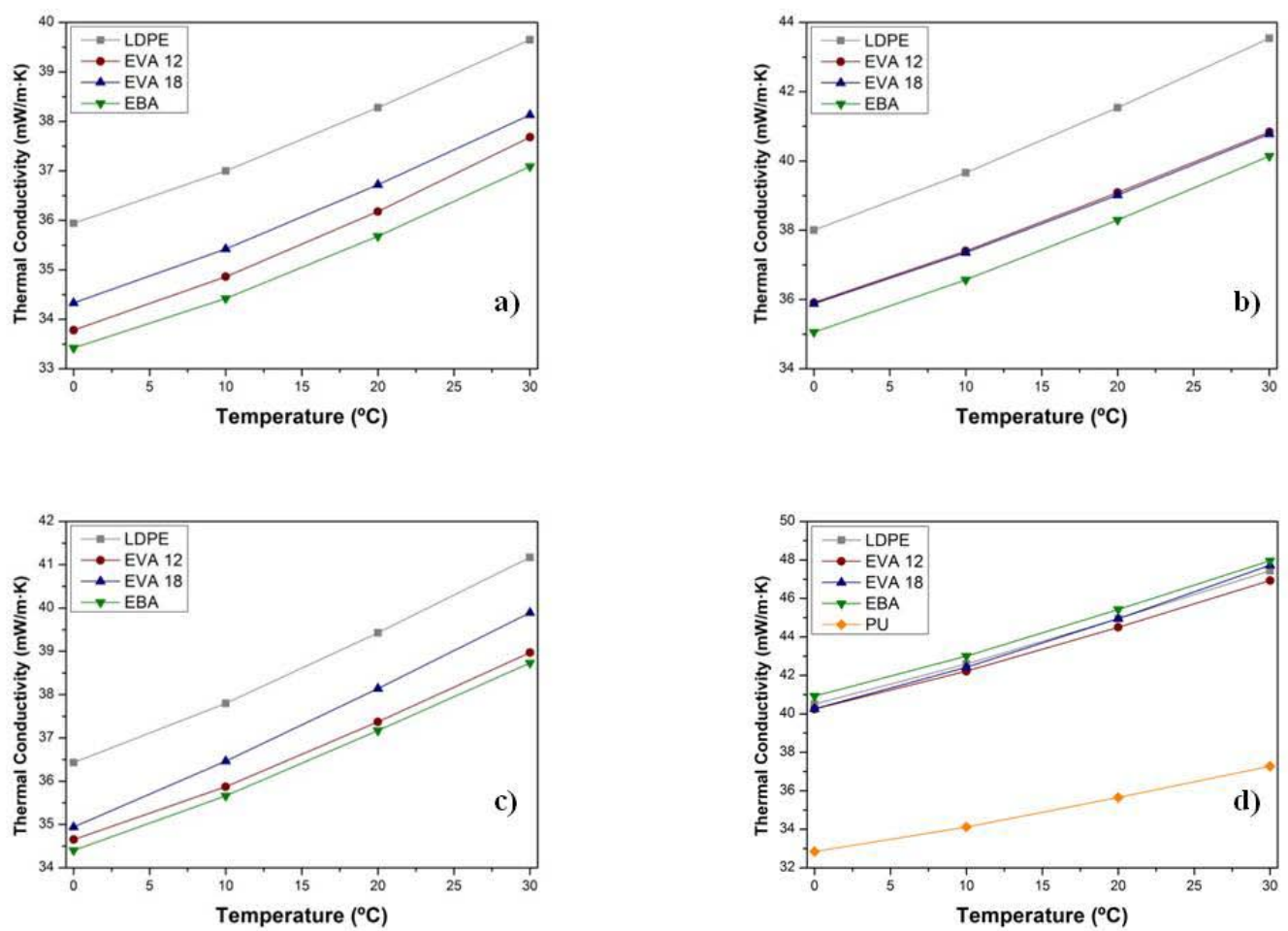

Figure 7.6. Thermal conductivity $(\mathrm{mW} / \mathrm{m} \cdot \mathrm{K}$.) versus temperature: a) CC; b) MO; c) OC HT and d) OC LT and PU foams.

Focusing on Figure 7.6 a), Figure 7.6 b) and Figure 7.6 c), it is observed that there is a clear effect of the polymeric matrix on the thermal conductivity since the densities of the foams are quite similar. The following trend is observed in the three cases:

$$
\lambda(\text { LDPE })>\lambda(\text { EVA 18) }>\lambda(\text { EVA 12) }>\lambda(\text { EBA })
$$

The contribution due to the heat flow through the polymeric matrix explains why the thermal conductivity values of the LDPE-based foams are the highest of the series. This contribution has been already reported by other authors [13,14]. Concerning EVAbased foams, it seems that the increase in the vinyl acetate content induces an increase in the thermal conductivity values, presenting EVA 12-based foams lower thermal 
conductivity values than the EVA 18-based foams. EBA-based foams present the lowest thermal conductivity values of the series, giving an extra value to the use of this polymeric matrix, previously described in section 7.2.

Figure 7.6 d) shows the results for the open-cell foams with low tortuosity. The results of the open-cell PU foam used as a reference are also included in this figure. Previously, it was explained that the OC LT foams displayed the highest values of the thermal conductivity. However, the open-cell PU foam has very low values of thermal conductivity (around $33 \mathrm{~mW} / \mathrm{m} \mathrm{K}$ at $0{ }^{\circ} \mathrm{C}$ ) in comparison to the OC LT foams. The difference between them can reach values as considerable as $9 \mathrm{~mW} / \mathrm{m} \cdot \mathrm{K}$.

According to these results, it can be concluded that the open-cell foams based on polyolefin present poorer thermal insulation properties than the flexible open-cell PU foams.

\subsection{Conclusions}

The previous chapters of this thesis cover the analysis of the mechanical and acoustic properties in conjunction with the oil absorption of the foams under study. This chapter intends not only to present foams produced by using a non-used polymer matrix for foaming purposes, such as EBA but also provides information about three properties which have not been covered before: the viscoelastic properties, the thermal stability and the thermal conductivity.

This section intends to show a global comparison between all the foams, extracting the main conclusions from it.

Concerning dynamic mechanical properties, it has been observed that the complex modulus was higher for closed-cell foams than for the rest of the foams. Furthermore, differences in the contribution of the polymer matrix can be extracted from these values, as observed in Figure 7.7, where the values of the complex modulus at $0{ }^{\circ} \mathrm{C}$ for all the materials are displayed. 

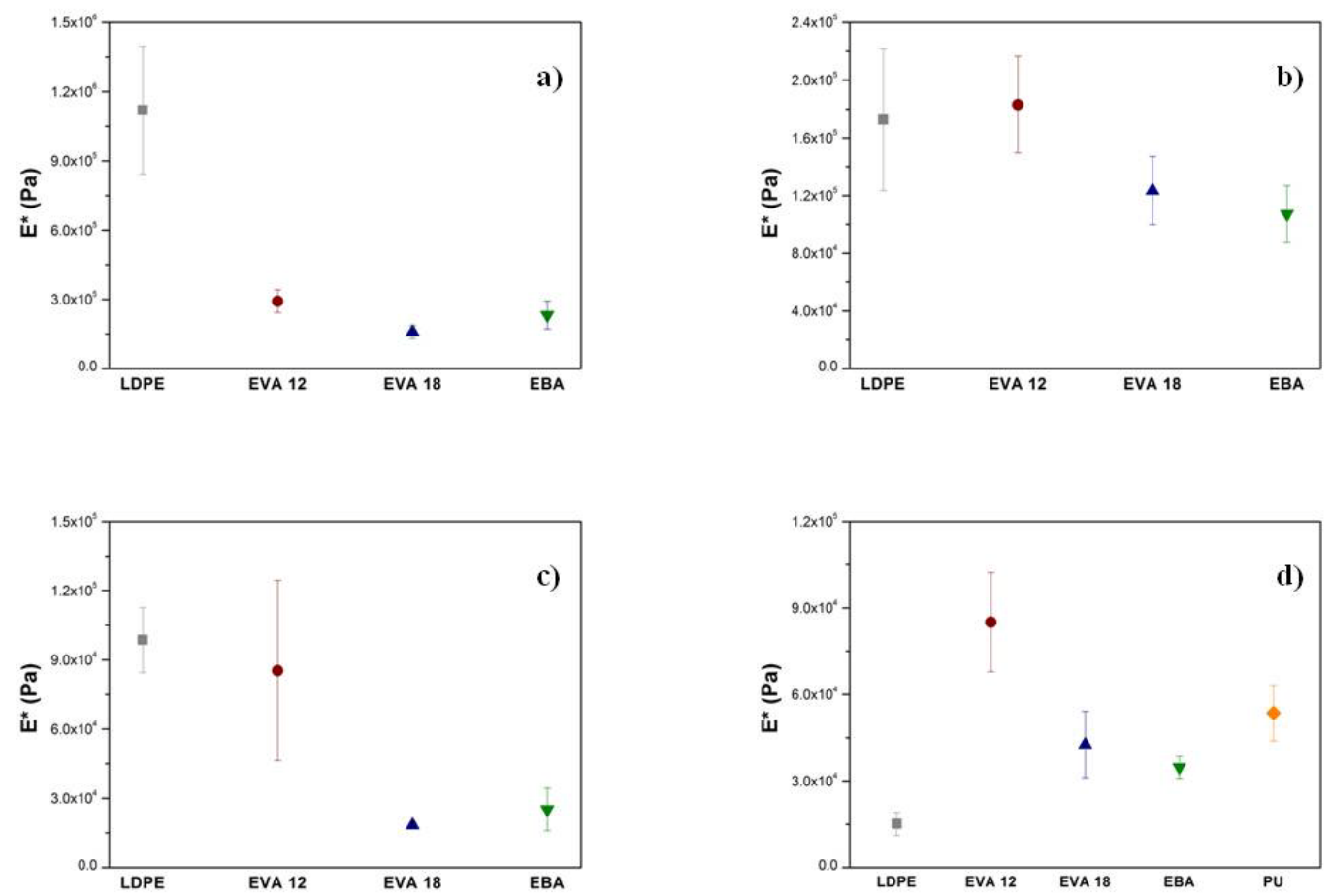

Figure 7.7. Complex modulus at $0^{\circ} \mathrm{C}$ for: a) $\mathrm{CC}$ foams; b) MO foams; c) OC HT foams and d) OC LT foams.

Since closed-cell materials are the most homogeneous materials in terms of cellular structure, it can be observed in Figure 7.7 a) the effect of the type of polymer matrix on this parameter. The stiffness of the LDPE is higher than the other copolymers, and as a result, the complex modulus of LDPE CC is the highest. Furthermore, as the content of vinyl acetate increases, the flexibility of the polymer matrix also does, and as a consequence, EVA $18 \mathrm{CC}$ has a smaller complex modulus than EVA $12 \mathrm{CC}$. EBA CC presents a behavior in between both EVA CC foams. This trend is also observed for MO and OC HT foams, in which LDPE and EVA 12 foams present the highest complex modulus values (Figure 7.7 b) and Figure $7.7 \mathrm{c}$ ). However, this trend is not observed for OC LT foams. According to Figure 7.7 d), the LDPE OC LT foam is the softest one, and this is in agreement with what was observed in the TMA analysis, which showed that the LDPE OC LT foams are the less thermally stable foam of the series. Even though LDPE is the most crystalline polymer, this parameter is not playing a key role in OC LT foams, showing this foam the lowest complex modulus of the series. On the other hand, the effect of the vinyl acetate content is observed again in OC LT foams. For all levels of interconnectivity, it is observed that the increase of vinyl acetate content is bonded to low values of complex modulus due to the reduction in the crystallinity. The effect of crystallinity is shown in Figure 7.8: 

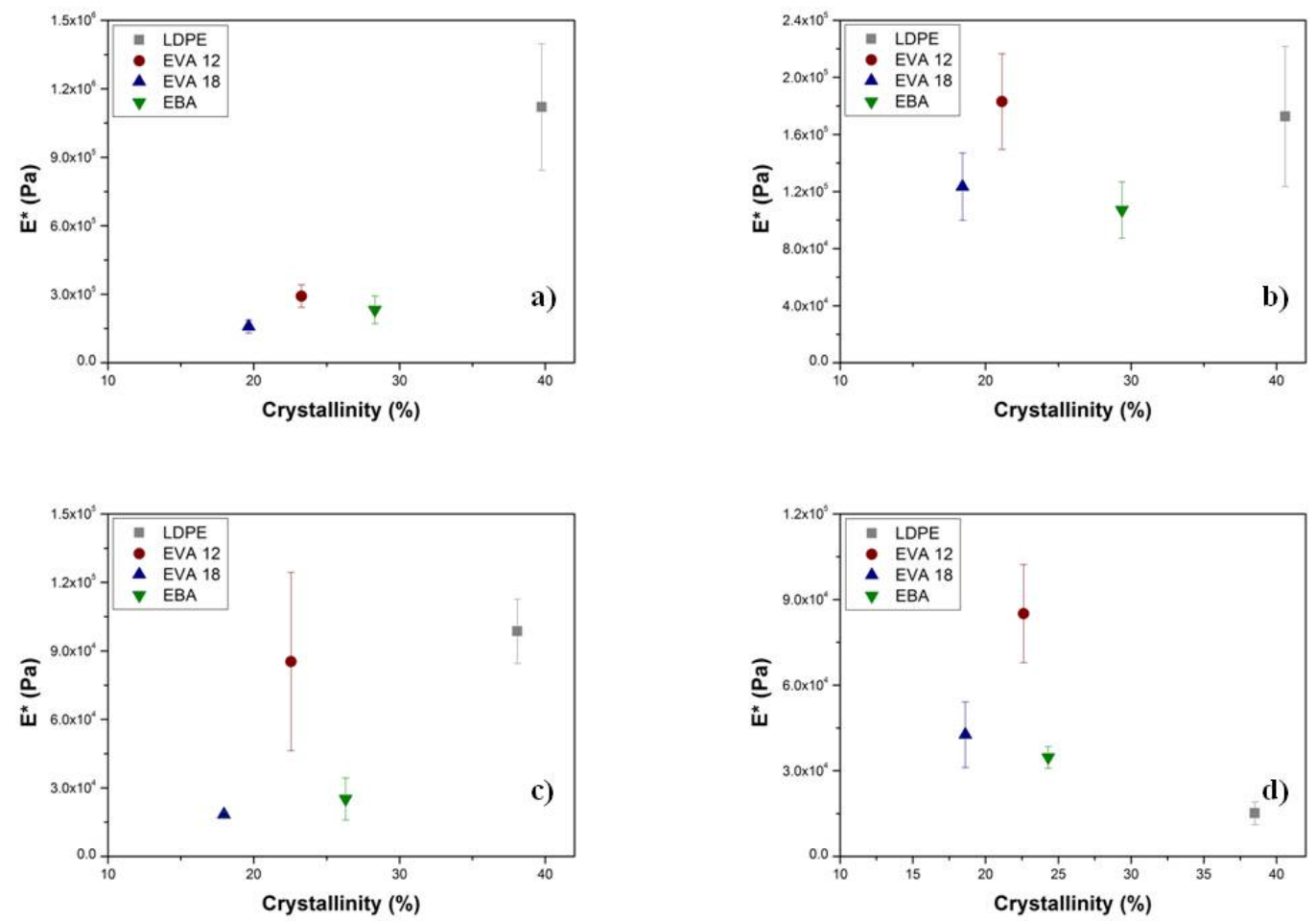

Figure 7.8. Complex modulus at $0^{\circ} \mathrm{C}$ versus crystallinity: a) CC foams; b) MO foams; c) OC HT foams and d) OC LT foams.

Figure 7.8 allows analyzing the effect of crystallinity on the complex modulus. As it was previously discussed, the complex modulus depends on the crystallinity of the polymeric matrix for foams with a low level of interconnectivity. This contribution is clearly observed in CC foams (Figure 7.8 a). For MO, OC HT and OC LT foams, there is not a clear trend between crystallinity and complex modulus. The cellular structure plays a major role in the complex modulus that is not directly linked to the nature of the polymeric matrix (Figure $7.8 \mathrm{~b}$ ), Figure $7.8 \mathrm{c}$ ) and Figure $7.8 \mathrm{~d}$ ).

Figure 7.9 shows an analogous comparison as the previous one, but representing the value of $\tan \delta$ at $0{ }^{\circ} \mathrm{C}$ : 

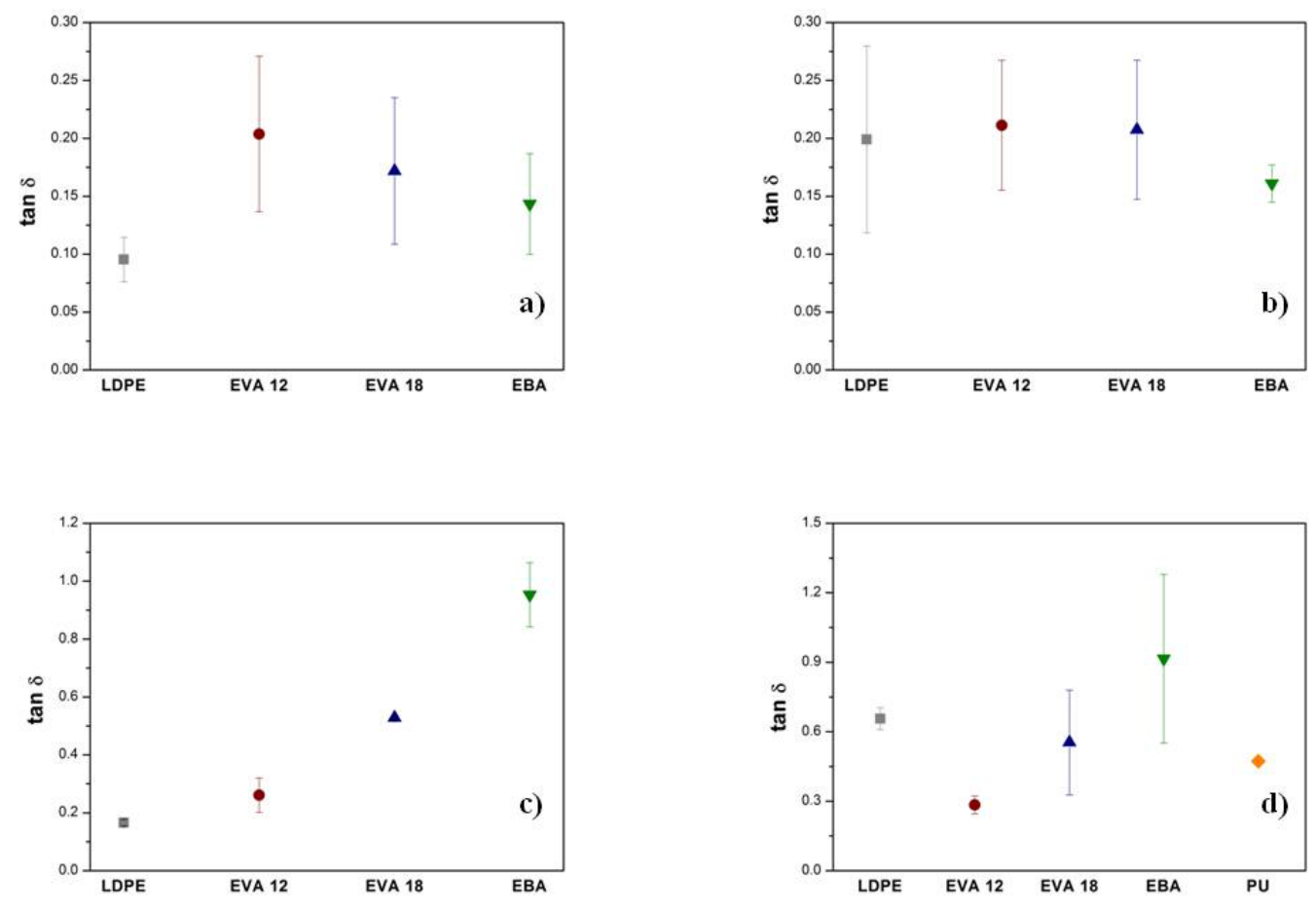

Figure 7.9. $\tan \delta$ at $0{ }^{\circ} \mathrm{C}$ for: a) CC foams; b) MO foams; c) OC HT foams and d) OC LT foams.

$\mathrm{CC}$ and MO foams present the lowest $\tan \delta$ values (Figure 7.9 a) and Figure 7.9 b), whereas open-cell foams have higher $\tan \delta$ values than the non-interconnected or partially interconnected foams. The differences between the CC and MO materials with similar compositions are small.

Concerning open-cell foams, both high and low tortuous foams are excellent foams to be used for damping mechanical vibrations. The majority of these foams present higher $\tan \delta$ values than the open-cell PU foam used as a reference. Open-cell EBA foams stand out due to their high $\tan \delta$ values, much higher than those obtained for the other foams. Differences in the tan $\delta$ values up to 0.69 in high tortuous foams and 0.63 are registered when EBA is compared to EVA 12.

The effect of the crystallinity of the polymeric matrix on tan $\delta$ is shown in Figure 7.10: 

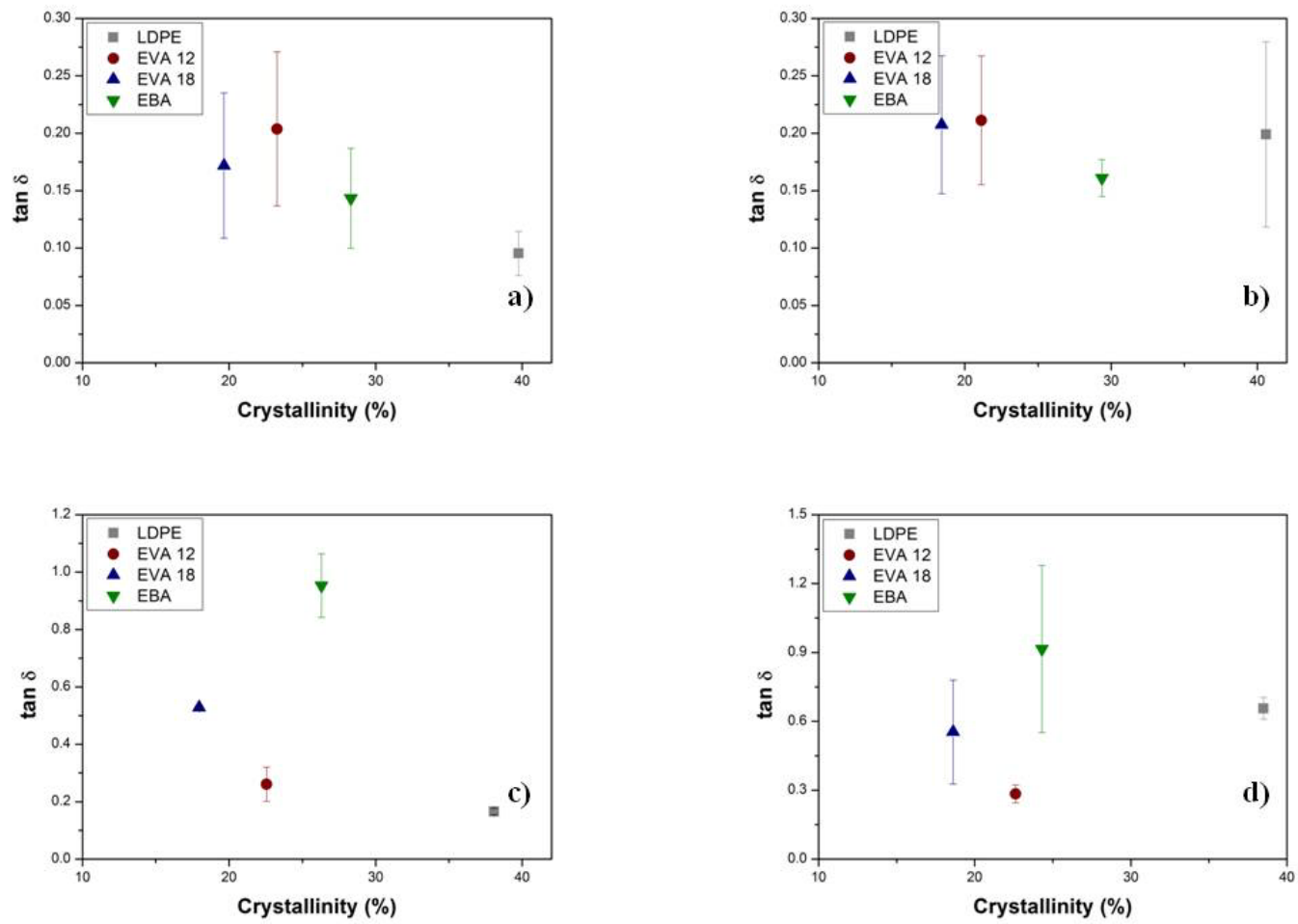

Figure 7.10. Complex modulus at $0^{\circ} \mathrm{C}$ versus crystallinity: a) CC foams; b) MO foams; c) OC HT foams and d) OC LT foams.

As it can be observed in Figure 7.10, it is not possible to establish a clear trend between $\tan \delta$ and the crystallinity of the polymer. It should be expected that more crystalline polymers present lower tan $\delta$ values than the more amorphous ones, what is fulfilled for closed-cell foams (Figure 7.10 a). However, this trend is not so clear (as in the complex modulus) in MO, OC HT and OC LT foams (Figure 7.10 b), Figure 7.10 c) and Figure $7.10 \mathrm{~d}$ ). The same conclusion as the one described for the complex modulus can be extracted from the analysis of the effect of crystallinity on tan $\delta$ : for high levels of interconnectivity, the tortuosity is the main parameter affecting the physical property.

The dynamic mechanical analysis allowed us to extend the range of potential application of the open-cell foams developed in this work. Besides the mechanical, acoustic and oil absorptive properties of open-cell foams with low tortuosity, these materials are able to damp properly mechanical vibrations due to the high values of $\tan \delta$. If this property is combined with the excellent sound absorption in the lowfrequency range, crosslinked open-cell polyolefin foams are excellent candidates to be used in the automotive or aeronautics sectors. For instance, as it was previously mentioned, open-cell PU foams are used in the motor to simultaneously absorb the sound and the mechanical vibrations coming from it. Looking at the results, open-cell polyolefin materials with low tortuosity fulfil both requirements and considering their low emission of volatiles or toxic gases; these materials also introduce an additional advantage. 
Concerning the thermal stability of the foams, Figure 7.11 summarizes the effect of the polymeric matrix on the results:
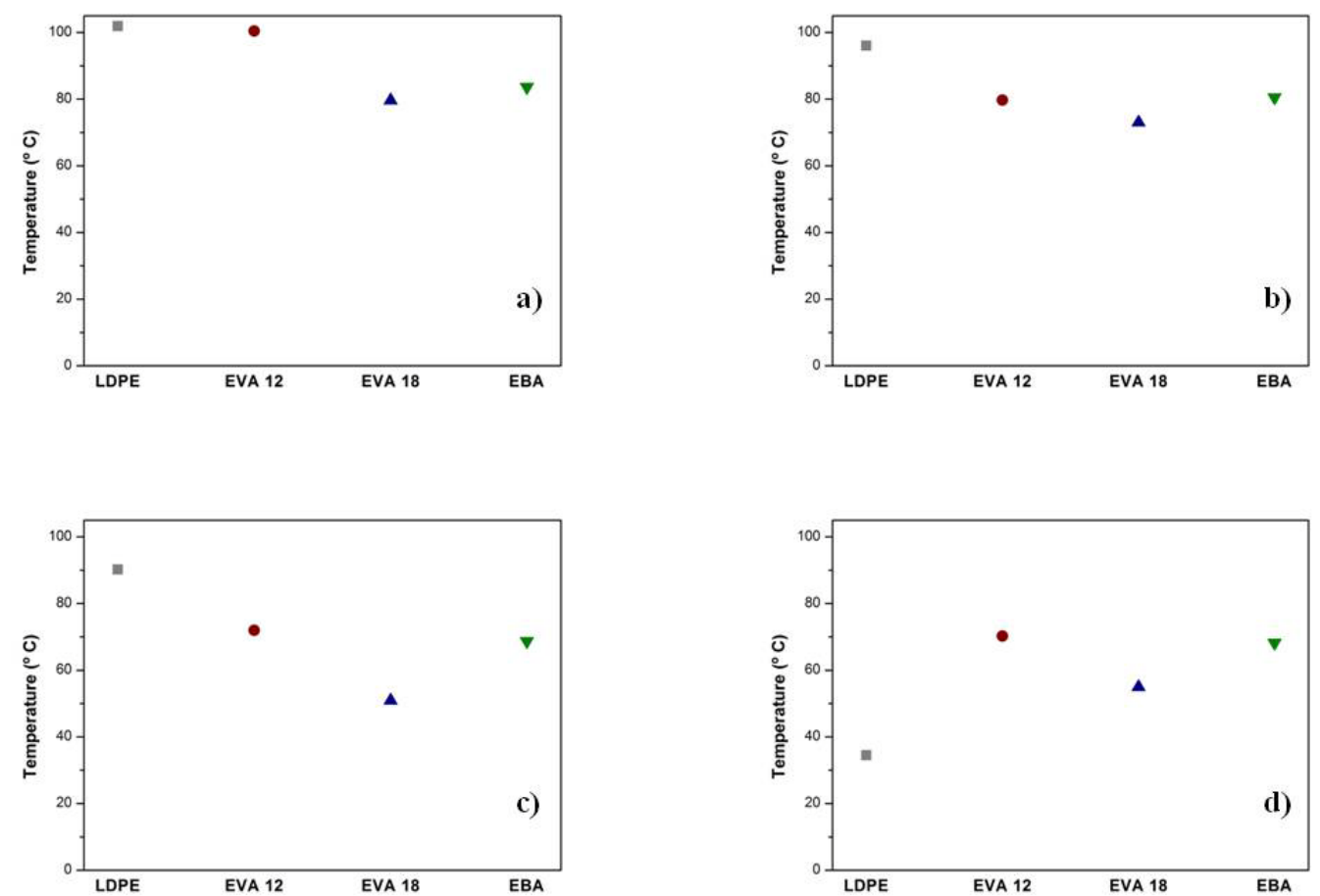

Figure 7.11. Temperature to reduce the thickness of the foam by 10\%.: a) CC foams; b) MO foams; c) OC HT foams and d) OC LT foams.

As it was discussed in section 7.3, LDPE foams are the most thermally stable ones except for the LDPE OC LT whose thermal stability is the lowest one of the series. The effect of the vinyl acetate content is clear in all the types of the foams, being EVA 12 foams more thermally stable than the EVA 18 ones due to the higher melting point of the polymeric matrix. EBA-based foams present thermal stability between the ones shown by the EVA-based foams.

It is mandatory to understand why the open-cell foams exhibit in general this poor thermal stability. Several reasons could be behind this non-desirable result. One reason is related to the presence of gas inside the cells in CC or MO materials that delays the rapid collapse of the foams when the polymer softens.

In the case of open-cell foams, the when the temperature increases the biaxially oriented cell walls start to reduce its length due to a relaxation of this orientation promoting a premature collapse of the foam because the internal gas cannot compensate this effect. It is interesting to point out the higher values of EBA foams in comparison with EVA18 foams. These EBA foams present values of the stiffness similar or even lower than EVA18 foams (Figure 7.7), but they present better thermal stability. 
It is obvious that low thermal stability is the main critical limitation of the open-cell foams with low tortuosity. This limitation could mean that these materials could not be used in several applications because they do not pass the requirements for the maximum temperature of use.

Solutions to this issue must be sought in order to replace open-cell PU foams (these materials can be used at higher temperatures due to its thermoset character). Further investigations should lead to approximations, which help to provide the open-cell materials of this research with better thermal stability.

To conclude this section, an analogous comparative as the ones shown in sections 4.4 and 5.4 of this thesis, between the thermal conductivity values of the foam characterized in this study and several commercial foams, is displayed in Figure 7.12:

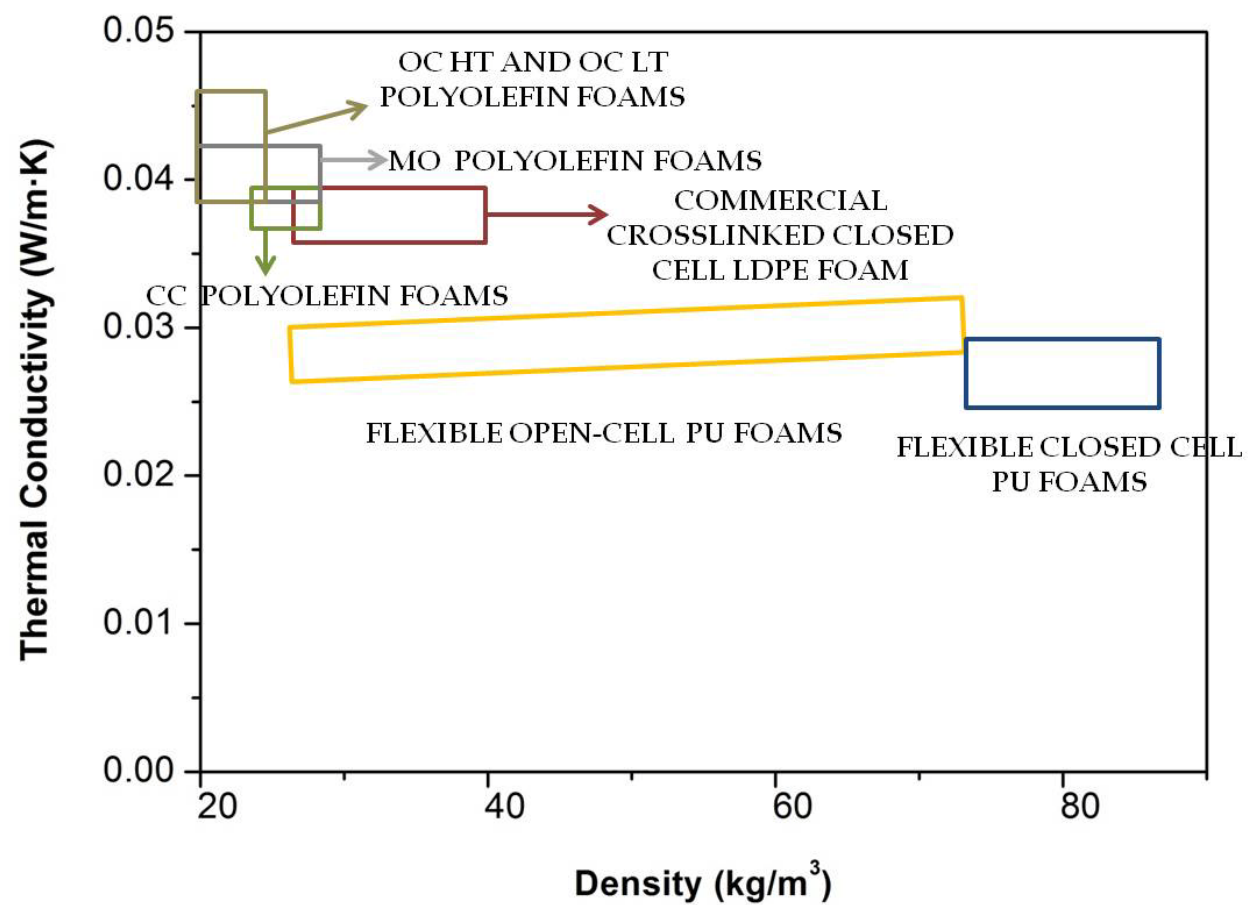

Figure 7.12. Thermal conductivity values for several commercial foams and the foams under study (CC, MO, OC HT and OC LT).

The CC foams display similar thermal conductivity values than the commercial crosslinked closed-cell LDPE foams. The highest thermal conductivity values belong to the open-cell polyolefin foams developed in this work. It can be concluded that the open-cell materials based on polyolefins are not adequate options for thermal insulation. The difference between commercial flexible open-cell PU foams and the ones based on polyolefin is up to $15-20 \mathrm{~mW} / \mathrm{m} \cdot \mathrm{K}$. This difference is quite notorious, being the flexible open-cell PU foams better choices for thermal insulation. 


\subsection{References}

[1]. M.A. Moyano, R. Paris, J.M. Martin-Martinez. International Journal of Adhesion and Adhesives, 65, 47-53, 2016.

[2]. X. Lu, U. Isacsson, J. Ekblad. Materials and Structure, 32, 131-139, 1999.

[3]. X. Lu, U. Isacsson. Construction and Building Materials, 14, 79-88, 2000.

[4]. G. Polacco, S. Berlincioni, D. Biondi, J. Stastna, L. Zanzotto. European Polymer Journal, 41, 2831-2844, 2005.

[5]. B. Sengoz, A. Topal, G. Isikyakar. Construction and Building Materials, 23, 19861992, 2009.

[6]. J. Zhu, B. Birgisson, N. Kringos. European Polymer Journal, 54, 18-38, 2014.

[7]. A. Rosales-Jasso, G. Arias, O.S. Rodriguez, N.S. Allen. Polymer Degradation and Stability, 68, 253-259, 2000.

[8]. F. Romani, R. Corrieri, V. Braga, F. Ciardelli. Polymer, 43, 1115-1131, 2002.

[9].R.D. Corsaro, L.H. Sperling. Sound and Vibration Damping with Polymers. ACS Symposium Series, American Chemical Society, Dallas, 1989.

[10]. D. Campbell, R.A. Pethrick, J.R. White. Polymer Characterization $2^{\text {nd }}$ Edition. CRC Press, London, 2000.

[11]. M.A. Rodriguez-Perez. Thermal and Mechanical Properties of Polyolefin Foams. PhD Thesis, University of Valladolid, 1999.

[12]. C.Y. Zhao, T.J. Lu, H.P. Hodson, J.D. Jackson. Materials Science and Engineering A, 367, 123-131, 2004.

[13]. M.A. Rodriguez-Perez, O. Alonso, J. Souto, J. de Saja. Polymer Testing, 16, 287298, 1997.

[14]. M. Borhani, H.A. Bioki, Z.A. Mirbagheri, F. Tabbakh, G. Mirjalili. Applied Radiation and Isotopes, 70, 1-5, 2012. 
8. CONCLUSIONS AND
FUTURE WORK 



\section{INDEX}

8.1 Conclusions

8.1.1 Production and cellular structure of the open-cell polyolefinbased foams .308

8.1.2 Analysis of the physical properties...............................................310

8.1.2.1 Mechanical properties......................................................310

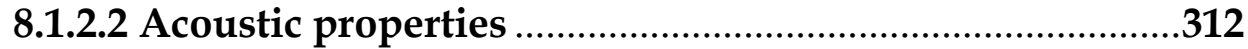

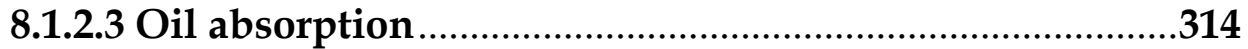

8.1.2.4 Viscoelasticity, thermal stability and thermal conductivity ..316

8.2 Future work 318 
8. Conclusions and Future Work 


\subsection{Conclusions}

This final chapter summarizes the main conclusions which can be extracted from the work covered in this thesis.

Before getting into the discussion of the conclusions of this work, it is important to remind the scheme followed in this thesis:

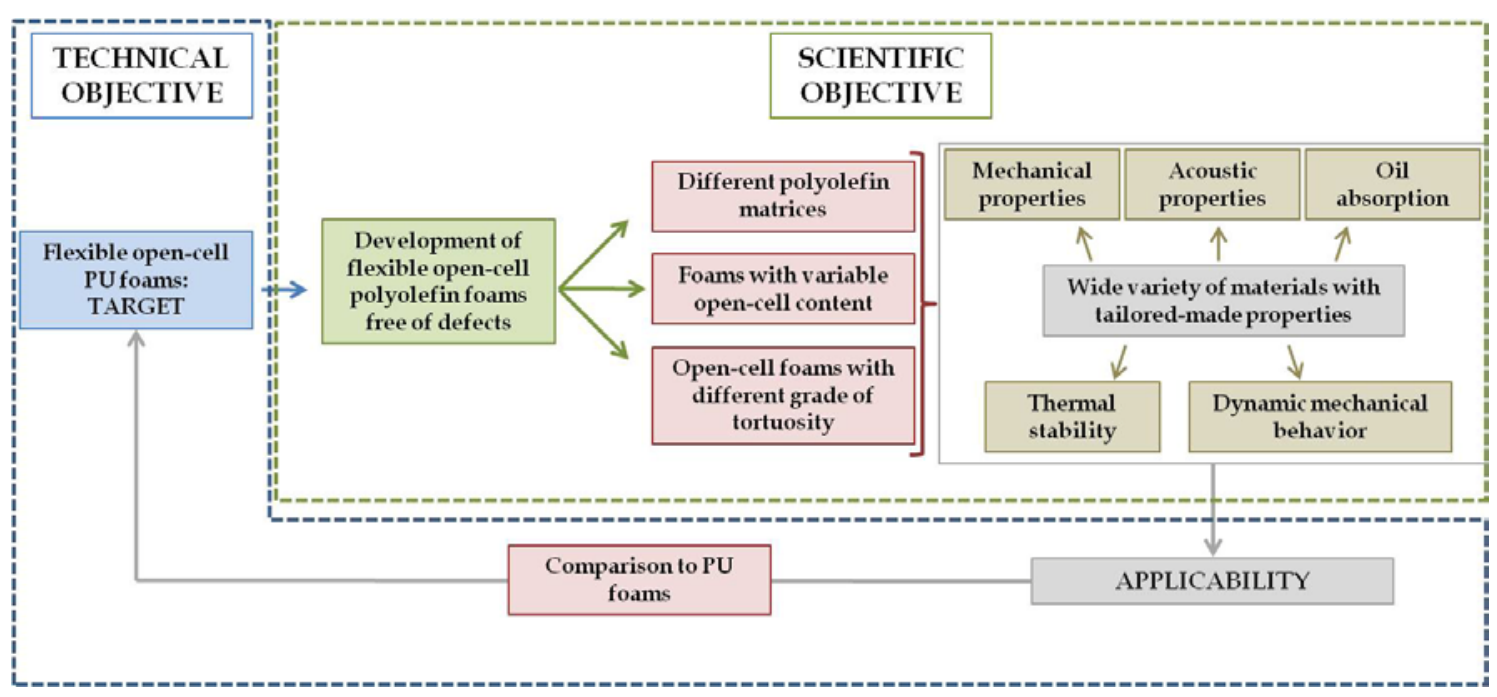

Two main objectives have been described throughout the successive chapters of this thesis. Initially, the scientific objective was defined as follows:

\section{STUDY OF THE STRUCTURE-PROPERTIES RELATION IN FLEXIBLE OPEN- CELL POLYOLEFIN BASED FOAMS}

The scientific objective is related to the production and characterization of polyolefinbased foams with different level of interconnectivity and tortuosity. The effect of the cellular structure (interconnectivity and tortuosity) and the polymer matrix (crystallinity) on the physical properties have been described, and several conclusions can be extracted from this analysis. These conclusions are framed inside the scientific objective.

Furthermore, a technical objective was also defined in the introductory chapter of this thesis (Chapter 1, section 1.3):

\section{THE PRODUCTION OF NOVEL FLEXIBLE CROSSLINKED OPEN-CELL CELLULAR POLYMER BASED ON POLYOLEOFINS TO REPLACE FLEXIBLE OPEN-CELL PU FOAMS IN SEVERAL APPLICATIONS}

The comparison of the response polyolefin-based foams with that displayed by a flexible open-cell PU foam defines the technical objective. This comparison allows determining the potential applicability of these foams. The conclusions extracted from this comparison are related to the technical objective of the thesis. 
This chapter has been divided into several sections. Firstly, the main conclusions relative to the production and the cellular structure characterization of the polyolefinbased foams are discussed (scientific objective).

Next, the analysis is focused on the conclusions extracted from the characterization of the physical properties of the foams. Each physical property will be addressed individually, isolating three effects separately:

- Effect of the cellular structure interconnectivity (closed-cell versus open-cell foams) on the physical properties (scientific objective).

- Effect of the gas phase tortuosity (open-cell foams with high and low tortuosity) on the physical properties (scientific objective).

- Comparison of the results obtained for the open-cell polyolefin-based foams and the reference open-cell PU foam (technical objective).

\subsubsection{Production and cellular structure of the open-cell polyolefin-based foams}

Polyolefin foams with different cellular structure interconnectivity and tortuosity have been produced by using the two-steps compression molding process. This technology is quite common at industrial scale in the manufacture of closed-cell polyolefin foams. However, this process is only used by one single company in the production of opencell polyolefin foams but adding a post-process in which the cell walls are opened by using compressive deformations.

CellMat Laboratory and CellMat Technologies developed in 2015 a methodology to produce open-cell polyolefin foams during the foaming process without performing compressive deformations after foaming. However, these prototypes were not homogeneous; they presented internal defects. The tortuosity of these foams was too high, far from the values of flexible open-cell PU foams and only LDPE was used as the polymer matrix.

Keeping in mind this scientific background, the main conclusions extracted during the production of the open-cell polyolefin foams are summarized below:

- The fabrication process was optimized, aiming at producing open-cell materials with high and low tortuosity without internal defects, using for this purpose four different polymeric matrices (LDPE, EVA 12, EVA 18 and EBA).

- For comparative purposes, closed-cell foams (less than 50\%), foams with intermediate open-cell contents (around 65\%) and two types of open-cell foams (more than 95\%; with high and with low tortuosity) were produced for the four polymer matrices.

- The interconnectivity of the polyolefin open-cell foams was quite different from the one typically observed in flexible open-cell PU foams. The cells in flexible open-cell PU foams consist of struts without cell walls, whereas the interconnectivity in open-cell polyolefin was generated by the creation of holes in the cell walls. 
- The tortuosity of the open-cell polyolefin foams is given by the size and the number of the holes in the cell walls. On the one hand, high tortuous (value of tortuosity of around 4.0) open-cell foams present tiny and few holes; on the other hand, low tortuous (value of tortuosity of around 2.0) open-cell foams are characterized by the presence of large and many holes.

- The compressive deformation led to the formation of tiny holes. However, the tortuosity can be tuned depending on the number of times, in which the foam is deformed, although low levels of tortuosity are quite difficult to be reached.

- The crystallinity of both the polymeric matrix and the foams were also estimated. The order of crystallinity of the solid polymeric matrices used was:

$$
\text { LDPE }(46 \%)>\operatorname{EBA}(31 \%)>\operatorname{EVA} 12(30 \%)>\operatorname{EVA} 18(17 \%)
$$

Focusing on cellular materials, the crystallinity decreased when the polymer is a foamed regardless of the interconnectivity (values below for closed-cell foams):

\section{LDPE CC (35\%) > EBA CC (22 \%) > EVA 12 CC $(20 \%)>$ EVA 18 CC (16 \%)}

We believe that this reduction is explained considering two effects:

1) The crosslinking of the polymer matrix which hinders the ordered crystallization of the molten crystals.

2) The restriction in space for the crystallization, since the polymer crystallizes in the cell walls.

It was not found any trends in the reduction of the crystallinity with the cellular structure interconnectivity or the tortuosity.

- Concerning the crosslinking process, it was explored the use of high-energy sources (electron beam irradiation) to crosslink the polymeric matrix. This study was performed using HDPE as the polymeric matrix. It was found that high irradiation doses were necessary to obtain a homogeneous cellular structure with small cell sizes. However, this alternative was not considered in the production of the foams developed in this thesis.

- Furthermore, it was also investigated the effect of the electron beam irradiation on the azodicarbonamide (blowing agent used in this thesis) powder. It was concluded, that the interaction between irradiation and the powder modified the crystalline structure of the azodicarbonamide, lowering the interplanar distances. This effect was translated into a reduction of the decomposition temperature of the azodicarbonamide as a function of the irradiation dose (from $216{ }^{\circ} \mathrm{C}$ for the non-irradiated ADCA to $210{ }^{\circ} \mathrm{C}$ from the ADCA irradiated with $150 \mathrm{kGy})$.

At this point, novel open-cell foams with low tortuosity were developed. Apparently, these foams seemed to be more similar to flexible open-cell PU foams than the initial 
prototypes developed before this thesis. For this purpose, it was mandatory to characterize the physical properties of the foams with different interconnectivity and tortuosity and an open-cell flexible PU foam used for seats in the automotive to establish differences and analogies between them.

\subsubsection{Physical properties}

The mechanical, acoustic and dynamic mechanical properties, the oil absorption, the thermal stability and thermal conductivity of the foams have been characterized. Each property has brought different results and conclusions which are covered in the following subsections. It is important to clarify that the same open-cell PU foam was used for all comparative purposes and to obtain enough information about the technical objective of this thesis.

\subsubsection{Mechanical properties}

The mechanical properties of the materials under study have been analyzed at low and high strain rates. Three mechanical parameters were measured: the effective gas pressure and the collapse stress both of them in the post-collapse region and the density of absorbed energy in the whole load stress-strain curve. Three different effects are taking into account to explain the main conclusions concerning the physical properties: the effect of the cellular structure interconnectivity, the effect of the cellular structure tortuosity and the effect of the polymeric matrix.

Effect of the cellular structure interconnectivity: closed cell versus open-cell foams

Several conclusions can be extracted from the characterization of the mechanical properties depending on the interconnectivity of the cellular structure:

- At low and high strain rates, it was found an expected behavior: the contribution of the gas in the post-collapse region increased as the level of interconnectivity decreased (around 70\% for closed-cell foams and less than 5\% for open-cell foams).

- Closed-cell foams presented higher collapse stress values than the open-cell foams. In the case of EBA foams, the collapse stress value at low strain rates of the CC was up to 13.24 times higher than that obtained for the OC LT foam. At high strain rates, values up to 4.03 times higher were found for LDPE.

- Closed-cell foams were able to absorb more energy than the open-cell foams. The comparative between CC and OC LT foams shows considerable differences at both strain rates (up to 18.57 times higher for LDPE CC than for LDPE OC LT at low strain rates and 6.32 times higher for EBA CC than EBA OC LT at high strain rates).

Therefore, as it was expected, the cellular structure interconnectivity has a critical contribution to the mechanical properties. The second parameter to be analyzed is the cellular structure interconnectivity. 
Effect of the cellular structure tortuosity: open-cell foams with high and low tortuosity

The effect of the interconnectivity on the mechanical properties has been widely studied. However, the effect of the tortuosity has not ever been analyzed, and this work allows extracting some conclusions valid not only for open-cell polyolefin-based foams but also for other open-cell materials:

- The effect of the tortuosity is negligible at low strain rates, behaving both opencell foams with high and low tortuosity similarly to the flexible open-cell PU foam used as a reference.

- The negligible effect of the tortuosity was also confirmed in the estimation of the density of absorbed energy. Both open-cell foams were not able to absorb a considerable amount of energy (less than $0.80 \mathrm{~J} / \mathrm{cm}^{3}$ ) as in the case of the opencell PU foam, whereas the closed-cell foams or the foams with intermediate open-cell contents were more suitable for this purpose (higher than $4.20 \mathrm{~J} / \mathrm{cm}^{3}$ for CC foams).

- At high strain rates, the tortuosity has a critical effect on the mechanical response. On the one hand, the contribution of the gas in the open-cell foams with high tortuosity increased markedly behaving similarly to closed-cell foams (from less than $5 \%$ up to $70 \%$ ). On the other hand, the contribution of the gas also increased in the open-cell foams with low tortuosity and in the flexible open-cell PU foam, but slightly not as markedly as in open-cell foams with high tortuosity.

- This unexpected behavior was confirmed in the estimation of the density of absorbed energy, absorbing the open-cell foams with high tortuosity as much energy as the closed-cell foams. The OC HT foams can absorb up to 26.14 times more energy (for EVA 18) at high strain rates in comparison to low strain rates.

- Considering the velocity of the test and the dimensions of the sample, a simple estimation of the gas, which remains in the structure during the mechanical test at high strain rates, was performed obtaining that a $70 \%$ of the gas remained inside during the mechanical test at high strain rates for OC HT foams. The explanation behind this result is connected to the speed of the test. At low strain rates, the gas has enough time to leave the foams regardless of the level of tortuosity. However, at high strain rates, as the time necessary to leave the sample is considerably reduced, the gas cannot escape through the tiny holes of the foams with high tortuosity, remaining a considerable amount of it inside.

- Therefore the open-cell foams with high tortuosity present an interesting double behavior depending on the strain rate of deformation increasing their versatility and applicability: comfort-related applications at low strain rates and packaging or body protection at high strain rates.

The effect of tortuosity is crucial to explain the results obtained for open-cell foams. A different behavior has been found depending on this parameter and the strain rate of deformation. The last parameter to consider is the polymeric matrix. 


\section{Effect of the polymeric matrix}

Four polymeric matrices with different properties (crystallinity, melting points, tensile strength, etc...) have been used. It is also essential to determine the effect of this parameter. In addition, the results were also compared to a flexible open-cell PU foam used as the reference. The main conclusions referred to this analysis are described below:

- The effect of the polymeric matrix on the mechanical parameters was found for CC foams. However, no trends were observed for foams with high interconnectivity. The main parameters affecting the mechanical properties of these foams were the open-cell content and the tortuosity.

- For CC foams, there is a trend, which connected the results with the polymeric matrix. Both the values of collapse stress and the density of absorbed energy decreased as the crystallinity also did:

\section{Mechanical properties: LDPE CC > EBA CC > EVA 12 CC $>$ EVA 18 CC}

To exemplify some results, the collapse stress value of the LDPE CC foams was 3.89 times higher than the EVA $18 \mathrm{CC}$, and the density of absorbed was 1.62 times higher.

- Both OC HT and OC LT foams presented similar values of the mechanical parameters analyzed in this study at low strain rates to those exhibited by the flexible open-cell PU foam. However, at high strain rates, the behavior of the OC HT foam changed completely, resembling this foam the mechanical response of a closed-cell foam. The OC LT foam also behaved similarly to the flexible open-cell PU foam at high strain rates.

\subsubsection{Acoustic properties}

Open-cell PU foams are commonly used in applications in which sound absorption is required due to the excellent attenuation of the sound waves by these foams. However, their feature is reduced in the low-frequency range (below $2000 \mathrm{~Hz}$ ).

The sound absorption capacity of open-cell polyolefin-based foams was measured, and their acoustic response was compared to that obtained for the reference open-cell PU foam. The conclusions obtained isolating the three previous contributions are described below:

Effect of the cellular structure interconnectivity: closed-cell versus open-cell foams

- The sound absorption depended critically on the cellular structure interconnectivity. The sound absorption of OC foams is markedly superior to the $\mathrm{CC}$ foams, which presented very poor sound absorption. 
- The normalized absorption coefficient for CC foams did not exceed values higher than 0.25, whereas OC LT foams displayed normalized absorption coefficients above 0.65 .

- This result is in agreement with the theory, in which it is indicated that the most suitable cellular materials for acoustic absorption are those with a cellular structure highly interconnected.

Effect of the cellular structure tortuosity: open-cell foams with high and low tortuosity

- The tortuosity affects the sound absorption capacity of the foams, exhibiting the low tortuous foams higher sound absorption coefficients than the high tortuous materials regardless of the polymer matrix. Enhancements up to $80 \%$ were obtained (EBA OC LT in comparison with EBA OC HT) in the whole range of frequencies (from 500 to $6400 \mathrm{~Hz}$ ).

- The open-cell high tortuous foams cannot be considered as promising materials for this particular application since the normalized absorption coefficients oscillated between 0.35 and 0.50 far away from the value displayed by the opencell PU foam (0.73) in the whole range of frequencies.

- The normalized absorption coefficients for open-cell foams with low tortuosity are slightly lower than the reference open-cell PU foam in the whole range of frequencies. This difference in the coefficient is about 0.05 , far from being relevant. Even, the EBA OC LT foam presented a higher coefficient (0.74) than the open-cell PU foam, but it is also important to clarify that this open-cell PU foam is used for seats, not for sound absorption applications.

Effect of the polymeric matrix

- No notorious differences were found for the different polymeric matrices used in this thesis. As the mechanisms involved in the attenuation of the sound waves are more connected to the cellular structure (similar type of cellular structure for all foams) than to the nature of the polymeric matrix, it was not expected considerable differences in the normalized acoustics between materials with similar cellular structure interconnectivity and tortuosity (0.07 between EBA and EVA 12 OC LT foams in the whole range of frequencies and 0.15 between EBA and EVA 18 OC HT foams).

- Due to poor sound absorption of the open-cell PU foams at low frequencies, the sound absorption capacity from 500 to $2000 \mathrm{~Hz}$ was isolated aiming at determining if the open-cell polyolefin foams improved the sound absorptions of the open-cell PU foam.

- Both open-cell polyolefin foams with high and low tortuosity improved the acoustic response of the open-cell PU foam in the low-frequency range due to the presence of maximums in the curves below $2000 \mathrm{~Hz}$.

- Remarkably, the normalized absorption coefficients for the open-cell polyolefin foams with low tortuosity ( 0.68 for EBA OC LT) doubled the value of the opencell PU foam (0.34). 
- This outstanding result widened the applicability of the open-cell polyolefin foams with low tortuosity since few materials in the market absorb sound below $2000 \mathrm{~Hz}$.

\subsubsection{Oil absorption}

The properties previously described are conducted to improve and make human life more comfortable. However, it is also essential to cover properties which allow us preserving the environment.

The oily nature of polyolefins could be a solution for reducing the impact of oil spills in the ecosystem. As a consequence, the oil absorption capacity of the open-cell polyolefin was tested. Furthermore, if it is taken into account that the materials used for this application must display high oil-water selectivity, the hydrophobicity of the foams was also measured. Finally, the reusability of the materials was also addressed, since they must be used as many times as possible.

Some interesting conclusions were obtained from the study, and the most relevant ones are discussed next.

Effect of the cellular structure interconnectivity: closed-cell versus open-cell foams

- As it was expected, the interconnectivity plays a critical role in this property. Cellular structures highly interconnected were necessary to absorb considerable amounts of oil.

- In Chapter 6, the analysis of the results is focused on the comparison between OC HT and OC LT foams. However, the oil absorption capacity of CC and MO foams was also measured, despite not appearing in the thesis.

- The oil-absorptive response of the foams is classified as follows regardless of the polymeric matrix:

\section{OC LT foams > OC HT foams > MO foams > CC foams}

- Considerable differences in the amount of oil absorbed were obtained if the most extreme cases are compared. For instance, the LDPE OC LT foam was able to absorb up to 7 times more $15 \mathrm{~W} 40$ oil than the LDPE CC foam.

Effect of the cellular structure tortuosity: open-cell foams with high and low tortuosity

- As in the attenuation of the sound waves or the mechanical properties, the tortuosity also affected the oil absorption capacity. The open-cell foams with low tortuosity presented absorptions up to 3.26 times higher for EVA 18 or 4.13 times higher for EBA than the counterparts with high tortuosity.

- Quite high oil absorptions were obtained, in many cases, higher than 40 grams of oil per gram of foam. 
- To isolate the effect of the density, the oil absorption efficiency (OAE) was estimated showing that OC LT foams efficiencies above 0.60 , even in some cases up to 0.90 . The efficiency of the open-cell PU foam was also quite high ( 0.80 for sunflower oil), confirming that the high density of this foam limited its oil absorption.

- The polyolefin-based foams can be considered hydrophobic since their water absorptions were below 1 gram of water per gram of foam. This entails a considerable advantage over PU since PU foams tend to absorb water.

- Despite using three types of oils, (motor oil 15W40, motor oil $80 \mathrm{~W} 90$ and sunflower oil) the effect of the viscosity of the oil on the oil absorption could not be extracted due to the different cellular structures of the foams and the methodology used for this characterization. The large size of many cells and the high open-cell content limited the measurements since small samples were employed. In the hypothetical case of having similar cellular structures, low viscous oils should be absorbed easily by capillarity than high viscous ones.

- The reusability of the open-cell foams with low tortuosity was also tested by using two methods: compression tests at low strain rates and oil reabsorption cycles. Both methodologies simulate the collection and the removal of the oil from the structure. These OC LT foam can be considered reusable at least 50 times, except for the LDPE OC LT foam, which collapsed after few cycles due to the high stiffness of the polymeric matrix.

Effect of the polymeric matrix

- Due to the reasons previously exposed in the effect of the viscosity of the oil on the oil absorption capacity of the foams (low homogeneity of the cellular structure and the small size of the samples), the effect of the polymer matrix could not be isolated. Again in the same hypothetical case, the oil absorption capacity should be as follows:

\section{LDPE-based foams > EBA-based foams > EVA 12-based foams > EVA 18- based foams}

The order is connected to the polarity of the polymer chain. LDPE is a completely non-polar polymer, and its oil absorption must be the highest, followed by EBA and EVA 12. Finally, the high vinyl acetate content of the EVA 18 resulted in an increase of the polarity of the chain, which would lead to a lower affinity towards oil.

- The open-cell polyolefin foams with low tortuosity absorbed much more oil than the open-cell PU reference. However, it was pointed out that there are examples of open-cell PU foams in the literature with higher oil absorptions than our materials, but these foams were treated to make them superhydrophobic. 
- At least, EVA 18 OC LT and EBA OC LT can be considered as an alternative not only to open-cell PU foams but also to the current methods of oil recovery, being this application quite innovative for these materials.

\subsubsection{Viscoelasticity, thermal stability and thermal conductivity}

Open-cell foams with high and low tortuosity presented properties which made them promising materials for several applications such as comfort, sound and oil absorption for open-cell foams with low tortuosity or comfort and energy absorption (depending on the strain rate) for open-cell high tortuous materials.

It was also believed convenient to determine three additional properties: 1) the viscoelastic behavior which provides useful information about the capacity of damping mechanical vibrations; 2) the thermal stability to determine in which range of temperatures a material can be used and 3) the thermal conductivity of the foams.

These three analyses allowed us obtaining several results which are summarized below:

Effect of the cellular structure interconnectivity: closed-cell versus open-cell foams

- In DMA, it has been observed that the modulus of the complex modulus $\left(E^{*}\right)$ increased as the level of interconnectivity decreased (higher for closed-cell foams).

- $\tan \delta$ increased as the interconnectivity also did. Values up to 6.40 times higher for EBA or 6.90 times higher for LDPE were obtained when OC LT foams are compared to CC foams. The mechanism behind this response is connected to the possibility of the air to flow through the cellular structure of open-cell foams during the mechanical cycling, whereas this flow is restricted in closedcell foams since the gas in enclosed inside the cells.

- Concerning the thermal stability, CC foams were the most thermally stable materials regardless of the polymeric matrix. This parameter is directly related to the interconnectivity:

\section{CC foams $>$ MO foams $>$ OC HT foams $>$ OC LT foams}

- Differences in temperature of $15{ }^{\circ} \mathrm{C}$ for EBA, $30^{\circ} \mathrm{C}$ for EVA-based foams and 67 ${ }^{\circ} \mathrm{C}$ for LDPE were found when CC foams are compared to OC LT foams.

- Furthermore, the thermal conductivity also depended on the interconnectivity. The lowest values of thermal conductivity were obtained for CC foams, increasing this parameter as follows regardless of the polymeric matrix:

$$
\lambda(\text { CC foams })<\lambda \text { (MO foams) } \approx \lambda \text { (OC HT foams) }<\lambda \text { (OC LT foams) }
$$


The difference in the thermal conductivity between CC and OC LT foams reached values up to $7 \mathrm{~mW} / \mathrm{m} \cdot \mathrm{K}$ at $20{ }^{\circ} \mathrm{C}$ for LDPE and EBA and up to 8 $\mathrm{mW} / \mathrm{m} \cdot \mathrm{K}$ at for EVA 12 and EVA 18 at the same temperature.

\section{Effect of the cellular structure tortuosity: open-cell foams with high and low tortuosity}

- Negligible differences in the complex modulus were obtained when OC HT and OC LT foams are compared.

- Both OC HT and OC LT foams showed very high values of tan $\delta$ at $0{ }^{\circ} \mathrm{C}$, and therefore these foams were able to damp efficiently mechanical vibrations due to the mechanism previously explained in the comparison between closed and open-cell materials.

- The combination of high sound absorption capacity and damping of mechanical properties makes the OC LT foams in promising materials to be used in the automotive or aeronautic sectors.

- The critical limitation of the open-cell polyolefin foams is their low thermal stability. OC HT foams can withstand higher temperatures (between 51 and 90 ${ }^{\circ} \mathrm{C}$, depending on the polymer matrix) than the OC HT foams (between 34 and $70{ }^{\circ} \mathrm{C}$, depending on the polymer matrix).

- The poor thermal stability of these foams could be a severe restriction for several industrial applications analyzed in this thesis.

- The effect of the tortuosity on the thermal conductivity is critical, being the values of the thermal conductivity of OC HT foams much lower than those obtained for OC LT materials.

- The values of the thermal conductivity of the OC HT oscillated in a range from 37.20 to $39.40 \mathrm{~mW} / \mathrm{m} \cdot \mathrm{K}$ at $20{ }^{\circ} \mathrm{C}$ for OC HT foams (depending on the polymeric matrix), whereas these values were located in a range from 44.50 and $45.40 \mathrm{~mW} / \mathrm{m} \cdot \mathrm{K}$ for OC LT foams at the same temperature.

\section{Effect of the polymeric matrix}

- The effect of the polymeric matrix on the viscoelastic properties was found for CC foams. However, no trends were observed for foams with high interconnectivity. The main parameters affecting the viscoelastic properties of these foams are the open-cell content and the tortuosity.

- For CC foams, LDPE CC showed the highest $E^{*}$ at a fixed temperature of $\left(0^{\circ} \mathrm{C}\right)$ whereas EVA 18 CC presented the lowest value (7 times higher for LDPE CC than for EVA $18 \mathrm{CC}$ ). The explanation behind this result is the higher crystallinity of LDPE in comparison to EVA or EBA copolymers.

- Concerning the flexible open-cell PU foam, its complex modulus (at $0{ }^{\circ} \mathrm{C}$ ) was higher than those displayed by the OC LT foams due to its higher density (up to 1.54 times higher).

- The tan $\delta$ value of the PU foam at $0{ }^{\circ} \mathrm{C}$ was lower than those obtained for OC LT and OC HT foams, indicating that the open-cell polyolefin-based foams presented the better capacity to damp vibrations than this particular PU foam. 
- It has also been observed in CC foams how the thermal stability depends on the polymer matrix since each material has its melting point at different temperatures. LDPE CC showed the best thermal stability $\left(101{ }^{\circ} \mathrm{C}\right)$ whereas EVA $18 \mathrm{CC}$ started collapsing at lower temperatures $\left(79^{\circ} \mathrm{C}\right)$. Furthermore, the effect of the vinyl acetate content is reflected in this property; EVA 12 due to the lower vinyl acetate content collapses at higher temperatures $\left(85^{\circ} \mathrm{C}\right)$ than EVA 18.

- The thermal conductivity of the polyolefin-based foams also depended on the nature the polymeric matrix. The following trend has been obtained in the thermal conductivity values:

$$
\lambda(\text { LDPE })>\lambda(\text { EVA 18) }>\lambda(\text { EVA 12) }>\lambda(\text { EBA })
$$

- The open-cell PU foam presented the lowest values of the thermal conductivity, even lower than those measured for CC foams $\left(35.65 \mathrm{~mW} / \mathrm{m} \cdot \mathrm{K}\right.$ at $\left.20^{\circ} \mathrm{C}\right)$. The differences between the PU foam and the OC LT foams at $20^{\circ} \mathrm{C}$ reached values up to $9.78 \mathrm{~mW} / \mathrm{m} \cdot \mathrm{K}$.

\subsection{Future work}

This thesis is based on the patented technology to create open-cell polyolefin foams developed by CellMat Technologies and CellMat Laboratory. Following this methodology, it was possible to develop new open-cell materials with two levels of tortuosity using four different polymer matrices. Furthermore, the physical properties of the foams were characterized. The materials have shown promising properties, and due to this, future research on this topic will be necessary.

- The cell size of the materials characterized in this thesis is quite different depending on the level of interconnectivity and the polymer matrix. To establish a methodology allowing better control of the cell size would be relevant progress in the production of these materials.

- It would also be quite interesting to produce materials with levels of tortuosity out of the range, in which these materials belong (between 1.9 and 4.2). Lowering the level tortuosity (below 1.9) could be translated into an enhancement of the physical properties of these open-cell foams.

- In this thesis, the production of open-cell polyolefin-based foams was extended from one polymer matrix (LDPE) to four (LDPE, EVA 12, EVA 18 and EBA). Polyolefin elastomers (POE) are also suitable candidates to be used for this purpose. The excellent elastomeric properties make these polymers quite interesting for comfort applications. The use of this type of polymeric matrix could be quite interesting, aiming at extending the versatility of the process and improving the properties of the materials required for some specific applications. 
- Azodicarbonamide was the blowing agent used for producing the materials characterized in this thesis. However, there is an increasing concern about the use of azodicarbonamide in the manufacture of foamed products. Since its ban on food packaging, the companies are aware of possible restrictions of this product in the coming years. But not only for its possible ban but also for the high emission of volatiles (automotive sector), other blowing agents must be considered.

- Concerning the physical properties, the sound absorption of the OC LT foams is excellent in the low-frequency range. However, in the whole range of measured frequencies, the open-cell PU foams showed better behavior. Keeping the excellent sound absorption showed by the OC LT foams at low frequencies in the whole frequency range would convert these foams into the most suitable option for sound absorption applications.

- Finally, the most relevant issue to be solved short-term is the poor thermal stability of the open-cell foams with low tortuosity. This critical limitation restricts the use of these foams in several applications. As a consequence, solutions to this issue must be found to overcome this problem. One possible option could be to perform an additional crosslinking of the polymer after foaming, for example, irradiating the foams with electrons at different doses. This alternative is ongoing, and the results will be obtained soon. Another possibility to improve this property is related to the search for new ways of cell opening.

- It could also be interesting to replicate the cell opening methodology to other fabrication technologies. Based on this, one option could be analyzing how open-cell polyolefin-based foams can be produced using a continuous process. This approximation is attractive since many companies produced polyolefin foams by using this process.

- Finally, it is important to point out that the formulations used in the production of the cellular materials do not contain any specific additive. As a consequence, it would be interesting to develop specific open-cell materials with different additives (flame retardants, colorant fillers, IR blockers, etc...), which provide additional properties. 
8. Conclusions and Future Work 